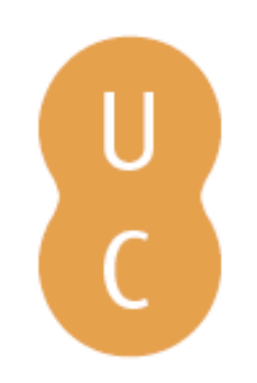

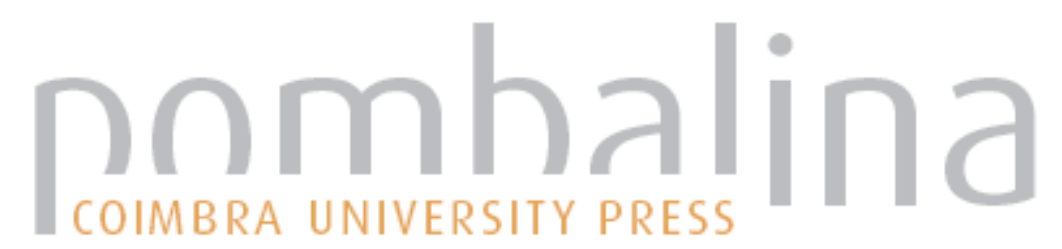

\title{
De ayer a hoy: influencias clásicas en la literatura
}

\begin{tabular}{|c|c|}
\hline Autor(es): & $\begin{array}{l}\text { López, Aurora, ed. lit.; Pociña, Andrés, ed. lit.; Silva, Maria de Fátima } \\
\text { ed.lit. }\end{array}$ \\
\hline Publicado por: & $\begin{array}{l}\text { Centro de Estudos Clássicos e Humanísticos da Universidade de } \\
\text { Coimbra; Imprensa da Universidade de Coimbra }\end{array}$ \\
\hline $\begin{array}{l}\text { URL } \\
\text { persistente: }\end{array}$ & URI:http://hdl.handle.net/10316.2/9730 \\
\hline DOI: & DOI:http://dx.doi.org/10.14195/978-989-721-038-9 \\
\hline
\end{tabular}

Accessed : $\quad$ 26-Apr-2023 14:16:07

A navegação consulta e descarregamento dos títulos inseridos nas Bibliotecas Digitais UC Digitalis, UC Pombalina e UC Impactum, pressupõem a aceitação plena e sem reservas dos Termos e Condições de Uso destas Bibliotecas Digitais, disponíveis em https://digitalis.uc.pt/pt-pt/termos.

Conforme exposto nos referidos Termos e Condições de Uso, o descarregamento de títulos de acesso restrito requer uma licença válida de autorização devendo o utilizador aceder ao(s) documento(s) a partir de um endereço de IP da instituição detentora da supramencionada licença.

Ao utilizador é apenas permitido o descarregamento para uso pessoal, pelo que o emprego do(s) título(s) descarregado(s) para outro fim, designadamente comercial, carece de autorização do respetivo autor ou editor da obra.

Na medida em que todas as obras da UC Digitalis se encontram protegidas pelo Código do Direito de Autor e Direitos Conexos e demais legislação aplicável, toda a cópia, parcial ou total, deste documento, nos casos em que é legalmente admitida, deverá conter ou fazer-se acompanhar por este aviso.

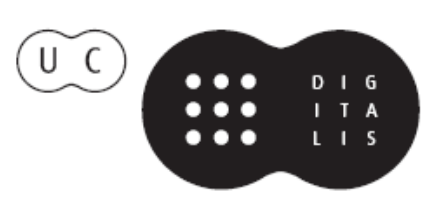




\section{De ayer a hoy}

\section{Influencias clásicas en la literatura}

\section{Aurora López, Andrés Pociña, Maria de Fátima Silva (coords.)}




\section{De ayer a hoy:}

\section{influencias clásicas en la literatura}

Aurora López, Andrés Pociña, Maria de Fátima Silva (coords.) 
Todos los volúmenes de esta serie están sujetos a valoración científica independiente.

\section{CoOrdinadores}

Aurora López, Andrés Pociña, Maria de Fátima Silva

Título

De ayer a hoy: influencias clásicas en la literatura

EDITOR

Centro de Estudos Clássicos e Humanísticos da Universidade de Coimbra

Imprensa da Universidade de Coimbra

EDICIÓN:

1a/ 2012

Coordinador Científico del Plan de Edición

Maria do Céu Fialho

Consejo Editorial

José Ribeiro Ferreira, Maria de Fátima Silva, Francisco de Oliveira e Nair Castro Soares

Director Técnico de la Colección:

Delfim F. Leão

Concepción Gráfica y Paginación:

Rodolfo Lopes, Nelson Ferreira

IMPRESIÓN:

Simões \& Linhares, Lda. Av. Fernando Namora, n. ${ }^{\circ} 83$ Loja 4. 3000 Coimbra

ISBN: 978-989-721-037-2

ISBN DigiTAL: 978-989-721-038-9

DOI: http://dx.doi.org/10.14195/978-989-721-038-9

Depósito Legal: 353374/13

(C) Imprensa da Universidade de Coimbra

(C) Centro de Estudos Clássicos e Humanísticos da Universidade de Coimbra

(C) Classica Digitalia Vniversitatis Conimbrigensis (http://classicadigitalia.uc.pt)

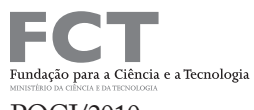

$\mathrm{POCI} / 2010$

Reservados todos los derechos. En términos legales, queda expresamente prohibida la reproducción total o parcial por cualquier medio, ya sea en papel o en edición electrónica, sin autorización expresa de los titulares de los derechos. Queda excluida de esta prohibición la utilización en circuitos académicos orientados a la enseñanza o a la extensión cultural por medio del e-learning. 


\section{ÍNDICE}

Presentación 9

Liturxia DE Tebas De M. Lourenzo. Economía dramática y punto de vista Personal. 13

$M^{a}$ Teresa Amado Rodríguez (Universidad de Santiago de Compostela)

Medeia em Seus espelhos

Sônia Aparecida dos Anjos (Universidade de Coimbra)

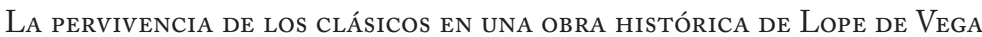

Andréa Antunes (Escola Politécnica de Saúde Joaquim Venâncio)

El discurso de las mujeres del Agamenón de Séneca

Carmen Arias Abellán (Universidad de Sevilla)

La Odisea de César Brie: Ulises en Tiempos de la Globalización

Alicia María Atienza (Universidad Nacional de la Patagonia Austral)

Quando um brasileiro lê Plauto

Tereza Virgínia Barbosa (Universidade Federal de Minas Gerais)

VESTÍGIOS GREGOS EM TERRAS BRASILEIRAS

Vanessa Ribeiro Brandão (Universidade Federal de Minas Gerais )

Dioniso E IL Dionisismo:

le Baccanti di Euripide e la Morte a venezia di Thomas Mann

Anna Maria Belardinelli (Universidad de Mar del Plata)

Mauricio Kartun como adaptador del teatro griego: comedia y utopía

Milena Bracciale Escalada (Universidad de Mar del Plata)

UMA ELECTRA PORTUGUESA DO SÉCULO XVIII:

“Tragedia em cinco actos, tirada da historia grega”, de Francisco Dias Gomes

María Fernanda Brasete (Universidade de Aveiro)

Aristófanes y el arte de lo posible en Salto al Cielo de Mauricio Kartun:

POLÍTICA Y CONCIENCIA POÉTICA EN UNA FARSA (GRIEGA) APÓCRIFA

Emiliano J. Buis (Universidad de Buenos Aires - CONICET)

Quid PRO QUO Em SuAssuna

Tereza Pereira do Carmo (Instituto Superior de Educação Anísio Teixeira)

Dentro e Fora Da PERSONAGEM:

Como encarnar o coro no Hipólito de Eurípides?

Ana Seiça Carvalho (Universidade de Coimbra)

Dos MITOS GRIEGOS EN UN ESCRITOR NOVEL:

LAS SIRENAS Y LA FUNDACIÓN DE ATENAS, DE Roberto SAYAR

Pablo A. Cavallero (Universidad de Buenos Aires - UCA - CONICET)

El personaje de Antígona en Sófocles y Gambaro:

LA CREACIÓN DE UNA NUEVA TRAGICIDAD

María Victoria Coce (UBA - IUNA)

Y dice Eurídice. Sobre UnA ANatomía de la sombra de Alejandro Tantanian

Marcela Inés Coll - María Gabriela Simón (Universidad Nacional de San Juan) 
"Miran al cielo Y piden un deseo:

Contido la noche más bella”. De la Trama del tejido a las delicias del Omophagos

María Cecilia Colombani (Univ. de Morón - Univ. Nacional de Mar del Plata)

Los rastros de MEDEa de Eurípides en MEdeA de Elena Soriano.

EL TÓPICO DE LOS CELOS

María Silvina Delbueno (Universidad Nacional del Centro de la Provincia de Bs As)

El Hércules cristiano en Fieras afemina amor de Calderón de la Barca

Eliane Demoraes (Univ. Cat. de Petrópolis - Univ. Fed. do Estado de Rio de Janeiro)

DiVINA INFIDELIDAD:

UNA VUELTA SOBRE EL TEMA DE ANFITRIÓN EN EL TEATRO ESPAÑOL

Viviana M. Diez (Universidad de Buenos Aires - UBACyT)

UM ANFITRIÃO EXTEMPORÂNEO:

Ecos do texto Plautino em Guilherme de Figueiredo

Carlos E. Gomes (Universidade Federal de Minas Gerais)

Del diÁlogo al TEXTO DRAMÁtico:

una Adaptación brasileña de los Diálogos de los muertos de Luciano de Samosata

Matías Sebastián Fernández Robbio (Universidad Nacional de Cuyo)

Relectura y fusión de un mito griego en un drama de Horacio Rega Molina

Alfredo Eduardo Fraschini (Universidad Nacional de Villa María)

ACERCa de los imaginarios trágicos de ALTERIDAd y SU PERVIVENCIA EN EL TEATRo ARgentino actual: Antígona(s) y Medea(s)

Lidia Gambon (Universidad Nacional del Sur)

REFACCiÓN DE Mitos CLÁSICOS EN EL TEATRO GALLEGo CONTEMPORÁNEO

María Pilar García Negro (Universidad de A Coruña)

LE BACCANTI DI EURIPIDE: Un'OPERA POST-MODERna?

Giovanni Greco (Theatron - Universitá di Roma La Sapienza)

El mito de Perseo y Andrómeda en el teatro de Lope de Vega y

Calderón de la Barca

Remedios Higueras González (I.E.S. Luis Bueno Crespo)

La ANTígona de María Zambrano o el oficio de la Piedad

Alfonso Lázaro Paniagua (I.E.S. Luis Bueno Crespo)

AdAPtACión de un teMA ClÁSICO A UNA TENDENCIA DEL TEATRO ESPAÑOL DEL SIGLO XX:

LA NIETA DE FEDRA de Halma Angélico

Aurora López (Universidad de Granada)

De Albert Camus a Alejo Carpentier: mito y tragedia clásica

Inmaculada López Calahorro (Universidad de Granada)

Platón y Lorca: filosofía en la escena (El público)

Concepción López Rodríguez (Universidad de Granada)

Sófocles y Antonin Artaud. La tragedia y el teatro de la crueldad:

TENSIÓN Y DESGARRO DE UNA INTERIORIDAD PERDIDA

Jorge Mallearel (Universidad de Morón)

Os CLÁsSICOS EM MARIONETAS

Susana Maria Marques (Universidade de Coimbra) 
Os Mitos E A CONDIÇÃo Humana:

As confrarlas, de Jorge Andrade e Antígona, de Sófocles

Andréia Garavello Martins (Universidade Federal de Minas Gerais)

Dos Antígonas cubanas en el nuevo milenio

Elina Miranda Cancela (Universidad de La Habana)

Mito e política: variações sobre o tema de Antígona nas recriações de António

Sérgio e de Salvador Espriu

Carlos Morais (Universidade de Aveiro)

El mito de Fedra en la literatura ÁRABe ClÁsica de origen oriental

Celia del Moral (Universidad de Granada)

LA TRAGEDIA DE LA INMIGRACIÓN:

LA POÉTICA TRÁGICA COMO INTERTEXTO PARA LA FORMACIÓN DEL GROTESCO CRIOLLO

Pablo Moro Rodríguez (Univ. Nal. del Centro de la Provincia de Buenos Aires)

“ÉL Y ÉL, UNIDOS POR EL AMOR NEFANDO...”:

Maternidad y travestismo en MEDEA ES UN BUEN CHICO DE Luís Riaza

Hernán Ocantos (IES N² "Mariano Acosta")

El mundo clásico en el teatro de Lope de Vega:

VARIACIONES DEL ABORDAJE A TRAVÉS DE SU MODELO DRAMÁTICO

Mayra Ortiz Rodríguez (Univ. Nacional de Mar del Plata - CONICET

Teseo y las princesas de Creta en Amor es más laberinto

Mónica G. Paladino (Universidad Nacional de Mar del Plata)

El ciclo troyano y las pircas diaguitas en Silencio DE PIEDRA De Guillermo

Montilla Santillán

Liliana Pégolo, Florencia Meardi, Cristian Ramírez, Ulises Romero (Universidad de Buenos Aires)

Las mujeres en Bacantes de Eurípides: ménades de Hades y perras de Lýssa

Cecilia Josefina Perczyk (Universidad de Buenos Aires)

El nuevo Orfeo. La visión de Vinicius de Morales sobre el encantador de almas

María José Pérez (Universidad Nacional de Mar del Plata)

As marcas poeticomusicais de Medeia de Eurípides refletidas em Gota d'ÁGUA de Chico Buarque e Paulo Pontes: Uma visão por meio da retórica

Luísa H. Figueiredo Peixoto (Universidade Federal de Minas Gerais)

Una sorprendente pasión por el tema de Fedra e Hipólito:

Sus cuatro reescrituras por Manuel Lourenzo

Andrés Pociña (Universidad de Granada)

ARS RETÓRICA / ARS TEATRAL Y EL DECORUM COMO FACTOR DE ESCRITURA:

una traducción argentina de Miles Gloriosus para la escena

Aldo Rubén Pricco (Universidad Nacional de Rosario)

Huyendo del insularismo teatral. La pasión según Antígona Pérez

José Luis Ramos Escobar (Universidad de Puerto Rico)

A reconstrução do mito de Orfeu no Carnaval Brasileiro

Ana L. Souza Ribeiro (Universidade Federal de Minas Gerais) 
EL TÉRMINO TRAGICOMEDIA EN EL DRAMA HUMANíSTICO

María Dolores Rincón González (Universidad de Jaén)

Vestigios de Valerio Flaco en El vellocino de oro de Lope de Vega

Antonio Río Torres-Murciano (Universidad de Santiago de Compostela)

Consejeras, instigadoras y Hechiceras:

Similitudes entre el personaje de la nodriza, en el Hipólito de Eurípides y el de

Celestina, en la Celestina de Fernando de Rojas

Ana Cecilia Rivabén (Universidad Nacional de Mar del Plata)

“iNo HABRÁ TRANSUBSTANCIACIÓN NI VÍCTIMA EMISARIA!”

subversión del mito y desencanto en ANTíGONA... ;CERDA! De Luis Riaza

Ezequiel Gustavo Rivas (Universidad de Buenos Aires)

Animalizar lo masculino: penteo en Bacantes de Eurípides

Elsa Rodríguez Cidre (Universidad de Buenos Aires - Conicet)

La filosofía de Séneca en el auto sacramental El gran teatro del mundo de Pedro

Calderón de la Barca

Julio Juan Ruiz (Universidad Nacional de Mar del Plata)

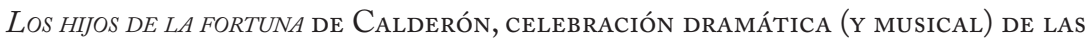

ETIÓPICAS

Ofelia Salgadom (Cambridge)

E os ClÁsSicos SE FIZERAM Um ABSURDo...

Ana C. Fonseca dos Santos (Universidade Federal de Minas Gerais)

Antígona se vuelve plural en la argentina: Antígonas, LINAJE DE HEMBRAS De Jorge Huertas

Susana Scabuzzo (Universidad de Bahía Blanca)

Una Medea portuguesa: Eduarda dionísio, ANTES QUE a NOITE VENHA

Maria de Fátima Silva (Universidad de Coimbra)

El mito de Antígona en Hedor Maldito de Gustavo Casanova.

María Cristina Silventi (Universidad de Cuyo)

Las Comedias de Terencio: Una traducción Para la escena

Marcela A. Suárez (UBA - Conicet), Rómulo Pianacci Adrán (UNMdP), Mariana

Breijo (UBA- Conicet), Violeta Palacios (UBA), Romina L. Vazquez (UBA)

REBELIONES FILIALES MÍTICAS EN EL TEATRO HISPANOAMERICANO CONTEMPORÁNEO

Stéphanie Urdician (Université Blaise Pascal - Clermont-Ferrand)

Mitos y parodia en una comedia burlesca de Calderón de la Barca

Marta Villarino, Graciela Fiadino (Universidad Nacional de Mar del Plata)

Honor y pasión en Fedra de Miguel de Unamuno

Patricia Zapata (Universidad Nacional de la Patagonia Austral)

ÍNDICE DE AUTORES Y DE OBRAS CITADAS 


\section{Presentación}

El libro que tienes en las manos, estimada lectora, estimado lector, es una nueva respuesta a un hermoso proyecto de establecer y propugnar una relación fluída y constante entre quienes nos dedicamos a los estudios de Filología Clásica en España y Portugal y quienes lo hacen al otro lado del Atlántico, en los países de habla española y portuguesa de América. Fue hablando sobre este asunto, sobre la necesidad de hacerle frente a un absurdo aislamiento de muchos siglos que ni tiene sentido alguno, ni nos beneficia en absoluto, durante un almuerzo y descanso en las sesiones de "Actualidad de los clásicos. III Congreso de Filología y Tradición Clásicas Vicentina Antuña in memoriam", celebrado en La Habana, del 8 al 12 de diciembre de 2009, bajo la sabia y amable dirección de la Profesora Elina Miranda Cancela, cuando un reducido grupo de colegas de Argentina, España y Portugal nos planteamos una actividad que estuvo en la base de la gestación de los estudios contenidos en este libro. Se tratataba, pensamos en aquella ocación, de organizar un congreso de tema en cierto modo semejante al que estábamos celebrando en La Habana, esto es, concerniente al mundo clásico grecolatino, pero desde la particular perspectiva de su actualidad y pervivencia hasta nuestros días; para que no resultase uno de esos macro-congresos, tan frecuentes en nuestra especialidad, en los que el hecho de dar cabida a cualquier tipo de tema los convierte en absolutamente inabarcables y poco productivos, decidimos acotar el campo de tratamiento al tema, muy actual sin duda, de la pervivencia del mundo greco romano en el teatro moderno y contemporáneo.

De este modo se gestó "CLASTEA. Congreso Internacional sobre la pervivencia de los modelos clásicos en el teatro iberoamericano, español y portugués", que tendría lugar, efectivamente, tal como acordamos ya en aquella reunión de La Habana, en la bellísima ciudad argentina de Mar del Plata, durante los días 23 al 27 de agosto de 2011. Estábamos presentes en la reunión 
cubana las personas que nos comprometimos a llevarlo a cabo, y que decidimos repartirnos la responsabilidad de la siguiente manera: sería Presidente el Dr. Arq. Rómulo Pianacci Adrán (Univ. de Mar del Plata), Secretaria general la Dra. Mónica Paladino (Univ. de Mar del Plata), Vicepresidenta por España la Dra. Aurora López (Univ. de Granada), Vicepresidenta por Portugal la Dra. Maria de Fátima Silva (Univ. de Coimbra), Coordinador para España el Dr. Andrés Pociña (Univ. de Granada), Coordinadora para Portugal la Dra. Maria do Céu Fialho.

El Congreso tuvo como sede la que fue en un tiempo hermosa residencia veraniega de la universalmente famosa Victoria Ocampo, en la actualidad convertida en el edificio público Centro Cultural Victoria Ocampo. Fueron responsables de la organización del mismo el Grupo Nova Scaena de las Univs. de Mar del Plata y Central de la Provincia de Buenos Aires, la Univ. Nacional de Mar del Plata (Argentina), la Univ. de Granada (España) y la Univ. de Coimbra (Portugal); contó con los auspicios de la Asociación Argentina de Estudios Clásicos, la Secretaría de Cultura de la Municipalidad de Gral. Pueyrredon (Mar del Plata), la Sociedad Española de Estudios Clásicos, el Centro de Estudios Clássicos y Humanísticos de la Universidad de Coimbra, la Asociación Argentina de Teatro Comparado, y la Asociación de Críticos de Teatro. Bajo la Presidencia absolutamente entregada y generosa del Prof. Pianacci, auxiliado en todo momento por la Secretaria Dra. Paladino, trabajaron con toda dedicación en el Comité Ejecutivo las Sras. Cecilia Rivabén, Pamela Flores, Lucía García Almeida y María Cecilia Taborada, todas ellas pertenecientes a la Universidad de Mar del Plata.

Entre las diversas actividades que tuvieron lugar durante los días de sesiones (proyecciones cinematográficas, visitas, excursiones, etc.), ocupó un lugar de especial relieve, tanto por su relación con el tema general del Congreso, como por su original puesta en escena, la representación en el Aula Magna del Complejo Universitario Manuel Belgrano de la comedia La ollita de Plauto, montada expresamente para este acontecimiento y muy acertadamente dirigida por el Dr. Rómulo Pianacci, Presidente del Congreso. Y en la Sesión de clausura, la Vicepresidenta Dra. Aurora López ofreció un recital de canciones, acompañándose ella misma al piano propiedad muy querida de Victoria Ocampo, y estrenando dos composiciones suyas, sobre poemas de la famosa escritora de Mar del Plata María Wernicke, cuya presencia confirió una especial emoción al final de las sesiones del Congreso.

Nuestro volumen ofrece un total de sesenta y cuatro trabajos, todos ellos realmente defendidos por sus autores y autoras en las diferentes sesiones, queriendo quienes fuimos responsables del Congreso señalar que todos ellos corresponden a una misma categoría, a la que se puede dar el nombre de ponencia, comunicación, conferencia..., según se considere oportuno, 
pero siempre teniendo presente que no hubo rango distintivo alguno en su presentación. El número de autores y autoras de esos trabajos ascendió a setenta y dos, correspondiendo sobre todo a centros de Argentina (en número muy superior), y en menor medida, por orden decreciente, de España, de Brasil y de Portugal; completaron la lista representantes de Italia, Cuba, Francia, Puerto Rico y Reino Unido. La variedad de los trabajos que publicamos, que abarca no sólo comediógrafos y tragediógrafos, sino también autores de otros géneros literarios, de la Grecia y la Roma clásicas, y escritores y escritoras, generalemnte teatrales, desde el siglo XVI a nuestros días, en países de ambos lados del Océano Atlántico, ha provocado que nos pareciese prácticamente imposible, a quienes preparamos la edición de estas Actas, someterlos a cualquier tipo de organización, que siempre resultaría muy cuestionable en su validez; en consecuencia, hemos estimado oportuno ordenar la presentación de los trabajos de acuerdo con el apellido de sus autores y autoras.

La revisión de los textos para su publicación ha corrido a cargo de Aurora López, Andrés Pociña y Maria de Fátima Silva, que somos también responsables del título final dado al libro, De ayer a hoy: influencias clásicas en la literatura. Y no quisiéramos finalizar estas breves notas de Presentación sin agradecer profundamente, en nombre propio y en el del conjunto de autores y autoras de los trabajos, a la Profa. Dra. Maria do Céu Fialho, como Coordinadora del Centro de Estudos Clássicos e Humanísticos de la Universidad de Coimbra, el patrocinio generoso de la publicación; por otra parte al Prof. Dr. Delfim F. Leão, como Director de la Imprensa da Universidade de Coimbra, y también como responsable técnico de la colección Classica Digitalia Vniversitatis Conimbrigensis, el haberse hecho cargo de la publicación de este volumen en ambas instituciones de la forma más atenta y generosa. 


\title{
LituRXIA DE TEBAS DE M. Lourenzo. ECONOMÍA DRAMÁTICA Y PUNTO DE VISTA PERSONAL
}

\author{
Ma Teresa Amado Rodríguez \\ Universidad de Santiago de Compostela
}

\begin{abstract}
Manuel Lourenzo es el dramaturgo contemporáneo más importante de Galicia. Fascinado por el teatro grecolatino ha escrito una abundante producción, sustentada por hipotextos de Sófocles, Eurípides y Séneca. Su transformación de los mismos es un ejercicio en el que se combinan actualización y pervivencia de la intemporalidad del mensaje, manejados con la maestría de un gran conocedor de todos los aspectos del hecho teatral, por su condición de actor y director. En este caso abordamos el estudio de su obra Liturxia de Tebas, analizando la dependencia del Edipo Rey sofocleo en el aspecto temático y la transformción del componente espectacular en aras de una economía que facilite la representación.
\end{abstract}

Manuel Lourenzo pertenece a la Generación Abrente, un grupo de hombres de teatro, surgido en torno a la Mostra de Ribadavia, caracterizado por su compromiso político y su empeño en la regeneración cultural de Galicia ${ }^{1}$. Desde sus inicios profesionales demuestra una auténtica fascinación por los mitos ${ }^{2}$, a los que va a recurrir continuamente para la puesta en escena ${ }^{3}$ y para la creación dramática ${ }^{4}$ La recurrencia a Grecia, a través sobre todo de Eurípides, es una

\footnotetext{
${ }^{1}$ Son hombres de teatro en el más amplio sentido, ya que además de escribir participan como actores y directores y ejercen el magisterio dramático. Su conocimiento de todos los aspectos de la actividad teatral y de las necesidades y limitaciones de la puesta en escena condiciona en buena medida su forma de hacer teatro, que tiende a ser minimalista y ceremonial (Fernández Roca 2002: 103). Para los rasgos que definen al grupo vid. Riobó (2000: 76)

${ }^{2}$ Así lo confiesa en la dedicatoria del original mecanografiado de la Traxicomedia do vento de Tebas namorado dunba forca: "Aos mitómanos. Doutro que o é: o autor". El manuscrito se encuentra en la biblioteca de la fundación March de Madrid. La versión impresa se edita, junto con Todos os fillos de Galaad, en Sada (A Coruña), Ediciós do Castro 1981 (Ragué Arias 1991: 40) y no incluye esta dedicatoria.

${ }^{3}$ En 1968 hace la versión gallega y dirigiera el montaje del Prometeo de Esquilo y después de esta primera experiencia con el texto de un dramaturgo de la antigüedad clásica vendrán Ipólito de Eurípides (1973), Edipo Rei de Sófocles (1983), por el que obtuvo el premio Artur Carbonell en el XVI Festival Internacional de Teatre de Sitges 1983 y el premio a la mejor dirección en el I Festival Internacional de Teatro de Ribadavia 1984. Unos años después hace la traducción y dramaturgia de Electra (1994) y Troianas de Eurípides (1997) y Lisistrata de Aristófanes (2003).

${ }^{4}$ Tres son las tendencias en las que se pueden reagrupar los textos dramáticos de Manuel Lourenzo, según Manuel Vieites: ciclo mítico, ciclo histórico y ciclo de la dramática urgente o del teatro inmediato (Ruibal 2000: 25). Su primera obra original basada en los mitos griegos es Romería ás covas do demo, estrenada en 1969. Se trata de una parodia del Hipólito de Eurípides (Fernández Delgado 1996: 74-83).
} 
constante que el autor justifica en estos términos: "Por seguridad y comodidad. Los personajes están hechos, los temas también, sólo hay que buscar el lenguaje preciso. Y, además, puedes tratar cualquier conflicto actual"'s. Efectivamente Lourenzo aprovecha la versatilidad de los mitos clásicos para interpretar la realidad compleja del mundo actual o para reflexionar con puntos de vista nuevos sobre los eternos problemas existenciales del hombre, conjugando actualización e intemporalidad, en una continua renovación de la dimensión simbólica del mito.

Con Liturxia, estrenada en $1994^{6}$, el autor vuelve a la casa de Tebas, de la que ya se había ocupado años antes ${ }^{7}$ y tomando como base Edipo Rey de Sófocles, sitúa la acción en el intervalo cronológico que media entre Edipo Rey y Edipo en Colono, después de la muerte de Yocasta y antes de la partida hacia el destierro. En un momento de distensión, Edipo, que aún es rey pero pronto traspasará la corona a Creonte, en un acto de responsabilidad, necesita justificarse delante de aquéllos que lo recibieron como salvador, lo sentaron en el trono y le dieron a Yocasta por esposa ${ }^{8}$. En esta comparecencia desnuda su alma y cuenta los hechos desde su perpectiva personal, en un discurso, supuestamente de defensa, que en realidad es un monólogo en el que se enfrenta a sí mismo. Si en Sófocles, Edipo más que el personaje central "es la tragedia entera, pues de él parten todos los estímulos y todos llegan a él", en Lourenzo todo desaparece ante su figura, para quedar como en realidad estuvo siempre: existencialmente solo. Siguiendo la tendencia minimalista del momento, un único personaje en un escenario desnudo presenta la historia, con la lucidez aportada por el conocimiento del desenlace, empleando el recurso a la narración que tan bien manejaron los dramaturgos griegos para dar a conocer hechos que no podían o no debían llevar a escena.

${ }^{5}$ Vid. Vieites 2003: 251.

${ }^{6}$ La compañía Elsinor Teatro,a la que pertenecía Lourenzo, la estrena, en julio de 1994, en la sala Galán de Santiago de Compostela, un espacio alternativo que acogió los movimientos de vanguardia y experimentales. Un año más tarde, bajo el título O perfil do crepúsculo, se publica el texto junto con otras dos obras también de tema clásico, Agamenón en Aulide y Os Persas, en los cuadernos editados por la propia compañía (Lourenzo 1995: 1-8). E1 21 de agosto de 2003 el teatro estudio Casahamlet la pone de nuevo en escena en el emblemático auditorio de Sargadelos y posteriormente la lleva por toda Galicia con el propio Lourenzo en el papel de Edipo, por el que obtiene el IV premio de interpretación teatral Maruxa Villanueva en 2004. La pieza aparece publicada de nuevo en los cuadernos Casahamlet (Lourenzo 2004), de donde tomamos todas las citas que aparecen en este trabajo.

${ }^{7}$ En Traxicomedia do vento de Tebas namorado dunha forca trataba el conflicto de Antígona, aunque con referencias que sobrepasaban la trayectoria vital de la heroína (Fernández Delgado 1996: 83-88). La pieza obtuvo el Premio Abrente en la Mostra de teatro de Ribadavia en 1978 y se publicó en 1981 (Lourenzo 1981).

8 "Eu son rei, e como rei reclamo o meu dereito a me xustificar, tras vos ter anunciado a miña abdicación. Eis un favor que me outorgo libremente, como prólogo ao traspaso da coroa desta miña cabeza que non é quen de aturala, á nobre e digna testa de Creonte" (p.40).

${ }^{9}$ Vid. Vara Donado 1988: 337. 


\section{El contenido}

El relato de los hechos va precedido de una especie de proemio de justificación de la comparecencia pública, a la que califica de "liturxia". El pueblo, según sabemos por Sófocles, había acudido ante su rey en actitud suplicante en busca de su intervención salvadora que los librase de la peste. Edipo responde como se espera de él, comprometiéndose a descubrir la raíz del mal y a acabar con el culpable. Ahora, cumplida la promesa, hay que explicar lo ocurrido y es a Creonte en su papel de embajador real a Delfos y como futuro guía de los destinos de Tebas, a quien corresponde esta tarea. Sin embargo, Edipo, en un último acto de grandeza moral y en correspondencia a las espectativas que se habían depositado en él, pide y obtiene de Creonte, el permiso para contar los hechos desde su punto de vista, no con la intención de rebajar el grado de su culpa, sino para evitar una posible justificación de su cuñado, en virtud de los lazos que los unen ${ }^{10}$. Edipo, que siempre pareció ser lo que no era, quiere vaciar su alma ante Tebas y presentarse como lo que es, el asesino de su padre que ha cometido incesto con su madre, sin contemplar como atenuantes las circunstancias que lo llevaron a la situación en la que se encuentra: "Eu matei meu pai e casei con miña nai, e de ambos actos fico responsábel” (p.40). Esa es la única verdad desnuda y objetiva que le interesa al pueblo.

Explicados los motivos y las intenciones de la comparecencia, Edipo empieza a desgranar sus recuerdos y, con una estructura anular que empieza y termina con la mención de la peste, sin seguir un orden cronológico traza una historia cuyos hechos esenciales son los que conocemos a través de Sófocles. Varía, sin embargo, el énfasis que se pone en unos u otros episodios y, sobre todo, cambia la percepción de algunos de ellos al conocer además motivaciones y sentimientos insospechados que movieron al protagonista, ahora mucho más humano.

Igual que la revelación del oráculo impulsa la acción en la tragedia sofoclea, también aquí la evocación de la respuesta délfica pone en marcha el motor de los recuerdos que se centrarán primero en Layo, ya que en su asesinato está la clave de la desgracia. Los hechos son sobradamente conocidos y unas cuantas pinceladas bastan para dibujar la historia de la muerte del antecesor y la subida al trono de Edipo. A Lourenzo le interesa más profundizar en los sentimientos, poco explorados en la tragedia clásica, que nos van a descubrir aspectos desconocidos de nuestro protagonista, obsesionado por la sombra de Layo, objeto de auténtica devoción por parte de la ciudad.

10 "A súa voz amiga (de Creonte) ía propender inxustamente a presentar a miña deformidade como filla de adversas circunstancias, restando iniquidade ao conxunto das miñas accións” (p.40). 
La memoria de Edipo pasa a Corinto y en esta primera evocación de la ciudad de su infancia sólo recuerda el oráculo que le cambió la vida. El horror del vaticinio no le permite regresar y viéndose asesino e incestuoso va sin rumbo en busca de sus orígenes como una "incerteza camiñante". Este sentimiento de inseguridad y duda ya no le abandonará y el deseo de saber que de él emana será en adelante el motor de sus actos. Precisamente en ello se centra su siguiente reflexión.

Edipo dirige ahora sus recuerdos a Tebas para rememorar sus años de reinado y de convivencia con Yocasta, incidiendo en dos puntos esenciales: la actitud opuesta de los cónyuges y la evocación de los tiempos de Layo. La primera se manifiesta en los diálogos de los esposos en su alcoba. En esos momentos de intimidad el espectador descubre la normalidad de lo cotidiano y la cara menos heroica del protagonista. Edipo desnuda su alma y deja al descubierto temores y deseos ante la reina, quien, con la misma actitud que en el episodio tercero de la tragedia de Sófocles (vv.1056ss.), quiere dejar todo como está y aconseja una y otra vez, como quien repite una letanía: "CALA, Cala, Edipo. Non fales, Edipo. Non penses, Edipo" (p.42).

La evocación de los tiempos de Layo, a través de Yocasta, nos traslada a un tiempo ideal, una especie de Edad de Oro caracterizada por los tópicos de belleza y bienestar que la tradición le reconoce: "sempre hai tempos pasados que recordan paraísos” (p.42). Después de su muerte, la Esfinge provoca el cambio y sólo la intervención de Edipo pudo restaurar la situación anterior. Pero la paz exterior no se corresponde con la situación del alma del nuevo rey, siempre inquieto y angustiado por una culpa que no sabe identificar e inmune al consuelo de la reina. Esa desazón no es ocasional, ni imputable a la duda suscitada por el oráculo, sino existencial y congénita, pues acompaña al héroe desde sus primeros recuerdos, cuando no había indicios para desconfiar o temer. Así lo demuestran los siguientes recuerdos que nos trasladan a Corinto, a la soledad de una infancia que tiene como únicos compañeros un caballo de cartón y un perro imaginario, depositario de las primeras dudas del niño. Conocemos su falta de identificación con la ciudad y la permanente inquietud alimentada por comentarios y cuchicheos y por la falta de una explicación convincente para sus pies maltratados. La tranquilidad en la ciudad contrasta con la tormenta interior del personaje también en esta etapa de su vida. Es entonces cuando comienza la búsqueda de su identidad y se convierte en el caminante que estaba destinado a ser.

Edipo vuelve al pasado inmediato y cierra el círculo de sus recuerdos con la evocación de la peste y la declaración de aceptación de un castigo que él mismo decretó para el culpable, cuando ni sospechaba de su identidad: dejará el trono y se irá, volviendo a ser el caminante del principio. 
Las últimas palabras de Edipo constituyen una especie de epílogo en el que, junto a episodios de la historia ya contados, rememora algún otro aún no mencionado. Entre los primeros pone énfasis en los detalles de su acogida en Tebas, organizada, según cuenta, como un ceremonial para honrar a un dios: una procesión encabezada por niños, carros de vírgenes coronadas, ofrecidas como esposas con dotes de inimaginable valor, regalos de bienvenida a sus pies. Es la imagen de la grandeza de Edipo, paralela a la que ofrece el proemio de la tragedia sofoclea, e igual que allí también en Liturxia la escena contrasta con la del hombre derrotado y desposeído de todo, a punto de marchar al exilio. Pero además en esta parte aparecen dos datos nuevos: el suicidio de Yocasta y una breve referencia al papel de Tiresias en el descubrimiento, única huella del intenso diálogo entre el rey y el adivino en el episodio primero de la tragedia griega. Falta en cambio cualquier alusión a la ceguera a la que el mismo Edipo se condena. La obra termina con palabras de bendición del rey al auditorio que lo escucha.

Como podemos ver, el Edipo de Lourenzo da a conocer una versión de la historia que en sus hechos esenciales no difiere de la de Sófocles, aunque escenas que constituían el núcleo de los episodios trágicos, como la discusión de Edipo con Creonte en el episodio segundo o su diálogo con el mensajero en el tercero, se obvian en esta versión, mientras que se desarrollan otros aspectos que en la tragedia o no están o sólo se sugieren, sin que ello implique contradición con el texto clásico, sino ampliación o complementación. Nos referimos a los detalles de la infacia en Corinto, de la relación con Yocasta, del recibimiento de Edipo en Tebas y de las características del reinado de Layo o de sus cualidades personales. Lo más interesante es sin duda la perspectiva nueva que obtenemos de la exposición monológica, pues al ver todo a través de los ojos del protagonista cambia la percepción de los hechos, sin necesidad de alteraciones importantes y, sobre todo, cambia la idea que teníamos del personaje principal, adornado aquí con nuevos rasgos que lo enriquecen y humanizan, como veremos a continuación. Se pierde en cambio la tensión que Sófocles administró tan hábilmente al dosificar la información y la incertidumbre producida por la aportación de cada nuevo dato. Claro que Sófocles pone en escena la fase final del proceso de descubrimiento, mientras que en la versión gallega se ha distendido el clímax y se habla desde la tranquilidad de que todo lo que había de pasar ha pasado ya.

\section{Los personajes}

La mayor novedad de Liturxia está en el tratamiento de los personajes. Han desaparecido prácticamente aquéllos que en la tragedia tienen sólo una vinculación circunstancial con Edipo y por lo tanto sus caracteres no están muy desarrollados, como Tiresias y el mensajero. En los demás casos unas veces 
se pierden matices, pero otras se ganan, ofreciendo una imagen que puede modificar sustancialmente el carácter del personaje.

En sus primeras palabras Edipo se dirige a los dedicatarios del discurso como "señores convidados", tratamiento que mantendrá a lo largo de toda la intervención. La identidad de éstos se puede deducir a partir de algunas pistas que aporta el rey: ellos son los que le ofrecieron el trono de Tebas y a Yocasta como esposa. De su forma de ser y actuar sólo conocemos la rectitud y la justicia de sus actos, que los exculpa de cualquier responsabilidad en la desgracia presente. Estos convidados no son el pueblo, que en esos momentos pide castigo para los culpables ${ }^{11}$, sino un grupo con dignidad superior, que podríamos identificar con esos ancianos, $\chi \omega \omega \rho \alpha \varsigma$ óv $\alpha \kappa \tau \varepsilon \varsigma$, componentes del coro en la tragedia sofoclea. Por su edad unos y otros son conocedores de los sucesos antiguos, por su dignidad responsables del ascenso al trono de Edipo y por ambas cosas destinatarios naturales en esta Liturxia de las explicaciones del rey. Sin embargo hay algunas diferencias en la actitud de ambos colectivos. El coro de la tragedia sofoclea está perfectamente definido y perfilado a través de sus reflexiones que analizan toda la complejidad de los sentimientos humanos. La adhesión a su rey no tiene fisuras y, ni siquiera cuando el trágico desenlace lo deja en una situación tan terrible, el afecto que le profesan no se desmiente ni en una sola frase ni en solo gesto ${ }^{12}$, y es el propio Edipo el que pide el destierro ${ }^{13}$. Con el planteamiento monológico de Liturxia, se pierde todo el lirismo y también la profundidad que aportaban sus reflexiones, pero la ausencia de palabras no impide ver un cambio de actitud hacia su rey en su nueva situación. Si en los momentos de gloria, la adhesión tiene tintes de veneración, tal como se deduce de la descripción que hace Edipo del recibimiento en Tebas, ahora, aunque sin palabras de reproche, su gesto delata la incomodidad que les produce la presencia del rey "Vexo nos vosos ollos alustrar unha ameaza: "vaite, Edipo"' (p.45); Esta nueva actitud se explica no tanto por resentimiento hacia él cuanto por el temor de verse ellos mismos perjudicados por la ira del pueblo: "O pobo, embravecido, armado de desesperanza, asalta as torres onde nos fortificamos. Nós, a grandeza de Tebas" (p.44).

La figura de Creonte se define por los lazos de parentesco y afectividad que le unen a Edipo: "meu cuñado", "meu tío", "voz amiga". Precisamente

11 "O pobo, embravecido, armado de desesperanza, asalta as torres onde nos fortificamos" (p.44).

${ }^{12}$ Vid. Errandonea 1984: 11.

13 "Pero en cuanto a mí jamás esta ciudad patria juzgue adecuado acogerme para que habite en ella vivo. Al contrario, déjame que habite en la montaña, allí donde hay una famosa, la mía, el Citerión, ese que mi madre y mi padre me asignaron en su vida como sepultura definitiva, a fin de que muera a instancias de ellos, los que pretendían matarme" (vv. 1449-1954). Todas las traducciones de Edipo Rey son de Vara Donado (2004). 
por el temor a que esta relación lo predisponga a rebajar culpas y justificar iniquidades, el rey suplica su silencio para ser él mismo quien explique a su pueblo lo ocurrido. Pero la situación trágica, de la que Edipo es causante y víctima, si bien afecta a la ciudad, es fundamentalmente un asunto privado y Creonte, al acoger favorablemente el ruego, acepta la exhibición pública de algo que no debiera traspasar los muros del palacio. Esta actitud contrasta con la del personaje de Sófocles, impaciente por hacer entrar en casa al desdichado rey para evitar que su deshonra quede a la vista de $\operatorname{todos}^{14}$ : No hay por parte de Edipo reticencia alguna hacia él en este momento de distensión dramática, ni referencia a que las hubiera en otro tiempo. Nada queda, o al menos no se manifiesta, de la desconfianza que lo llevó a hacer injustas acusaciones de traición al final del episodio primero ${ }^{15}$, ni de la arrogancia mostrada en la violenta discusión con Creonte a principio del segundo, que provocó la repulsa del coro sorprendido por el inusual comportamiento de su rey ${ }^{16}$. A Edipo no le interesa recordar la imagen errónea del personaje que él construyó en otro tiempo, sino destacar la nobleza y dignidad probada de quien lo va a suceder. En el Creonte que evoca el rey nada hay de reprochable ni sospechoso.

Yocasta es recordada por Edipo en su faceta de esposa y confidente. Es la única que conoce la parte menos heroica del rey, sus debilidades que en la imagen pública no se manifiestan. En la intimidad de las noches compartidas, cuando Edipo se muestra tal como es y confiesa aquello que lo intranquiliza, Yocasta se define por dos rasgos dominantes: simpatía, en el sentido griego del término, y miedo a la verdad. Aún sin entender la tormenta interior por la que pasa el rey, ella comparte su sufrimiento y reacciona con un instinto de protección que la lleva a actuar como madre consoladora con el esposo: "Quixera ser nai túa para aloumiñarte. Dime o que hei de facer para tornarte á calma dos felices días" (p.43). Estas palabras podrían resumir la actitud de la reina en el episodio segundo de la tragedia de Sófocles (vv.707-861), cuando intenta tranquilizar a Edipo respecto a las predicciones del adivino y los oráculos. Pero nuestra Yocasta también está intranquila, porque tiene miedo a la verdad, y su primera reacción es ocultarla: "CALA, Cala, Edipo. Non fales, Edipo. Non penses, Edipo” (42), igual que hace el personaje clásico en el episodio tercero al suplicar al rey que desista de investigar sus orígenes ${ }^{17}$. Por

14 "En fin, introducidlo en casa cuanto antes, pues compete a la familia especialmente la obra piadosa de contemplar las calamidades familiares, y sólo a ella oírlas” (1429-1431).

15 "Creonte ¡el fiel!, ¡el amigo de siempre!, desea expulsarme de ella en secreta intriga" (vv. 385-386).

16 "Que al amigo juramentado jamás lo metas para su deshonor en inculpaciones basado sólo en argumentos indemostrables" (vv. 656-657).

17 “Por los dioses! Si es que te importa algo, por poco que sea, tu propia vida no indagues eso. Bastante hay con que sufre yo" (vv. 1060-1061). 
eso, cuando la evidencia pone la verdad al descubierto, incapaz de aceptarla y enfrentarse a ella, busca en la muerte la salida al problema. No tiene Yocasta, ni en la versión sofoclea ni aquí la grandeza humana de los héroes, sino la actitud de las personas corrientes "que evaden, niegan o buscan ocultar el delito"18.

Dice Aristóteles que Sófocles pintaba a las personas como deben ser y Eurípides como son ${ }^{19}$ y el magistral retrato de Edipo es, sin duda, el mejor ejemplo para ilustrar la primera parte de esta afirmación. La extremada prudencia y bondad hacen de él un modelo de héroe, un personaje moralmente intachable. En la obra de Lourenzo la imagen que los tebanos perciben de su rey probablemente no difiere mucho de la del héroe sofocleo. Lo tienen por salvador, ponen la ciudad a sus pies y. Edipo responde como se espera de él, asumiendo como propios los intereses de sus súbditos ${ }^{20}$. No hay nada en la dimensión pública de nuestro Edipo que pueda merecer reproche y por eso con los años la veneración del pueblo se consolida. Sin embargo esa imagen monolítica se quiebra, no porque la concurrencia de circunstancias adversas pongan en evidencia su fragilidad, sino porque sus palabras, un auténtico flujo de su conciencia, revelan aspectos inconfesables de su personalidad, algunos conocidos o intuídos por Yocasta, pero en cualquier caso pertenecientes al ámbito privado, aunque con repercusión en su actividad pública. Por eso ahora, al presentarse ante el pueblo, no lo hace como rey, sino como ser humano: "é só a testemuña do desastre e non un rei desfiuzado quen reclama a vosa audiencia" (p. 40).

Lo primero que sorprende de nuestro Edipo es la inseguridad, causada por la soledad de su infancia ${ }^{21}$ y por la sensación incomprensible de no sentirse integrado en la que creía su casa y su tierra. Un caballo de cartón, compañero de juegos y confidencias, fue el único alivio para su alma torturada, aunque sólo durante un breve período de tiempo, porque en la vida de Edipo todo es efímero $^{22}$. Las tribulaciones de nuestro personaje empiezan, pues, mucho antes que las del héroe de Sófocles, cuando, aun sin evidencias inquietantes, vive angustiado por recuerdos difusos que no sabe interpretar y por rumores que no puede entender. En la tragedia clásica hay momentos puntuales de desasosiego existencial surgidos de la duda sembrada por los oráculos, pero aquí Edipo es un atormentado permanente. Su inseguridad es consustancial a su carácter,

${ }^{18}$ Vid. Easterling 1990: 337.

${ }^{19}$ Arist. Po. $1460 \mathrm{~b} 33$.

20 "Como rei de Tebas, acumulo na miña vontade as vontades peculiares dos meus súbditos" (p. 40).

21 "Fillo único, falto de irmáns e de amizades do meu tempo, compañeiro, non máis, dalgún paxaro malferido que viñera morrer ao meu refuxio" (p. 43).

22 "A primeira vez que experimentei Corinto, que tiven a sensación de ser de alí foi cando abrín a caixa que meu pai me regalara e admirei, con ollos extasiados, o precioso cabaliño de cartón" (p. 43). 
aunque las circunstancias hayan favorecido su desarrollo, como lo es también el deseo de saber, que brota de ella y que lo echa a los caminos como única forma de dar sosiego a su alma. Este Edipo es un eterno peregrino y su forma natural de vida es vagar por los caminos en busca de su identidad. Sus estancias en Corinto y en Tebas no son más que un paréntesis en lo que constituye la esencia y la razón de su vida, la búsqueda de sí mismo. Por eso habla de sí mismo como "camiñante" o "incerteza camiñante", y todo el discurso teatral gira en torno a su permanente caminar ${ }^{23}$.

Con el tiempo Edipo llega a Tebas y el pueblo construye una imagen de él a partir de su victoria sobre la esfinge: es un héroe de cualidades excepcionales, digno de asumir en la ciudad y en la casa el papel de Layo, pero nada sabe de los miedos y dudas que lo atormentan. Edipo no es lo que parece, o al menos no es sólo lo que parece. Precisamente en su estancia en la ciudad se revela uno de sus aspectos más sorprendentes: la envidia, un vástago más nacido de la inseguridad. Todo ocurre como una cadena trágica, en la que unos sentimientos llevan a otros de manera inevitable. La veneración del pueblo por su antecesor empieza a hacer mella en él y provoca el proceso de su transformación. Primero los recuerdos de los súbditos y los de la propia Yocasta hacen brotar en él la admiración por Layo y despiertan su deseo de saber más, con el fin de aclarar las circunstancias de la muerte y hacer justicia. Pero la omnipresente figura de su antecesor se convierte en obsesión cuando Edipo se empeña en emularlo: "Todo eu me imaxinaba -atributos de home comprendidos- gloriosamente transformado en Laio" (p.41). Entonces, empequeñecido por la figura del antecesor, pierde la confianza en sí mismo y la emulación degenera en envidia y odio por no llegar a ser y al mismo tiempo por dejar de ser él mismo. Ahora tiene un motivo para investigar distinto al que conocemos, que no sustituye, pero sí complementa el tradicional: al interés por aclarar la muerte del rey se une el deseo de encontrar algo en la muerte de Layo que haga desmerecer su figura: "Procuraba un retrato de Laio que me devolvese, por infame, a confianza nos meus propios méritos" (p. 41). La mala conciencia por estos sentimientos hace que Edipo se sienta un miserable y que no encuentre paliativos para sus culpas. Por eso a lo largo de toda su intervención insiste en que hay que hacer un juicio de los hechos en toda su crudeza y la única realidad es que mató a su padre y se casó con su madre.

Hasta ahora el perfil del personaje de Lourenzo quiebra un poco la grandeza moral que caracterizaba al héroe sofocleo, pero su humanidad no se

${ }^{23}$ Cuando Manuel Lourenzo hace el montaje de Edipo Rey de Sófocles en 1983 ya declara lo siguiente: "Sempre pensei que o importante en Edipo é o que pasaba antes de chegar a reinar; quer dicer, o Camiño de Delfos e o Camiño de Tebas: a ruta sen, sen máis" (Ragué Arias 1991: 47). Vid. también Ragué Arias 2006: 98. 
diseña sólo con miserias, sino con rasgos positivos que lo engrandecen. Nos referimos al sentimiento hacia Yocasta. En la versión clásica el matrimonio con la reina va unido al trono, como un elemento más de la recompensa por los servicios a Tebas, sin tener en consideración la existencia o no de amor, sino la conveniencia política. En la versión de Lourenzo los hechos son idénticos. La ciudad le ofrece el trono y a su reina, porque encuentran en él el perfil adecuado para que ocupe el lugar que Layo había dejado vacante. Edipo acepta, pero impulsado por otros motivos que pertenecen al ámbito de lo personal y privado: se ha enamorado de la reina y el deseo de poseerla eclipsa cualquier otra razón y realidad. Ha sido un flechazo fulminante. En el momento en que es recibido con honores propios de un dios, cuando la ciudad pone a sus pies riquezas y a todas sus vírgenes dispuestas para un eventual matrimonio, aparece la reina a recibir al salvador de la ciudad y el mundo se borra para él, quedando sólo ella ${ }^{24}$ Otra vez más, igual que en el caso de la investigación de la muerte de Layo, nos encontramos con que Edipo persigue el mismo objetivo que la ciudad, pero movido por motivos diferentes o complementarios. Por eso, aunque la dimensión pública del personaje de Lourenzo no ha variado sustancialmente, descubrimos unas interioridades que en la tragedia clásica no se sospechan. Sus actuaciones no están regidas sólo por la ley divina, sino por sentimientos, a veces poco edificantes. Ya no es un modelo intachable de virtud, pero a cambio se ha hecho más humano, y por su fragilidad y en sus miserias el público se identifica con él en mayor medida.

Hasta aquí llega nuestro análisis. Una vez más una historia y un personaje milenario, ahora más humano y vulnerable, renace y se actualiza en una nueva demostración de intemporalidad y universalidad.

24 "Cando hai anos me tentábades coas vosas fillas pretendidamente virxes, coa abundancia dos vosos obsequios, houbo un lapso en que deixei de estar alí, convosco. Non entendía as vosas lerias nin sentía as vosas voces. Unha emoción máis grande me asaltaba. Ela paralizou os meus sentidos, mareados polo tintinear das vosas buxigangas. Serena, no esplendor dos pórticos, a Raíña comparece. Ela, muller de carne, mais de carne lustrada por milenios de serenidade aristocrática, miña nai ignorada e impresentida, tórnase, por decisión unánime das miñas partes de varón, en desexo voraz, intransixente" (p. 45). 


\section{Bibliografía}

Amado Rodríguez, Ma T. (2010), "La editorial Galaxia y la traducción de los clásicos grecolatinos en la dictadura franquista”, EClás 138, pp. 73-94.

Easterling, P.E. (1990), “Sófocles”, en P. E. Easterling y B. M. W. Knox (eds.) Historia de la Literatura Clásica. I. Literatura griega, Madrid, Gredos, pp. 327-349

Errandonea, I. (1984), Sófocles. Tragedias. Edipo Rey. Edipo en Colono, Madrid, CSIC.

Fernández Delgado, J. A. (1996), "La tradición griega en el teatro gallego”, EClás 109, pp. 59-89.

Fernández Roca, X.A. (2002), "Se Manuel Lourenzo volvese a Tebas", en Fernández Roca, X. A. / Martínez López, M. J. (edd.) Vir bonus docendi peritus, A Coruña, Universidade, pp. 93-104.

Lourenzo, M. (1981), Traxicomedia do vento de Tebas namorado dunha forca, Sada, Ediciós do Castro.

(1995), O perfil do crepúsculo, Cadernos de Teatro n¹, Oleiros, Elsinor Teatro.

-_ (2004), Liturxia de Tebas. Casahamlet. Revista de Teatro 6, A Coruña, Estudio Teatral Casahamlet, pp. 40-45.

Pérez Rodríguez, L. (1991), "Breve historia do teatro galego na Arxentina”, Cadernos da Escola Dramática Galega 89.

Ragué Arias, Ma J. (1991), Los personajes y temas de la tragedia griega en el teatro gallego contemporáneo, Sada (A Coruna), Ediciós do Castro.

- (2006), "Raíces e memoria do mito no teatro de Manuel Lourenzo", en R. Pascual (ed.), Palabra e acción. A obra de Manuel Lourenzo no sistema teatral galego, Lugo, TrisTram, pp. 93-103.

Rico, G. / Ferreira, I. (2007), Contos troianos, Manuais Casahamlet. Teatro 8, A Coruña, Deputación Provincial.

Riobó, P. P. (2000), O teatro galego contemporáneo 1936-1996, A Coruña, Universidade.

Rodríguez Domínguez, J. P. (1996), "El teatro griego y latino en Galicia a partir de la posguerra”, en A.L. Pujante / K. Gregor (edd.), Teatro clásico en traducción: texto, representación, traducción, Murcia, Universidad, pp. 123-129. 
Ruibal, E. (2000): "Manuel Lourenzo", Gran Enciclopedia Gallega. Apéndice 2000, Tomo 35, pp. 25-26

Vara Donado, J. (1988), “Sófocles”, en A. López Férez (ed.), Ha de la Literatura Griega, Madrid, Cátedra, pp. 312-351.

(2004), Edipo Rey, en Esquilo. Sófocles. Eurípides. Obras completas, Madrid, Cátedra, pp. 325-372.

Vieites, Manuel, F. (2003), “Entrevista con Manuel Lourenzo Premio Nacional de Literatura Dramática", Crónica do teatro galego 1992-2002 (críticas, artigos, estudios, entrevistas, recensións...), Vigo, Universidade, pp. 247255. 


\section{Medeia em seus espelhos}

Sônia Aparecida dos Anjos

Universidade de Coimbra

O objetivo dessa comunicação é analisar três personagens singulares, Medéia, Virgínia e Maria inseridas respectivamente em Medéia, de Eurípides; Anjo Negro, de Nelson Rodrigues; Medea en el espejo, de José Triana. A escolha das peças deve-se, justamente, porque as protagonistas de autores tão distantes no espaço e no tempo possuem em comum o assassinato dos próprios filhos, crime considerado terrível e monstruoso. Analisaremos, sobretudo, a adaptação do mito realizada por Eurípides, e as releituras dos dramaturgos brasileiro e cubano.

O objetivo dessa comunicação é construir uma breve análise em torno do mito de Medeia recuperado na figura de três personagens intrigantes: Medéia, Virgínia e Maria inseridas respectivamente em Medéia, de Eurípides; Anjo Negro, de Nelson Rodrigues; Medea en el espejo, de José Triana.

A escolha do título esboça a metáfora do espelho em seu sentido primordial, ou seja, o espelho nos oferece simultaneamente a imagem do real e o seu duplo. Tal percepção nos possibilita confrontos, desdobramentos e inversões; além disso, os espelhos nos apresentam um caminho para compreendermos a apropriação dos clássicos como matéria-prima para novas criações, demonstrando, assim, que a questão de como ler e adaptar os clássicos ganhou espaço nos estudos literários e culturais.

Enquanto personagem trágica Medeia é resultado da realidade social de seu tempo e das emoções que caracterizam o ser humano. A escolha das peças deve-se, em primeiro lugar, à estrutura que, temática e estruturalmente, mantém convergências com a tragédia grega e, em segundo, porque as três apresentam uma personagem singular: uma mãe que assassina a prole.

Ora, a morte dos filhos pela mãe traz em si um caráter antinatural, que consiste no fato de tanto vítima quanto agente pertencerem à mesma espécie e terem laços consanguíneos. Nesse sentido, nos apropriamos das palavras de Tereza Virgínia Ribeiro Barbosa em tratar dessas mulheres "ferozes" e "vorazes":

Neste ponto, contudo, contradizendo o senso comum, saltam furiosas à nossa mente não só as terríveis e cotidianas notícias de jornal como também todas as velhas e antigas Medeias: a de Eurípides, a de Sêneca, a de Ovídio... lançam-se como cadelas a nos morder ${ }^{1}$.

\footnotetext{
${ }^{1}$ Barbosa, Tereza Virgínia Ribeiro, "Violência na tragédia grega: infanticídios e parricídios”.
} 
Portanto, a figura de Medeia, mulher estrangeira, conceituada em magia e em outros conhecimentos serve de indagação aos sentimentos passionais contrapostos à razão humana. ${ }^{2}$ Assim, mais do que uma história de ciúme, vingança e traição extraconjugal, podemos extrair da história de Medeia um gesto que extrapola os limites da traição: a violência em sua potência, o assassinato dos filhos.

A peça de Eurípides, encenada em 431 a. C., tem início com o abandono de Medeia por Jasão. Ele trai a mulher que, em nome do amor, cometeu uma infinidade de crimes, inclusive contra os próprios familiares para protegê-lo. De tal modo, ela e Jasão foram perseguidos até se refugiarem em Corinto, na corte do rei Creonte. Teriam vivido em paz, mas o rei resolveu casar sua filha com o herói da Tessália. Por ambição e interesse, pensando na linhagem nobre dos futuros filhos, Jasão cede à tentação de desposar a filha do rei ${ }^{3}$.

Vítima de um ultraje, maldizendo sua biologia, Medeia afirma preferir mil vezes o escudo que dar a luz uma só vez. ${ }^{4}$ Debulhada em lágrimas, de face voltada para o chão e entregue ao sofrimento, ela evidencia as características psicológicas mais profundas da alma humana, mas ela precisa encontrar forças para promover a reviravolta.

Ela lança para os filhos um olhar de touro, como se estivesse prestes a fazer algo terrível ${ }^{5}$. Seu gesto oscila entre a ternura e horror, não obstante o ódio e o desejo de vingança são mais fortes do que qualquer outro sentimento. Assim, do texto de Eurípides, selecionamos o relato de Medeia denunciando a difícil tarefa que deveria empreender. Matar os filhos que lhe eram tão caros.

Medéia: Amigas, decidida está minha ação: matar os filhos o mais depressa possível que puder e evadir-me desta terra, não vá acontecer que, ficando eu ociosa, abandone as crianças, para serem mortas por mão mais hostil. É absoluta a necessidade de as matar, e já que é forçoso, matá-la-emos nós, nós que as geramos. Mas vamos, arma-te coração! Porque hesitamos e não executamos os males terríveis, mas necessários? (Erguendo a mão) Anda, ó minha mão, empunha a espada, move-te para a meta dolorosa da vida, não te deixes dominar pela covardia, nem pela lembrança dos teus filhos, de como eles te são caros, de como os geraste. vv. 1236-1246. (...)

Jasão: Eu vim para salvar a vida dos meus filhos, não vão os parentes fazer-lhes alguma coisa para vingar o crime materno.v. 1306 (...)

In.: Nuntius Antiquus. Belo Horizonte, no 5, julho de 2010, p. 132.

2 Cancela, Elina Miranda. "Medea y la voz del otro en el teatro Latino-americano contemporáneo”. Revista La Ventana, no 22/2005, pp. 70-72.

${ }^{3}$ Tradução de Maria Helena da Rocha Pereira.

${ }^{4}$ Cf. Eurípides, Medeia, v. 250-251.

${ }^{5}$ Romilly, Jaqueline, A tragédia grega. Lisboa, Edições 70, 1997.p. 111. 
Coro: Teus filhos estão mortos pela mão de sua mãe. v. 1309. (...) Jasão: Que me concedas dar sepultura a estes cadáveres e chora-los.

Medéia: Isso não, que eu mesma com minhas mãos lhes darei sepultura... vv. 1377-1378.

O coro repudia a atitude de Medeia. Porém, se o crime da feiticeira é resultado de sua ilimitada paixão, o erro de Jasão decorre de seu egoísmo também ilimitado. Quando Jasão recebe a notícia da morte dos filhos entra em desespero, não lhe é concedido o direito de uma última carícia nos filhos e tão pouco o direito de dar-lhes sepultura e chorar sobre os cadáveres. Medeia os sepultará sozinha, fugindo de Corinto no carro do Sol (deus ex machina).

Dramaturgo inquieto, Nelson Rodrigues tinha predileção por personagens que se consideram acima do bem e do mal e que por isso se colocam no plano mítico. Tem-se, então, no plano religioso ou moral protagonistas sórdidos, ensandecidos, monstros que praticavam crimes hediondos sem serem julgados ou punidos ${ }^{6}$; no plano humano, seres divididos, complexos, assolapados em suas bases familiares pelas muitas contingências da vida.

Desta forma, a renovação da dramaturgia brasileira por Nelson Rodrigues se dá através de um retorno a uma tradição mitológica primordialmente registrada na tragédia grega, uma das matrizes do teatro ocidental ${ }^{7}$.

Em Anjo Negro, de 1948, a ação se desenvolve na intimidade do lar. ${ }^{8}$ A ausência de teto desvela uma noite incessante que paira sobre a casa ${ }^{9}$ e que amplia o cosmo teatral, recuperando o espaço aberto do teatro grego, ainda que de forma ficcional. As paredes crescem de um ato para outro, acentuando a atmosfera angustiante, o cenário se configura numa fortaleza inexpugnável, onde as leis da sociedade não podem atingi-la.

Para não deixar dúvidas em relação ao espaço cênico como uma projeção da mente atormentada dos protagonistas, Rodrigues criou uma rubrica poética: "a casa não tem teto para que a noite possa entrar e possuir os moradores. Ao fundo, grandes muros que crescem à medida que aumenta a solidão do negro" ${ }^{10}$.

A peça tem seu início no velório de uma criança, o terceiro filho do casal. $\mathrm{Na}$ cerimônia fúnebre, está presente um coro de mulheres que lamenta a terceira morte consecutiva dos filhos daquela casa. O coro modernizado, formado por dez pretas idosas e descalças, funciona como na tragédia grega, servindo para mostrar ao espectador a opinião de alguém que está fora da trama ${ }^{11}$.

${ }^{6}$ Fraga, Eudinyr, Nelson Rodrigues Expressionista. São Paulo, Ateliê Editorial, 1998, p. 89-91.

${ }^{7}$ Legangneux, Patrícia, Les tragédies grecques sur la scène moderne: Une utopie théâtrale, Louvain, Presses Universitaires Septentrión, 2004, p. 18.

${ }^{8}$ Rodrigues, Nelson, Anjo Negro, Rio de Janeiro, Nova Fronteira, 2005, p. 7.

${ }^{9}$ Facina, Adriana, Santos e Canalhas, Rio de Janeiro, Civilização Brasileira, 2004, p. 111.

${ }^{10}$ Fraga, Eudinyr, Nelson Rodrigues Expressionista, 1998, pp. 89-91.

${ }^{11}$ Rodrigues, Nelson, Anjo Negro, 2005, pp. 7-23. 
As negras comentam que Virgínia não amava o filho porque ele nasceu com a cor do pai; que ela não chorou nenhuma lágrima; que os outros dois filhos do casal morreram com a mesma idade, em circunstâncias igualmente suspeitas. Aparece-nos, portanto, uma questão inevitável: por que estas crianças morrem tão misteriosamente?

A motivação do infanticídio desvela outro crime: o estupro de Virgínia por Ismael. Os filhos negros são a lembrança "viva" dessa violência ${ }^{12}$. A marca do estupro se inscreve no corpo de Virgínia, principalmente na geração de filhos pretos, reflexos do pai.

Ismael: (...) Por que odiaste meus filhos?

Virgínia: (recuando) Não odiei teus filhos.

Ismael: Odiaste. Antes deles nascerem, quando estavam ainda no seu ventre tu já os odiava. Porque eram meus filhos... os odiava. Porque eram meus filhos... (...) E porque eram pretos e se pareciam comigo. Tu mesma disseste - que tinham o meu rosto...

Virgínia: (olhando a fisionomia do marido) Tinham o teu rosto...

Ismael: Eles morreram porque eram pretos...

Virgínia: (com terror) Foi o destino.

Ismael: (contendo-se ainda) Porque eram pretos. (novo tom) Pensas que eu não sei? Virgínia: (recuando, num sopro de voz) Não, Ismael, não!...

Ismael: Que fizeste com meus filhos?

Virgínia: (apavorada) Nada - não fiz nada...

Ismael: Mataste (baixa a voz). Assassinaste. (com violência contida) Não foi o destino: foste tu, foram tuas mãos, estas mãos... (...) Um por um. Este último, o de hoje, tu mesma o levaste, pela mão. Não lhe disseste uma palavra dura, não o assustaste; nunca foste tão doce. Junto do tanque, ainda o beijaste; depois, olhaste em torno. Não me viste, lá em cima, te espiando... Então, rápida e prática - já tinhas matado dois -, tapaste a boca do meu filho, para que ele não gritasse... Só fugiste quando ele não mexia mais no fundo do tanque...

Virgínia: (feroz, acusadora) Então, porque não gritou? Por que não impediu? (...)

Ismael: Não impedi porque teus crimes nos uniam ainda mais; e porque meu desejo é mais depois que te sei assassina - três vezes assassina. Ouviste? (com uma dor maior) Assassina na carne dos meus filhos...

Virgínia: (selvagem) Eu queria livrar minha casa de meninos pretos. Destruir, um por um, até o último. Não queria acariciar um filho preto... ${ }^{13}$.

Ela confessa a negação contra o marido, impedindo que este perpetue sua descendência, pois não quer ver nos filhos a cor e, por conseguinte, o homem

\footnotetext{
${ }^{12}$ Rodrigues, Nelson, Anjo Negro, 2005, pp. 30-35.

${ }^{13}$ Rodrigues, Nelson. Anjo Negro, 2005, pp. 51-53.
} 
que ela rejeitara. Porém, diferentemente das personagens masculinas das outras peças, Jasão e Julián, Ismael é cúmplice do infanticídio. Essa cumplicidade representa metaforicamente o crescimento do desejo do suicídio por Ismael. ${ }^{14}$ Ismael não quer transmitir a sua "cor" a outras gerações. Como ele mesmo não se aceitava, consentia que a esposa matasse uma parte de si.

Ismael tentava se esquecer de tudo que pudesse lembrá-lo de sua afrodescendência, afastando-se de qualquer comportamento que o aproximasse da cultura negra: não ingeria bebida alcóolica, não jogava ou frequentava ambientes suspeitos de malandragem. Ele assimilou os "bons costumes" da elite branca ${ }^{15}$, e desejava se aproximar, no plano aparente, ao branco (nariz afilado, cabelos lisos, lábios finos, cútis clara) ${ }^{16}$, de maneira que a negação de sua ancestralidade pode ser compreendida como uma fuga étnica. ${ }^{17}$ Ainda vivíamos os vestígios da propagação eugenista e a política do branqueamento da nação. De forma que racismo no Brasil manifestava-se pelo branqueamento (físico e psicológico) dos indivíduos bem sucedidos e o enegrecimento ou empardecimento dos fracassados ${ }^{18}$.

Redimensionando nossa pesquisa em torno da violência materna em outro espaço e tempo, apresentamos Medea en el espejo, do dramaturgo cubano José Triana. Triana despontou nos primeiros anos da Revolução Cubana através da fundação do Teatro Nacional. Sua obra em estudo foi levada ao palco em 1960, em pleno triunfo da Revolução ${ }^{19}$ e aborda a cultura, os costumes e os ritos afro-cubanos ${ }^{20}$.

O nome Medeia, por exemplo, aparece no título acompanhado por um elemento dos rituais afro-cubanos utilizado para encontrar uma pessoa desaparecida: o espelho, que também possuía a função de oráculo. ${ }^{21} \mathrm{O}$ uso do espelho obriga Maria a se reconhecer como mulata ao mirar-se nele. A cor da pele, nesse sentido, aparece como estigma, pois Maria transmite informações sobre sua identidade social mesmo contra a própria vontade ${ }^{22}$.

${ }^{14}$ Magaldi, Sábato, Teatro da Obsessão, São Paulo, Global, 2004, p. 60.

${ }^{15}$ Rodrigues, Nelson. Anjo Negro, 2005, pp. 28-29.

${ }^{16}$ Facina, Adriana, Santos e Canalhas, 2004, p. 112.

${ }^{17}$ Martins, Leda Maria, A Cena em Sombras, São Paulo, Perspectiva, 1995, p. 164.

${ }^{18}$ Schwarcz, Lilia Moritz, "Nem preto, nem branco, muito pelo contrário: cor e raça na intimidade". In: Novais, Fernando, História da Vida Privada no Brasil, Vol. IV, São Paulo, Cia das letras, 1998, p. 182.

${ }_{19}$ Miranda Cancela, Elina, "Medea y la voz del otro en el teatro Latino-americano contemporáneo", 2005, p. 73.

${ }^{20}$ Fernández, Carolina Ramos, "Redescubriendo a los mitos griegos desde el continente americano: la Medea mulata de José Triana", The Hebrew University of Jerusalem, Vol. 2, no 1 , Feb/2009, p. 126.

${ }^{21}$ Croguennec-Massol, Gabrielle, "Marginalisation et identité dans Medea en el espejo, de José Triana”, Université Paris-Sorbonne Paris IV, p. 2.

${ }_{22}$ Croguennec-Massol, Gabrielle. "Marginalisation et identité dans Medea en el espejo, de José Triana”, p. 4. 
A grande preciosidade dessa peça encontra-se na abundância de didascálias responsáveis pela caracterização física e psicológica das personagens, bem como aos seus movimentos ${ }^{23}$. O espaço cênico é um solar indicando unidade de espaço. ${ }^{24} \mathrm{~A}$ peça, dividida em três atos, apresenta unidade temporal, começando ao entardecer, atravessando as primeiras sombras da noite até o raiar da aurora. A linguagem vale-se, sobretudo, de expressões de origem iorubá comuns entre as classes sociais mais baixas.

Maria é uma mulata, amante de um branco, que reside no solar compartilhando a vida com outras pessoas igualmente pobres. Submissa ao amante, Julián, ela não aceita e nem conhece outro destino ${ }^{25}$. Porém, enfrenta a grande reviravolta de sua vida ao descobrir que seu amado se casará com outra: uma moça branca, filha do dono do solar onde ela vive: Pierico Piedra Fina ${ }^{26}$. Ao descobrir as intenções de Julián, ${ }^{27}$ Maria decide vingar-se. Ela assassina o futuro sogro e a esposa do ex-amante, envenenando-os ${ }^{28}$.

O aparecimento de dois velhos negros, Madame Pitonisa e o Doutor Mandinga ${ }^{29}$, traz para o palco os ritos da religiosidade afro-cubana. Através da intervenção dos "bruxos", Maria entra em transe, uma forma de mediação direta com os ancestrais ${ }^{30}$.

Os "bruxos" a aconselham a buscar pela luz, possível apenas se ela eliminar Julián de sua vida ${ }^{31}$. Porém, basta ela olhar para os filhos e ver neles o reflexo do amante. Ela não se vê refletida neles, portanto, eliminar o amante é insuficiente, é preciso acabar com o elo máximo entre os dois: os filhos.

María:(...) Es necesario que me levante contra esa María que me arrastra y me humilla. (Se levanta.) (...)Yo soy la otra, la que está en el espejo (...).(Enérgica.) (...) Ahora no tengo miedo. (...) Ahora sé qué soy (Breve riso histérico.) Que soy, que ya no existen ataduras, ni temores, ni humillaciones, porque sólo sabiendo, yo soy yo; que ya no me importan ni el bien ni el mal, que toda esa patraña la he

${ }^{23}$ Ferreira, Luísa de Nazaré, "A permanência do trágico em Medeia ao Espelho, de José Triana", Boletim de Estudos Clássicos, Universidade de Coimbra, Vol. 33, 2000 (Junho), p. 127.

${ }^{24}$ Fernández, Carolina Ramos, "Redescubriendo a los mitos griegos desde el continente americano: la Medea mulata de José Triana”,2009, p.127. Cf.: Prandi, Reginaldo, "O candomblé e o tempo", Revista Brasileira de Ciências Sociais, vol. 16, n. 47, outubro/2001, p. 45.

${ }_{25}$ Miranda Cancela, Elina, "Medea y la voz del otro en el teatro Latino-americano contemporáneo", 2005, p. 74.

${ }^{26}$ Croguennec-Massol, Gabrielle, "Marginalisation et identité dans Medea en el espejo, de José Triana", p. 4.

${ }^{27}$ Triana, José, Medea en el espejo, 1960, p. 108.

${ }^{28}$ Triana, José, Medea en el espejo, 1960, pp. 111-112.

${ }^{29}$ Fernández, Carolina Ramos, "Redescubriendo a los mitos griegos desde el continente americano: la Medea mulata de José Triana”, 2009, pp. 129-130.

${ }^{30}$ Croguennec-Massol, Gabrielle. "Marginalisation et identité dans Medea en el espejo, de José Triana”, p. 4.

${ }^{31}$ Triana, José, Medea en el espejo, 1960, p. 118. 
borrado; ahora soy; que tus brazos, Julián, que tu cuerpo, Julián, son una triste historia; yo que he estado aferrándome a un fantasma, que necesito la vida, sí, la vida: en el horror; en la sangre, en la ternura, en la indiferencia, en el crimen. Sé que necesito la vida, que este cuerpo me empuja hacia la vida, que antes estaba muerta y que ahora soy María, soy yo. (Pausa. Repentinamente ausente.) ¿Dónde están mis hijos? (En un grito.) Erundina. (Pausa. Otro grito.) Señorita Amparo. (Pausa.) ¿Dónde se han metido? (Pausa. Con odio, pero tranquila.) Me vengaré Julián. No podrás detenerme. (...)(Gritando.) Mis hijos. ¿Dónde están mis hijos? (Pausa. Otro tono.) Ahora no es el amor; o quizás, sí; un amor que va más allá de ti y de mí y de las palabras; un amor que exige el sacrificio y el odio; un amor que lo destruye todo para siempre empezar de nuevo. (Pausa larga.) Silencio. Ahí están mis hijos. Que nadie los despierte. Julián ha muerto y ellos seguirán dormidos para siempre. (Hace gesto de silencio.) Mi vida empieza, Julián. Mi vida empieza, hijos míos. María se ha encontrado. (Como si viera aparecer multitud de espejos en el escenario.) Un espejo, ahí. Un espejo, allí. Otro espejo, aquí. Estoy rodeada de espejos y yo también soy un espejo ${ }^{32}$.

Ela deseja aniquilar todas as lembranças de sua vida anterior e se reconhece enquanto corpo, vida e vontade ${ }^{33}$. O espelho também lhe revela uma mulher que carregava nos ombros séculos de estereótipos étnicos negativos. Maria renasce a partir dos inúmeros espelhos que a cercam e a constituem em sua magnitude assassina ${ }^{34}$.

A solução final do conflito de Triana possui inegável relação com a peça de Eurípides. Maria, após o infanticídio, está completamente fora de si se autointitulando a deusa da vingança. O coro, chamando-a de assassina ao som dos tambores, a carrega como um troféu a exemplo do deus ex machina.

Triana critica a sociedade cubana da época, uma sociedade profundamente dividida e estruturada, deixando as áreas menos favoráveis aos que não pertencem a raça branca ${ }^{35}$. Em sua potência máxima, Maria faz renascer uma Medeia para além do ódio e do ciúme, capaz de recuperar suas raízes africanas atrofiadas pelo preconceito de uma sociedade elitista. Em seu movimento espiralar, Maria submerge de sua invisibilidade e se torna uma alegoria de Cuba que renascia após o movimento revolucionário.

${ }^{32}$ Triana, José, Medea en el espejo, 1960, pp.119-121.

${ }^{33}$ Triana, José, Medea en el espejo, 1960, p.118.

${ }^{34}$ Triana, José, Medea en el espejo, 1960, pp.119-121.

35 Fernández, Carolina Ramos, "Redescubriendo a los mitos griegos desde el continente americano: La Medea mulata de José Triana”, 2009, p. 140. 


\section{Bibliografía}

Barbosa, Tereza Virgínia Ribeiro, "Violência na tragédia grega: infanticídios e parricídios”, In: Nuntius Antiquus. Belo Horizonte, no 5, julho de 2010, pp. 141-152.

Croguennec-Massol, Gabrielle, "Marginalisation et identité dans Medea en el espejo de José Triana". In: Université Paris-Sorbonne Paris IV.

Facina, Adriana, Santos e Canalhas, Rio de Janeiro, Civilização Brasileira, 2004.

Fernández, Carolina Ramos, "Redescubriendo a los mitos griegos desde al continente americano: la Medea mulata de Jose Triana", In: The Hebrew University of Jerusalem - vol. 2. no 1. Feb-2009, pp. 126-141.

Ferreira, Luísa de Nazaré, "A permanência do trágico em Medeia ao Espelho, de José Triana", Boletim de Estudos Clássicos, Universidade de Coimbra, Vol. 33, 2000 (Junho), pp. 124-135.

Fraga, Eudinyr, Nelson Rodrigues Expressionista, São Paulo, Ateliê Editorial, 1998.

Legangneux, Patrícia, Les tragédies grecques sur la scène moderne: Une utopie théâtrale, Louvain, Presses Universitaires Septentrión, 2004, p. 18.

Magaldi, Sábato, Teatro da Obsessão, São Paulo, Global, 2004.

Martins, Leda Maria, A Cena em Sombras, São Paulo, Perspectiva, 1995.

Miranda Cancela, María Elina, "Mito y mujeres en el teatro cubano actual", In: Favaretto, Silvia, Narrative e femminili cubane: mito e realtá, Venezia, 2003. pp. 53-73.

,"Medea yla voz del otro en el teatro Latino-americano contemporáneo", Revista La Ventana, no 22/2005, pp. 69-90.

___ ,Entre cubanos: del cara al mundo clasico", Revista Opus Habana, pp. $17-25, \mathrm{~s} / \mathrm{d}$.

___ "Palinodia de Medea en el teatro cubano actual", Universidad de La Habana, pp. 289-296.

Rodrigues, Nelson, Anjo Negro, Rio de Janeiro, Nova Fronteira, 2005.

Romilly, Jaqueline, A tragédia grega, Lisboa, Edições 70, 1997.

Schwarcz, Lilia Moritz, "Nem preto, nem branco, muito pelo contrário: cor e raça na intimidade", In: Novais, Fernando, História da Vida Privada no Brasil, Vol. IV, São Paulo, Cia das letras, 1998.

Triana, José, Medea en el espejo, 1960. 


\section{LA PERVIVENCIA DE LOS CLÁSICOS EN UNA OBRA HISTÓRICA DE LOPE DE VEGA}

Andréa Antunes

Escola Politécnica de Saúde Joaquim Venâncio

La presente investigación tiene como objetivo comprobar la supervivencia de los clásicos en la obra histórica del dramaturgo español Lope de Vega El Principe Perfecto. El rey portugués D. João II es el protagonista de su propio vivir en la obra de este gran dramaturgo. A través de la utilización de los modelos clásicos, y de los aspectos que hacen de este rey un paradigma monárquico son evidenciados porque lo compara a los grandes héroes de la historia universal.

Félix Lope de Vega Carpio es considerado el creador del drama español. $\mathrm{Su}$ producción literaria es excepcional. No solo por la cantidad de obras, sino también por su calidad. Su obra maestra es El arte nuevo de hacer Comedias, donde define y enseña a escribir comedias. Además de la presencia del trágico y del cómico, están presentes en su teatro elementos que resaltan la memoria colectiva del pueblo español. Sus fuentes de inspiración son las leyendas tradicionales y la historia, por lo que sus temas favoritos son los que exaltan este sentimiento nacional (que rescata del pasado las glorias españolas); los de honor (un sentimiento propio de la sociedad española de la época); y el ideal religioso (lo que exalta al maravilloso y al miraculoso).

Los asuntos mitológicos forman parte de un campo de relieve entre los dramaturgos del "Siglo de Oro". Y no podría ser diferente en Lope. Entre sus obras más significativas sobre este tema, podemos subrayar Adonis y Venus - que se basa en el mito de Adonis, al que se agrega el de Atalanta - El Vellocino de Oro - sobre el mito griego que aparece en la historia de Jasón y los Argonautas- y El laberinto de Creta -una lectura del mítico héroe griego Teseo y el Minotauro.

La obra El Principe Perfecto está inserida entre las Comedias Históricas del dramaturgo Lope de Vega, fue puesta en escena, así como la mayor parte de su producción, durante el reinado de Felipe III, cuando Portugal está bajo la corona de España. Este rey pasó a la historia como un "rey débil"1, sin grandes hechos, que abandonó el poder en manos del duque de Lerma, provocando en la gente un sentimiento de desamparo. Fue en esta época que el teatro llegó a su máximo esplendor y la escena dramática fue ofrecida a un público que abarcaba todas las escalas sociales. Momento

\footnotetext{
${ }^{1}$ Díaz-Plaja, Fernando, La Vida y la Época de Felipe III, España, Editorial Planeta, 1997
} 
oportuno poner en relieve un monarca virtuoso y templado, un espejo de reyes.

Como ya mencionado, la obra El Principe Perfecto cuéntanos la historia del rey D. Juan II, nacido en el año de 1455, en Lisboa, hijo de los reyes D. Alfonso y D. Isabel, de Portugal. A través de la réplica de los personajes y por el ingenio del dramaturgo, el carácter de este rey es primorosamente construido. Y muchas son las situaciones teatrales en las que podemos comprobar la pervivencia de los clásicos en esta obra lopesca, principalmente cuanto a la conciliación entre el cristianismo y el paganismo.

Así que, en el primero acto de la obra, el entonces príncipe D. Juan en una lucha mata a un hombre. Pero, esto no causa ninguna mácula a la figura de tan justo y virtuoso príncipe. Por la conducción del dramaturgo este asesinato se convierte en una actitud de heroísmo e ingenio. Comprobamos en la situación teatral $n^{\circ}$, en un diálogo entre los personajes Clara y Esperanza:

(...) ESPERANZA - ¡Qué notable gallardía!

¡Matar uno y herir tres!

CLARA - El es hombre que en Castilla

le tienen por maravilla

del mundo: un Hércules es.

En la batalla de Toro

fue divino su valor...

En fin salió vencedor.

En África tiembla el moro

desde que le vio en Arcila

acometer la muralla. (...)"2

Cuando recurre al mito griego del héroe Hércules, hijo de Zeus y de la mortal Alcmena, símbolo de fuerza y coraje, el dramaturgo ya empieza a desvelar que D. Juan no es un hombre cualquiera, es un ejemplo adonde puso Dios grandezas tales que está más allá de lo que es humano, llega a lo que es celestial.

La "situación" teatral 1 es la más significativa en la obra de Lope, es el "retrato" del rey D. Juan II, ofrecido a los reyes católicos D. Fernando y D. Isabel, a través de la réplica del personaje D. Juan de Sosa, que allí está de embajador. La reina D. Isabel se vuelve curiosa respecto al rey D. Juan II:

REINA. - El hombre que he deseado ver con mayor aficción

${ }^{2}$ Vega, Lope de, El Principe Perfecto, en Obras Escogidas, Teatro, II, Ed. de Federico Carlos Sainz de Robles, Madrid, Aguilar, 1987, p. 1113. 
es vuestro Rey.

D.JUAN. - Si pintado

de mi corta relación

con más verdad que cuidado,

señora, le queréis ver,

podré, haciéndole, correr

la cortina a su retrato ${ }^{3}$.

En este momento, el personaje D. Juan de Sosa empieza la construcción primorosa de la imagen del magnánimo y valeroso rey, donde se mezclan rasgos físicos y morales:

El invicto Rey don Juan

el Segundo, aunque el primero

en el heroico valor,

en el militar esfuerzo,

Rey tercio de Portugal,

desde el Santo Alfonso el Bueno

a quien dio sus mismas llagas

por armas el Rey del cielo,

es hombre proporcionado

de suerte en mediano cuerpo,

con tal rostro e gravedad

que entre mil hombres diversos

le conocerán por Rey;

que luego obliga a respeto"4.

D. Juan de Sosa sigue con sus consideraciones respeto al rey, ahora comparándole al gran paradigma monárquico: el rey Salomón. Leemos:

Desde que volvió su padre, a quien volvió a dar el reino que le había dado en vida, digna hazaña de su pecho, ningún sábado ha dejado de ver los presos y pleitos, que allá relación llamamos, en que parece que vemos un ejemplo de Salomón con divino entendimiento 5 .

\footnotetext{
${ }^{3}$ Ibid, p. 1117.

${ }^{4}$ Ibid, p. 1117.

${ }^{5}$ Ibid, p. 1117.
} 
Salomón fue un rey respetado por todas las religiones. Según los escritos no era una persona común, tampoco un santo, solo tenía una gran sabiduría y estaba muy por delante de los hombres de su tiempo.

Se le conoce como el "rey constructor" porque recibió de su padre, David, la tarea de construir el Templo de Jerusalén, dedicado al Dios de Abraham, donde debería guardarse el Arca de la Alianza con las Tablas de la Ley. Después de la construcción del templo, Salomón lo convirtió en un lugar para el perfeccionamiento de los seres humanos.

Siguiendo con el "retrato", un otro mito clásico es usado como referencia para exaltar a los atributos de este rey:

Es en el dar Alejandro, pero da mejor que el griego;

que él miró la propia fama

y este el ajeno provecho ${ }^{6}$.

La utilización del modelo de Alejandro Magno no es solo debido a la muestra de la generosidad de este emperador, sino también a los proyectos emprendidos por él, que dominaba un área de alrededor de 3,8 millones de kilómetros cuadrados siendo uno de los grandes conquistadores de la humanidad. Fundó más de 80 ciudades, entre ellas Alejandría, considerada la “joya de la corona”. Y además de ser un señor de la guerra, tenía una pasión por la música, la poesía y fue un discípulo de Aristóteles. Ha creado colonias militares para difundir la civilización a los bárbaros, y también se rodeó de eruditos y artistas que difundieron la cultura helénica.

Lo mismo se aplica a D. Juan II, era reverenciado por su ideal expansionista. En su gobierno las exploraciones portuguesas en la costa africana eran prioridades, buscando llegar hasta la India. Además de muchos otros logros, como por ejemplo el inicio de la colonización de las islas Santo Tomé y Príncipe. Y era igualmente admirado por sus modales elegantes y refinados.

Sigue D. Juan de Sosa con la caracterización del rey. Habla de las cosas de placer de D. Juan II haciendo una comparación al gran rey persa Ciro:

\footnotetext{
Son sus entretenimientos músicas, toros y danzas, ver luchar fuertes mancebos y ejercitar varias armas... Pero vanamente emprendo no siendo yo Jenofonte,
}

${ }^{6}$ Ibid, p. 1117. 
pintaros con rudo ingenio

$\tan$ nuevo cristiano Ciro; ${ }^{7}$

Cuéntanos la historia que Ciro, este gran conquistador, también legisló, así como D. Juan II, según preceptos divinos. Es lo que comprobamos con el siguiente pasaje bíblico:

"Ciro, rei da Pérsia, decreta: Javé, o Deus do céu, entregou a mim todos os reinos do mundo. Ele me encarregou de construir para ele um Templo em Jerusalém, na terra de Judá. Todos os que pertencem a esse povo e vivem entre nós, podem voltar para lá. E que Javé, seu Deus, esteja com eles"8.

Y con los últimos versos a los reyes católicos la imagen del rey es edificada y empleada como ejemplaridad por el dramaturgo:

porque tengo por muy cierto

que para ejemplo de reyes

hizo este Príncipe el cielo?

La capacidad y el ingenio de este dramaturgo a través de las réplicas de sus personajes, desvela a nosotros su erudición y competencia para utilizar referencias clásicas en sus obras. Esto señala la pervivencia de estos modelos en el teatro español del siglo XVII. Es decir, Lope de Vega supo enlazar los temas barrocos con los clásicos, lo que confirió a sus comedias un carácter propio, un carácter transformador.

\footnotetext{
${ }^{7}$ Ibid, p. 1117.

${ }^{8}$ (Crónicas 36:23) In A Bíblia Sagrada., Op. Cit. P.498

${ }^{9}$ Ibid, p. 1117.
} 


\section{Bibliografía}

Delerue, Maria Luisa - Oliveira, Maria Manuela, D. João II: Um Rei Emblemático, Lisboa, Grupo de Trabalho do Ministério da Educação para as Comemorações dos Descobrimentos Portugueses, 2000.

Díaz-Plaja, Fernando, La Vida y la Época de Felipe III, España, Editorial Planeta, 1997.

García, José Manuel, Breve Panorama Bio-bibliográficosobre D. João II, Comissão Nacional para as Comemorações dos Descobrimentos Portugueses, Lisboa, 1999.

Guinsburg,J. - Coelho Netto, José Teixeira - Cardoso, Reni Chaves, Semiologia do Teatro, São Paulo, Perspectiva, 1988.

Le Goff, Jacques, Uma Vida para a História: conversações com Marc Hergoun, Editora UNESP, 1994.

—_, O Imaginário Medieval, Editorial Estampa, 1994.

___ Para um Novo Conceito de Idade Média, Editorial Estampa, 1979.

—_ São Luis, tradução de Marcos de Castro, Rio de Janeiro, Record, 1999.

Moises, Massaud, A Literatura Portuguesa Através dos Textos, São Paulo, 14a edição, Editora Cutrix, 1985.

Pina, Rui de, Crónicas, Porto, Lello \& Irmãos - Editores, 1977.

Resende, Garcia de, Crônica de D. João II e Miscelânea, Lisboa, Imprensa Nacional - Casa da Moeda, 1973.

Rodrigues, Maria Idalina Resina, De Gil Vicente a Lope de Vega: Vozes Cruzadas no Teatro Ibérico, Lisboa, Editorial Teorema Ltda, 1999.

Serrão, Joaquim Veríssimo, História de Portugal, Volume I: Estado, Pátria e Nação (1080-1415), 2. a ed., Lisboa, Verbo, 1978.

Vega, Lope de, El Principe Perfecto, en Obras Escogidas, Teatro, II, Ed. de Federico Carlos Sainz de Robles, Madrid, Aguilar, 1987.

__ _ El Príncipe Perfecto, en Obras Escogidas, Tomo II - Poesía, Lírica, Poema, Prosa, Novelas, Ed. de Federico Carlos Sainz de Robles, Madrid, Aguilar, 1953.

- El Mejor Mozo de España in Obras Escogidas, Teatro, Tomo III. Madrid, Ed. Aguilar, 1987. 
Peres, Lygia Vianna, A Tecedora de Espanha ou O Sonho da Infanta: Leitura de El Mejor Mozo de España de Lope de Vega, in Arrabaldes, Cadernos de História, série I, Cultura e Imaginário no Ocidente Medieval, Org. Fróes, Vânia Leite. Niteroi, ICHF/UFF, 1996.

—_- La Historia en el Teatro, el Teatro de la Historia. La tradición emblemática y la representación de algunos reyes peninsulares en obras del "Siglo de Oro", In "Actas del V Congreso de la Asociación Internacional Siglo de Oro", Münster, Iberoamericana Vervuert, 1999.

http://www.ricardocosta.com/

http:// www.artehistoria.com/historia/personajes 


\title{
El discurso de las mujeres del $A$ Gamenón de Séneca
}

\author{
Carmen Arias Abellán \\ Universidad de Sevilla
}

\begin{abstract}
El análisis del plano del léxico como instrumento de indagación literaria me ha permitido, en un conjunto de trabajos previos sobre el teatro de Séneca, avanzar en cuestiones no afinadas hasta ahora suficientemente por la crítica literaria tradicional. Partiendo de este principio metodológico, la investigación que propongo intenta, como indica su propio título, analizar los personajes femeninos del Agamenón a partir de una "escucha pormenorizada" y de una "indagación exhaustiva" de sus palabras, alcanzando así una caracterización del tratamiento peculiar senecano de dichos personajes y de su "distintividad" respecto a los originales griegos y respecto a las sendas de evolución posteriores a Séneca.
\end{abstract}

Uno de mis ejes de investigación preferentes consiste en la caracterización de los personajes (y de los temas) de las tragedias de Séneca a partir del análisis del vocabulario, o, dicho en otros términos, en el examen del trazado dramático en el nivel de la palabra.

Y es que, según mi criterio, y sobre todo en campos como el de la tragedia, es la escucha atenta del discurso de los personajes, especialmente el que emplean ellos sobre sí mismos, pero también el referido a un personaje concreto por otro personaje, la que nos puede trazar -de modo más contundente y "afinado" que el puro examen literario- el retrato de su singularidad subjetiva, sus tomas de posición respecto al núcleo trágico y respecto a los demás actores.

Esta especificidad subjetiva de los actores sería, además, la que, al partir de las entrañas de los mismos, marcaría la conformación del fondo temático de la tragedia de un modo mucho más determinante que otros factores, comúnmente señalados, pero advenidos "desde fuera", como el destino, la repetición de crímenes y venganzas a lo largo de las generaciones, la fortuna, el poder, etc.

El prisma de la "posición", de las "elecciones" de los datos de la realidad hechas por los personajes, posición y elecciones que obedecerían básicamente a su interioridad subjetiva, va a ser, por tanto, el que ocupe mi mirada en este trabajo.

El estudio de la subjetividad -objeto de la Medicina y de la Psicologíareconoce como parte esencial de la misma la dualidad (pulsional) de "vida" / "muerte" (o de "amor / "odio") ${ }^{1}$, que se conecta respectivamente en el primer

${ }^{1}$ Este principio doctrinal de S. Freud ha sido explicado de un modo muy claro por D. Lagache: "Le pulsioni di vita o eros avviluppano nel medesimo nucleo l'opposizione della conservazione 
caso ("vida" / "amor") con procesos que significan (en el trato que tiene el ser consigo mismo, con la realidad y con los demás) apego, búsqueda del otro, compromiso, etc.; y en el segundo caso ("muerte" / "odio"), con procesos de no vinculación, separación del otro, destrucción, agresividad, etc. ${ }^{2}$.

Contando con esta dualidad (que se manifiesta según cada personalidad con equilibrio de sus dos polos, o con predominio de uno sobre el otro) puede trazarse el dibujo de la especificidad subjetiva de los personajes, plano del que paso a ocuparme centrándome -según lo señalado en el título- en las protagonistas femeninas del Agamenón.

II. El cuadro femenino de esta tragedia lo conforman dos figuras centrales, Casandra y Clitemestra, y dos más colaterales, Electra y la nodriza.

Dadas las limitaciones espaciales y temporales de esta ponencia, haré un recorrido más sucinto por las dos últimas figuras, Electra y la nodriza, deteniéndome en las dos mujeres básicas de la obra, Casandra y Clitemestra.

III. Las actuaciones de Electra y la nodriza se orientan a la salvaguarda de la vida y trazan, por tanto, un dibujo de las mismas ubicado en esta posición vital. Electra, hija de Agamenón y Clitemestra, se ocupa esencialmente de salvar la vida de su hermano Orestes (amenazado por Egisto y Clitemestra, a los que terminará matando vengando así a su padre Agamenón); la nodriza, por su parte, intenta apuntalar la posición vacilante e insegura que, como vamos a ver, caracteriza a su reina (Clitemestra), intentando inclinarla, en todos sus consejos, hacia el vínculo conyugal, hacia la evitación del asesinato de Agamenón y hacia el triunfo, por tanto, del compromiso y de la vida.

IV. Frente a estas dos figuras positivas, Casandra se sitúa en el espacio negativo de la autodestrucción y de la muerte.

Ya a primera vista, llama la atención en este personaje la magnificación del dolor, de la adversidad, cuestión que -además de en sus intervenciones más detenidas, que analizaremos posteriormente- se palpa en la repetición machacona de estos contenidos en el nivel léxico, actualizados sobre todo en el plano sustantivo, de los que recogemos algunos ejemplos a título de ilustración:

aerumnae meae (661)

cladibus meis (662)

nostris malis (663)

di sé e della conservazione della specie... lo scopo consiste nel "legame" (Bindung), ossia nel fatto di satabilire delle unità sempre più vaste e destinate quindi a persistere. Le pulsioni di morte tendono allo sgretolamento dell'insieme, poiché l'ultimo approdo di ogni essere vivente è il ritorno all 'inorganico" (D. Lagache, La Psicanalisi, Milano 1999, 27 [traducción de La Psychanalyse, Presses Universitaires de France, Paris, 1996]).

${ }^{2}$ Procesos que se engarzan, de manera evidente, con la motivación primera de "conservación" / "destrucción" recogida en la nota anterior (cf. P. Bofill - J. L. Tizón, Qué es el Psicoanálisis, Barcelona, Herder, 1994, 90 ss.). 
tantas ruinas (669)

nostra mala (695), etc.

Esta magnificación del sufrimiento -a través de estos lexemas concretosse inserta en la postura mortífera de Casandra, postura que se dibuja más claramente a partir del examen del total de su discurso en la obra, trazándonos tres rasgos esenciales de su "subjetividad": IV.1) su incapacidad para establecer vínculos; IV.2) su abulia o estatismo; IV.3) su relación "gozosa" con la muerte.

IV.1. Aunque quepa ver en ellas cierta búsqueda de privacidad y autonomía (estoica) en su duelo, son esencialmente palabras de absoluta "desvinculación" -y con ello examinamos la primera característica de Casandra- las que les dirige al coro de troyanas cuando éste llora la caída de su ciudad e intenta aliviarla compartiendo con ella el dolor por el fallecimiento de su padre y recordándole que sólo la trampa engañosa del caballo hizo posible la destrucción de Troya (CHO. 664 y 666: Lacrimas lacrimis miscere iunat.../ iunat in medium deflere suos $^{3}$ : "Lágrimas con lágrimas mezclar agrada... agrada llorar en compañía a los suyos"):

CA. Cohibete lacrimas...

... et ipsae uestra lamentabili

lugete gemitu funera: aerumnae meae

socium recusant. Cladibus questus meis

remouete. Nostris ipsa sufficiam malis (659-663)

("Contened las lágrimas... y lamentad vosotras mismas vuestras muertes con gemidos de duelo: mis miserias no admiten alianza. Evitad las quejas por mis infortunios: yo sola me bastaré para mis males").

IV.2. La "inmovilidad" ante su dolorosa historia (proyectada en un anclaje a su pasado y, con ello, en una apatía y aniquilación de su vida actual) constituye la segunda marca de Casandra. Su diálogo con Agamenón, cuando éste intenta atraerla a la realidad presente, muestra nítidamente esta actitud:

AG. Festus dies est. CA. Festus et Troiae fuit (791):

(AG. "Es un día de fiesta". CA. "También fue un día de fiesta para Troya").

AG. Veneremur aras. CA. Cecidit ante aras pater

(AG. "Veneremos los altares". CA. "Mi padre cayó delante del altar").

AG. Ionem precemur pariter. CA. Herceum Ionem? (793)

(AG. “Imploremos juntos a Júpiter”. CA. “¿A Júpiter Herceo?”).

AG. Credis uidere te Ilium? CA. Et Priamum simul (794)

${ }^{3}$ En todos los textos siguientes del Agamenón sigo la edición y traducción de B. Segura Ramos (cf. La tragedia de Agamenón, rey de Micenas, Sevilla, 2008, 26-91). 
(AG. “¿Crees que es Ilión lo que ves?”. CA. "Y a Príamo a un tiempo”).

AG. Hic Troia non est. CA. Vbi Helena est, Troiam puto (795)

(AG. "Aquí no está Troya”. CA. "Donde está Helena, creo que es Troya”), diálogo que tiene un punto culminante en su valoración final positiva de la muerte:

AG. Secura uiue. CA. Mibi mori est securitas (797)

(AG. "Vive sin preocupaciones". CA. "Para mí morir es la ausencia de todas las preocupaciones").

IV.3. El reflejo de este texto, su valoración positiva de la muerte, conforma el último rasgo definitorio de Casandra.

La princesa expresa de nuevo dicho aprecio cuando vaticina el final de Agamenón y el suyo propio ${ }^{4}$ :

CA. ... Iuuat per ipsos ingredi Stygios lacus, iunat uidere Tartari saeuum canem

auidique regna Ditis! Haec hodie ratis

Phlegethontis atri regias animas uehet, uictamque uictricemque (750-754).

("Me gusta caminar por los mismos lagos de la Éstige, me gusta ver el cruel perro del Tártaro y el reino del avaricioso Dite. Hoy esta barca del oscuro Flegetonte transportará ánimas regias, la vencida ${ }^{5}$ y la vencedora”6),

y lo vuelve a repetir cuando, una vez asesinado el rey, va a morir a ella misma por orden de Clitemestra ${ }^{7}$ :

CA. Ne trabite, uestros ipsa praecedam gradus.

Perferre prima nuntium Phrygibus meis

propero: repletum ratibus euersis mare,

captas Mycenas, mille ductorem ducum,

ut paria fata Troicis lueret malis,

perisse dono, feminae stupro, dolo.

Nibil moramur, rapite: quin grates ago:

Iam, iam iuuat uixisse post Troiam, iuuat (1004-1011)

("No me arrastréis, yo misma caminaré delante de vosotros. Me apresuro para ser la primera en llevar las noticias a mis frigios: el mar está repleto de barcos

${ }^{4}$ También anunciará antes de morir el final de Clitemestra y Egisto a manos de Orestes, el hijo de Clitemestra y Agamenón, que vengará con ello a su padre: Veniet et uobis furor (1012).

${ }^{5}$ La propia Casandra.

${ }^{6}$ Agamenón.

${ }^{7}$ Cly. At ista poenas capite persoluet suo / captiua coniunx, regii paelex tori: / trabite ut sequatur coniugem ereptum mibi (1001-1003): "Esa, en cambio, pagará con su cabeza el castigo, la esposa cautiva, mi rival en el real lecho: arrastradla para que acompañe al esposo que me ha arrebatado”. 
hundidos; Micenas, tomada; el comandante de mil jefes ${ }^{8}$-para pagar con un destino idéntico los desastres de Troya- muerto por un presente, por el adulterio de su mujer, por engaño. No me opongo en absoluto, arrastradme; al revés, os doy las gracias: ahora, ahora me agrada haber sobrevivido a Troya, sí, me agrada").

En estos dos textos se percibe nítidamente su posición interior de "gozo por la muerte y el sufrimiento" (la "Lust am Tode" y la "Leidenswollust" de Lefèvre ${ }^{10}$ ): CA.... Iunat per ipsos ingredi Stygios lacus, / iunat uidere Tartari saeuum canem/ auidique regna Ditis. (750-752): "Me gusta caminar por los mismos lagos de la Éstige, me gusta ver el cruel perro del Tártaro y el reino del avaricioso Dite"; CA. Ne trahite: uestros ipsa praecedam gradus.../ Nibil moramur $(1004 ; 1010)$ "No me arrastréis: yo misma caminaré delante de vosotros... No me opongo en absoluto").

Hay diversas causas objetivas para este gozo: la cancelación definitiva de los problemas que la muerte le traería consigo ${ }^{11}$, el anhelo por ver de nuevo a los suyos y notificarles la destrucción de la flota griega (a su regreso de Troya), la toma de Micenas por un nuevo poder ${ }^{12}$ y la muerte de Agamenón. En todos estos hechos (destrucción de la flota griega, la conquista de Micenas y el final de Agamenón) interpreta Casandra una situación paralela a la sufrida por Troya ("el mar está repleto de barcos hundidos; Micenas, tomada; el comandante de mil jefes ${ }^{13}$ - para pagar con un destino idéntico los desastres de Troya- muerto"..., 1006-1009) y una equiparación final -tema tan euripídeo- de vencedores y vencidos (“... los frigios, vencidos, hemos vencido. Bien está; te levantas, Troya. Has arrastrado al caer junto a ti a Micenas, tu vencedor vuelve la espalda”, 869871), aspectos los dos que constituyen una base importantísima de reparación para ella y su familia (y de ahí su urgencia por notificárselo).

Su desgana de la vida, su deseo de morir se ubica, sin embargo, en el plano, previo a cualquier circunstancia, que es su "esencia interior"; desde esta esencia -llena de gozo por el dolor y la autodestrucción ${ }^{14}$ - Casandra ha elegido -en lugar de la aminoración de las adversidades de la vida, apostando así por dicha vida- el protagonismo de estas adversidades -tan actualizado, según hemos visto ya, en el léxico-, haciendo así una jugada de cesión a la muerte ${ }^{15}$.

${ }^{8}$ Agamenón.

${ }^{9}$ Cf. E. Lefèvre, "Schicksal und Selbstverschuldung in Senecas Agamemnon”, Hermes, 94, 1966, 488.

${ }^{10}$ Cf. E. Lefevre, "Die Schuld des Agamemnon. Das Schicksal des Troja-Siegers in stoicher Sicht”, Hermes, 101, 1973, 89.

${ }^{11} \mathrm{Cf}$. nota 15.

${ }^{12}$ Egisto.

${ }_{13}^{13}$ Agamenón.

${ }^{14}$ Cf. notas 9, 10, y 15.

${ }^{15}$ Ya hemos visto en las notas 9 y 10 que Lefèvre se sitúa en este mismo planteamiento 
Al inicio del estudio de esta figura anunciábamos su ubicación mortífera, su pulsión de muerte, pulsión que se ha visto confirmada a través de sus tres peculiaridades analizadas: aislamiento, desistimiento en la superación de su desgraciado destino y voluntad de dejar la existencia.

V. El personaje de Clitemestra se ubica entre estas dos posiciones de vida (Electra y Nodriza) y de muerte (Casandra).

Son diversos los factores condicionantes de su comportamiento con Agamenón: el más importante quizá, el sacrificio por parte de éste de su hija Ifigenia ${ }^{16}$, pero también su larga ausencia con motivo de la guerra de Troya ${ }^{17}$, sus amoríos ${ }^{18}$, con el último de los cuales, Casandra, regresa, como ya hemos visto, a la patria ${ }^{19}$, las posibles consecuencias de esta relación con la princesa troyana sobre sus hijos y sobre el poder de Micenas ${ }^{20}$, e, incluso, el propio sentimiento de culpa de Clitemestra por su infidelidad a Agamenón mediante su relación con Egisto ${ }^{21}$.

Dichos factores no son, sin embargo, la clave determinante de sus actuaciones, quedando relegados a un segundo plano respecto a su problemática

al destacar en la esencia de Casandra las dos posiciones básicas de "Lust am Tode" ("gozo en la muerte") y de "Leidenswollust" ("gozo total en el sufrimiento"). Esta elección subjetiva de Casandra, de búsqueda de la muerte frente a la vida, señalada abiertamente por ella en el verso 797 -mibi mori est securitas-, encuentra un eco -aunque sacada del ámbito de la subjetividad y transferida a un plano más general y filosófico- en el pensamiento estoico de la mors libera, pensamiento expuesto ampliamente por el coro de troyanas en los versos 589-610 de esta obra.

${ }^{16}$ Cly. ... iugales filiae memini faces / et generum Achillem (158-159): “... me acuerdo de la antorcha nupcial de mi hija, así como de Aquiles, mi yerno” (se refiere Clitemestra a la conducta de Agamenón, que reclama a su esposa y a su hija Ifigenia con la excusa de casar a ésta con Aquiles, cuando lo que hace en realidad es sacrificarla a Artemis para facilitar el curso de la flota griega).

${ }^{17}$ Cly. Decem per annos uidua respiciam uirum? (156).

${ }^{18}$ Cly. amore captae captus (175)"cautivado por el amor de una cautiva", ardore sacrae uirginis iam tum furens (177): "enloquecido ya entonces por la pasión de una virgen sagrada", inter ruentis Graeciae stragem ultimam / sine hoste uictus marcet et Veneri uacat / reparatque amores... (182-184): "En medio de los estragos postreros de Grecia derrumbándose, vencido sin enemigo, se deja embotar y dedica su tiempo a Venus, y encadena amoríos".

${ }^{19} \mathrm{Cly}$. Nunc noum uulnus gerens / amore Phrygiae uatis incensus furit, / et post tropaea Troica ac uersum Ilium / captae maritus remeat et Priami gener (188-191): "Ahora, portando una nueva herida, anda loco, abrasado por el amor de la pitonisa frigia, y tras los trofeos de Troya y la destrucción de Ilión, retorna marido de una cautiva y yerno de Príamo".

${ }^{20}$ Cly. Pigra, quem expectas diem? / Pelopia Phrygiae sceptra dum teneant nurus? / An te morantur uirgines uiduae domi / patrique Orestes similis? Horum te mala / uentura moueant, turbo quis rerum imminet: / quid, misera, cessas? En adest natis tuis / furens nouerca (193-199): "perezosa, ¿qué día aguardas? ¿Hasta que nueras frigias empuñen el cetro de los Pelópidas?... conmuévante los males venideros... he aquí que llega una madrastra enfuercida para tus hijos"

${ }^{21} \mathrm{Cly}$. Licuit pudicos coniugis quondam toros / et sceptra casta uidua tutari fide; / periere mores, ius, decus, pietas, fides, / et qui redire cum perit nescit pudor (110-113): "Otrora me cupo guardar con casta fidelidad el lecho pudoroso de esposa y el cetro privado de dueño. Han muerto las costumbres, la justicia, el decoro, la devoción, la fe y el pudor, que, cuando se pierde, no sabe volver" (cf. igualmente, vv. 116-124 y 134-138). 
fundamental, que no reside en el exterior, sino en su subjetividad, una subjetividad perdida y errática, que actualizan claramente adjetivos y procesos verbales referidos a su persona, de entre los que entresacamos, a título de modelo, los siguientes:

impos sui: "no dueña de sî"(117);

consilii impotens: "incapacitada para una decisión" (126);

animus errat: "su alma anda extraviada" (144), etc.

Es esta "ambivalencia" que habita su "interioridad" la que motiva su indecisión entre el asesinato de Agamenón (muerte) y el vínculo con el compromiso de su matrimonio (vida).

Dicha ambivalencia -de cuya caracterización léxica acabamos de ver unas cuantas muestras- se vierte con toda contundencia en sus siguientes reflexiones ante la nodriza:

\section{CLY....Fluctibus uariis agor}

ut, cum binc profundum uentus, hinc aestus rapit,

incerta dubitat unda cui cedat malo (138-140)

("Me impulsan oleajes encontrados, como, cuando el viento por aquí, por allí la marea arrastra las profundidades, la ola desorientada duda a qué mal ceder")

CLY. Proinde omisi regimen e manibus meis:

quocumque me ira, quo dolor, quo spes feret, hoc ire pergam (141-143)

("En consecuencia, he dejado escapar el timón de mis manos: doquiera me lleve la cólera, doquiera, el dolor, la esperanza, por ahí echaré a caminar”) ${ }^{22}$,

y ésta, la nodriza, capta la raíz psicológica de la situación, advirtiéndole que la resuelva allí, en su psiquismo, domesticando su agresividad y pacificando sus contradicciones:

NVT. ... comprime affectus truces

mentemque tibimet ipsa pacifica tuam (224-225)

("reprime tus terribles sentimientos y pon tu mente en paz contigo misma").

Pero dada la irresoluble vacilación interior de la reina, sus contradicciones podrán ser desanudadas sólo por otra persona, por Egisto, quien, llevado por

${ }^{22}$ Cf. en la misma línea: Cly. mixtus dolori subdidit stimulos timor (133): "mezclado al dolor, el temor le ha prestado a él estímulos"; Cly. ... hinc animum iugo / premit cupido turpis et uinci uetat; / et inter istas mentis obsessae faces, / fessus quidem et deuictus et pessumdatus, / pudor rebellat (134-138): “... de un 
el afán de venganza y por el deseo de poder ${ }^{23}$, hará inclinarse la personalidad oscilante de Clitemestra hacia el lado destructivo ${ }^{24}$, con el asesinato final de Agamenón.

V. Este recorrido por los personajes femeninos del Agamenón desde las claves de su singularidad, para la que he tomado como criterio definidor la organización -deducida de sus propias palabras- de los componentes "amor" / "odio" (o "vida" / "muerte") en su estructura psíquica, nos permite resaltar, en el momento de las conclusiones, la actitud vital de Electra y la nodriza, el abandono en la muerte de Casandra, y la ambivalencia entre estas dos pulsiones de Clitemestra.

${ }^{23}$ Quiere vengar a su padre Tiestes (expulsado de Micenas por su hermano Atreo) y recuperar el reino de Micenas, fines para los que debe impedir a toda costa la posibilidad de que Clitemestra perdone a Agamenón (hijo de Atreo) y la posibilidad, con ello, de que éste siga con vida y manteniendo el poder de Micenas.

${ }^{24}$ No sin las vacilaciones previas que ella -de acuerdo con su perenne duda entre la muerte y la vida- muestra: cf. Cly. Amor iugalis uincit...: / remeemus illuc unde non decuit prius / abire; sed nunc casta repetatur fides, / nam sera numquam est ad bonos mores uia: / quem paenitet peccasse paene est innocens (239-243): "Se sobrepone el amor conyugal...: volvamos allí, de donde antes habría convenido no partir. Mas ahora busquemos de nuevo la casta fidelidad, pues nunca es tarde la vuelta a las buenas costumbres: el que se arrepiente de haber cometido una falta es inocente casi"; Cly. Aegisthe, quid me rursus in praeceps agis / iramque flammis iam residentem incitas? (260-261): "Egisto, ¿por qué me empujas de nuevo al abismo y reavivas con llamas la cólera ya apaciguada?"; Cly. Surgit residuus pristinae mentis pudor; / quid obstrepis? Quid uoce blandiloqua mala / consilia dictas? (288-290): "Se rebela un resto de pudor de mi prístina forma de ser. ¿Por qué me lo afeas? ¿Por qué me dictas malos consejos con tu voz acariciadora?”. 


\title{
LA Odisea de César Brie: Ulises en Tiempos de la Globalización
}

\author{
Alicia María Atienza \\ Universidad Nacional de la Patagonia Austral
}

Desde una relación de traspase entre teatro y ritual, la propuesta de Brie trata de unir experimentación y tradición, y utiliza como recurso el grotesco, la yuxtaposición despiadada de lo trágico y lo humorístico, del pasado con el presente. En una propuesta escénica profundamente intercultural la matriz mística se entreteje con voces, músicas y danzas americanas, en un texto híbrido que restituye el núcleo metafórico de los antiguos mitos y los reviste de una dignificación comprometida y actual.

Fatal accidente en Flores. Mueren dos personas y un boliviano.

Crónica

La adaptación teatral de relatos míticos griegos ocupa un importante espacio en la obra de César Brie ${ }^{1}$, dramaturgo, actor y director argentino, radicado en Bolivia, fundador del Teatro de los Andes en Yotala, cerca de Sucre $^{2}$. Brie comparte con E. Barba (director del Odin Theatre donde trabajó varios años) la creencia en que:

Muchos símbolos están carcomidos, y en la boardilla del siglo XX yacen bolsas y bolsas de esperanzas marchitas. Con los mitos no sucede lo mismo. Los mitos son sombras indelebles. Se han ido del gran mundo de una vez y para siempre pero nutren los pequeños mundos. Vivimos en dos mundos. El Pequeño mundo es el ambiente en el cual nos movemos, la trama de nuestras relaciones, el paisaje que nos pertenece y que podemos adaptar a nuestras necesidades (Barba, 2005: 70).

Con ese sentido, Brie vuelve a textos antecedentes de la cultura occidental, los poemas homéricos ${ }^{3}$ y el drama satírico homónimo de Eurípides, para

${ }^{1}$ César Brie nació en Argentina, exiliado en Europa durante la dictadura de Videla, trabajó junto al Odin Theatre de Dinamarca durante nueve años y se formó con Iben Nagel Rasmussen. A principios de los '90 se establece en Bolivia, compró una finca en Yotala y fundó el Teatro de Los Andes, compañía que se convirtió en un paradigma de las artes escénicas en Bolivia y llevó al teatro boliviano al ámbito internacional. Brie, C. (2009) "El arte cambia por dentro a las personas”, http://www.artezblai.com/artezblai/cesar-brie-el-arte-cambia-por-dentro-a-laspersonas.html (Consulta: 11-04-2011)

${ }^{2}$ Resulta significativo señalar que cuando regresa a América Brie busca instalarse "en un país latino que valiera la pena por su cultura. Por eso Bolivia".

$\underline{3}$ La elección de los textos antiguos es de por síllamativa, e implica un cruce no sólo de siglos 
reescribir tres piezas de tema griego: la Ilíada, la Odisea y El Cíclope, quizá como alusión indirecta a las trilogías trágicas del teatro clásico. Brie (2005: 49) defiende el valor de reapropiarse de los textos griegos desde un país latinoamericano como Bolivia cuando explica:

Ciertas ceremonias y rituales del mundo griego antiguo se me presentaban como acciones que en Bolivia se practican hoy día. Usé esta constatación, en modo algo terrorista, para callar la boca a los ignorantes y nacionalistas de siempre que ponían a priori mala cara, dudando que tuviera sentido y legitimidad proponer un clásico griego en la Bolivia contemporánea.

Desde una relación de traspase entre teatro y ritual la reescritura de Brie traduce la Ilíada en una advertencia sobre "el regreso de la violencia" en América Latina y la Odisea en un relato sobre la problemática de la migración, donde Ulises encarna la figura de los migrantes latinoamericanos que intentan ingresar y vivir en los Estados Unidos.

Nos ocuparemos aquí de la versión teatral de la Odisea, de César Brie, para reflexionar sobre las transformaciones del texto fuente en dos aspectos centrales: el cambio de género, de texto narrativo a dramático y el pasaje intercultural de la cultura griega arcaica al ámbito latinoamericano actual. En primer lugar analizaremos algunos de los procedimientos de la adaptación intergenérica por los cuales el texto origen cambia su estatuto inicial y pasa a participar de un tipo de texto diferente, la adaptación teatral, uno de los géneros centrales para el intercambio internacional en que se plantea la problemática del comparatismo (Cilento, 2000: 9). En segundo lugar consideraremos la

sino de género. De la cultura griega a Bolivia, de la narración heroica a la escena. En lugar de las habitualmente revisitadas obras de teatro clásico, Brie elige las fuentes primarias y proteicas que fueron también en su época fuente para los dramaturgos griegos. En referencia a las crisis en la historia del grupo y a la puesta en escena de La Odisea, comenta Pablo Ortiz: "Como si se tratase de un castigo de los dioses del Olimpo, esta crisis duró exactamente el tiempo en que no presentaron obras de Homero, desde la última presentación de La Ilíada, hasta el comienzo del trabajo para la adaptación de La Odisea. Ahora Ithaca es Yotala y la hacienda que cobija al grupo, un castillo desde el que intentan reinventarse." Ortiz, P. (2008) "Todos somos Ulises en La Odisea", http://www.eldeber.com.bo/brujula/2008-11-22/nota.php?id=081121222833 (consulta 11-2-2011)

4 "La Odisea" ofreció 44 funciones en una gira por Italia, se estrenó por primera vez en España el 10-10-2009 en el IX Festival Iberoamericano de Teatro Contemporáneo de Almagro, y luego participó del festival de Cádiz. El tema del IX Festival giró en torno a la relación 'Teatro y Compromiso', y el núcleo monográfico lo constituyeron los montajes del Teatro de los Andes. Fue posible compartir la historia y las técnicas de esta compañía a través de un taller y el grupo recibió además el Premio Gallo de la Veleta, que otorga el Festival. http:// www.artezblai.com/artezblai/teatro-de-los-andes-recibe-el-premio-gallo-de-la-veleta-enel-ix-festival-iberoamericano-de-teatro-contemporaneo-de-almagro.html (11 octubre 2009) (Consulta: 23-03-2011) 
transformación poética del texto en cuanto adaptación intercultural, en el cruce Occidente/comunidades latinoamericanas, tipo de adaptación que como expresa Dubatti (2008: 161) "marca el encuentro de visiones del mundo y concepciones estéticas muy distintas y distantes, de allí su especial fascinación en la fundación de terceras territorialidades".

\section{Del relato a la acción: la transformación genérica}

Teatro es lo que ocurre. Jorge Eines

La adaptación genérica implica la trasposición del texto de un modo representativo a otro (narrativo/dramático) por medio de una serie de operaciones textuales, entre ellas, alteraciones en la temporalidad, variaciones en la velocidad y frecuencia en el relato de los hechos, reelaboración de la instancia narrativa. ${ }^{5}$ La reescritura de Brie resuelve con eficacia un doble desafío: por un lado, trasponer la historia épica en una extensión viable para la escena y, por otro, traducir a un discurso actual y latinoamericano el verso épico griego, sin que la reescritura pierda en profundidad y poder de significación. ${ }^{6}$ Conserva el título, Odisea que declara desde el inicio el vínculo con el texto fuente, condición insoslayable de la adaptación en tanto género específico

${ }^{5} \mathrm{E} 1$ Coro, los prólogos e incluso los relatos de mensajero que cuentan o recitan la acción en vez de representarla son algunos de los tantos remanentes de lo épico presentes en la forma dramática clásica que la reescritura de Brie conserva, no de manera formal sino a nivel funcional. La música en vivo está a cargo de los nueve integrantes del elenco que tocan distintos instrumentos cuando no le toca actuar. Guitarra, violín, chelo, tambor, clarinete y charango intervienen en las partituras creadas por el músico Pablo Brie. (Arias, 2010)

${ }^{6} \mathrm{El}$ parlamento de los personajes es en verso, a lo que se suma los actores músicos que están siempre en escena, los cantos y la coreografía coral de los grupos, elementos que exhiben la relación de dependencia con el modelo clásico (el canto épico y el coro teatral). Las intervenciones grupales están concebidas de manera semejante al coro en el teatro griego, con canto, coreografía y musicalización Al final de la primera escena, especie de prólogo, la didascalia indica la párodos o entrada del Coro: "Entran los actores y se ponen los zapatos. Cantan"1.1. Lo mismo el canto de las esclavas (1.3), la canción del aeda Femio, en las escenas del primer acto (1.5.3). Las mujeres de Circe bailan al son de los tambores (2.1). En el acto dos un Leitmotiv acompaña el primer sueño de Ulises en su patria, y el reconocimiento entre Ulises y Telémaco y el abrazo entre Telémaco y su madre (2.5, 6 y 7$)$. El canto y la música disimulan el estruendo de la masacre de los pretendientes en la última escena: "A ver, cantame, Yotaleña... No esa otra, viva mi patria. A ver...Desde lejos... Y ese huaynito... Eso seguí..." le dice Ulises a Femio, y las didascalias indican "Popurri de canciones que no acaban" (2.13.1). Cantan mientras las esclavas sacan los cuerpos y limpian. Luego forman en fila. Femio entona un punteado que acompañará el texto de Melanto (2.13.2). Durante el viaje de bailan kullawada y potolos, danzas bolivianas de tradición prehispánica, ya que el grupo trabaja con las fuentes culturales andinas que se expresan a través de la propia música, fiestas y rituales. En la escena final de la guerra civil suenan los tambores, golpean con trapos, gritan al unísono (2.13.5). 
(Dubatti, 2010, 154-5). El reconocimiento de la precedencia textual y el homenaje al autor como referente de autoridad son explicitadas por el coro:

El viaje, la ausencia, el destino, la furia/ la angustia, el regreso, el naufragio, el dolor./ Esta vieja historia la contaba un ciego./ ¿Cuándo comenzó? ¿Quién partió primero?/ ¿Para qué se fueron, quién los expulsó? (1.4)

La estructura dramática tiene dos actos, organizados a su vez en escenas, once en el primero y 13 en el segundo, número análogo a los 24 cantos de la Odisea homérica. La secuencia reformula sin transformaciones radicales los núcleos de la historia odiseica: la Telemaquia, las aventuras de Odiseo, el regreso, la venganza sobre los pretendientes. Sin embargo, una primera mirada al índice muestra ya una serie de modificaciones significativas, especialmente en el itinerario del viaje de Ulises, que se desdobla en el viaje de ida del primer acto, y en el regreso del segundo acto. Desde los títulos se marca la trasposición de Europa al territorio americano y el viaje de Ulises por el Mediterráneo a la migración actual de miles de latinoamericanos a USA. Así leemos "México", "La frontera", "El desierto", "Minuteman”, "E1 destino de los emigrantes", "La deportación". Por otro lado, el título de la última escena "Guerra civil" pone nombre a la inversión del desenlace, sobre la cual volveremos.

Brie reelabora la instancia narrativa, "una de las principales opciones estructurales para el adaptador" (Cilento, 2000: 22) relacionada con la desaparición del narrador épico, heterodiegético y externo. ${ }^{7}$ Distribuye el elemento narrativo en los parlamentos de los personajes lo que implica también la construcción y distribución de variados puntos de vista sobre los acontecimientos. Las palabras vivientes en el presente de la escena, operan la trasmutación del pasado en presente y del mundo griego al contexto actual de Latinoamérica y del mundo globalizado.

Telémaco visita al viejo Néstor ${ }^{8}$ para tener noticias de su padre, pero en vez de encontrarlo en la playa dirigiendo el sacrificio a Poseidón en el seno

${ }^{7}$ Identidad del narrador según conceptos de G. Genette (1989). El poema homérico favorece la operación por su reconocido carácter teatral en sentido amplio, ya que más de la mitad del texto está contada por el discurso directo de los personajes (el relato autobiográfico de Odiseo en el país de los feacios es el más extenso y ocupa cuatro de los veinticuatro cantos).

${ }^{8}$ Néstor pertenece al bando vencedor pero lejos de repetir el discurso triunfalista presenta la guerra a través de la pérdida de su hijo Antíloco, apenas aludida por el texto de origen: Lo llevé a las naves. Sus ojos abiertos/ya no me miraban, su boca no hablaba,/sólo perdía sangre./"Hijo, soy tu padre, aunque seas un hombre,/aunque tengas hijos/sigues siendo un niño dentro de mí./ Regresa te ruego,/vuélvete pequeño./No sabes hablar, por eso te callas,/ llora solamente, sólo tienes hambre,/ sólo tienes sueño, estás en mis brazos/ ponte a descansar. Regresa hijo mío,/ la muerte no existe, es sólo un mal sueño."/ Así le decía mientras lo cargaba,/ su cuerpo ya tieso, frío entre mis brazos,/ su alma hecha viento ya nada decía. Pero me vengué...(1.7.2) 
de una comunidad armónica, lo encuentra en un hospital, entre los lisiados y heridos de la posguerra de Troya, símbolo metonímico de todas las guerras:

Entré a los quirófanos, busqué en los repartos. Los niños de Troya, de Bosnia, de Irak, de Rwanda, Vietnam, los que se salvaron luego del incendio allí se encontraban. Los rostros quemados, llagas de napalm. Otros habían creído que llovían del cielo uvas de metal y allí estaban, ciegos, sin brazos, sin piernas. Habían jugado con frutos prohibidos de dioses siniestros. Lo encontré a Néstor, en silla de ruedas, su mano temblaba, los ojos perdidos miraban afuera, los muertos quemados, la hoguera y el humo, el jardín, las casas, la línea del mar. $(1.7 .2)$

En el pasaje intergenérico la diosa Atenea sigue siendo un personaje con funciones actanciales propias (impulsa el regreso de Ulises, fortalece a Telémaco, consuela a Penélope, protege a Ulises y su familia), pero asume también la voz de un testigo con efecto de distanciamiento, sin que se pueda homologar con el presentador del teatro épico brechtiano completamente separado de la acción dramática. Relata episodios del texto fuente relegados al espacio extraescénico, realiza una síntesis reductiva de pasajes importantes, y con frecuencia expresa la función valorativa frecuente en la voz del narrador homérico. Así plantea la situación de la nostálgica Penélope haciéndola extensiva a todas las mujeres e hijos de inmigrantes que sufren abandono y acoso, mientras esperan en vano a los maridos y padres ausentes:

Penélope esposa, tu cama vacía son cientos de camas/ tu hijo pequeño no es único hijo./ Edificios llenos de niños sin padres,/ casas acosadas por los pretendientes./ por deudas, parientes, por falsos amigos./ Penélope, un nombre y miles los rostros/ que esperan, que miran la nave que nunca/ traerá de regreso a sus seres queridos. (1.5.5)

El salto de género de la épica al drama supone una metábasis állo génos y exige una síntesis reductiva rigurosa ${ }^{9}$. Brie desecha numerosos materiales del texto homérico y enfatiza algunos aspectos y acontecimientos que el poema griego, dirigido a la exaltación del orden heroico, sólo roza o presenta de manera tangencial. Por ejemplo, desarrolla in extenso la relación del héroe con Calipso, que Homero trata con la discreción propia de la épica. Incorpora a

\footnotetext{
${ }^{9}$ A nivel de la historia se respeta en líneas generales el hipotexto, pero las operaciones de compresión y expansión de las escenas (algunas en un solo episodio y otras desarrolladas en varias microescenas) introducen la variación. Las reflexiones de Brie (2000: 9) sobre la Ilíada, son aplicables a la Odisea también: "Me angustia la duración de la obra. Tendría material para seis horas pero decido no superar los dos actos y tratar de no sobrepasar las tres horas. Terminan siendo dos actos con una duración de dos horas y 25 minutos en total”.
} 
la diosa Afrodita, ausente del texto homérico, para marcar la resignificación del episodio focalizado ahora ya no sobre el triunfo de la philía familiar sino sobre las aventuras eróticas del personaje. La relación entre Ulises y Calipso se invierte ya que es ella la que expresa el deseo de sentirse mortal. En una escena cargada de violencia y erotismo, donde lo corporal adquiere preeminencia, los amantes luchan cuerpo a cuerpo y Calipso atisba por primera vez la experiencia de la mortalidad:

Bajo el sol de la mañana por primera vez pienso en el tiempo y en el tiempo que habrá sin él. De veras soy nueva para esto y quisiera ser humana y mortal como él. Porque justo esto yo no lo conozco. No conocía esperar encontrar hallar. No conocía. Y no conozco perder. ¿Qué es lo que queda de lo que fue? (Esc. 6)

Otra de las transformaciones textuales, central para la concepción poético ideológica de la obra es la reiteración en tono ritual del relato de la masacre de los pretendientes, las esclavas y los sirvientes, con sórdidos detalles y los tonos más crueles:

Mi padre va a regresar./ A todos los pretendientes les cortará la cabeza./ Verán cómo va a quedar el patio de casa lleno / de tripas, brazos cortados, ojos, lenguas, / y en la sangre me voy a lavar la cara./Y también a las esclavas que con ellos se acostaron/ las vamos a exterminar. Las ahorcaremos en el patio / todas juntas a una cuerda. Recogeré la mierda / que chorreará de sus piernas para abonar nuestra huerta/ Y a los siervos, los traidores, les cortaremos la lengua,/ los castraremos después, luego los mutilaremos/ y el tronco lo arrojaremos a los cerdos/ que los coman mientras lloran y suplican./ Muéranse hijos de puta, mueran todos de una vez. (1.8.6)

Este pasaje se convierte en un leitmotiv que todos los actores de cara al público gritan al final de la obra en un estallido de violencia física y verbal.

De la cultura griega arcaica al presente latinoamericano: el largo viaje intercultural de la Odisea

Itaca se parece mucho a Bolivia.

C. Brie

Brie diseña la primera escena a manera de prólogo donde se presenta al personaje principal y se plantea la poética teatral de la adaptación en el plano temático y transvalorativo. Los dioses, como en la Odisea homérica, están reunidos, no en el Olimpo sino en una playa con reposeras, anteojos de sol y cigarrillos, atributos placenteros de la modernidad global. Zeus colecciona con 
displicencia, como quien junta caracoles en la arena, zapatos que la marejada acerca a la costa, restos macabros de los que mueren en el mar. Atenea reconoce un zapato y dice: "Yo conozco al dueño. / Ulises se llama, hace mucho tiempo/ que se fue a la guerra y nunca volvió./ Lo atrapa una diosa de una isla lejana."(1.1) Las comunicaciones globales ponen en contacto los extremos del planeta y conectan el plano humano con el plano divino. Hermes responde un llamado de Ulises a su celular:

Aló, sí ¿Ulises? ¿Ulises Choque?/ ¿Estás en España, en el aeropuerto?/ ¿Barajas se llama? ¿Qué problemita?/ ¿El de migraciones, un tal Polifemo?/ ¿Te falta la visa, quieren deportarte, no te hacen pasar? (1.1)

Enseguida Afrodita recibe otro llamado:

¿Aló, Ulises Quispe? ¿No estás en Ushuaia? / ¿En Londres... México... en el Paso? / No escucho... Hay ladridos ¿Los perros guardianes de la policía de Escila y Caribdis? (1.2)

El mestizaje del nombre griego con los apellidos peruanos, Choque o Quispe, resemantiza el estatuto del personaje aproximándolo al de un rol tipificado, el de cualquier inmigrante. Su identidad se vuelve plural y ubicua, inscripta en una geografía donde los espacios se multiplican. Ulises es cualquier migrante y puede estar en España, Ushuaia, Londres, México, o El Paso, lugares definidos como ámbitos de riesgo, fronterizos y señalados como no lugares por las palabras "aeropuerto", "migraciones", "visa", "deportar".

Coherentes con el cambio de contexto, los célebres monstruos homéricos sufren también una metamorfosis: en el aeropuerto de Barajas Polifemo es el empleado de migraciones que lo de-porta dejándolo afuera del mundo deseado del bienestar; Escila y Caribdis son los perros de la policía de frontera en México. Por su naturaleza polimórfica propia de lo monstruoso, Caribdis encarna luego los peligros del golfo de México, y Polifemo el jefe de la mara Salvatrucha que opera en la frontera mexicana:

Polifemo Blacky, jefe de la mara de La Salva Trucha.. Tres veces al fresco allá en California: vendía cocaína, me pude escapar. Mara Salvatrucha. Mi himno y mi lema: Quiero vida loca, sexo, plata y droga....Controlamos trenes, robamos, asaltamos. Si hallamos mujeres, el peaje es violarlas. (2.11.3)

Es durante el viaje de Ulises donde se produce más profundamente la resemantización de los personajes y del espacio geográfico y cultural. Ulises, como en el texto original, cuenta el viaje en primera persona, como protagonista de los hechos. Comienza su relato diciendo: "Yo partí de Troya, o sea Bolivia". 
En un juego especular el espacio troyano, punto de regreso, se hace uno con la tierra patria, Bolivia, la dirección del viaje se hace reversible, la ida y la vuelta se funden y se desdibujan las coordenadas geográficas. En un itinerario que atraviesa Perú, Ecuador, Colombia y Guatemala, las etapas del viaje odiseico se homologan, con desviaciones pero siempre reconocibles, a los episodios de la migración de latinoamericanos a USA.

Del otro lado de la frontera, los males no terminan, se interpone Escila (el desierto de Arizona, los perros de la policía de frontera, el coyote o pollero cruza a los ilegales por el desierto), los grupos parapoliciales, "los voluntarios del Minuteman" que "defienden su patria de los miserables". Hasta que, superadas la últimas pruebas los emigrantes se dispersan a sus diferentes destinos: Chicago, Houston, Miami, Monterrey, la Itaca, no griega sino de N. York, destino de Ulises. Una terror terminó pero una nueva pesadilla comienza en la última escena del primer acto, es la verdad del sueño americano:

Lo tuyo es vivir escondido siempre,/ trabajando duro por buena moneda./ Aprender inglés./TODOS: Yes sir, I can do,/ULISES: Hacer los trabajos que los demás gringos no quieren hacer. (1.9)

El viaje heroico no conduce a la conquista del nuevo territorio sino al fracaso y a la infelicidad, a la pérdida del nombre, de la identidad, de la propia historia desgajada de la comunidad de origen: "Nadie te llamabas, ahora eres Ulises, Ulises Mamani, Ulises Morales..."

En clave paródica, los Estados Unidos son el reino de Circe, cuya poción mágica es la coca cola, allí se impone el abandono de la lengua, la comida chatarra para los hambrientos y la diversión obscena para los solitarios:

Pasen, adelante, pobres extranjeros,/ Venían de lejos, estaban con hambre/ Hamburguesas hot dogs, chizines papitas./ ¿Sajta, fricasé, feijoada tal vez?/ Comida chatarra. Todo lo que quieran./ Coman mis cerditos, hasta hartarse bien./ ...En la isla de Circe nadie va a llorar.../ ¿Para qué acordarse? No van a volver.../

-..ंYa no hablan su lengua? (2.1)

El destino de los ilegales está permanentemente amenazado por la deportación, que reelabora el episodio de los Feacios en la figura por funcionarias insensibles y vulgares (el coro). Los hombres declaran su nombre y nacionalidad: Ulises Quispe, Ulises Laertida, Ulises Ramaciotti, Ulises 
Achirico $^{10}$, de Bolivia, Argentina, Uruguay, Perú ${ }^{11}$. Ninguno de ellos tiene visa, son "turistas", su proveniencia es Itaca, Itaca su destino también ${ }^{12}$.

La llegada de regreso a Itaca/Bolivia implica la humillación más dolorosa, la de los compatriotas que no lo reconocen como tal ${ }^{13}$. Ulises no retorna a la Itaca que dejó, ni es el mismo que era al partir. La profecía de Tiresias se cumple y describe una sociedad que ha quedado desgarrada, signada por la injusticia y el rencor, preñada de odio y violencia:

La Itaca que dejaste ya no existe más./ Tu casa invadida por hombres voraces,/ que asedian tu esposa y asaltan tus bienes./ Tu tierra en desorden, sin ley, llena de odio./ Verás a los hijos golpear a sus padres./ Oirás en las plazas a los demagogos provocar desorden, llamar a venganza./ Fuera, en las montañas, verás que el silencio de los campesinos/ afila guadañas, sostiene el arado con fuerza excesiva. Deberás elegir y no será fácil/ entre sumisión o fuerza, lo legal, lo justo, entre el silencio y la furia, entre el dolor y el desgarro./ Verás separarse calma y dignidad, verás la justicia contraerse en el odio.(2.2)

\section{La peregrinación del nombre: Ulises Quispe, Polifemo Blacky}

La Odisea de Brie hace de Ulises un colectivo donde habitan los migrantes de todos los pueblos arrasados del planeta; Troya es Guatemala, Bolivia, Palestina, Irán, Afganistán, Libia, cualquiera de los países asolados por la guerra, el hambre y el miedo; Itaca se desdobla, umbral de partida y destino a la vez, de un viaje de ida y vuelta, siempre repetido, impulsado por un deseo irrealizable y condenado al fracaso; el inmigrante siempre fracasa, piensa Brie, más allá de que tenga algún éxito en la tierra de adopción.

${ }^{10}$ Se incorpora el registro autobiográfico porque Ramaciotti y Achirico son los apellidos reales de los actores. Más adelante, en una especie de parábasis, cada actor abandonará por un momento a sus personajes para presentarse directamente al público con su verdadera identidad (2.5).

11 "Teatro de Los Andes es una muestra viva de la interculturalidad. En su seno conviven argentinos, bolivianos, brasileños, italianos, daneses... y sus montajes siempre están dirigidos a expresar temáticas actuales con la intención de contribuir a mejorar la sociedad." http://www. artezblai.com/artezblai/el-celcit-abre-la-convocatoria-para-participar-en-el-taller-pasantiacon-cesar-brie-y-teatro-de-los-andes-en-el-marco-del-ix-festival-iberoamericano-de-teatrocontemporaneo-de-almagro.html (Consulta: 15-04-2011)

${ }^{12}$ En la grotesca escena las funcionarias les escriben con lápiz labial en el culo el sello de DE POR TA DOS y los despachan como bultos. Estalla el odio y la bronca colectiva por la humillación y la desigualdad: “¿Y la publicidad "más allá de las fronteras”?/ Que se les mueran sus hijos./ Revienten en su veneno./ ¿Y quién les hizo las casas?/ ¿Quién cosechó sus verduras?/ ¿Quién les alza la basura?/ ¿Quién les cuida sus ancianos?/ ¿Quién los coloca en sus tumbas?/ Muéranse todos bastardos./Ignorantes llenos de oro. Ávidos hijos de puta" (2.4).

${ }^{13}$ Atenea reaparece en la escena 5 para disipar las dudas de Ulises sobre la tierra a que ha llegado y que no alcanza a reconocer, Itaca adquiere valor polisémico para designar cualquiera de los países pobres del planeta: "Atenea: -Su nombre es Itaca./ Todos: -Turquía Bolivia Argentina Irán/ Uganda Uruguay Italia Marruecos Méjico Libia” (2.5). 
En la adaptación los dioses pierden la majestad y el poder que los caracterizaba en Homero, tienen escasa participación efectiva en la acción, y son figuras crueles y morbosas que observan desde sus reposeras, tomando sol, el reality show de un mundo depredado por la globalización. Zeus colecciona zapatos de inmigrantes muertos devueltos por la marejada. Hermes se comunica con Calipso por celular, y Ulises ya no es el hijo de Laertes sino Ulises Choque o Ulises Quispe. Polifemo es funcionario de migraciones o jefe de la mara que lo asesina en la frontera mexicana. Caribdis es el mar amenazante y con Escila ladran los perros de la policía y quema el desierto. El grotesco y la pornografía colorean los encuentros de los Ulises americanos con mujeres fatales como Calipso y Circe.

Es en el final donde opera una de las mayores diferencias con el paradigma clásico. Su título, "La guerra civil", se contrapone al episodio "Las paces", escena de reconciliación y olvido que cierra la Odisea homérica. Esta inversión del sentido orienta la recepción de toda la historia. En la Itaca del relato griego, Atenea aparece en un brillante dea ex machina para declarar la amnistía e imponer la pacificación y el olvido. Su intervención vuelve las cosas a un estado de orden y gobernabilidad en beneficio del héroe, su familia y sus aliados. E1 nóstos culmina y se realiza de manera plena y estable. La reescritura de Brie transforma por inversión el modelo canónico de la historia heroica, en la Ítaca latinoamericana del presente, el regreso es doloroso y la paz imposible.

Hechos documentales (4 de julio de 2006 en Portopalo, Sicilia; 1980, Guatemala; agosto de 2011 en el Mediterráneo), identidades reales que dibujan el atlas inmigratorio actual, conviven con episodios y personajes del mito y la ficción en un cruce que otorga al texto una actualidad vertiginosa. Hoy, mayo o agosto de 2011, los periódicos informan de que "centenares de inmigrantes desesperados murieron ahogados en las últimas semanas al intentar cruzar el Mediterráneo a bordo de embarcaciones precarias". En una propuesta escénica profundamente intercultural la matriz mítica se teje con voces del presente y el resultado es un texto complejo que restituye el núcleo metafórico de los antiguos mitos y los reviste de una significación comprometida y actual. La perspectiva se ha invertido, y el destino esperanzador del héroe antiguo deviene un drama colectivo que presenta una visión enteramente pesimista de los efectos reales de la globalización sobre las poblaciones de los países pauperizados del planeta. 


\section{Corpus}

Bérard, V. (ed), (1999) L’Odyssée, Les Belles Lettres, París

Brie, César, (2011) La Odisea, Buenos Aires, CELCIT, No 316, www.celcit. org.ar.

—__, (2000) La Ilíada, Sucre, Teatro de los Andes.

\section{Bibliografía}

Arias, S. (2010), “120 cañahuecas sirven de guía para La Odisea”, en Los Tiempos, 13/05/2010.

Barba, E. (2005), "Fabricantes de sombras (conversación nocturna con Atahualpa del Cioppo)", Cuaderno de Picadero No 7, Instituto Nacional del teatro, 66-70.

Brie, C. (2000), "Preguntas, motivaciones y reflexiones sobre La Ilíada", en La Ilíada, Sucre, Teatro de los Andes.

- (2005), "Risa y llanto en el teatro andino", Cuaderno de Picadero № 7, Instituto Nacional del teatro.

Cilento, L. (2000), “Adaptación de narrativa extranjera: la voz transtextual”, en Dubatti, J. (comp.) Nuevo teatro Nueva crítica, Bs. As., Atuel.

Dubatti, J. (2010), Cartografía teatral. Introducción al teatro comparado, Bs. As., Atuel.

Genette, G. (1989), Figuras III, Barcelona, Lumen.

Lyotard, J-F. (1997), Lecturas de infancia. Joyce. Kafka. Sartre. Valèry. Freud. Bs.As., EUDEBA.

Minchin, Elizabeth (2001), Homer and the Resources of Memory. Some Applications of Cognitive Theory to the Iliad and the Odyssey. USA, Oxford Un. Press.

Pavis (1996), Diccionario de Teatro. Dramaturgia, estética, semiología, Barcelona, Paidós.

Pianacci, Rómulo (2008), Antígona: una tragedia latinoamericana, USA, Gestos.

Zayas de Lima, Perla (2010), Mitos griegos en el discurso teatral argentino, No 11. www.telondefondo.org.ISSN1669 6301 


\title{
Quando um brasileiro lê Plauto
}

\author{
Tereza Virgínia Barbosa \\ Universidade Federal de Minas Gerais
}

\begin{abstract}
Pretendemos observar aspectos da recepção do mundo antigo pela viés da transplantação e resignificação (entre outros) dos clássicos no teatro brasileiro, especificamente, na obra $O$ Santo e a porca de Ariano Suassuna. Perguntamos: quem somos, como vemos os gregos e latinos? A peça é capaz de transplantar a peça plautina, de nome Aulularia, para as terras tropicais sem quaisquer problemas. $\mathrm{O}$ título da obra brasileira concretiza também todo um processo do fazer poético de Suassuna, a saber, criar uma interseção entre o erudito e o popular.
\end{abstract}

Creo que los argentinos, los sudamericanos en general [...] podemos manejar todos los temas europeos, manejarlos sin supersticiones, con una irreverencia que puede tener, y ya tiene, consecuencias afortunadas. Por eso repito que no debemos temer y que debemos pensar que nuestro patrimonio es el universo; ensayar todos los temas, y no podemos concretarnos a lo argentino para ser argentino: porque o ser argentino es una fatalidad, y en ese caso lo seremos de cualquier modo, o ser argentino es una mera afectación, una máscara.

"El escritor argentino y la tradición" - Jorge Luis Borges

Em agosto de 2009 foi criada, pela Universidade de Oxford, uma revista especializada na recepção dos antigos que leva o título de Classical Receptions Journal e pretende cobrir todos os aspectos da recepção da arte (sejam eles oriundos dos textos ou mesmo da cultura material) advinda do mundo antigo greco-romano. Com esse propósito em vista, o periódico inglês explora os clássicos pelo viés da transmissão, interpretação, tradução, transplantação, reescrita e ressignificação, permitindo possibilidades várias para a comparação das diferenças culturais, linguísticas e ideológicas através dos tempos.

O caminho proposto é seguramente transdisciplinar e envolve todas as manifestações da cultura ${ }^{1}$. Segundo a editora do primeiro número, Lorna Hardwick, a pesquisa acerca do tema cresceu muito rapidamente e abriu uma vasta área de investigação que acarreta reflexões sobre transformações, manutenções, assimilações ${ }^{2}-\mathrm{e}$, de nossa parte, acrescentamos: rejeições e

\footnotetext{
${ }^{1}$ http://www.oxfordjournals.org/our_journals/crj/about.html

${ }^{2}$ Hardwick, Classical Receptions Journal, 2009, p. 1.
} 
sufocamentos ${ }^{3}$ - que acabam por provocar um exercício de juízo de valor com reavaliações éticas, morais e estéticas.

Hardwick sugere, para uma nova abordagem do tema "tradição clássica", a substituição do termo "tradição" por "recepção". A intenção de tal escolha é: não desprezar nem o clássico do passado nem as novas manifestações e, ainda, e mais importante: não fazer julgamentos pré-adquiridos ${ }^{4}$. Para isso, Lorna Hardwick propõe que a área adote o patronato de Proteu e Camaleão.

Desse modo, serão contemplados tanto a simples adaptação do texto antigo, que pode inclusive mudar de gênero (da épica para o teatro ou cinema, por exemplo) e configurar-se como um trabalho totalmente diferente, até um processo mais sofisticado, a saber, o procedimento de apropriar-se do estilo, do significado, da simbologia utilizada por um determinado autor antigo em um produto aparentemente desvinculado da tradição. Adaptações e apropriações são, portanto, exercícios de escritas que explicitam ou ocultam propósitos intertextuais do autor. Em outras palavras, adaptações e apropriações são - em muitos aspectos - um ramo da prática da intertextualidade abordada inicialmente por Julia Kristeva e considerada um dos princípios centrais do chamado pós-modernismo ou, se preferirem, poderíamos também afirmar que as adaptações e apropriações estariam igualmente bem representadas no interesse dos estudos pós-coloniais desenvolvidos por Homi Bhabha com a ideia de 'hibridismo', perspectiva teórica que indaga como as coisas são realocadas, traduzidas e repetidas à sombra da tradição ${ }^{5}$.

Nós buscamos um desvio. Não queremos pensar em dominação nem em subserviência; optamos por pensar a interação, as relações de amizade, o jogo e as trocas - a química literária que Eliot sugere ${ }^{6}$.

Mantendo-nos à luz do poeta e teórico de língua inglesa que postula que “cada raça tem não apenas sua tendência criadora, mas também sua tendência

${ }^{3}$ Recordamo-nos de mais um trecho de Borges, parte da aula que nos serviu de epígrafe, para pensar acerca dos procedimentos de recepção dos clássicos na America Latina. O escritor afirma: "[la] historia argentina puede definirse sin equivocación como un querer apartarse de España, como un voluntario distanciamiento de España. [...] entre nosotros el placer de la literatura española, un placer que yo personalmente comparto, suele ser un gusto adquirido; yo muchas veces he prestado, a personas sin versación literaria especial, obras francesas e inglesas, y estos libros han sido gustados inmediatamente, sin esfuerzo. En cambio, cuando he propuesto a mis amigos la lectura de libros españoles, he comprobado que estos libros les eran difícilmente gustables sin un aprendizaje especial; por eso creo que el hecho de que algunos ilustres escritores argentinos escriban como españoles es menos el testimonio de una capacidad heredada que una prueba de la versatilidad argentina." http://archivosborges.blogspot.com/

${ }^{4}$ Hardwick, Classical Receptions Journal, 2009, p. 2.

${ }^{5}$ Panorama do tema pode ser encontrado em Sanders, Adaptation and appropriation, 2006, p. $2-17$ ss.

${ }^{6}$ Eliot, Tradição e talento individual, p. 42, 43. 


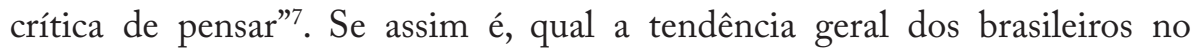
tratamento com os clássicos?

Pode-se notar facilmente que, em grande parte, a literatura brasileira opta mais frequentemente pela apropriação, ou seja, ela oculta suas fontes sempre que possível, rechaça-as, contesta-as, sufoca-as e deforma-as mantendo-as sobre seu controle, gerando um novo produto culturalmente assimilado ${ }^{8}$. Ela constrói sobre as ruínas.

Contudo, O santo e a porca, a peça que escolhemos para nossos breves comentários, é uma exceção. O texto é bem comportado, no que diz respeito à retomada dos antigos - e talvez por esse motivo seja tão comentado - e ao modo de marcar nitidamente a escolha do texto fonte e a visão pessoal do autor sobre Plauto, o tema por ele abordado e a sua reescrita pela cultura brasileira. Para expressar-se, o paraibano Suassuna escolhe a transferência cultural, atualiza a forma, reinterpreta o contexto e garante, em boa medida, a autoridade do arquétipo?.

Mas não nos enveredemos por especificidades; o tempo é curto para distinguir se se trata das muitas formas de abordagem dos clássicos, se a partir de versão, variação, interpretação, continuação, transformação, imitação, pastiche, paródia, falsificação, travestimento, transposição, reavaliação, revisão, reescrita, eco $^{10}$, reverberação, tradução ${ }^{11}$ etc. Navegando por abordagens teóricas, vamos somente repensar a recepção dos clássicos no teatro brasileiro e, em particular, nessa comédia de Ariano Vilar Suassuna ${ }^{12}$ como um protótipo zeloso e afetuoso para com os textos antigos. Nossa hipótese é a de que, quando um brasileiro se curva à beleza dos clássicos, ele se utiliza de um procedimento harmônico e delicado, atento e diligente, porém sempre irreverente diante do passado tal como sugeriu Jorge Luis Borges em nossa epígrafe, pois "podemos manejar todos los temas europeos, manejarlos sin supersticiones, con una irreverencia que puede tener, y ya tiene, consecuencias afortunadas."

E isso nos leva a citar novamente Eliot, que afirma que:

\footnotetext{
${ }^{7}$ Eliot, Tradição e talento individual, p. 37.

${ }^{8}$ Características de 'apropriação' arroladas por Sanders, Adaptation and appropriation, 2006, p. 26.

${ }^{9}$ Sanders, Adaptation and appropriation, 2006, p. 3.

${ }^{10}$ Sanders, Adaptation and appropriation, 2006, p. 18.

${ }^{11}$ Spivak, "Rethinking Comparativism." In: New Literary History, Volume 40, Number 3, Summer 2009, p. 609-626.

${ }^{12} \mathrm{~A}$ obra de Ariano Suassuna é vista por alguns com resistência devido às questões políticas. Suassuna é filho do governador da Paraíba (1928) João Suassuna, que foi assassinado no Rio de Janeiro em 1930. Nascido, portanto, no meio de contendas políticas, o escritor paraibano tornou-se um herói das letras marcado pelas contradições e ambiguidades de suas origens.
} 
o sentido histórico implica não somente a percepção da caducidade do passado, mas de sua presença [pois] o sentido histórico leva um homem a escrever não somente com a própria geração a que pertencem seus ossos, mas com um sentimento de que toda a literatura europeia desde Homero e, nela incluída, toda a literatura de seu próprio país têm uma existência simultânea e constituem uma ordem simultânea ${ }^{13}$.

Nessa existência simultânea, nessa mistura atemporal, com etnia mesclada, observaremos mais determinadamente aqueles traços que acometem-nos: a mestiçagem geradora da ambivalência, o sincretismo, o medo que retrai a ação e a fé que impele à transgressão.

Poeta de nascença, advogado, filósofo e professor por profissão, dramaturgo por pura paixão, Suassuna nasceu em 1927, na cidade de Nossa Senhora das Neves, situada na colorida, calorosa e luminosa Paraíba. Mudouse na juventude para o Recife e lá se estabeleceu. Sobre o escritor, a poeta Rachel de Queiroz ${ }^{14}$ afirmou, em prefácio ao Romance d'A Pedra do Reino e o príncipe do sangue do vai e volta ${ }^{15}$, que ela própria "[só] compara[va] o Suassuna no Brasil a dois sujeitos: a Villa-Lobos e a Portinari”. E prosseguiu: "Neles a força do artista obra o milagre da integração do material popular com o material erudito, juntando lembrança, tradição e vivência, com o toque pessoal de originalidade e improvisação".

De fato, esses poetas - um da letra, outro do som e um terceiro da imagem - para Queiroz e para nós próprios são, sem dúvida, paradigmáticos no que diz respeito à maneira harmoniosa de integrar o erudito e o popular, temática esta que é a de toda a obra de Suassuna. Aqui daremos somente uma pequena mostra. Um título de peça cômica nos basta para refletir a mistura do erudito e do popular ${ }^{16}$ e do sagrado e do profano. Trata-se da denominação da obra que nos motiva neste ensaio, $O$ santo e a porca. Mostraremos como o nome escolhido é carregado dos parasitas, dos ecos, das alusões e fantasmas do texto de Plauto ${ }^{17}$.

Ora esse título - O santo e a porca - serve para o poeta veicular, à moda brasileira, a peça plautina de nome Aulularia, escolha léxica que, no passado, foi popular, porém hoje, no Brasil, se faz conhecida só para eruditos. Pois bem, o milagre aludido por Rachel Queiroz aqui se dá outra vez: Suassuna une as tramas antigas pelo léxico e pelos variados sentidos desse léxico de

${ }^{13}$ Eliot, Tradição e talento individual, p. 39.

${ }^{14}$ Prefácio ao Romance d'A Pedra do Reino e o príncipe do sangue do vai e volta, p. 16.

${ }^{15}$ Que nomearemos a partir de agora apenas como A Pedra do Reino.

${ }^{16}$ Para noções gerais acerca da interseção entre o erudito e o popular em Suassuna sugerimos Rabetti, Maria de Lourdes. A comédia da contemporaneidade: encenar hoje uma comédia antiga, 2005.

${ }^{17}$ Gilbert \& Gubar, The Madwoman in the Attic after Thirty Years, p. 46. 
forma hospitaleira e bem humorada e, já como em uma petição de princípio (petitio principii), acolhe o escritor latino que escrevera, no século III-II a.C., a Aulularia.

Mas talvez devêssemos nos perguntar antes: por que a Aulularia? Resposta imediata seria: a Aulularia configurou-se como texto relevante, com fortuna literária, com um enredo facilmente compreensível para todos os públicos tanto os novos como os antigos -, um texto que pode ser tratado sem grandes esforços através dos processos de aproximação e de atualização. Neste sentido a transposição do enredo dessa comédia latina gera, igualmente, um outro produto bastante agradável e construído fundamentalmente e extraordinariamente à maneira de Plauto. O santo e a porca é próximo da comédia nova grega, sóbrio, com intrigas urbanas à volta de uma história de amor entre dois jovens bem intencionados. A trama é plausível e os personagens, simpáticos, tal como sugere Beacham para Plauto.

As peças da Comédia Nova Grega que Plauto tomou como seu ponto de partida eram essencialmente polidas, sóbrias e com intrigas urbanas. Muitas vezes o enredo era centrado em uma história de amor de um "bom rapaz" que, depois de algumas aventuras um pouco indecorosas, descobre que o objeto de sua afeição (a despeito das primeiras impressões) é uma boa escolha para um casamento. (...) O enredo é, de maneira geral, plausível e as personagens, apesar de exageradas em função de um efeito cômico, são simpáticas ${ }^{18}$.

De acordo; em primeiro plano temos grandes aproximações, mas que impulsos específicos e ideológicos, pessoais e históricos moveram Suassuna nessa adaptação? Podemos nos aproximar da questão retomando nossa intenção de incidir sobre o título da peça: $O$ santo e a porca.

Nada mais vivo na rotina do povo brasileiro que as palavras "santo" - seja ela no contexto do cristianismo ou no âmbito do candomblé. Também a palavra "porca" é bastante familiar para o povo da terra brasílica. Ela está na boca da população rural para referir-se à provedora de leitõezinhos para a mesa, está à venda, nos sinais de trânsito das capitais como pote de cerâmica para guardar moedas e ainda surge no palavrório de xingamento de toda a nação. Como insulto, porca, no Brasil designa a "mulher malcheirosa, suja".

A mesa está presente no título antigo também: Aulularia significa "panelinha" ou "cozido de carnes" assim como "porca", no Brasil, é um

18 "The Greek New Comedy plays, which Plautus took as his point of departure, were essentially mild-mannered, sober, and urbane intrigues. Often the plot centered on the love affair of a well-to-do young man, who after some not to unseemly adventures discovers that the object of his affections is (despite first impressions) a fit choice for marriage. (...) The plot is generally plausible and the characters, although exaggerated for comic effect, sympathetic" (Beacham, 1995, p. 30). 
prato requintado. Da mesma forma, em sentido secundário, para romanos e brasileiros, "porca", na peça focalizada, é um cofrezinho de guardar moedas. Santo milagroso - com afirmou Rachel de Queiroz - é o poeta paraibano, que irá unir o domínio de "cofre", "dinheiro" e "sujeira" a Deus. Vejam, estamos dizendo a Deus e não à igreja como instituição, o que facilmente se ligaria a quaisquer desses substantivos. Por certo, o dramaturgo dirá - acerca da porca - no prefácio da obra: "Ela [a porca] apresenta a vida como um impasse, cuja única saída é Deus"19. Assumindo, logicamente, os riscos da interpretação, podemos traduzir esta afirmativa "A porca apresenta a vida como um impasse, cuja única saída é Deus." da seguinte forma: "Para o ventre, para a insegurança advinda da falta ou excesso de riqueza, para o medo e a covardia, só Deus - o Santo - propõe uma saída”.

Por que o poeta atrela a porca, que abrange o campo semântico da gula, da ganância e da preguiça, a Deus? Para tentar explicar a estratégia, vamos recorrer a outros textos do poeta e filósofo brasileiro e evocar um termo precioso para ele: "emboscada". Inegável é o peso dado - em especial para o Romance d'A Pedra do Reino e o príncipe do sangue do vai e volta e para a História d'O rei degolado nas caatingas do sertão ao sol da Morte Caetana ${ }^{20}$ - para essa palavra $^{21}$ que acaba por significar, na amplitude do mundo literário do escritor paraibano, a própria periculosidade que é o viver.

Viver, nestas obras, é a espera vigilante pela hora da morte, que vem de tocaia, na surdina, para em cilada atacar o incauto como uma onça, um bandido. A partir da palavra "emboscada" é possível entender o pensamento desse brasileiro sobre a vida. N'A bistória d'o rei degolado Suassuna declara que a vida é uma jornada onde pessoas vão:

[c]aminhando, com seus companheiros de viagem, para um perigo de morte. [...] A Moça Caetana [que é a morte sedutora e violenta], sob a forma de Onçapintada que tinha assumido, com a Cobra-coral no pescoço e seguida por suas três Aves-de-rapina, andara pela Caatinga, macia e traiçoeira como um gato. Caminhara assim um pedaço, até se aproximar do local onde se encontravam os tocaieiros emboscando $(\ldots)^{22}$.

O pequeno romance de onde retiramos o trecho acima, ergue-se sob a efígie da Moça Caetana. Seu título completo é longo: A história d'o rei degolado nas caatingas do sertão. A obra foi publicada pela primeira vez no folhetim Diário do Pernambuco sob o nome Ao sol da onça Caetana estabelecendo um

\footnotetext{
${ }^{19}$ Suassuna, $O$ santo e a porca, p. 5 .

${ }^{20}$ Nomeado de agora em diante $A$ bistória do rei degolado.

${ }^{21}$ Não nos cabe aqui espaço para comprovação. Faremos somente breves pontuações.

${ }^{22}$ Suassuna, $A$ história do rei degolado, p. 44.
} 
gênero literário de duplo rótulo, o do Romance Armorial e o da Novela Romançal Brasileira. ${ }^{23}$ Todavia, estamos, na verdade, em presença de uma epopeia cuja protagonista é a morte vigilante e implacável, a Moça Caetana que à maneira de Hesíodo, na Teogonia, v. 25-34 , apresenta-se como uma Musa pervertida:

A Moça Caetana reflete ali agora, sob a forma de Onça divina e alada da Morte, passeando a vista por todos aqueles lugares sagrados onde em breve jorrará sangue. Com seus olhos que enxergam ao mesmo tempo o presente, o passado e o futuro, vê [...]. [...] a morte Caetana, com sua mente e seus olhos divinos, sabe, vê, e ouve tudo, e sorri. Está contente farejando sangue ${ }^{24}$.

Portanto, a Moça Caetana configura-se como a (in)esperada morte que tal como uma esfinge tropical - sob o sol sufocante, ofuscador, ensinador, enceguecedor dos países mais próximos do zênite - atraiçoa a raça brasileira.

$\mathrm{Na}$ apresentação que faz de sua peça, o escritor, além de chamar $O$ santo $e$ a porca de Imitação Nordestina de Plauto, ele diz:

(...) O santo e a porca apresenta a traição que a vida, de uma forma ou de outra, termina fazendo a todos nós. A vida é traição, uma traição contínua. Traição nossa a Deus e aos seres que mais amamos. Traição dos acontecimentos a nós, dentro do absurdo de nossa condição, pois, de um ponto de vista meramente humano, a morte, por exemplo, não só não tem sentido, como retira toda e qualquer possibilidade de sentido à vida ${ }^{25}$.

Todavia não pensemos que Ariano seja um "sentimentalóide religioso". Não. Nosso autor é - e essa é mais uma assimilação que ele faz com os antigos - um devoto profano que faz sua homenagem simultânea ao Santo e à Porca - ou se quisermos, ao dinheiro e à divindade (contrariamente ao que é preconizado no Evangelho de Mateus, capítulo 6, versículo 24). Em suas palavras,

Assim, confessando que talvez esteja ainda mais no escuro do que os outros sobre o que faço, tenho aqui [n' Santo e a Porca] uma ordenação - ou uma das ordenações possíveis - para o mundo tumultuoso que inventei, não sei bem por quê nem para quể ${ }^{26}$.

Ora, o mundo inventado pelo idealizador de Dom Pedro Dinis Quaderna e companhia ilimitada é um amálgama de cultura latina (e grega, na medida em que Plauto recupera os modelos gregos) com o cristianismo, mas o cristianismo

\footnotetext{
${ }^{23}$ Dos Santos, Idelette Muzart Fonseca. In: Suassuna, $A$ história do rei degolado, p. xiii.

${ }^{24}$ Suassuna, $A$ história do rei degolado, p. 14 e 15 respectivamente.

${ }^{25}$ Suassuna, O santo e a porca, p. 4.

${ }^{26}$ Suassuna, $O$ santo e a porca, p. 4
} 
sertanejo, ou seja, um cristianismo que permite a bandidagem com devoção, o crime sangrento com fé, a política e a religiosidade (de Lampião e Maria Bonita, do padre Cícero). Essa bandidagem se dá, na trama da peça (que focaliza o roubo da porquinha de dinheiro), na trapaça de umas personagens contra as outras, no estilo brasileiro de escrever teatro, estilo que bandidamente rouba do clássico sua beleza, mas confunde e mescla as coisas. Efetivamente, a versão brasileira é mais cheia de trapaçaria que em Plauto. $\mathrm{O}$ próprio Suassuna admite: “... a peça é um tumulto, e as opiniões que se formam em torno dela é outro; o que, de certa forma, nos autoriza a procurar, na medida do possível, um sentido para aquilo que talvez nenhum sentido claro possua" 27 .

Mas a lei do coronel nordestino, um tipo tupiniquim de pater familias, impera com Eudoro e Euricão sobre os filhos Dodó e Margarida. A regra de Plauto se mantém: o pai pode "vendê-los como escravos e seu consentimento é necessário para o casamento" (sell them into slavery, his consent to their marriage was needed - Beacham, 1995, p. 38). Adaptada ao sertão, a peça mostra Margarida, a filha de Euricão, vivendo em estado de miséria sob o comando do avaro pai e Dodó, o herdeiro de Eudoro, fugindo da imposição paterna que o obriga a estudar. A situação é paralela à de Megadoro e Licônides, seu sobrinho, e ainda à de Euclião e sua filha Fédria.

As trapaças, os dolos das personagens parecem-nos mais exagerados que os dolos e astúcias dos antigos. Na peça brasileira, porém, paira o tom trágico de enfrentar a "traição contínua da vida" e com isso justificam-se todos os atos de fraude, grandes ou pequenos, cruéis ou ingênuos. Mistura-se o joio e o trigo, e somente ao final da colheita serão eleitos os justos. No cômputo mais geral, patenteia-se o valor pedagógico da declarada intenção do brasileiro de homenagear o poeta anterior, em sintonia com o Movimento Armorial, que, por sua vez, tem o propósito de ajudar a construir a identidade do povo brasileiro a partir da mestiçagem irreverente, conquanto respeitosa. Divulga-se, ensina-se e manifesta-se a erudição na cultura popular.

O resultado é a variedade, mobilidade e riqueza da vida, as quais, por essa razão, refletem um dos principais recursos plautinos, o quid pro quo que, no caso de Suassuna, amplia-se, vai do espacial e do linguístico e atinge o religioso. Latinos, sim: mas latino-americanos, mutatis mutandis. Temos, então, resolvido um dos muitos enigmas da obra, a saber, a inserção da palavra "santo" no nome que poderia simplesmente recuperar aqueloutro latino e ser traduzido como Panelinha; afinal, nenhum artista existe, de forma completa, sozinho; o que mostra seu gênio e talento é a sua relação com outros artistas, vivos ou mortos, concreta ou metaforicamente, de ontem, de hoje e de amanhã ${ }^{28}$.

\footnotetext{
${ }^{27}$ Suassuna, O santo e a porca, p. 3.

${ }^{28}$ Eliot, Tradição e talento individual, p. 39.
} 


\section{BibLIOgRAFIA}

Beacham, Richard. The Roman Theatre and Its Audience. Harvard: Harvard University Press, 1991.

Eliot, T. S. "Tradição e talento individual", In: Ensaios. São Paulo: Art Editora, 1989, p. 37-48.

Hardwick, Lorna. "Editorial", In: Classical Reception Journal, Vol. 1, nº 1, 2009, p. 1-3.

Moore, Timothy J., The theater of Plautus: playing to the audience. Austin, University of Texas Press, 1998.

Rabetti, Maria de Lourdes. Estudos sobre Ariano Suassuna e outros ensaios. Rio de Janeiro: Viveiros de Castro Editora Ltda, 2005.

Rabetti, Beti. "A comédia da contemporaneidade: encenar hoje uma comédia antiga". In: Rabetti, Maria de Lourdes. Estudos sobre Ariano Suassuna e outros ensaios. Rio de Janeiro: Viveiros de Castro Editora Ltda, 2005.

Sanders, Julie. Adaptation and appropriation, 2006, p. 18.

Spivak. "Rethinking Comparativism", In: New Literary History, Volume 40, Number 3, Summer 2009, p. 609-626.

Suassuna, Ariano. O santo e a porca e O casamento suspeitoso, Rio de Janeiro, José Olympio, 1976.

—__ A Pedra do Reino e o príncipe do sangue do vai-e-volta, Rio de Janeiro, José Olympio, 2005.

- - História d'O rei degolado nas caatingas do sertão: ao sol da Onça Caetana, Rio de Janeiro, José Olympio, 1977.

Torrano, Jaa, Hesíodo, Teogonia, São Paulo, Iluminuras, 1995.

West, M. L., Hesiod Theogony, Oxford, Clarendon Press, 1966.

http://www.oxfordjournals.org/our_journals/crj/about.html 


\title{
VESTÍGIOS GREGOS EM TERRAS BRASILEIRAS
}

\author{
Vanessa Ribeiro Brandẽo \\ Universidade Federal de Minas Gerais
}

\begin{abstract}
O presente trabalho tem por objetivo observar e estudar vestígios da literatura clássica na obra Auto da Compadecida, do escritor brasileiro Ariano Suassuna. Será estudada, primeiramente, a semelhança entre elementos do auto e do teatro grego. A seguir, serão evidenciadas e estudadas a astúcia e a habilidade de convencimento do personagem João Grilo e então comparadas às de Odisseu, herói grego reconhecido por sua esperteza. Ao longo da análise, será verificado se também seria possível comparar esses traços marcantes da personalidade de João Grilo com o comportamento dos sátiros, seres mitológicos e burlescos reconhecidos por sua capacidade de enganar e trapacear.
\end{abstract}

O presente trabalho tem por objetivo observar e estudar vestígios da literatura clássica grega na obra Auto da Compadecida, do escritor brasileiro Ariano Suassuna. É uma peça em três atos que conta a história de João Grilo e seu amigo Chicó, dois homens pobres que trabalham para o mesquinho padeiro e sua esposa. São personagens cômicos: Chicó, pela sua ingenuidade; João pela astúcia de usar a avareza e a ambição dos ricos da cidade contra eles mesmos. A personagem mente e engana cada um deles a fim de garantir a comida e o conforto que a estrutura social daquele lugar não the permite. Ao longo da trama, encontra-se um personagem-tipo, o palhaço, que tem função de narrador e diretor da peça. Ele explicita as rubricas e norteia os atores na construção da cena.

Os dois primeiros atos narram como João Grilo e Chicó enganam o padre, o bispo, os patrões e o cangaceiro Severino, que mata todos esses personagens no final do segundo ato, exceto Chicó. Severino também acaba morrendo por acreditar na mentira dos dois trapaceiros. No terceiro ato, acontece o julgamento das personagens por Jesus, chamado na peça de "Manuel"; pelo diabo, chamado de "Encourado" por estar representado conforme o imaginário nordestino; e logo depois, também pela Compadecida, que é Maria, mãe de Manuel, que, a pedido de João Grilo, intercede por ele.

A religiosidade, o cangaço e a cultura nordestina evidenciados na obra estão diretamente relacionados a um movimento organizado por alguns artistas na década de 70, no Recife, chamado de "Movimento Armorial". Ele, segundo a pesquisadora Idelette Santos, veio a se tornar, "um dos pólos da criação artística do Nordeste da época", com o intuito de provocar questionamentos como a denominação e a definição de cultura popular ${ }^{1}$.

\footnotetext{
${ }^{1}$ Santos, Em demanda da poética popular: Ariano Suassuna e o Movimento Armorial, p.13-14.
} 
Dessa forma, o questionamento sobre o conceito de "popular" se faz importante. Conforme as teorias de Pierre Bourdieu no campo da ciência social citadas por Idelette Santos², o "popular" apresenta três características principais: relaciona-se à manifestação do povo, à margem do que seria o "modelo culto", apresentando um caráter socioeconômico; substitui a voz do povo, relacionado ao que chamamos de folclore; e seduz o povo, de forma a ser aquilo admirado por ele. Tomando como base tais conceitos, a peça representa o popular tanto pelas personagens como pelo enredo.

A pesquisadora também afirma que o movimento propunha uma revitalização da arte nacional por meio de um resgate de três formas artísticas distintas, que seriam os Romanceiros Populares do Nordeste (Literatura de Cordel) junto da música de viola, rabeca ou pífano que os acompanham e a xilogravura que ilustra suas capas. Percebe-se isso facilmente pelo enredo, que se baseia em folhetos nordestinos, apontados também por ela e diversos teóricos, inclusive o autor da obra. São eles: O enterro do cachorro, de Leandro Gomes de Barros, História do cavalo que defecava dinheiro, anônimo, O castigo da soberba, de Anselmo Vieira de Souza, e A peleja da alma, de Silvino Pirauá de Lima.

A inspiração das peças em mitos e histórias já conhecidas e aceitas por um povo acontece desde a época clássica. Além disso, a manifestação da religiosidade popular brasileira (sobretudo nordestina) alude aos festivais quando eram representadas peças de teatro em honra ao deus Dioniso. Também o caráter educativo do gênero "auto", uma modalidade teatral de grande relevância didaticopedagógica que usa a alegoria para reafirmar os valores e dogmas cristãos impostos pela Igreja, inaugurado na Idade Média, pode aludir às teorias que corroboram que a tragédia teria fins educativos. Schiller, em sua Teoria da tragédia (1991, p.14), afirma que se crê que a tragédia presta "um relevante serviço quando, em lugar do frívolo propósito de deleitar, se lhes imputa um fim moral”. Na introdução dessa obra, Anatol Rosenfeld afirma que a tragédia

proporciona ao espectador a possibilidade de experimentar, livremente, lucidamente, o cerne na existência moral em todos os seus conflitos, em todas as suas virtualidades negativas e positivas (1991, p.11).

Ainda que a tragédia e o auto apresentem fins moralizantes, na obra de Suassuna as personagens, diferentemente da tragédia e como se espera de figuras cômicas, não são nobres, mas "populares", figuras que representam o povo. O público se reconhece e reconhece as pessoas que participam de seu

\footnotetext{
${ }^{2}$ Idem, pp.14-15.
} 
cotidiano em cada um deles. Como são alegorias, apresentam uma identidade coletiva, representando não só a existência de um indivíduo, mas de uma classe, de um grupo religioso, de um status social, de uma manifestação cultural. Essa tipificação dos personagens salienta-se, inclusive, pela opção do autor em não nomear alguns deles, como o padre, padeiro, mulher do padeiro; o que acontece nas tragédias com os mensageiros, coros, amas.

Dos personagens da peça, o que mais se destaca quanto à representação popular é João Grilo, que se aproveita da avareza e da ambição dos ricos da cidade para enganá-los e conseguir o pão que lhe falta diariamente. Tal comportamento, na peça, é tolerado e aceito devido à falta de opção aos brasileiros e nordestinos que precisam driblar a miséria e a mesquinhez dos patrões. Tanto que, quando João Grilo morre e é julgado por Jesus, que na peça é chamado de Manuel, clama pela Compadecida que não o condena, afirmando que ele não tinha escolha para a sobrevivência. No final, Manuel, a pedido da mãe, acaba deixando João voltar à vida.

A COMPADECIDA: Intercedo por esses pobres que não têm ninguém por eles, meu filho. Não os condene. (p.174)

(...)

A COMPADECIDA: João foi pobre como nós, meu filho. Teve de suportar as maiores dificuldades, numa terra seca e pobre como a nossa. Não o condene, deixe João ir para o purgatório. (184)

(...)

A COMPADECIDA: Dê-lhe então outra oportunidade.

MANUEL: Como?

A COMPADECIDA: Deixe João voltar. (p.185)

(...)

JOÃO GRILO: Quer dizer que posso voltar?

MANUEL: Pode, João, vá com Deus. (p. 188-189)

Um personagem grego que também é conhecido pela astúcia e pela arte de enganar é Odisseu, herói grego que passou dez anos tentando retornar ao lar e que, depois de perder os amigos e a própria nau (canto XII), consegue chegar a seu destino graças a sua grande eloquência, capacidade de persuadir e de encontrar soluções para problemas que pareciam impossíveis de serem resolvidos. Assim como João Grilo, Odisseu tinha uma importante protetora, a deusa Atena. Entretanto diferentemente da Compadecida, que apenas intercede por João a fim de que não seja condenado e não morra, Atena age diretamente na empreitada de Odisseu, como no episódio em que o disfarça de mendigo para que não fosse reconhecido por seus inimigos (canto XIV).

Outro personagem conhecido pela meticulosidade e astúcia é Sileno e seus filhos sátiros. Como João Grilo e Odisseu, eles trapaceiam e mentem, porém 
com fins nada nobres, geralmente relacionados à adoração quase patológica que mantêm pelo vinho e por sexo, presentes do deus de cujo séquito fazem parte, Dioniso. Por mais que o comportamento de tais figuras seja inconveniente e ilícito para o cidadão ateniense, ele é risível e até aceito, pois representam "outra faceta inconfessável ao ser humano, a faceta anti-heroica mais elementar e natural"'. Os sátiros assemelham-se aos jovens aristocratas atenienses do século $\mathrm{V}$ a.C, quando se entregam à bebida e ao sexo nos banquetes ${ }^{4}$. Tal comportamento, dessa forma, torna-se desculpável por existir uma razão de ser, que é a entrega a Dioniso, assim como é aceitável a trapaça de João Grilo, pois ela é motivada pela necessidade de sobrevivência.

Logo os dois tipos de comportamento são demonstrações de condutas típicas de sua cultura: os sátiros são os jovens em honras a Dioniso em um banquete, enquanto a astúcia de João Grilo demonstra o típico "jeitinho" brasileiro. São condutas imorais, que se tentam ocultar, mas que fazem parte da cultura popular e que às vezes, mesmo que veladamente, são vistas com certo orgulho patriótico.

Assim como a alegoria a que se prestam as personagens nos mostram características culturais e cidadãs do país e da região a que pertence a peça, a estrutura e o enredo do Auto da Compadecida evidenciam traços da cultura e da realidade brasileiras, o que pode ser observado pela pluralidade de fontes e de estilos, o que remonta também à hibridez do drama satírico. $O$ fato de a peça constituir-se de um auto, com moralidade católica, mas um diabo vestido de couro é um traço disso. Outro aspecto relevante e que merece atenção é a presença do palhaço.

Podemos dizer que ele é um traço metalinguístico no texto e também é um dos responsáveis pela comicidade da peça, sendo um ligado ao outro, quando ele organiza, por exemplo, a passagem do segundo para o terceiro ato, como pode ser observado a seguir:

PALHAÇO (entrando) : Peço desculpas ao distinto público que teve de assistir a essa pequena carnificina, mas ela era necessária ao desenrolar da história. Agora a cena vai mudar um pouco. João, levante-se e ajude a mudar o cenário. Chicó! Chame os outros.

CHICÓ: Os defuntos também?

PALHAÇO: Também.

CHICÓ: Senhor Bispo, Senhor Padre, Senhor Padeiro! Aparecem todos.

PALHAÇO: É preciso mudar o cenário, para a cena do julgamento de vocês.

3 "La otra faceta inconfesable del ser humano, la faceta antiheroica más elemental y natural". Eire, Reflexiones sobre la lengua del drama satírico, p. 93.

${ }^{4}$ Griffith, Satyrs, citizens, and self-presentation, p. 174. 
Tragam o trono de Nosso Senhor! Agora a igreja vai servir de entrada para o céu e para o purgatório. $\mathrm{O}$ distinto público não se espante ao ver, nas cenas seguintes, dois demônios vestidos de vaqueiro, pois isso decorre de uma crença no sertão do Nordeste. Agora os mortos. Quem estava morto?

BISPO: Eu.

PALHAÇO: Deite-se ali.

PADRE: Eu também.

PALHAÇO: Deite-se junto dele. Quem mais?

JOÃO GRILO: Eu, o padeiro, a mulher, o sacristão, Severino e o cabra.

PALHAÇO: Deitem-se todos e morram.

JOÃO GRILO: Um momento.

PALHAÇO: Homem, morra, que o espetáculo precisa continuar! (p. 134-136)

Da mesma forma, o coro de sátiros, no drama satírico, dança e canta de forma cômica, como relata Barbosa a seguir:

As danças báquicas da comédia e drama satírico figuram bailarinos bêbados possuídos pelo deus (é o caso das ninfas, sátiros, Pã e silenos). De acordo com Platão, suas posturas imitam ações que deveriam ser encomendadas para os escravos e estrangeiros (cf. Leis, 7, 816 e). Os espectadores, vendo o feio, saberiam reproduzir o seu oposto. (...) O coro de Dioniso, mais maduro e ciente, deve saber produzir - com seus gestos - tanto a nobreza e grandeza exigida na emméleia, dança da tragédia, quanto a vulgaridade e baixeza da síkinnis e do kórdax, danças do drama satírico e da comédia respectivamente. Elas são úteis para fazer conhecer o ridículo e grotesco (Barbosa, 2008, p. 5).

Ambas as peças apresentam, como se pode observar, personagens cômicos por natureza, além de a peça, seja ela o Auto da Compadecida ou qualquer drama satírico, também apresentar, em suas cenas, situações risíveis. Isso pode ser evidenciado nas trapalhadas dos protagonistas do auto ao enganarem os líderes religiosos da cidade convencendo-os a enterrar um cachorro (Primeiro ato), ou nos dramas satíricos, como o Ciclope, quando Sileno tenta enganar o ciclope Polifemo e Ulisses, arriscando convencer o primeiro de que estava protegendo os seus pertences da tentativa de roubo do herói grego.

Assim, é possível perceber que a peça Auto da Compadecida, de Ariano Suassuna, apresenta traços moralizantes e cômicos que remetem ao teatro grego do século $\mathrm{V}$, sobretudo à tragédia e ao drama satírico. $\mathrm{O}$ enredo e as personagens evidenciam ambas as características tanto na obra contemporânea como na antiga, evidenciando, dessa forma, os resquícios e herança clássica na cultura, no teatro e até mesmo na tradição brasileira. 


\title{
DiONISO E IL DIONISISMO: \\ le BacCanti di Euripide e la Morte a venezia di Thomas Mann
}

\author{
Anna Maria Belardinelli \\ Universidad de Mar del Plata
}

\begin{abstract}
Nelle Baccanti di Euripide il tema dominante è costituito dall'epifania di Dioniso che porta destabilizzazione nella vita dei personaggi coinvolti nella vicenda. Da questo nucleo tematico di base si diramano altri elementi narrativi: il ritorno del represso, la possessione, la contaminazione intesa come fenomeno ambivalente di perdita dell'identità, la fascinazione dell'ospite misterioso. Una eco del tema della contaminazione è stata individuata dalla critica nella Morte a Venezia di Thomas Mann. Ma le Baccanti, senza dubbio un pilastro della cultura occidentale, possono essere considerate un archetipo dell'opera di Thomas Mann che pure si è misurato per tutta la vita con il mito o i riecheggiamenti dei nuclei tematici della tragedia euripidea sono un ritorno di temi 'eterni'.
\end{abstract}

1. Nelle Baccanti di Euripide Penteo, ossessionato dal culto bacchico che ha indotto le donne di Tebe, tra cui la madre Agave e le di lei sorelle Autonoe e Inò, ad abbandonare le case per officiare i riti dionisiaci sul Citerone, viene informato di quanto accade sul monte dal Mandriano-Messaggero, che, giunto in scena, recita una lunga rhesis (vv. 676-774): le baccanti, definite in un primo momento un vero miracolo d'ordine per la compostezza con cui, una volta risvegliate dal sonno, si accingono a celebrare i riti dionisiaci (si sciolgono i capelli: v. 695; si assicurano alla spalla le nebridi, allacciandole con serpenti: vv. 696-698; allattano i cuccioli di animale: vv. 699-702; si cingono il capo con corone e con il tirso fanno prodigiosamente zampillare dal terreno acqua, vino, latte e miele, prova ed emblema della natura divina di Dioniso: vv. 704-713); si mostrano poi in tutta la loro eccitazione estatica, allorché il Messaggero e i suoi compagni mandriani tentano di catturare Agave e condurla prigioniera a Penteo: le baccanti fanno strage delle loro mandrie e delle loro greggi (vv. 737-747); con furia irrefrenabile mettono a soqquadro due borghi alle pendici del Citerone (vv. 748-764); infine, tornate nella radura montuosa da cui si sono mosse, lavano i loro corpi nelle sorgenti fatte scaturire miracolosamente (vv. 765-768). Il Messaggero, inorridito da quanto ha visto sul Citerone, conclude il racconto dicendo

Il 'demonio' chiunque egli sia, mio padrone, accogli in città: ché è grande in ogni cosa, 770 e dicono, a quanto sento, che abbia dato la vite che spegne agli uomini il dolore. 
Ese non cè il vino, non esiste Amore, non esiste un altro piacere per gli uomini ${ }^{1}$.

Penteo, che considera il nuovo culto bacchico alla stregua di un'epidemia ${ }^{2}$, decide quindi di recarsi al monte Citerone per punire le donne di Tebe. In realtà egli è vittima di Dioniso, che gli tende una trappola nella quale il giovane re cade irretito dal dio: travestito da Baccante per spiare i riti oggetto della sua ossessione, sarà brutalmente dilaniato dalla madre Agave, che, insieme alle sue sorelle, lo ucciderà convinta di essersi avventata su di un leone.

Il protagonista de La Morte a Venezia, lo scrittore Gustav von Aschenbach, in vacanza a Venezia per soddisfare un improvviso bisogno di evasione da una creatività metodica e faticosa ${ }^{3}$, una notte, in preda ad un'ossessione amorosa nei confronti di un giovane polacco, ospite dello stesso albergo, Tadzio, di bellezza androgina e molto simile a quella delle statue dell'arte greca classica, fa un sogno angoscioso e piacevole al tempo stesso: nella visione onirica si svolge un baccanale orgiastico, opera de "Il dio straniero" (Der Fremde Gott), cui fa da sfondo un'atmosfera improntata al suono, alla musica e al buio della notte. Da questo sogno Aschenbach, vittima di tale esperienza dionisiacaerotica $^{4}$, si risveglia senza forze e schiavo del demone. Come tutti gli amanti, desidera piacere e al tempo stesso è assalito da un'angoscia amara. Dinanzi alla dolce giovinezza di Tdazio che lo ha sedotto prova ripugnanza per il proprio corpo in declino. Pertanto si decide, dietro consiglio del barbiere dell'albergo, di tingersi i capelli e di truccarsi il viso; così 'travestito', si reca in spiaggia: qui osserva Tadzio, che sta giocando con gli amici; ma la morte, causata dal

${ }^{1}$ La traduzione qui usata è stata elaborata nell'ambito del laboratorio di traduzione di Theatron. Progetto Teatro Antico alla Sapienza da me coordinato cui hanno partecipato gli studenti di Lettere Classiche: nella redazione finale, in versi e per la messa in scena, è stata curata da Giovanni Greco cui si deve anche la regia de Le Baccanti di Euripide prodotte dal succitato progetto.

${ }^{2}$ Cf. vv. 778-779; ma si vedano già i vv. 343-344.

${ }^{3}$ Il tema su cui Thomas Mann ha incentrato la sua prima produzione è "quello della condizione artistica nella sua duplice essenza sublime ma inadeguata alla vita, eletta ma per ciò stesso segnata dalla sofferenza"...Aschenbach è il "grande artista paralizzato nelle sue capacità inventive, spinto dallo stallo della sua creatività all'abbraccio dell'eros dionisiaco con la morte" (Crescenzi 2011, pp. 21 e 22). Pubblicato nel 1912, Morte a Venezia conferisce a Thomas Mann, non ancora quarantenne e già famoso per il clamoroso successo giovanile dei Buddenbrook, la dignità di un classico della letteratura. Dalle stesse matrici narrative nasce, proprio tra il 1912 e il 1913, La Montagna Magica che, pensata come novella con l'aspetto di un "pendant umoristico", verrà poi pubblicata, in due volumi, nel 1924.

${ }_{4} \mathrm{Nel}$ testo tedesco Aschenbach-sognatore viene definito der Heimgesuchte: "i termini heimsuchen e Heimsuchung designano un concetto chiave che ricorre in tutta l'opera di Thomas Mann. La Heimsuchung, parola intraducibile nella sua polisemia, è idealmente connessa all'irruzione, repentina e violenta, di forze primordiali e incontrollabili. Nella rappresentazione letteraria manniana la Heimsuchung appare spesso sotto forma di una devastante esperienza dionisiaco-erotica" (Galvan 2009, pp. 250-251). 
colera che ha infestato Venezia, lo coglie nel mentre il ragazzo si dirige verso il mare e condivide con lui un ultimo sguardo. Lo scrittore è totalmente estasiato dall'irraggiungibile bellezza del ragazzo, il quale alza il braccio verso l'orizzonte, a voler indicare una via di salvezza che purtroppo non vi sarà.

Le affinità tra $\mathrm{i}$ due passi, sia contenutistiche (la descrizione dei comportamenti estatici causati da Dioniso) che strutturali (precedono la morte del protagonista vittima di un comportamento estatico), sono del tutto evidenti.

E' tuttavia questione dibattuta tra gli studiosi, germanisti e comparatisti, se nella costruzione della Morte a Venezia Mann sia stato influenzato da un'attenta lettura delle Baccanti di Euripide o, se, più genericamente, dalla sua cultura classica e, in particolare, quella mitologica, che gli derivano dallo studio di saggi, quali la Griechische Kulturgeschichte di Jacob Burckhardt e Psiche di Erwin Rohde ${ }^{5}$. Le allusioni a Dioniso e al dionisismo non sono infatti limitate al racconto del sogno e alla ripetuta citazione de "Il dio Straniero": esse costellano la narrazione da quando l'azione si sposta a Venezia per concentrarsi sul personaggio di Tadzio che incarna, oltre alle figure di Eros, Narciso, e Hermes psicopompo (per il succitato gesto con cui nel finale sembra accompagnare il protagonista verso il regno dei morti), anche quella di Dioniso: e per la bellezza androgina e per l'ossimorica sensazione, dolce e selvaggia, che pervade von Aschenbach, allorché lo scrittore sente pronunciare il nome del giovane: "Tadziu" . E, se è vero che la definizione di Dioniso quale "dio straniero" è ascrivibile alla lettura di Burckardt, il quale parla dell'originaria estraneità del dio dal pantheon ellenico ${ }^{7}$, è altresì vero che l'ossimoro sembra un puntuale riferimento alla tragedia euripidea e, precisamente, ai vv. 860-861, dove Dioniso-Straniero, in conclusione della succitata scena, a commento della decisione presa da Penteo, da lui convinto a travestirsi da baccante per recarsi al monte Citerone, afferma che il re conoscerà così la vera natura di Dioniso, che è dio fino in fondo, il più tremendo, ma il più dolce per gli uomini.

${ }^{5}$ Per la prima ipotesi, cf., ad esempio Dierks 1972, (cap. 1, in particolare pp. 13-14) che considera la novella come una riscrittura delle Baccanti sulla base di una serie di paralleli testuali, giungendo ad avanzare l'ipotesi di una edizione commentata della tragedia di Euripide come fonte primaria del racconto: il ricorso a Euripide sarebbe derivato da un rapporto molto stretto con La nascita della tragedia di Nietzsche. Di parere contrario Deuse 1992, pp. 41-62 e, da ultima, Galvan 2009, pp. 260-261, secondo i quali Mann avrebbe largamente attinto dai succitati saggi. Fusillo 2006 ritiene che "una lettura in chiave dionisiaca dell'intera Morte a Venezia sia ancora possibile se si supera l'impostazione in termini di modello strutturale, e si considera invece il rapporto con le Baccanti come un riecheggiamento, una variazione libera sul tema"(p. 186).

${ }^{6}$ Va notato che tra i suoni di sottofondo al sogno c'è quello della " $u$ prolungata", la vocale che predomina nella percezione di Aschenbach quando per la prima volta sente chiamare per nome Tadzio: per cui cf. Galvan 2009, p. 32.

${ }^{7}$ Cf. vol. II, p. 95. Per il tema dello straniero presente sotto forma di molteplici varianti in tutto il racconto, cf. Galvan 2009, p. 261, n.132. 
2. In favore dell'ipotesi che Mann abbia attinto direttamente al testo delle Baccanti e non si sia limitato alla lettura dei due succitati saggi (in particolare quello di Rohde per la descrizione del sogno) mi sembra si possano avanzare alcune considerazioni di carattere testuale. E' senz'altro indubbio che in incipit del racconto l'espressione ciceroniana motus animi continuus usata in riferimento all'ansia creativa di Aschenbach sia stata presa dall'epistolario Gustav Flaubert ${ }^{8}$. Tuttavia la descrizione dell'arrivo in ritardo di Tadzio a colazione a causa di un sonno prolungato ispira a Thomas Mann la citazione diretta del v. 249 del VIII libro dell'Odissea, dove si parla dei Feaci e della loro ottima qualità di vita che prevede musica, danze, bagni caldi, riposo 9 . D'altra parte l'arte di Mann - è stato notato - consiste anche nel saper utilizzare le fonti, nascondendone abilmente le tracce ${ }^{10}$. Mi sembra pertanto suggestiva la ricorrenza nel testo manniano di un termine come Dämon (demone) significativamente presente nel quinto e ultimo capitolo nel quale la presenza ominosa di Dioniso diventa più incombente: Aschenbach non riesce più a tener a freno la 'mania' di seguire Tadzio spinto nei suoi passi dalle indicazioni del demone e, in preda a questo eccitamento erotico, viene colto dal sogno 'dionisiaco' alla fine del quale è schiavo del demone. Ebbene, nelle Baccanti una parola chiave è appunto daimon, usato sempre, direttamente o indirettamente, in riferimento a Dioniso, nelle battute di Penteo (vv. 220, 256, 481), di Dioniso-Straniero (v. 23) e nelle succitate parole del messaggero (v. 769). Daimon è un termine, che, di etimologia incerta, indica nella lingua greca propriamente una potenza divina: da questo significato di base derivano due accezioni differenti tra loro, "dio" e "fato". Tale oscillazione semantica ('dio' e 'fato') si spiega anche con il fatto che daimon può riferirsi a una potenza non

${ }^{8}$ Si tratta di una lettera a Louise Colet del 15 luglio 1853. In Cicerone (nel dialogo De oratore), in luogo di continuus, si legge, in realtà, toties o celeres. Sulla questione e sui rapporti di Mann con l'epistolario di Flaubert, cf. Galvan 2009, p. 242.

${ }^{9}$ La citazione è tratta dalla traduzione di Johann Heinrich Voß (1781), il quale tuttavia rende eunai del v. 249 con "Ruhe", "riposo" e non "amore": euné, che indica propriamente il letto, può essere usato anche in riferimento al letto coniugale e dunque all'amplesso amoroso. Per il rapporto di Mann con i testi greci classici, si veda Fertonani 1975, pp. 17-26 e, da ultima, Galvan 2009, pp. 251-255.

${ }^{10}$ Cf. Crescenzi 2011, p. 27, che adduce come significativo esempio di questa tecnica manniana una citazione da Heinrich Wölfflin, il quale in uno studio del 1905 su Albrecht Dürer forniva una interpretazione dell'incisione Melencolia I sulla base della visione tradizionale della genialità melencolica. La lettura di questo saggio avrebbe messo Mann per la prima volta in contatto con il pensiero della melencolia geniale della tradizione medico-filosofica dalla quale avrebbe tratto ispirazione per i personaggi dei suoi romanzi, da Aschenbach a Hans Castorp della Montagna magica. In Morte a Venezia la citazione occulta di Wölfflin "è collocata in un punto poco appariscente del racconto, all'inizio del viaggio di Gustav von Aschenbach da Pola alla volta di Venezia; ma è assai ben mascherata e per coglierla bisogna ricordare le parole con cui Wölfflin aveva reso, nel suo studio, la scena rappresentata da Dürer nell'incisione” (pp. 2728). 
tout court divina, e, tuttavia, non umana, una sorta di potere occulto di cui non si vuole o non si può pronunciare il nome: a partire da Esiodo infatti il termine viene usato per indicare un semidio, un demone e, acquisendo via via fino all'era cristiana una valenza sempre meno vaga e contestualmente sempre più negativa, viene utilizzato per indicare uno spirito maligno. Nelle Baccanti il daimon Dioniso è una forza divina che non si può nominare: dio dell'ambiguità, Dioniso è "demone/demonio". ${ }^{11}$ La presenza di Dämon nel testo tedesco in due punti significativi della sezione dionisiaca del racconto non può essere stata determinata dalla sola lettura di Burckhardt e di Rohde. A mio parere indica una riflessione diretta sul testo euripideo, seppure filtrata da una traduzione. In questo senso mi sembra anche non casuale la definizione del gruppo baccanale attivo nel sogno come 'branco' (Rotte): thiasos, altra parola chiave della Baccanti (ricorre tredici volte), indica un' istituzione caratteristica del mondo arcaico e classico greco, e, in particolare, una istituzione pedagogica delle donne in Grecia le cui modalità organizzative sono determinate dal culto a una divinità dalla quale tutto promana e alla quale tutto si conforma. Nelle Baccanti l'istituzione femminile indicata con thiasos è in realtà un gruppo di donne che vive in condizione animale: diventare seguace di Dioniso assicura, come annuncia il Coro nella parodo (vv. 65-166), la liberazione dagli affanni e dalle pene, ma comporta anche lo smarrimento, l'oblio di sé e l'assunzione di una forza e di un comportamento di tipo animalesco che rimette il/la baccante in contatto con la parte più istintuale, elementare, irrazionale ${ }^{12}$.

Certo a livello tematico si può notare che la morte di Aschenbach non è una morte violenta, tragica e punitiva, come quella di Penteo; al contrario è intrisa di eros, ed è soprattutto "un evento totalmente privato: la morte di un borghese di fronte al suo io, al suo corpo, al ruolo che gli ha dato la società, mentre quella di Penteo è un evento collettivo: la morte di un re che non ha saputo affrontare le forze che sconvolgevano la propria comunità"13. Tuttavia non si può non tener conto che le Baccanti, composte in un momento di crisi della società ateniese e della cultura periclea ${ }^{14}$, riflettono un esasperato

${ }^{11}$ E' invece sinonimo di theos presente negli interventi del coro (v. 75) e di Tiresia (vv. 200, 298), occorrenze nelle quali chi parla crede nell' essere divino e non demonico di Dioniso.

${ }^{12}$ La condizione animale nel mito dionisiaco (e nelle Baccanti di Euripide) si realizza anche e soprattutto nelle ipostasi del dio: Dioniso s'incarna di volta in volta in un toro, in un leone, in un serpente e i/le suoi/e seguaci/e, in preda alla trance, lo vedono e lo adorano nelle sembianze di uno di questi animali sacri (come toro lo vede anche Penteo: vv. 616-626).

${ }^{13}$ Fusillo 2006, p. 202.

${ }^{14}$ Le Baccanti, messe in scena postume, probabilmente nel 403 a. C., segnano la fine sia dell'attività di Euripide sia di quel genere teatrale con cui l'Atene del V secolo a.C. aveva raggiunto la massima espressione artistica. La sconfitta subita da Atene nel 404 è un evento storico che determina una svolta epocale per la polis classica, nella quale si instaura un nuovo rapporto tra la città e l'individuo. Si avvia così quel processo politico, economico e culturale che si compirà con l'avvento dell'Ellenismo. 
senso dei ristretti limiti della condizione umana, una consapevolezza della fragilità dell'uomo che cerca di sopravvivere ricorrendo a scelte edonistiche e a vie di fuga ed evasione ${ }^{15}$. Le Baccanti sono dunque, al pari di numerosi altri drammi euripidei, una tragedia 'moderna' che può essere stata sentita da Thomas Mann vicina a quelle istanze intellettuali e poetiche del suo tempo: la vicenda di Gustav von Aschenbach, che evade dalle limitazioni della sua esistenza di scrittore non solo geograficamente, ma anche edonisticamente, diventa l'occasione perché le allusioni e le citazioni dal testo euripideo, lungi dall'essere uno sfoggio di mera erudizione, siano la cornice dentro la quale dare voce alle riflessioni sulla cultura romantica e decadente, il cui tema per eccellenza amore e morte si intreccia con l'insaziabile aspirazione all'infinito e all'illimitato, al raggiungimento della libertà dello spirito quale affrancamento dalle ristrettezze della condizione terrena.

Una cultura in cui, sebbene si sia affermata la scoperta dell'inconscio che porta alla considerazione dell'uomo come natura duplice e in continua lotta per la conquista della propria identità ${ }^{16}$, le parole pronunciate dal Coro nel terzo stasimo delle Baccanti a commento dell'evasione 'bacchica'

\author{
Felice chi dal mare \\ fugge tempesta e tocca porto; \\ felice chi dimentica gli affanni; \\ solo chi sta nel giorno per giorno è \\ felice, quella è la beatitudine (vv. 902-911) \\ suonano terribilmente e dolcemente appropriate.
}

${ }^{15}$ Così Di Benedetto 1971, pp. 271-302, il quale a ragione osserva che non bisogna chiedersi se le Baccanti siano o no la testimonianza di una conversione di Euripide alla religione dionisiaca.

${ }^{16}$ Giova ricordare che Thomas Mann nel 1924 pronuncerà un discorso in lode di Ricarda Huch, autrice di uno studio sul Romanticismo, apparso in due volumi tra il 1899 e il 1902 nel quale la questione romantica viene per la prima volta considerata il punto di partenza per l'elaborazione di un manifesto della modernità: la Huch riconosce ai romantici il merito storico di essere stati i veri "scopritori dell'inconscio". Sul rapporto di Thomas Mann e Ricarda Huch, cf. Crescenzi 2011, pp. 15-19.ß 


\section{Bibliografía}

Luca Crescenzi, Melancolia occidentale. La montagna magica di Thomas Mann, Roma, 2011.

W. Deuse, Besonders ein antikisierendes Kapitel scheint mir gelungen: Griechisches in "Der Tod in Venedig", in G. Härle (a cura di), Heimsuchung und süßes Gift": Erotik und Poetik bei Thomas Mann, Frankfurt a. M., pp. 41-62.

Vincenzo di Benedetto, Euripide: teatro e società, Torino, 1971.

Manfred Dierks, Studien zu Mythos und Psycologie bei Thomas Mann, München, 1972.

Eric R. Dodds, Euripides Bacchae, Oxford, 1960 (2a ed.).

Roberto Fertonani, Echi classici in Der Tod in Venedig di Thomas Mann, "Acme" 23, 1975, pp. 17-26.

Massimo Fusillo, Il dio ibrido. Dioniso e le "Baccanti" nel Novecento, Bologna, 2006.

Elisabeth Galvan (a cura di), Thomas Mann. La Morte a Venezia, Venezia, 2009. 


\title{
Mauricio Kartun como adAPtador del teatro griego: COMEDIA Y UTOPÍA
}

\author{
Milena Bracciale Escalada \\ Universidad de Mar del Plata \\ El hombre, siguiendo dicho ideal, \\ llegará a ser un superpájaro que, \\ lejos de nuestra atmósfera, \\ cruzará los espacios infinitos entre los mundos, \\ transportado a su verdadera patria, \\ a una patria aérea, por fuerzas aromales.
}

Gastón Bachelard

\begin{abstract}
A través de esta ponencia proponemos abordar el texto dramático Salto al cielo de Mauricio Kartun, estrenado en el Teatro de la Campana el 4 de noviembre de 1991, con dirección de Villanueva Cossa, como una adaptación no ortodoxa de Las Aves de Aristófanes. El objetivo es determinar en la selección que hace Kartun, en tanto escoge no sólo una comedia dentro del vasto repertorio griego, sino también una pieza marginal dentro de la producción de Aristófanes. En este sentido, observar la elección de un género menor y de una pieza marginal, así como también las modificaciones que Kartun ejerce en dicha adaptación con respecto al original, sumado al modo en que allí funciona el concepto de utopía, nos permite acercarnos a ciertas particularidades de la poética del autor que pueden ser relacionadas con la totalidad de su obra y, además, con el contexto inmediato de producción de la pieza: la Argentina de principios de los 90.
\end{abstract}

De acuerdo con Patrice Pavis ${ }^{1}$, la adaptación es un trabajo dramatúrgico a partir de un texto destinado a ser escenificado. A diferencia de la traducción, esta práctica teatral no teme modificar el sentido de la obra original, por el contrario, goza de gran libertad. La relectura de los clásicos es un tipo de adaptación bastante frecuente que implica una intervención, una reescritura, una recreación que, lejos de ser inocente, compromete la producción de sentido. A partir de esta idea, proponemos analizar la adaptación realizada por Mauricio Kartun de "Las Aves" de Aristófanes en su obra "Salto al cielo", estrenada en el Teatro de la Campana a fines de 1991, bajo la dirección de Villanueva Cosse. Nos interesa observar las razones que operaron en Kartun para seleccionar como fuente dicho texto $y$, a su vez, plantear las posibilidades de reconocer

${ }^{1}$ Pavis, Patrice, Diccionario del Teatro. Dramaturgia, estética, semiología, Buenos Aires, Paidós, 2007, p. 35-36. 
en esta elección y en la construcción del nuevo texto rasgos particulares de su poética de autor.

Tal como él mismo relata ${ }^{2}$, este trabajo surgió a partir de un pedido por parte del Teatro Nacional Cervantes ${ }^{3}$ de un texto para su temporada. Para ese entonces, Kartun ya era un dramaturgo consolidado en la escena porteña aunque aún no dirigía sus propias piezas, actividad que emprendió recién en la última década. Según sus propias palabras, llegó a "Las Aves" de Aristófanes por azar. Sin embargo, desde nuestra perspectiva, ese acto aparentemente azaroso no se produjo por mera casualidad. En primer lugar, dentro del vasto repertorio de clásicos griegos Kartun opta por la comedia, es decir que, en comparación con la tragedia, su primera elección es la de un género menor e, incluso, dentro de la producción de Aristófanes, selecciona de las once comedias que de él se conservan una de sus piezas menos reconocida. Aquí aparece, entonces, una primera peculiaridad que puede relacionarse con la poética general del autor: la opción por lo marginal o, dicho de otra manera, el trabajo creativo a partir de un género menor.

En segundo término, la antigua comedia ateniense, de quien Aristófanes fue no sólo el principal cultivador sino prácticamente su único representante, reúne dos características centrales que a nuestro entender cifran otras dos marcas insoslayables de la estética dramatúrgica de Kartun: el carácter político y el humor. Es sabido 4 que tanto la comedia como la tragedia nacieron en las fiestas de Baco, cuyo culto contenía multitud de elementos dramáticos. Pero la primera, a diferencia del carácter serio y triste que adquirió la tragedia conforme a los sufrimientos aparentes del dios, se desarrolló a partir de la más desenfadada alegría. Parte de estos festejos lo constituía el comos, festín bullicioso con picarescos chistes y canciones de sobremesa, donde los convidados se entregaban medio beodos a danzas desenvueltas y entonaban un himno a Baco en el que al dios del vino se asociaban Falo y Fales, representantes de la fuerza generatriz de la naturaleza. A esta canción báquica se le llamaba la Comedia y solía repetirse en una procesión que se organizaba luego del festín. Los comensales, disfrazados con grotescas máscaras, con coronas de flores y tiznados de vino recorrían en carros el lugar donde se llevaba a cabo la fiesta. Finalmente, esta ebria mascarada buscaba como blanco de sus burlas al primero que se le ofrecía ante su vista y lanzaba sobre él un verdadero diluvio de chistes irrespetuosos, resaltando los defectos del elegido a viva voz y avergonzándolo frente a la multitud.

\footnotetext{
${ }^{2}$ Dubatti, Jorge. Reportaje, "El teatro de M. Kartun: Identidad y utopía”, en Kartun, Mauricio, Teatro, Buenos Aires, Corregidor, 1993, pp. 279-286.

${ }^{3}$ Finalmente, la puesta en el teatro Cervantes nunca se concretó, de ahí que el texto haya sido estrenado en el Teatro de la Campana.

${ }^{4}$ En Baráibar y Zumárraga, D. Federico, "Introducción” a Comedias de Aristófanes. Tomo primero, Madrid, Hernando, 1942, pp. 1-16.
} 
Así, la comedia nació de las fiestas dionisíacas y con su natural alegría e imaginación pasó pronto a la censura del ciudadano particular, aspirando a la justicia y la virtud, proponiendo en medio de las ironías y las enormes chanzas un ideal al espectador, señalando al vicioso por su propio nombre. De aquí el carácter eminentemente político de la comedia, que con la afición de intervenir en el gobierno y en la constitución democrática de Atenas, llegó a convertir a la escena en una segunda tribuna, juzgando con audacia las decisiones que el pueblo adoptaba en el Ágora y proponiendo además reformas y medidas. A partir de lo descripto, es factible sostener que Kartun encontró en Aristófanes un mundo poético y una atmósfera dramática que se relacionaba directamente con su propia producción: un teatro eminentemente político, donde la crítica al statu quo se ve atravesada por el humor, el desenfado y la sexualidad.

Ahora bien, dentro de este mundo general con el que Kartun se identifica como autor, "Las aves" condensa en una sola obra otros dos hitos constitutivos de su dramaturgia: la utopía y la patria como búsqueda de una identidad. En sus propias palabras ${ }^{5}$ :

Por otro lado reaparece aquí, como dije antes, una constante de mis desvelos: la utopía, la dificultad de su concepción, las imposiciones de la realidad (...) Salto... es mi humilde aporte a la polémica. Creo en la necesidad vital del hombre de construir utopías. Sin ellas sólo nos queda del deseo, su cadáver; la utopía es el vehículo de ese deseo, es su camino y su motor. Sin ella sólo nos quedaría responder a nuestras necesidades más inmediatas, más primarias. Deseo es pasión, y sin ella es imposible toda concreción histórica (...) a la muerte de una utopía corresponde el nacimiento de otra, y éste es un acto orgánico, vital, independiente de toda voluntad especulativa.

Siguiendo los aportes de Gastón Bachelard ${ }^{6}$, podemos incluir, primero a "Las Aves", y luego, por añadidura, a "Salto al cielo", cuyo título es elocuentemente ilustrativo al respecto, dentro de las imágenes literarias que pertenecen a la imaginación ascensional y en relación con una filosofía del movimiento. De acuerdo con este autor:

Entre todas las metáforas, las de altura, de elevación, de profundidad, de rebajamiento, de caída, son metáforas axiomáticas por excelencia. Nada las explica y lo explican todo. O, en forma más simple: cuando se las quiere vivir, sentir y sobre todo compararlas, se comprende que llevan un signo esencial y que son más naturales que todas las demás. Nos comprometen más que las metáforas visuales, más que cualquier imagen resplandeciente (...) tienen un

\footnotetext{
${ }^{5}$ Dubatti, Jorge, Op. cit., pp. 285-286.

${ }^{6}$ Bachelard, Gastón, El aire y los sueños. Ensayo sobre la imaginación del movimiento, México, Fondo de Cultura Económica, 1958.
} 
poder singular: dominan la dialéctica del entusiasmo y de la angustia (...) No se puede prescindir del eje vertical para expresar los valores morales. (pp. 2021)

De esta manera, es factible sostener que tanto la obra de Aristófanes como la de Kartun se construyen como una gran metáfora, donde la acción imaginante, tal como explica Bachelard ${ }^{7}$, consiste en deformar las imágenes suministradas por la percepción, esto es, en proponer uniones inesperadas de imágenes. Sumado a esto, resulta ilustrativo enfatizar que el epíteto del sustantivo "aire" es, precisamente, "libre" y que, por lo tanto, las metáforas asociadas al vuelo y a la ascensión hacen hincapié, de manera transversal, en la valoración de la libertad. Tanto en el texto clásico como en su reescritura, el eje de la trama es un viaje emprendido por dos hombres, jóvenes en el caso de Kartun, que huyen de su patria, cansados de las injusticias y de la vida que allí se lleva, en busca de un mundo mejor. Quieren fundar una ciudad e interrogan para ello a un pájaro, que ha sido antes hombre y que por lo tanto ha recorrido todo el universo conocido y podrá indicarles el lugar propicio para ese acto. Tal sitio, por supuesto, no existe. $Y$ es así como se les ocurre fundar la ciudad en el cielo, interrumpiendo de esa manera el trato que existe entre los dioses y los hombres, y devolviéndole el poder a los pájaros, originales dominadores del universo.

Kartun va a tomar como modelo la obra de Aristófanes, llevando al extremo los procedimientos de este autor e imprimiéndole su sello personal. Lo primero que salta a la vista es el uso de tipos de aves locales, presentes en la geografía latinoamericana, frente a las que usa Aristófanes. Así, si bien conserva el nombre de los dos protagonistas, Evélpides y Pistétero, utiliza como aves artífices de la escena al tero, al colibrí, al flamenco, al biguá. Esta transformación evidencia una intención deliberada de vincular al texto con el contexto de producción y escenificación, de forma tal que el espectador/lector no sienta un distanciamiento producido por nombres extraños o ajenos a su cotidianeidad.

En la obra de Aristófanes ${ }^{8}$, Evélpides, en un momento, le habla directamente al público: "No lo olvidéis, espectadores: nuestra enfermedad es completamente opuesta a la de Sacas"(P. 9). Este procedimiento que en la época, y sobre todo en la comedia, sería corriente, no es de todas maneras algo que llame la atención en la pieza, pues se da solo en unos pocos momentos y con

\footnotetext{
${ }^{7}$ Bachelard, Gastón, Op.cit.

8 Aristófanes, Las aves, en Comedias completas. Volumen II, Barcelona, Iberia, 1957, pp..546. En las próximas referencias textuales a esta obra se indicará el número de página entre paréntesis.
} 
referencias muy sutiles, como la expuesta. Sin embargo, Kartun, como ya hemos dicho, extrema algunos de los procedimientos que aparecen en germen en Aristófanes. Y éste es uno de esos casos, ya que desde el principio de "Salto al cielo" el personaje del Tero oficia de narrador, interrumpiendo las escenas para realizarle comentarios al público o presentar lo acontecido. En sus palabras, el humor, la ironía y la autorreferencialidad serán marcas constitutivas. Así, leemos al comienzo de la obra:

TERO - Historia de los pajaritos. Obsérvese. Obra de teatro. ¿Por qué las aves siempre se van? ¿Es el murciélago un ave o qué? ¿Por qué los pájaros gritan al atardecer? Y otros interesantes misterios de la ornitología. Todo acá según el amigo: Belenopterus Cayennensis: Tero, Terencho o Teruteru. En un solo día aristotélico al fin. Que en otro tiene los huevos. Noche oscura en esta fábula. Minutos antes del amanecer en esta fábula. Un páramo. Allá piedras. Allí precipicio. Comedia: imitación de los hombres - como se ha observado - peor de lo que son. Evélpides, atrás Pistétero. Jóvenes. Abandonan su patria cansados de la injusticia de esa tierra, y llegan a estos aires, a esta escena, anhelando un lugar donde fundar un mundo mejor. Buscan en su marchita al extravagante Picaflor, el colibrí que alguna vez fue humano, para que él les recomiende en su sabiduría de viajero el territorio donde elevar ese mundo nuevo (p. 229).

La cita precedente, que es además el primer texto de la obra, permite observar ya la mayoría de los procedimientos llevados a cabo por Kartun en esta pieza. Primero, la presencia de un narrador que irá no sólo haciendo comentarios al respecto de la trama, sino también relatando al público el paso del día. Segundo, la autorreferencialidad a esta pieza en particular y al teatro en general. Irónicamente, el Tero hará referencias metateatrales a las imposiciones aristotélicas, al supuesto respeto que implica el abordaje de un clásico y será, asimismo, el encargado de nombrar puntualmente a Aristófanes así como también de ser el portavoz del autor brindando su visión del teatro: "La comedia es siempre una utopia en escena. Tero. Todo sueño es creible, todo recurso es verosímil. Obsérvese" (p. 251). En tercer lugar, aparece el juego de palabras como una de las formas a través de las cuales se genera el humor. Así, se observa en la cita el juego, por ejemplo, con el sustantivo "marchita", que indica literalmente la marcha, el traslado, el recorrido de los jóvenes, a través del uso del diminutivo, pero que también refiere como adjetivo a la condición de una flor muerta, y que metafóricamente alude a esa patria abandonada, donde los sueños ya no pueden concretarse. Así, más adelante, el Tero será el encargado de "en-terar"

${ }^{9}$ Kartun, Mauricio, Salto al cielo, en Teatro, Op. cit., pp. 227-278. En las siguientes citas a este texto se indicará el número de página entre paréntesis. 
al público sobre lo acontecido, oficiando de este modo como una especie de “por-tero" "...que cuenta patrañas en la puerta” (277-8) y, finalmente, será un "embus-tero", ya que hacia el final se descubrirá que escondido debajo de una máscara fue el pajarero que les vendió los cuervos como guía a los jóvenes para encontrar al picaflor. Toda la obra está llena de juegos de palabras, que sumado a la ironía de muchos de los parlamentos, al uso satírico de los refranes populares y los lugares comunes, a los encuentros sexuales entre Procne y Evélpides y a las acciones payasescas de golpes y equívocos entre Neptuno, Hércules y el Pez Piloto, otorgan al texto un ritmo ágil propio de la comedia, donde el juego y las referencias humorísticas son constantes. En la cita se observa además la concepción de la obra, de la "escena", como "aire", así como también el uso del infinitivo "elevar" en el sentido de construir el nuevo mundo, pero también en el sentido de ascender. Esta pieza es, justamente, eso. Un ascenso al mundo de los sueños, donde todo es posible. Sin embargo, tal como afirma Pistétero, " $;$ Lo difícil no es ascender, pájaro, sino mantenerse en el aire!” (Kartun: 267). Y, así, con esta frase, se resume la concepción de Kartun de la utopía como una búsqueda permanente.

Entre las modificaciones que Kartun le imprime a la pieza de Aristófanes, aparece, además de las ya mencionadas, otra más que nos gustaría destacar y que se relaciona directamente con la poética autoral de Kartun: el cruce de registros. Así, lo coloquial se cruza con lo culto, y las referencias locales y/o profanas se entremezclan con las alusiones al mundo de la antigüedad clásica. Del mismo modo, Evélpides entona subrepticiamente una canción, intercalándose así entre el diálogo de los personajes y el relato a público, la música que, simboliza, además, una de las particularidades de los pájaros: el canto. En esta canción, Evélpides resume la mayoría de las ideas que venimos describiendo y que, además, fueron descriptas por Bachelard como características de la imaginación ascensional:

Amasando deseos la cabeza / como el barro en la rueda, el alfarero / pongo manos a la arcilla de mis sueños / modelando la tierra que venero / (...) Un viento en llamas que se llama libertad. / Por ellos toco mi cielo con las manos, / siembro esos vientos y recojo eternidades, / echo a volar en alas de su soplo, / y hago de cosas en el aire, realidades. / Ese es el mundo que pongo por las nubes / mi mundo airoso, un mundo de alto vuelo / regia región, nación aún no nacida... (pp. 236-7)

Como se observa, la cita está plagada de imágenes o metáforas del ascenso: viento, cielo, volar, alas, soplo, nubes, aire, airoso (en el sentido de poseedor de mucho aire). Y éstas, a su vez, tal como sostiene Bachelard, se relacionan directamente con la idea de libertad. Se trata de la constitución de una realidad otra, de la posibilidad de desear, de soñar, de modificar lo establecido. Tanto es 
así, que Kartun agregó aún más detalles al sueño de fundar una ciudad en el aire propuesto por Aristófanes, incorporando, por ejemplo, al personaje de Ícaro, ausente en Aristófanes, estableciendo una suerte de genealogía entre aquellos que han soñado con la posibilidad de elevarse en el aire, e incluso, como Dédalo, han perdido la vida en el afán de volar. El mito de Ícaro representa el fracaso, aunque no por eso el abandono del sueño. La imagen de la cabeza amasando deseos como metáfora de pensar, de imaginar, de soñar, se relaciona asimismo con la visión que Kartun tiene del teatro: un espacio privilegiado para explotar al máximo la imaginación, un espacio de entretenimiento, donde el humor sea un elemento constitutivo, pero, a su vez, donde ese humor esté plagado de ironía y esa ironía de crítica. El teatro puede, de esta forma, contribuir a la constitución de una identidad, en el sentido de que funciona como un relato de la patria y, con esta obra en particular, puede contribuir a la utopía de fundar una nación, en el sentido primigenio de la palabra: como nacimiento de algo nuevo. Así, tal como afirma Bachelard, los valores morales son indisociables de la verticalidad. Y aquí, por moral se entiende la constitución de un mundo justo.

En "Salto al cielo", a pesar de ser una adaptación directa del modelo griego, pueden percibirse con claridad los rastros de la poética de autor de Kartun, de sus obsesiones como dramaturgo, de su estilo escriturario. Así, decide escribir a comienzos de los años `90 para escenificar en un teatro nacional una obra clásica que es eminentemente política y que critica abiertamente la situación actual del país; una obra que funciona como desafío a la realidad, entendiendo por ésta los lugares comunes, la pretendida sensatez: “Sensatez! ¿Qué valor es ese, compañero, que te corta las alas...?"(240). El teatro, de esta manera, funciona como la posibilidad de "prestar alas" al espectador, aplacando el lado racional e intensificando la fantasía, la creatividad y la imaginación para concebir el mundo. Tal como afirma el Tero, "Hasta prestar alas es posible. Un acto de lesa literatura que si le sirvió a Aristófanes, bien le puede servir a este tero" (252). E1 teatro como una apuesta al futuro.

Como conclusión, creemos, junto con Laura Mogliani ${ }^{10}$, que se trata de una adaptación no ortodoxa realizada por Kartun y que, tal como afirmábamos con Pavis al comienzo de estas páginas, adaptar implica intervenir, reescribir, recrear, en un acto que, lejos de ser inocente, compromete la producción de sentido. Así es como Kartun no elige inocentemente la pieza a adaptar ni el autor al que pertenece, sino que ya en esa elección hay una primera operación cargada de un fuerte sentido, en tanto revela la concepción que el dramaturgo posee del teatro. Aristófanes condensa el cruce entre lo marginal, lo menor,

${ }^{10}$ Mogliani, Laura, “Salto al cielo: el desarrollo de una utopía”, en Pellettieri, Osvaldo (Ed.), Teatro Argentino de los '90, Buenos Aires, Galerna, 1992, pp. 79-83. 
lo popular, el humor, la irreverencia, la crítica, la política, las imágenes fálicas. El conflicto en ambas piezas se suscita cuando la realidad impone conflictos materiales para la construcción de la ciudad, cuando el hombre, "ventajero", pretende favorecerse individualmente con el nuevo proyecto; y alcanza su clímax cuando los dioses descubren que su relación con los hombres se verá interrumpida y que se si funda esa ciudad perderán poder sobre el universo. Así, la obra termina con una especie de paz a medias, a través del casamiento de Evélpides con una ninfa, pero la realidad es que ese proyecto contradice el deseo original de los jóvenes. Por ello, aunque Kartun respeta la escena final del matrimonio, plantea un cierre circular en tanto el biguá y el flamenco planean la continuidad de la utopía ya no en el aire, pues ese espacio ha sido también viciado, sino bajo las aguas:

¡Hay un mundo allí bajo las aguas, como esperando que uno lo desnude! ¿No te provoca? ¿Qué harás aquí, Canario? ¿Cantarás en la corte? (...) Demencia es no cambiar nada ¿Loco es lo imposible? ¡Y qué, si lo posible es apenas imbécil! (...) (Flamenco y Biguá, con una última mirada de despedida levantan vuelo y parten) (276-277)

La obra se construye, entonces, no como una simple adaptación sino como la voluntad explícita de producir un nuevo sentido a partir del original. Un sentido que se relaciona directamente con el contexto de producción, pero que además no se contenta con el final "a medias" propuesto por Aristófanes sino que implica la escenificación del pensamiento de Kartun que citamos en las primeras páginas: a la muerte de una utopía le corresponde el nacimiento de una nueva, y así hasta el infinito. 


\section{Bibliografía}

\section{Fuentes primarias:}

Aristófanes, Las aves, en Comedias completas. Volumen II, Barcelona, Iberia, 1957.

Kartun, Mauricio, Salto al cielo, en Teatro, Buenos Aires, Corregidor, 1993. Reportaje final de Jorge Dubatti.

\section{Bibliografía teórico-crítica:}

Bachelard, Gastón, El aire y los sueños. Ensayo sobre la imaginación del movimiento, México, Fondo de Cultura Económica, 1958.

Baráibar y Zumárraga, D. Federico, "Introducción” a Comedias de Aristófanes. Tomo primero, Madrid, Hernando, 1942.

Mogliani, Laura, "Salto al cielo: el desarrollo de una utopía”, en Pellettieri, Osvaldo (Ed.), Teatro Argentino de los `90, Buenos Aires, Galerna, 1992.

Pavis, Patrice, Diccionario del Teatro. Dramaturgia, estética, semiología, Buenos Aires, Paidós, 2007. 


\title{
UMA ELECTRA PORTUGUESA DO SÉcUlO XVIII: \\ "TRAGEDIA EM GINCO ACTOS, TIRADA DA HISTORLA GREGA", DE Francisco Dias Gomes
}

María Fernanda Brasete

Universidade de Aveiro

\begin{abstract}
O objectivo principal desta comunicação é explorar as ressonâncias da antiga tragédia grega na Electra de Francisco Dias Gomes, impressa em 1799 na Tipografia Régia Silvina no século XVIII, uma obra rara e muito pouco conhecida, presentemente disponível na Web em formato digital.
\end{abstract}

0. Em 1799, um ano depois de ter publicado Ifgénia ${ }^{1}$, Francisco Dias Gomes $^{2}$ imprime na Tipografia Régia Silvina uma tragédia «em cinco actos, tirada da História Grega», intitulada Electra ${ }^{3}$. Se tomarmos em consideração a opinião de Luiz Francisco Rebello4 de que Portugal não é «um país de forte tradição dramatúrgica», e se reconhecermos que as traduções, adaptações ou recriações do teatro greco-latino tiveram um carácter episódico, especialmente até ao século XX, esta tragédia setecentista sobre Electra constitui um exemplo assaz singular na história da recepção da tragédia grega no Teatro Português.

Pertencendo a um grupo de autores portugueses do século XVIII quase desconhecidos, apesar de o seu nome aparecer referenciado oito vezes no Dicionário de Literatura de Jacinto Prado Coelho 5 , a importância de Francisco Dias Gomes (1745-1795) deverá medir-se, em primeiro lugar, pelo contributo literário-cultural que prestou à época setecentista, enquanto poeta (Obras Poéticas, 1799), filólogo (Análises e Combinaçôes Filológicas, 1745-1795) e crítico literário, além de autor de duas tragédias inspiradas em arquétipos

${ }^{1}$ Francisco Dias, Ifggenia: tragedia tirada da historia gregal de Francisco Dias, Lisboa, Off. de João Antonio da Silva, 1798, 76 pp., 15 cm. Exemplar em mau estado de conservação. Obra digitalizada a partir do original. OMGAR 2537p (ULFL-OM). http://bibliotecadigital.fl.ul.pt/ ULFLOM02552/ULFLOM02552_item1/

${ }^{2}$ Se bem que fosse este o nome completo do autor, o apelido "Gomes" aparece como um acrescento manuscrito na capa de rosto da peça e, geralmente, não figura nas citações bibliográficas da sua obra, como se pode comprovar, por exemplo, na "Biblioteca Digital" da Faculdade de Letras da Universidade de Lisboa. Esse foi o critério adoptado neste estudo.

${ }^{3}$ Francisco Dias, Electra: tragedia em cinco actos, tirada da historia grega / de Francisco Dias, Lisboa, Typ. Régia Silvina, 1799, 108 pp., $16 \mathrm{~cm}$. Obra digitalizada a partir do original. OMGAR 2536p (ULFL-OM). http://bibliotecadigital.fl.ul.pt/ULFLOM02551/ULFLOM02551_ item1/ A partir de agora, todas as citações da Electra de Francisco Dias Gomes serão feitas a partir do ano (1799) desta edição digitalizada, seguido do número da(s) página(s).

${ }^{4}$ Fragmentos de uma Dramaturgia, Lisboa, Imprensa Nacional-Casa da Moeda, 1994, p. 155.

5 Vd. Vol. 5, "Índices", p. 1274. 
gregos - Ifigénia e Electra. Uma vez que estas duas peças têm sido praticamente ignoradas pelos estudiosos do Teatro Português ${ }^{6}$, pensei que este seria um momento oportuno para ensaiar um breve estudo da tragédia Electra, a heroína trágica que mais tem marcado o meu percurso académico.

1. No âmbito da recepção da tragédia grega na literatura portuguesa setecentista, a Electra de Francisco Dias Gomes rememorava, em finais do século XVIII, o conflito trágico protagonizado por uma das mais célebres protagonistas da tragédia sofocliana. Tendo em linha de conta que estamos perante uma tragédia estruturada em actos e composta em versos decassilábicos, será possível prever, de imediato, que a relação de intertextualidade mantida com o texto arquetípico conciliava a retoma dos modelos greco-latinos consagrados com uma estética teatral fermentada pelo anseio de originalidade. Sob a influência do novo alento que o movimento arcádico concedera ao teatro clássico, Manuel de Figueiredo, um prolixo autor dramático ${ }^{7}$, que se empenhou a fundo na renovação do teatro nacional, lera na Arcádia em 1757 a sua tragédia Édipo. tendo posteriormente composto uma Andrómaca, inspirada em Racine e Eurípides. Se bem que relativamente esparsa no panorama heterogéneo do teatro setecentista português, a recuperação do modelo trágico legado pela Antiguidade tendia a mostrar-se ainda demasiadamente presa a questões genológicas e de estilo, mesmo quando denotava a preocupação de reivindicar não uma imitação servil dos clássicos, mas a criação de obras originais. As peças trágicas de Francisco Dias Gomes enquadram-se, portanto, num contexto estético-literário em que a mimese dos tragediógrafos gregos pressupunha uma erudição notável, e pela emulação dos clássicos procurava-se servir e dignificar a produção dramática da época ${ }^{8}$.

Assim se entende que a complexa questão de originalidade aparece abordada na "Advertência" (1799: 3-4) preambular que antecede esta Electra setecentista. Nesse breve texto introdutório, Francisco Dias Gomes compraz-se

${ }^{6}$ Curiosamente, nem o nome de Francisco Dias Gomes, nem o título das peças são mencionados na obra de referência de Duarte Ivo Cruz, História do Teatro Português, Lisboa, Verbo, 2001. Ainda assim, uma menção breve a estas duas tragédias pode encontrar-se na obra de Luiz Francisco Rebello, Breve História do Teatro Português, Lisboa, Publ. Europa-América, 1968, 5 a ed., p. 88, e na tese de doutoramento de Tatjana Manojlović, "Personagens da Tragédia Grega no Drama Português Contemporâneo: demanda da identidade na tríade de Hélia Correia", Lisboa, FLUL, Centro de Estudos de Teatro, 2008, p.25. (http://repositorio.ul.pt/ bitstream/10451/573/1/20242_ulsd_re506_TD.pdf)

$7 \mathrm{Um}$ das oito tragédias produzidas pelo Árcade que «mais a fundo se empenhou na renovação da cena nacional» (Luiz Francisco Rebello, Breve História do Teatro Português, Lisboa, Publ. Europa-América, 1968, 5a ed., p. 86). Cf. ainda Duarte Ivo Cruz, História do Teatro Português, Lisboa, Verbo, 200, pp. 112-3.

${ }^{8}$ Cf. J. do Prado Coelho, Dicionário de Literatura, vol. 1, s.v. «Arcádia Lusitana», Porto Figueirinhas, 1984, p. 65. 
em elucidar que, "pela primeira vez em Portugal, e tal em Espanha»" esta sua tragédia «imita» uma das peças mais famosas e aplaudidas do «maior trágico dos Antigos» (Sófocles), sublinhando, de imediato, os aspectos que, na sua opinião, marcavam a originalidade da sua tragédia, face ao modelo imitado. Enquanto ressalta os traços mais originais da sua obra, Francisco Dias Gomes aproveita o ensejo de mencionar a aprovação lisonjeira que as inovações introduzidas na sua peça haviam já merecido por parte de «pessoas sapientíssimas nesta Arte» ${ }^{10}$, acrescentando que:

Os mesmos Sábios, sem ter motivos de lisonjear o Autor, assentam que o $\mathrm{V}$ Acto desta tragédia é superior ao $\mathrm{V}$ de Orestes de Voltaire ${ }^{11}$, o qual muitos Franceses censuraram de frio (...). (1799:3)

À autoridade do modelo grego associavam-se, assim, os juízos elogiosos dos críticos que contribuíam para legitimar o valor literário desta sua Electra, em sintonia com os padrões e a sensibilidade da época do autor que, engenhosamente, termina esta "Advertência" preliminar com as palavras seguintes: «merece esta peça estimação pela perícia do estilo, pela dicção da Poética e pela harmonia dos versos» (1799:4)

2. Num anseio de imprimir à sua tragédia de tema clássico uma marca de originalidade, Francisco Dias Gomes ousa criar o seu próprio estilo, se bem que sempre sob a influência do seu modelo de eleição - Sófocles. Escorando a intriga dramática na tragédia sofocliana homónima, preferiu, no entanto, a moderna estruturação em cinco actos, prescindiu da figura do Coro, esse elemento ancilar da antiga tragédia grega, e apresenta Ismene como irmã de Electra. Estas inovações anunciavam, de imediato, uma reescrita do drama da filha do malogrado Agamémnon, mas a originalidade do nosso autor setecentista seria ainda mais ousada e manifestar-se-ia também num nível mais profundo, que se reflectia na forma como a acção se organizava e entretecia ao sabor do ritmo eloquente do verso decassilábico, renovando assim a tensão trágica dos diálogos que devolviam à cena figuras arquetípicas do teatro sofocliano.

Electra continua a protagonizar o conflito trágico da peça que recria algumas das cenas mais paradigmáticas da tragédia homónima de Sófocles (como é o caso das célebres cenas da urna, de anagnórise ou de tiranicídio), mas as variações intencionalmente introduzidas produzem uma ressonância muito mais ampla e profunda, que faz ecoar outras peças conhecidas da

\footnotetext{
${ }^{9}$ Será curioso reproduzir o comentário explicativo que o autor fornece de seguida: «Digo em Espanha, porque os seus Dramáticos mais famosos quase nenhuma lição tiveram dos Trágicos Gregos, cujo idioma ignoravam para os poder imitar» (1799: 3)

${ }_{10}(1799: 3)$. As citações desta obra serão apresentadas numa grafia actualizada da língua portuguesa.

${ }^{11}$ Em 1750, Voltaire publicara Orestes, uma tragédia em cinco actos.
} 
tradição sofocliana como por exemplo Antígona ou Rei Édipo. Essas variações, umas vezes mais subtis, outras mais audaciosas, evidenciam-se logo no próprio elenco de personagens (como é o caso da participação de Ismene, como irmã de Electra), mas também ao nível da caracterização da protagonista, no modo como se recriam cenas tão emblemáticas como a da urna ou a de anagnórise e até mesmo, como o próprio A. refere na "Advertência" (1799:3), no facto de «a nobre e heróica disputa entre Pílades e Orestes, no Acto IV, não [ser] imitada de ninguém».

Fica-nos a impressão de que, numa tentativa de conjugar tradição e inovação, Francisco Dias Gomes procurou alicerçar a originalidade da sua tragédia, não no sentido moderno de ignorar a tradição herdada, mas a partir do modelo grego consagrado construir uma peça que nobilitasse, no seu tempo, aquele que foi considerado, desde sempre, o género maior do Teatro Ático. O grande mérito de um dramaturgo que versasse um tema clássico residia na forma de o tratar e é a esse ponto que, de seguida, me irei dedicar.

3. Como na Electra de Sófocles, a acção da tragédia portuguesa decorre em Micenas, mas a cena representa um templo majestoso (onde estão depositadas as cinzas de Agamémnon), com as portas abertas, junto a uma região costeira, numa zona arborizada que deixa entrever uma humilde casa de campo - que nos traz à memória o humilde casebre do Lavrador da Electra euripidiana.

No Acto I, composto por seis cenas, o diálogo reparte-se por cinco personagens: Ismene (irmã da protagonista), Idamante (o velho aio de Agamémnon, uma figura equivalente à do Pedagogo), Electra, Clitemnestra e Egisto. Neste espaço dramático, o diálogo inicial entre Ismene e Idamante ${ }^{12}$ recontextualiza as principais coordenadas míticas da situação dramática que vão conceder o primeiro plano a Electra, se bem que prenunciando significativas alterações na reconstrução trágica do conflito da peça. Enclausurada na sua dor extrema, firme no desejo de vingar a morte cruel do pai, implacável na cólera que nutre pelo usurpador do trono familiar, mantém, em termos gerais, os traços sofoclianos da princesa de ânimo inquebrável, destemida e obstinada, que resiste na esperança de que o regresso do seu irmão Orestes possa retaliar a ofensa de um crime de sangue violento e intolerável. Esses permanecem como os traços de carácter da protagonista que no decurso da acção vão ganhar, todavia, novos matizes e conferir ao drama familiar uma dimensão política, de certa forma análoga à do conflito de Antígona. É certo que muitos pontos de contacto se poderiam estabelecer entre as duas heroínas trágicas sofoclianas:

${ }^{12} \mathrm{O}$ nome de Idamante traz-nos à memória o filho homónimo de Idomeneu, o rei de Creta a quem Wolfgang Amadeus Mozart dedicou uma célebre ópera, composta em 1781, e cujo libreto, escrito em italiano, era uma adaptação de uma tragédia francesa de Antoine Danches. 
ambas são princesas obcecadas por um crime de sangue familiar; ambas se isolam numa dor extrema que reclama vingança; ambas sentem ameaçada a sua linhagem real; ambas são vítimas do poder de um tirano. Assim, o efeito de estranhamento que a primeira cena da tragédia portuguesa provocava não punha em causa a tradição sofocliana, mesmo no surpreendente diálogo de abertura estabelecido entre Ismene, a irmã proscrita de Electra (1799:6, 10), com Idamante, o velho aio que salvara o jovem príncipe «do furor do tirano» (1799: 13), Egisto. E é precisamente esse tom político que vai marcar a diferença na caracterização da Electra de Francisco Dias Gomes, como entoam as palavras de Ismene, no final da Cena I:

Antes esses excessos enfurecem

Cada vez mais a dura crueldade

Do fero Egisto, que domina, e manda,

Qu' tudo pode no sublime trono

Do grande Agamémnon... mísera Electra! (1799:8)

Ao tradicional dever de vingança familiar acrescenta-se, assim, o desejo desatemorizado de retaliar o golpe cruel desferido por Egisto contra o seu malogrado pai. Mesmo alimentando ainda a esperança de que Orestes vive (1799:14), o clamor de vingança grita alto no coração de Electra que assume a hipótese de ela própria a pôr em prática:

«Quê? Pública há-de ser minha vingança.

(...)

Meu frágil braço aqui verás erguido

Para no sangue infame do tirano

Tua afronta lavar, qu'está pedido

Ao Céu, e à terra pública vingança. (1799: 14, 15-16)

Se na tradição trágica grega, o dever de vingança foi sempre entendido como um requisito apolíneo, que Orestes jamais ousou desrespeitar, nesta tragédia portuguesa a referência ao oráculo parece ter um valor meramente convencional, e não determina o comportamento de Orestes. Também na Electra de Sófocles, como salientou Maria do Céu Fialho ${ }^{13}$ «a decisão do regresso, ainda que Electra a veja marcada pela intervenção divina, parte do próprio Orestes» e, mais do que em qualquer outra peça, «o dramaturgo deixa-nos a impressão de os Olímpicos estarem tão longe dos determinantes da acção humana». Ora não é de estranhar que nesta tragédia setecentista

13 "O Deus de Delfos na Electra de Sófocles", Minerva, Revista de Filologia Clássica 20 (2007) 45 . 
os deuses estejam verdadeiramente ausentes, pois, em consonância com a mundividência cristã, é aos Céus que a protagonista dirige os seus lamentos e as suas imprecações. Mas também ela se sente só. $\mathrm{O}$ silêncio divino, a traição cobarde da sua mãe e os apelos à moderação da sua irmã resignada, Ismene, fazem com que Electra, como Antígona, não ceda nunca na sua obsidiante contenda, nem refreie o seu exacerbado desejo de vingança. A sua condição feminina não a impede, no entanto, de expor a ira impiedosa que sente pela mãe e por Egisto, porque, como declara (Cena IV):

Uma vingança nobre e gloriosa

Só nos pode fazer clara e famosa (1799:25)

A diferença desta Electra é que ela não pretende ser uma protagonista passiva, uma vítima patética de um destino trágico que a condena a uma sobrevivência lamentosa e resignada.

Também as personagens de Clitemnestra e de Egisto dão provas do subtil trabalho de assimilação e de adaptação operado pelo dramaturgo português. Ecos da congénere euripidiana ressoam na recaracterização da personagem de Clitemnestra: uma mãe flagelada com a vida infortunada dos seus filhos; uma cúmplice penitente do crime sanguinário que confessa; uma rainha subjugada ao poder implacável do seu marido-tirano; uma mulher atemorizada e desiludida com as desventuradas de uma vida que a oprime e a leva a implorar a morte $^{14}$. A cena entre mãe e filha assume novas proporções de ódio e de vitupérios, que se intensificam quando Clitemnestra lhe anuncia a proposta de casamento com o filho de Egisto como a solução planeada para unir as duas famílias.

A última cena termina precisamente com um diálogo entre Egisto e Clitemnestra, em que ela lhe comunica a recusa veemente de Electra de unir-se a Cléon, num matrimónio indigno e aviltante para o destino do seu oikos.

No Acto II, dominam as personagens masculinas: Orestes e Pílades que se encontram primeiro com Idamante e depois com Egisto. Retomando a tradição o filho de Orestes chega incógnito à terra pátria (desta vez encarnando o papel de náufrago), acompanhado do seu fiel amigo Pílades, que, como em Ésquilo, não é uma personagem muda, mas cuja intervenção se reveste de uma importância dramaticamente consistente e surpreendente.

Logo no início da primeira cena, o leitor tomava conhecimento, através de uma sucinta didascália, da inovação introduzida na paradigmática "cena da urna”: ela continha as cinzas de Cléon. Subsumia-se assim o estratagema

${ }^{14} \mathrm{Cf}$. Cenas IV e V. Note-se que esta última cena é um breve monólogo (11 versos) de Clitemnestra. 
engendrado por Egisto para unir as duas famílias. Mas é a Idamante que Orestes revela primeiramente a identidade das cinzas que a urna contém (1799:39) e é com a cumplicidade do velho aio que narra a falsa história da morte do irmão de Electra às mãos de Cléon, "Que num estreito passo se encontravam/ sem ceder um a outro» (1799: 43). As ressonâncias da passagem equivalente do Rei Édipo são inquestionáveis, mas o desfecho trágico do encontro dos Labdácidas opõe-se ao desta narrativa artificiosa (1799: 44-5), que encerra este Acto II. É a falsa notícia da morte infausta de Orestes às mãos de Cléon que, fazendo crescer a tensão dramática no Acto III, alimentada pelas reacções contraditórias das personagens em confronto (Electra e Idamante/Egisto), vai motivar a aguardada cena de reconhecimento. Perante o sofrimento lancinante da irmã, Orestes resiste ao «vivo impulso» de lhe falar (1799: 72), mas, a conselho do sempre previdente Pilades, evita a revelação da sua verdadeira identidade que acaba, no entanto, por ser descoberta por Electra, mediante a conjugação de dois indícios desconhecidos da tradição: o colar de Agamémnon que ela própria colocara no pescoço do seu jovem irmão, mas que Orestes diz ser um prémio da sua vitória sobre Cléon; e o sinal de nascença no peito que ela vislumbra, quando, num arremesso desvairado de retaliação, lhe rasga as vestes para desferir o punhal contra aquele que julgava ser o infame assassino do seu irmão.

No Acto IV, «não imitado de ninguém», conforme adverte o A. (1799: 3), as variações multiplicam-se na construção de uma intriga que ganha intensidade dramática na incapacidade que confronta Egisto e Clitemnestra em reconhecerem Orestes. Estimulante para o curso da acção é o paródico qui pro quo que protela o reconhecimento do jovem príncipe atrida, accionado pelo perspicaz Pílades no intuito de salvar a vida do amigo da morte decretada por Egisto ao guarda Fanor. Neste processo de recriação dramática do reconhecimento de Orestes, o uso ardiloso de um tópico não convencional (1799: 82) cria uma cena patética de impasse (Cena III) que, além de protelar o desfecho da anagnórise, fornece uma motivação para o tiranicídio mais consentânea com o pensamento ético-moral coevo. A desmesura do rancor vingativo de Egisto manifesta-se no acto de um rei desesperado que também ordena aos guardas a prisão e morte de Electra (1799:91), mas que a mãe impede com inesperada força persuasiva:

Suspendei-vos, indignos, ninguém ouse

Com sacrílega mão tocar em Electra (1799:91)

É no último Acto da peça que acontece o tão esperado tiranicídio, mesmo sem se ter cumprido o matricício, que o antecedia na Electra sofocliana. Respeitando as convenções da antiga tragédia grega, o acto homicida não é perpetrado em cena. A função do antigo mensageiro é desempenhada, primeiro por Ismene, que presenciara a cena e, com genuína comoção, relata à mãe os 
antecedentes e os pormenores desse confronto sangrento, em que Orestes agiu em legítima defesa e derrotou com valentia Egisto.

(...) entre clamores,

Entre aplausos de gentes infinitas,

Como em triunfo Orestes é levado,

E como rei por todos aclamado (1799: 95)

As reminiscências da tragédia sofocliana parecem implícitas na descrição da morte de Egisto como um acto vitorioso de Orestes, a que o reconhecimento público garantirá o almejado kleos. Também Édipo agira em legítima defesa, quando matou o estrangeiro numa encruzilhada; e o próprio Orestes sofocliano executara o tiranicío, «imaginando o seu acto como um gesto glorioso» ${ }^{15}$. As dissemelhanças começam a insinuar-se, no entanto, quando Electra rejubila ao recordar a Ismene os pormenores mais cruentos do acto de vingança que há muito tempo desejara ver realizado (1799: 102-3). Seria do maior interesse determo-nos um pouco mais na comparação das duas narrativas que revelam as diferentes focalizações das irmãs do homicídio, e as articulássemos de seguida com a pungente reacção de Orestes (1799: 103-5), na penúltima cena da peça.

Limitar-nos-emos apenas a ilustrar, numa breve citação, os efeitos nefastos do acto homicida, provocados no espírito daquele príncipe, que agira na ilusão de que realizava um feito glorioso, porque justo e justificado:

Ó lembrança do crime que me oprimes;

Tira-me a vida triste, e aborrecida,

Já que valor não tenho, esforço, e audácia

Para tentar contra os meus próprios dias,

E dar fim a meus males lastimosos.

Mas... ah! ... que vejo? ... os fogos da vingança

Em vossas mãos já brilham... Negras Fúrias...

Monstros, deixai-me ...um triste, e um desgraçado,

Que até compaixão vossa merece. (1979:106)

Bem longe do modelo sofocliano, esta Electra portuguesa do século XVIII não só suprimiu o matricídio do enredo trágico como atribuiu um papel crucial às emoções que o agir das próprias personagens potencia enquanto forma de aprendizagem e de conhecimento, que as transforma e lhes subtrai o valor de uma vida auspiciosa. A visão delirante das "Negras Fúrias" funciona simbolicamente como um eco esquiliano do sofrimento desmesurado daquele

${ }^{15}$ Maria do Céu Fialho, "O Deus de Delfos na Electra de Sófocles", Minerva, Revista de Filologia Clássica 20 (2007) 47. 
homem que toma consciência do horror do acto criminoso praticado, mesmo sem ter chegado ao extremo de matar a sua própria mãe. Ao conflito político e familiar sobrepõe-se, agora, um dilema ético-moral, com repercussões psicológicas devastadoras e bem visíveis no pungente espectáculo de dor que domina a parte final da peça. As interrogações desiludidas de Electra (1979: 105) e as súplicas lancinantes de Clitemnestra, para que a morte a liberte dos remorsos que a corroem, pontuam essa mudança de perspectiva, essa reviravolta que conduziu à catástrofe os membros daquela família amaldiçoada por um destino cruel que lhe parece negar qualquer esperança de futuro.

Se bem que tanto a Electra sofocliana como a tragédia de Francisco Dias Gomes confrontem as suas personagens com o estranho paradoxo da existência, os versos finais da peça portuguesa deixam entreaberta a possibilidade de um horizonte venturoso para a vida humana.

Infeliz quem mal vive, e mal acaba!

Ditoso quem bem vive, e quem bem morre. (1799:108) 


\section{Bibliografía}

Jacinto do Prado Coelho, Dicionário de Literatura, 5 vol., Porto, Figueirinhas, 3a ed., 1984.

Francisco Dias, Ifigenia: tragedia tirada da historia gregal de Francisco Dias. Lisboa: Off. de João Antonio da Silva, 1798. - 76 p.; 15 cm. - Exemplar em mau estado de conservação. Obra digitalizada a partir do original. OMGAR 2537p (ULFL-OM). http://bibliotecadigital.fl.ul.pt/ ULFLOM02552/ULFLOM02552_item1/

Francisco Dias, Electra: tragedia em cinco actos, tirada da historia grega / de Francisco Dias. - Lisboa : Typ. Régia Silvina, 1799. - 108 p.; 16 cm. Obra digitalizada a partir do original. OMGAR 2536p (ULFL-OM). http://bibliotecadigital.fl.ul.pt/ULFLOM02551/ULFLOM02551_item1/

Maria do Céu Fialho, "O Deus de Delfos na Electra de Sófocles", Minerva, Revista de Filologia Clássica, 20 (2007) 39-45.

—_ Electra, Introdução e Tradução do Grego. In: Maria Helena da Rocha Pereira, José Ribeiro Ferreira, Maria do Céu Fialho (edd.), Sófocles. Tragédias, Coimbra, Minerva, 2003, 91-166.

Tatiana Manojlovic, "Personagens da Tragédia Grega no Drama Português Contemporâneo: demanda da identidade na tríade de Hélia Correia", Diss. Dout., Lisboa, FLUL, Centro de Estudos de Teatro, 2008. http:// repositorio.ul.pt/bitstream/10451/573/1/20242_ulsd_re506_TD.pdf

Luis Francisco Rebello, Fragmentos de uma Dramaturgia, Lisboa, Imprensa Nacional-Casa da Moeda, 1994.

—_ Breve História do Teatro Português, Lisboa, Publ. Europa-América, $1968,5^{\text {a }}$ ed. 


\title{
Aristófanes y el arte de lo posible en SALTo al Cielo de Mauricio Kartun: POLÍTICA Y CONCIENCIA POÉTICA EN UNA FARSA (GRIEGA) APÓCRIFA
}

\author{
Emiliano J. Buis \\ Universidad de Buenos Aires - CONICET
}

\begin{abstract}
Quizás por las dificultades propias del género, los intentos por adaptar la comedia griega a los escenarios contemporáneos han sido poco frecuentes. El caso de Salto al Cielo (1991), del dramaturgo argentino Mauricio Kartun, es interesante: si bien parte en su trama inicial de las mismas estructuras dramáticas y del mismo esquema actancial de Aves, la obra desplaza las alusiones políticas explícitas por una reflexión metateatral sostenida en torno de la factura misma de la comedia y de la función liberadora del arte. Analizaremos aquí cómo, en su búsqueda literaria, Kartun modifica el desarrollo del argumento de Aristófanes y autoriza nuevos espacios resemantizando el precedente 'clásico' e imprimiendo nuevos senderos y límites al fenómeno de lo cómico.
\end{abstract}

\section{Introducción ${ }^{1}$}

Por su permanente cruce de registros, su apelación directa a la coyuntura política y su habitual procacidad, la comedia aristofánica ha sufrido una suerte menos digna que la tragedia ática a la hora de su recepción, reproducción o adaptación a los escenarios contemporáneos ${ }^{2}$. No obstante ello y a pesar de dicha dificultad inherente al género, muchas obras han vencido la barrera de la mostración simultánea de lo político y lo procaz -quizás las dos características centrales de producción aristofánica- y se han visto representadas a lo largo de

\footnotetext{
${ }^{1}$ Este trabajo ha sido realizado en el marco del Proyecto de Investigación 20020090200095 «Genealogías violentas y problemas de género: conflictividades familiares y perversiones del oikos en la literatura griega antigua», dirigido por la Dra. Elsa Rodríguez Cidre y codirigido por mí en la Universidad de Buenos Aires (Programación UBACyT 2010-2012) y del Proyecto I+D+I "Familia y Propiedad en el Derecho Griego Antiguo», acreditado por el Ministerio de Ciencia y Tecnología de España (FFI2008-00326/FILO) y dirigido por la Prof. Dra. Inés Calero Secall en la Universidad de Málaga. En particular, forma parte de mi tema personal de investigación en ambos proyectos, que consiste en relevar los múltiples niveles (directos y metafóricos) de las relaciones de parentesco en la comedia aristofánica y sus alcances jurídicos.

2 Reconociendo dicha complejidad, un autor como Cartledge (1990) sostuvo (con un reconocido anacronismo) que la comedia antigua fue "'something like burlesque ... broad farce, comic opera, circus, pantomime, variety, revue, music hall, television and movie satire, the political cartoon, the political journal, the literary review and the party pamphlet".
} 
la historia en distintos escenarios del mundo ${ }^{3}$. Pensemos por ejempolo en la comedia Aves del año 414 a.C., que -quizás por su carácter más bien utópicoha conseguido a menudo resistir los embates de la tradición dramatúrgica para configurarse en las últimas décadas (y fundamentalmente desde la famosa puesta en escena censurada de la compañía de Karolos Koun en Atenas en 1959) como una obra en permanente revisión.

En esta ponencia, en particular, nos ocuparemos de examinar uno de esos intentos recientes, el llevado a cabo en nuestro país por Mauricio Kartun en Salto al cielo. La obra, que debutó en el Teatro de la Campana en noviembre de 1991 bajo la dirección de Villanueva Cosse, parece dar cuenta (al menos desde la trama inicial) de las mismas estructuras dramáticas y del mismo esquema 'actancial' del original, y sin embargo termina instalando profundas divergencias con su texto de base. Nos ocuparemos aquí, precisamente, de examinar esos cruces y distanciamientos.

\section{De Aristófanes a Kartun: derrotero de una metapoética cómica}

Desde una primera lectura, la comedia Salto al cielo, que Kartun compuso a pedido del Teatro Nacional Cervantes, ${ }^{4}$ deja entrever un esquema dramático similar al que había imaginado Aristófanes veinticinco siglos antes. Un protagonista, Pistetero, se propone crear un nuevo mundo en el que los hombres puedan vivir con las aves, impidiendo que los dioses los gobiernen desde las alturas. La distribución 'actancial'básica de los personajes se estructura análogamente en ambos textos: los pájaros primero se oponen con firmeza a la iniciativa de Pistetero, y sin embargo a medida que avanzan las escenas se convierten en cercanos colaboradores de la empresa propuesta. Por su parte, los dioses -que se constituyen en una fuerza opositora- intentarán derribar el plan del protagonista.

La referencia explícita a los aspectos políticos del universo litigioso y del imperialismo jurídico, que claramente identificados en la comedia aristofánica, están lógicamente ausentes en Kartun. No hay referencias al problema acuciante de la ciudadanía ni a preocupaciones directas sobre la toma de decisiones políticas contemporáneas. Como explica Sikora (1993) y como veremos, Kartun insiste en el carácter utópica de la trama para justificar su mise

\footnotetext{
${ }^{3}$ Cf. los excelentes estudios sobre la "actualidad" aristofánica de Van Steen [2000], Hall \& Wrigley [2007] y Sommerstein [2008], inter alia.

${ }^{4}$ Recordemos que ya se trataba en ese entonces de un autor consagrado. Nacido en San Martín en 1946, su primera obra Civilización... ¿̇ barbarie? (escrita con Humberto Rivas) se estrenó en 1973 el el Teatro Comedia. Cf. "Kartun, Mauricio", en Cortés, E. \& M. Barrea Marlys (2003: 29). En su variada producción se advierten trazos sociales que van desde las contradicciones culturales de su infancia (Bye Misterix, 1980) hasta la propia historia argentina (Pericones, 1987). Adaptó y transformó variadas tradiciones teatrales, entre ellas el sainete criollo.
} 
en scène. Desde el comienzo mismo, la obra se construye como una estructura atemporal, organizada sin embargo en torno de alusiones concretas a la realidad local americana de las aves pampeanas. Faltan aquí los encuentros discursivos que hallábamos en Aves entre Pistetero y los visitantes de Nephelokokkygía, puesto que la comunicación entre los personajes está condenada a los malos entendidos y al fracaso. En esto cobra especial importancia un personaje típicamente cómico que Kartun emplea para describir su mundo y que no aparece en el original aristofánico: se trata de Tero, quien no sólo es un portavoz del autor, sino que tiene una posición privilegiada en tanto mediador: es testigo de los episodios (desde el interior y a la vez desde afuera) y es capaz de dar a conocer su entramado metapoético. Siguiendo la línea de la reflexión aristofánica sobre el fenómeno artístico, la primera intervención de Tero que abre la pieza instala la dimensión teatral e informa a la audiencia que se dejará de lado toda ilusión dramática (Pasaje 1)

En la superficie son notorios los paralelismos formales: la búsqueda del rey de las aves que alguna vez fue humano, el deseo de escapar de las injusticias, la pretensión de un lugar pacífico en el que establecerse, la guía de los dos pájaros al inicio que orientan al par cómico, entre otros elementos. Pero también se abre lugar a las disparidades: Tero sabe bien que los dos personajes necesitarán suerte para tener éxito en su aventura. Pronto explicará que estos sueños de volar fracasarán y que todos volverán a la realidad (Pasaje 2). La función dramática de Tero consiste, pues, en presentar la verdadera naturaleza de la obra, permitirle al público comprender el sentido del argumento. Es un traductor, un veedor de la acción que comparte sus impresiones con los espectadores, que anuncia lo que sucederá. Como lo indica el juego de palabras, su deber es el de enterar (Pasaje 3).

Según sus palabras, entonces, Kartun subvierte los cimientos de la comedia antigua: el destino tradicional del héroe cómico con su victoria escénica -el triunfo final que Whitman (1964) considera una constante en la producción de Aristófanes- deja de verse garantizado en el nuevo contexto. En la perspectiva de Kartun y en las declaraciones de Tero, la comedia se percibe como un extraño híbrido, que va más allá de la definición que la escuela aristotélica sugiere a partir de la Poética y que debe encontrar en el pasado griego sus raíces precisamente para distanciarse de ellas. Así, las nuevas reglas de la ciudad de Salto al cielo se vinculan más con parámetros literarios que con disposiciones jurídicas. Si la antítesis entre el protagonista y los visitantes a Nephelokokkygía se construía en Aves sobre la base de un rechazo político de Atenas, en la versión argentina la voluntad de excluir a los intrusos se reinterpreta permanentemente en términos teatrales. Cuando el Corifeo aparece en escena y el coro solicita alas, se advierten referencias explícitas a la naturaleza dramática de la obra (Pasaje 4). 
Poco después, el protagonista reaccionará frente al pedido de alas del Corifeo y prometerá reflexionar sobre la posibilidad de permitir que el coro vuele y viva con los pájaros. El Corifeo entonces se irrita y acusa a su enemigo de violar los principios del teatro clásico (Pasaje 5). La violación de las reglas del género es percibida como la comisión de un crimen político, y los culpables de traicionar los modelos clásicos deben ser condenados al exilio. En una pieza en la que la política parece ausente de la estructura superficial, no debe sorprender que la modernización de los géneros tradicional y los cambios en el esquema dramático sean descriptos como actos de sedición e insurrección. En la lógica de Salto al cielo, la denegación de alas al coro implica abolir un elemento esencial del drama griego y merece un castigo que, por supuesto, también es humorístico. Apenas cuenten con las alas reclamadas, Tero mencionará las posibilidades que brinda la comedia y definirá los ataques contra la tradición literaria, una vez más, como emergente de una violencia totalitaria (Pasaje 6).

Las cuestiones de poder, sin embargo, no son ignoradas en Salto al cielo. E1 objetivo político de Pistetero se torna evidente en cuanto se erigen las murallas de Meteoronópolis. El personaje tiene un fin personal, y para alcanzarlo no se inquietará por el sufrimiento de las aves que lo ayudan. Como algunos críticos han señalado, se vislumbran algunos rasgos de explotación demagógica en cuanto el público presencia un oscurecimiento progresivo del argumento, una suerte de desesperanza creciente que pasa a teñir toda acción sobre el escenario. A diferencia de los roles de Aves, los personajes aquí parecen haberse despojado de sus personalidades individuales para volverse parte de una voz colectiva y oprimida. Y esta opresión caracterizada por la corrupción y el engaño sobrevuela pronto todo el drama.

En su introducción teórica, publicada como prefacio a la obra, Kartun hace referencia a la dificultad de transmitir la experiencia como una de sus mayores obsesiones. Una obsesión que encuentra su rumbo en la obra a través del abandono de una aproximación realista (generalizada en el teatro argentino) y de la consolidación de lo que él llama una "farsa excéntrica", una farsa que se vuelve más sutil en la medida en que no ataca a la política por su nombre sino que sugiere una posición ideológica. Bajo un juego metateatral con las palabras y las ideas, en el que los límites del discurso político parecen estar ausentes, hallamos un profundo interés en el contexto social cuando evaluamos el mensaje que dejan entrever el proyecto de Pistetero y su derrota final.

Colocar la política fuera de su lugar central es, en este sentido, una manera alternativa de referirse a lo político en un momento en el que todo lo que el teatro había tenido que decir al respecto estaba plagado de alegorías y metáforas. El propio Kartun se había ocupado abiertamente de la política 
en sus obras presentadas durante el Teatro Abierto, ${ }^{5}$ tales como La casita de mis viejos (1982) o Cumbia morena cumbia (1983). ${ }^{6}$ Pero dado que el realismo parece ya poco posible en el teatro argentino de comienzos de los noventa, la utopía parece tomar su lugar en la condena de la corrupción y el autoritarismo. ${ }^{7}$ Como ha dicho Pellettieri, en Salto al cielo la ciudad creada por Pistetero es un espacio para la literatura en el que el poder está determinado por las palabras y la fantasía. A tal extremo llega la primacía de lo ficcional que Kartun decide modificar drásticamente el final de la comedia aristofánica. Mogliani explica este distanciamiento afirmando que, mientras en Aves la utopía es inalcanzable, en el texto de Kartun la esperanza se preserva porque los pájaros terminan iniciando un nuevo sueño. ${ }^{8}$ Nos resulta difícil compartir esta opinión, dado que precisamente en Aristófanes el protagonista consigue lo que en Salto al Cielo se ve obligado a abandonar. En Aves, precisamente, el triunfo de Pisetero, que logra obtener a Basíleia como esposa y vencer así a los dioses al heredar los atributos de Zeus, representa la victoria cómica del plan. Pisetero se ha transformado en el más elevado de los dioses (v. 1756) y ha podido derribar a todos sus adversarios políticos, a tal punto que se dedica a asar los pájaros anti-democráticos en el momento en el que la embajada del Olimpo hace su entrada en escena. En Salto al cielo, en cambio, son los dioses mismos los que le ofrecen a Basileia al protagonista, son ellos quienes lo persuaden de dejar de lado su proyecto para evitar una masacre de hombres y aves (Pasaje 7). Y el propio Pistetero reconocerá su fracaso al preguntarle a su compañero Evélpides en qué se equivocaron (Pasaje 8).

En este final amargo, el triunfo ya no pertenece a la empresa individual de un héroe cómico que, al usar su conocimiento retórico-político, consigue imponerse, como ocurría en Aves. Al contrario, la obra en estas instancias

5 "The phenomenon of Teatro Abierto (1981-1984) becomes the shared experience in which the entire theatrical community participates and unites, in both a real and metaphorical sense, and expresses the essence of the generational entelechy. Coming as it did in the final years of the thirty-year period, Teatro Abierto should be seen as the culminating act of the Generation of 1956 since it represents both the fulfillment of the generational task and the resolution of the generational conflict. Teatro Abierto stands as an objective correlative of the generation, the fusion of its desire for freedom from socio-political repression and its concommitant search for freedom and identity in a unique theatrical style" (Roster, 1991). Esta aproximación realista al mundo fue puesta en jaque de modo paulatino por las nuevas voces de la Generación de 1971, que incluyó a autores como Ricardo Monti, Mauricio Kartun, Eduardo Rovner y Roberto Perinelli, entre muchos otros.

${ }^{6}$ Graham-Jones (102-107).

${ }^{7}$ Al analizar diacrónicamente la obra de Kartun, Cosentino (1991: 36) considera que el movimiento problemático de la infancia a la adolescencia que se percibe en sus primeras obras es reescrito en el corpus posterior en términos de un desplazamiento de los hombres hacia una tierra sin hombres.

${ }^{8}$ Mogliani (1992: 79-82). 
se cierra con una celebración ambigua en la que los dioses conservan su superioridad ancestral. El Colibrí y los pájaros -que antes habían decidido seguir a Pistetero en su revolución- intentarán ahora ganar una posición y dar una buena impresión a los dioses poderosos. El matrimonio de Pistetero, por su parte, implica una renuncia a sus sueños y una aceptación de los condicionamientos divinos. Los hombres, nos enseña la obra, no pueden dejar de ser lo que son, y de ahí la necesidad de su imperiosa capitulación.

El fin de Pistetero y la gran clausura de la obra se acercan. Y Tero, nuevamente, aprovecha para pensar las tensiones contenidas en la trama cómica (Pasaje 9). Recurre a un juego de palabras al mostrar que, en breve, el derrotero se aproxima a la derrota. En un cruce entre ficción y realidad ("La vida es un rumor lanzado por un pajarito, puro desplume y terotero, sin ninguna seriedad “), entre sueño y vigilia ("Acaba el sueño, y quedan del sueño los restos"), la comedia procura restablecer el equilibrio perdido, pero termina aceptando que la trama ha perdido su camino. Tero ya no controla el desarrollo del argumento; tampoco lo controlan los restantes personajes. Pero ello no resulta problemático, en la medida en que la comedia, de hecho, solamente puede ser comprendida en el seno de la paradoja que instalan esos cruces: las normas clásicas que deben ser respetadas son transgredidas hacia el final. Muy poco antes del último discurso de la obra, Tero duda acerca de si la pieza culminará con risas o llantos (Pasaje 10). Si, de acuerdo con la tradición aristotélica, la comedia debía contar con un comienzo, un medio y un fin, Kartun demuestra que, para ser tal, debe también expresar su habilidad para subvertir y desmantelar su propia estructura.

\section{Recapitulación}

Mediante el logrado desdoblamiento del héroe-protagonista de Aves en dos figuras complementarias (no en vano llamadas Piste-tero y Tero), Salto al cielo autorizará frente al público nuevos espacios de interacción desconocidos en el pre-texto aristofánico. En esta dialéctica fuertemente metateatral que se establece entre los propios personajes -y entre algunos de ellos y los espectadores- se va generando un progresivo oscurecimiento de los bordes entre lo literario y lo real, entre la tierra y el aire; se trata de una desarticulación textual que sugiere en la nueva ciudad una (con)fusión extraña, y nunca desprovista de conflicto, entre el rol público del dramaturgo y la autoridad.

Al desplazar las alusiones políticas explícitas por una reflexión sostenida en torno de la factura misma de la comedia y de la función liberadora del arte, como hemos visto, Salto al Cielo instaura una profunda crítica al realismo propio del teatro argentino, como señalan Pellettieri (1993) y Sikora (1993). Kartun parece lanzarse en una búsqueda literaria que, apoyándose en el juego ya instalado por Aristófanes sobre la falta de ilusión dramática, sorprende al espectador y termina trastocando el desarrollo del argumento. Mediante una 
vuelta de tuerca, el nuevo final que consagra la pieza resemantiza el precedente "clásico" ateniense e implanta nuevos senderos (y nuevos límites) para el fenómeno de lo cómico.

Incluso la oposición entre aire y tierra, permanente a lo largo de la obra, se ve minada en el final, en cuanto los pájaros remplazan el frustrado designio de Pistetero y conciben un nuevo sueño (un nuevo plan literario) para comenzar de nuevo. El aire y la tierra son expulsados por un tercer elemento que Tero advierte en sus palabras: el agua (Pasaje 11).

La obra nos pone frente a un Canario avergonzado que toma la decisión de quedarse en el cielo, junto a Pistetero, Basileia y el Colibrí, y servirá a los dioses. Tratándose de un artista, está forzado a aceptar su condición. Kartun deja en claro una vez más su marca poética y regresa a la relación entre poder y arte, entre política y literatura. Cuando los dioses obligaron a Pistetero a aceptar su trato, el protagonista explicó a la Urraca que era preciso que lo hiciera para poder proteger Meteoronópolis (Pasaje 12). Si el ejercicio de la autoridad implica llevar a cabo el arte de aquello que es posible, como sostiene, entonces uno podría afirmar en cierta medida que la comedia, en tanto género, supone una actividad semejante. La obra se desenvuelve como puede, como resulta posible. Pero una última vuelta de tuerca le permite a Kartun dejar a Aristófanes un poco más atrás. La mayor parte de los pájaros han decidido huir del cielo. Formularán una propuesta inesperada que, en el marco del argumento tradicional, no parece posible. Si la tierra y el aire se ven reconciliados y el status quo recobrado, el único modo de permanencia con que cuenta la comedia es el descubrimiento de nuevos espacios. Encontrar un nuevo sendero que no parezca retomar ningún precedente. Un sendero que rechace tanto las modalidades políticas argentinas en materia de puestas teatrales durante los ochenta como los indicadores formales de las performances atenienses de fines del s. $\mathrm{V}$ a.C.

En un delicado balance entre poesía y política, Kartun consigue crear un territorio dramático único en el que resulta posible experimentar, discutir y jugar en torno del papel central del arte. Es un nuevo sendero en el que, en definitiva, el paisaje utópico -donde no están vigentes las reglas- resulta ser la comedia misma. 


\section{BibLIOgRAFÍA}

\section{Ediciones y comentarios}

Coulon, V. (19778) Aristophane: Les Oiseaux. Lysistrata. Tome III. Texte établi par V. Coulon et traduit par H. Van Daele, Paris, 1928.

Dunbar, N. (1995) Aristophanes’ Birds. Oxford.

Kartun, M. (1991) “Salto al Cielo”, en Pellettieri, O. (1993) (ed.) Del parricidio a la utopía: el teatro argentino actual en 4 claves mayores (Colección Telón, Teatro Contemporáneo, 3), Ottawa: Girol Books.

Kartun, M. (1993) Teatro I. Buenos Aires: Corregidor (con estudio preliminar de Osvaldo Pellettieri).

Rogers, B. B. (1924) Aristophanes. The Peace. The Birds. The Frogs. With the English Translation of B. Bickley Rogers, Vol. 2, Cambridge (MA) \& London.

Sommerstein, A. H. (1987) (ed.) The Comedies of Aristophanes, vol. 6. Birds. Edited with translation and notes by Alan H. Sommerstein, Warminster.

Zanetto, G. (1987) (ed.) Aristofane. Gli Uccelli. Introduzione e traduzione de D. Del Corno, Milano.

\section{Bibliografía crítica}

Cortés, E. \& M. Barrea Marlys (2003) (ed.) Encyclopedia of Latin American Theater, Westport: Greenwood.

Cosentino, O. (1991) "El teatro de los 70: Una dramaturgia sitiada”, Latin American Theatre Review 24 (2); pp. 31-39.

Dubatti,J.(1993) “El teatro de Mauricio Kartun: identidad y utopía” (entrevista a Mauricio Kartun), en Teatro I. Buenos Aires: Corregidor; pp. 279-286.

—_. (2001) (ed.) Mauricio Kartun. Escritos 1975-2001, Buenos Aires: Universidad de Buenos Aires, Libros del Rojas (Colección Teoría).

-_. (2005a) "Conversazione con Mauricio Kartun. Autore, docente e collezionista di "vecchie carte", en Hrelia, F. (cur.) Teatro nel Cono Sud. Esperienze e voci della scena ispanoamericana; Roma: Editoria \& Spettacolo; pp. 77-86.

-(2005b) "Mauricio Kartun: poética teatral y construcción relacional con el mundo y los otros", en Dubatti, J. El teatro sabe. La relación escenal 
conocimiento en once ensayos de Teatro Comparado, Buenos Aires: Atuel; pp. 151-172.

___.(2009) "Pericones de Mauricio Kartun: estructura dramática, novelas de piratas y sujetos históricos", Stichomythia 9; pp. 9-13.

Graham-Jones, J.(2000) Exorcising History: Argentine Theater under Dictatorship, Lewisburg (PA): Bucknell University Press.

Hall, E. \& A. Wrigley (2007) (ed.) Aristophanes in Performance 421 BC-AD 2007: Peace, Birds, and Frogs. London.

Mogliani, L. (1992) “Salto al Cielo: el desarrollo de una utopía”, en Pellettieri, O. (1992) Teatro argentino de los ‘90, Buenos Aires: Galerna; pp. 79-85.

Pelletieri, O. (1990) Cien años de teatro argentino (1886-1990), Buenos Aires: Galerna.

-(1991) “La puesta en escena argentina en los 80: realismo, estilización y parodia", Latin American Theatre Review 24 (2); pp. 117-131.

___(1999) “Mauricio Kartun y el teatro nacional”, Teatro, Tomo II, Buenos Aires: Corregidor, pp. 9-28.

Rivera, V. A. (1989) La composición dramática. Estructura y cánones, México: Escenología.

Roffo, A. (1987) "La utopía de organizar el caos” (entrevista con Mauricio Kartun), Teatro, Revista del Teatro Municipal General San Martín No 29; pp. 42-48.

Roster, P. (1991) "Generational Transition in Argentina: From Fray Mocho to Teatro Abierto (1956-1985)”, Latin American Theatre Review 25 (1); pp. 21-40.

Sikora, M. F. (1993) "La comedia griega en Salto al Cielo de Mauricio Kartun", en Pellettieri, O. (ed.) De Esquilo a Gámbaro. Teatro, mito y cultura griegas y teatro argentino (Cuadernos del GETEA No 7), Buenos Aires: Galerna; pp. 117-126.

Sommerstein, A. H. (2008) "Lysistrata turns a somersault: comedy, war and Eric Linklater", Classics Ireland 14; pp. 1-43.

Van Steen, G. A. H. (2000) Venom in Verse. Aristophanes in Modern Greece, Princeton: Princeton University Press.

Whitman, C. H. (1964) Aristophanes and the Comic Hero, Cambridge (MA): Harvard University Press. 


\section{Anexo. Citas de pasajes analizados}

Pasaje 1:

TERO.- Historia de los pajaritos. Obsérvese. Obra de teatro. ¿Por qué las aves siempre se van? ¿Es el murciélago un ave o qué? ¿Por qué los pájaros gritan al atardecer? y otros interesantes mesterios de la ornitología. Todo según aca el amigo: Belenopterus Cayennensis: Tero, Terencho, Teruteru. En un solo día aristotélico al fin. Que en otro tiene los huevos. Noche oscura en esta fábula. Minutos antes del amanecer en esta fábula. Un páramo. Allá piedras. Allí precipicio. Comedia: imitación de los hombres -como se ha observadopeor de lo que son. Evélpides, atrás Pistétero. Jóvenes. Abandonan su patria cansados de la injusticia de esa tierra, y llegan a estos aires, a esta escena, anhelando un lugar donde fundar un mundo mejor. Buscan en su marchita al extravagante Picaflor, el Colibrí que alguna vez fue humano para que él les recomiende en su sabiduría de viajero el territorio donde elevar ese mundo nuevo. Llevan de guía a un par de cuervos. Grajos morochos que los arrastran a su destino. A su suerte. Que falta les hará. Obsérvese. (p. 145).

\section{Pasaje 2:}

TERO.- ¡Amanecer de la historia! ¡Amanecer de la obra! Sueño de juventud. Ya luego volar, no se sueña más. Ya luego el tiempo pondrá: (Terrible) Los pies sobre la tierra. (Rie). Tero. (p. 147).

\section{Pasaje 3:}

TERO: - (...) Tero. Desafío. Obsérvese. Aire contra tierra. ¿Qué palabra habrá pronunciado en su lengua el augur? Mesterio. Nunca lo entenderán los oídos humanos que siempre esperan por comprender todo. Klage, klage, Urutaú, In den Zweiden des Yatay. War einmal ein Paraguay Wo gerboren Ich und du: klage, klage, Urutaú! El misterio es un poder. ¿'Y qué contestará el profeta a las palabras del héroe? Por gentileza de este traductor, y gracias a la magia del teatro, todo trama y convención, se enterarán ustedes de aquello que los protagonistas no se enterarán nunca. Se enterarán. De enterar. Que no es otra la función del tero. Se entiende. Obsérvese. (p. 161).

\section{Pasaje 4:}

CORIFEO - (Entrando. Máscaras, coturnos, y grandeza trágica.) ¡Alas...! ¡Alas...! ¡¿Dónde reparten alas...?! (Descubriendo a Pistétero). ¡ ¿Eh...?! ¡¿Ya te procuraste tú las tuyas?! ¡Juro a Tespis! ¡¿Cómo has...?! ¡¿Pero en virtud de qué infracción a la poética toda has podido?! ¡El corifeo soy de esta comedia! ¡A esta trama pertenezco como la nata a la leche! ¡Cómo pudo alguien enterarse antes que yo...! (Reacciona). Salvo que tú fueses... (Avergonzado) Claro, claro. 
Sí. Definitivamente tú eres el protagonista. No había tenido hasta ahora el gusto de... ¡Je! Mi coro, el de los humanos no ha hecho aún su entrada en escena, por eso... (Trans.) Apenas terminado el acto anterior calcé mis atavíos, y hacia aquí me apresuré para ser pionero en la ciudad (p. 169).

Pasaje 5:

CORIFEO.- (Estalla grandilocuente) ¡¿Permitir?! (Al coro.) i¿Permitir ha dicho?! ¿YY qué permiso necesita un coro para habitar su propia comedia...?! ¿¿O es que eres, también tú, de los que sueña con abolirnos...?!

PISTETERO:- No, no se trata de...

CORIFEO:- (Interrumpe.) ¡Ahhh...! Así que de esos eres, de los que esputan sobre las reglas...

PISTETERO:- Yo...

CORIFEO:- ¡De los que ultrajan a Aristóteles! ¡De los que estupran su poética!

PISTETERO:- No hablaba yo de...

CORIFEO:- ¡Comedia sin coro: pájaro sin alas! ¿No comprendes, insurgente, el inexcusable equilibrio de una estructura dramática?! (...) ¡¿En nombre de qué abstrusa modernidad expulsas al coro de la escena?! ¿Sabes a qué exilio lo condenas? (Irónico.) ¡Eres joven, claro...! ¡Quieres cambiarlo todo! ¡Pues comienza por respetar lo clásico! ¡Por venerarlo! (Contenida amenaza.) Pero si así no lo hicieras, $\underline{\text { faccioso }}$, asume frente a Apolo, Dios de las artes, el riesgo de tu gesto impío. (Ordena.) ¡Al destierro! ¡Vamos! (p. 170).

Pasaje 6:

TERO.- Todo alborozo. Todo regocijo. Hasta prestar alas es posible. Un acto de lesa literatura que si le sirvió a Aristófanes, bien le puede servir a este tero. Un vivalajoda. Aún lo emotivo encuentra su lugar en la comedia. Obsérvese. (p. 164).

\section{Pasaje 7:}

NEPTUNO.-(A Pistetero. Aparte.)Blup.(Pistetero, amigo, soy de tu causa. $¿$ ¿No lo ha dicho acaso con elocuencia mi regalo...? ¡Cómo no comprenderte, si también yo al igual que tu, cargo sobre las espaldas como un Atlas, el peso de mi mundo el de las aguas! Mas, no puedo así contra la ira de Hércules. Lo que pides es excesivo, y mal puedo defender tu posición cuando todo el Olimpo estallaría. Si te allanaras al menos a pedido más sensato... sé que tienen los pájaros su fuerza, mas piénsalo, pronto sería aquello una carnicería donde colgaran desollados aves y humanos.) ¿Blup...? (¿Por qué no aprender del junco, que sabe doblarse sabio cuando el viento y alzarse luego en la calma? ¿Prefieres la rigidez del inflexible cardo que se quiebra y muere...? Por qué 
pensar en guerra cuando te ofrecen los dioses por mi boca, protección, ventura, abundancia, y hasta te conceden en matrimonio el más preciado himen del Olimpo.) (p. 180)

\section{Pasaje 8:}

PISTETERO. - (Infaltable. Con la angustia correspondiente) Evélpides.... ¿En qué nos equivocamos...? (Evélpides esboza una sonrisa triste y se encoje de hombros. Comienzan a entrar algunos invitados que unen sus voces en el festejo.) (p. 183)

\section{Pasaje 9:}

TERO.- (Sobre una música que sigue subiendo. Restos y polvo caen desde la ciudad.) Noche profunda al final. Noche cerrada. Cancel. Sube la helada. Baja el sereno. Las cosas buscan desesperadamente su equilibrio. Obsérvese. La historia acaba como puede. Acaba el sueño, y quedan del sueño los restos. Residuos del deseo que fue. La historia es solo una polución nocturna. Un pegote infecundo entre las piernas. El cadáver de un pájaro boyando en el cielo. $\mathrm{El}$ ave en el aire ha muerto, no sabiendo cómo se cae. ¿Cuál es este cuento al final? ¿De qué se trata? ¿Es una treta? Obsérvese. La vida es un rumor lanzado por un pajarito, puro desplume y terotero, sin ninguna seriedad. ¿Una vileza? ¿Un tero quebrado? ¿Un tero taimado? Un tero apenas terotero, que en un lado pega el grito y en otro tiene los huevos. Un portero que cuenta patrañas en la puerta. Un inocente que ríe, gritando que derrota, derrotero quiere decir camino, y derrumbe: perder el rumbo. ¡Tero! Un cuidador del jardín en lo oscuro de la noche. Un guardabosque asustado. Un cobarde al fin que despierta a todos con sus gritos de miedo cuando el peligro asecha. ¡Tero! ¡Tero! ¡ Un timorato que alborota mientras huye! ¡Tero! ¡Qué se yo...! Mesterio...!! ¡Tero! ¡Tero! ¡Tero! (Bajan las lucen sobre sus gritos de alarma.) Tero. (pp. 186/187).

Pasaje 10:

TERO. - (Estropeado.) Ocaso. Obsérvese. Tardecita en esta murmuración, en este chisme, en esta puesta. Poniente. Puesta de sol. De espaldas. Como si fuera poco caer, caen también las primeras sombras. Tero. Se ensombrece el argumento, la vida, la tarde, la era. ¿Cuál era...? Gritería de pájaros al atardecer del día, del ciclo, del siglo. Un atavismo de aquí en más entre los pajarracos. Implacable se acerca el desenlace. De enlace y moño para este caso. Para este casorio. ¿Será de reir? ¿Será de llorar? No sé. Yo no me llevo de cuentos. Todo tiene en el mundo, Aristotélico al fin, planteo, nudo y resolución. ¡Olor a mar, a marisco, a marisma! ¡Insigne pescau se acerca obsérvese, al mundo de los pajaritos! (p. 177) 
Pasaje 11:

ÑANDÚ. - ¿Y dónde habría otro lugar para nosotros...? ¿Hacia dónde mudaríamos los pájaros...?

FLAMENCO. - Hacia el mar. Hacia las costas.

(...)

CANARIO.- ¿Qué haría un flamenco en las aguas...?

FLAMENCO. - Hacerse a ellas si fuera preciso. ¿Nunca has soñado sumergirte...? Se despierta uno con la sensación de que el aire es insuficiente; de que al pájaro le está dado algo más. ¡Hay un mundo allí bajo las aguas, como esperando que uno lo desnude! ¿No te provoca? ¿Qué harás aquí, Canario? ¿Cantarás en la corte...?

CANARIO.- (Avergonzado.) Soy un artista. (p. 185)

Pasaje 12:

PISTETERO. - ¡Hay que estar en mi lugar para darse cuenta! ¡Lo difícil no es ascender, pájaro, sino mantenerse en el aire! ¡Gobernar, Urraca, es el arte de lo posible! 


\title{
QUID PRO QUO EM Suassuna
}

\author{
Tereza Pereira do Carmo \\ Instituto Superior de Educação Anísio Teixeira
}

\begin{abstract}
A grande força do teatro de Plauto, no nosso ponto de vista, está na inauguração de estratégias cômicas que permanecem. Entre elas destacamos o quid pro quo. É Plauto que introduz na comédia latina o recurso do quid pro quo, estratégia que tem por objetivo criar confusão com uma finalidade cômica. Tal recurso plautino será apropriado no teatro posterior. Ariano Suassuna utiliza o quid pro quo em suas peças. Neste trabalho vamos elencar algumas de suas peças e observar a utilização desse recurso em 3 delas: $O$ santo e a porca, $O$ casamento suspeitoso e o Auto da compadecida.
\end{abstract}

Plauto é um poeta pensador e de grande cultura. A isto se chega pela elevação de sua arte que se alimenta do conhecimento e do estudo. Só Horácio diz que Plauto "desejava vender bem suas obras". Varrão e Cícero fazem-lhe justiça, reconhecendo nele um poeta original e de profundo espírito latino, apesar de compor apenas palliatas.

As personagens de suas comédias eram tipos comuns da vida humana ${ }^{1}$, apresentados sem preocupações moralistas, com a finalidade exclusiva de fazer rir. Daí sem dúvida a grande popularidade do poeta. As personagens da comédia plautina não chegam a encarnar caracteres. São apenas "tipos" quase genéricos, capazes de provocar o riso pela elementaridade dos seus traços sociais e morais. Mas a grande força do teatro de Plauto, no nosso ponto de vista, está na inauguração de estratégias cômicas que permanecem. Entre elas destacamos o quid pro quo. É Plauto que introduz na comédia latina o recurso do quid pro quo, estratégia que tem por objetivo criar confusão com uma finalidade cômica. Tal recurso plautino será apropriado no teatro como herança clássica.

No vocabulário do povo brasileiro o quid pro quo se transforma em, qüiproquó até chegar ao quiprocó. Toda e qualquer confusão é um grande ou pequeno quiprocó.

No Brasil, Ariano Suassuna, em 1957, escreve O santo e a porca, e a subintitula de uma "Imitação Nordestina de Plauto". A palavra imitação, usada por Suassuna,

${ }^{1}$ As personagens podem ser reduzidas a um limitado número de tipos que, em geral, apresentam poucas surpresas: o escravo inteligente, o homem velho, o jovem amante, o cafetão, o parasita, o soldado fanfarrão. Esses tipos são revelados no prólogo, onde não são seus próprios nomes que são enfatizados, mas sim sua designação por tipos (o velho, o adolescente, etc). Deste modo, desde o começo a platéia tem pistas de como ocorrerão as ações ao longo de cada etapa da peça. (Conte, 1999). 
nos remete ao conceito aristotélico de mímesis, cujo sentido não representa apenas uma imitação à semelhança de algo, uma cópia, mas a representação de uma realidade, mais exatamente de uma revelação da essência dessa realidade.

A peça que contém a brincadeira plautina e inspira Suassuna é Aulularia. O fundador do Movimento Armorial tenta resgatar na peça não somente o mundo clássico, mas sobretudo conjugar na mesma toada a herança medieval portuguesa e o romanceiro popular nordestino da literatura de cordel. Nele existe uma tendência para destacar uma estética que se compromete com a religiosidade e a transfiguração poética da realidade (Lemos, 2007, pag.15).

A influência de Plauto no dramaturgo brasileiro é ampla. Ele se utiliza em outras de suas peças da estratégia cômica do quid pro quo. Na nossa proposta, vamos elencar algumas de suas peças e observar a utilização desse recurso em 3 delas: $O$ santo e a porca, $O$ casamento suspeitoso e o Auto da compadecida.

\section{O Santo e a Porca}

O Santo e a Porca narra a história de um velho avarento conhecido por Euricão Árabe. Ele é devoto de Santo Antônio e esconde em sua casa uma porca cheia de dinheiro. O religioso e o profano se misturam ao tema da avareza.

Santo Antônio é um santo de grande devoção popular nos países de origem latina. No Nordeste brasileiro, esse santo é grandemente festejado durante as festas juninas. É popularmente conhecido no Brasil como "santo casamenteiro”. Euricão Árabe, o velho avarento de O Santo e a Porca, invoca o santo, questiona-o, do início ao fim de sua aventura. Embora, em alguns momentos, oscile entre o santo e a porca, mantém-se fiel ao santo de sua devoção. Esta oscilação poderia representar o movimento entre espiritualidade e materialidade inerentes ao ser humano.

Euclião, a personagem de Plauto, no entanto, é a imagem da personificação da avareza. Apela para o deus ou divindade que melhor atender à necessidade de determinado momento.

Nesse contexto de crenças e costumes, a avareza das duas personagens está representada em dois objetos: a panela (vaso) com o ouro de Euclião, escondida na lareira, e a "porca de madeira, velha e feia (...) com pacotes de dinheiro" (Suassuna, 1984, p.13), depositada na sala de Euricão sob a imagem de Santo Antônio.

Como exemplo, temos, em O Santo e a Porca (pg. 74-75), a cena em que Dodó chega para confessar a Euricão que esteve no quarto de Margarida, filha de Euricão, considerando-se assim o causador da aflição do velho avarento. Entretanto, Euricão entende que Dodó havia roubado a sua porca cheia de dinheiro, verdadeiro motivo pelo qual estava desolado. Enquanto Dodó fala de Margarida, Euricão fala da porca e assim se faz o quid pro quo. 
EURICÃO - Como é que você teve coragem de tocar naquilo que não the pertencia?

[...]

DODÓ - A culpa foi das circunstâncias. E eu não já vim pedir desculpas?

EURICÃO - Não gosto desses criminosos que prejudicam os outros e depois vêm pedir desculpas! Você sabia que ela não era sua, não devia ter tocado nela!

DODÓ - Mas eu não já disse que o que aconteceu foi coisa tola?

EURICÃO - Coisa tola o quê? Você não veio confessar? $\mathrm{E}$ depois, de repente, começa a se desdizer, dizendo que não tocou nela! Como é, tocou ou não tocou?
DODÓ - Bem, tocar, toquei, mas não foi nada que pudesse ofendê-la. Mas já que o senhor considera essa tolice um crime, por que não aceita os fatos e não me dá de vez esse tesouro?

EURICÃO - Como é, assassino? Você quer ficar com meu tesouro? Contra minha vontade?

DODÓ - Eu não estou the pedindo? A coisa que eu mais desejo no mundo é ficar com ela!

$[\ldots]$

EURICÃO - Ah, não, você tem que devolver!

DODÓ - Devolver? Eu não já disse que não tirei nada? Devolver o quê? (Suassuna, 1989 p. 74-75)

A cena apresentada é idêntica a cena de Plauto na Aulularia, que se apresenta desta forma:

EUCLIÃO - Mas como é que tu ousaste fazer isto? Tocar no que não te pertencia?

[...]

LICÔNIDAS- Mas eu venho espontaneamente pedir-te desculpa da minha estupidez.

EUCLIÃO - Não gosto dos homens que depois de terem feito o mal vêm pedir desculpa. Tu sabias que ela não te pertencia, não devias ter tocado.

LICÔNIDAS - Mas, já que tive a audácia de tocar, não vejo nenhum impedimento a que não fique com ela! EUCLIÃO - Então tu vais ficar, contra minha vontade, com a...
LICÔNIDAS - Eu não a exijo contra tua vontade. O que eu acho é que deve ser minha. Tu mesmo vais concordar, Euclião, que ela deve ser minha.

EUCLIÂO - Se tu não tornas a trazer... LICÔNIDAS - Não torno a trazer o quê?

EUCLIÃO - Aquilo que me pertencia e que tu tiraste. Olha que te levo ao pretor e te levanto uma ação.

LICÔNIDAS - O que te pertencia e eu tirei? Donde? Afinal que é isso?

(Plauto, SD. p. 122-123)

Suassuna utiliza desse recurso em o Santo e a porca diversas vezes. Conhecedor da obra latina e deixando isso claro no subtítulo da peça, o autor 
brasileiro sabe que trocar uma coisa por outra funcionou na época de Plauto e continua a funcionar ainda hoje.

\section{O Casamento Suspeitoso}

O Casamento Suspeitoso conta o enlace matrimonial por interesse, em que a noiva, mãe e amante estão envolvidos em uma trama para enganar o noivo, até o plano ser descoberto por amigos do "pretendente".

Aqui o quid pro quo acontece em formato diferente. A confusão é deliberada. As personagens Canção e Gaspar realizam o falso casamento dos noivos, após fingirem um ser o frade franciscano e o outro ser o juiz. Geraldo, o noivo, está à espera de Lúcia, a noiva, para a noite de núpcias e depara com Canção, que está disfarçado de Frei Roque. Em seguida, temos Roberto, o amante, que está à espera de Lúcia, noiva de Geraldo e amante de Roberto, e depara com Gaspar, amigo do noivo, que está à espera de Susana, mãe da noiva e sogra de Geraldo. A cena acontece na completa escuridão:

\section{[(...) Canção bate no quarto de Geraldo] CANÇÃO - Geraldo! Geraldo! GERALDO - (abrindo a porta $e$ abraçando-o) Meu amor! \\ CANÇÃO - Epa, que negócio é esse? Vá pra lá! \\ GERALDO - Ingrata, cruel! Você não se envergonha de me tratar assim? \\ CANÇÂOO - Era o que faltava! GERALDO - o que é isso? Você está e barba! Frei Roque! É o senhor? \\ CANÇÃO - Claro! Pensava que era São Francisco! \\ Suassuna $(2002,108)$}

[(...) Gaspar entra tateando]

GASPAR - Amor, onde está você?

ROBERTO- (Também entrando) Amor, é você?

GASPAR- Sou. Onde está você, coração de pedra?

ROBERTO- Aqui. Que rouquidão é essa? Está gripada?

GASPAR- Que gripado que nada! Você também está rouquinha, coração de lajedo!

ROBERTO- $\mathrm{Au}, \mathrm{au}, \mathrm{au}$ !

GASPAR- Ah, agora deu pra latir, hein?

Deixe ver cá essa cachorra!

ROBERTO- Ai, não me faça cócegas!

$\mathrm{Au}, \mathrm{au}, \mathrm{au}$ !

Suassuna $(2002,110)$

Na cena descrita Suassuna usa do quid pro quo de outra forma, não se toma uma coisa pela outra e sim uma personagem por outra. A confusão está armada, uma coisa em vez de outra ou uma personagem em vez de outra, gera o riso herdado de Plauto e que Suassuna mantém. 


\section{Auto da Compadecida}

Em o Auto da Compadecida temos dois tipos populares, João Grilo, espécie de malandro, e Chicó, um mentiroso ingênuo, que participam de uma confusão por causa do enterro de um cachorro. Este Deus-nos-acuda envolve também um padeiro e sua mulher, um bispo, um padre e um sacristão, todos corruptos, o cangaceiro Severino e seu lugar-tenente.

A confusão acontece em o Auto da compadecida (Suassuna, 2005, p. 32 -34) em função de um plano de João Grilo que deixa o Padre João em maus lençóis com o Major Antônio Moraes: enquanto o Padre fala sobre benzer a cachorra, o Major fala sobre seu filho que está doente e vai para o Recife tratar-se. Para o Padre João, era a cachorra (animal) do Major que estava doente; para Antônio Moraes, sua mulher estava sendo ofendida pelo padre. Portanto, o "encaixe" das falas faz o quiproquó funcionar, proporcionando efeitos de sentido diferente para cada sujeito da cena enunciativa.

Padre: É o que vivo dizendo, do jeito que as coisas vão, é o fim do mundo! Mas que coisa o trouxe aqui? Já sei, não diga, o bichinho está doente, não é?

Antônio Moraes: É, já sabia?

Padre: Já, aqui tudo se espalha num instante! Já está fedendo?

Antônio Moraes: Fedendo? Quem?

Padre: O bichinho!

Antônio Moraes: Não. Que é que o senhor quer dizer?

Padre: Nada, desculpe, é um modo de falar!

Antônio Moraes: Pois o senhor anda com uns modos de falar muito esquisitos!

Padre: Peço que desculpe um pobre padre sem muita instrução. Qual é a doença? Rabugem?

Antônio Moraes: Rabugem?

Padre: Sim, já vi um morrer disso em poucos dias. Começou pelo rabo e espalhou-se pelo resto do corpo.

Antônio Moraes: Pelo rabo?

Padre: Desculpe, desculpe, eu devia ter dito "pela cauda". Deve-se respeito aos enfermos, mesmo que sejam os de mais baixa qualidade.
Antônio Moraes: Baixa qualidade? Padre João, veja com quem está falando. A Igreja é uma coisa respeitável, como garantia da sociedade, mas tudo tem limite!

Padre: Mas o que foi que eu disse?

Antônio Moraes: Baixa qualidade! Meu nome todo é Antônio Noronha de Brito Moraes e esse Noronha de Brito veio do Conde dos Arcos, ouviu? Gente que veio nas caravelas, ouviu?

Padre: Ah bem e na certa os antepassados do bichinho também vieram nas caravelas, não é isso?

Antônio Moraes: Claro! Se meus antepassados vieram, é claro que os dele vieram também. Que o senhor quer insinuar? Que a mãe dele procedeu mal? Padre: Mas, uma cachorra?

Antônio Moraes: O quê?

Padre: Uma cachorra!

Antônio Moraes: Repita!

Padre: Não vejo nada de mal em repetir, não é uma cachorra, mesmo?

Antônio Moraes: Padre, eu não mato o senhor agora mesmo porque o senhor é padre e está louco [...]

(Suassuna, 2005, p. 32) 
Em algumas cenas Suassuna cria seu quid pro quo idêntico ao de Plauto em outras, no entanto, Suassuna é inventivo, proporciona ao espectador o gozo do riso, através de cenas que possuem uma complexidade e qualidade não encontrada em Plauto.

A presença do recurso do quid pro quo em Plauto e em Suassuna garante o riso no teatro ontem e hoje. $\mathrm{O}$ autor brasileiro tem falas mais curtas, texto rápido e cenas cômicas em maior quantidade. $\mathrm{O}$ autor clássico tem falas longas, pois necessita das didascálias internas para esclarecer o espectador. Cada fala descreve a ação seguinte, ou seja, o personagem adianta o que vai fazer e o que está ocorrendo; sobretudo, o riso se dá pelo que o espectador vê em cena.

A estratégia comum dos dois autores nos mostra que para provocar o riso os recursos recorrentes são válidos em qualquer época e cultura. Desta forma o clássico se atualiza na cena contemporânea. 


\section{Bibliografia}

Aristóteles; Horácio; Longino. A poética clássica, Trad. Jaime Bruna, São Paulo, Cultrix, 1990.

Cardoso, Zélia de Almeida, A literatura latina, São Paulo, Martins Fontes, 2003.

Costa, Aída, Plauto, Aulularia: a comédia da panelinha, São Paulo, DIFEL, 1967.

Grimal, P., O teatro antigo, Lisboa, Ed. 70, 1986.

Plauto, A comédia latina: Anfitrião, Tradução e notas de Agostinho da Silva, Rio de Janeiro, Ediouro, s/d.

Prado, D. A., O teatro brasileiro moderno, São Paulo, Perspectiva, 1988.

Suassuna, Ariano, Auto da Compadecida, Rio de Janeiro, Agir, 2005.

—_, O casamento suspeitoso, Rio de Janeiro, José Olympio, 2002.

—_, O Santo e a porca, Rio de Janeiro, José Olympio, 1989. 


\section{DENTRO E FORA DA PERSONAGEM: Como encarnar o CORO No HIPÓLITO de Eurípides?}

Ana Seiça Carvalho Universidade de Coimbra

El grupo de teatro universitario Thiasos de la Facultad de Letras de la Universidad de Coimbra empezó a preparar, en 2010, el 12 Festival Internacional de Teatro de Tema Clásico, llevando a escena una nueva tragedia, el Hipólito euripidiano. Es nuestro intento presentar aquí el trabajo y la filosofía dramática del grupo, describiendo las opciones de los directores, los efectos visuales y la plasticidad intrínseca a su puesta en escena. ¿Ante el sentimiento trágico, será el Coro del Hipólito un simple personaje mudo de la obra? ¿Qué tendrán que decir o callar las quince mujeres de Trezena?

\section{Introdução}

É nosso intento, com este trabalho, dar a conhecer a encenação da tragédia Hipólito, de Eurípides, pelo grupo Thíasos, da Faculdade de Letras da Universidade de Coimbra. Trata-se de uma peça pela qual desenvolvi um imenso carinho, não só por ter sido a primeira da qual fiz parte, no elenco original, mas igualmente porque se tornou objecto de estudo do meu relatório de estágio, conferindo-me o grau de Mestre em Maio passado.

Autor de "uniões culpadas" - assim denomina Aristófanes o grande tragediógrafo em Rãs (v.850) - Eurípides envereda, para a construção das suas tragédias, por uma busca da realidade vivenciada pelo ser humano num quotidiano que o marca e que lhe provoca o desencadear de incontidas paixões ou o confronto com terríveis dilemas.

Vivendo a pesada ambiência da Guerra do Peloponeso, o poeta dispõe em cena momentos do foro emocional, da ordem do psicológico, que justificam os grandes monólogos durante os quais as personagens se debatem com os seus sentimentos, reflexões e dúvidas perante o poder divino ${ }^{1}$. O

${ }^{1}$ De ter em conta o precioso estudo de J. Romilly (1997), com maior ênfase no capítulo "Eurípides ou a tragédia das paixões": "Eurípides é o primeiro a ter representado o homem vítima das suas paixões, a ter procurado descrever os seus defeitos”. Fortemente influenciado pela sofística, pela desordem social e política que Atenas vivenciava e pela instabilidade da própria vida pessoal, o tragediógrafo, "dramaturgo da depuração religiosa" (na designação de M.C. Fialho 1996: 34) acabou por trazer ao palco personagens muito humanas, desprovidas de qualquer halo divino (M. C. Fialho 1996: 110). Eurípides construía antes personagens de "almas arrastadas em direç̧ões contrárias" (M. C. Fialho 1996: 115), que apresentavam uma visível perturbação psíquica e luta interior (F. Lourenço 1996: 13). Como também nota M. F. Silva, as personagens apresentam "las debilidades inherentes a su propria naturaleza 
sentido da realidade em Eurípides leva-o a conferir às suas personagens uma dimensão muito humana, capaz de comover o público que se revia assim nos seus sentimentos e nas lutas psicológicas interiores ${ }^{2}$. $\mathrm{O}$ grande salto contrastivo entre Eurípides e os seus antecessores, Ésquilo e Sófocles, se podemos afirmá-lo, terá sido a clara oposição entre a devoção austera das obras de Ésquilo, a crença numa justiça divina que, com o tempo, perde o seu poder e é questionada ${ }^{3}$.

\section{Hipólito de Eurípides em cena}

Do drama de Fedra, ocupou-se Eurípides em dois diferentes textos, o Hipólito Coroado, que se conserva até aos nossos dias, e o Hipólito Velado. Cingimo-nos, nesta rápida análise, à tradicional ideia de como Eurípides terá redigido esta segunda versão devido à escandalosa recepção que a primeira teve por parte do público ${ }^{4}$.

A Fedra da primeira versão mostrava-se, aparentemente, uma matrona sedutora que, ostensivamente, procurava aliciar o enteado numa atitude pouco própria de uma mulher casada. Na segunda versão, a que presentemente abordamos, Fedra, pelo contrário, embora consumida por uma paixão incontornável ${ }^{5}$, recusa-se a confessar os seus sentimentos,

humana, (...), lo que venía a constituir un elemento nuevo dentro del teatro trágico» (2008: 105).

${ }^{2}$ J. Romilly 1986: 156.

${ }^{3}$ Os limites do homem e o seu sofrimento ganham contornos mais humanos nas obras euripidianas, chegando o autor a criticar e a satirizar as concepções tradicionais mitológicas (Vide D. J. Conacher 1967: 52-53). A dependência dos deuses transforma-se, o homem é responsável pelos seus actos e, com Eurípides, denota-se uma clara ruptura na visão da religião e do poder do ser humano (Cf. J. Romilly 1986: 5-6). Segundo B. Knox (1979: 206), no Hipólito nota-se claramente, mais do que nas restantes obras do autor, que o homem não tem qualquer oportunidade de agir intencionalmente e construir o seu próprio caminho: o destino está traçado desde o prólogo de Afrodite, que clarifica as razões da sua vingança. Não obstante, defendemos que as personagens, apesar da incapacidade visível de seguir um rumo pessoal, possuem em si mesmas a decisão do modo como o conduzem, ainda que o desfecho esteja desde logo traçado pela deusa, detentora omnisciente do destino futuro dos seres humanos.

${ }^{4}$ Cf. F. Lourenço 1996:10-12 e W. S. Barrett 1964: 30: Eurípides apresentava, na sua primeira visão do mito, uma Fedra extremamente sensualizante, que atraía e seduzia o enteado, atitude que chocou o público. Fedra preparava encantamentos com que seduzir o enteado, lançando-se impulsivamente numa conquista sexual clara, alegando as infidelidades do marido e a sua própria solidão (M. F. Silva 2005: 174). Segundo J. Romilly 1986: 5, "Après Eschyle et Sophocle, il innove, il découvre, il fait un peu scandale. Il est, si l'on peut dire, moderne en son époque. Mais en même temps il se trouve que, par là, il rejoint par divers traits notre époque à nous".

${ }^{5}$ Fedra é comparável a Estenebeia: casadas e devoradas por um amor inexplicável por um jovem, que não corresponde à afeição sentida. Como vingança, denunciam os jovens como seus violadores/sedutores (cf. M. F. Silva 2005: 170). 
lutando interiormente para preservar o seu segredo ${ }^{6}$. A rainha demonstra nas suas atitudes de reclusão e silêncio um claro desejo de morte (vv.131140). Eurípides mantém, todavia, a imagem de uma mulher sensualmente possuída por uma força exterior inexorável, que se debate, no leito, proferindo palavras desconexas que lembram caçadas e florestas (vv.208-211, 215-222, $228-231)^{7}$.

A encenação que levámos ao palco em Abril de 2010, e que com orgulho ainda mantivemos este ano de 2011, adopta de igual forma esta ideia de carnalidade, de sensualidade física, a principiar pelo Prólogo Coreográfico (figura 1) com que iniciamos o espectáculo:

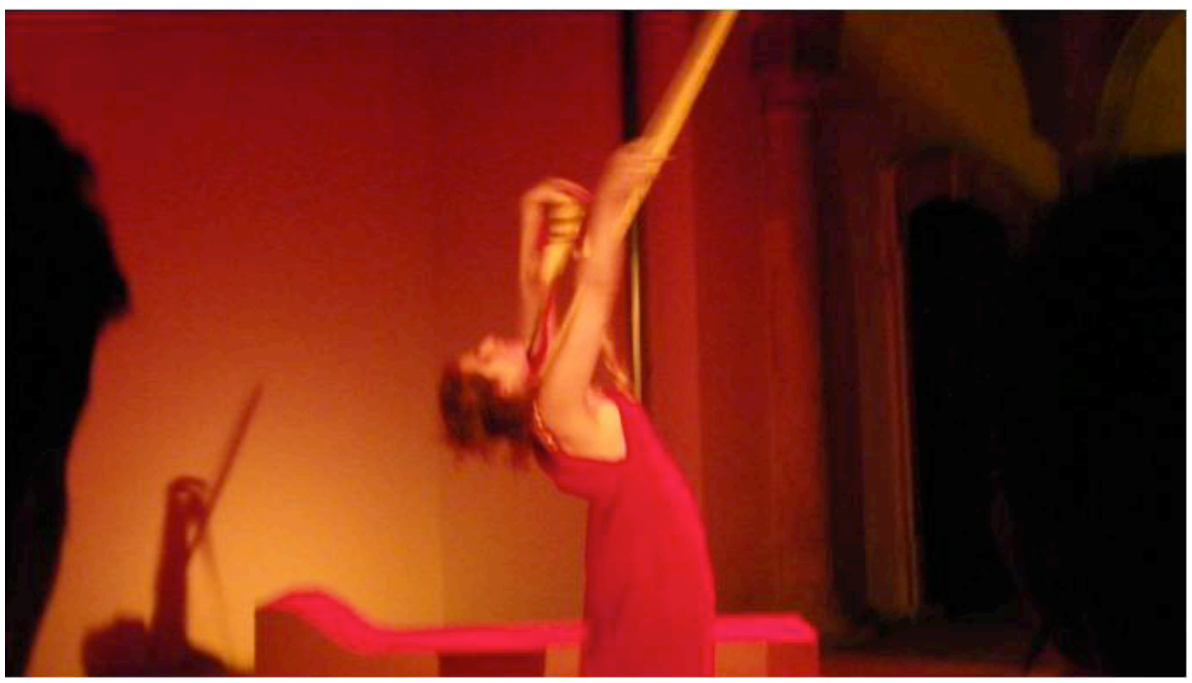

Fedra entra em cena trajando um decotado vestido vermelho escuro, e dança ao redor do leito central, leitmotiv de toda a obra.

A rainha acaricia-se, parece abraçar uma figura imaginária no leito revolto e termina a dança, segurando uma fita bordeau que agita no ar, com ela envolvendo o pescoço, numa prolepse metafórica da sua morte. A sua pose e atitude sensuais, ainda que desvairadas, demonstram uma imagem bem diferente da Fedra que depois entrará velada, na companhia da Ama, quase tropeçando na direcção do leito. Eurípides compraz-se, por completo, em

${ }^{6}$ Veja-se o artigo de J. Diggle, 1996: 119-126.

${ }^{7}$ Eurípides apresenta uma nova Fedra, ou seja, uma mulher honrada que, apesar do sofrimento da carne, resiste à paixão e ao contacto com Hipólito, mas que nunca deixa de ser a mulher casada que sonha e deseja o incesto, ainda que o considere uma grave ofensa. 
mostrar os sintomas exteriores que a paixão gerada por Afrodite impregna na Rainha.

Quando o Coro entra em cena, no Párodo, já após o Prólogo de Afrodite ${ }^{8}$ e uma breve aparição de Hipólito e dos companheiros vindos da caça, o espectador compreende que a casa e a família de Teseu e Fedra está condenada, que a colunata que a sustinha ruirá, devido ao estado de saúde da rainha exilada.

O Coro caminha apressadamente pelo palco, cada um dos quatro elementos com um pano esvoaçante branco nos braços, que agita e sacode com energia mas elegantemente, compondo em conjunto o leito conjugal e principiando a falar entre si numa cena muito familiar e doméstica (figura 2):

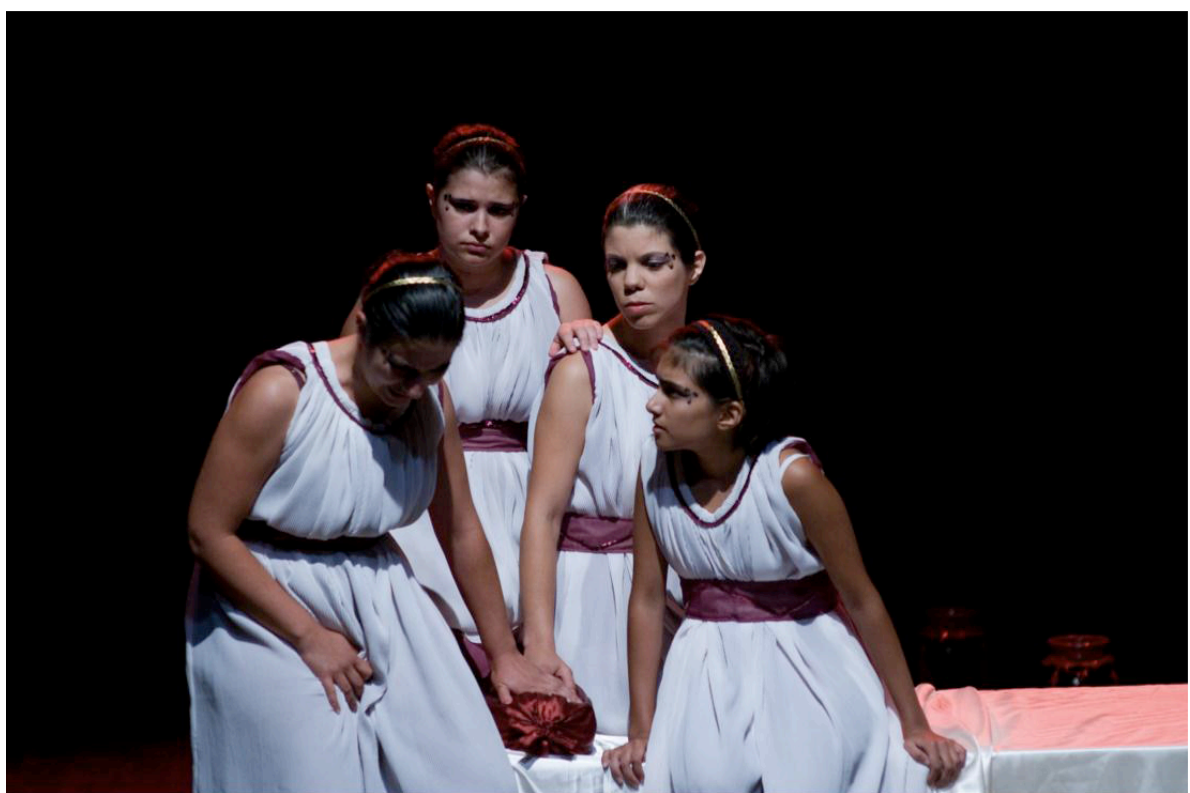

as mulheres de Trezena, elas também mães e matronas, interrogam-se sobre o estado da sua senhora, numa angústia que não conseguem compreender.

${ }^{8}$ Afrodite e Ártemis aparecem em cena no Hipólito como deusas visíveis e antropomórficas, identificadas, no original, por duas estatuetas, ao contrário do que Eurípides já acreditava. É interessante o facto de, na presente encenação, ambas as personagens terem sido papel de uma só actriz. Tratou-se, por isso, de um trabalho de grande concentração e mesmo de modulação de voz, procurando criar, com efeito, uma distância abissal entre a Afrodite sensual e vingativa do Prólogo com uma Ártemis sentenciosa mas doce, podemos dizê-lo, e apaziguadora (M. C. Fialho, 2008: 126-127). 


\section{A simbologia da encenação do Hipólito}

Diversas foram as razões que nos levaram a escolher um cenário simples, não só por motivos práticos e de movimentação, mas sobretudo pela sua carga simbólica: um leito e seis bancos de madeira.

O leito de Fedra, de grandes dimensões, em madeira, ocupa o centro da cena. É à sua volta que se dispõem os bancos do Coro e evolucionam as personagens. O leito, que é antes de mais o ninho dos conjugais aposentos de Fedra e de Teseu, é o mesmo leito onde, nos seus mais recônditos sonhos, a rainha deseja unir-se a Hipólito. Nesse mesmo leito, morrerá a rainha, assim como Hipólito, moribundo, ao colo do pai, definhará pelas feridas do terrível acidente.

Outros são os objectos menores que compõem a peça: desde o pano púrpura, aos tecidos brancos, colmatando com as fitas de ginástica; todos acarretam uma simbologia muito especial.

É com o pano púrpura caído sobre as costas que Afrodite caminha pelo público até ao palco, largando-o com brusquidão aos pés do leito e sentando-se sensualmente 9 . Este mesmo tecido, com laivos de um brilho azulado, será erguido pelas Coreutas e utilizado como mortalha para envolver os futuros cadáveres, ironicamente, daqueles que nunca se encontram em vida, Fedra e Hipólito. Simbolicamente, Teseu também se sentará nesse leito de morte, com o filho nos braços.

Os tecidos brancos que compõem o leito são trazidos pelas Mulheres de Trezena, no Párodo, depois de simularem uma caminhada ao rio, onde os lavam e estendem. Numa cena tipicamente interior e marcadamente feminina, as Coreutas agitam os tecidos brancos (as cores não foram seleccionadas sem propósito, pois a brancura destes panos alude efectivamente à sua inocência, em contraste com os vermelhos e os bordeaux, já que o Coro desconhece ainda as tormentas da sua senhora).

Quanto às fitas de ginástica, estas criam uma profunda e significativa ligação entre a rainha, Afrodite e os elementos do Coro. Fedra empunha uma, desde a sua entrada no Prólogo Coreográfico; no Primeiro Estásimo, será a vez de as mulheres do Coro dançarem cada uma com a sua fita, rodopiando em êxtase erótico; uma dessas fitas será de novo utilizada por Fedra para se dependurar imageticamente, num simulacro de morte; na última coreografia,

\footnotetext{
${ }^{9}$ Afrodite não torna a aparecer em cena, mas o seu plano cumpre-se tal como dita no Prólogo da obra e a prova da maldição que se abaterá sobre Fedra e os seus fica caída em palco: o manto púrpura que a deusa enverga aos ombros e que, num arrebatamento, num gesto preciso e rápido, desfere em palco (durante os vv. 5-6). Púrpura essa que simboliza o amor, a paixão incontrolável e o sangue que será derramado, como veremos ao longo do artigo. A Ama é uma das personagens que reconhecerá o poder arruinador da deusa do amor, vv.359-361 (vide M. C. Fialho, 2008: 131).
} 
uma das Coreutas, durante o discurso do Mensageiro, trará de novo a ideia das fitas como rédeas dos cavalos desvairados que Hipólito não é capaz de dominar; rédeas essas que são também as rédeas com que Eros prende e subjuga o ser humano; rédeas da paixão e do castigo pela insubordinação ao poder divino.

Mas retomemos o fio condutor: logo após a rhesis de Fedra, deitada no leito em que se revolve, num longo discurso em que expõe a sua intensa paixão pelo enteado (análise psicológica desenvolvida, marca euripidiana ${ }^{10}$ ), a Ama procura persuadi-la a lançar sobre si mesma um encantamento para suavizar o seu desejo sensual.

É nessa linha de conta que, entoando a Ode a Afrodite, o Coro em êxtase partilha do ardor amoroso que assola a rainha. Procurámos na nossa encenação, uma verdadeira fusão/entrelaçamento o mais equilibrado possível entre o texto e a coreografia: as odes são proferidas em uníssono, à medida que os elementos do Coro se acariciam ao som da música. De seguida, iniciam uma dança propositadamente descoordenada: num rompante, como se a deusa tivesse penetrado os seus corpos, as Coreutas erguem-se do solo; Afrodite, a deusa materialmente humana em cena, que se mantivera sentada de costas como se de uma estatueta se tratasse, caminha languidamente pelo palco, entregando nas mãos de cada coreuta uma fita bordeau.

À semelhança de Fedra, no Prólogo Coreográfico, as coreutas dançam empunhando a fita, utilizando-a como metáfora do Amor nos seus diversos prismas (figura 3):

${ }^{10}$ Diggle, J. (1996), “The Eros of Phaedra and the Psychology of Crime”, in A. A. Nascimento, V. Jabouille e F. Lourenço (eds.), Eros e Pbilia na Cultura Grega, Lisboa, Centro de Estudos Clássicos, 119-126, p. 120. 


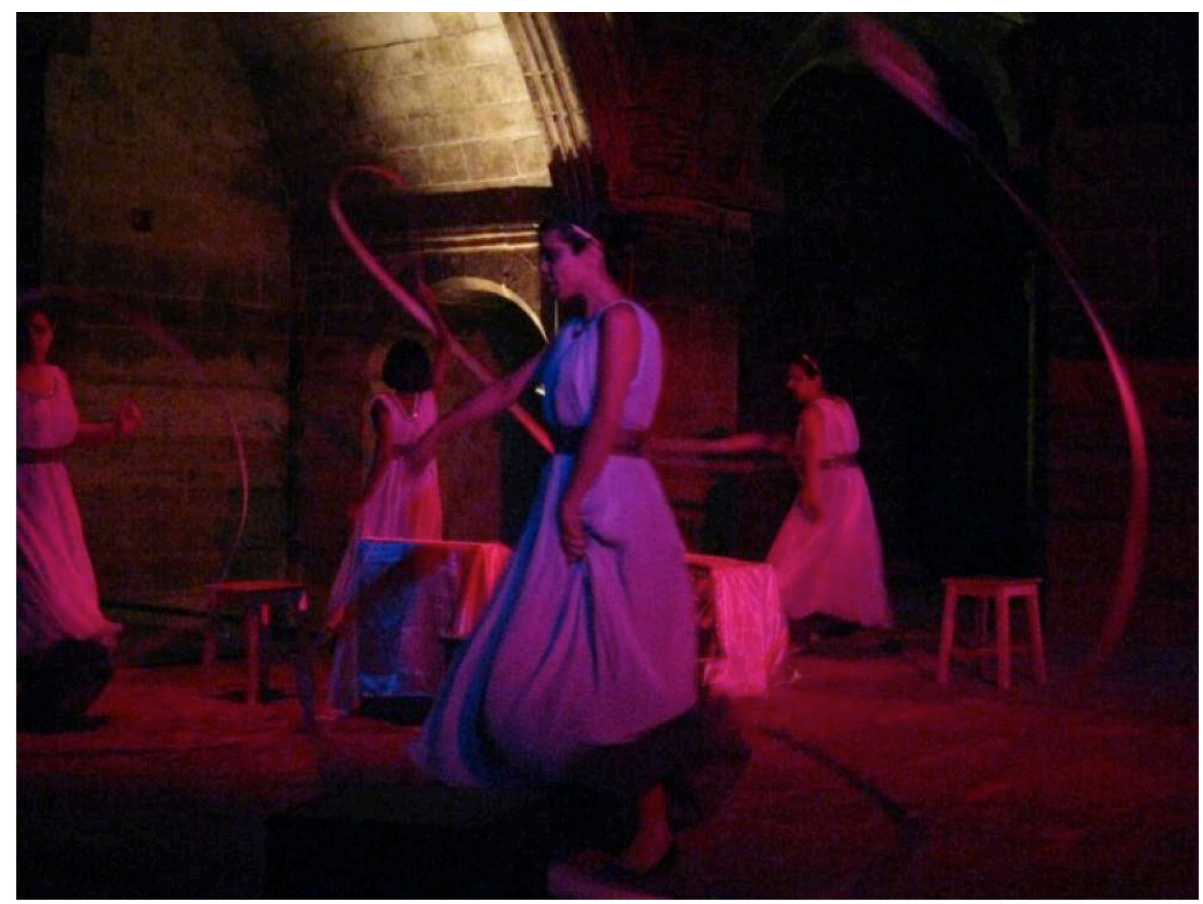

as mulheres acariciam-se sensualmente ao som da música, como se tivessem sido possuídas por Afrodite e Eros; e na manifestação dessa possessão e loucura, agitam-se em movimentos frenéticos, rodeando o corpo com elas numa simbologia de paixão amorosa, contornando sensualmente o tronco com as fitas; finalmente, numa metáfora de prisão e morte, envolvem o corpo e o pescoço com a fita,imagem inequívoca da forca que antecipa, em prolepse visual, a morte de Fedra.

Quando a música termina, as Coreutas tornam a assumir uma posição fixa e rígida, como se se tornassem invisíveis em cena. Seguem-se, no entanto, os grandes agônes, entre a Ama e Hipólito e, de seguida, entre a $\mathrm{Ama}^{11}$ e Fedra. Uma vez mais, o Coro estará presente, mas reservado e silencioso ${ }^{12}$. Ao seu papel,

${ }^{11}$ Um breve apontamento sobre esta personagem parece impor-se, mesmo que o nosso estudo não a contemple, pela importância singular que Eurípides the confere na sua segunda versão. No Hipólito Velado, é Fedra a única responsável por todos os encantamentos e feitiços aos quais se submete para seduzir o enteado. Ao passo que, na peça que estudamos, é nas mãos da Ama que o autor inculca a ideia de administrar poções e o próprio desvendar do segredo (vide M. F. Silva, 2008: 113).

${ }^{12} \mathrm{O}$ Coro assiste à degradação física de Fedra, assiste à argumentação da Ama, à ideia dos encantamentos suavizadores do desejo, à cedência da rainha (olhar automático e simétrico da Ama e do Coro, de cada lado do leito); observa o desvendar do segredo, da Ama a Hipólito, a decisão do suicídio de Fedra; a descoberta da tabuinha por Teseu e a expulsão de Hipólito: testemunhas mudas são o que são. São fulcrais os silêncios dos elementos do Coro. Não obstante, a sua presença é pressentida por manifestações silenciosas, que se traduzem por movimentos sincronizados em determinados momentos chave da obra. Hipólito, em desespero, acaba por pedir ao palácio que não cale a verdade que ali se camufla fatalmente, mas será em vão (vv. 911, 
mais ou menos passivo, de testemunhas silenciosas, correspondem no seu traje, a inocência com que contemplam o sofrimento daquele lar (a brancura das vestes) mas, ao mesmo tempo, a culpa pela sua permissividade (a púrpura dos cintos).

Sente-se, assim, a reviravolta e o sentimento trágicos ${ }^{13}$; uma dança imbuída de paixão segue-se uma dança hipnótica e de horror, após a rainha anunciar a sua intenção de suicídio. Durante o Segundo Estásimo, o Coro caminha lentamente pelo palco, um elemento a seguir o outro, num ritmo cadenciado, como se o estado em que se encontrassem fosse hipnótico (figura 4).

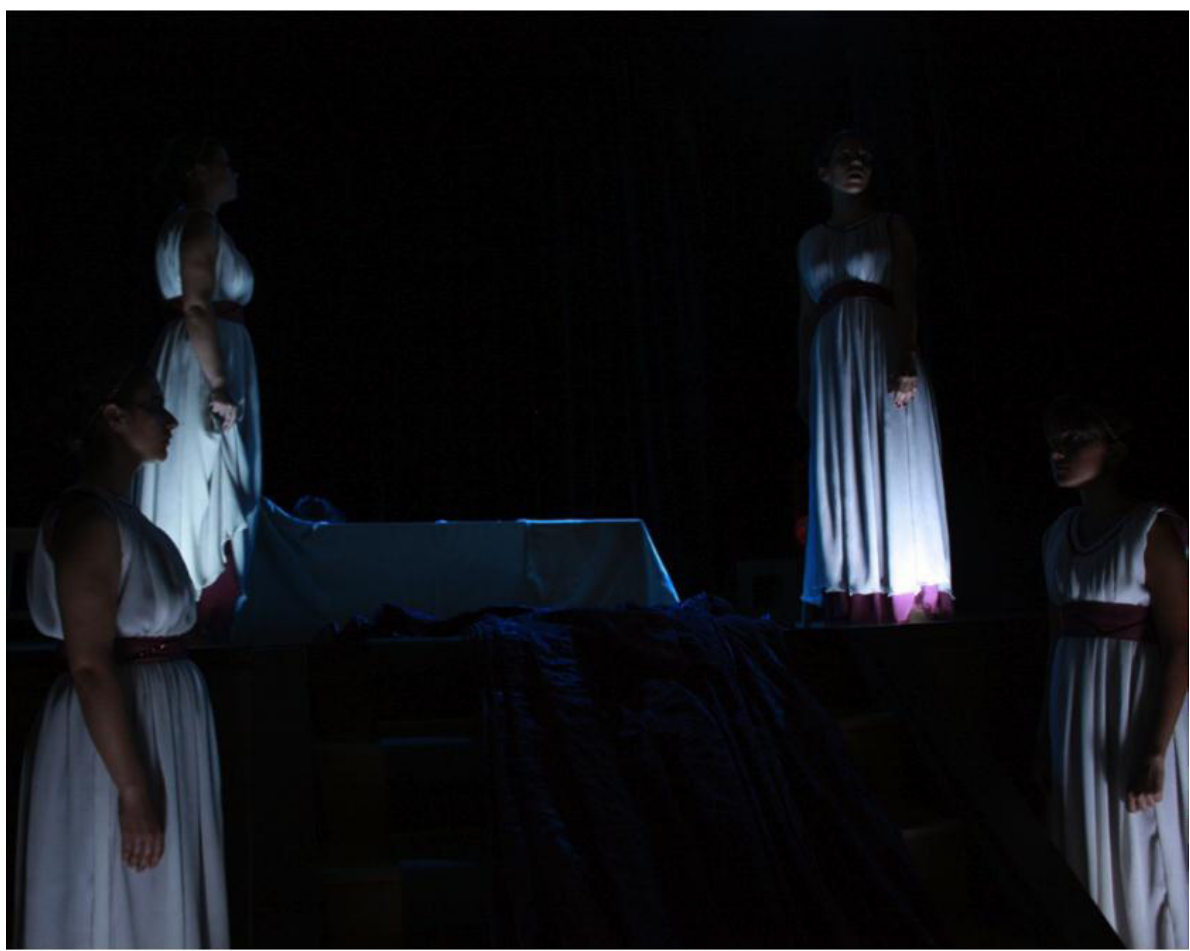

Proferem o cântico escapista em tom monocórdico, cavo e tenso, entoando os versos, cada uma por si, ao mesmo tempo, numa ladainha em transe, desordenada, que chega a ser desagradável ao ouvido do espectador.

1074-1075, O. Longo 1989: 59, "E lo stesso coro, che quand'è il momento potrebbe, e vorrebbe, ristabilire la verità proclamando l'innocenza di Ippolito, è costretto al silenzio". Somente Ártemis, já no epílogo, como deusa ex-machina, fornece a última prova de como a história de Fedra e Hipólito não será calada nem esquecida (vv. 1430-1431).

13 "But, as always, in tragedy, the celebration will be short-lived. The tragic reversal is imminent and will quickly change the nature of the dance", Henrichs, A. (1996), "Dancing in Athens, Dancing on Delos: Some Patterns of Choral Projection in Euripides”, Philologus 140: 48-62. 
Caminham de olhos vidrados em frente, até se reunirem ao centro para erguer o manto púrpura, que Afrodite deixara caído. Com o manto cobrem o leito de Fedra e sobem aos quatro bancos que colocam em redor. É com alguma surpresa que, mais tarde, na presença de Teseu ("Servos, abri as portas, tirai as trancas, para que eu possa olhar a visão amarga da mulher que, morrendo, me destruiu", vv. 809-811), deixam o manto cair no solo, antevendo o cadáver de Fedra, estendido.

Durante o discurso horrendo do Mensageiro, uma das Coreutas desenha, através de uma coreografia baseada no corpus textual, as palavras da personagem, numa tentativa de criar plasticamente o quadro descrito. A dança tem o seu início no preciso momento em que o Mensageiro refere a chicotada imprimida aos cavalos, a fita estala no ar e a coreuta principia a rodopiar, erguendo a fita, simulando a visão da onda gigantesca que assola a praia; de seguida, cobre com a fita o olhar, perante a aparição horrenda do touro monstruoso; simula a força e o segurar com as mãos quase em ferida as rédeas, pois os cavalos, assustados, empertigam-se ferozmente e derrubam o seu auriga, arrastando-o pelo solo; assim a coreuta se arrasta com a fita enrolada no corpo, como prisão, até ao momento em que o carro salta, o auriga cai por completo, partindo a cabeça. Desenlaçando-se da fita num tremor de dor e ferimentos, a dança termina e a coreuta retoma a sua posição como personagem. Por momentos, encarna uma imagem de Hipólito, um alter-ego que recria de forma coreográfica um acidente horrendo e sanguíneo, que não aparece em cena.

Em contrapartida, na encenação deste ano, para além da morte de Hipólito, nos braços do pai, em pietà final, a morte de Fedra também é visualizada pelo público: através do pano púrpura, com projectores estrategicamente localizados, os espectadores vêem a sombra da rainha, em contra-luz, perto do leito, a enlaçar o pescoço com a fita e a enforcar-se.

As danças são claramente inventadas, pois desconhecemos por completo o modo como o Coro evolucionava em cena. Podemos projectar a ideia de que o Coro, em Eurípides já possuidor de um papel dito menor, se manteria estático, enquanto as restantes personagens intervinham, e que dançaria quando lhe cabia a palavra ${ }^{14}$.

\section{Conclusões}

"It is impossible for exactly the same constellation between actors and spectators to occur another time", Erika Fischer-Lichte ${ }^{15}$. Os espectadores e os efeitos neles provocados serão necessariamente diferentes de performance em

${ }^{14}$ Davidson, J. F. (1996), “The Circle and the Tragic Chorus”, $G$ E $R 33$ (1): 38-46.

${ }^{15}$ Erika Fischer-Lichte, "Performance as event - Reception as Transformation". In Hall, Harrop: 2006, p.37. 
performance. Uma performance existe somente como evento: quando termina o acto autopoético, de igual forma a performance deixa de existir, pois é do domínio da presentness efémera e transitória, jogando com a intensidade óbvia de um presente que não torna a repetir-se.

A aposta da encenação, sobretudo no que ao Coro diz respeito, embora se destine a um público português, que compreende, por isso, a linguagem inerente e o texto, baseia-se, podemos afirmá-lo, em diversos elementos visuais. A teatralidade das cenas euripidianas permitiu aos encenadores criar um todo que se compõe, se o analisarmos, de diversos quadros consecutivos. No decorrer da tragédia, as personagens - e esse detalhe pode ser avaliado pela observação do conjunto de fotografias de que dispomos - recriam verdadeiros quadros de uma beleza e simetria singulares ${ }^{16}$.

Desde a roupagem escolhida, à gama cromática, passando pela utilização de determinados objectos cénicos - desenham e iluminam a ideia de uma prisão sexual que domina a obra.

O Coro, muito embora, como temos vindo a apreciar, não demonstre uma influência directa nas personagens e não possua aquela grandeza que os autores trágicos antecedentes lhe conferiam, transmite, como vimos, uma clara mensagem de conselho para os meros mortais: que não desejem incorrer em bybris, já que a perda do equilíbrio humano é causa de sofrimento.

Como grupo de teatro universitário, o nosso objectivo primordial, por excelência, é procurar desenvolver uma filosofia e dinâmica conjunta, uma aprendizagem escolar, um trabalho de equipa, que nos torne mais coesos, que nos permita debruçarmo-nos sobre diversas opções estéticas, linguísticas, coreográficas e cénicas, explorando a voz, o corpo, a dança, adquirindo e desenvolvendo, cada vez mais, competências, no mundo do teatro e na vida em si mesma, em actuações especiais e irrepetíveis ${ }^{17}$.

16 "Greek tragedy is fascinated by its own imitation of beautiful, alluring bodies; at moments of quintessentially tragic emotion involving pity and fear, eros and thanatos, tragic figures (especially females) are often compared with paintings or statues, in an implicit acknowledgement of the visual objectification of the characters represented.”, Felix Budelmann, "Bringing Together Nature and Culture". In Hall, Harrop: 2006, pp. 118-133.

17 "Tragedy is comprehended and defined differently through performance than on page, and performance offers a living laboratory for exploring a genre prematurely declared dead”, Helen Foley, “Generic Ambiguity in Modern Productions of Greek Tragedy”. In Hall, Harrop: 2006, p. 150. 


\section{Bibliografía}

W. S. Barrett (1964), Euripides. Hippolytos, Oxford, Clarendon Press.

D.J. Conacher (1967), Euripidean Drama: Myth, Theme and Structure, Toronto, University of Toronto Press.

J. F. Davidson (1996), "The Circle and the Tragic Chorus", $G$ \& $R 33$ (1), 3846.

J. Diggle (1996), "The Eros of Phaedra and the Psychology of Crime". In A. A. Nascimento, V. Jabouille e F. Lourenço (eds.), Eros e Pbilia na Cultura Grega, Lisboa, Centro de Estudos Clássicos, 119-126.

M. C. Fialho (1996), "Afrodite e Ártemis no Hipólito de Eurípides", Máthesis 5, 33-51.

M. C. Fialho (2008), "Deuses e Homens no Hipólito de Eurípides". In A. Pociña, A. López (eds.), Fedras de ayer y de hoy, Granada, Universidad, 125-146.

E. Hall, S. Harrop (eds), Theorising Performance, Greek Drama, Cultural History and Critical Practice, Duckworth, 2010,

A. Henrichs (1996), "Dancing in Athens, Dancing on Delos: Some Patterns of Choral Projection in Euripides", Philologus 140: 48-62.

B. Knox (1979), Word and Action, Essays on the Ancient Greek, Baltimore and London, The Johns Hopkings University Press.

O. Longo (1989), "Ippolito e Fedra fra parola e silenzio", QUCC 32: 47-66.

F. Lourenço (21996), Eurípides. Hipólito. Lisboa, Colibri.

J. Romilly (1986), La modernité d'Euripide, Paris, Puf Écrivains.

M. F. Silva (2005), Ensaios sobre Euripides, Lisboa,Livros Cotovia. (2008), "La Fedra de Eurípides, ecos de un escándalo". In A. Pociña, A. López (eds.), Fedras de ayer y de hoy, Granada, Universidad, 105-123.

S. Sontag (2001), "The artist as exemplary sufferer". In Against interpretation and other essays, Picador, USA Edition, pp.39-48. 


\title{
DOS MITOS GRIEGOS EN UN ESCRITOR NOVEL: LAS SIRENAS Y LA FUNDACIÓN DE ATENAS, DE Roberto Sayar
}

\author{
Pablo A. Cavallero \\ Universidad de Buenos Aires - UCA - CONICET
}

Con un pseudónimo, Sayar redactó Las sirenas, que recrea un pasaje de la Odisea, y La fundación de Atenas, que dramatiza los orígenes míticos de la ciudad. Ellas reproducen la estructura de obras griegas. Pero el autor finge ser editor-traductor: antepone un estudio donde presenta la 'tradicición' textual, por la que un antiguo códice habría llegado al Plata y quedado oculto hasta su hallazgo fortuito. Añade notas eruditas y bibliografía, de modo que las piezas aparecen como enmarcadas en una moderna edición académica. Pretendemos, pues, dar noticia de ellas y llamar la atención sobre cómo en el siglo XXI y en los extremos del hemisferio sur aún perviven modelos formales y de contenido clásicos.

Con el pseudónimo Nëkiwâa. ${ }^{n}$ el joven cuasi egresado de la carrera de Letras, en la orientación clásicas, de nuestra Universidad de Buenos Aires, Roberto Sayar, ha redactado dos piezas de teatro que motivan esta presentación. Interesado en la literatura comparada, especialmente a causa de tener ancestros japoneses, ha indagado también en la mitología griega a raíz de sus estudios de grado.

Estas dos piezas dramáticas cuentan con una edición reducida, artesanal, hecha por el mismo autor. Las sirenas, que data de 2008, recrea el mito más conocido de los dos, es decir, el pasaje del canto XII la Odisea, vv. 39-54 y 154200 , en que el héroe protagónico aplica un ingenioso recurso de tapar los oídos a sus marineros y de ser atado al mástil de la nave, para poder oír el canto de esos pájaros sin sufrir su daño ${ }^{2}$. En La fundación de Atenas, publicada en 2009, Sayar dramatiza los orígenes míticos de la capital helénica, por los que Posidón y Atenea se disputan la posesión y protección de la ciudad de Cécrope, el rey hombre-serpiente nacido de la tierra, y se incluye el nacimiento de Erictonio, su futuro hederero, nacido de Hefesto y la tierra y cuidado por Atenea ${ }^{3}$.

Es evidente, pues, que en ambas obras sobreviven mitos clásicos. En el caso de Las sirenas, quizás la mayor innovación respecto de la fuente homérica es que Odiseo dialoga con las aves y, tentado, es salvado de la seducción sucesivamente por el corifeo, por Euríloco y por Atenea en persona, mientras que en el canto XII 192 ss. de la Odisea el héroe no responde y Perimedes

\footnotetext{
${ }^{1}$ Significa "Demonio del templo oriental".

${ }^{2}$ Para un estudio sobre estos seres míticos y su presencia literaria, Cf. Cavallero 1985-6.

${ }^{3}$ Cf. Grimal 1997.
} 
y Euríloco refuerzan las aturadas de su jefe. En el caso de La fundación, se introduce una asamblea democrática en la que triunfa la opinión femenina y una lucha entre los dioses; también se recrea la fabricación de armas por parte de Hefesto, motivo del canto XviII de la Ilíada y, en vez de relatar que Hefesto persigue a Atenea y derrama semen en su pierna, el cual cae a tierra, donde engendra a Erictonio, dice que el dios-herrero le regala una joya, un corazón de oro y diamantes que, al caer a tierra, la fecunda. Sin embargo de estos detalles míticos y de las variantes elaboradas, la adaptación de los modelos antiguos en estas piezas no se limita al contenido.

También la estructuración de ambas obras se inspira en el teatro griego antiguo. En Las sirenas hay un prólogo a cargo de Posidón en diálogo con la Muerte (que puede ser recreación del prólogo de Alceste de Eurípides, donde hablan Apolo y Thánatos); hay párodos o canto de entrada del coro; además, cinco episodios, cuatro stásima o cantos corales intermedios, un kommós o lamento, de estructura estrófica, y una éxodos o retirada del coro. En La fundación de Atenas, el texto va precedido por varias hypothéseis -es decir, presupuestos para la lectura, comentarios de gramáticos o escoliastas- y, luego, se desarrolla la pieza en sí con prólogo a cargo de Hermes en diálogo con Zeus, párodos en semicoros, cinco episodios y cuatro stásima, éstos con estructura estrófica, un interludio lírico 'traducido' en verso rimado y la consabida éxodos. Mientras que en Las sirenas el coro es de marineros, en La fundación, el coro es de ciudadanos, pero en el estásimo segundo se distinguen dos semicoros, de hombres y de mujeres.

Es importante señalar que el autor se presenta no como tal sino que finge ser el editor-traductor del texto, de modo que en ambas portadas se lee "edición revisada, anotada y traducida por el editor" y, en el caso de La fundación, se añade editio princeps. Es decir, las piezas no se presentan como recreaciones del siglo xxI, como fueron en su momento las Antígona de Jean Anouilh, de Salvador Espriu o de Leopoldo Marechal, o el Anfitrión 38 de Jean Giraudoux o La guerra de Troya no tendrá lugar, del mismo dramaturgo, para mencionar sólo algunos casos; sino que estas obras aparecen como ediciones de textos antiguos que habrían sido rescatados del olvido. De tal modo, el oculto autor antepone a sendas piezas un estudio introductorio. En el primero dice que el autor de Las sirenas es un tal Delocleón de Aisa, nacido en el 443 a.C., de cuya familia da detalles, como así también de personas y episodios contemporáneos (Tucídides, Aristófanes, la guerra del Peloponeso, etc.). Delocleón -cuyo nombre no está registrado en diccionarios pero sigue las normas habituales de la onomástica griega y significaría 'famoso revelador', o algo así, mientras que el pseudodêmos de origen es una de las maneras de decir 'destino'- este Delocleón, decíamos, habría sido, además de dramaturgo, comerciante y poeta elegíaco; se habría ocultado y exiliado por razones políticas; se mencionan también 
algunos títulos de obras perdidas. Todo esto surge, según el fingido editortraductor, de una serie de escolios o comentarios antiguos que acompañan al único manuscrito que transmite la obra. La ficción de este supuesto autor y de este códice se construye en el apartado de la introducción titulado "Tradición textual”, en el que se dice que la hija de Delocleón salvó un manuscrito del incendio provocado por su padre, lo hizo copiar en Macedonia y esta copia llegó a los eruditos alejandrinos; las reproducciones medievales derivadas de ellos habrían llegado a Francia con los caballeros de la V Cruzada pero habrían sido destruidas por san Luis IX, salvo una que, tras pasar por Génova y Lisboa, llegó a Río de Janeiro, pasó a Colonia y quedó en manos del Virrey Cevallos, según dicen escolios latinos. La recuperó Urquiza, quien ordenó arrojarla al agua en una botella. Claro está, la copia se salvó y llegó a las autoridades del partido de Merlo. Tras relatar este fabuloso derrotero, el editor-traductor describe el supuesto códice, llamado Merlicus, resume el argumento y enumera y caracteriza a los personajes, señalando que hay también algunos mudos; aclara cómo los papeles pueden estar distribuidos entre solamente cuatro actores.

En la segunda pieza, La fundación de Atenas, el falso editor-traductor dice que el autor es pseudo-Delocleón, un antagonista del supuesto autor de Las sirenas, llamado en realidad Eutifrón, nombre que sí se registra y que como adjetivo significa 'de buen sentimiento'o ‘que piensa correctamente'( $\varepsilon \dot{\theta} \theta \dot{v} \varphi \rho \omega v)$. Incluye en la introducción a la obra datos de este señor, de su producción, de la que quedaría esta pieza en una segunda versión, y muchos detalles históricos de fines del s. v y comienzos del IV a.C., además de una reseña del argumento, una caracterización de los personajes y un esquema de los contenidos de la pieza en su estructura interna. En cuanto a la 'tradición' del texto, éste habría llegado a la actualidad a partir de una copia constantinopolitana del s. XIII, que habría pasado a España y arribado al Plata en manos de Juan de Ayolas y que sería el códice que Garay sostiene en el famoso cuadro de la fundación de Buenos Aires. Tras pasar por diversos conventos, la copia habría quedado oculta hasta un hallazgo fortuito, nada menos que en oportunidad de la construcción de un subterráneo. Este códice, llamado 'Catalino', por haber sido preservado en el convento de las Catalinas, incluye dos obras de Eutifrón y tres de Delocleón, de modo que supuestamente con él se amplía la recuperación de obras extraviadas de estos quiméricos dramaturgos.

Esta ficción del manuscrito viajero no es original y menos aún la de suponer su casual salida a luz. Para remitir a un ejemplo quizás poco conocido, ya en las Memorias de un repórter de los tiempos de Cristo ${ }^{4}$ se había recurrido a un proceso similar: Myles Connolly, un periodista estadounidense a quien su jefe encarga una biografía de Jesús escrita como en su tiempo, para lo que se

\footnotetext{
${ }^{4}$ Cf. Heredia 1946.
} 
traslada al cercano Oriente, habría hallado 'traspapelado' en un monasterio sinaítico un códice escrito en griego por un judío hispano; se trata de una larga novela histórica, no de un drama, en la que un tal Rafael Ben Hered cuenta detalles de la vida de Jesús y sus apóstoles. El periodista hace que unos frailes franciscanos de Jerusalén se lo traduzcan y su jefe lo publica en Boston. Al final de la introducción en que se explica esto, hay una nota a pie de página que dice:

Estas Memorias publicadas en forma de libro son las que ahora damos a conocer. Téngase presente que estas Memorias no son traducción literal del original griego de hace dos mil años, sino una 'adaptación' a nuestro medio, costumbres y lenguaje. A nadie debe, pues, extrañar que se usen palabras y locuciones enteramente modernas, equivalentes a las que usó el 'repórter hebreo' de la época de Tiberio César. Los textos de la [Sagrada] Escritura van con caracteres especiales para distinguirlos de la restante narración, obra de Ben Hered $^{5}$.

A esta buena advertencia acompaña un retrato del anciano centenario Ben Hered, debido a un pintor de la escuela pompeyana. En el capítulo 57 del primer libro, el periodista retoma la palabra y dice que se permite unas vacaciones, por las que suspende su tarea de "traducción y adaptación" que ya le lleva dos años; se queja allí del estado de los pergaminos, de la ilegibilidad de letras griegas, hebreas o siríacas. Cuando comenta que su autor era un "hombre de mundo" aprovecha a señalar como cualidad que "estaba dispuesto a no cerrar sus ojos a la verdad", porque "no era de la escuela de Ben Renanus", indicación sarcástica contra la biografía de Jesús debida a Renan; también hace comentarios literarios: por ejemplo, que la obra es "el resultado de una investigación que el Rabbí español, sin plan preconcebido, va haciendo (...) Por eso no hay que esperar orden alguno cronológico" ${ }^{7}$. Estos intervalos epistolares aparecen también en la mitad y al final del libro tercero (capítulos 18 y 91). 'Casualmente', quien figura como autor de esta obra es Carlos María de Heredia, jesuita mexicano (1872-1951): es posible vincular su apellido con el del supuesto autor Ben Hered, también hispano, como el epílogo se ocupa de aclarar; y, así, la novela llega al lector a partir de un inventado códice griego, que es traducido por un periodista en Jerusalén e impreso en Boston, impresión periódica sobre la que luego se hace esta edición como libro con los respectivos marcos explicativos, estructurados cual un intercambio epistolar entre el periodista y su jefe quien da noticia de la gradual aparición de la obra y de los comentarios positivos que ella genera ${ }^{8}$.

\footnotetext{
${ }^{5}$ P. 16.

${ }^{6}$ Cf. tomo III, p. 222.

${ }^{7}$ Cf. tomo III, p. 223.

${ }^{8}$ La edición hecha por la Editorial Difusión añade, además, 'prólogos' modernos como el de Federico Gamboa (tomo I, pp. 7-8), el de Joaquín Cardoso (tomo III, pp. 231-234).
} 
Empero, a pesar de la fabulación que hay tanto en este antecedente cuanto en los dramas que nos ocupan ahora, no es inverosímil un descubrimiento fortuito, pues sabemos que muchas piezas literarias se han hallado de ese modo en lugares inesperados ${ }^{9}$ e, incluso, que algunos manuscritos, aunque no tan antiguos, han llegado a América ${ }^{10}$. Pero a dicha ficción Roberto Sayar añade la de presentarse él mismo como editor e, implícitamente, como estudioso y traductor de ese texto griego. En el caso de La fundación dice de modo explícito:

Luego de un arduo trabajo de recuperación por parte de los eruditos, se pudo al fin tener acceso a él [el códice] para traducir y observar su contenido (p. 16).

Obviamente, "los eruditos" - paralelos a los frailes franciscanos de la novela- no existen sino que son un eslabón más en la ficticia cadena de hechos y personas que intervienen en la llegada de los textos al lector. De ahí que, gracias a que puede "observar" el contenido, en sendas introducciones incluye análisis literarios y filológicos y que remite a bibliografía secundaria; y de ahí que a lo largo del texto y de sus hypothéseis incorpore, por una parte, acotaciones sobre las partes componentes de las piezas o detalles escenográficos y remisiones a los versos del 'original' griego; y, por otra, notas eruditas con diverso tipo de información: loci similares de otras obras literarias, explicaciones mitológicas (por ejemplo, quiénes son los ciclopes o las Moiras o detalles de los dioses mencionados), aclaraciones de orden etimológico, filosófico, histórico, geográfico o cultural (como los ritos y festividades de los griegos), comentarios literarios (por ejemplo, sobre la oscuridad de un pasaje o sobre la inclusión de una parodia) o indicaciones codicológico-ecdóticas, como señalar una laguna en el texto. Este tipo de estudio y de anotación no están en el antecedente al que nos hemos referido.

De este modo, las piezas teatrales aparecen enmarcadas en una moderna edición académica, fruto de la investigación científica aplicada a un hallazgo arqueológico, tales como las que se hacen habitualmente, tanto respecto de textos ya secularmente conocidos, cuanto de textos que se van descubriendo.

En el caso de Las sirenas, se lee al pie de la portada, a modo de subtítulo, la indicación: "Una deliciosa parodia de los estudios de obras clásicas y de los grandes trágicos y cómicos"; y reaparece como "Otra deliciosa parodia" en la portada de La fundación de Atenas. Estos comentarios dan una idea de la intención literaria del autor. Un estudioso del mundo helénico compone dos dramas supuestamente traducidos del griego, a los que rodea de una

\footnotetext{
${ }^{9}$ Para mencionar un solo caso, a mediados del s. xx apareció el único códice que testimonia el Dýskolos de Menandro.

${ }^{10}$ Para dar dos ejemplos, el ms. Wisconsin, de las Crónicas del Canciller Ayala, o un códice italiano del s. xviii conservado en Buenos Aires (Cf. Cavallero 1995).
} 
'parafernalia' de erudición académica, con la que recrea nuestras labores de investigación y de docencia universitaria, produciendo con mucha habilidad y conocimiento una parodia jocosa, a veces hiperbólica, de este serio oficio, sazonándolo con un poco de diversión, haciéndoles guiños cómplices a los estudiosos de hoy.

Pretendemos, pues, en el espacio reducido de esta ponencia, dar noticia de estas obras y llamar la atención sobre cómo en el siglo xxi y en los extremos del hemisferio sur aún perviven modelos formales y de contenido clásicos trasvasados a productos originales. 
Dos mitos griegos en un escritor novel: Las sirenas y la fundación de Atenas, de Roberto Sayar

\section{Bibliografía}

Cavallero, P. (1985-6), "Las sirenas de la antigüedad grecolatina y el motivo de las sirenas en la literatura hispano-argentina”, Anales de la Academia Nacional de Ciencias de Buenos Aires XIX-XX, 152-173.

(1995): "De Roma a Buenos Aires: un manuscrito latino fechado en 1709”, Anales de filología clásica XIII, 40-51.

Grimal, P. (1997): Diccionario de mitología griega y romana, Buenos Aires, Paidós (orig. francés, 1951).

Heredia, C. M. de (1946), Memorias de un repórter de los tiempos de Cristo, Buenos Aires, Difusión.

Nëkiwá! (2008), 'Las sirenas' de Delocleón, edición revisada, anotada y traducida por el editor, Buenos Aires, Éditions de l'Â!.

- (2009),'Fundación de Atenas', de Eutifrón (pseudo-Delocleón), editio princeps revisada, anotada y traducida por el editor, Buenos Aires, Éditions de l'Â!. 


\title{
El personaje de Antígona en Sófocles y Gambaro: LA CREACIÓN DE UNA NUEVA TRAGICIDAD
}

\author{
María Victoria Coce \\ (UBA-IUNA)
}

\begin{abstract}
El objetivo del trabajo es comparar la construcción del personaje 'Antígona' en los textos de Sófocles y Gambaro, Antígona Furiosa, haciendo hincapié en el concepto de tragicidad que las define como heroínas en dos universos ficcionales opuestos. Partimos de la hipótesis de que el texto de Griselda Gambaro está construido mediante un diálogo intertextual con la obra de Sófocles, pero a partir de una contraposición paródica de las características que definen al personaje sofocleo, especialmente de su carácter trágico. Demostramos que la Antígona de Gambaro resulta un sujeto trágico que desplaza su sentido en la medida en que la 'tragicidad' no depende de la muerte de la heroína, en tanto elemento fundamental para el retablecimiento de la justicia, sino de la insistencia de una muerte infinitamente repetida a partir de una causalidad absurda.
\end{abstract}

\section{Antígona: la tragedia como 'acrecentamiento'.}

Recordamos que la acción dramática sofoclea comienza delante del palacio real en Tebas, y que se inicia con las primeras luces de la madrugada. El prólogo de la obra aparece construido por el diálogo entre Antígona y su hermana Ismene, quienes con sus réplicas informan al público los antecedentes necesarios de la acción. Además dicho preámbulo cumple la función de adelantar el conflicto central de la pieza: Antígona comunica a Ismene el decreto de Creonte de prohibir el entierro de Polinices bajo pena de muerte. Y la invita a cumplir junto con ella el enterramiento debido a pesar de que esto contradiga el decreto de Creonte y de que implique la decisión de morir ${ }^{1}$. La negativa de Ismene plantea ya el denso conflicto trágico de la pieza. La protagonista se desvincula de su hermana, estableciendo claramente el conflicto dramático en términos de una disyunción absoluta: cumplir el deber para con los dioses a pesar de ir en contra de las leyes de la ciudad o traicionar el mandato sagrado ${ }^{2}$. En su parlamento Antígona anuncia que espera una "bella muerte" (kalón thanein ${ }^{3}$ ), siendo ésta, entonces, una consecuencia trágica de su elección y no un funesto fin inevitable. La plantea

\footnotetext{
1 Cf. Sophocle (1955), v. 41-44.

2 Cf. Sophocle (1955), v. 45-46 y 71-76.

3 Cf. Sophocle (1955), v. 72.
} 
como algo bueno para ella, en la medida en que la considera un acto que le permite concordar con la voluntad divina. Pero en el mismo párrafo el poeta deja también planteado la tensión dramática, pues el dilema en el que está puesta Antígona no resulta en ninguno de sus dos términos opuestos un bien absoluto: ella yacerá muerta tras cometer "un piadoso crimen" ${ }^{4}$. Oxímoron que definiría, pues, a esta heroína sofoclea, que con su desmesurada pasión por cumplir con las leyes de los dioses choca con el orden de la ciudad y su reglas. Antígona es piadosa y sacrílega a la vez, genera un desequilibrio que recién se restablecerá después de su muerte.

Finalmente el coro prepara la entrada de Creonte, quien establece un agón con el Corifeo y se empieza a mostrar el exceso de este héroe trágico que pretende con su edicto contra Polinices, regir sobre realidades que están más allá de los vivos ${ }^{5}$. Así, es posible observar que desde el inicio Creonte encierra motivaciones justas, que hacen al orden y al bienestar de la ciudad, pero por otro lado su heroísmo está teñido de hybris, al pretender invadir el dominio de los dioses infernales. Por eso es que el Corifeo empieza a tomar distancia de su gobernante cuando le ordena que vigile y haga cumplir su mandato ${ }^{6}$. En este diálogo aparece por primera vez la asociación entre la idea de la muerte (thánatos) y la de 'acrecentamiento' (tó kérdos), que postulamos como constitutiva del significado que Antígona da a su muerte. Relación que define a su vez la oposición Creonte/Antígona, es decir determina la contradicción protagonista/antagonista, que se resolverá con la muerte, como acto existencial imprescindible para alcanzar el equilibrio perdido tanto de la ciudad como de la heroína, que logra con ello su cometido.

No podemos recoger aquí las citas textuales en donde se relacionan la idea de morir o de muerte (thanéein, thánatos) y acrecentamiento existencial (tó kérdos), pero podemos señalar que reaparecen sistemáticamente y le dan sentido a todo el conflicto que anima la acción dramática, de la cual retomaremos algunos de sus puntos culminantes que nos permitirán constatar lo planteado.

En efecto, luego de que Antígona da sepultura a su hermano y se entera Creonte del hecho, el rey insiste con la motivación del lucro como motor de la desobediencia a su ley ${ }^{7}$ y profiere la amenaza de muerte para los guardias si no entregan al autor del sepelio. En la condena misma reaparece la palabra tó kérdos ${ }^{8}$ y $\operatorname{kerdainein}^{9}$ como única causa del delito, evidenciándose la ignorancia

\footnotetext{
${ }^{4}$ Cf. Sophocle (1955), v. 74.
}

${ }^{5}$ Sophocle (1955), v. 213-214: "en efecto, a ti te es posible servirte de todo tipo de leyes, tanto a cerca de los muertos como de cuantos estamos vivos".

${ }^{6}$ Cf. Sophocle (1955), 215-216.

${ }^{7}$ Cf. Sophocle (1955), v. 289-303.

${ }^{8}$ Cf. Sophocle (1955), v. 310.

${ }^{9}$ Cf. Sophocle (1955), v. 312. 
por parte del gobernante acerca de qué otras implicancias tiene el término en boca de sus oponentes.

En la segunda escena, el Guardia trae a Antígona para entregarla ante el rey. En el interrogatorio se da cuenta de los detalles de rito fúnebre y de los prodigios ocurridos: se revela, en este caso, el segundo indicio temporal que ofrece la pieza, al señalarse que el acto se produjo cuando sol ocupó el medio del cielo. Y se marca, asimismo, la lectura simbólica del huracán hecha por los guardias como indicio de una desgracia divina en ciernes ${ }^{10}$. Antígona, por su parte, asume en este agón su responsabilidad y su destino, fundamentando su accionar en las leyes "inquebrantables y no escritas de los dioses"11. Las plantea como incuestionables y define su propia muerte como tó kérdos (acrecentamiento) ${ }^{12}$. Hecho que, como declara ella misma genera ausencia de sufrimiento ${ }^{13}$, porque tiene esperanzas en el después de la muerte, en reencontrarse con los suyos y ser querida por ellos ${ }^{14}$ y en llegar a ser como la hija de Tántalo, la mítica Níobe ${ }^{15}$, divinidad asociada entre otras cosas con la poesía como una forma de trascendencia. El coro, en efecto, responde a este canto de lamentación de Antígona, recordando el destino de la figura mítica para consolarla, y confirma la idea de que le espera un destino equiparable al de los dioses como el que le tocó a Níobe ${ }^{16}$.

La palabra tó kérdos está también en el centro de la disputa entre Creonte y Tiresias ya que es interpretada con sentidos opuestos: Tiresias trata de convencer al rey de que recapacite respecto de su decisión de matar a Antígona ${ }^{17}$ apelando a una "conveniencia" (tó kérdos) que no es económica. Sin embargo, Creonte retoma el término revirtiendo su sentido y acusando al adivino de corromperse por dinero y de complotarse con los tebanos para atentar contra su poder ${ }^{18}$.

\section{Antígona Furiosa: la tragedia como resentimiento.}

Siguiendo ahora el mismo esquema de análisis, trataremos de destacar la importancia del manejo de la relación acción dramática / flujo temporal, con le objetivo de dar cuenta de la reinterpretación que la autora hace del personaje sofocleo ya que, como en el caso de la Antígona griega, consideramos al personaje como sujeto de la acción dramática, inserto a la vez en un espacio/

\footnotetext{
${ }^{10}$ Cf. Sophocle (1955), v. 415-416.

${ }^{11}$ Cf. Sophocle (1955), v. 454-455.

${ }^{12}$ Cf. Sophocle (1955), v. 461-462: "y si muero antes de tiempo, lo llamo acrecentamiento".

${ }^{13}$ Cf. Sophocle (1955), v.468: "ahora ya no sufro por estas cosas".

${ }^{14}$ Cf. Sophocle (1955), v. 897-904.

${ }^{15}$ Cf. Sophocle (1955), v. 823-833.

${ }^{16}$ Cf. Sophocle (1955), v. 836-838.

${ }^{17}$ Cf. Sophocle (1955), v. 1026-1027.

${ }^{18}$ Cf. Sophocle (1955), v. 1037-1039.
} 
tiempo que configuran el universo ficcional de la obra en el que adquiere sentido.

La acción se inicia cuando Antígona se descuelga de una horca en el ámbito de un bar y comienza a entonar un canto de lamentación por su muerte:

"Antígona (canta).- Se murió y se fue, señora;

El césped cubre su cuerpo,

Hay una piedra a sus pies" ${ }^{19}$.

La canción es interrumpida por las intervenciones de Corifeo y Antinoo, que se burlan negando la muerte:

"Corifeo.- Debiera, pero no hay. ¿Ves césped? ¿Ves piedra? ¿Ves tumba? Antinoo.- Nada ${ }^{20}$ "

Sin embargo Antígona continúa e introduce otro elemento, el sudario, que más adelante devela su significado: representa el cuerpo muerto de Polinices, agregando de esta manera una gran carga simbólica de sacrificio cruento. Pero la solemnidad de la canción fúnebre aparece denegada, entrecortada por el contexto de burla y por la charla de bar en el que aparece inserta.

Enseguida Corifeo que toma la máscara de Polinices y representa su papel, actúa otra muerte en el escenario, con la cual parodia la de Antígona que acaba de ocurrir y la neutraliza, la denuncia como un hecho teatral, literario. E incluso desarrollan una pequeña versión burlesca de la intriga de toda la pieza, anticipando el tono y el contenido de la acción dramática de la obra:

Antinoo.- ¡Que nadie lo toque! ¡Prohibido! (Como ajena a lo que hace, le saca la corona al Corifeo, la rompe)

Antinoo.- ¡Te sacó la coronita!

Corifeo.- ¡Nadie me enterrará!

Antinoo.- Nadie

Corifeo.- ¡Me comerán los perros! (Jadea estertoroso).

Antinoo.- Pobrecito (Lo abraza. Ríen, se palmean). ${ }^{21}$

Así Corifeo, tomando el papel de Polinices, actúa y se ríe tanto de su muerte como de la condena posterior a no ser enterrado. Mediante el recurso de la duplicación-repetición de la representación teatral en escena obtenemos una nueva versión de la tragedia de Antígona. Además la oposición entre el contenido fatal de la muerte y las acotaciones jocosas de las didascalias provocan un efecto de distanciamiento burlesco del sentido trágico del personaje sofocleo.

Más adelante, la acción central de la pieza es el ritual de la ceremonia fúnebre, que Antígona desarrolla en escena contradiciendo abiertamente a

\footnotetext{
${ }^{19}$ Gambaro (1988), p. 179.

${ }^{20}$ Gambaro (1988), p. 179.

${ }^{21}$ Gambaro (1988), p. 179.
} 
la norma del tirano ${ }^{22}$. Ésta es realizada sin hablar, en presencia de Corifeo y Antinoo quienes actúan de espectadores privilegiados. Una vez más, se reproduce en espejo la situación teatral, en este caso Antígona es protagonista y los otros, dos espectadores que observan la representación del hipotexto sofocleo, del cual ellos por momentos participan, por momento observan y por momentos narran o anticipan ${ }^{23}$.

La invasión de pájaros que lanzan sus excrementos sobre la mesa del bar, signo de la peste desatada por la impureza del cadáver insepulto, hace avanzar la acción dramática y preanuncia la referencia al discurso de Tiresias ${ }^{24}$, quien de ser un aliado de Antígona en el texto de Sófocles, aquí aparece criticado por la heroína. Esto puede ocurrir porque el conflicto ya no está centrado en la oposición ley divina/ley humana, en consecuencia el sacerdote resulta un estorbo y se lo asocia con el poder del estado, como un órgano más de control ${ }^{25}$.

La trama está, pues, diseñada a partir de la narración en pasado de los hechos de la fábula mítica, que a veces es actuada paródicamente por los personajes de la acción dramática, y otras es comentada. En todo momento se desmiente y se provoca un distanciamiento crítico del hipotexto griego a partir del procedimiento de reduplicar y poner al descubierto la ficción teatral. Asimismo el manejo del tiempo, la relación entre hechos en pasado, en presente y en futuro apoya estructuralmente la ambigüedad y el sentido paródico de la acción de Antígona con respecto al original griego. Este nuevo contexto la desautoriza, la burla y la condena sin causas ni razones.

Un pre-final feliz, paródico en donde se niega el contenido del diálogo devela, pues, la farsa mediante el procedimiento de especularidad de una nueva escena teatral dentro de la pieza. En esta ocasión Corifeo toma la máscara de Creonte y actúa su rol, procedimiento que lleva al extremo la metateatralidad:

Corifeo.- ¡Los perdono! ¡No saben lo que hacen! Pretenden condenarme, a mí, que dí mi hijo, mi esposa al holocausto. Antígona que trajiste tantos males sobre mi cabeza y mi casta, ;te perdono!

Antinoo.- (Teatral) ¡Bravo!

(Sale el Corifeo de la carcasa, saluda) ${ }^{26}$

Esto provoca una relectura paródica tanto del arrepentimiento y perdón de Creonte como así también de su condición de héroe trágico. Este falso arrepentimiento actuado por el falso Creonte que es en realidad Corifeo

\footnotetext{
${ }^{22}$ Gambaro (1988) didascalia, p.183.

${ }^{23}$ Cf. Gambaro (1988), p. 183.

${ }^{24}$ Cf. Gambaro (1988), p. 191.

${ }^{25}$ Gambaro (1988), p.191-192.

${ }^{26}$ Gambaro (1988), p. 193.
} 
enmascarado, contrasta también con el final de la pieza, el cual vuelve al conflicto inicial y a negar nuevamente el reconocimiento y el perdón de Creonte:

Antinoo.-Los corazones más duros pueden ablandarse, a último momento. ¿Oíste su llanto? Te perdonó.

Antígona.-No aún quiero enterrar a Polinices. Siempre querré enterrar a Polinices. Aunque nazca mil veces y él muera mil veces.

Antinoo.- ¡Entonces siempre te castigará Creonte! ${ }^{27}$

Los personajes vuelven a oponerse ciegamente como si no hubiera transcurrido la acción dramática y con ella el tiempo. Antígona, resentida e impermeable al diálogo, demuestra una única motivación, enterrar a Polinices, alejada de todo contexto y de toda realidad. De la fábula mítica queda, pues, el enfrentamiento pero llevado al extremo.

Finalmente la acción dramática se cancela cuando la heroína se da muerte a sí misma, volviéndose así al comienzo. La intriga, pues, no sucede de acuerdo con una hilación cronológica, y la disposición de los hechos no guarda tampoco relación de causalidad. Observamos también el mismo procedimiento de inversión en la representación del espacio dramático, en la medida en que el ámbito del bar marca las antípodas de espacio trágico griego, regido por la coherencia de la imitación de acciones y gente nobles. Espacio dramático que concordaba también con una escena carente de actos sangrientos, cuestión que también aparece contradicha. En efecto, el hecho de que Antígona aparezca colgada de una horca en un café con dos hombres burlándose de ella, resulta una inversión paródica tanto del espacio dramático-escénico como del personaje en la medida en que se trivializa el sacrificio. La muerte de la heroína es relativizada en tanto deja de ser un hecho irrepetible, acto único y definitivo, porque lo que resulta eterno es el devenir histórico en el cual no se encuentra solución a las contradicciones. Antígona está furiosa y resentida, declara como objetivo último su deseo ciego y maquinal de enterrar a Polinices. El sacrificio de Antígona viene a dar cuenta del absurdo proceso militar que producía muertes fuera de todo ordenamiento legal, de justicia y de ética. Encontramos en el texto una estructura circular que se erige en testimonio del acto de morir como denuncia y única resistencia al abuso de poder. En este círculo la justicia está ausente, la tensión constitutiva del héroe trágico, y el restablecimiento del orden están, asimismo, ausentes. Y se opone al mediodía de la Antígona sofoclea, punto máximo de acercamiento con el mundo divino, momento de ritual funerario. Se opone al camino de la acción que acompaña al ocaso del día, una trama que guarda concordancia entre el orden cósmico, temporal y

\footnotetext{
${ }^{27}$ Gambaro (1988). p. 193.
} 
divino, un universo ficcional que finaliza junto con la muerte acompañando el ciclo vital. La realidad en la ciudad de Tebas cambió luego del sacrificio de Antígona, pero este discontinuum, aparece inscripto en el continuum de la eternidad del mundo, de la justicia de los dioses, y de la eterna convivencia de la heroína con sus seres queridos y con los dioses. Lo que el mito de Antígona eterniza es la inserción de la conducta humana en el ciclo cósmico y divino. La muerte de Antígona es 'acrecentamiento' porque restablece una dike que presupone un existir posterior incondicionado. 


\section{Bibliografía}

Sophocle (1955), Antigone, Paris, Les Belles Lettres.

Gambaro, Griselda (1988), Antígona Furiosa, en Gestos, Abril. 


\title{
Y Dice Eurídice. \\ Sobre Una anatomía de La SOMbra De Alejandro Tantanian
}

\author{
Marcela Inés Coll - María Gabriela Simón \\ Universidad Nacional de San Juan
}

\begin{abstract}
El texto dramático Una anatomía de la sombra de Alejandro Tantanian (2000) puede ser leído como una reescritura contemporánea del mito de Orfeo. La escritura de Tantanian se inscribe en el marco de la producción de la llamada nueva dramaturgia argentina, que surge en la década del 90, una de cuyas características reside en el diálogo con textos clásicos. En este caso el intertexto es el mito de Orfeo, uno de los más proteicos para el arte occidental. En nuestro trabajo nos preguntamos en qué sentidos este mito es resignificado desde la mirada de un dramaturgo argentino en el siglo XXI.
\end{abstract}

I. Abordamos el texto dramático Una anatomía de la sombra de Alejandro Tantanian (2000) el cual puede ser leído como una reescritura contemporánea del mito de Orfeo. La escritura de Tantanian se inscribe en el marco de la producción de la llamada nueva dramaturgia argentina, que surge en la década del 90. E1 diálogo con textos clásicos es una de las características de esta nueva dramaturgia. En este caso el intertexto es el mito de Orfeo, uno de los más proteicos para el arte occidental. Nos preguntamos en qué sentidos este mito es resignificado desde la mirada de un dramaturgo argentino en el siglo XXI. Una anatomía de la sombra también dialoga con la ópera Orfeo y Eurídice de Ch. W. Gluck, como en un juego de cajas chinas: Texto dramático>ópera>mito.

E1 texto de Tantanian constituye una reescritura que se propone, desde el epígrafe mismo, relatar lo que el mito calla: "Asi comienza... sobre lo que el mito calla". Con este epígrafe, el dramaturgo inaugura el monólogo de Ella (Eurídice), monólogo que estructura la obra. Una primera inversión: ahora es la voz femenina la que dará su versión del mito, a diferencia de las versiones canónicas de Orfeo que están a cargo de la voz masculina. El texto todo es un largo monólogo sin interrupciones, ni indicaciones escénicas, en el que se alternan dos modalidades discursivas - prosa/verso- según el personaje se refiera a los diferentes momentos/espacios entre los cuales transcurre su historia. Desde su presente de espectro, su voz se hace verso cuando cuenta su vida en la tierra antes de morir, junto a Orfeo, su boda, el encuentro con el hombre amado, su muerte, su misma existencia de espectro cuando regresa a la tierra. Aparece la prosa cuando Eurídice cuenta su experiencia en el reino infernal, la experiencia del olvido y el dolor. Ella regresa del país de los muertos, pero vuelve como una sombra, un no-cuerpo. No vuelve porque fue rescatada por Orfeo, esta vez tampoco pudo. Orfeo, cuenta Eurídice, siempre fue un 
impío, no cree en los dioses y no cumple con el pacto con los dioses infernales: no mirar hacia atrás. Pero aún cuando Orfeo gira la cabeza para comprobar su presencia, cuando intenta mirarla, no la ve, no puede verla. La perdió por segunda vez. A pesar de lo cual Ella regresa a la tierra. Ella sí puede verlo.

Es esta existencia de espectro, la que se plantea como una paradoja en relación con el título ya que la misma palabra anatomía sugiere una experiencia de disección, de análisis de las partes de un cuerpo, entonces nos preguntamos ¿puede hacerse una anatomía de una sombra?, pregunta imposible, allí donde la respuesta necesariamente deviene silencio.

II. Escuchamos la voz de una sombra, allí donde el título anuncia la anatomía de una sombra. Entonces nos preguntamos: la anatomía, esta operación sobre el "no cuerpo" ¿se reduplica en el texto? Encontramos una relación entre la anatomía como operación de disección y la alusión a la omofagia y al desmembramiento (diasparagmós) del que es víctima Orfeo (¿víctima?). Cabría preguntarnos también si es venganza o ritual.

Estas prácticas rituales (omofagia y diasparagmós), que reenvían al culto dionisíaco, son las que dan muerte al vate tracio según distintas versiones del mito y es también la forma de morir de Orfeo que retoma Tantanian en el final del relato.

Abren sus bocas

Grito

Bañan sus cuerpos en su sangre (...)

Cortan con los dientes su cabeza.

Una de ellas arranca sus pies.

$Y$ los devora (...)

Devoran.

Su cuerpo. (Tantanian, 2007: 70)

Las relaciones entre el dionisismo y el mito órfico son múltiples, en algunos aspectos se implican. ¿En qué consiste el ritual? Para celebrar sus misterios, las mujeres (thiasos) en estado de posesión realizan danzas orgiásticas para alcanzar el éxtasis, hasta consumar la unión con el dios a través del desmembramiento ritual de un animal (diasparagmós) y de la omofagia, comer carne cruda, en un intento de volverse de nuevo tierra, naturaleza (Cfr. Andrade, 2003, Bauzá, 2004, Vernant, 2002).

Una vez más, la otra cara de la tradición. En este texto Eurídice se identifica de alguna manera con una ménade. Las otras ménades quieren destruir y vengarse de Orfeo; Eurídice quiere poseerlo, "vivir" con él. Es en este deseo de la unión-totalidad que se insinúa la omofagia que deviene antropofagia o al menos intento de ella. 
Yo mujer, animal al fin (...)

Mis pies aprendieron el lenguaje de la danza (...)

Sus pies en la oscura cavidad de mi boca (...)

Y quise comérmelo.

Quise, aquella noche, ser aquel monstruo que devora (...)

$Y$ decidi entonces tragar su cuerpo.

Alimentar mi cuerpo con el suyo.

Y comencé por sus pies. (Tantanian, 2007: 65-66)

Tal vez por ese anhelo, por aspirar a la totalidad que sólo pueden conocer los dioses, es castigada y no puede consumar el banquete, transgrede la ley del padre de Orfeo, el dios sol. En una de las vertientes del mito, la menos difundida, se considera a Orfeo como hijo de Apolo, cuyo epíteto es "el brillante", identificado con Febo entre los latinos (Cfr. Bauzá, 2004). Este punto es de vital relevancia pues nos permite repensar cuáles son los sentidos de la antropofagia, del "banquete" por parte de Eurídice y de las otras mujeres en esta obra. "Pero el sol, su padre, no me permitió terminar con el banquete / $A$ otras bocas su bijo estaba destinado" (Tantanian, 2007: 66).

¿Por qué razón es castigado Orfeo? ¿Las ménades son enviadas por Dioniso? La respuesta canónica considera que las mujeres enfurecidas con Orfeo, ya que no accede a sus deseos "amorosos", deciden despedazarlo. Pero este thiasos actuaría solo por mandato de su dios, Dioniso. Entonces es éste el que quiere vengarse de Orfeo. ¿Por qué? Una posible respuesta relacionaría el desmembramiento de Orfeo con Apolo. Orfeo estaría próximo a Apolo. Dioniso, celoso, por no ser reconocido, se enfurece contra el músico. Dice al respecto Bauzá: "En efecto, el mito nos refiere que Orfeo muere despedazado a manos de las mujeres tracias no tanto por sentirse éstas desairadas al rechazar la pasión que por él experimentaban sino -y muy especialmente- porque el amor que Orfeo sentía por Apolo le había hecho olvidarse de Dioniso, y éste se valió entonces de sus Ménades para vengarse de la afrenta recibida" (Bauzá, 2004: 91).

Otra posibilidad: Orfeo, a través del ritual dionisíaco, sería integrado a la naturaleza divina ya que ha sido iniciado en los misterios, que sólo pueden conocer algunos "elegidos": para entrar al infierno, sé que desafió a los dioses y a los hombres (Tantanian, 2007: 66)

El mito de Orfeo es resignificado a partir de las preocupaciones de un hombre del siglo XXI. El dramaturgo le da voz a una mujer y es Ella ahora no sólo la que busca sino la que desea devorar.

III. En el texto, Eurídice es una sombra, un espectro: "Ser entonces este espectro" (Tantanian, 2007: 65). Si leemos la sombra desde la lógica 
del espectro (Derrida, 1994), nos interesa entonces estudiar cuáles son las implicancias de esa sombra-espectro. Lo primero para recordar: el espectro es alguien que me mira sin reciprocidad posible, frente a él, yo estoy ciego, ciego por situación. El espectro dispone del derecho de mirada absoluta. (Cfr. Derrida, 1998: 151-152). Dice Eurídice: "Arrancada de entre los muertos/ otra vez aquil y nadie puede verme/nadie puede oirme" (Tantanian, 2007: 63)

Escribe Derrida: "En efecto, los muertos están muertos. (...) Pero esto no cambia en nada la ley del retorno, y me refiero aquí al retorno de los muertos. Que estos ya no existan no significa que se haya terminado con los espectros. Al contrario, el duelo y el tormento se desencadenan entonces" (Derrida, 1998: 164). El mito en la versión de Virgilio (Libro IV de Las Geórgicas) cuenta el duelo de Orfeo. Eurídice muere. "Orfeo, inconsolable, descendió al Hades en busca de su amada esposa. Con los acentos de su lira, encanta no sólo a los monstruos del Tártaro sino incluso a los dioses infernales. (...) Hades y Perséfone acceden a restituir a Eurídice a un esposo que da tales pruebas de amor, pero ponen una condición: que Orfeo vuelva a la luz del día es decir a la tierra, seguido de su esposa sin volverse a mirarla antes de haber salido de su reino. Orfeo acepta y emprende el camino. Ha llegado casi a la luz cuando duda: ¿no se habrá burlado Perséfone de él? ¿Lo sigue realmente Eurídice? Entonces se vuelve y Eurídice se desvanece y muere por segunda vez, Orfeo trata de recuperarla nuevamente, pero esta vez Caronte permanece inflexible y le impide el acceso al mundo infernal. Desconsolado, regresa al mundo de los humanos" (Cfr. Grimal, 2001: 391393).

En el texto de Tantanian, el duelo se desencadena en Eurídice, o sea en el espectro mismo, y en el lector. Para Eurídice, la mortal muerta, no hay posibilidad de reencuentro con su amado, sólo ser testigo invisible de su desmembramiento. Para el lector, regresa, reaparece, un espectro: Ella. Una muerta sin nombre.

Pero como nos advierte Derrida, el espectro no es simplemente alguien al que vemos volver. "El totalmente otro -y el muerto es el totalmente otro- me mira, y me mira dirigiéndose a mí pero sin responderme (...) me mira, me incumbe, no se dirige sino a mí, al mismo tiempo que me excede infinita y universalmente, sin que yo pueda intercambiar una mirada con él" (Derrida, 1998: 151). Eurídice no (nos) da respuestas, no viene a contarnos su versión, bien lo muestra, la muerte es el límite: entre lo visible y lo invisible, entre el cuerpo y el espíritu, entre la presencia y la ausencia (Cfr. Derrida, 1994). Por eso mismo, por la ausencia de respuestas, la tragedia se hace doble: por el dolor de Ella y por la interpelación, sutil interpelación, al lector. 
IV. Para terminar queremos detenernos en la forma en que es designada Eurídice en el texto de Tantanian. Su nombre propio es sustituido por el pronombre personal Ella. Ella es la protagonista. Y es el lector el que recupera mentonímicamente el nombre. Barthes escribe que no puede imaginar el uso del pronombre para hablar del ser amado. Su nombre es signo del amor de esa voz que lo nombra. A lo que agrega: "El nombre propio tiene como sustituto preliminar él/ella. Por ende, ausenta al otro: convierte al otro en ese/esa de quien hablo" (Barthes, 2003: 155).

La desolación de Eurídice es absoluta, sin nombre, sin voz audible, sin poder ser vista, sin poder tener el amor de Orfeo, regresa a la tierra para ser testigo de su sombra. Ha sido abandonada por los dioses, por su amado y por los mortales. Pero asumir ese destino es lo que le toca a un mortal muerto, intensidad de la muerte en la obra de Tantanian:

"la música de mi hombre abre las puertas del infierno, aniquila lo imposible, lo entrega al infierno, lo sume en la noche, le muestra el camino hacia el cuerpo sin alma, espectro, horror eterno, de su amada, y yo sé que viene a buscarme, sé que desafió a los dioses y a los hombres, sé que esa música es la salida del laberinto y sé también que mi cuerpo descansa bajo tierra y que de nada servirá volver a ella. Sin embargo la tragedia debe cumplirse" (Tantanian, 2007: 66). 


\section{Bibliografía}

Andrade, Nora (2003), "Estudio preliminar" en Eurípides, Bacantes, Buenos Aires, Biblos, pp. 9-28.

Barthes, Roland (2003), Cómo vivir juntos, Buenos Aires, Siglo XXI.

Bauzá, Hugo Francisco (2004), Voces y visiones. Poesía y representación en el mundo antiguo, Buenos Aires, Biblos.

Derrida, Jacques (1994), Espectros de Marx, Madrid, Trotta.

Derrida, J. - Stiegler, B. (1998), “Espectrografías” en Derrida, J., Ecografías de la televisión, Buenos Aires, Eudeba, pp. 141-166.

Grimal, Pierre (1999), Diccionario de mitología griega y romana, Buenos Aires, Paidós.

Irazábal, Federico (2007), "Prólogo. Una dramaturgia del silencio o del exceso" en Tantanian, A., Cine quirúrgico. Una anatomía de la sombra. El Orfeo. Ispahan. Los mansos, Buenos Aires, Losada, pp. 7-25.

Tantanian, Alejandro (2007), "Una anatomía de la sombra” en Tantanián, A., Cine quirúrgico. Una anatomía de la sombra. El Orfeo. Ispahan. Los mansos, Buenos Aires, Losada, pp.61-71.

Vernant,Jean P.(2002), “E1 Dioniso enmascarado de las Bacantes de Eurípides” en Mito y tragedia en la Grecia Antigua, Vol. II, pp. 223-252.

Virgilio (1994), Geórgicas, Madrid, Cátedra. 


\title{
"Miran al cielo Y piden un deseo: \\ Contido la noche más bella". De la Trama del tejido a \\ LAS DELICIAS DEL OMOPHAGOS
}

\author{
María Cecilia Colombani \\ Univ. de Morón - Univ. Nacional de Mar del Plata
}

\begin{abstract}
El proyecto de la presente comunicación consiste en pensar la relación entre las bacantes, fieles adoradoras de Dionisos en el ritual dionisíaco, y la categoría de espacio como marca subjetivante. Para ello tomaremos la espacialidad en el marco de los procesos de subjetivación femenina y opondremos dos tipos de espacialidad, funcionales a dos modelos identitarios femeninos: la montaña y el oikos, el menadismo, propio del ascenso a la montaña, y el tejido, como actividad territorializante de la identidad femenina. Del oikos a la montaña, del telar a la ceremonia de iniciación báquica, el colectivo femenino borda la marca de la diferencia.
\end{abstract}

\section{a. Introducción}

El proyecto de la presente comunicación consiste en pensar la relación entre las bacantes, fieles adoradoras de Dioniso en el marco del ritual dionisíaco, y la categoría de espacio como marca subjetivante.

Para ello tomaremos la espacialidad en el marco de los procesos de subjetivación femenina y opondremos dos tipos de espacialidad, funcionales a dos modelos identitarios femeninos: la montaña y el oikos, el menadismo, propio del ascenso a la montaña, y el tejido, como actividad territorializante de la identidad femenina.

En realidad, al tiempo que se oponen dos espacialidades, se están oponiendo dos modelos de constitución femenina, exactamente en el horizonte de la construcción histórico-cultural del topos de lo Mismo y de lo Otro como configuraciones político-culturales.

\section{b. E1 tejido como trama subjetivante}

En el mundo griego, el tejido se perfila como una actividad femenina por excelencia, inscrita en el imaginario de la mujer desde muy joven. Sin duda, la metáfora del tejido como marca de la ficción femenina ha sido, ya desde el mito, una huella primera de identidad genérica. Basta pensar en la

\footnotetext{
${ }^{1}$ El título de la presente comunicación pertenece a una canción del cantautor español Ismael Serrano, cuyo título es "Amores imposibles".
} 
primera mujer, la primera novia del mito de Prometeo que Hesíodo incorpora como logos fundacional tanto en Teogonía como en Trabajos y Dias. Repasemos el relato. Sabemos que Zeus decide castigar a Prometeo con el envío de la mujer como castigo para todos los hombres; así, "ordenó al muy ilustre Hefesto mezclar cuanto antes tierra con agua, infundirle voz humana y hacer una linda y encantadora figura de doncella semejante en rostro a las diosas inmortales. Luego encargó a Atenea que le enseñara sus labores, a tejer la tela de finos encajes. A la dorada Afrodita le mandó rodear su cabeza de gracia, irresistible sensualidad y halagos cautivadores; y a Hermes, el mensajero Argifonte, le encargó dotarle de una mente cínica y un carácter voluble" (Trabajos y Días, 60-68). Pandora aparece como una doncella linda, encantadora, graciosa, irresistible y sensual, cautivadora, cínica y voluble. Una perfecta mujer que inaugura un modelo femenino, no sólo en los aspectos exteriores e interiores que ficcionan modos de subjetivación, sino en el propio destino laboral de la mujer: labores y tejidos como actividades antinomádicas por excelencia, en tanto implican cierta inmovilidad-fijación de los cuerpos en el espacio, así como cierta gestión celular, privada, interior. La mujer queda relegada al ámbito doméstico y reproductivo y, por ende, excluida del ámbito público, eminentemente político. La clave de la exclusión es, como sabemos, la menor racionalidad que ostenta, en el marco de una lógica viril.

La política y la economía son dos actividades dominante e históricamente masculinas porque exigen precisamente un alto nivel de racionalidad, exactamente en la huella semántica del verbo bouléuo que significa celebrar consejo, deliberar, decidir, planear, ser miembro de un consejo, la boulé es el consejo o asamblea deliberante que, entre los griegos, constituye el órgano decisorio por excelencia. Allí está el logos viril, capaz de transacciones políticas y económicas.

La actividad política, que encarama al aner politikos a la esfera pública, constituye en Occidente un hito fundacional de la emergencia de una racionalidad androcéntrica que se materializa topológicamente en el agora como topos falocéntrico.

Efectivamente, la plaza pública es el espacio público por excelencia, de plena visibilidad, porque allí se despliega la racionalidad dominante, carta de triunfo del agonismo dialéctico y mercantil. El agora representa simultáneamente una espacialidad doble: plaza pública y mercado y alberga una funcionalidad también doble: política y mercantil, baluartes de una histórica y dominante hegemonía masculina.

Por fuera del orden de la visibilidad del espectáculo que la política encarna, el oikos también alberga una bifuncionalidad ficcionada históricamente: la maternidad y el trabajo femenino, de fuertes enclaves en el cuerpo.

Nomadismo y sedentarismo parecen ser las bisagras que determinan particiones binarias y asignan las espacialidades y las funciones que corroboran 
las huellas de género. Tal parece ser la consolidación del espacio de la mujer al interior de la sociedad conyugal en el relato jenofonteo.

La polis se abre, tiende líneas de fuga, más allá de sus límites geográficos, borra sus fronteras desterritorializándolas permanentemente; lo mismo ocurrió con el mar, escenario privilegiado de las aventuras odiseicas. El oikos y las mínimas extensiones urbanas permitidas a las mujeres, representan una pura interioridad sedentaria, con desplazamientos acotados, con marcas de circulación recortada y espacializaciones restringidas. Pura inmanencia, urbana y doméstica, que conoce los confines de una subjetividad que se construye en el corazón de un proceso de sedentarización.

La construcción de las identidades roza una cuestión topológica, donde la apropiación del territorio-poder inaugura nuevas e inéditas subjetividades.

Frente a la subjetividad femenina, anclada a un dispositivo de sedentarización, el varón parece representar el movimiento desterritoralizante y nómade por excelencia.

Para él, el espacio se abre en una cartografía compleja de múltiples aristas, que neutraliza el espacio estriado, reticulado, de las identidades sujetadas a territorios custodiados. La exterioridad del mar o la expansión de la polis como espacio del trabajo y la productividad, invierten el proceso de sedentarización y colocan al territorio en el punto de una experiencia de exploración y apropiación subjetivante.

El nomadismo amplía las fronteras de instalación, abre una nueva dimensión del espacio, porque derriba los confines y al mismo tiempo inaugura una nueva temporalidad. El tiempo doméstico no es el mismo tiempo que el de la navegación, el comercio o el de la política, que el agora conoce como ritualización dominante.

Tiempo, espacio e instalación en el mundo hablan de dos universos masculino y femenino- que guardan peculiares y específicas características, que fundan, a su vez, particulares y diferenciados modos de subjetivación.

Asignadas las variables antropológicas, tiempo, espacio y funciones, quedan perfectamente delimitados los campos genéricos al tiempo que se consolida el territorio de lo Mismo; el logosviril queda territorializado al espacio funcional de la utopía política y el cuerpo femenino queda territorializado al modelo de la buena esposa, la esposa de los kaloi kai agathoi para dar cuenta de la relación entre mujer y constitución política. Pero, conocemos la lección antropológica que Occidente ha construido históricamente: el campo de lo Mismo tensiona el topos de lo Otro, como modo de reafirmar su constitución identitaria. A esta primera tensión hombre-mujer recorrida, se suma, al interior del colectivo, otra marca de otredad que duplica la trama de género: ser bacante. 


\section{c. El menadismo: las delicias de acariciar al taurino}

Del oikos a la montaña, del telar a la ceremonia de iniciación báquica, el nuevo colectivo femenino borda las marcas de la diferencia, de la más radical otredad.

Para instalarse en el corazón de la experiencia de la manía extática, hay que transitar la configuración del menadismo como doble forma de ilustrar el presente trabajo: por un lado, encontrar en la locura, mania, la forma más sublime de acortar la distancia ontológica que separa y territorializa a hombres y dioses a topoi diferenciados, y, por otro lado, recorrer un constructo paradojal para nosotros los contemporáneos, donde la locura aparece exaltada por sus valores.

El menadismo se nos impone como un fenómeno de singulares características y parece constituir una unidad de sentido con la oreibasía, conformando el corazón íntimo y palpitante del ritual. El mismo comienza precisamente con la oreibasía o danza en la montaña, reflejo de un ritual practicado por sociedades de mujeres en Delfos hasta la época de Plutarco. No se trata de simples danzas de alegría o miméticas, como las que se practicaban en Eleusis, dando la bienvenida a Deméter, sino que se trata de verdaderas danzas de posesas, con lo cual empezamos a intuir que la dimensión de la fiesta transita por las fronteras del horror. Estos estados salvajes de entusiasmo no parecen provenir de un fondo imaginativo; por el contrario, según refiere Diodoro, "en muchos estados griegos se reúnen cada dos años congregaciones de mujeres (Bakcheia) y a las muchachas solteras se les permite tomar el tirso y tomar parte en los transportes de las mayores"2. Cabe señalar que el verbo bakcheuein no significa gozar, jaranear, sino tener una clase particular de experiencia religiosa, la experiencia de comunión con el dios que transforma a un ser humano en bakchos, bakche.

Si bien cada región guarda particularidades propias, parece existir un denominador común que es la inclusión de orgias de mujeres de tipo extático, las cuales, a menudo, incorporaban la oreibasía o danzas en las montañas. Así, "El estampido con que irrumpe su divino cortejo y el propio Dioniso, el ruido que desencadena el enjambre humano tocado por su espíritu, es un auténtico símbolo del advenimiento de los espíritus. Con el terror, que es al tiempo fascinación, con la exaltación, que se asemeja a la parálisis, con la exaltación de las percepciones comunes y naturales de los sentidos, lo monstruoso irrumpe de pronto en la existencia. Y en la exaltación última, un profundo silencio resuena en ese estruendo enloquecido" ${ }^{3}$. Locura en estado puro, donde ha

\footnotetext{
${ }^{2}$ Dodds, E. R. Los griegos y la irracional, p. 251.

${ }^{3}$ Otto, Walter, Dioniso. Mito y culto, p. 71
} 
quedado suspendida la actividad consciente para ceder paso a esa ambigüedad espectral que anuncia la deliciosa presencia del dios.

La oreibasía es un ritual nocturno, en mitad del invierno, cuya significación simbólico-ritual no parece tener las características de una danza celebrada para hacer crecer las cosechas, por magia de afinidad. Estas danzas son anuales, no bianuales, y primaverales, coincidiendo con el tiempo de cosecha, no invernales. Asimismo, se recortan en la fertilidad de los campos, no en las cimas áridas de las montañas, residencia natural de la gente del pueblo. La finalidad parecer ser otra. Los autores griegos tardíos les imponen un matiz conmemorativo. Danzan, dice Diodoro, imitando a las ménades, que en los tiempos antiguos estuvieron asociadas con el dios ${ }^{4}$. Dodds acepta la idea y sugiere que efectivamente debe haber habido un tiempo en que las ménadas, o thyadas o bakchai eran, por espacio de algunas horas o de algunos días, lo que su nombre implica: mujeres salvajes cuya personalidad humana habia sido reemplazada temporalmente por otra 5 .

En los momentos iniciales del ritual, las mujeres portan thyrsos, vara adornada con hojas de parra y coronan sus cabezas con hojas de yedras. Es propiamente el momento de inicio de la danza, de la entrega de sí mismo, fácil de comenzar pero difícil de darle fin. "La ménade, cuyo agudo grito nos parece haber oído, nos asusta por su petrificada mirada, en la que se refleja lo monstruoso, lo que la ha enloquecido, (...) la silente se agita febril, con la cabeza caída a un lado. Pero también puede vérsela erguida, en silencioso recogimiento, cual estatua de piedra"6.

Extraordinaria locura danzante, sumamente contagiosa; voluntad de bailar que se apodera de las personas, desplazando la voluntad consiente, puro deseo que domina y se vuelve él mismo indomable. Verdadera obsesión compulsiva que reaparece a intervalos regulares. Canalizando esta histeria en un rito organizado una vez cada dos años, el culto dionisíaco la contuvo dentro de unos límites y le dio una válvula de escape, la cual resultaba inofensiva.

Ahora bien, parece existir una dualidad en la consideración de este fenómeno. En primera instancia, lo que la letra trágica parece indicarnos es la dimensión de la histeria sometida al servicio de la religión, menadismo blanco; en cambio, la histeria en crudo, menadismo negro, que tiene lugar en el Citerón, desciende con fuerza inusitada, arrastra sin distinción de clases y edad y se impone, aún en contra de la voluntad, como un castigo epidémico. Dioniso sostiene ambas dimensiones.

Así, entre estas mujeres entregadas a excesos y que constituyen grupos que reciben diversos nombres, Ménades, Thyadas, Bacantes, Lenai, la presencia

\footnotetext{
${ }^{4}$ Dodds, E. R., Los griegos y la irracional, p. 252.

${ }^{5}$ Dodds, E. R., Los griegos y la irracional, p. 252.

${ }^{6}$ Otto, W., Dioniso. Mito y culto, p. 72.
} 
de instrumentos musicales parece ser una pista insoslayable. La embriaguez religiosa, como forma de la locura sagrada, que determina el corrimiento de las barrearas del yo consciente, parece estar acompañada por flautas y tímpanos o timbales que pautan la danza de la ménade. Las características del instrumento parecen vincularse con la peculiaridad de la estructura ritual, al mismo tiempo que, en la línea de los núcleos ambivalentes que venimos persiguiendo, pueden provocar la locura, pero también curarla. El ruido acompaña al propio Dioniso desde sus más arcaicos epítetos. Se le llama "el del trueno", Bromio. Es el que "profiere gritos" y es, precisamente, por los terribles gritos rituales, euoi, que es llamado él mismo Euios, y las mujeres de su peculiar cortejo, Euádes. Los vagabundeos por lugares desiertos y las danzas frenéticas a la luz de las antorchas llevan a las ménades a adoptar ciertas posturas que parecen inscribirse en el mismo horizonte de la eficacia. El porte de la cabeza en el éxtasis dionisíaco es motivo de inquietud en la literatura y en las artes. En las Bacantes hay referencias periódicas a la cabeza echada violentamente hacia atrás y hacia adelante, con sacudidas violentas que llevan el pelo con fuerza en todas direcciones, realzando un aspecto salvaje, donde la garganta vuelta hacia arriba plasma el estado mismo de posesión. El gesto no es ornamental ni aleatorio, ni siquiera una convención literaria o artística. Una vez más el gesto "realiza" y en, tal sentido, es eficaz, realizador.

La danza y la música extática, las sacudidas de la cabeza, las agitaciones frenéticas, el aspecto salvaje nos muestran que la ménade está plena deo, entheos, poseída por el dios. "La presencia del dios frenético era sentida y escuchada.(...) En el retumbar de los tonos, notas y gritos habita la locura, y también habita el silencio. De aquella se deriva el nombre con que se designa a las mujeres que siguen a Dioniso, las Ménades. Atrapadas por ella, avanzan presurosas, giran furibundas en círculos, o permanecen inmóviles, petrificadas"7. Ruido, mucho ruido, pero también ese silencio espectral que anuncia la muerte. Extraña alianza del grito y del silencio, que se recorta de ese fondo paradojal y ambiguo que acompaña toda la epifanía dionisíaca.

En el marco de esta configuración ritual, se da el acto culminante de la danza dionisíaca: el acto capital de despedazar y tragar crudo un cuerpo animal. Sparagmos y omofagos. Si el primer momento descrito del ritual da la impresión de una perfecta comunión con la naturaleza, donde la fecundidad vegetal y animal parece emerger libremente, más allá de ciertos rasgos que ya preludian la violencia, el segundo momento marca una crueldad inusitada. La orgía parece encauzarse en carriles que rompen todo marco familiar. El Dios está allí, entre sus danzantes de la montaña. Es esta la verdadera comunión con

\footnotetext{
${ }^{7}$ Otto, W., Dioniso. Mito y culto, p. 73.
} 
el dios, ya que, esos animales despedazados, esa sangre vertida, son epifanías o encarnaciones del Señor que seduce a las mujeres.

La imagen del toro salvaje, enfurecido, se hace presente ante la mirada del adepto. En Bacantes, incluso, el coro convoca al dios para que se haga presente en forma de toro. Las mismas ménades portan cuernos para asimilarse a su adorado dios y el toro es finalmente víctima y presa de Dioniso. "No es sólo la plenitud vital y fuerza generatriz lo que convierte al toro en una de las formas que adopta Dioniso, sino también su furia, su peligrosidad" ${ }^{8}$. Dios y animalidad guardan una misma configuración que duplica la alianza vida-muerte en una sintonía donde la vida misma se enlaza con la muerte. Esa alianza es ella misma pura Otredad.

Bajo una u otra forma, siempre hallamos en el centro del ritual dionisíaco la experiencia extática de un frenesí más o menos violento, la manía. Esta locura constituía de algún modo la prueba de la divinización del adepto. Aquella experiencia era, con seguridad, inolvidable, pues suponía una participación en la espontaneidad creadora, en la libertad embriagante, en la fuerza sobre humana y en la invulnerabilidad de Dioniso. La comunión con el dios rompía durante algunas horas la condición humana, pero sin llegar a transmutarla9.

Esa ruptura implica, asimismo, la discontinuidad del tiempo y del espacio. En la línea de lo que anticipáramos en el inicio de este trabajo, la misma dualidad ontológica o brecha metafísica se observa en dos topoi importantes en la economía general de una lógica de la ambigüedad: el tiempo y el espacio. ${ }^{10}$ En cada caso, ambas estructuras reconocen una dualidad sustancial, un tiempo vano, no realizador y un tiempo fuerte, realizador. Un espacio vulgar, topológicamente homogéneo, y un espacio sacralizado, heterogéneo, que discontinúa la estructura de lo vano. Se trata de un espacio consagrado, que, en su misma geografía, hace patente la presencia de lo sagrado.

Hemos asistido a un rito de características sacramentales en la medida en que parece darse la comunión y reunión con la divinidad. Enthusiasmos y éxtasis. El rito asegura la permeabilidad de los topoi, la apertura de las fronteras, el atravesamiento de los planos, la desterritorialización de la identidad, el contacto con lo monstruoso, como forma de lo Otro. Aunque no sea más que por un instante. Pero ese instante es intransferible. Es una verdadera orgía de placer. El placer de penetrar, no sin costos, en el topos más íntimo de la diferencia. De eso se trata la fiesta a la que el iniciado es invitado. Fiesta ruidosa y final de fiesta silencioso. Goce y horror, entretejiendo los finos hilos de un entramado

\footnotetext{
${ }^{8}$ Otto, W., Dioniso. Mito y culto, p. 122.

${ }_{9}^{9}$ Eliade, M., Historia de las creencias y de las ideas religiosas, p. 383.

${ }^{10}$ Sobre este punto, véase la obra de Mircea Eliade en torno a la dualidad entre el tiempo profano y el tiempo sagrado y el espacio profano y el espacio sagrado.
} 
sólo reservado al iniciado. Fiesta que se sabe cómo comienza, pero nunca cómo termina. Esa es la fascinación de la fiesta y esa la enorme seducción de un dios que no puede ser previsto. Atrás ha quedado el oikos; lejos ha quedado el telar y los finos encajes enseñados por Atenea; distantes las marcas identitarias de la buena esposa, de la esposa mélissa de un kalokagathos. Ruido, mucho ruido en una orgía desterritotrializante de espacios, temporalidades y funciones.

"El mundo familiar en que los hombres se habían instalado, seguros y cómodos ya no está ahí. El alboroto de la llegada dionisíaca lo ha barrido. Todo se ha transformado. Pero no en cuento amable, en un paraíso de infantil ingenuidad. Surge el mundo ancestral, las honduras del Ser se han abierto, las formas primigenias de todo lo creativo y destructor con sus infinitos dones y sus terrores infinitos se alzan trastocando la inocua imagen del mundo familiar perfectamente ordenado. No traen ensueño ni engaño, traen la verdad...una verdad que enloquece"11.

Aletheia y manía. Tal parece ser la alianza que reactualiza la lógica del mito. Una alianza que transita por la espesura de la sabiduría, en el enclave donde mania y sofia intersectan sus territorios; lejos del oikos, cerca de la montaña; lejos del tejido, cerca de la divinidad.

${ }^{11}$ Otto, W., Dioniso. Mito y culto, p. 73. 


\section{Bibliografía}

Colombani, M. C., Hesiodo. Una introducción critica, Buenos Aires, Santiago Arcos, 2006.

Detienne, M., Dioniso a cielo abierto, Gedisa, Barcelona, 1986.

Vernant, J. P., La muerte en los ojos, Gedisa, Barcelona, 1986.

Dodds, E. R., The Greeks and the Irrational, Berkeley, University of California Press, 1964.

Gernet, L., Antropología de la Grecia Antigua, Madrid, Editorial Taurus, 1981.

Gernet, L. y Boulanger, A., El genio griego en la religión, México, Editorial Uteha, 1960.

Jaeger, W. Paideia, México, Editorial Fondo de Cultura Económica, 1974.

Nilsson, M. P., Historia de la religiosidad griega, Madrid, Editorial Gredos, 1969.

Otto, W., Teofanía, Buenos Aires, Editorial Eudeba, 1968.

—_, Dioniso. Mito y Culto, Madrid, Ediciones Siruela, 1997. 


\title{
Los rastros de MEDEA de Eurípides en MEDEA de Elena SORIANO. El TÓPICO DE LOS CELOS
}

\author{
María Silvina Delbueno \\ Universidad Nacional del Centro de la Provincia de Bs As
}

No es casual que la obra de Elena Soriano comience con el discurso de Eurípides, que a modo de epígrafe, refiere a las mujeres entorno a la posesión o no del tálamo nupcial. El quiebre de éste desata el conflicto desde los inicios, tanto de la tragedia como de la novela española. Sin embargo en la última, el tópico de los celos parece ceñirse a un tiempo anterior al presente del relato, a la sublevación del instinto materno de la protagonista que se transforma en la hembra capaz de rivalizar con su pequeña hija por el amor del hombre.

No es casual que la obra de Elena Soriano comience con el discurso de Eurípides, que en la voz de Jasón y, a modo de epígrafe, refiere a las mujeres entorno a la posesión o no del tálamo nupcial:” Así sois las mujeres: mientras está a salvo vuestro tálamo, creéis poseerlo todo; pero si sufre menosprecio, sentís odio hacia lo mejor y más hermoso..."1.

La autora española tiene la intención de recobrar el conocido mito griego en ésta, según su parecer, novela parodiada. Para ello retoma los caracteres intrínsecos de la maga colquidense y los aúna en la personalidad de Daniela Valle, su nueva Medea. En el presente de la narrativa delimitada en cinco partes: (1 un diálogo entre dos mujeres, la protagonista y una amiga. 11 otro diálogo entre la amiga y el antagonista. 1ll un soliloquio del antagonista. $1 \mathrm{~V}$ encuentro de la protagonista y el antagonista. $V$ la joven desposada, el desenlace trágico.) la actriz Ella Valley (Daniela) venida a menos, experimenta el paso del tiempo, un tiempo pasado irrecobrable frente a un presente denigratorio. Aquel pasado esplendor se revela desde la representación de un mito griego, el de Acteón, pues la novela está plagada de ellos. En este caso, la poetisa y albacea, Alba Rosa Palma, presenta en sociedad a la protagonista a partir de la interpretación escénica de la diosa Diana, que refiere al despedazamiento del joven por sus propias fieras y, que parecería funcionar como preámbulo del trágico desenlace.

Ahora irrecobrable es el hombre, Miguel Dargelos, por el cual fue capaz de atravesar "tantas y tan duras pruebas..." (op. cit., p, 15). Homologada en la situación de Medea, Daniela se reconoce en ella, en un primer término, como

\footnotetext{
${ }^{1}$ Soriano, Elena (1985), Medea, Barcelona, Plaza y Janés Editores.

${ }^{2}$ López, Aurora, "La novela Medea 55 de Elena Soriano", en López, Aurora y Andrés Pociña, Medeas: Versiones de un mito desde Grecia hasta hoy, Granada, Eds.Aurora López y Andrés Pociña, 2002, vol. 11, p. 951.
} 
traidora de su patria:"abandoné a mi padre y a mi patria..."y lo hizo con la estoica decisión de quien abandona a un muerto (op. cit., p. 159). Es decir no sólo ha llevado a cabo, por el amor del hombre, infinidad de actos que han transgredido su esencia genérica femenina sino que se constata como mero instrumento del arbitrio de aquél. Su relación es definida como... "un sucio chantaje, un trueque de ambición por lujuria...un trueque que perdurase, aunque sólo fuera por la fuerza de tantos delitos compartidos...” (op. cit., p. 59).

Sin embargo lejos del enamoramiento de Medea hacia Jasón, nuestra protagonista ya era poseedora de un pasado vertiginoso, pues aún perteneciendo a una buena familia, con educación, con principios, la muchacha fue quien "lo acosó, lo provocó y lo arrastró” (op. cit., p. 52) ya que el contacto con Miguel significó la aspiración de toda mujer: "ser la protagonista en la vida de un hombre" (op.cit., p. 135). Este, en sintonización con el argonauta, tenía sobre las mujeres un concepto peyorativo implacable...”jamás en su vida tuvo que solicitarlas y mucho menos perseguirlas...su sentimiento estaba mezclado de rencor hacia el ser inferior que le obligaba a claudicar físicamente...” (op. cit., p. 84).

El segundo término de sinonimia con la tragedia griega se visualiza en la afrenta que estas mujeres viscerales, de intolerancia extrema, deben sufrir. El agravio, eje del conflicto, está pautado desde los inicios de ambas obras: Primer episodio en la tragedia y Capítulo primero de la novela. El motivo: el quiebre del matrimonio por el abandono del hombre y sus consecuentes nuevas nupcias con otra mujer. Por tanto se evidencia el engranaje de una situación triádica: son tres los personajes que encadenan la trama de la acción: Jasón-Medea-Creusa por una parte y Miguel-Daniela- la joven hija de un político influyente, por otra.

Sin embargo la nueva mujer, en la tragedia como en la narrativa española, no se erige por sí misma en rival, pues su falta de personalidad, de ethos, la hace empalidecer frente a la envergadura pasional de la primera mujer. El verdadero sentido de rivalidad surge a partir del hombre que traiciona, al igual que estas mujeres han traicionado a sus padres. Daniela sabe que ese nuevo matrimonio es "...el incumplimiento desleal de la otra parte en un compromiso absoluto...” (op.cit., p. 50) ..."un cálculo suyo, una conveniencia egoísta. En el mismo tenor recordemos el cinismo en las palabras que Jasón profiere ante Medea en el verso 553 del Segundo Episodio:”...habiéndome convertido en un desterrado, ¿qué hallazgo más afortunado habría encontrado que casarme con la hija del rey?...."y para, tras haber engendrado hermanos a tus hijos, ponerlos al mismo nivel, y para que lleguemos a ser felices, después de haber enlazado nuestras familias..."vv. 562-5653.

\footnotetext{
${ }^{3}$ Eurípides (2008) Medea, Traducción, Introducción y notas: César Guelerman, Buenos Aires, Editorial Biblos.
} 
Sin embargo desde ese conflicto que entreteje a estas obras a partir del tópico común de los celos, podemos enfatizar el vértice de una diferencia que llevará al extremo Elena Soriano: la maternidad frustrada, el acto fallido por todos los hijos muertos de Daniela y el reciente embarazo desconocido por Miguel, con el que vanamente intentará retener al hombre.

Desde otra perspectiva los hijos de la protagonista griega se erigirán en la instrumentalización del castigo hacia el hombre, y a partir de sus muertes, la bárbara se consolidará en la filicida y destructora de su propio oikía $\alpha^{4}$. Ella es la matadora de su progenie y en ella jerarquiza el castigo por el que aniquila desde adentro al esposo, el peor de los hombres. Medea, la apátrida, ya no tiene a dónde ir, y debido a ello llevará una vida errática de exilio. Por otro lado Jasón prefirió el lecho de la griega al de la extranjera, a partir del cual se despojaba de su situación de desterrado y consolidaba al mismo tiempo su aspiración al trono.

Cabe recordar que en la tragedia la mujer eslabona la venganza ya que se presenta la causa de una mujer bárbara contra un griego que la ha agraviado ${ }^{5}$. Pero no es sólo una bárbara sino sobretodo es una mujer que se arroja a esa perenne lucha que libran hombre y mujer ${ }^{6}$. Medea es maníaca y su locura es efecto del amor desairado y de la indignación por la justicia que se le niega en el choque entre su desamparo y la conciencia de la maldad intolerable. Por ese mismo motivo es capaz de desenvainar la espada para matar con ella, usurpando el privilegio de la naturaleza masculina. Esa actitud viril, su masculinización, es, entre otras, la que la caracteriza como mujer bárbara.

Medea y Daniela se hallan transidas por la demasía de la pasión, la desmesura que se aviene en ű $\beta ı \iota$, , la transgresión de los límites previstos. Para Daniela el amor ha sido siempre" una atadura fortísima de por vida" cuyo quiebre no es capaz de tolerar. Como consecuencia lindante a ese extremo, estas mujeres parecieran denotar ciertos ribetes de monstruosidad. Para ello debemos tener en cuenta que lo monstruoso de acuerdo con Vernant ${ }^{7}$ y retomado por Loraux y por Rodríguez $\mathrm{Cidre}^{8}$ oscila entre dos polos: lo aterrador y lo grotesco. El filicidio se incluye en el ámbito de lo monstruoso

${ }^{4}$ Biglieri, Aníbal A. (2005) Medea en la Literatura Española Medieval, La Plata, Fundación Decus.

${ }^{5}$ Murray, Gilbert (1951) Eurípides y su época. México-Buenos Aires, Fondo de Cultura Económica.

${ }^{6}$ Loraux, Nicole.,Las experiencias de Tiresias (lo masculino y lo femenino en el mundo griego), Trad.: C. Serna y J. Pórtulas, Barcelona, Editorial El Acantilado.

${ }^{7}$ Vernant, Jean Pierre (2001), La muerte en los ojos. Figuras del Otro en la antigua Grecia, España, Editorial Gedisa.

${ }^{8}$ Rodriguez Cidre, Elsa,"Medea y lo monstruoso: tratamiento diferencial en Eurípides y en Séneca" en López Aurora y Andrés Pociña, Medeas: Versiones de un mito desde Grecia hasta hoy, Granada, Eds. Aurora López y Andrés Pociña, 2002, vol.1. 
que presenta fuertes valencias animales y formula el clímax de un proceso progresivo en la animalización del personaje. Entonces Medea comienza a metamorfosearse en monstruo cuando repudia a sus hijos, los niega y los desconoce y sabe que es allí por donde destruirá al hombre: vv:1051-1055.

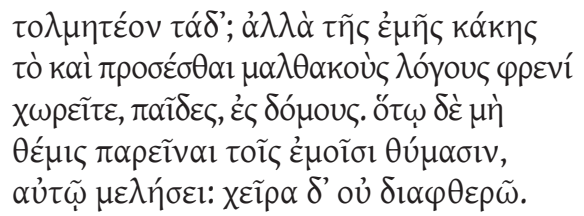

Tengo coraje para estas cosas.

Sin embargo desde mis males voy a esparcir dulces palabras en mi mente.

Retiraos, oh hijos, a la casa.

Para quien la ley divina no está presente en mis sacrificios.

Yo lo procuraré a mí misma, mi mano no se va a debilitar

En el caso de Daniela se limitó a enumerar en el recorte destinado a la nueva consorte, los hijos que pudo haber tenido de Miguel Dargelos y que no tuvo.;"le describía cómo los concibió y los destruyó, le transmitía su gran sabiduría frustradota y le rogaba que a él mismo le comunicase la pérdida del último, tres días atrás solamente...” (op. cit., p. 218).

En ambas obras ha sido el hombre el que inició el proceso de destrucción. En la novela española lo primero que destruyó Miguel fue la maternidad, la salvación de aquel primer hijo en el vientre significó el argumento decisivo para huir, comenzando el camino del exilio, pero "aquella fue la horrible travesía en el viejo carbonero portugués...en el que debió arrojar por la borda el leve fardo entrañable..." (op. cit. p. 45). Aquel triste hecho traería dos consecuencias importantísimas: despertar en Miguel el sentimiento de paternidad y en ella algo terrible: los celos.

La segunda de sus hijas, ya en tierra extranjera, también es alcanzada por la muerte, imprevistamente, a pesar de los esfuerzos prodigados por aquellos que la cuidaban en el campo, ya que Daniela no se encargó de ella. Miguel ni siquiera pudo acudir a verla morir y ella llegó tarde pues casi "inconscientemente, sin confesármelo jamás, la sentía entre los dos como una cuña entrañable y dolorosa...porque su arte, la actuación, era un pretexto para apartarla, para quitarla de en medio de nuestro mutuo disfrute feroz y exclusivo..."(op. cit.p,49). Es entonces que la mujer empieza a sentirse "monstruosa", pues su hija fue su mayor rival, y comienza a palpitar su terrible condición destructiva. A partir de ahora Daniela ya no será la mujer ni la madre sino la hembra pues 
como afirma Aurora López" "su amor es elemental, directo, sensual, reducido a la posesión física del amante”. Empieza a jugar en ella la ambivalencia femenina. A partir de esa segunda muerte se inicia el proceso de disgregación, de aversión, de repulsión entre los esposos. Los hijos no unen, según su parecer, sino encadenan y todo amor encadenado se destruye en la lucha por liberarse.

La hija la desgarró "sin cicatriz posible" y en ella se perfila la antítesis: utopía- realidad que se entreteje hasta el final de la novela: aspiraba a que el hombre viera a la mujer pero en la realidad sólo verá a la madre, la frustrada, la imposible.

Desde esta perspectiva y quizá por sus repetidas infidelidades, el hombre soportaba a las mujeres mientras sólo fuesen “jocundos animales amatorios”... (op.cit.p,145). Por ello nunca tuvo intención de hacer de aquella mujer la compañera de su vida, ni siquiera estaban casados, pues Daniela era tan deficiente e insatisfactoria como las demás mujeres, incapaz de compartir sus ideales políticos y sus móviles de acción. Como consecuencia todo lo que los une es "la vergonzante limosna de amor, la media hora bestial que era lo único que Daniela siempre le había otorgado...”(op.cit.p,64). Y lo hace porque su amor es catalogado de inviolable, sin importar las infidelidades que ella debió cometer para salvarlo. En este mismo derrotero situamos el discurso de Jasón del Segundo Episodio, vv 572-575 del que se desprende el epígrafe de la novela española:"... Sería necesario que los hombres engendraran hijos de alguna otra manera y que no existiera el sexo femenino; así, por cierto, ninguna imperfección habría para los seres humanos...”

A partir de esas dos muertes, las de sus hijos, comienza a gestarse en Miguel el sentimiento inverso: de ser el esposo amante surgió el padre amante que anhela ver en los otros niños a su niña muerta.

Ahora Daniela empieza a ser la maga, la que se interpone con su seudo-arte, con un nuevo embarazo desperado para intentar retenerlo hasta llegar a convertirse en la mítica Hera justiciera, torturada y torturante.

Igualmente fallido, como en la tragedia, es el nuevo matrimonio de este hombre. Acomodaticia es la circunstancia política que lo gesta aunque parece haber elegido en la niña-joven el resabio de la imagen de su pequeña muerta. Sin embargo en el diálogo final entre ambos descree de Daniela, ya que considera que su embarazo es una promesa enloquecida, extralimitada, una artimaña improbable a la que no puede sacrificar su valioso presente.

Es entonces, cuando los acontecimientos se precipitan, surge la venganza con el desenlace fatal por los celos de Daniela, hacia el hombre infiel en dos

${ }^{9}$ López, Aurora, "La novela Medea 55 de Elena Soriano", en López, Aurora y Andrés Pociña, Medeas: Versiones de un mito desde Grecia hasta hoy, Granada, Eds.Aurora López y Andrés Pociña, 2002, vol. 11, p. 963. 
términos: hacia sí y hacia la otra, en el aborto voluntario que se realiza por un lado y, por otro, en "el envenenamiento simbólico" de la inocencia de la joven esposa. La ha matado con la mostración despiadada en recortes de un pasado común que los unió.

Estas mujeres, en definitiva, han matado metafóricamente al hombre.

Medea y Daniela, por el filicidio, son fieles a esta última tendencia, a la irracionalidad, al arrebato, en definitiva, a la instancia monstruosa de la criminalidad gestada en un tópico común: los celos.

Finalmente Elena Soriano resemantiza en esta obra al personaje euripídeo, lo transforma pues su protagonista, lejos de la apoyatura mítica, dejó de ser mujer, dejó de ser esposa y madre a fin de erigirse en la hembra, en la portadora del instinto bestial. Despojada del tálamo y del hombre, al tiempo que sintiendose odiada por él, se metamorfosea en "la devoradora de cada Prometeo". 


\section{Bibliografía}

Biglieri, Aníbal (2005), Medea en la Literatura Española Medieval, La Plata, Fundación Decís.

(2001), Medea, la destructora, University of Kentucky. Troianalexandrina, pp. 55-84

Gambón, Lidia (2002),"Medea y la imagen de las Simplégades en Eurípides”, en López, Aurora y Andrés Pociña, Medeas: Versiones de un mito desde Grecia hasta hoy, Granada, Eds. Aurora López y Andrés Pociña, vol 1, pp. 133-145.

(2009), La institución imaginaria del olkos en la tragedia de Euripides, Bahía Blanca, Editorial de la Universidad Nacional del Sur.

Eurípides (1995), Tragedias. Medea-Hipólito-Andrómaca, Introd., Trad. y notas: Alberto González Medina y Juan Antonio López Férez, Argentina, Planeta DeAgostini.

- Medea (1938), The text edited with introduction and commentary by Denys L. Page, Oxford at the Clarendon Press.

(1977), Medea, Tome 1, Collection des Universités de France. Texte établi et traduit par Louis Méridier, Paris, Societé d' Édition "Les Belles Letres”.

___ (2008), Medea, Trad., Introd. y notas: César Guelerman, Buenos Aires, Editorial Biblos.

(2007), Tragedias. Introd. y Trad. de Juan Tobías Nápoli, Buenos Aires, Colihue.

Gónzalez de Tobia, Ana María (2002), ”Doble lógos en Medea”, en López, Aurora y Andrés Pociña (2002), Medeas: Versiones de un mito desde Grecia hasta hoy, Granada, Eds. Aurora López y Andrés Pociña. vol.1.

López, Aurora y Andrés Pociña (2002), Medeas: Versiones de un mito desde Grecia hasta hoy, Granada, Eds.Aurora López y Andrés Pociña, vols. 1 y 11.

Loraux, Nicole (2004), Las experiencias de Tiresias (lo masculino y lo femenino en el mundo griego), Trad. de C. Serna y J. Pórtulas, Barcelona, El Acantilado.

Murray, Gilbert (1951), Eurípides y su época, México-Buenos Aires, Fondo de Cultura Económica.

Nápoli, Juan Tobías (2001), "La "locura amorosa” en Hipólito de Eurípides: análisis filológico de la $\mu \omega$ pía femenina”, Sintesis 8 (2001), pp. 87-105. 
Rodriguez Cidre, Elsa (2002),"Medea y lo monstruoso: tratamiento diferencial en Eurípides y en Séneca", en López, Aurora y Andrés Pociña, Medeas: Versiones de un mito desde Grecia hasta hoy, Granada, Eds.Aurora López y Andrés Pociña, vol 1.

(2010), Cautivas Troyanas. El mundo femenino fragmentado en las tragedias de Eurípides, Córdoba (República Argentina), Ediciones del Copista.

Sala Rose, Rosa (2002), "La Medea de Eurípides: el enigma del infanticidio”, en López, Aurora y Andrés Pociña, Medeas: Versiones de un mito desde Grecia hasta hoy, Granada, Eds. Aurora López Andrés Pociña, vol. 1, pp. 293-313.

Soriano, Elena (1985), Medea, Barcelona, Plaza y Janés Editores.

Vernant, Jean Pierre (2001), La muerte en los ojos. Figuras del otro en la antigüa Grecia, Barcelona, Gedisa. 


\section{EL HérCULES CRISTIANo en FieRAS AFEMINA AMOR DE Calderón de la Barca}

Eliane Demoraes

Univ. Cat. de Petrópolis - Univ. Fed. do Estado de Rio de Janeiro

La ponencia se propone a evidenciar, con una mirada crítica, la emulación que hizo Calderón de la Barca a Hércules en su obra Fieras afemina amor. Tal recreación del mito hace del héroe, herencia de los griegos, un cristiano que, además, es un estranjero en aquel espacio escénico, una vez que, utilizando su característica andariega, se encuentra fuera de sus territorios y, como tal, recibe el tratamiento adecuado a la época.

Partiendo de teóricos como Ernest Curtius, Sebastián de Covarrubias, José María de Cossío, entre otros, nuestra propuesta es ver cómo Calderón trató el mito de Hércules, nombre en la mitología romana del héroe de la mitología griega Heracles, que ahora nos aparece como siendo una metátesis del nombre griego. Esta reflexión se propone a evidenciar, con una mirada crítica, la emulación que hizo Calderón de la Barca a Hércules en su obra Fieras afemina amor. Tal recreación del mito hace del héroe, herencia de los griegos, un cristiano que, además, es un estranjero en aquel espacio escénico, una vez que, utilizando su característica andariega, se encuentra fuera de sus territorios y, como tal, recibe el tratamiento adecuado a la época. El mito es readaptado a los patrones cristianos de entonces. El héroe se vuelve "el otro", "el exótico", que decía Todorov en La conquista de América, cuando apunta que hay que ser antropófago cultural, o sea, hay que absorver la cultura del más fuerte. De la misma forma, la teoría de Marc Augé también se aplica a la cuestión, visto que el héroe se desplaza de su lugar natural, el campo, en su país, hasta el jardín del palacio, hecho que, según Augé, hace con que se borre su identidad. De igual modo Julia Kristeva, en su libro Estrangeiros para nós mesmos, hace una observación respecto al estranjero. Dice ella que: "a alteridade cristaliza-se então como autêntico ostracismo: o estrangeiro exclui, antes mesmo de ser excluído, muito mais do que o excluem". ("La alteridad se consuma, entonces, como auténtico ostracismo: el estranjero excluye, antes mismo de ser excluido, mucho más que lo excluyen"). Sabemos que la relectura hecha por Pedro Calderón de la Barca está de acuerdo con el modelo presentado por la monarquía ibérica, o sea, la Iglesia y la corte de Felipe IV que tenía el dramaturgo como empleado oficial. Calderón seguía los modelos ideológicos propuestos, incluso porque era también teólogo. Vamos a tener en cuenta el concepto de transducción como una forma de relectura, hasta porque como fábula, la historia del mito clásico, Hércules, puede ser contada de forma 
que más interese a su autor. El trabajo propone reflexiones alrededor de los ejes temáticos de las teorías del Teatro, de la Literatura, así como de la Historia.

Este trabajo hace parte de la investigación doctoral en Teoría del Teatro que se desarrolla en la Universidade Federal do Estado do Rio de Janeiro - Unirio. Para este momento pensamos abordar el tema de cómo Pedro Calderón de la Barca trató la mitología clásica, y, más específicamente el semidiós, Hércules, en su drama mitológico Fieras afemina amor.

En esta obra, el dramaturgo expone, como personaje principal a Hércules pero, con características particulares, o sea, el mito clásico se presenta como pagano y, su nombre como una metátesis, o sea, una alteración fónica del nombre griego, Heracles.

Calderón es considerado por sus críticos como uno de los más grandes intérpretes cristianos del mito clásico porque, reconociendo la importancia y la extensión del conocimiento clásico pagano, recibido cuando estudió con los Jesuitas y la impotencia de la Iglesia en extinguirlo, lo utiliza en su teatro tal vez, como un recurso para mantenerlo (Neumeister, 2000, p. 96); el autor apunta que los mitos siguen alegorizados en el Renacimiento y el Barroco, igual que en la Edad Media, con un solo sentido, fijado para que un cristiano pudiera leerlo y comprenderlo (p. 29). Es interesante observar que en las fiestas de corte, Calderón vugariza el mito, para cristianizarlos en los autos sacramentales.

Concordamos con Curtius (1996, p. 305), cuando dice que junto a la Iglesia la antiguedad también venció en los versos de los "famosos poetas e oradores" (idem, p. 305); ahí, la Inquisición no conseguió llegar. Imposíble sería borrar la tradición que se perpetua a través de las obras mitológicas. Lygia Peres (2001, p. 19) esclarece que la tradición fue utilizada como medio de fijar el concepto de Dios único, "Autor dos mirabilia" (autor de maravillas).

La mitología aparece representada durante este periodo tanto en las obras literarias, en Lope de Vega y en Calderón, como en las pinturas de Velázquez, por ejemplo.

Las antiguas fábulas de los dioses de la mitología clásica, desde siempre han atraído al hombre, probablemente a causa de su eterna búsqueda por conocimiento. E1 hombre, siempre estuvo inspirado por ellas, las fábulas, que han sido, de cierta forma, creadas para que él propio se sintiera un poco dios y, movido por esta necesidad, consiguiera vencer la enorme distancia entre el hombre y dios o, podemos decir, la enorme distancia entre el mundo material y el mundo espiritual, entre tierra y cielo, incluso porque las "fábulas de los dioses son testimonios de los hechos de hombres heroicos" (Neumeister, 2000, p. 87). Además, apunta el autor (p. 112), aún, que las obras mitológicas proponen temas centrales de la vida humana, de ahí, suponemos, el interés de Calderón, en usarlas. 
La Iglesia se aprovechaba de estas historias conforme le convenía. Algunas veces las vulgarizaba en dramas como El monstruo de los jardines, también de Calderón; esta vulgarización aparece en la pintura de Velázquez, pintor oficial de la Corte de Felipe IV, contemporáneo, por tanto, de Calderón, en telas como La fragua de Vulcano y Los triunfos de Baco, conocido también como Los borrachos. En estas obras podemos percibir que los antiguos "dioses" aparecen ejerciendo funciones junto a personas comunes, junto a la plebe, destituídos, por tanto, de sus características divinas.

En Fieras afemina amor, Hércules se presenta de forma ridiculamente afeminada, demostrando, en sus últimas escenas, estar ya vencido por el amor; ahora bien, jel amor es un sentimiento cristiano!

En la extensa producción calderoniana, diecisiete dramas y diez autos sacramentales son mitológicos, es decir, los autos presentan el mito clásico ya cristianizado. En El divino Jasón, por ejemplo, los personajes ya se presentan cristianizados, Jasón representa el Cristo; Hércules, San Pedro; Teseo, San Andrés; Argos, el Amor Divino; Orfeo, San Juan Bautista, además de presentar Medea como el Alma.

La manera elegida por Calderón para contribuir con la perpetuación del conocimiento clásico en su obra fue a través de la alegorización, por su sentido moralizante y pedagógico, siguiendo la tradición de la Edad Media (Neumeister, 2000, p. 87).

En el drama Fieras afemina amor, Calderón muestra la presencia del sagrado interfiriendo sobre la vida del semidiós pagano. Otros dos dioses actúan en esta obra, Venus y Cupido que, por venganza, interfieren en la vida del héroe, infundiéndole el veneno de la pasión que culminará en su sometimiento al amor, es decir, su cristianización, o sea, el recurso del Maravilloso, el poder divino que rescata, "salva" el hombre. El dramaturgo eligió un episodio para presentar al aclamado héroe en un instante de total debilidad.

Calderón buscó inspiración en uno de los episodios narrados por Sêneca para escribir su obra que se inicia con la primera hazaña de Hércules, cual sea, su victoria sobre el león.

El héroe se muestra también como una fiera, y, por esta razón, se aleja más del amor divino y del patrón social, la discreción, necesario para la corte. Sus réplicas muestran el desprecio por este sentimiento y consecuentemente por las mujeres. Estas réplicas lo presentan bastante racional, y así es que, se puede comprobar, por medio de ellas, que confunde el amor carnal con el amor perfecto, divino.

Al transcurrir la obra percibimos el movimiento de pasaje rumbo a su total cristianización. Por medio del amor, el héroe cambia su vida. Calderón revela su maestria, cumpliendo sus funciones: habla del mito así como atiende a la Iglesia, transformando el héroe en el tipo común a la época, cual sea, en un discreto. 
Tratando de atender al punto central de esta comunicación, buscamos apoyo en Marc Augé (2007, p. 54), que esclarece que el desplazamiento altera la identidad. En Fieras afemina amor, Hércules se desplaza, lo que ocasiona, por tanto, una alteración en su identidad. Al entrar en el palacio se aleja del campo, ambiente natural a las batallas, en donde conquistó sus glorias. Ya hemos visto que Calderón lo hace rude intensionalmente. Por su rudeza, la cual podemos pensar potencializada por este choque de identidad, sigue profiriendo, el héroe, duras palabras respecto al amor.

Hércules representa la fuerza, fue entrenado en las artes del arco, de la lucha libre, de las armas, en las artes de la guerra. Realizó varios trabajos que dependían de la fuerza bruta y, así, "conquistó la imaginación popular" como apunta Harvey (1998). De esta forma, se alejó del amor.

El héroe pone en evidencia otra cuestión apuntada por Augé (2007, p. 25): la del "otro exótico". En esta condición, alejado de su mundo rudo, pasó a ser el diferente, el otro exótico, el extranjero, provocando reacciones desfavorables al ambiente cortesano. Todos somos exóticos cuando somos evaluados desde un punto de vista tomado a partir de nuestra propia interpretación, que se define pensando en un nosotros idéntico. Augé (p. 30) esclarece que en cualquier nivel de análisis siempre vamos a “...interpretar la interpretación que otros hacen de la categoría del otro en los diferentes niveles en que sitúan su lugar e imponen su necesidad: la etnia, la tribu, la aldea, el linaje o cualquier otro modo de agrupación...”.

Julia Kristeva (1994, p. 31) hace una observación con relación al extranjero. Dice ella que: "a alteridade cristaliza-se então como autêntico ostracismo: o estrangeiro exclui, antes mesmo de ser excluído, muito mais do que o excluem." ("la alteridad se cristaliza entonces como auténtico ostracismo: el extranjero excluye, antes mismo de ser excluido, mucho más que lo excluyen.”) Volviendo el pensamiento a la obra, la afirmación de Kristeva nos hace pensar que tanto Yole como Hércules se pensaban y se trataban como extranjeros, por eso se excluían.

La cuestión de la alteridad nos ayuda a comprender la situación vivida por el héroe mitológico en la obra.

Todorov (2003, p. 269) esclarece que este es el tipo de "julgamento de valor (um plano axiológico): o outro é bom ou mal, gosto dele, ou, como se dizia na época, me é igual ou me é inferior (pois, evidentemente, na maior parte do tempo, sou bom e tenho auto-estima...)" - (juicio de valor (un plan axiológico) el otro es bueno o malo, me gusta o no me gusta, o, como se decía en la época, me es igual o me es inferior (pues, evidentemente, la mayor parte del tiempo, soy bueno y me autoestimo...)).

Todorov (2003, p. 282) sigue aclarando que, apoyándonos en algunas semejanzas superficiales, podemos ver en el otro lo que no somos, pero tal vez, 
lo que nos gustaría ser. Apunta, aún, que a la medida que Yole sigue en esa posición de observar el otro como diferente indica, claramente, que cada uno pertenece a su clase y condición social (p. 289).

Hércules es el diferente en el ambiente del palacio y atrae para sí toda la atención, generando, así, un juego por oposición. El héroe es exótico en varios aspectos: por su condición de nacimiento, con relación a la Iglesia, por ser personaje mitológico, o sea, pagano, y por no ser discreto.

Todas estas cuestiones nos apuntan para el juego propio del teatro que se da en la obra. El héroe es hijo del dios Júpiter con la mortal Alcmena, hecho que le pone en una condición poco clara y dudosa: no es un dios ni tampoco un mortal. Tal hecho nos remite a Gracián y al discreto, pues, también aquí podemos pensar que "el cielo lo hizo indefinido". ¿Podríamos tomar esta aproximación como un juego más de oposicines propuesto por Calderón?

Por otro lado, Hércules no se adecuó al palacio por cuestiones culturales, por su singularidad que se contrapone al ambiente primoroso de la corte. En verdad, la situación del héroe siempre fue transtornada.

El tipo y la situación eran comunes a la época y, en Fieras afemina amor, Hércules tuvo su desenlace alterado por el amor, un sentimiento, repito, puramente cristiano. Al final de la obra siempre vence el bien.

Pensando en la historia de España, en el tiempo de Carlos I, de España y V, de Alemania, el gran Emperador que conquistó el mundo, que era rey desde el Occidente hasta el Oriente, por consiguiente, mantenía un Estado rico, extendemos el pensamiento del siglo XVII, cuando, ya en casi total estado de decadencia política y económica, el rey utiliza el arte, fundamentalmente el teatro, como un mensaje al extranjero, puesto que envía las portadas de las obras, escritas en oro, a las otras cortes de Europa, como apuntado por Neumeister (2000, p. 126/127).

De igual forma, este mensaje les sirve también como recurso didáctico para mantener el orden interno, evidenciando, así, el poder real. El teatro es utilizado como instrumento de seguridad nacional.

Una lectura sobre este Hércules en el drama Fieras afemina amor, y sobre la obra en general, que se puede establecer es mirarla por su carácter político. Pensamos posíble que el héroe represente a todo extanjero, así como también represente un mensaje de que aquí, en este lugar, en este país, el otro, el extranjero debe someterse a nosotros. Tenemos la fuerza de un Hércules, somos todavía grandes, aún podemos defendernos.

Debe, el extranjero, permitir ser tragado y, de la misma forma, tragar la cultura del lugar; hay que volverse en "antropófagos culturales", tragando la cultura del más fuerte, como apunta Todorov (2003).

Tal (re)lectura del clásico pone en evidencia las varias posibilidades de uso de una fábula. Sabemos que podemos adaptarla de la forma que más nos interese, 
que no hay reglas fijas. Cuando Calderón se apropia de este conocimiento, hace la transducción, siguiendo los modelos ideológicos propuestos, y porque era teólogo manejaba muy bien estos temas. Además, la mitologia estaba de moda en Europa en aquellos tiempos. Lo hace con seguridad, exponiendo su gran ingenio. 


\section{Bibliografía}

Augé, Marc, Los no lugares: Espacios del Anonimato. Una antropología de la sobremodernidad, Barcelona, Editorial GEDISA, 2007.

Calderón de la Barca, Pedro, Obras Completas. Dramas, Tomo II, Recopilación, Prólogo y notas por Angel Balbuena Prat, 2a ed., Madrid, Aguilar, 1987.

Corvin, Michel, Contribución al análisis del espacio escénico en el teatro contemporáneo, 1976, In: Bobes Naves, M. C., Teoría del teatro. Madrid, Arco Libros, 1997, p. 201-228.

Cossío,José María, Fábulas mitológicas en España, Madrid,Espasa-Calpe, 1952.

Covarrubias Horozco, Sebastián de, Tesoro de la lengua Castellanao española, Edición Integral e Ilustrada de Ignacio Arellano y Rafael Zafra, Madrid, Iberoamericana, 2006.

Curtius, Ernest Robert, Literatura Européia e Idade Média Latina, São Paulo, SP: Edusp, 1996.

Hansen, João Adolfo, Alegoria: Construção e interpretação da Metáfora, São Paulo, Atual Editora Ltda, 1986.

Harvey, Paul, Dicionário Oxford de Literatura Clássica - Grega e Latina, Tradução Mário da Gama Kury, Rio de Janeiro, Jorge Zahar Editor, 1998.

Kristeva, Julia, Estrangeiros para nós mesmos, Rio de Janeiro, Rocco, 1994.

Neumeister, Sebastián, Mito clásico y ostentación, Zaragoza, Reichenberger, 2000.

Peres, Lygia Rodrigues Vianna, O Maravilhoso em Calderón de la Barca - Teatro da Memoria, Rio de Janeiro, Ágora da Ilha, 2001.

Todorov, Tzvetan, La vida en común. Ensayo de antropología general, Buenos Aires, Taurus, 2008.

—_ A conquista da América, A questão do outro. São Paulo, Martins Fontes, 2003.

—_ Nós e os outros. A reflexão francesa sobre adversidade humana, Vol. 1, Rio de Janeiro, Jorge Zahar Editor, 1993. 


\title{
Divina INFIDELIDAD: \\ UNA VUELTA SOBRE EL TEMA DE ANFITRIÓN EN EL TEATRO ESPAÑOL
}

\author{
Viviana M. Diez \\ Universidad de Buenos Aires - UBACyT
}

\begin{abstract}
Amphitruo es una de las comedias plautinas más revisitadas a lo largo de los siglos que nos separan de su primera representación. Esta lista de reelaboraciones no incluye ejemplos relevantes en castellano, pero encontramos en el siglo XX una obra de A. Sastre, Los dioses y los cuernos, que se propone explícitamente como una vuelta sobre el tema de Anfitrión. Este trabajo se propone analizar los vínculos entre estas dos obras, centrándonos en el tratameinto del tema de la infidelidad, la construcción de los personajes femeninos y la utilización de ciertos recursos, como la frecuente ruptura de la ilusión escénica.
\end{abstract}

Las comedias de Plauto, tal como lo atestiguan numerosas fuentes, gozaron de enorme popularidad, tanto en el momento de su composición, como posteriormente. Una de las composiciones que más se destacó en este sentido es Amphitruo, obra única en más de un aspecto, tanto por su tema mitológico, que no aparecerá en otra del corpus plautino, como por su particular tratamiento del adulterio. Estas características han influido en que esta haya sido una de las composiciones más revisitadas a lo largo del tiempo que nos separa de su primera representación. Esta larga tradición incluye a autores de muy diversas nacionalidades, entre otros, a Camoens, Molière, Dryden, Antonio José da Silva, Kleist, Kaiser, Giraudoux y Pinter (Segal, 2001: 205-206). Sin embargo, este listado de obras consagradas no incluye composiciones en idioma castellano, ya que los pocos ejemplos relevados en nuestra lengua no revisten demasiado interés (Shero, 1956). La situación se modifica con la aparición de la obra contemporánea de Alfonso Sastre, Los dioses y los cuernos, estrenada en 1995. Esta composición presenta una vinculación explícita con la comedia plautina, tal como reza su portada, debajo de su título y autor: "sobre Anfitrión de Tito Maccio Plauto". E1 objetivo de este trabajo es analizar los vínculos entre Amphitruo y Los dioses $y$ los cuernos y examinar las continuidades y rupturas que se presentan entre ambas composiciones, separadas por más de 2000 años. De la vasta cantidad de cuestiones que podrían analizarse, tomaremos en esta oportunidad dos, a saber: la utilización de ciertos recursos teatrales, como la ruptura de la ilusión dramática, y la construcción de los personajes femeninos, relacionada con el tratamiento del tema de la infidelidad.

La comedia plautina presenta un uso abundante de recursos metateatrales (Moore, 1998). Es notoria la manera en que Sastre retoma esta tradición, 
poniéndola en primer plano y resignificándola. Revisaremos algunos ejemplos del funcionamiento de estos recursos dramáticos en ambas obras.

En Amphitruo podemos observar, desde el mismo prólogo, una cantidad muy variada de alusiones al acontecimiento convivial, a la expectación y a la poíesis, en suma, a los elementos que definen el hecho teatral (Dubatti, 2008:28). En este sentido, Mercurio se refiere a las condiciones concretas de la representación de este modo: "ahora, Júpiter me ordenó pedirles esto a ustedes, que unos inspectores vayan asiento por asiento por todas las gradas para vigilar a los espectadores, si vieran a algún favorecedor de actores, que se le tome la toga en prenda"1 (vv.64-68). También explica el recurso escénico que permite el juego de identidades: "estos signos [una pluma y un cordoncito que distinguen a Mercurio de Sosía y a Júpiter de Anfitrión respectivamente] no los podrá ver ninguna persona de la casa, solamente ustedes los verán"2 (vv.146-147) y combina el anuncio de lo que será representado con la circunstancia de representación: "ahora mi padre quiere burlar a Anfitrión: lo haré y será burlado eficazmente, espectadores y ustedes lo verán” ${ }^{3}$ (vv. 997-998).

Este tipo de alusiones, que ponen en primer plano la conciencia de estar frente a un hecho teatral y son muy abundantes en la obra del sarsinate, se incluyen en la obra de Sastre y proliferan en nuevas formas y sentidos. Pueden organizarse en dos tipos, el primero formado por aquellas alusiones puestas en boca de los personajes y el segundo por el complejo sistema de didascalias propuesto por el dramaturgo.

Los personajes revelan todo el tiempo la conciencia de su actuación y, del mismo modo que en la palliata, esta deviene fuente de comicidad. Dice Sosía: “ Todo es posible ahora! ¡Esto parece una obra de teatro! ¡Pero no una obra cualquiera! ¡Una obra de vanguardia!” (p. 83). En un intercambio con el amo, las referencias se multiplican:

Sosía -(se cubre la cabeza, viendo la espada en alto) ¿Y cuándo he protestado? ¿Qué delito cometí contra vosotros naciendo?

Anfitrión -(le corrige en voz baja) Eso es de otra obra.

Sosía -(igual) Pero va bien aquí, ¿no?

Anfitrión - Allá tú, Luego se lo explicas al autor.

1 "nunc hoc me orare a uobis iussit Iuppiter / ut conquistores singula in subsellia / eant per totam caueam spectatoribus, / si quoi fauitores uiderint, / ut is in cauea pignus capiantur togae" (vv. 64-68). Todas las citas en latín corresponden a la edición de Lindsay (1959) y las traducciones son propias.

2 "ea signa nemo homo horum familiarium / uidere poterit: uerum uos uidebitis" (vv. 146-

${ }^{3}$ nunc Amphitruonem uolt deludi meu'pater: faxo probe / iam hic deludetur, spectatores, vobis inspectantibus" (vv. 997-998) 
Sosía - Vale. Sigamos. Ahora voy a decir algo de Plauto, acto segundo, escena primera. (Otra vez en voz alta y en situación) Tuyo soy. Por consiguiente, haz lo que creas más cómodo $[. .$.

Anfitrión - ¡Qué falta de respeto! Te arrancaré la lengua (Aparte a Sosía) Esto también es de Plauto. (pp. 81-82)

Por otra parte, estas rupturas de la ilusión escénica constituyen en la obra de Sastre el lugar para la introducción de anacronismos. Observamos la combinación de varios elementos en este monólogo de Sosía:

"Aquí marcho yo, valientemente, lo cual que tiene un mérito grande en estos tiempos, conociendo como yo conozco las costumbres de nuestra juventud, que a poco que te descuides te sacan una chaira, o sea, un pincho o baldeo, y, o les entregas la bolsa o te dan una mojada que te mueres; que por cierto yo no tengo ninguna bolsa que entregar, pues soy más pobre que una rata, ¡maldito esclavo!, ¡propiedad privada de este espadón de mierda!, el cual que me trae a mal traer, el muy cabrito. Pobre de mí, desde que me hicieron prisionero estos hijos de mala madre de tebanos y me llevaron de la Persia, que es mi patria, que por eso y mis aventuras y picardías me llaman mis amigos el golfo pérsico (ríe); que yo era tan libre como un pájaro, ay, me cago en la mar. ¡Maldita sea mi estampa! ¿Pero qué es eso? ¿Qué se está moviendo por ahí? ¿ No parece un fantasma? ¡Ay, no! (Suspira aliviado) Era una lechuza que parecía un demonio. (Se santigua y en seguida el actor se da cuenta del anacronismo y hace su autocrítica) ¿Pero qué hago yo, si en aquella época no había cristianismo? Ustedes perdonen y sigan acompañándonos, por favor" (pp. 57-58)

En este pasaje se combinan una referencia intertextual al monólogo del Sosía plautino, de los versos 153-154: "Habrá alguien más audaz o confiado que yo, que conociendo las costumbres de la juventud, ande solo a estas horas de la noche"4, comentarios anacrónicos referidos a la propiedad privada y al cristianismo, la mención directa de los espectadores y la introducción de lexemas de un idiolecto solo comprensibles en el marco de la representación contemporánea 5 .

En cuanto al sistema de discalias, este presenta una marcada expansión, no desde luego en relación con el texto plautino, que carece de ellas, sino con las habituales en el teatro contemporáneo. En efecto, es esta zona del texto la que Sastre utiliza para introducir variadas reflexiones personales acerca del hecho teatral, que exceden en mucho la indicación escénica. Un ejemplo de

\footnotetext{
4 "qui me alter est audacior homo aut qui confidentior, / iuuentutis mores qui sciam, qui hoc noctis solus ambulem?” (vv. 153-154)

5 El chiste verbal de "golfo pérsico" solo en comprensible conociendo la variante del significado de "golfo" como "deshonesto, falto de vergüenza, holgazán” (cfr. RAE, s.v. 2)
} 
esto se aprecia en el cierre de la escena primera, en la que se han reencontrado Alcmena y Júpiter, bajo la apariencia de Anfitrión:

Júpiter - ¡Amor mío! (Se abrazan. El oscuro puede hacerse sin más, pero si el actor y la actriz lo prefieren -y al director le parece bien- pueden realizar sobre el lecho una pequeña escena erótica. De este modo el oscuro sería más emotivo, creo yo, pero no me gusta solicitar a los actores prestaciones innecesarias y además creo mucho en las elipsis como un modo óptimo de expresión artística frente a las servidumbres del naturalismo. Naturalemente, una acotación no es el lugar adecuado para plantear y discutir estos temas...)

Las didascalias también entran en diálogo con los personajes, como en este pasaje, en el que Anfitrión y Sosia observan asombrados la noche artificialmente extendida por Júpiter:

Anfitrión - Que no amanece.

Sosía - ¿Y cómo puede ser? Ya le veía yo preocupado, con perdón. ¿Será un fenómeno natural?

Anfitrión -(mira al cielo y dice en plan de personaje shakespereano) Todo hace pensar que el gran dios nocturno se ha embriagado esta noche y se ha perdido errático por estos rumbos de los cielos [...] y en parte alguna del Universo la noche cede su paso al día.

Sosía - respetuoso) ¿Puedo yo también decir algo en plan shakespereano?

Así, el texto dramático adquiere características particulares, ingresando en una zona de hibridez que combina teatralidad y reflexión sobre la poética. Ambos recursos, la voz del autor que ingresa en las didascalias y las referencias de tipo metateatral, revelan un alto grado de conciencia no solo sobre el proceso de creación (Romano, 1998:287), sino también sobre la variada cantidad de elementos incluídos en el espesor del despliegue del acontecimiento teatral (Dubatti 2008:95-95), destacándose especialmente la reflexión acerca de la propia pertenencia a la tradición teatral occidental.

En cuanto al segundo aspecto señalado, la construcción de la identidad femenina, Los dioses y los cuernos presenta diferencias importantes en relación con la comedia plautina. La fundamental es la aparición del personaje de Juno, ausente en la palliata. La diosa compañera de Júpiter interviene en dos escenas, la primera y la última que son además agregados significativos a la estructura dramática latina. ${ }^{6}$ Consideramos que en la comedia de Sastre, el plano de las identidades femeninas del sistema de personajes es el que

\footnotetext{
${ }^{6}$ Denominadas "Prólogo en el cielo" y "Epílogo en el cielo" presentan a los dioses Juno, Júpiter y Mercurio interactuando entre ellos en espacios celestiales, aunque domésticos, y ocupados en la planificación de la acción en la primera y recordándola y reflexionando sobre ella en la segunda.
} 
complejiza la estructura de duplicaciones que aparecía en Plauto (además de los pares Júpiter/Anfitrión y Mercurio/Sosías, el doble parto de Alcmena y la innovación plautina de la doble perpetración del adulterio divino ${ }^{7}$ ). Como llevando al extremo la observación que realiza el Sosía latino en el verso 786: "omnes congeminavimus" (todos nos hemos duplicado) por un lado aparece el par Juno/Alcmena y, por otro, se presentan dos relaciones ausentes en la comedia antigua: el vínculo amoroso entre Sosía y Bromia (la esclava de Alcmena) y el de amo/esclavo entre esta misma y su ama, que duplican respectivamente el malentendido amoroso de los amos de la casa y la relación entre Sosías y Anfitrión.

La aparición de Juno y la Alcmena que construye Sastre permiten problematizar la monolítica figura de la matrona plautina. Esta, en efecto, se presenta en Amphitruo como una suerte de reservorio de los ideales morales romanos, como se puede ver en su parlamento de los versos 633-654 cuando resalta en qué grado la valentía y el triunfo militar la compensan de la tristeza de la ausencia de su marido en casa y también en el orgullo con el que se defiende de las acusaciones de adulterio, llegando al punto de formular en el verso 928 la fórmula del divorcio ("tibi habeas res tuas") y declararse compañera de la virtud ("comitem mihi Pudicitiam duxero": tendré por compañera a la Virtud, v.930). ${ }^{8}$ Frente a ella, la Alcmena moderna presenta una condición femenina más sutil en la que caben el deseo y la posibilidad de optar entre sistemas de conducta diversos. Lo primero queda evidenciado en la escena en que se reencuentra con su supuesto marido Anfitrión (Escena primera: "La noche más larga de la historia"), ausente en la palliata. Las acciones físico-verbales que Los dioses y los cuernos muestra en esta parte de la comedia son las que relata Mercurio en el prólogo (versos 132 y ss.), donde anuncia que su padre ya está disfrutando de las relaciones con Alcmena. También en este sentido podemos interpretar el agregado que aparece en la Escena octava "Júpiter trata de arreglar la situación" cuando luego de la reconciliación entre Júpiter y Alcmena, esta aparece vestida provocativamente (p.114). La segunda cuestión, es decir la convivencia de sistemas axiológicos diversos y el valor de la elección que se realice aparecen en boca de Alcmena del siguiente modo, al defenderse de las acusaciones de infidelidad: "Almena (con una sonrisa triste ahora): Mira, Anfitrión. Yo no soy como las chicas de hoy... Yo soy una chica chapada a la antigua... Y yo estoy triste hoy" (p.100) o en el cierre de la obra: “(...) soy una pobre chica, mientras tú eres un ilustre tebano, pero yo tengo un gran tesoro que no está de moda en estos tiempos,

\footnotetext{
${ }^{7}$ Segal (2001:214).

8 "Ella è, senza il minimo dubbio (...) la più grande incarnazione di pietas dal palcoscenico romano" en Segal (1975:254).
} 
mi virtud. Es una palabra olvidada que ahora hace reír a quien la recuerda de otros tiempos." (p.144). Esta comedia moderna desarrolla en la escena aquellos elementos solo esbozados o ausentes en la antigua que le permiten la incorporación de nuevos significados.

Por otro lado, las acciones desarrolladas por Juno abren la posibilidad de reelaboración del tema de la infidelidad. Sastre propone el cambio fundamental que, en el nivel de la historia, diferencia su obra de la del sarsinate: en la escena final de la obra "Epílogo en el cielo", Juno relata a Júpiter que ella también lo ha engañado, ya que tomó la apariencia de Alcmena y de este modo, la infidelidad de Jupiter con la mortal no ha sido tal, dado que fue con la propia Juno con la apariencia de Alcmena con quien tuvo relaciones. Esta sorpresiva vuelta de tuerca que sucede poco antes del fin de la pieza, sumada a los rasgos que señalamos en Alcmena, instala un cambio abrupto en el sentido, que nos permite plantear las profundas diferencias en la subjetividad interna (Dubatti, 2008:117-120) de cada una de las obras estudiadas, que retomaremos a continuación, a modo de conclusión.

Los dioses y los cuernos, según refiere el autor Alfonso Sastre, fue escrita por él a pedido de unos grupos de teatristas independientes que le planteron la inquietud de contar con una obra que revisitara el mundo cómico plautino. ${ }^{9}$ Frente a esta demanda, el dramaturgo opta por la reelaboración de Amphitruo, antes que por una pieza que reúna un potpurrí de recursos y obras del sarsinate. Así, esta selección retoma toda la carga literaria de la fábula y pone en primer plano la problemática de la infidelidad y su vasta potencialidad cómica.

De acuerdo a los aspectos que hemos considerado, observamos una suerte de continuidad en cuanto a los procedimientos dramáticos examinados y una fuerte ruptura entre los sentidos construídos por ambas piezas.

Con respecto a lo primero, señala Romano (2008:288): "Con la inclusión de los espectadores reconocidos en su presencia y los comentarios sobre el teatro y sus convenciones, Sastre vuelve al drama antiguo pasando por alto siglos de rigor teatral y las reglas del clasicismo francés [...] y de este modo su versión del tema se acerca al modelo de la fabula palliata de tan vasta progenie".

En relación con el segundo aspecto, si bien en ambos casos el final de las obras plantea el retorno a la normalidad, esta tiene características muy diferentes en cada uno. En la comedia de Plauto hay un regreso a la identidad sin alteraciones, toda la situación fue producto de la voluntad divina que, con su intervención final, ha reestablecido el orden. Un orden que puede resultar por momentos incomprensible, pero que existe sin dudas. Así, Amphitruo resulta una cómica y saludable reflexión sobre la condición humana y su exposición a los caprichos divinos (Slater 2001:202).

\footnotetext{
${ }^{9}$ En Prefacio (Sastre, 1995:7).
} 
En cambio, en Los dioses y los cuernos presenta un doble final, uno en la tierra y uno en el cielo, coherentemente con la estructura exacerbada de duplicaciones que hemos señalado. En el primero, luego de ver la incomodidad de Anfitrión frente a lo que ha sucedido y la conversación que este tiene con Alcmena, Sosía dice: "Vivimos pues, señoras y señores, en el reino de la Mentira. Queda terminantemente prohibido ver los cuernos de Anfitrión. [...] ¡Este es el Nuevo Orden! Al principio huele bastante mal, pero luego se acostumbra uno" (p.144-145). Al pasar a la última escena, en el cielo, se produce la referida confesión de Juno con respecto a la forma en que se consumó la infidelidad. Frente a esta revelación, Júpiter la amonesta y ella manifiesta su desagrado, refiriéndose a la situación de subordinación de las mujeres y cerrando la escena en lo que podríamos denominar una tensa calma:

Júpiter - ¡Eres su diosa, Juno! Sé fiel a las damas del hogar y se acabó el teatro. ¿De acuerdo? [...]

Juno - (muy seria, fija en él su mirada y dice tan solo fríamente) Se te va a enfriar la sopa, querido ¿Qué se acabó el teatro dices? Sí, de acuerdo [...] (Júpiter la mira con inquietud, pero esto es, efectivamente, una comedia, y ellos empiezan a tomar su sopa en silencio. Puede suponerse, pues que es un final feliz ...) (p. 151)

Observamos así que en ambos finales se esboza un cuestionamiento del orden imperante, que toma como blancos principales el valor de la verdad y las posibilidades de la condición femenina. Sostenemos que el planteo de esta problemática, a partir de la ineficacia de la acción divina para reorganizar una situación de normalidad, abre un espacio de reflexión acerca de la identidad humana, una vez que esta ha sido desprovista de sentidos trascendentes que organicen la existencia. El hombre está solo, no hay orden que brinde seguridad y ni siquiera hay unicidad en su ser. Sastre reflexiona en el texto de presentación de la obra: "Decía Gérard de Nerval que, de pronto, se dio cuenta de «una verdad terrible»: de que «el hombre es doble». Yo no creo que sea una verdad terrible y hasta pienso que somos, por lo menos dobles, pues hay muchos que son triples y hasta se multiplican en más contradictorias identidades". Pues bien, dada esta condición existencial, el teatro se constituye como esa zona de experiencia y aprendizaje en la que es posible transitar la inestabilidad, para poder atravesar "estos tiempos verdaderamente calamitosos, en los que, sin embargo, la historia va a continuar, pues el mundo, efectivamente, ha de cambiar de base" ${ }^{10}$.

\footnotetext{
${ }^{10}$ Ambas citas fueron tomadas de la página web citada en la nota 5 (cfr.supra)
} 


\section{Bibliografía}

Dubatti, J. (2008), Cartografía Teatral, Buenos Aires, Atuel.

Moore, T. (1998), The theater of Plautus. Playing to the audience, Austin, University of Texas.

Q. Horati Flacci Opera, Ed. F. Klingner (1959), Lipsiae.

Romano, A. (1998), "Nuevamente el tema de Anfitrión”, en Pociña, A. Rabaza, B. (edd.), Estudios sobre Plauto, Madrid, Ediciones Clásicas, pp. 261-288.

Sastre, A. (1995), Los dioses y los cuernos, Hondarribia, HIRU.

Segal, E. (1975), "Perché Amphitruo", Dioniso 46, pp. 247-257.

Segal, E. (200I), The Death of Comedy, Cambridge, Harvard University Press.

Shero, L. R. (1956), "Alcmena and Amphitryon in Ancient and Modern Drama”, TAPhA 89, pp. 192-238.

Slater, N. (2001), “Amphitruo, Bacchae and Metatheatre” en Segal, E. (ed), Oxford Readings in Menander, Plautus and Terence, Oxford, Oxford University Press.

T. Macci Plauti Comoediae, Ed. W. M. Lindsay (1959), Oxford. 


\title{
UM ANFITRIÃO EXTEMPORÂNEO: Ecos do texto Plautino em Guilherme de Figueiredo.
}

\author{
Carlos E. Gomes \\ Universidade Federal de Minas Gerais
}

\begin{abstract}
O trabalho buscará perceber de que maneira é recuperado na peça Um deus dormiu lá em casa (1949) o esquema básico daquele estabelecido em Anfitrião. Figueiredo se apropria da temática religiosa presente no original, oferecendo-a contornos que fazem com que seja possível o diálogo desta com o público de sua época -Brasil pós Segunda Guerra Mundial. Diante de realidades históricas tão dispares tentamos perceber quais são os mecanismos que permitem a aproximação efetivada pelo autor brasileiro e como esse discurso encontrou eco em uma audiência tão díspar da original, que não comunga de seus valores religiosos, tão presentes no argumento da peça.
\end{abstract}

O presente trabalho busca cotejar duas peças tentando perceber seus pontos de contato e distanciamento, sobretudo em questões que envolvem a retomada e/ou adaptações do argumento principal que as conduz. Para tanto, foram escolhidas duas comédias, a saber: Anfitrião de Plauto e Um deus dormiu lá em casa de Guilherme de Figueiredo. Passemos, assim, à apresentação dessas para que sejamos capazes de vislumbrar os principais elementos que as constituem.

O texto plautino é indicado por Fonseca (1993) como um daqueles do período de maturidade de Plauto, com a possibilidade de essa comédia ter sido uma das últimas - senão a última - produzidas por esse autor. Tito Mácio Plauto viveu entre 250 e 184 a.C., e esse dado apontado por Fonseca nos sugere que a peça tenha sido encenada no início do II século antes de nossa era.

A peça trata de um embuste de Júpiter para que ele consiga ter, por uma noite, Alcmena. Transmutado em Anfitrião, esposo dela, e com a ajuda de Mercúrio - que se faz passar por Sósia, escravo de Anfitrião -, a divindade alonga a noite e deita-se com a esposa do general tebano que está no campo de batalha em uma peleja contra os teleboanos.

Anfitrião, ao regressar da batalha com seu escravo Sósia após muitas confusões em cena, descobre o adultério cometido por sua esposa e contra esta se enfurece. A situação só será resolvida após a intervenção mesmo de Júpiter, que põe fim à questão deixando claro que Alcmena gerava dois filhos: um de Anfitrião e outro, temporão, que seria filho do próprio deus. É ainda descrita a narrativa mitológica do ataque das serpentes a este filho de Júpiter que é Hércules. Mas em que medida essa comédia nos apresenta elementos de seu contexto histórico? 
Roma havia saído vitoriosa da Segunda Guerra Púnica e vivia um período de reestruturação política. As relações que se observavam nesse panorama eram a de clara desvirtuação das relações institucionais, que passavam agora a albergar em si os interesses de famílias ou conjuntos de cidadãos ilustres, que manipulavam o jogo político para que fossem mantidas as suas influências e poderes. O papel do Senado passava a ser cada vez maior e os magistrados destacavam-se cada vez mais. Astin (2006) esboça esses elementos da seguinte maneira:

Em tal contexto, política era primariamente a expressão de competições pessoais, nas quais cada um trabalhava para suplantar os outros na aquisição de honra e poder para ele mesmo e sua família. [...] A ideia de que uma maior fonte de poder político era uma rede de conexões sociais, a qual tendia a ser transmitida de uma geração de uma família poderosa à próxima, sugeriu uma subsequente hipótese de influência. (Astin, 2006, p. 169) ${ }^{1}$

É este o panorama geral de encenação da peça de Plauto: o de uma Roma vitoriosa, mas que germinava os elementos que, posteriormente, levarão ao declínio do Período Republicano e início do Período Imperial. Por isso, Anfitrião fala bem próximo de seu horizonte histórico. O general de batalha que volta vitorioso da disputa nos é mostrado como alguém pleno de honrarias e títulos, que demonstram a valorização de seu caráter frente à sociedade na qual ele está colocado. Ao encontrar seu lar aviltado pela possibilidade de um adultério, sua reação imediata é a de tentar extirpar de sua imagem essa mancha que possa trazer dano à sua reputação.

A solução encontrada para a aceitação do adultério pelo personagem passa, então, por uma releitura da função da relação extraconjugal de Alcmena. Com a intervenção de Júpiter, mostra-se ao espectador - ou ao leitor - de Plauto a importância do pensamento religioso que imperava no período. Júpiter não anula a glória de Anfitrião! Antes, enaltece-a! Por meio da geração de gêmeos, Alcmena, de maneira simbólica, representa a associação da imagem da divindade à do líder guerreiro. E seu filho divino - talvez o maior herói do mundo antigo - sinaliza que sua prole é digna de excelentes frutos desde o nascimento.

O contexto político romano pode figurar, portanto, como possível chave de leitura para a comédia plautina. O jogo personalista da política que se

\footnotetext{
${ }^{1}$ In such a context politics was primarily the expression of personal competition in which each sought to surpass others in acquisition of honour and power for himself and his family. [...] The idea that a major source of political power was a network of social connections which tended to be passed from one generation of a powerful family to the next prompted a further influential hypothesis.
} 
estruturava transforma-se, caso se aceite a aproximação proposta, em elemento que traduz, de alguma maneira, as reações de Anfitrião ao longo da peça.

Cardoso (2010), ao falar a respeito da ilusão no teatro antigo, destaca exatamente o diálogo entre real e ficcional que seria esboçado nas comédias grecorromanas; tal intercâmbio figuraria como principal elemento de distinção entre estas e a tragédia grega. Nas palavras da autora:

No contexto da polêmica em torno da ilusão dramática no teatro greco-romano antigo, os estudiosos inclinam-se a aceitar a existência de ilusão ininterrupta na tragédia grega, contrastando com a comédia grega e romana (sobretudo com a de Aristófanes e Plauto), em que a ilusão seria frequentemente interrompida. (Cardoso, 2010, p. 100)

Assim esperamos apontar, neste primeiro momento, que há, na peça de Plauto, um possível diálogo entre real e ilusório que talvez perpasse o cenário político que se desenhava.

Guilherme de Figueiredo, por sua vez, retoma o principal argumento da peça plautina. Ele traz, mais uma vez, o general tebano que é enviado para a batalha por Creonte para que liderasse os cidadãos no combate contra os teleboanos. Na peça de Figueiredo, há, no entanto, um complicador: uma profecia do adivinho Tirésias diz que um homem dormiria na casa de Anfitrião na noite em que ele estaria fora para o combate.

A fim de evitar que a profecia se cumprisse, Anfitrião e seu escravo Sósia retornam furtivamente a casa no meio da noite - fugindo do campo de batalha - e, passando-se por Júpiter e Mercúrio respectivamente, armam uma cena para a esposa Alcmena. Esta, muito afeita aos deuses, cede aos impulsos do falso deus (por momentos podemos crer que ela até mesmo força uma aproximação com ele) e eles dormem até o alvorecer, quando, então, saem os falsos deuses, retornando ao campo de batalha. Ao regressar vitorioso para casa, o falso Júpiter apresenta à esposa o engodo, mas, para a população, adota o discurso do adultério. Isso se dá justamente pela posição social que ele ocupa: um líder em campo fugir no meio da noite para regressar a casa por preocupação com a integridade do lar seria, no mínimo, inaceitável.

Haveria, dessa feita, elementos nessa comédia que pudessem resgatar informações históricas do contexto em que foi encenada? Quais informações da sociedade brasileira poderiam ser retomadas a partir da leitura ou encenação desse trabalho?

A peça de Figueiredo foi escrita em 1949, ou seja, no período imediatamente após a Segunda Guerra Mundial. O Brasil, conforme se sabe, passava por um processo de reestruturação sociopolítica. E ainda que o número de soldados mortos em batalha tenha sido pequeno comparado aos de outras nações envolvidas no combate, houve o problema de - no regresso à pátria 
- encontrar um ditador totalitário aos moldes daquele que havia sido deposto na Europa. Eram as próprias bases de organização social que se alteravam. Esse período de redemocratização (1945-1964) foi caracterizado, em seus primeiros momentos, por um otimismo econômico em vários setores e esse se refletirá na atmosfera social. Os brasileiros se abrem às influências estrangeiras propagadas, sobretudo, nos valores do conhecido american way of life.

O sucesso e o respeito social apregoados por esse modelo de vida encontram ecos na sociedade tradicionalista brasileira e logo se tornam valores moralizantes que nortearam os núcleos familiares. Ainda que as mulheres houvessem galgado alguns degraus no contexto da guerra, principalmente em decorrência de sua maior participação na vida econômica das nações envolvidas na disputa bélica, os homens ainda detinham o prestígio de serem vistos como os "chefes de família" e, em virtude disso, deveriam ser sempre verdadeiros "exemplos sociais". As questões de cunho privado deveriam ser relegadas a segundo plano a fim de que essas se mostrassem como pilares sólidos para a construção de uma sociedade nova, moderna e progressista. É essa a chave de leitura que propomos para a interpretação do argumento plautino retomado por Figueiredo.

Ao apresentar uma Alcmena com iniciativas, vontades e atitudes, o autor relê a figura da Alcmena traçada pelo romano, adequando-a à nova situação social de maior independência feminina do final da primeira metade do século XX. O papel da mulher é mesmo destacado na peça de Guilherme de Figueiredo e isso se nota já pela própria dedicatória que este faz de seu texto: à atriz Tônia Carreiro, que foi a principal Alcmena quando da montagem de seu trabalho. São ainda recorrentes, no texto de Figueiredo, reprovações de Alcmena a algumas posturas adotadas por Anfitrião. Um exemplo disso é o momento do primeiro ato, quando esta critica a conduta de seu marido por blasfemar os deuses e acusa-o, ainda, de ser mau orador.

TESSALA: - Não vais ouvir teu marido, Alcmena?

ALCMENA: - Não. Anfitrião não sabe falar em público e isto me envergonha. Além disso, lá está de novo a provocar os deuses. Creonte nunca devia ter dado a um livre-pensador o pôsto de general.

(Figueiredo, 1964, p. 8)

A personalidade marcante de Alcmena perpassa vários momentos da peça, ressaltando claramente essa perspectiva de início de liberação feminina. Ainda que o sufrágio feminino tivesse sido instituído há dezessete anos - no governo Getúlio Vargas -, o papel da mulher era o de submissa frente ao homem da família e a autonomia dessas tardaria alguns anos para se disseminar. Porém os ecos das iniciativas de alterações podem ser sublinhados no texto.

No personagem Anfitrião, é possível também perceber os embates que até então se estabeleciam entre o público e o privado para o homem 
de antanho - mais precisamente os conflitos inerentes à figura pública esperada para os homens e as agonias que estes cultivavam no âmbito privado. Um diálogo entre Anfitrião e Alcmena aponta claramente esse choque de perspectivas.

ALCMENA: - Um Deus não se dignaria a preferir tua pobre Alcmena.

ANFITRIÃO: - Quanto a isto, estou seguro. Porque não existem. Mas há certos homens... Porque raio foram inventar esta guerra!

ALCMENA: - (quase divertindo-se, coquette) Imagina, Anfitrião, se Júpiter viesse aqui...

ANFITRIÃO: - Isto é tolice. Eu falo de homens. Falo de Creonte, que não vai à batalha. Falo do Filho de Demoneto, por quem as mulheres suspiram na agorá. Falo dêsses anciãos, que não têm forças para erguer um escudo, mas ficam por aí dizendo pilhérias senis às mulheres nas portas das casas de confeitos... Todos êsses. Escuta, Alcmena, escuta bem: você é filha do rei de Mitileno, casada com o primeiro homem de Tebas. Você deve proteger-se. Prometa... Jure... Jure que ninguém, ninguém...

ALCMENA: - Ninguém, tolo... Se o inimigo soubesse que você está assim, em vez de um exército mandaria o seu mais belo soldado para te atormentar...

(Figueiredo, 1964, p. 14)

Como se torna evidente após a leitura, Anfitrião se mostra alguém fragilizado pelas obrigações pátrias (dever público o qual deve honrar) e as dúvidas de foro íntimo que são indicadas pelas dúvidas quanto à fidelidade de Alcmena. Tais situações aparecem de forma recorrente ao longo do texto e esses elementos acabam por reforçar a postura cada vez mais independente da mulher no cenário. $\mathrm{O}$ vigor de $\mathrm{Alcmena}$ e as dúvidas de Anfitrião são marcados em um diálogo deste - já fantasiado de Júpiter - com sua esposa:

ANFITRIÃO: - (aflito) Quer dizer que, se eu viesse metido na pele de um outro qualquer, você poderia pensar que era Júpiter... e receberia o simulador? ALCMENA: - Eu trataria de saber se era Júpiter ou um mortal...

ANFITRIÃO: - E se não pudesses distinguir, de tão perfeita minha caracterização?

ALCMENA: - Aí, então, Senhor... eu me entregaria a Júpiter.

ANFITRIÃO: - (explodindo) Eu sabia! Eu sabia que você me enga... que você enganava a seu marido! Eu sabia! Não fosse eu um deus! Eu sabia!

ALCMENA: - Afinal, Senhor, isto diz respeito a meu marido, e não aos deuses. Se eu engano a meu marido, êle é que deve ficar furioso.

ANFITRIÃO: - Saiba... Saiba... que eu zelo pela honra do seu marido... É a minha função. Os deuses foram feitos para proteger os lares!

ALCMENA: - Não é bem isto o que Júpiter faz agora em minha casa. ANFITRIÃO: - Eu... eu sou diferente. Eu sou um deus. A um deus a gente deve dar tudo. 
ALCMENA: - Não tem sido outra a minha maneira religiosa de proceder. ANFITRIÃO: - Quer dizer que trairias o teu marido com Júpiter?

ALCMENA: - Não é um sacrifício lisonjeiro? Não devo estar orgulhosa de me terdes preferido a mim, e não a uma outra mulher? (estendendo os ombros) Vinde, Senhor, estou pronta a receber-vos!

(Figueiredo, 1964, p. 32-33)

E ainda, ao final da peça, é a própria Alcmena que destacará as incongruências inerentes a esse homem moderno ao colocar em cheque a posição de Anfitrião, coagindo-o a posicionar-se de maneira tal a assumir o suposto adultério a fim de que sua reputação não ficasse maculada perante os cidadãos.

ALCMENA: - (olha-o, entre surprêsa e comiserada, séria) Falaste muito, Anfitrião, falaste demais. E se eu te disser que desde o primeiro momento, desde que esbarrei com Júpiter nesta sala, eu vi que eras tu? Se eu te disser que me prestei a acompanhar-te até o fim da farsa? Se eu te disser que não sabes fazer o papel de Júpiter, e só consegues fazer o de marido que suspeita? Se eu te disser que sabia, e te deixei na humilhação de um grotesco, porque me lisonjeava o teu pavor e me divertia ver-te simulando um deus em quem não crês? Eu sabia que eras tu, tolo. Eu sabia, general covarde.

ANFITRIÃO: - Não, Alcmena! Não era eu! Era Júpiter!

ALCMENA: - Como, se não crês que êle exista?

ANFITRIÃO: - Não creio? Como não creio? Pois se êle não me inspirou no comando do exército? Não me deu a vitória? Não me deu a glória com que tanto sonhava? Não me deu todos os motivos para que tu te orgulhes de mim? Enquanto eu comandava os Tebanos, sentia que uma fôrça sobrenatural me inspirava, me emprestava uma lucidez, uma...

ALCMENA: - Então crês nos deuses?

ANFITRIÃO: - Creio. Do fundo da minha alma...

ALCMENA: - Como tu és sórdido! Estás convertido?

ANFITRIÃO: - (bumilde) Estou convertido.

ALCMENA: - Podes ir embora. Queres tua mulher, queres a glória e por isso fazes uma transação abjeta. Admites que eu seja capaz de me entregar a outrem, a um deus que seja, contanto que isto te dê a oportunidade de passar por bravo à frente do exército, e contanto que isto não te furte dos prazeres com tua mulher.

ANFITRIÃO: - (num desespêro) Eu te amo, Alcmena!

ALCMENA: - (irônica) Como amas os deuses?

ANFITRIÃO: - Podes dizer tudo, menos que eu não te amo.

ALCMENA: - Tens que escolher entre seres um covarde ou um marido enganado.

(Figueiredo, 1964, p. 53-54) 
A partir desse ponto a peça caminha para seu desfecho. Neste, o Anfitrião de Figueiredo optará pelo reconhecimento do adultério para a manutenção de sua imagem pública ao invés de declarar a verdade quanto aos acontecimentos. Caso o fizesse, declararia ao povo de Tebas que ele, general do exército, colocara os interesses pessoais acima do bem coletivo.

Finalizando, percebemos que a temática religiosa que serviu de base para o argumento de Plauto e que dialoga com o contexto sociopolítico da Roma Republicana é aproveitada por Guilherme de Figueiredo. No entanto, este o faz adaptando-a à nova situação social que se descortina no cenário do pósguerra. Se, na comédia latina, é dado um Anfitrião firme, resoluto, que ilustra a figura do militar vitorioso e líder de seu povo, em Figueiredo dá-se o contrário. O Anfitrião brasileiro já não é mais um homem que se pauta pelos valores militares e cívicos, ainda que se sinta na obrigação de honrar tais compromissos mesmo que apenas em seu discurso.

O próprio papel do homem é que passa a ser retraçado e o elemento feminino da peça ganha destaque para sublinhar os pontos de conflito da postura entre público e privado que então se estabelece. Por esses motivos, podemos indicar de fato a extemporaneidade de Anfitrião, este ser que figura aparentemente de forma anacrônica, retirado da Roma do século II a.C. e colocado nos palcos brasileiros do século XX, mas que, por mais estranho que pareça, consegue dialogar com os dois contextos desde que observadas as motivações que envolvem as figuras masculinas e femininas em ambos os cenários. 


\section{Bibliografia}

Astin, A. E., Roman government and politics, 200-134 B.C. In Astin, A. E. et al. The Cambridge Ancient History - Volume VII: Rome and the Mediterranean to 133 B.C. $2^{\mathrm{a}}$ edição; $7^{\mathrm{a}}$ reimpressão, Cambridge, Cambridge University Press, 2006. (p. 163-196).

Cardoso, Isabella Tardin, Ilusão e engano em Plauto. In Cardoso, Zélia de Almeida; Duarte, Adriane da Silva (org.), Estudos sobre o teatro antigo, São Paulo, Alameda, 2010. (p. 95-126).

Figueiredo, Guilherme, Um deus dormiu lá em casa; $A$ rapôsa e as uvas; Os fantasmas; A muito curiosa história da virtuosa matrona de Éfeso, Rio de Janeiro, Civilização Brasileira, 1964. (Coleção Vera Cruz - 72).

Gassner,John, 6. Menandro, Plauto e Terencio. In Gassner, John, Mestres do teatro I. $3^{\text {a }}$ edição, São Paulo, Perspectiva, 2005. (Estudos - 36) (p. 105-118).

Plauto, Anfitrião, Introdução, tradução do latim e notas: Carlos Alberto Louro Fonseca, Lisboa, Edições 70, 1993. (Clássicos Gregos e Latinos - 10).

Ubersfeld, Anne, Para ler o teatro, São Paulo, Perspectiva, 2005. (Estudos 217). 


\title{
Del diálogo al TEXTO DRAMÁtico: \\ UNA ADAPTACIÓN BRASILEÑa DE LOS DIÁLOGOS DE LOS MUERTOS De Luciano de Samosata
}

\author{
Matías Sebastián Fernández Robbio \\ Universidad Nacional de Cuyo
}

\begin{abstract}
Los Diálogos de los muertos son un conjunto de treinta diálogos escritos por Luciano de Samosata. Si bien primero se los consideró independientes entre sí, luego se dio paso a una comprensión unitaria de los mismos que posibilitó nuevas lecturas. La obra fue adaptada para su escenificación en 1990 por el Grupo Giz-en-Scène (Araraquara, Brasil), y, en 1996, María Celeste Consolin Dezotti publicó una traducción integral de los diálogos, que complementaría en 2003 con la publicación de su versión teatral. Analizamos aquí esta adaptación con el fin de descubrir el paso del diálogo literario al dramático, la reestructuración de la obra, y sus acotaciones escénicas y escenográficas.
\end{abstract}

\section{Transmisión de los diálogos}

Luciano de Samosata, escritor griego y ciudadano romano aunque de origen sirio, es uno de los principales representantes de la literatura griega escrita durante el Imperio Romano en el siglo II d.C. Entre sus escritos se encuentran prolaliái, diálogos, narraciones ficticias e incluso una tragedia y varios epigramas. Su obra no sólo refleja la originalidad del samosatense, sino que además evidencia su conciencia del acto mismo de creación literaria. Entre sus diálogos, se encuentra un conjunto de treinta diálogos breves que presentan pequeñas escenas dramáticas de corte menipeo situadas en el Hades, los Diálogos de los muertos.

Durante siglos, los filólogos y la crítica literaria consideraron que estos diálogos sólo constituían una unidad por su temática. El motivo de la lectura individual de los mismos se encontraba en la transmisión de los textos mismos. Dejando de lado algunos manuscritos mixtos e interpolados, los manuscritos principales de la obra de Luciano han sido agrupados en las familias $\beta$ y $\gamma$. El manuscrito B, perteneciente a la primera familia, fue el utilizado por Jacobitz al preparar la edición de la obra luciánica para Teubner. En este manuscrito, los Diálogos de los muertos aparecen en un orden que no permite leerlos como una unidad coherente sino como pequeños cuadros individuales, al modo en que luego los interpretaron Bompaire, Jones, Alsina o Baldwin (Gonzàlez Julià, 2009: 2). Sin embargo, cuando MacLeod editó estos diálogos para Oxford en 1987, siguió el orden dispuesto por el manuscrito $\Gamma$ (Vaticanus Graecus 90) de 
la familia $\gamma$, y dio paso a una nueva forma de comprenderlos que reconocía en ellos una cierta unidad narrativa.

Entre las relecturas más modernas, es necesario mencionar la de Lluís Gonzàlez Julià, quien ha propuesto considerar el conjunto de los diálogos como una "novela escénica", apuntando que:

"los Diálogos de los muertos contienen suficientes evidencias internas para que consideremos que fueron concebidos y presentados en público por Luciano -no sabemos si en audiciones o en forma de libro- como una obra unitaria y cerrada, donde las distintas piezas que la forman están interrelacionadas las unas con las otras, de manera que cada diálogo se une al anterior y al siguiente por un hilo narrativo común y por referencias metatextuales que enlazan las conversaciones. Luciano dibuja, de este modo, un viaje por el Hades en una historia completa de principio a fin, donde cada diálogo tiene su lugar." (2009: 17)

Según este mismo autor, siguiendo la numeración de MacLeod, el orden correcto de estos diálogos sería: 1, 2, 4, 5, 6, 3, 7, 8, 9, 10, 11, 12, 13, 14, 15, 16, $17,18,19,21,22,23,26,27,28,29,30$. Como se puede ver, no habría lugar para los diálogos 20, 24 y 25, que, según él, estarían interpolados.

\section{Pastiche y plasticidad en los Diálogos de los muertos}

Luciano, creador literario consciente, recurrió en sus obras a los más variados recursos y temas de la tradición literaria. Su originalidad lo llevó incluso a desafiar la distinción entre géneros literarios, hecho por el cual fue satíricamente llevado a juicio por la Retórica y el Diálogo en su propio Bis Accusatus. Al respecto, afirman Mestre y Gómez:

"Si algo caracteriza a Luciano es su carácter inclasificable. Como adalid de una cultura auténticamente individual, aparece siempre al margen de cualquier tipo de compromiso, repudió a Retórica y contaminó a Diálogo de comedia." (2001: 122)

Esta marginalidad de su obra justifica que sus diálogos sean clasificados propiamente como "diálogos luciánicos", entendidos como "una combinación de recursos de la comedia antigua y del diálogo platónico" (Cabrero, 2007: 222). La armonía entre estos dos elementos podría estar dada de diversas formas. Cabrero considera que Platón aportaría la forma, y Aristófanes, la intencionalidad satírica (ídem). De un modo parecido, Mestre y Gómez coinciden en que el diálogo es una forma pero señalan que "lo cómico" no es una intencionalidad sino un contenido que se define por oposición a "lo trágico" (2001: 113). En cambio, Wiater sostiene que la comedia no es un contenido sino una forma representacional que por su vivacidad y su inmediatez permite 
alcanzar el objetivo del diálogo filosófico, enseñarles a los lectores nuevos modos de ver y comprender el mundo (Wiater, 2009: 15). Este autor agrega que, si bien los diálogos luciánicos se parecen a la comedia en su contenido, lo que más tienen en común es lo formal: el uso de nombres cómicos, la presentación de personajes de todas las clases sociales que interactúan entre sí, la representación de acciones elevadas y cotidianas, y la utilización de vocabulario de todos los registros (16). Estos recursos, combinados con el diálogo, la diégesis in medias res y los deícticos, constituyen lo que Wiater ha propuesto llamar la "cualidad mimética" de los diálogos de Luciano, que transforman a los lectores en espectadores en la medida en que el texto contribuye a crear un escenario invisible en sus mentes. (17)

Lanaud, por su parte, propone una interpretación similar de estos textos híbridos al señalar que, en ellos, Luciano propone una puesta en escena del Hades radicalmente teatral que transforma a su obra en una "comedia infernal" (Lanaud, 2010: 23).

El pastiche utilizado como procedimiento de creación literaria a partir del diálogo platónico y la comedia aristofánica, entonces, se vuelve al mismo tiempo la causa principal de la plasticidad de estos diálogos, que ha posibilitado su adaptación teatral.

\section{E1 Grupo Giz-en-Scène y su recepción de los diálogos}

El Grupo Giz-en-Scène de lectura dramatizada de textos clásicos es un elenco brasileño que fue formado en 1987 en Araraquara (São Paulo, Brasil). Desde sus inicios ha estado integrado por profesores y alumnos de griego y latín de la Faculdade de Ciências e Letras de la Universidade Estadual Paulista Júlio de Mesquita Filho y un profesor de sánscrito de la Universidade de São Paulo. Los intérpretes y adaptadores de las obras, si bien son actores aficionados, son académicos que trabajan en el campo de los estudios clásicos.

Su relación con los Diálogos de los muertos fue mediada por la actuación profesional de Maria Celeste Consolin Dezotti, profesora de lengua y literatura griega en la FCLAR-UNESP. E1 elenco puso estos diálogos en escena en 1990. Entre los años 1990 y 1991, Consolin Dezotti dirigió cuatro proyectos de iniciación científica de alumnos becarios que estudiaron tres obras de Luciano: Diálogos de los muertos, Caronte e Icaromenipo. Luego, en 1996, publicó una traducción de estos diálogos y, finalmente, en 2003, salió a luz su adaptación dramática del texto, basada en su traducción. Si esta adaptación fue publicada en 2003 basándose en una traducción de 1996, cabría preguntarse qué texto sirvió de guión al elenco en 1990 y si existe alguna relación entre ese texto desconocido y la adaptación que finalmente se publicó. 


\section{Adaptación del texto original}

Los Diálogos de los muertos de Luciano, como se comentó, son un conjunto de treinta diálogos situados en el Hades, el mundo de los muertos griego regido por el dios homónimo y su esposa Perséfone, o Plutón y Proserpina en la tradición latina. Según el mito, a esta región sombría conduce Hermes, el psychopompos, a las almas de los muertos, que deben atravesar un río para ingresar al Hades conducidos en una embarcación por Caronte, personaje mitológico que cobra un óbolo por la travesía. Aquí se dan encuentro los más variados personajes (dioses, héroes, reyes, filósofos, atletas, ricos y cazadores de testamentos) igualados por la muerte y transformados en simples esqueletos y calaveras.

El texto dramático está formado por dos partes y un epílogo. La distinción de dos partes obedece a la necesidad de marcar dos momentos diferentes en la historia. La primera parte se divide en tres escenas desarrolladas junto al barco de Caronte antes de la muerte de Menipo, un filósofo cínico. La segunda parte arranca justamente después de que éste se suicidara y llegara junto a la barca de Caronte. Durante la primera escena de esta parte, los personajes embarcan en la nave del barquero y son conducidos hacia el otro lado del río. Apenas descienden, Hermes les indica a los muertos el camino que los llevará hasta el tribunal de los muertos, representado aquí únicamente por Minos. Desde ese momento, las escenas van situándose en zonas cada vez más profundas del Hades hasta llegar, en las escenas 7 y 8, a los aposentos reales de Plutón y Perséfone. Finalmente, el epílogo es un diálogo entre Hermes y Caronte, en el que este último indica su deseo de conocer el mundo de los vivos, anticipando así quizás una futura o posible puesta en escena de Caronte, otra obra de Luciano.

Las acotaciones dramáticas incluidas son escasas. En general, acompañan este movimiento desde el río hacia el interior del Hades señalando grupos de personajes que se encuentran a lo largo del recorrido y poco a poco aparecen en primer plano.

De principio a fin, la narración avanza con una construcción abierta (García Barrientos, 2003: 77) a medida que se profundiza en el Hades. No hay una acción unitaria que dé sentido a la obra ni hay un único personaje que actúe como protagonista de la misma, a pesar de que se destaquen las figuras de Diógenes en la primera parte y Menipo en la segunda. Al contrario, priman constantemente la variedad y la expansión de la historia. Por lo tanto, la adaptación propuesta puede ser considerada un drama de ambiente, en el que se suceden escenas y personajes que contribuyen a formar una imagen del mundo de los muertos.

La adaptación de los textos implicó una selección y una reordenación de los diálogos para construir una historia con una cierta coherencia entre 
los personajes que entran y salen de escena y los espacios en los que se encuentran. Por un lado, fueron descartados los diálogos 4, 8, 10, 11, 12, $16,22,23,25$ y 30 . Por el otro, los diálogos escogidos fueron reordenados libremente en las diferentes partes y escenas sin respetar los órdenes propuestos por ninguna de las ediciones del texto original griego. E1 siguiente cuadro sistematiza la relación entre las secciones de la comedia y los diálogos adaptados en ellas:

\begin{tabular}{|l|l|l|}
\hline Secciones & Diálogos adaptados \\
\hline Parte I & Escena 1 & $14,26,13,29$ \\
\cline { 2 - 3 } & Escena 2 & $17,18,19,15$ \\
\cline { 2 - 3 } & Escena 3 & 21,1 \\
\hline \multirow{5}{*}{ Parte II } & Escena 1 & 20 \\
\cline { 2 - 3 } & Escena 2 & 2,5 \\
\cline { 2 - 3 } & Escena 3 & 9 \\
\cline { 2 - 3 } & Escena 4 & 7 \\
\cline { 2 - 3 } & Escena 5 & 6 \\
\cline { 2 - 3 } & Escena 6 & 24 \\
\cline { 2 - 3 } & Escena 7 & 27,28 \\
\cline { 2 - 3 } & Escena 8 & 3 \\
\hline \multirow{5}{*}{ Epílogo } & & Ninguno (Posible referencia a Caronte, obra de \\
& & Luciano) \\
\hline
\end{tabular}

El escenario es caracterizado por medio de una única acotación escénica inicial (Consolin Dezotti, 2003: 6). La escenificación del espacio dramático recurre a cuatro elementos característicos del Hades: el río que los muertos deben cruzar y que separa una zona desértica del Hades, el barco que conduce Caronte, Cerbero, el perro guardián de la entrada al Hades, y un árbol de granada, la fruta que el dios Hades le ofreció a Perséfone para forzar su matrimonio (cf. Himno homérico a Deméter, 370-383). Si bien no se encuentran otras acotaciones escénicas, por medio de los diálogos se infiere que el río debería desaparecer a partir de la escena 3 de la segunda parte y que en la escena 4 debería haber un lago. Quizás el epílogo, protagonizado por Hermes y Caronte, deba ser representado junto al barco y al río pues ese último personaje jamás abandonaba esa zona.

En relación con los personajes, su cantidad es menor pues varios diálogos han sido dejados de lado. Además, en los casos en los que es posible, algunos personajes han sido reemplazados por otros que, por lo tanto, han aumentado su participación en la obra. En la escena 2 de la primera parte, el pasaje basado en el diálogo 18 utiliza a Cenofante en lugar de Damnipo. Luego, en la misma escena, el pasaje basado en el diálogo 19, pone las palabras de Símilo en boca de Calidémides. Por último, en las escenas 5 y 7 , basadas respectivamente 
en los diálogos 6 y 27, Minos reemplaza a Éaco, pues ambos eran parte del tribunal del Hades.

Richard Walton, al referirse a los problemas de la traducción de piezas teatrales antiguas, sintetiza las condiciones que una buena traducción debe cumplir: traducir no es sólo la transmisión de un lenguaje a otro sino también la transferencia de un contexto y la búsqueda de balance en las referencias con la finalidad de ser fieles al original y, al mismo tiempo, posibilitar puestas en escena creativas. No se trata de traducir "arco" por "rifle" sino de encontrar un lenguaje que le permita al director crear un mundo escénico donde tanto los arcos como los rifles puedan parecer apropiados (2008: 155). Es decir, la traducción debe lograr una cierta universalidad que permita al espectador establecer una analogía entre su mundo y el mundo antiguo. En el caso particular de esta adaptación, la traducción evita este problema pues, aunque recurre a personajes mitológicos e históricos, la comicidad no se encuentra en la erudición sino en la crítica de tipos y de costumbres fácilmente reconocibles por el espectador. Además, el lenguaje coloquial griego ha sido adaptado a la lengua portuguesa hablada en Brasil. De esta manera, se garantiza que el espectador tenga una experiencia teatral que supere la brecha temporal que se extiende desde la escritura de este texto en el siglo II d.C. hasta su lectura o su escenificación en la contemporaneidad. 


\section{Bibliografía}

\section{Fuentes}

Luciano, Diálogos dos mortos, Trad.y adapt. de Maria Celeste Consolin Dezotti, Araraquara, Faculdade de Ciências e Letras - UNESP, 2003.

Macleod, Matthew (ed.), Luciani opera. t. IV, Nueva York, Oxford University Press, 1987.

\section{Bibliografía Crítica}

Cabrero, María del Carmen. “¡Arriba el telón! Discurso, identidad e ideología en tres diálogos de Luciano”, Nova Tellus 25,2, 2007, 209-230.

González Juliá, Lluís, “Luciano ensaya la novela escénica: apariencia episódica y estructura unitaria de los Diálogos de los muertos", en: Brandão, Jacyntho Lins (ed.), Actas del V Colóquio Internacional do Grupo Interdisciplinar de Pesquisas sobre as Sociedades Antigas (GIPSA) "Luciano e a tradição luciânica”, Ouro Preto, Brasil, 2009. [En prensa]

Mestre, Francesca, “Retórica y Diálogo contra el Sirio”, Synthesis 4, 1997, 21-31.

Mestre, Francesca y Pilar Gómez, "Retórica, comedia, diálogo. La fusión de géneros en la literatura griega del s. II d.C.”, Myrtia 16, 2001, 111-122.

Lanaud, Michaël, Le monde des morts selon Lucien de Samosate: une recréation originale du thème de l'Hadès au IIe siècle, Mémoire de Master 1 Poétique et histoire littéraire. Université de Pau et des Pays de l'Adour, 2010. [Fecha de consulta: 12/06/2011] Disponible en: http://dumas.ccsd.cnrs. fr/docs/00/49/04/61/PDF/2008-2009_Michael_Lanaud_master_1. $\mathrm{pdf}$

Walton, J. Michael, “Enough give in it': translating the classical play", en: Hardwick, Lorna y Christopher Stray (eds.) A companion to classical receptions, Oxford, Blackwell Publishing, 2008, pp. 153-167.

Wiater, Nicolas, "Tragedies to laugh at - Lucian on the failures of mimesis", en: Mosaïque, $\mathrm{n}^{\circ} 1$, junio 2009. 


\title{
RELECTURA Y FUSIÓN DE UN MITO GRIEGO EN UN DRAMA DE Horacio Rega Molina
}

\author{
Alfredo Eduardo Fraschini \\ Universidad Nacional de Villa María
}

\begin{abstract}
Polifemo o las peras del olmo, de Horacio Regas Molina (1945), pertenece a ese grupo de producciones teatrales argentinas cuyo argumento se inspira en un mito griego, pero cuya acción se enmarca en algún momento de la historia argentina. Polifemo representa la figura del campesino atado a sus costumbres y habituado a la libertad que otorga la llanuera ilimitada. Ulises es el forastero que viene a traer novedades que el criollo considera negativas. Galatea se casa con Ulises, Polifemo muere en el río y la joven, embarazada, sostiene que el hijo que espera será la reencarnación de aquel que la amaba. La traslación del mito en estos términos constituye una alegoría de la ola inmigratoria producida en la Argentina de fines del siglo XIX y principios del XX.
\end{abstract}

\section{Palabras liminares}

La recurrencia a la cultura griega - mito e historia - ha generado en la dramaturgia argentina un grupo de producciones valiosas. Desde Los reyes (1949) de Julio Cortázar, ambientada en la entrada misma del laberinto cretense, hasta La oscuridad de la razón (1993) de Ricardo Monti, cuyo marco histórico es la época de Rosas, se han sucedido obras inspiradas en la historiacomo Temístocles en Salamina (1949) de Román Gómez Masía y La peste viene de Melos (1956) de Osvaldo Dragún -; en la mitología pura - como Las nueve tías de Apolo de Juan Carlos Ferrari y Prosérpina y el extranjero (1951) de Omar del Carlo - o en mitos ya elaborados por los tragediógrafos griegos - como Antígona Vélez (1950) de Leopoldo Marechal, El reñidero (1962) de Sergio De Cecco, La frontera (1964) de David Cureses y Antígona furiosa (1986), de Griselda Gambaro ${ }^{1}$. Estos dramaturgos que bebieron de la fuente clásica han elaborado, por lo general, su reescritura trasladando el mito en el tiempo y el espacio hacia la Argentina de los siglos XIX y XX.

Dentro de esa línea de producción teatral se ubica Polifemo o las peras del olmo, calificada como "misterio dramático pastoril" por su autor, Horacio Rega Molina, estrenada en Buenos Aires en 1945 en el histórico Teatro del Pueblo,

\footnotetext{
${ }^{1}$ Ya en 1826 Juan Cruz Varela había recurrido a las fuentes clásicas para sus tragedias Dido y Argia. Son dignas de mención, en el siglo XX, La copa inhallable, de Leopoldo Lugones, La cooperativa de los Diógenes, de Velia Malchiodi Piñero, Penélope ya no teje, de Malena Sandor, Penélope aguarda, de Rodolfo Modern y Jorgelina Loubet, y Partenopeo, de César Magrini.
} 
cuya acción se desarrolla en la llanura pampeana a comienzos del siglo XX, cuando se produce la ola inmigratoria hacia nuestro país.

\section{Las fuentes}

Rega Molina fusiona en su obra dos aspectos del mito de Polifemo: el de raíz homérica (Odisea, IX, 105-505), cuyo modelo teatral se da en el drama satírico El cíclope de Eurípides, y el que surge del género pastoril con Teócrito (Idilio XI) y se proyecta hasta la célebre Fábula de Polifemo y Galatea de Luis de Góngora y Argote. El primer aspecto se revela en el enfrentamiento entre Polifemo y Ulises; el segundo, en el frustrado idilio entre el cíclope y Galatea, la preferencia de la joven por Acis y la metamorfosis de este último en río.

\section{La trasposición}

Rega Molina construye un Polifemo hombre de campo, de vida sencilla, trabajador y amante de su tierra, aficionado a la música y el canto ${ }^{2}$. Ulises es una suerte de turista que viene "a tomar posesión de estas tierras" como primer paso para "civilizar" a Polifemo ${ }^{3}$. Esa civilización consiste en la puesta en marcha de la última tecnología aplicada al campo, previa delimitación de la propiedad: alambrados, maquinaria agrícola, elaboración de conservas de alimentos, entre otras cosas. Naturaleza y artificio frente a frente.

Mediante sus conexiones con el poder (el comisario, el escribano) el forastero le quita las tierras a Polifemo, seduce a Galatea y se casa con ella. Polifemo muere en el río, mientras trata de alcanzar la nave en la que huyen Ulises y Galatea. Ella finalmente da a luz un niño al que decide llamar Polifemo.

Mientras Ulises considera que Polifemo es "un niño grande, pastor y labriego, capaz de hachar un monte solo, de hacer, en fin, los trabajos de Hércules", el campesino afirma que la diferencia entre ellos no está en sus vidas sino en lo que cada uno quiere de la vida y piensa de la muerte. "Yo creo - dice Polifemo - que hay una gran diferencia entre la vida y la muerte, como lo han de creer el caballo y la vaca. Ninguna hormiga se afana, trabaja y ahorra y junta para mil años. Ulises es la hormiga que cree que nunca morirá."

Galatea - a quien Polifemo describe como "tan ligera que la hierba que ella pisa vuelve a enderezarse (...) corre como los arroyos (...) siempre se ata el pelo con un vivo de margaritas silvestres (...) y hallando agua clara se mira en ella, hace muecas, dice locuras y ríe" - dice de Polifemo que "si por él fuera, se

\footnotetext{
${ }^{2}$ Este elemento proviene de Teócrito; también lo incluye Marechal en el personaje del ciego Polifemo en Adán Buenosayres.

${ }^{3}$ Tradicionalmente Ulises es un hombre de muchos recursos (el epíteto homérico polytropos lo define); lo que varía, en las diversas reescrituras del mito, es la dimensión ética de esos recursos.
} 
cubriría con una piel de tigre. Le ha hecho la cruz a lo que hay más allá de sus tierras; y dentro de ellas bien poco que hay".

Y aquí vemos uno de los ejes temáticos de este enfrentamiento de culturas, y es el concepto de pobreza y riqueza que cada uno de los principales agonistas afirma. Dice Ulises: "El ABC del rico o del que llega a rico es tener idea de la pobreza. (...) Y tú no tienes ideas al respecto, es decir, no tienes ambiciones. (...) El mundo está hecho de tal manera que el que puede comprar una vaca de juguete es rico, comparado con el que tiene una vaca de verdad."

Hada - una mezcla de Nausicaa, Circe y Calipso del mito homérico - se dirige a los dos para trazar un retrato contrastante: "No te aflijas, Polifemo, no importa que Ulises te deje ciego y sin lazarillo. Tú eres hermoso, fuerte, bien plantado. Hueles a romero, a tomillo, a hierbas húmedas y no a lociones como Ulises. Desde aquí escucho la respiración de tu pecho, y es lenta y honda, como el ruido del mar. Y tú, Ulises, ¡tú haces el ruido de la bronquitis crónica!"

\section{Personajes, arquetipos y símbolos}

El autor ha incluido veintinueve personajes en su obra, de los cuales se puede hacer una clasificación acorde con la fuerza representativa de cada uno y con las características de su desenvolvimiento en el decurso de la acción.

Los tres personajes centrales pueden considerarse arquetípicos: Polifemo, el habitante de la pampa, con sus caracteres ya mencionados; Ulises, el forastero soberbio, ávido de quedarse con los bienes del campesino; Galatea, la joven inocente, amada y admirada por Polifemo, que cae presa de los ardides del extranjero.

En un segundo plano, los personajes que encarnan un símbolo. El Poeta, que recita la Biblia y parece conocer la historia de los personajes del drama. Ulises lo detesta y llama al comisario para que lo detenga. El Comisario es el símbolo del poder al servicio de los ricos. Cuando arresta al poeta le dice a Ulises: "Usté es muy güeno, pero yo le voy a quitar a ese sotreta las ganas de decir cosas que uno repite de güena fe y comprometen la autoridá”. Las personificaciones del río, la tierra y el viento son el símbolo de la naturaleza virgen - ámbito de Polifemo - opuesta al arsenal tecnológico que pretende imponer Ulises. En el río muere Polifemo y son la tierra y el viento los encargados de anunciar esa muerte.

Dos personajes tienen perfiles esotéricos o metafísicos: Cándida, con sus temores y presentimientos, que es algo así como la voz del pueblo y de la conciencia colectiva del mundo rural, y el linyera, en quien Galatea cree reconocer la imagen de Polifemo, un desconocido que parece tener conciencia de lo que ocurre, pero no lo revela. Aquella actúa como trasposición del coro trágico griego; el linyera, como un Tiresias parco y misterioso. 
Hacia el final de la obra Cándida entona una antífona sobre el nacimiento del hijo de Galatea en la que los personajes presentes en la escena actúan como coro ${ }^{4}$. Aquí hay un reflejo de cristianismo que se extiende y amplía hasta el final de la obra. Polifemo renace "en la tierra de su amor y su dolor", y como un Cristo gaucho "volverá sobre la tierra y bajará a la tierra y así por los días de los días y por los siglos de los siglos". Esa resurrección corresponderá siempre a una renovación de los valores tradicionales a través de las futuras generaciones.

\section{Símbolos del marco escénico}

Frente a la idea de una pampa sin límites, los elementos de medición y demarcación (teodolitos, alambrados, palos) adquieren carácter simbólico, de manera análoga a los certificados de propiedad de los que Polifemo carece y Ulises valora en grado sumo. El arma con la que Ulises mata al pájaro que anuncia la llegada de Galatea es un símbolo de la fuerza irracional y de la destrucción de la belleza y de los sentimientos mediante la violencia.

Las innovaciones que impone Ulises al hacerse dueño de las tierras de Polifemo conforman una violenta ruptura de costumbres que, hasta ese momento, encarnan símbolos de la vida del criollo de campo: corta los sauces porque traen moscas; prohíbe hacer compras en la pulpería; rechaza el modo de ordeñar de los peones; implanta el mate cocido porque le molesta el ruido del mate con bombilla; da por terminados los cuentos de aparecidos, los velorios con baile y la práctica de curanderismo; echa a los perros; saca del medio a los antiguos pobladores y toma peones gringos.

\section{Sentido alegórico de la obra}

En la fuente homérica, Ulises representa la civilización griega que acaba de vencer a los troyanos, y Polifemo la mostruosidad de lo desconocido a lo que hay que destruir o limitar. El vino es un medio para debilitar al cíclope y quebrarlo. En la fuente pastoril, la fealdad de Polifemo contrasta con la belleza de Galatea; pero el cíclope se manifiesta a través de una forma bella, la música y el canto, en tanto ella lo desdeña y prefiere a alguien que es bello y que finalmente se transforma en río.

La suma de arquetipos y símbolos y la fusión de las vertientes del mito configuran una alegoría de la invasión de determinados valores en una persona o en una sociedad "inocente", con el pretexto de mejorarla ${ }^{5}$. Esa invasión,

\footnotetext{
${ }_{4}$ Puede advertirse en este pasaje una huella del teatro de Federico García Lorca, particularmente de Yerma.

${ }^{5}$ El término "inocente" pertenece al filólogo Richard Moorton - "The Innocence of Italy in Vergil's Aeneid,” AJP 110 (1989) 105 ss. -, quien analiza el mito de Eneas y la guerra que su
} 
resistida al comienzo, termina por generar una identidad que no reniega de sus valores primitivos y acepta, de los nuevos, aquellos que no la deterioran. El hecho de que el hijo de Galatea y Ulises se llame Polifemo es un dato que sintetiza esta idea. Es ella la que confronta en el hijo los caracteres de uno y otro: “Míralo bien! ¡Pésalo en tus brazos! ¡Arrima tu cara a su rostro! ¡Tómale el aliento! ¡Y verás que es Polifemo; de su raza y de mi sangre; y a medida que crezca será más él y menos tú! Y te sobrevivirá con su amor a la tierra, con su simplicidad, con su pureza de labriego y de pastor".

Como en La gringa de Florencio Sánchez, en los sainetes de Armando Discépolo y en el Adán Buenosayres de Leopoldo Marechal, el hombre nuevo se plasmará con la fusión de sangres de diverso origen en un suelo cuya desmesura geográfica permite abrir caminos hacia el futuro, siempre que medie el amor en ese proceso.

\section{Palabras finales}

Quiero reflexionar brevemente sobre la invasión cultural que se cierne sobre nosotros en nuestros días y la supuesta inocencia de quienes la padecemos. Una invasión que, con pretextos tecnológicos y apelaciones hedonísticas mucho más zafadas que el tramposo vino de la Odisea, actúa sobre la memoria, exalta lo instantáneo (para desecharlo inmediatamente), reniega del pasado y lo desconoce, y plantea una suerte de futuro virtual tecnificado y consumista, en el que poco espacio ocupen la tradición, la discusión, el pensamiento y la voluntad.

En ese universo del olvido están ocultos nuestros poetas, nuestros pensadores, nuestros pintores y escultores, nuestros científicos, nuestro teatro, nuestra música. Y exagero con los posesivos porque, como el Polifemo de Rega Molina, somos dueños de esa cultura enorme y rica sin exhibir títulos de propiedad. No podemos comprender el presente sin conocer el pasado; no podemos planificar el futuro sin saber quíénes somos, qué sentimos, qué necesitamos, qué objetivos nos proponemos. Esperemos que los Ulises que diariamente llaman a nuestra puerta y se meten en nuestras casas no se lleven todo lo que legítimamente nos pertenece y que su accionar no esterilice la posibilidad de nacimiento de renovados Polifemos.

\footnotetext{
presencia genera en los pueblos del Lacio y alrededores (cantos VII a XII de la Eneida); para él, los pueblos itálicos se defienden de una invasión extranjera, son "inocentes" en la medida en que desean permanecer en su estado cultural y no permitir la intromisión de un grupo capitaneado por un troyano. Una tira de la famosa historieta "Olaf el vikingo" muestra a un monje que llama a la puerta de Olaf y le dice: "Vengo a traerte la civilización". Desde adentro Olaf responde: "Déjela en el umbral, que después yo la entro". Hay quienes ven en el mito de Santos Vega derrotado por Juan Sin Ropa un enfrentamiento entre la tradición local y la invasión que significa la inmigración masiva en la pampa criolla.
} 


\section{Bibliografía}

Blanco Amores de Pagella, Ángela, Motivaciones del teatro argentino en el siglo XX, Buenos Aires, Ediciones Culturales Argentinas, 1983.

Bravo de Laguna Romero, Francisco, "La pervivencia de las heroínas griegas en el teatro argentino contemporáneo", Myrtia, 14, 1999, pp. 201-218.

Cotello, Beatriz, “La mitología clásica en la ópera argentina”, Circe 8, 2003, pp. 123-142.

Fraschini, Alfredo, "Tratamiento humorístico de dos temas griegos en el teatro argentino", En Boletin del Instituto de Teatro de la Facultad de Filosofia y Letras de la U.B.A. 4, 1984, pp. 7- 15.

Rega Molina, Horacio, Polifemo o las peras del olmo, Buenos Aires, Editorial Poseidón, Colección Pandora, 1945.

Seibel, Beatriz, Historia del teatro argentino, Buenos Aires, Corregidor, 2010. 


\section{ACERCA De los imaginarios TRÁGicos DE ALTERIDAd Y SU PERVIVENCIA EN EL TEATRO ARGENTINO ACTUAL: Antígona(s) y MedeA(s)}

Lidia Gambon

Universidad Nacional del Sur

Difícil comenzar un trabajo referido a la alteridad y su presencia en el imaginario dramático de la antigüedad griega sin hacer referencia al conocido pasaje de Diógenes Laercio (Vit. Phil. 1.33.10-34.4) ${ }^{1}$ que atribuye a los filósofos -Sócrates o Tales- aquella antitética división tripartita sobre la que habría de cimentarse la identidad del hombre heleno. Hombre/bestia, varón/mujer, griego/bárbaro definen, entre otros, un sistema organizado de diferencias, conforman los lugares de oposiciones sustanciales a través de las que, para el orden cultural griego, se configura su imaginario, según podían señalarlo sus propios pensadores y según se mostró y demostró, asimismo, en la construcción y representación de esta alteridad en el drama ático ${ }^{2}$.

En efecto, la noción de 'imaginario', que permite -como ha sido señalado ${ }^{3}$ poner el acento en la complejidad y diversidad de las sociedades, aplicada a la antigüedad griega deja ver fundamentalmente el lugar significativo que ocupa su teatro. Así lo advertía P. Vidal-Naquet (1997), exponente conspicuo de la escuela antropológica francesa, al definir en esencia a la tragedia antigua como una reflexión sobre el "Otro". Y es que la tragedia griega fue en buena medida el género que "inventó" a los "Otros", la creación simbólica que dio vida a esa alteridad marginal y temida, tan susceptible a la desviación de la norma, considerada digna de censura, control o rechazo, aunque imposible de ignorar, en la medida en que le permitía a la polis reflexionar e interrogarse a sí misma. Género "unddeniably androcentric” (Foley, 2001: 12), la tragedia dio sobre todo cuerpo y voz en sus personajes a lo "Otro" femenino. Y a la par que afirmó en la representación del mito la concomitancia de los imaginarios de alteridad, expuso, a través del carácter multifacético de sus personajes, la complejidad de sus variadas facetas. Acaso ningún ejemplo resulte en este

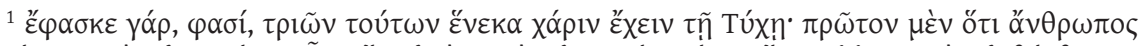

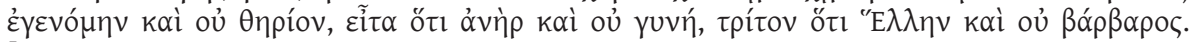
[«Decía, dicen, que daba gracias a la fortuna por estas tres razones:' primero porque nací hombre y no bestia, luego porque soy varón y no mujer, en tercer lugar porque soy heleno y no bárbaro'»].

${ }^{2}$ P. Cartledge añade otros dos pares más, además de los que se señalan aquí, estableciendo así cinco dicotomías en las que se funda la identidad del hombre heleno (griego/bárbaro, hombre/ mujer, ciudadano/extranjero, hombre libre/esclavo, dioses/mortales). Cfr. Cartledge (1993).

${ }^{3}$ Cfr. Le Goff, citado por Escobar Villegas (2000: 114-115).
} 
sentido más emblemático que el de la misma Medea, esposa extranjera, mujer bárbara y hechicera poderosa, a la que Eurípides invistió de rasgos paradójicos al hacerla portavoz de la problemática matrimonial y la experiencia femenina de la esposa como el "Otro" en la Grecia antigua.

El teatro clásico creó así personajes de una gran profundidad y de inmensa trascendencia y pervivencia en la literatura posterior, personajes de un vasto legado interpretativo y mimético que, como podrá concluirse de nuestras referencias, muestran una importante trayectoria en la dramaturgia argentina, en especial a partir de la segunda mitad del s. XX. Tal es el caso de Antígona y Medea, figuras de una incidencia comparativamente mayor en relación a otras de la mitología griega, cuya proyección en el teatro nacional de las últimas décadas pone de relieve asimismo su vigencia como expresión de la alteridad ${ }^{4}$.

Ciertamente el nuevo escenario americano, definido en buena medida por las fronteras geográficas de la conquista "civilizadora", por un borde territorial configurado en el antagonismo de civilización y barbarie, puso al descubierto formas ignoradas de alteridad, como la de ese "Otro" preexistente, el indio, protagonista de varias de las nuevas versiones míticas latinoamericanas (e.g. Antigona Vélez, Medea mapuche). Un rasgo común a las reescrituras de nuestro continente, como se ha reconocido, es la resistencia de los personajes dramáticos a compartir el universo homodiegético de sus predecesores clásicos ${ }^{5}$. En el caso de las Antígonas y Medeas nacionales del último medio siglo, y más allá de una alteridad que se corresponde con las nuevas coordenadas espacio-temporales, es posible destacar la vinculación con aquella otredad que le viene determinada por su género. Concebidas en un escenario patriarcal predominante, nacidas en el contexto histórico de las luchas y conquistas de las mujeres en el terreno político y social de la Argentina de las últimas décadas, estas nuevas Antígonas y Medeas se constituyen desde su propia especificidad cultural asimismo en testimonio de la voz del "Otro".

Ciñéndonos a los límites de este trabajo, y basándonos en buena medida en los datos de investigaciones previas, comenzaremos por puntualizar, los resultados del relevamiento de la presencia de estas dos figuras en nuestro teatro nacional en el período del último medio siglo ${ }^{6}$. Referiremos, luego, a la

\footnotetext{
${ }^{4}$ Que Antígona y Medea se cuentan entre las figuras que más han seducido a los dramaturgos contemporáneos lo prueba no solo su vasto legado mimético, sino el hecho de que son varios los casos en que un mismo autor se atrevió a incursionar en nuevas versiones de ambas figuras. Tal es el caso de J. Anouilh con sus Antígona (1942) y Medea (1946); José Bergamín Medea, la encantadora (1954) y La sangre de Antígona (1955), y en el caso de un autor argentino, D. Cureses con La Frontera (1964) y La cabeza en la jaula (1987).

${ }^{5}$ Cr. Miranda Cancela (2002); Pianacci (2008).

${ }^{6}$ En el siglo XX, especialmente a partir de la década del 50, se producen nuevas versiones teatrales de tragedias griegas. Antígona Vélez de Leopoldo Marechal, Electra (1964) de Julio
} 
Acerca de los imaginarios trágicos de alteridad y su pervivencia en el teatro argentino actual

resemantización de la alteridad en dos obras que representan una de las más nuevas versiones de Antígona y de Medea que ofrece nuestro teatro nacional: Antigonas, linaje de hembras (2001) de Jorge Huertas y Medea de Moquehua (1992) de Luis M. Salvaneschi.

Sobre el mito de Antígona en particular, y su lugar en el teatro latinoamericano de posguerra, contamos con el reciente trabajo de Rómulo E. Pianacci ${ }^{7}$. Una veintena de Antígonas criollas constituyen el corpus de análisis de este estudio, acotado a las piezas producidas entre 1952 y 2007, el momento histórico de un continente "plagado de Creontes" y de un teatro signado, entonces, por una fuerte connotación ideológica, política y social ${ }^{8}$. Entre las Antígonas argentinas se mencionan':

Antígona Vélez (195210) de Leopoldo Marechal, obra en seis cuadros ambientada en el período argentino de la conquista del desierto.

El limite (1958) de Alberto de Zabalía, tragedia en dos actos ambientada en el s. XIX, durante el gobierno de Juan Manuel de Rosas.

Imbert, El Reñidero (1966) de Sergio De Cecco, Medea (1967) de Héctor Schujman, y las restantes versiones que puntualizaremos en este trabajo son algunos de los ejemplos. Para el relevamiento que nos proponemos aquí nos hemos basado en los aportes de investigaciones previas: Pianacci (2008); Bañuls Oller \& Crespo Alcalá (2008); López \& Pociña (2010); Zayas de Lima (2010). Ellas no hacen sino confrontarnos con las dificultades de una investigación de esta índole, basada en fuentes que con frecuencia permanecen inéditas.

${ }^{7}$ Cfr. Pianacci (2008). Además del estudio de Pianacci, deben mencionarse para las Antígonas latinoamericanas la investigación de José Vicente Bañuls y Patricia Crespo de la Universidad de Valencia, que pasan revista a más de doscientas recreaciones del mito de Antígona, entre ellas las Antígonas que Pianacci focaliza en su estudio, y el artículo de los profesores A. López y A. Pociña (2010), que recoge, además, la bibliografía referida a las versiones latinoamericanas del mito.

${ }^{8}$ Cfr. Pianacci (2008: 76). El autor analiza una veintena de Antígonas latinoamericanas: Brasil: Pedreira das almas (1979) de Jorge Andrade; Chile: Antígona, historia de objetos perdidos (2002) de Daniela Cápona Pérez; Colombia: Antígona y Actriz (2004) de Carlos Eduardo Satizábal; Cuba: Antígona (1993) de Joel Saéz; México: La joven Antígona se va a la guerra (1968) de José Fuentes Marel, Los motivos de Antígona (2000) de Ricardo Andrade Jardí y La ley de Creón (2001) de Olga Harmony; Nicaragua: Antígona en el infierno (1958) de Rolando Steiner; Perú: Antígona (1964) de Sarina Helfgott y Antígona (2000) de José Watanabe; Puerto Rico: La pasión según Antigona Pérez (1968) de Luis R. Sánchez; República Dominicana: Antígona-Humor (1968) de Franklin Domínguez y Hernández; Venezuela: La fiesta de los moribundos (1966) de César Rengifo y Antígona (1978) de José Gabriel Núñez. Además, el estudio de Pianacci menciona en la introducción otras seis piezas colombianas y una venezolana estrenadas en el Festival Magdalena Antígona en el encuentro "Mujeres, Arte y Parte en la Paz de Colombia” (Bogotá, 2006). López \& Pociña (2010) citan otra Antígona cubana: Detrás queda el polvo (1968) de José Triana.

${ }^{9}$ Las obras que aquí se mencionan han sido citadas por su año de publicación, en muchos de los casos, como se verá, sustancialmente alejado del año de su estreno teatral.

${ }^{10}$ Recientemente la obra volvió a presentarse en el mismo teatro Cervantes cuya temporada inaugurara en 1951. La dirección estuvo entonces a cargo de Enrique Santos Discépolo, y Nancy Navarro actuó en el papel de Antígona. 
La cabeza en la jaula (198711) de David Cureses, tragedia en tres actos ambientada en la villa de Guaduas (Colombia), a comienzos del s. XIX.

Antígona furiosa (1986) de Griselda Gambaro, Antígona atemporal que cuenta su historia en el tiempo de la Argentina de la última dictadura.

Golpes a mi puerta $\left(1988^{12}\right)$ de Juan Carlos Gené, pieza en tres actos ambientada en un lugar indeterminado de Latinoamérica.

Antígonas, linaje de hembras (2001) de Jorge Huertas, que contextualiza la historia de Antígona en una Buenos Aires contemporánea, en un tiempo impreciso posterior a la crisis económica de 2001.

Antígona... con amor $\left(2003^{13}\right)$ de Hebe Campanella, obra breve enmarcada en la Argentina de los años previos al advenimiento de la dictadura (1973-76). Antígona, ;No! (2003) de Yamila Grande (inédita) ${ }^{14}$.

Sobre Medea y su presencia en el teatro latinoamericano, en cambio, no contamos con un estudio sistemático, aunque debemos mencionar aquí aquellos que recogen, aunque solo sea de modo parcial, su presencia en distintos países de nuestro continente ${ }^{15}$. Específicamente sobre las Medeas argentinas, en un reciente artículo de Perla Zayas de Lima se referencian un número importante de versiones, muchas de ellas obras desconocidas de teatristas locales, que permanecen inéditas o han alcanzado una escasa difusión ${ }^{16}$ :

${ }^{11}$ La obra se estrenó con dirección del propio Cureses en el Teatro El Gorro Escarlata (T.E.G.E) el 12 de julio de 1963, y fue reestrenada posteriormente en el Teatro Candilejas de Rauch con la misma dirección el 26 de octubre de 1985. La edición de la obra es, sin embargo, posterior. Fue el mismo grupo de teatro El Gorro Escarlata el que la editó en 1987, con prefacio del escritor argentino Manuel Mujica Láinez.

${ }^{12}$ La obra fue estrenada en Caracas (Venezuela) el 11 de julio de 1984 por el Grupo Actoral 80 (GA 80), que fue el mismo que la representó, un año después, en el Teatro Municipal General San Martín de Buenos Aires. La primera publicación de Torres Agüero Editor fue corregida en una segunda edición de Ediciones de la Flor (1994), que es la que hemos consultado.

${ }^{13}$ La obra, que mereció una mención en el premio EDENOR, fue estrenada y publicada el mismo año en Teatro breve $x 5$ (Buenos Aires).

${ }^{14}$ Perla Zayas de Lima (2010: 7) menciona también Antígona la necia (2001) de Valeria Folini, espectáculo unipersonal, adaptación de la tragedia sofóclea.

${ }^{15} \mathrm{E}$. Miranda Cancela hace referencia a ocho versiones dramáticas latinoamericanas de la segunda mitad del s. XX: La selva, de Juan Ríos (Perú, 1950); Malintzin (Medea americana), de Jesús Sotelo Inclán (México, 1957); Medea en el espejo, de José Triana (Cuba, 1960); Além do Rio (Medea), de Agostinho Olavo (Brasil, 1961); Gota d'Agua, de Chico Buarque y Paulo Pontes (Brasil, 1975); Medea de Moquegua, de Luis María Salvaneschi (Argentina, 1992); El castillo interior de Medea Camuñas, de Pedro Santaliz (Puerto Rico, 1984); Medea de Reinaldo Montero (Cuba, 1997). A ellas deben añadirse las versiones argentinas, citadas por Perla Zayas de Lima (2010) y las latinoamericanas que referencia L. Campuzano (2007): Des-Medea, de Denise Stoklos (Brasil, 1994); Medea mapuche, de Juan Radrigán (Chile, 2000); Medea llama por cobrar, de Peky Andino (Ecuador, 2001). Cfr. Miranda Cancela (2002); Campuzano (2007).

${ }^{16} \mathrm{Cfr}$. Zayas de Lima (2010). La reiterada presencia de la figura de Medea en la dramaturgia nacional desde los noventa y su preferencia frente a la de Antígona llevan a la autora a concluir que ella se inspira en un tiempo histórico y social que, como el de Eurípides, se muestra escindido y contradictorio, un tiempo en que vivimos "inmersos en una realidad exenta de ilusiones, en una 
La Frontera (1964) de David Cureses.

Medea (1967) de Héctor Schujman, ambientada en Argentina, en la época actual.

La Navarro (198017) de Alberto Drago, "tragedia latinoamericana" en cinco cuadros, cuya acción se sitúa en Luján en la década del 20.

Ignea Medeas $\left(1985^{18}\right)$ de Juan Jerónimo Brignone (inédita).

Medea, paisaje de hembras (198719), creación colectiva de Máximo Salas, Laura Beltramo y Silvina Fernández Farel (inédita).

Despojos para Medea (1992) de José Luis Valenzuela.

Medea de Moquehua ${ }^{20}$ (1992) de Luis M. Salvaneschi, obra en dos actos cuya acción se ubica en la Buenos Aires contemporánea.

La Hechicera $\left(1997^{21}\right)$ de José Luis Alves, obra en 7 cuadros que sitúa la historia de Medea en el Tucumán del período colonial.

Medea del Paraná (2004) de Suellen Worstell de Dornbrooks (inédita).

Medea Fragmentada (2006) de Clodet y María Barjacoba (inédita).

De entre las Antígonas nacionales, y en relación con el tema que nos ocupa, destaca la versión de Huertas, Antígonas, linaje de hembras, representada por primera vez en Grecia en agosto de 2001 y estrenada finalmente en Argentina en septiembre de $2002^{22}$. La pieza, una versión poética y aporteñada, notoria por su brevedad y por el sincretismo de sus componentes dramáticos, se articula en torno a las escenas sustanciales del drama sofócleo (el encuentro entre Antígona e Ismena, el anuncio de Creonte de la prohibición de sepultura de Polinices, el descubrimiento del guardián de la acción transgresora de Antígona, los enfrentamientos sucesivos de Creonte con Antígona, Hemón y Tiresias, el lamento de despedida de la condenada hija de Edipo). Estas escenas son resignificadas a partir de un nuevo universo diegético (la contextualización de la acción en una Buenos Aires del siglo XXI en la que se entrecruzan de modo

ciudad en la que no hay ley ni justicia, ni orden, que no puede ya albergar Antígonas piadosas y sacrificadas, sino Medeas que dan curso libra a la ira, a la venganza y a la barbarie, conscientes de que todo crimen puede quedar impune" (p. 21).

${ }^{17}$ Texto disponible en http://www.autores.org.ar/adrago/obras.htm.

${ }^{18} \mathrm{La}$ obra fue escrita y dirigida por su autor bajo el pseudónimo de Iánnis Zómbolas.

${ }^{19}$ Versión libre de la tragedia de Eurípides, dirigida por J. Suárez y Q. Canellas, calificada como "teatro de transgresión". Participó de la Bienal de Arte Joven en Ciudad de Buenos Aires (1988) y del Festival de Teatro de Pelotas (1988).

${ }^{20}$ La obra ha sido indistintamente citada como Medea de Moquegua o Medea de Moquehua, en referencia a Moquehuá, nombre del pequeño poblado del partido de Chivilcoy del que proviene Medea. Como Las Marianas, otro poblado igualmente mencionada en la obra de Salvaneschi, se trata de parajes rurales surgidos al amparo del ferrocarril.

${ }^{21}$ La obra fue editada por Emcor en 1997.

${ }^{22}$ La obra se estrenó en 2002 en el Teatro Argentino de La Plata, bajo la codirección de Roberto Aguirre; en noviembre del mismo año se presenta en el Auditórium Jorge Luis Borges de la Biblioteca Nacional de Buenos Aires. 
permanente las referencias al pasado y al futuro del país), y de la incorporación de personajes identitarios: el Río (un Río de La Plata contaminado por los muertos desaparecidos durante la última dictadura militar), el Bandoneón (instrumento emblemático de la música porteña), la Embalsamada Peregrina (personaje que encarna la figura de una mítica Eva Perón, un alter ego de Antígona y un espejo de la ultrajada condición de Polinices) y un nuevo Tiresias (el fantasma de J. L. Borges). La obra mantiene una clara relación intertextual con la tragedia de Sófocles en los 19 breves fragmentos escénicos que la componen, mostrándose a un modo esencialmente fiel y ostensivamente transgresora con respecto a su hipotexto. Acaso uno de los puntos sustanciales de esta fidelidad radica precisamente en el modo en que el protagonismo femenino en la pieza se relaciona con los imaginarios de alteridad.

Ya la pluralidad del nombre "Antígonas" y la extraña mezcla de admiración e insulto que encierra la expresión "linaje de hembras" en el título de la pieza remiten a un conflicto genérico inmanente al mito, que reactualizaba el teatro trágico en su representación del "Otro". Dicho conflicto se reafirma en la versión de Huertas no solo mediante la incorporación de nuevos personajes (tal es el caso del controversial personaje de la Embalsamada Peregrina, que permite repasar el papel de la mujer en la historia sociopolítica argentina del último medio siglo), sino mediante el modo en que el dramaturgo resuelve personajes tradicionales del drama como el personaje colectivo del coro, al que le otorga una función central en su pieza. Se trata en Antigonas de un coro de mujeres, no de ancianos tebanos como en la tragedia sofóclea; ellas alzan su voz frente al abuso masculino, en un mundo en que la lucha femenina se plantea como la lucha de la/s Antígona/s-hembras enfrentadas al poder del "macho"- Creonte. La(s) Antígona(s) de Huertas encarna(n), pues, la raza genérica, esa raza de mujeres que, como la hija de Edipo, se rebelan y claman por sus derechos en una sociedad de hombres en la que son asimiladas recurrentemente a lo marginal:

Coro: Nosotras Antígonas

Las novias de la mugre

del hedor madres.

Las manchadas, las sucias,

las bárbaras.

Yo sé cómo se llama mi herida:

Hembras

Yeguas

Brujas

Locas

Putas.

Siempre Antígonas. 
Las de fatales y porteños padres

hermanas de hermanos

que se vacían de sangre ("Adiós, Antígona”, 62).

De nuestras Medeas, la obra Medea de Moquehua del dramaturgo y poeta Luis María Salvaneschi ${ }^{23}$ recupera también los imaginarios de alteridad en el marco de la contextualización del drama en una Buenos Aires contemporánea. Como la versión de Huertas, la de Salvaneschi tiene una notoria relación con su hipotexto, que se pone de relieve en la fidelidad al orden de secuencias de la tragedia euripidea. ${ }^{24}$ En relación con los personajes, sin embargo, solo la pareja de protagonistas - Medea y Jasón-conservan sus nombres. Creonte es en cambio "el dueño del hotel", un albergue de baja categoría que ha logrado mantener gracias a la colaboración de un Jasón cuyos servicios paga con el matrimonio de su hija. Dos viejos innominados (un jubilado que oficia de sereno y una sirvienta que acompaña a su señora en sus reiterados exilios criminales) asumen con un protagonismo más sostenido el rol de los esclavos anónimos del drama euripideo, trasladados por Salvaneschi a un espacio citadino que domina el poder del dinero.

El nuevo universo diegético de esta Medea desnuda con crudeza la imagen del exilio y marginalidad de la protagonista. Medea, oriunda de Moquehuá (un pequeño e ignoto pueblo de provincia), ha cambiado en la versión de Salvaneschi sus dotes de hechicera por las cartas del Tarot, pero en las "paredes de cartón, vergüenza y suspiros" de la ciudad en que ahora habita, allí "donde nada es privado” (p. 11), la inunda idéntica añoranza por su hogar natal como a su homónima euripidea. La otredad de esta Medea, más que nacer de su condición de mujer/esposa (una mujer unida a su hombre sin "papel legal", p. 23), descubre aspectos de la historia social de nuestro país. Otredad hiperbólica, como en la tragedia, que nace aquí de lo femenino en el cruce con una "triple marginación, la que sufre un pueblo de provincia respecto de la capital, la de las clases bajas respecto de las pudientes, y la dependencia de un país periférico en su relación con una cultura central" (Zayas de Lima, 2010: 16).

Las versiones que reseñamos de Antígona y Medea comparten entre otros rasgos las discordancias estilísticas que surgen de la imbricación en el texto de variados registros lingüísticos y musicales, lo que contribuye a remarcar

${ }^{23}$ Luis María Salvaneschi, nacido en Olivos (provincia de Buenos Aires), estrenó varias obras teatrales de su propia autoría o coautoría ("Vida y Risas del siglo XV", 1960; "Un, Dos, Tres", 1963; "El agua de todos los ríos", 1980; “Tiempo de fantasía”, 1982; "Segunda Familia”, 1984; "Una historia en cortocircuito", 1989), entre las cuales no se cuenta, por cierto, la pieza que es objeto de nuestro análisis, editada -aunque no estrenada- en el año 1992, en una edición por cierto limitada, que dificulta notoriamente el acceso al texto.

${ }^{24}$ Notable es, por ejemplo, la reelaboración de la escena prologal. 
asimismo la otredad de las protagonistas. Destacamos también el rol que en tal sentido desempeña el coro. ${ }^{25}$ Aunque se trata de dos coros de características notoriamente diferentes (un coro de mujeres no individualizados, en el caso de la Antígonas de Huertas, y un coro de murgueros individualizados, en la Medea de Salvaneschi), ambas versiones incorporan esta voz colectiva como expresión de lo marginal ${ }^{26}$.

Las limitaciones de nuestra investigación nos impiden aquí aventurar conclusiones como la que llevan a Perla Zayas de Lima (2010) a afirmar, en torno a la presencia de estas figuras míticas femeninas en la dramaturgia nacional, que el nuestro es más bien un tiempo de Medeas bárbaras y vengativas, no de Antígonas piadosas y sacrificadas. Demostrada la vigencia sostenida de ambas figuras, creemos que las referencias y los ejemplos escogidos permiten al menos plantear dos cuestiones importantes que señalaremos a modo de cierre: 1) Algunas figuras míticas han cobrado renovado interés y despertado nuevas lecturas en el teatro nacional de la última parte del siglo XX, "a partir del descubrimiento del otro en medio del complejo acontecer contemporáneo" (Miranda Cancela, 2002: 71); 2) el modo en que el referente clásico sigue aportando su carga simbólica, y la forma en que explica o se explica en nuestra historia sigue siendo hoy una deuda pendiente para un teatro en gran medida desconocido. El relevamiento exhaustivo de las obras contemporáneas que de forma explícita se basan n mitos clásicos aún resta por hacerse. Lo expuesto pretende ser una primera contribución.

${ }^{25}$ En un reciente ensayo, H. Foley (2007) concluía que las adaptaciones y representaciones más contemporáneas de la tragedia testimonian la revalorización de la voz colectiva del coro, más allá de las complejidades que plantea su inclusión en una obra.

${ }^{26}$ Jorge Huertas opta por un coro unívocamente femenino, Luis M. Salvaneschi, en cambio, por un coro de voces mixtas identificadas: el señor y la señora del bombo, el director de la murga, un travesti, la reina de la murga y el Tony. Estas voces se caracterizan por una desacralización ostensiva del lenguaje, manifiesta en el uso de registros lunfardos (en el caso de Huertas), y en ocasiones acompañado de gestos procaces (en el caso de Salvaneschi). 


\section{Bibliografía}

Alonso, L. (2010), “¿Qué será se la reina del Plata?’: Hybris, castigo y enigma en Antigonas: linaje de hembras de J. Huertas", en G. Fabry, I. Logie \& P. Decock (eds.), Los imaginarios apocalipticos en la literatura hispanoamericana contemporánea, Bern, pp. 313-326.

Bañuls Oller,J. V. - Crespo Alcalá, P. (2006), “Antígona, la génesis de un mito”, en J. V. Bañuls Oller, F. De Martino \& C. Morenilla Talens (eds.), El teatro clásico en el marco de la cultura griega y su pervivencia en la cultura occidental. El teatro greco-latino y su recepción en la tradición occidental, Bari, 15-58.

(2008), Antígona(s) mito y personaje. Un recorrido desde los orígenes, Bari.

Campuzano, L. (2007), "Medea en el metro de Nueva York", en J. V. Bañuls Oller - F. De Martino \& C. Morenilla Talens (eds.), El teatro grecolatino y su recepción en la tradición occidental. 2, Bari.

Cartledge, P. (1993), The Greeks. A Portrait of Self and Others, Oxford (rev. edn. 2002).

Escobar Villegas, J. C. (2000) Lo imaginario. Entre las ciencias sociales y la bistoria, Medellín.

Foley, H. (2001), Female Acts in Greek Tragedy, Princeton.

(2007), "Envisioning the Tragic Chorus on the Modern Stage", en C. Kraus, S. Goldhill, H. Foley \& J. Elsner (eds.) Visualizing the Tragic. Drama, Myth and Ritual in Greek Art and Literature, Oxford, pp. 353378.

López, A. - Pociña, A. eds. (2001), Medeas. Versiones de un mito desde Grecia hasta hoy, 2 vols., Granada.

(2009), En recuerdo de Beatriz Rabaza. Comedias, Tragedias y Leyendas Grecorromanas en el Teatro del s. XX, Granada.

- (2010), "La eterna pervivencia de Antígona”, FlorIlib 21, 345-370.

Martindale, Ch. (2007), "Reception”, en C. W. Kallendorf (ed.), A Companion to the Classical Tradition, Singapore; pp. 297-312.

Miranda Cancela, E. (2002), "Medea: otredad y subversión en el teatro latinoamericano contemporáneo", en C. Morenilla Talens \& F. De Martino (eds.), El Perfil de les ombres: el teatre clàssic al marc de la cultura grega i la seua pervivencia dins la cultura occidental, Bari; pp. 317-321.

Pianacci, R. E. (2008), Antigona: una tragedia latinoamericana, Irvine, CA.

Vernant, J-P. - Vidal-Naquet, P. (1972), Mito y tragedia en la Grecia antigua I, Madrid. 
Lidia Gambon

Zayas de Lima, P. (2010), "Mitos griegos en el discurso teatral argentino", Telondefondo 11, <http//:www.telondefondo.org >. 


\title{
REFACCión DE Mitos CLÁSICOS EN EL TEATRO GALLEGo CONTEMPORÁNEO
}

\author{
María Pilar García Negro \\ Universidad de A Coruña
}

\begin{abstract}
Estudiaremos el impacto de varios mitos clásicos de amplio trayecto histórico en el teatro gallego contemporáneo. En concreto, en cuatro obras que se corresponden con autores y autoras de otras tantas generaciones consecutivas de la literatura gallega de nuestros días. Son ellas: Edipo, de Manuel María; Antígona, a forza do sangue, de María Xosé Queizán; Nausícaa, de Millán Picouto; Cínicas, de Teresa Moure. Siendo todos ellos artífices bien singulares de la literatura gallega contemporánea, es llamativa una común orientación en estas obras: la refacción de personajes pro domo nostra, esto es, en claves comprensibles desde y para la historia de Galicia.
\end{abstract}

\section{Introito}

Estudiaremos el impacto de varios mitos clásicos de amplio trayecto histórico en el teatro gallego contemporáneo. En concreto, en cuatro obras que se corresponden con autores y autoras de otras tantas generaciones consecutivas de la literatura gallega de nuestros días. Son ellas: Edipo, de Manuel María (1929-2004); Antígona, a forza do sangue, de María Xosé Queizán (1939-); Nausicaa, de Millán Picouto (1949-); Cinicas, de Teresa Moure (1966-). Siendo todos ellos artífices bien singulares de la literatura gallega contemporánea, es llamativa una común orientación en estas obras: la refacción de personajes pro domo nostra, esto es, en claves comprensibles desde y para la historia de Galicia. De la primera de las citadas, es preciso marcar la distancia cronológica que media entre su escritura (1960) y su publicación (2003), así como su vinculación con un concurso literario patrocinado por el Centro Gallego de Buenos Aires. El Edipo manuelmariano -según propia confesión- resulta ser la estampa de un anti-Franco, el dictador que se padecía a la sazón.

Las obras de teatro debidas a la pluma de las escritoras mencionadas realizan propositalmente una lectura feminista, de Antígona, en el primer caso, y de un Diógenes convertido en mujer, en el segundo caso. El autor de Nausícaa es, quizá, quien más se aproxima al dibujo del personaje clásico. Se juega, igualmente, con las fronteras espacio-temporales. Así, la Antígona de María Xosé Queizán se desarrolla en la Edad Media gallega; Cínicas, de Teresa Moure, desafía la linealidad temporal y mezcla diferentes perspectivas cronológicas. Es "teatro líquido", en palabras de su autora. Los personajes se enfrentan a la historia y a su propia biografía. 
En los dos escritores tratados es patente su simultánea condición de poetas. De hecho, Nausicaa está escrita en verso y Edipo incluye fragmentos poéticos.

Constituyen, pues, estas cuatro obras un buen panel representativo del arte dramático gallego contemporáneo, siempre en diálogo con una realidad histórico-social tan marcante de la literatura gallega, desde el ejemplo insuperable de su fundadora moderna, Rosalía de Castro.

\section{Edipo (2003 [1960]), de MANUEL MARÍA}

El primer dato llamativo del Edipo manuelmariano es la distancia enorme que media entre la escritura y la publicación de esta obra: 1960 / 2003. Este autor es el más prolífico de la literatura gallega contemporánea y su obra conoce todos los géneros: poesía, narrativa, teatro, ensayo..., además de haber sido un eficiente propagandista, en Galicia y fuera de ella, de la literatura gallega clásica y moderna. En el prólogo de la obra editada, recuerda el autor como la escribió en tres tardes del mes de noviembre de 1960, para ser enviada a un concurso literario patrocinado por el "Centro Gallego" de Buenos Aires y con la intención clara de obtener un plus económico para completar los modestos ingresos de procurador de los tribunales, profesión que no le agradaba en absoluto. La obra se afilia claramente a una moda reinante en literaturas europeas en el ecuador del siglo $\mathrm{XX}$, donde resultaba eficaz la utilización de mitos clásicos para metaforizar el drama bélico o postbélico. En la obra del escritor gallego, tal utilización está al servicio de un discurso ideológico-estético que la censura del régimen dictatorial no permitiría jamás expresado en sus términos denotativos. Es el propio escritor el que confiesa, en efecto, que con su Edipo trató de crear un personaje que resultara ser un anti-Franco, "el tirano cruel y omnipotente que estábamos padeciendo. Un Edipo que fuese, más que un rey o un juguete del Destino y de la Fatalidad, un hombre bueno, generoso, inconmovible en sus principios éticos: el jefe humanísimo que jamás traiciona o traicionará a su gente, cumplidor de su deber hasta las últimas consecuencias, dispuesto a sacrificar la vida por sus ideales si tal fuera necesario"1 (Manuel María, 2003: 12).

Ahora bien, la gran novedad del tratamiento del mito edipiano reside en la figura de su hija, Antígona, acompañante fiel del rey convertido por Creonte en mendigo ciego, andador de mil caminos e irreductible en su digna oposición al tirano. Confiesa Manuel María que la Antígona que ideó se basa en el prototipo de la mujer fuerte, valiente, hija ejemplar y heroica,

\footnotetext{
${ }^{1}$ La traducción del gallego original al español, en esta obra como en las demás, es de nuestra responsabilidad. Téngase en cuenta que los calificativos "bueno y generoso" se refieren al original "bos e xenerosos" de la letra del Himno Gallego, cuyas letra y música se deben a Eduardo Pondal y a Pascual Veiga respectivamente.
} 
trasunto de tantas gallegas madres, esposas, hijas de emigrantes, responsables monoparentales... que "tan insuperable y esforzado cometido desempeñaron a lo largo de toda la historia de nuestro pueblo" (ibidem). A pesar de que la obra se publica en el régimen de monarquía parlamentaria vigente desde 1975, el autor considera que expedientes fundamentales abiertos por su Edipo seguían vivos en el incipiente siglo XXI: la normalización de la lengua gallega, de su literatura, de la vida soberana del pueblo gallego.

Si toda refacción de un clásico supone metaliteratura, en este caso este carácter es especialmente elocuente, pues será el "Narrador", en parlamento inicial, y el propio Edipo los que reconozcan que está viejo, cansado y fatigado de repetir su tragedia por los escenarios. La laudatio del personaje, tanto en su condición de rey como de ciego mendigo caminante, o ya muerto, corre a cargo del Coro que lo enaltece. Una vez expulsado por "impuro" del reino de Tebas, comienza su peregrinación, siempre acompañado por Antígona. En este su caminar sin tregua, uno y otro no ceden nunca a las pretensiones de asimilación que mensajeros de Creonte y el propio tirano les proponen. E1 camino será así metáfora del reinado verdadero: la dignidad, la libertad, la lealtad a su propia conciencia.

Este Edipo es personaje netamente existencialista ("una vaga sombra atormentada” [Manuel María, 2003: 87]) que utiliza el diálogo con su hija como catarsis posible para su angustia vital, pero Antígona refuerza siempre su condición inmortal, que pervivirá más allá de la vida física. Antígona se niega a casarse o a tener hijos, porque no renuncia por nada a su libertad y, además, porque "Un hombre es siempre un tirano que manda a su mujer poco menos que a un esclavo" (ibidem: 101). La lucha imposible de Edipo continuará, pues, en Antígona, que agregó a su amor filial otro componente fundamental: el aprendizaje que le ha dado la vida misma (el camino), la ruptura de la reclusión obligada como esposa dependiente. Edipo y Antígona, en fin, triunfan, pues no secundan los designios del tirano, víctima de la misma utilización maléfica del oráculo en virtud del cual condenó al destierro al rey Edipo. Ambos tendrán, en la historia futura, una fértil descendencia simbólico-literaria, el sello de su inmortalidad, mientras Creonte se asimilará al poder totalitario que nada puede contra la vida de las ideas, la palabra y la memoria.

\section{Antigona, a forza do sangue (1989), de MARÍA XOSÉ QUEIZÁN}

Tres grandes líneas de fuerza vertebran esta obra dramática de María Xosé Queizán. Ellas son el homoerotismo, aplicado a la relación igualitaria entre hermanos; el feminismo y el nacionalismo. A su servicio, la escritora dispone un marco espacio-temporal bien distinto y distante del original griego: Galicia, en la Baja Edad Media (siglo XI, en concreto), un tiempo decisivo en la existencia del Reino de Galicia. El tirano Creonte estará representado por 
el conde Oveco, capataz en Galicia del poder foráneo, castellano, secundado por su hijo Don Roi y auxiliado por el obispo Sisnando, representación de la alianza eclesiástica con el poder civil y militar que oprime a Galicia. Antígona será Elvira, máxima representación de la nobleza gallega no sumisa al poder extranjero y de la mujer digna que no admite sujeción de ningún elemento dominante masculino, sea el tirano, sea su hijo, con quien rechaza firmemente ser casada. Se niega a ser moneda de cambio política o sexual. El amor que siente por su hermano Fruela -por este correspondido- alcanza no sólo dimensión afectiva, sino que se convertirá en expresión de la rebeldía contra el poder despótico y en victoria post mortem, pues se dará muerte ella misma antes de caer como posesión vencida en manos del tirano.

Siendo el feminismo columna vertebral de toda la obra -narrativa, ensayística, poética..._ de esta escritora, brilla con toda claridad este pensamiento y su praxis en el personaje de Doña Elvira. Oveco utilizará con ella armas típicamente sexistas, en la más inveterada tradición conocida: una prostitución de lujo (el matrimonio con su hijo) y una ilusión de poder, el ejercido, por delegación, en el ámbito privado. Ante la sentencia del tirano: "La mujeres son flacas. No son educadas para usar la fuerza” (Queizán, 1989:40), Elvira, en ejercicio de dignísimo realismo, responde: "[Se acerca a la ventana]. Ven. Mira esos campos. Están arados y cultivados por mujeres. Aquellos bultos de allá, ¿puedes verlos?, son mujeres vencidas por el peso de esos enormes cubos de agua para tus baños, dobladas por esos haces de leña para calentar tus estancias. ¡Míralas bien! Esas no son flacas para servirte [Se retira de la ventana]. Las mujeres tenemos fuerza para parir, para cargar con los hijos a la espalda, incluso para arrastrar los cuerpos de los hombres que matáis en los campos de batalla y darles sepultura. Para esto debemos ser fuertes. Cuando se trata de contrariar vuestro poder, entonces somos débiles y delicadas" (ibidem). Elvira-Antígona pone el dedo en la llaga del cinismo de la doble moral sexista: reificación de las mujeres, sostén material y vital de la sociedad que hombres dirigen en su beneficio / sublimación idealizadora de su papel en el mundo, cuando a este poder masculino conviene.

Elvira hace suya la causa política defendida por su hermano Fruela, muerto por tropas de Oveco. Esta hermandad póstuma no sólo se sustancia en la exigencia de honras fúnebres acordes con su nobleza y heroísmo sino que se transformará en acción colectiva: la llamada al levantamiento en armas de la nobleza gallega no vendida al opresor:

"Escuchad, nobleza de Galicia, hermanos en armas, gentes de esta tierra! ¡Venid a honrar al mejor caballero, el más valiente, el más honrado de este país, para que su gloria perviva!

He de recorrer este reino de un confín a otro. Se levantarán los puentes levadizos, se bajarán las fortalezas, se abrirán las puertas de los palacios para 
escuchar mis invocaciones.

¡Abrid las conciencias! ¡Levantad lanzas de venganza!

¡Hermano, ahora yo seré tu cuerpo, tu voz, tu honra, la fuerza de la sangre por los siglos de los siglos!" (Queizán, 1989: 36).

La literatura gallega contemporánea, de la mano de su inauguradora, Rosalía de Castro (1837-1885), conoce unha completa y revolucionaria inversión del paradigma épico tradicional: el patrón heroico masculino y masculinista, semi-divino, individualista, superior a la masa que debe redimir... se verá en la obra rosalina sustituído por su antítesis: colectivo de mujeres; mayoría femenina trabajadora; sostén real de la sociedad; profundo humanismo de su actuación. La Antígona de Queizán (obra y personaje) se afilia a este mismo nuevo modelo: la épica moderna de que deriva inevitablemente una nueva óptica epistemológica, científica e histórica. Literatura como la que comentamos explana, por tanto, el camino para esta revolución del conocimiento todavía en ciernes.

\section{Nausícaa (2001), de MILLÁN PICOUTO}

Publicada en el primer año del presente siglo, la obra de Millán Picouto data en su escritura, no obstante, de varios años atrás, entre 1980 y 1984. Recuerda el autor como el episodio nucleado en torno a Nausícaa, hija del rey de los feacios y ayuda eficaz para el retorno de Ulises a Ítaca, merece poca atención en la Odisea de Homero. Perdidas las dos obras de Sófocles sobre tal tema, será Goethe quien advierta sobre la fertilidad y dramaticidad de un tema como el que esta heroína podía suscitar, pero no llegaron a cuajar en obra un título y unas notas manuscritas. Nausícaa cobra vida entera, pues, de la mano del escritor gallego, que recubre el centro temático inicial -el amor no correspondido de ella por Odiseo- de varios motivos máis del mayor interés, como la lucha de nobles apetentes de derrocar al rey; el amor homosexual, representado por dos esclavas, cuyo fin trágico quiere evitar la protagonista, o el perfil agrandado de la heroína, que se despide de la vida sumergiéndose en el mar que vio partir a su amor imposible. Se respeta el marco espacio-temporal original, así como otros procedimientos retóricos, como los parlamentos en verso, la existencia del coro y la verosimilitud ambiental. El guiño a la galleguidad está, con todo, conseguido gracias a la eficacia plástica y dramática de personajes como Marsias, el trovador contrahecho, experto en componer cantigas de escarnho y maldizer, en la senda de la espléndida tradición medieval gallego-portuguesa o, por ejemplo, en el duelo verbal Demódoco, rapsoda ciego, y el propio Odiseo, que recuerda vivamente la regueifa o retesía de la literatura popular gallega, en que dos contendientes compiten por el triunfo verbal y canoro. Nausícaa, al igual que Antígona, es ejemplo de dignidad femenina, de 
independencia y de sororidad. Su final nos recuerda la autoinmolación de la coprotagonista de La hija del mar de Rosalía de Castro, que vuelve por donde había llegado al pueblo marinero y al amor de la madre adoptiva que la acogen.

Nausícaa no sólo hace gala de su independencia de criterio, ironía y humor en el trato con sus pretendientes, a los que rechaza, o de su firme contestación al vituperio misógino de Marsias, sino que se yergue como sujeto titular de sus afectos, de su inclinación amorosa, contra el parecer de sus padres incluído. Odiseo, a pesar de la atracción y gratitud que siente por Nausícaa, debe cumplir su destino, el regreso a Ítaca, después de verse obligado a revelar su personalidad verdadera en el palacio del rey Alcínoo. En esta escena, Nausícaa anticipa ya su muerte. Aterrorizada por el castigo mortal anunciado para Filene y Glauce, las esclavas descubiertas por un despechado criado en relación amorosa, Nausícaa (revival de Safo) se posiciona claramente, en nuevo ejercicio de sororidad, en su favor: “ ¡No se castiguen, o también a mí! / ¡Premiadlas y mostradlas en la terraza / como blasón y gloria de las doncellas! / ¡Que el cielo brille más cuando se aman! / QQue invente la diosa la flor más exquisita / con que cubrir los campos de Feacia / cuando acaben de besarse!" (Picouto, 2001: 174). Y todavía: “QQue enamoradas sigan entre ellas: / se pondrán a salvo de palabras de hombre! / ¿Que se recluyan en ese amor sincedro: / no las defraudarán acciones de hombre!" (ibidem). Este clímax dramático se completa con la imprecación que Nausícaa lanza a su propia madre, escandalizada por sus palabras: “¡Tú no eres más que la retaguardia de ellos!" (ibidem).

La protagonista se convierte así, en crisol de varias rebeldías confluyentes: contra la autoridad paterna; contra la autoridad masculino-patriarcal; contra la determinación exterior de sus afectos; contra la única opción sexual admitida. Rechazada igualmente la solución-Telémaco, con quien tanto Odiseo como Alcínoo pretenden casarla, la desembocadura trágica está servida: una vez despedida de Odiseo y de recordarle que fue ella quien le salvó la vida, que él reconoce fervorosamente, la heroína se interna en el mar, como un retorno deseado al seno amigo de quien tanto la había contemplado. El Coro de esclavas, en fin, entona el ultimo canto de despedida: “Diosa Afrodita, sin cargo / navegue aquel que huyó, / pues sin rencor, sin embargo, / la que quedó se hundió / casando con el mar amargo! / ¡Diosa Afrodita, sin dolor / acoge ya el ser bendito / al que rehuyó el amor / y, por servirte mejor, / se casó con el mar infinito!" (Picouto, 2001: 187-188).

\section{Cinicas (2010), de TERESA MOURE}

La obra más reciente que comentamos se corresponde con la autora más joven y, al tiempo, la que practica una libérrima ruptura de marcos espaciotemporales. Definida por ella misma como "espectáculo teatral” más que como "obra dramática", "Cínicas es teatro líquido: no tiene las formas estables de 
los sólidos, se cuela por la rendijas del tiempo y permite que los personajes desafíen la línea de la historia y de la propia biografía. Se resisten, quizá, a cobrar cuerpo definitivo"(Moure, 2010: 7). La obra admite una primera lectura, de principio a final, y una segunda, que comenzaría por la nota que aparece en una pantalla y que cierra la obra. Este texto es la única prosa "denotativa" de la pieza e informa de que un incendio destruyó la vivienda de una anciana que vivía sola, víctima del síndrome de Diógenes, suceso en el que se vieron implicados funcionarios municipales de los servicios sociales, al igual que otras dos personas, sin identificar, que también perecieron en el incendio. Desde este final, en la lectura posible que sugerimos, podemos viajar de nuevo al principio y continuar la secuencia de los tres actos de que consta la obra.

El primero de ellos encierra un largo y tenso monólogo de Sara, la mujer de edad que rechaza ayuda de vecinas, amigas o servicios sociales, vive rodeada de todo tipo de restos y desperdicios y es perfectamente consciente de que padece el síndrome de Diógenes. Esta fusión de paciente-elemento activo, consciente, es particularmente importante, porque será ella quien realice una suerte de "auto-psicoanálisis", en un desdoblamiento de la personalidad que se acompasa con los súbitos cambios de humor y de ánimo. Increpa intermitentemente al público, con palabras indiciarias del simbolismo de la obra, como veremos: "A mí me da asco la gente, su ruindad, sobre todo la forma en que tratan las cosas. Tiran con todo. Tiran neveras, y lavadoras, $y$ cepillos de dientes, y pantalones, y mesas y cuadernos... Como si compitieran por ver quien fabrica más desperdicios, se apresuran en cambiar una cosa por otra. Yo, no; yo les doy otra vida a las cosas... Así comenzó todo: escogiendo entre los residuos esos restos que habían dejado de ser perfectos y que, sólo por eso, habían sido abandonados... ¡Como yo...! He hecho de mi casa un asilo, un hogar para pobres objetos desgraciados, para objetos con arrugas e insuficiencia respiratoria..." (Moure, 2010: 20).

En el segundo acto, Sara tendrá una existencia virtual, en pantalla, mientras los personajes "reales" explican la razón de la clase "práctica" o experimento para que los futuros funcionarios tengan un conocimiento in vivo, no in vitro, de una realidade tan lacerante como la que ofrecen dos mil personas dependientes, la mayoría ancianas, abandonadas en sus hogares. Inmediatamente se producirá la ruptura temporal, pues entran en escena el Ateniense acompañado de Diógenes, que resulta ser "una mujer peligrosa, una de esas filósofas" (Moure, 2010: 28). Aquel, representante del poder político y del orden, la describe como una anti-social, anti-cívica, despreocupada de todo bien material pero muy atenta al devenir social y dispuesta siempre a la sentencia sarcástica. Su mayor pecado consiste en "enaltecer el entusiasmo en vez del éxito, la naturaleza en lugar de la ley, y la razón en vez de los deleites (Moure, 2010: 31), esto es, la contravención completa del credo burgués-capitalista. Su 
código de respeto mayor se basa en el saber, que es "para los jóvenes templanza, para los viejos consuelo, para los pobres riqueza y para los ricos ornato. $\mathrm{La}$ sabia está por encima de riquezas, honores y poder..., pero se rinde al placer de conocer" (Moure, 2010: 36). Vivir sin apenas posesiones en una tinaja atenta, naturalmente, contra el lucro apetecido por el especulador inmobiliario, por el magnate constructor.

$\mathrm{E} 1$ tercer y último acto funde definitivamente una y otra época. Un nuevo personaje, Ana, se muestra cómplice de la Sara actual (la original se ahorca) y de Diógenes y propone un fuego purificador que, efectivamente, ejecutan como catártica limpieza destructiva.

Tal y como la leemos, la obra es, en realidad, una parábola sobre la acumulación capitalista y toda la destrucción, despersonalización y problemas de ella derivados. La rebeldía de los viejos se resuelve, simbólicamente, en la acumulación del reverso de la moneda: los restos, los desperdicios, la montaña de residuos reutilizables, en un aprecio estéril por lo construido por manos humanas y, por ello, merecedor de otro destino. En esta apoteosis de despilfarro, contraria a la tríada ecologista de la triple $\mathrm{R}$ (reducir, reciclar, reutilizar), naufraga la propia vida humana $\mathrm{y}$, desde luego, la vida de una naturaleza tan fieramente agredida. Un fuego bigiénico, en acto de limpieza final, tal vez simbolice la imposibilidad de reconstruir el sistema desde dentro de sus propias servidumbres y con sus instrumentos. Quizá un nuevo mundo adánico debiera ser creado, mundo que, en esta obra, es evaico, o sea, vinculado a un necesario protagonismo femenino o a la conversión en lábiles de las convencionales fronteras sexuales hombre / mujer.

\section{Conclusión}

El primero de los autores considerados, Manuel María, nació unos meses antes de la década de los treinta del pasado siglo. A continuación, diez años separan también la fecha de nacimiento de María Xosé Queizán y de Millán Picouto. Finalmente, la última escritora de referencia, Teresa Moure, nace en el ecuador de la década de los sesenta. Tenemos, pues, cuatro generaciones consecutivas de la literatura gallega contemporánea. Si nos fijamos en sus lugares respectivos de nacimiento (por comarcas: Terra Cha, Vigo, Ourense, Lemos), obtendremos también un cierto mapa de la variedad gallega, variedad que se mantiene malgré tanto artificio administrativo falso. La inclusión de dos escritoras como las mencionadas no representa un tributo a la corrección política de una paridad decretada, sino que se corresponde con la más estricta fotografía real. Sin volver a insistir en el papel fundacional de Rosalía de Castro - sin la cual la literatura gallega contemporánea no existiría o no sería cual fue y es-, se da la circunstancia de que, en la actualidad, la figura de la escritora no es rara avis en absoluto. No es anécdota: es categoría, y sin la tematización 
particular y variada que las escritoras actuales realizan sería incomprensible la literatura en su conjunto. Presentando, como ya se ha indicado, perfiles singulares estos cuatro escritores-as, resulta sorprendente la confluencia de una óptica común, a partir de los siguientes elementos: galleguización de la historia; enaltecimiento de la independencia y sabiduría femeninas; firme cuestionamiento de los poderes establecidos; triunfo de una justicia poética que se impone por encima de la ley tiránico-patriarcal. Todas estas obras no han merecido todavía vida teatral plena: su representación pública. Su calidad y potencia dramática así lo reclaman. Sean estas palabras invitación para remediarlo. 
María Pilar García Negro

\section{Bibliografía}

Manuel María (2003), Edipo, Biblioteca-Arquivo Teatral Francisco PilladoMayor, Universidade da Coruña.

Moure, Teresa (2010), Cínicas, Biblioteca-Arquivo Teatral Francisco PilladoMayor, Universidade da Coruña.

Picouto, Millán (2001), Ciclo de Venus, Ourense, ed. Linteo.

Queizán, Ma Xosé (1989), Antígona, a forza do sangue, Vigo, ed. Xerais. 


\section{LE BACCANTI DI EURIPIDE: UN'OPERA POST-MODERNA?}

Giovanni Greco

Theatron - Universitá di Roma La Sapienza

Le Baccanti sono un testo enigmatico, sincretistico, all'insegna della contaminazione: la storia di Dioniso e di Penteo ha molti punti di contatto con quella di Cristo; la condizione delle menadi, al seguito di Bacco, è molto simile a quella delle tarantolate, donne che nel profondo Sud dell'Italia (Puglia), hanno vissuto per secoli una trance dionisiaca, conseguenza del morso della taranta, mitico ragno, emblema della loro repressione sessuale, che le portava a danzare e cantare per giorni, al fine di scioglere le pulsioni pericolose; infine, la vicenda di Penteo, che vuole spiare la madre sui monti mentre compie ta orgia, sembra alludere al voyeurismo della scena primaria freudiana: il desiderio edipico di Penteo si realizza, ma in un senso macabro -potrà tornare nel grembo materno, ma fatto a pezzi, regredire ad un inizio che è fine, nel compimento di un principio di piacere che coincide con la pulsione di morte.

Una delle scene più famose della storia del teatro inizia al v. 912 delle Baccanti di Euripide. Penteo, giovane re di Tebe, fiero avversario di Dioniso e dell'introduzione del suo culto 'effeminato' a Tebe, rientra in scena travestito da donna e afferma di vedere 'due soli e due volte Tebe dalle sette porte'. Come è stato possibile che il persecutore della 'buona novella' dionisiaca sia diventato all'improvviso, nelle parole se non nei comportamenti, icona di Bacco?

Penteo ha osteggiato con tutte le forze lo Straniero, ovvero Dioniso che ha assunto sembianze umane come straniero che viene dall'Oriente; ha lottato contro le donne del suo seguito che hanno invaso Tebe e fatto proseliti: tra queste la madre di Penteo stesso, Agave, e le sue sorelle, Ino e Autonoe, che ora si trovano, in trance sul Citerone, a compiere ta orgia. Penteo ha fatto catturare lo Straniero effeminato, lo ha umiliato e lo ha sbattuto in carcere, ma quest'ultimo si è liberato dalle catene e la sua liberazione è coincisa con un terremoto straordinario che ha scosso la reggia alle fondamenta (vv. 576-604). Una volta libero, Dioniso-Straniero si è fatto beffe di Penteo, lo ha contro-umiliato (v. 616), facendolo correre dietro a fantasmi ed inganni, portandolo sull'orlo dell'esasperazione e della follia (vv. 616-641: lo racconta lo stesso Straniero alle donne del Coro terrorizzate dopo il terremoto). Esasperazione che tocca il suo culmine, quando, uscendo fuori dal palazzo, esausto di correre dietro alle illusioni dionisiache, Penteo trova Dioniso-Straniero libero e ascolta le parole del messaggero di ritorno dal Citerone, che racconta delle imprese mirabolanti delle donne sul monte (vv. 677-774). È a seguito di quest'ultimo racconto, che l'offensiva del re Penteo contro Dioniso e il dionisismo, si trasforma, prende una 
direzione inaspettata: la polemica di Penteo contro l'irrazionalismo del culto bacchico trova, grazie alle seduzioni dello Straniero e alle parole 'incredibili' del Messaggero, una nuova via di fuga. Penteo decide o crede di decidere, dopo qualche ultima resistenza, che sarà lui in persona a risolvere la 'vergogna' delle Baccanti sul Citerone: andrà lui sul monte, vestito da baccante 'per non farsi riconoscere', a spiare cosa fanno davvero le donne e metterà fine alle loro orgia. Entra dunque dentro il palazzo per prepararsi, cioè travestirsi da menade e muovere verso le donne, accompagnato da Dioniso-Straniero, che questa soluzione gli ha, subdolamente, suggerito (vv. 768-846).

Quando rientra in scena, al già citato v. 912, Penteo, che ha ormai l'aspetto di Dioniso-Straniero, dà l'impressione di vederci doppio o di essere sotto effetto di sostanze psicotrope, di essere ubriaco o addirittura impazzito, comunque preda dell'invasamento dionisiaco. Vestito con un peplo bianco, la cintura da donna, acconciato con i riccioli biondi della maschera dionisiaca e con in mano il tirso, freme di lanciarsi verso il Citerone, accompagnato da suo cugino Dioniso, che, come un bravo regista, perfeziona gli ultimi dettagli della messa in scena e lo rassicura sull'esito positivo del suo viaggio al monte: il dio del teatro traveste con le sue stesse fattezze l'iniziando, cioè la futura vittima sacrificale, nella cornice di una scena metateatrale che avrà una fortuna enorme, in forme più o meno esplicite, per tutta la storia del teatro. Questo perché la storia del teatro è, strutturalmente, storia en travestie e non si dà teatro senza mascheramento, scambio d'identità, ambiguità di genere, equivoco. $\grave{E}$ in questa scena delle Baccanti che si presenta, per la prima volta $\mathrm{e}$ in forma tragicomica, quella commedia degli errori o degli equivoci che da Euripide arriverà a Menandro e per il tramite di Plauto e Terenzio, attraverso Shakespeare irromperà nel teatro moderno e persino nel cinema. Le Baccanti, opera metateatrale che mette in scena il dio del teatro nel suo teatro, indaga e mette in mostra il meccanismo profondo del teatro stesso, il mistero della finzione e della convenzione teatrale, la dialettica inesauribile di straniamento e immedesimazione (Verfremdungeffekt e Einfüblung) tra attore e personaggio e lo fa in uno snodo storico cruciale come il 405-404 a. C.: la fine della Guerra del Peloponneso, la crisi della democrazia ateniese, la fine di un mondo e l'inizio di un altro. Tutto questo non sembra essere un caso.

La domanda è: cos'è che ha reso così fortunata questa scena? Cos'è che ce la fa piacere, che ci seduce, cioè ci fa ridere, fremere, forse piangere al contempo? A me pare si possa dire che questa scena sia fondativa di quella drammaturgia definibile come edipica, cioè di quella drammaturgia che realizza, nel suo intreccio, il complesso di Edipo, anche se non ne è direttamente consapevole e anche se il suo punto di vista è a- o anti-edipico nel senso freudiano, esattamente come sostenevano Vernant e Vidal-Naquet ormai quarant'anni fa. Se è vero che l'Edipo re di Sofocle ha poco o nulla a che fare con quello che 
Freud desume nell'Interpretazione dei sogni a partire dai vv. 980-982 dell'Edipo $r$, ciò non toglie che la drammaturgia tragica e comica post-classica (latina, rinascimentale, del Siglo de oro, etc.) sia profondamente familistica, tutta centrata sulla dialettica tra patri-monio e matri-monio, dedita con poche, significative eccezioni, all'infinita variazione sul tema del desiderio di uccidere il padre e giacere con la madre che da Edipo arriva a Amleto e da Amleto fino ai nostri giorni (in Italia, per esempio, all'incesto mancato dei Sei personaggi in cerca d'autore di Pirandello). La 'per-versione' del desiderio totalizzante del bambino che vuole essere e avere tutto all'interno delle mura domestiche, è tema che convive con altri per tutto il $\mathrm{V}$ secolo a. C. (per esempio il tema del dolore del corpo o quello dell'amicizia tradita o anche quello della sfida agli dèi), ma che, nelle mutate condizioni politiche, sociali ed economiche, vince e si impone a partire dal IV sec. a. C., in una casistica sterminata e ossessiva: nelle Baccanti la declinazione sosfisticata del complesso di Edipo è quella che, freudianamente, si definisce della 'scena primaria'. La scena primaria è, nella vulgata freudiana, uno dei paradigmi ineludibili nello sviluppo della personalità e nella costruzione dell'identità: il bambino vede concretamente, immagina o simbolizza l'evento topico dei genitori che fanno l'amore e, nelle multiple possibilità di attraversamento di quell'evento, prefigura la sua futura omosessualità o eterosessualità, le sue nevrosi, le sue psicosi, le sue perversioni voyeuristiche, etc. L'urgenza di Penteo di spiare la madre Agave e le sorelle di lei che compiono ta orgia sul monte (sono consapevole del fatto che orgia ha un significato non solo erotico ma anche sacrale), rappresenta una forma particolare, si potrebbe dire sado-masochistica, della scena primaria in assenza di padre, la cui conclusione, tragica, sarà, per il giovane re di Tebe, il ritorno al grembo materno, la regressio ad uterum dopo essere stato mangiato e bevuto dalla madre e dalle sorelle di lei, in una straordinaria coincidenza tra principio di piacere e pulsione di morte, che, per dirla ancora con Freud, va da Penteo alla madre e viceversa. Il racconto del secondo messaggero, di ritorno dal Citerone (vv. 1043-1152), mette in scena il desiderio finalmente realizzato del figlio fatto a pezzi, sacrificato e infine ritornato nel ventre materno come eucaristia, fractio panis e libagione del vino, dio mangiato nel corpo e nel sangue del suo iniziando.

Sì. Proprio eucaristia. Perché la conclusione della vicenda di Penteo in quanto figlio, 'crocifisso' all'abete sul Citerone, è una conclusione cristologica, l'ultimo atto di una mitopoiesi dionisiaca che intrattiene diversi punti di contatto con quella cristiana e in realtà con molte mitopoiesi orientali (si pensi soltanto a quella di Iside e Osiride). Anzi, Dioniso è diaframma inesauribile tra Oriente e Occidente (cfr. la parodo, in questo senso, vero e proprio evangelo dionisiaco, vv. 64-167) e, non a caso, le Baccanti sono l'opera con cui un anonimo autore medievale del XII secolo d. C. ha composto un'opera 
dal titolo Christus patiens che, centonando i versi di Euripide, racconta la passione, la morte e la resurrezione di Cristo. Noi ricostruiamo, infatti, una parte considerevole della lacuna che si apre al v. 1329 delle Baccanti (circa 50 versi), e cioè tutta la compositio membrorum e la lamentatio che segue al ritorno sulla scena di Agave ancora in trance con la testa del figlio infilzata al tirso (simbolo fallico) e che lentamente riprende coscienza, rendendosi conto di quanto ha fatto (vv. 1168 e ss.), proprio grazie al confronto con il Christus patiens. Le Baccanti sono, significativamente, costellate di eventi che rimandano alla passione di Cristo e alla sua vicenda umana e divina: dal terremoto con cui 'muore' e 'resuscita' lo Straniero (vv. 576-603, per cui si veda Matteo 27,51-53), al taglio della testa di Penteo, riportato in scena da e per una donna (la testa di Penteo, cugino di Dioniso, ricorda quella di Giovanni Battista, cugino di Gesù, riportata su un vassoio a Salomè). In qualche modo, la macabra comunione fisica che si realizza tra madre e figlio nel finale delle Baccanti, in senso freudiano, parrebbe rimandare, mutatis mutandis, alla compenetrazione tutta spirituale e sublimata tra la mater dolorosa che piange sotto la croce e poi al sepolcro e il figlio morto fatto a pezzi, crocifisso e offerto in sacrificio della tradizione cristiana. Nel primo caso, senza redenzione; nel secondo caso, per la salvezza dell'umanità.

L'eroe tragico (o comico), figura sempre replicata del canone occidentale, originerebbe, dunque, al contatto tra una humus edipica, sulle cui radici nel folclore di tutti i tempi ha scritto pagine insuperate Vladimir Propp, e la declinazione cristiana di questa humus, su cui pagine insuperate ha scritto invece Jan Kott proprio in relazione alle Baccanti. Questo eroe rimane, nel corso delle successive rivisitazioni, teatrali e letterarie, un eroe trionfante e sconfitto, un eroe dibattuto, che è, insieme e alternativamente, tyrannos e pharmakòs, re e 'crocifisso', che tocca il vertice dell'onore e quello dell'abominio, il più venerato e il più reietto di tutti gli uomini: l'eroe dell'ambiguità. Gli esempi sono molteplici, anche quando la forma che questa scena e il suo eroe o i suoi eroi assumono, li rende quasi irriconoscibili rispetto al punto di partenza. Mi limito ad un esempio vicinissimo a noi nel tempo, epoca di revival delle Baccanti euripidee e di una certa declinazione sincretica del dionisiaco, inteso non in senso nietzscheano come antitesi dell'apollineo, ma come sinonimo dell'identità ambigua, incompiuta, nomade e di una convivenza post-moderna degli opposti, che vuol dire meticciato, multidisciplinarietà, sottolineatura della dimensione ludica e performativa delle relazioni umane (persino paradigma di una tolleranza religiosa neopagana, rispetto al monoteismo tradizionale).

La ricerca filosofica più recente parla, in questo senso, dell'identità come gioco, come messa in scena, come performance: la stessa identità biologica non sarebbe un fatto naturale ma culturale, travestimento, maschera; il proprio 
genere (addirittura il proprio numero) non è dato una volta per tutte, ma giocato, recitato di volta in volta nel tempo e nello spazio, barattato e (ri)costruito perché l'essere è un ibrido che riesce per intervalla insaniae a stabilire una prevalenza, ma non sa imporla a se stesso e al mondo una volta per sempre. Cadono, nell'universo concettuale postmoderno e nelle sue pratiche, le distinzioni, i confini tra umano e animale, tra uomo e macchina, tra natura e cultura in senso più generale: si parla di post-umano, post-organico, si parla di corpo senz'organi (Artaud), ciò che rimodula o abolisce categorie politiche, etiche, estetiche. Ecco allora, tra le forme più estreme e dionisiache del postmoderno, le performance della body-art, che non propongono più all'analisi critica l'opera d'arte come oggetto prodotto da un soggetto, ma che fanno del corpo del soggetto stesso unopera d'arte, sezionandolo, ricostruendolo, estendendolo o riducendolo fino a renderlo equivoco, 'mostruoso', demonico ${ }^{1}$, nell'indistinzione tra vita e arte, tra etica e estetica. Alla base, seppure dimenticata o trasfigurata, resta, a mio parere, la scena madre o scena madre-figlio in assenza di padre da cui abbiamo cominciato:

\section{Dioniso}

Tu che vuoi vedere quel che non si deve, cercare quel che non si cerca, tu Penteo, esci dal palazzo, lasciati guardare, quel tuo vestitino da menade folle, 915 ci vai a spiare tua madre e il suo codazzo: hai le forme di una delle figlie di Cadmo.

Penteo

Ho l'impressione di vedere due soli, e due volte Tebe, dalle sette porte. $E$ tu che mi stai davanti sembri un toro, ti sono spuntate le corna sulla testa. Ma tu eri una belva un tempo? Ora sei un toro...

\section{Dioniso}

Dio è con noi, non ci voleva bene prima, ora è ben disposto: e vedi quel che devi.

Penteo

E come ti sembro? Ho l'anadatura di Ino, o magari quella di Agave, mia madre?

${ }^{1}$ Il versante comico-parodico di questa 'contaminazione' è Tootsie per il cinema, con Dustin Hoffmann; per quello letterario Creatura di sabbia di T. B. Jelloun; per il teatro Attempts to her life di Martin Crimp. 
Dioniso

Ti guardo e mi sembra di vedere loro.

Ma ti è andato un ricciolo fuori di posto,

non come l'avero messo io sotto il nastro.

Penteo

È che prima dentro a casa, e su e giù, io, a fare

la tua danza, mè uscito fuori posto.

\section{Dioniso}

Ma io, che ho solo cuore di essere il tuo schiavo, te lo tirerò su: forza alza la testa.

Penteo

Ecco, fammi bello: sono nelle tue mani.

Dioniso

La cintura s'è allentata, e le pieghette del vestito non scendono alle caviglie.

\section{Penteo}

Sembra anche a me, ma solo qui al piede destro, dall'altro mi pare scenda a perfezione.

Dioniso

Non mi farai il primo dei tuoi amici, quando le vedrai virtuose a dispetto di te?

Penteo

Il tirso lo prendo con la destra o l'altra

per assomigliare di più a una baccante?

Dioniso

Con la destra devi prenderlo ed il piede destro alzare: bravo, stai perdendo i freni

Penteo

E ce la farei a portare sulle spalle

il Citerone con tutte le baccanti?

\section{Dioniso}

Ce la fai, se vuoi: prima eri un po' frenato, ora invece stai bene, come si deve. 
Penteo

Portiamo le leve? O tiro su le vette

con le mani e me le metto in spalla o in braccio?

Dioniso

Ma distruggerai le case delle Ninfe,

le sedi di Pan dove i flauti risuonano.

Penteo

Ben detto; bisogna vincere le donne

senza forza: io tra gli abeti mi nascondo.

Dioniso

Ti nasconderai come s'ba da nascondere

uno che va a spiare ingannando le menadi.

Penteo

Secondo me stanno tra i cespugli come

uccelli presi nelle reti d'amore.

Dioniso

E non è per questo che vai ad esplorare?

Le prenderai se non sarai preso prima.

Penteo

Portami attraverso la terra di Tebe:

io sono di tutti l'unico a osar questo.

Dioniso

L'unico a soffrire per la città, l'unico:

ci sono le prove ad aspettarti debite.

Seguimi: tua scorta sono io tua salvezza,

ti riporterà un altro da lì.

Penteo

La madre?

Dioniso

L'esempio per tutti.

Penteo

Eper questo ci vado.

Dioniso

Portato verrai... 
Giovanni Greco

Penteo

Dici la mia delizia.

Dioniso

Tra mani di madre.

Penteo

Mi forzi a godere.

Dioniso

E che godimenti.

Penteo

Quelli che mi merito.

Dioniso

Tremendo tremendo vai alla tua passione tremenda, una gloria troverai fino al cielo. Allunga le mani, Agave, e voi che siete del seme di Cadmo: io porto il ragazzino alla grande prova; chi vincerà, io, sarà Bromio. Il resto significherà. 


\title{
El mito de Perseo y Andrómeda en el teatro de Lope de Vega y Calderón de la Barca
}

\author{
Remedios Higueras González \\ I.E.S. Luis Bueno Crespo
}

\begin{abstract}
En este trabajo haremos un estudio de la evolución del mito de Perseo y Andrómeda desde la narración que de esta fábula hace Ovidio, hasta enmarcarla en el contexto religioso de un auto sacramental de Calderón de la Barca, para llegar a la original versión que de este mito hace Lope de Vega.
\end{abstract}

\section{Introducción}

Las comedias mitológicas son un género difícil de cultivar. Los mitos suelen desenvolverse en un espacio temporal ilimitado, y constreñirlos a un tiempo adecuado al de una representación teatral es una tarea ardua. Sí ofrecen algo muy positivo, por una parte representan una fuente inagotable de inspiración y por otra, al ser múltiple las interpretaciones que de cada mito hay, el autor puede remodelarlos a su capricho y darles ese final feliz que se esperaba en la época de los autores que nos ocupan.

Para adaptar esos mitos al gusto del teatro del Siglo de Oro, tanto Lope como Calderón no dudan en introducir numerosos personajes y episodios que confieren a las historias un aire abigarrado y artificial en exceso, pero muy del gusto de los cortesanos a los que iban destinadas este género de representaciones, que procede directamente de las tragicomedias italianas que en la corte de Mantua y Florencia se pusieron muy de moda a comienzos del s. XVI.

La fuente de las que beben los dramaturgos no tiene por qué ser Ovidio, o sólo Ovidio, pueden ser manuales tan conocidos como las Genealogiae Deorum Gentilium de Boccaccio, las Mithología de Natale Conti, las Fabulae de Higino, el Mythologicon de Fulgencio o la muy libre traducción que de las propias Metamorfosis de Ovidio hizo en 1543 Jorge de Bustamante.

Con las posibilidades que les brindan los héroes paganos, Lope y Calderón construyen a su antojo obras con personajes míticos muy diferentes de los de la tradición clásica, pero sin desvirtuar nunca la esencia del mito.

\begin{tabular}{|c|c|c|}
\hline \multicolumn{3}{|c|}{ Personas } \\
\hline Lisardo, principe de Tebas & . Fineo & .Polinestor, capitán \\
\hline Armindo & . Medusa & . Soldados \\
\hline Palas & Apolo & .ElTiempo \\
\hline
\end{tabular}




$\begin{array}{lll}\text {.Virgilio y Músicos } & \text {. Envidia, Lisonja } & \text {. Lisandro } \\ \text {. Mercurio } & \text {. Ingratitud, Celos } & \text {. Andrómeda } \\ \text {. La Porfía } & \text {. Dos salvajes } & \text {. Laura } \\ \text {.Júpiter } & \text {. Mirelia } & \text {. Perseo } \\ \text {.Elisa } & \text {. Poetas } & \text {. Fenicio } \\ \text {. Dánae } & \text {.Virgilio } & \text {. Mitelio } \\ \text {.Atalante, rey de Mauritania } & \text {.Pastores } & \text {.Polidetes, rey de Acaya } \\ \text {.El rey de Tiro } & \text {. Diana } & \text {. Cazadores y criados }\end{array}$

E1 Perseo de Lope es una obra hecha por encargo del poderoso Duque de Lerma para ser representada ante cortesanos que, ante todo, exigían distracción. Se trata de un largo poema épico dividido en tres actos. En cada uno de ellos se cuenta un episodio. El nacimiento de Perseo y su rescate en el primer acto, la muerte de Medusa en el segundo y la liberación de Andrómeda en el tercero, todo ello aderezado con multitud de personajes y episodios de la cosecha propia del autor y que nada tienen que ver con el mito ovidiano.

PRIMER ACTO: El príncipe Lisardo, enamorado de Dánae, le muestra a Armando la torre en la que ésta ha sido encerrada por su padre Acrisio. Lisardo consulta al oráculo de Apolo la forma de acceder a su amada y éste le responde:

Oro la podrá vencer, oro rendirá sus brazos, porque el oro es la ruina de torres y muros altos (vs.142-145)

Júpiter, que oye a Apolo, enamorado también de Dánae, se apresura a convertirse en lluvia de oro- "Que venza la riquezal a la que vence a un dios, que es la belleza!'(vs.245-6)- y entra por los barrotes del recinto donde estaba la bella. Parece evidente que al escribir este episodio Lope se inspiró en el cuadro de Tiziano, pintado para Felipe II, "Dánae y la lluvia de oro", dada la gran plasticidad de la escena que nos recuerda sobremanera la célebre pintura ${ }^{1}$.

Dánae ha quedado embarazada del rey de los cielos y para resolver el problema del paso del tiempo ${ }^{2}$, Júpiter le pide al mismo Tiempo que transcurra muy rápidamente:

${ }^{1}$ El célebre cuadro de Tiziano fue pintado en 1.550 y no es el único cuadro del autor italiano que inspiró a Lope en algunos pasajes de sus comedias mitológicas. También lo hizo Adonis y Venus en la comedia del mismo título del autor, anterior a ésta.

${ }^{2}$ En el Arte nuevo de hacer comedias (vv.211-214), sobre el tiempo de la acción dramática nos dice Lope: "El sujeto elegido, escriba en prosa/ y en tres actos de tiempo le reparta,/ procurando, si puede, en cada uno/ no interrumpir el término del día”. 
Pues tiempo veloz, advierte

que pases en un instante

nueve meses adelante (vs. 424-426)

Nacido ya de forma tan rápida el hijo de Dánae, Acrisio ordena arrojarla al mar con el pequeño Perseo. En una nave a la deriva arriban madre e hijo a las costas de Acaya, donde unos pastores que compiten en hacer versos al más puro estilo virgiliano los salvan de una muerte segura. Polidetes, el rey de Acaya, que por azar andaba cazando en esos parajes, se prenda de la belleza de Dánae y la hace su esposa.

ACTO SEGUNDO: Perseo, convertido en joven cazador, abre el segundo acto con un largo soliloquio que nos recuerda al monólogo de Hipólito en la Fedra de Séneca ${ }^{3}$.

La diosa Diana aparece para comunicarle a Perseo su origen divino. Es inevitable recordar aquí la relación protectora que esta diosa tiene con Perseo, inspirada en la relación Diana/Hipólito de Eurípides y más tarde en la de Séneca. En un cambio drástico de escenario aparece Fineo ${ }^{4}$. Lo encontramos parlamentando con Medusa, a la que le cuenta el profundo amor que siente por Andrómeda, princesa de Tiro. Medusa, que es aquí una bellísima mujer, siente envidia de la joven Andrómeda y echa de su castillo a Fineo. El Lope más incisivo nos regala estos sabrosos versos puestos en boca de Fineo:

\section{Sólo puedo defender \\ mi ignorancia en avisar \\ que el hombre debe saber \\ que mujer no ha de alabar \\ delante de otra mujer (vs. 1.366-1.370)}

El eje de este segundo acto es la muerte de Medusa. E1 rey Polidetes, temeroso de que su hijastro Perseo le arrebate el reino lo envía a matarla con la secreta esperanza de que no vuelva. El episodio de la muerte de Perseo y Medusa nada tiene que ver con el mito clásico. Lope le imprime un sabor muy medieval al ubicar a Medusa en un castillo donde llega el caballero Perseo pertrechado con la espada y el escudo que Mercurio y Palas le han regalado. Caballeros alegóricos defienden la fortaleza ${ }^{5}$ : la Envidia, la Lisonja,

${ }^{3}$ Este monólogo de Hipólito se inspira en los versos que éste recita al empezar el primer acto de la Fedra de Séneca, versos inspirados a su vez en la invocación a Artemisa del Hipólito de Eurípides.

${ }^{4}$ En Lope no se hace alusión alguna al parentesco entre Fineo y Andrómeda, tío de ésta en Ovidio. Estos datos y otros más han hecho pensar que Lope no se valió de las Metamorfosis ovidianas sino de la conocida traducción que hizo Jorge Bustamante.

${ }^{5} \mathrm{La}$ introducción de personajes alegóricos en los mitos se cultivó mucho a partir de la 
la Ingratitud y los Celos y un gigante, la Porfía. Tras vencer sin esfuerzo a todos ellos gracias al escudo de Palas, Perseo por fin se encuentra con Medusa. Pero esta Medusa de Lope es tan bella, tan "humana", que no duda en intentar seducir al héroe con bellas palabras, y al no conseguirlo le muestra el retrato de una hermosa princesa, Andrómeda, de la que se enamora al instante el semidiós. Perseo no hace gala de gran caballerosidad, pues sin pretexto alguno le cercena la cabeza tras matarla, pero el desarrollo de la historia así lo requiere. La cabeza de Medusa será necesaria para llevar a buen término futuras empresas.

Este segundo acto, tan denso, se completa con la aparición de Virgilio, la fuente Castalia, las Musas y otros personajes. Sirviéndose de Virgilio, el autor aprovecha para hacer una alabanza a la casa de Austria y al Duque de Lerma ${ }^{6}$.

El segundo acto acaba con un diálogo entre Fineo y el rey Atalante de Mauritania. El rey astrólogo predice que llegará un griego que salvará a Andrómeda de un gran peligro.

ACTO TERCERO: Andrómeda y Laura conversan en una escena que nos recuerda a la del primer acto entre Dánae y Elisa. Andrómeda reconoce que Fineo está enamorado de ella y que no es correspondido. Laura, en cambio, se descubre enamorada de Fineo.

El rey de Tiro, padre de Andrómeda, cuenta apesadumbrado que ha aparecido un monstruo dispuesto a destruir su reino. Sólo el sacrificio de la princesa puede aplacarlo. Andrómeda, en un acto de generosidad, accede a ser inmolada y Fineo se vuelve loco al enterarse del horrible final que le aguarda a su amada. La locura de Fineo persiguiendo a una pastora a la que confunde con Andrómeda, rompe el dramatismo de la acción.

Perseo, que ya ha llegado a Tiro a lomos de Pegaso, nacido de la sangre de Medusa, es informado de que Andrómeda va a ser devorada por un terrible monstruo, una Andrómeda que esta vez aparece en actitud suplicante, atada a una peña y con los cabellos tendidos al viento, pidiendo al cielo que le de fuerzas para morir con dignidad: "Valor os pido, que baste para morir airosa" (vs. 2.614-2.615).

Fineo aparece en este escenario y en su delirio quiere liberar a Andrómeda con planes descabellados. Perseo en su caballo alado surge providencial y antes de dar muerte al monstruo, sabiendo que Fineo es su rival, en lugar de convertirlo en piedra (como ocurre en las versiones clásicas del mito), le devuelve la razón con el prodigioso escudo de Palas, que además le hace trocar la pasión que sentía por Andrómeda por Laura.

\footnotetext{
interpretación que de ellos hizo Boccaccio en su Genealogiae Deorum Gentilium.

${ }^{6}$ Lope aspiraba al puesto de cronista real. (vs. 1.797-1.812), con estos versos pretende congraciarse con el rey que criticaba su vida disoluta.
} 
Ya muerto el monstruo, Perseo, como no podía ser de otro modo en una comedia de esta índole, pide a Andrómeda en matrimonio y, enterado de la muerte de Acrisio, decide regresar a su Grecia natal de donde tan injustamente salió.

\section{EL MITO DE PERSEO Y ANDRÓMEDA EN CALDERÓN}

\section{ANDRÓMEDA Y PERSEO. AUTO SACRAMENTAL}

\begin{tabular}{lll} 
& \multicolumn{1}{c}{ Personas } & \\
. Andrómeda & . Medusa & . Albedrío \\
. Gracia & . Ciencia & . Centro \\
. Ignociencia & . Voluntad & . Perseo \\
. Fuego & . Aire & . Demonio \\
. Agua & .Tierra & . Mercurio
\end{tabular}

Acompañada de todo un cortejo de seres alegóricos que la arropan y festejan: la Gracia, la Ignociencia, la Voluntad, el Albedrío y los cuatro elementos: el Fuego, el Aire, la Tierra y el Agua, Calderón nos muestra a Andrómeda como una criatura inocente y bella en medio de un idílico jardín, el Paraíso.

Del Centro de la tierra ha nacido esta criatura gentil que se autodenomina "Humana Naturaleza". Casiopea y Cefeo, sus padres en la versión clásica del mito, han sido obviados para hacer surgir a Andrómeda de la misma tierra, del barro de las Sagradas Escrituras del que se creó al hombre.

En contraposición a tanto candor e inocencia Medusa y el Demonio esperan agazapados la oportunidad de actuar. Ambos no están solos, también el terrible monstruo marino, que en Ovidio y las interpretaciones que del mito se hicieron posteriormente siempre está presente, aquí aparece simbolizando el Pecado, ansioso por apoderarse de la bella.

Observemos que en el mito clásico Andrómeda está expuesta a un solo pero terrible peligro, el del monstruo marino, pero aquí son, además de éste, dos riesgos más los que la acechan: una Medusa perversa ${ }^{7}$ y un Demonio que ama y odia a la vez a la protagonista. Llama poderosamente la atención la implicación tan directa en el relato de un Demonio enamorado que le confiesa a Medusa su desazón:

Tan postrado, tan rendido, tan sujeto, tan penoso me tiene que, hasta que pueda

\footnotetext{
${ }^{7}$ Medusa desempeña aquí el papel de la serpiente que tienta a Eva en el Paraíso.
} 
llamarla mía, dispongo

no perdonar al deseo,

medio ninguno de todos

cuantos discurre un amante

y cuantos piensa un celoso. (vs. 383-398)

Medusa es requerida por tan amante enemigo para inducir a Andrómeda a cometer un acto de soberbia: desear la inmortalidad, como Dios, comiendo de un fruto prohibido. A pesar de las advertencias de su cortejo de Virtudes y Elementos, Andrómeda no puede resistir la tentación y come ante el regocijo de Medusa/Pecado. Es decir, ya tenemos una Andrómeda condenada, su destino es el dolor, que aquí se concretiza en el Monstruo marino/Culpa.

Este es el momento en que Calderón hace irrumpir a Perseo. Nada se dice de antemano sobre su origen y sus hazañas, importa aquí sólo su actuación inmediata, su arrojo para poner fin a una situación desesperada. Perseo mata a Medusa y redime y libera a Andrómeda. La Virtud vence al Pecado, el Bien al Mal, la Honestidad a la Soberbia.

La gran diferencia entre la Andrómeda del mito clásico y la de este Auto es que aquella es una víctima inocente de Casiopea y, sumisa, expía la culpa de su madre accediendo a ser inmolada, ésta, en cambio, no tiene ninguna dimensión trágica puesto que ella misma por una mala acción se ve abocada a sufrir un castigo, del que finalmente Perseo la redimirá.

\begin{tabular}{lll}
\multicolumn{3}{c}{ I. LAS FORTUNAS DE ANDRÓMEDA Y PERSEO } \\
PERSONAS \\
. Perseo & . Medusa & . Juno \\
. Bato, villano & . Libio, criado & . La Discordia \\
. Gilote, villano & . Libia & . El rey Cefeo \\
. Ergasto, villano & . Sirene & . Una Dueña \\
. Cardenio & . Palas & . Cuatro Damas \\
. Dánae & . Mercurio & . Laura, dama \\
. Polidites & . Andrómeda & . Seis Nereidas \\
. Fineo & . Morfeo & . Músicos \\
. Celio, criado & . Las tres Furias & . Criados \\
. Lidoro & . Júpiter & .Villanos
\end{tabular}

La sencillez del Auto Sacramental de Calderón contrasta con este drama de desbordante acción, dividido en tres Jornadas, denso y abigarrado por los muchos personajes que aparecen, los continuos cambios de escenario y la injerencia de los dioses olímpicos en el discurrir de los hechos.

JORNADA PRIMERA: Perseo es aquí el eje sobre el que gira la acción, de la misma manera que lo era Andrómeda en el Auto, pero este Perseo, allí 
héroe consolidado, aquí aparece inseguro y confuso, enfundado en un tosco sayal de villano que no corresponde a sus aspiraciones ni a su arrogancia, mientras se pregunta por su origen.

Dánae, que se hace llamar Diana, se muestra resignada y agradecida a Cardenio que los acogió a ella y a su hijo cuando fueron entregados al mar por la crueldad de Acrisio. Dánae recrimina a Perseo su inmodestia - "Siempre te tengo de hallar / altivo, sañudo y fiero?"-y no quiere revelarle su ascendencia sencillamente para protegerlo de la ira celosa de Juno. Este Perseo de Calderón en la jornada primera sufre y duda, se siente diferente a las sencillas gentes que lo rodean. La aparición de Lidoro, en otro tiempo enamorado de Dánae y de Fineo $^{8}$ de Trinacria, (aquí primo de Andrómeda, en Ovidio tío suyo) le van a dar a Perseo la oportunidad de convertirse en héroe. Perseo está ansioso por conseguir el reconocimiento que por nacimiento cree que no tiene pero que se merece. Recordemos en este punto la etimología que de su nombre Calderón relata: Perseo procede de per se, por sí mismo, el que se hace a sí mismo:

\section{Pues a quien se hace por si \\ la fortuna es a quien vi dar mayor estimación 9 .}

El reto de Perseo, siguiendo las líneas clásicas, va a ser matar al monstruo marino que atemoriza las costas de $\operatorname{Trinacria}^{10}$ (10), donde reinan Casiopea y Cefeo, monstruo que va a devorar a la desventurada Andrómeda, castigada por la diosa Venus y aniquilar a la otrora bella y ahora convertida en gorgona Medusa, que siembra el terror en un monte de África.

JORNADA SEGUNDA: Perseo por fin conoce su origen, todavía no directamente por boca de su madre, sino por un sueño en la gruta de Morfeo al que ha sido inducido por Mercurio y Palas, deseosos de ayudar a su hermano mortal. Con el fin de mantener la atención del público, el suspense del lector, Calderón opta por continuar con la confusión de Perseo, que sabe, pero no sabe, que ha soñado y que sospecha. Lidoro y Polídites, rey de Acaya, patria que ha acogido a Dánae y a su hijo, descorren la cortina de humo que envuelve al que quiere ser héroe. Ahora Perseo sí se siente llamado, como hijo del propio Júpiter, a cumplir los más altos objetivos, aunque aún duda: "¿ $S i$ es que sueño todavia?/ Pero sueñe o no, me bastal ser hijo de mis delirios / para emprender cosas

${ }^{8}$ Fineo es el personaje presentado de forma más caprichosa. En Ovidio tiene un gran protagonismo, lucha encarnizadamente contra Perseo y es convertido en piedra. Lope lo convierte en un hombre bueno al que hace perder la razón por amor a Andrómeda y lo incita a casarse con Laura. Calderón lo pinta como un ser celoso y cobarde que muere a manos de Lidoro.

${ }^{9}$ No ha sido posible encontrar versión canónica.

${ }^{10}$ Recordemos que en Lope el monstruo asolaba las costas de Tiro y en Ovidio las de Etiopía. 
altas". Pero nuestro héroe está dispuesto a emprender el camino de la gloria y Juno no lo puede permitir. Invocada por la Discordia pide a las Furias que intervengan para torcer los planes del hijo de Júpiter.

Andrómeda, a la que sólo se había nombrado en la Primera Jornada, hace su aparición en los bosques de Trinacria donde ha arribado Perseo. En nada se asemeja esta joven tan altiva y arrogante, forjada a medida del orgulloso Perseo, a la dulce criatura del Auto Sacramental. Andrómeda es aquí una doncella cazadora y osada sin otra opción que asumir su destino, morir para expiar la culpa de su madre.

TERCERA JORNADA: Perseo, provisto del caduceo regalado por Mercurio y el escudo, obsequio de Palas, cumple finalmente el primero de sus propósitos: mata a Medusa con el mismo caduceo divino que durmió al gigante Argos, guardián de Ío, y le corta la cabeza. Por primera vez en el desarrollo del drama, Perseo se muestra seguro y orgulloso de su genealogía, ya ha culminado una acción propia de un triunfador. A instancias de Lidoro, que ha visto sus montes liberados de Medusa, y le pregunta quién es, responde: "Perseo, hijo de Júpiter y Dánae." En Pegaso, que surge de las entrañas de la tierra, se dirige a concluir su gesta. Andrómeda, que se resiste a morir, implora piedad a las Nereidas, ejecutoras de la sentencia de Venus. De nuevo aquí aparece la dicotomía "dioses benefactores", compasivos (Mercurio, Palas y Júpiter) frente a "dioses vengativos", despiadados (Juno, Venus, la Discordia y las Nereidas). El desenlace no puede ser otro que el mitológico. Andrómeda, tan altiva antes, tan humilde ahora, se humaniza ante la visión de Perseo que al reconciliarse con su origen actúa como el semidiós que siempre ha sido. 


\section{La $A N T i ́ g O N A$ de María Zambrano o el oficio de la Piedad}

Alfonso Lázaro Paniagua

I.E.S. Luis Bueno Crespo

En este trabajo, centrado en La tumba de Antígona de la filósofa malagueña María Zambrano, se pretende destacar el valor de la tragedia como oficio de la piedad. Asimismo rescatar para la modernidad (en la medida de lo posible) el principio que inspira lo trágico: destino/ libertad.

La Antígona de Zambrano se abre con un soliloquio que es delirio. El delirio mana de una conciencia no reconciliada consigo misma, se manifiesta en el curso errático del desvarío. Las interrogaciones encadenadas así lo manifiestan. Pero el delirio de Antígona tiene una nítida procedencia, ya que se trata del hundimiento de una historia familiar que culmina en la lucha fratricida entre Eteocles y Polinices, sus dos hermanos. Antígona hereda ese hundimiento antes de franquear los umbrales de su autonomía personal y antes de celebrar las prometidas nupcias con Hemón. Antígona queda sin tiempo, petrificada entre el horror de su ascendencia y la privación de toda esperanza. Pero a diferencia de Sófocles, Zambrano no culminará su obra con la muerte de la heroína, pues eso despojaría su protagonismo: el alumbramiento de sentido que lleva la historia familiar y de la polis más allá de su puro hundimiento, de su pura destrucción, porque sobrepasándolos, los rescata. "Antígona, en verdad,- nos dice Zambrano- no se suicidó en su tumba, según Sófocles, incurriendo en un inevitable error nos cuenta", pues entonces, sigue Zambrano "el conflicto trágico no alcanzaría a serlo, a ingresar en la categoría

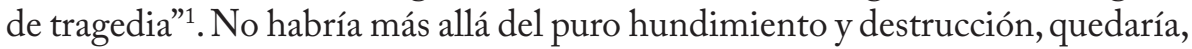
pues, la tragedia detenida en el lamento sin fin y sin finalidad. El lamento de Antígona en los primeros soliloquios de la obra, antes de hacerse anfitriona de las sombras que la visitan, es corrosivamente lúcido: "La desgracia golpeó con su martillo mis sienes hasta pulirlas como el interior de una caracola, hasta que fueron como dos oídos que sentían los pasos blandos de la desdicha, su presencia; esos pasos blandos con que la desdicha mucho antes de desatarse entra en nuestra cámara y viola el recinto del sueño sin mirarnos siquiera. Se presenta y está ahí fija, se queda exhalando terror, un terror que llega a ser como una túnica, ésta, ésta que me pusieron ya de niña, y que ha ido creciendo conmigo hasta ser como mi propia piel"2. Pero Antígona, para Zambrano, no

\footnotetext{
${ }^{1}$ Zambrano, María, p. 41.

${ }^{2}$ Ibid., pp. 45-46.
} 
podía ser el epígono del hundimiento familiar y político, la última víctima de un enloquecido destino que sepulta los acontecimientos y humilla la memoria soldándola a la catástrofe.

Éste es el hecho determinante de la obra de Zambrano, La tumba de Antígona. La heroína no podía morir, porque si así fuese se cerraría el hundimiento de la saga familiar en su propia condena. Antígona habrá de transformar la lucidez que llaga en luciente fármaco que alivia y sana. La tumba de Antígona no se sella conteniendo el cadáver, sino que, entreabierta, deja que se deslicen en su interior las sombras familiares que el delirio de la muchacha va constituyendo a modos de simulacros. Antígona los recibe como huéspedes y ellos, uno a uno, Ismene, Edipo, la nodriza Ana, Yocasta, la arpía, los hermanos, Hemón, Creonte irán revelando honduras de Antígona, dicho de otro modo, despertando su vocación: la vocación-Antígona. Y no será otra cosa esa vocación que la acción de la piedad. De ello hablaremos más adelante, pero ahora tratemos a cada personaje huésped en la intimidad de la anfitriona.

Antígona está en su tumba a medio abrir. En su descenso, la congestión del llanto. Presa de un delirio lúcido que antes hemos señalado, la heroína va fijando diversas sombras en su mente que insensiblemente, debido a la contextura del sueño en que se desenvuelve la escena, se emancipan de su imaginación y se objetivan como fantasmas que dialogan. Con Ismene, la propia Antígona se desdobla y le recuerda lo que ella sola había hecho: "acompañar a nuestro padre, después ir a lavar a nuestro hermano maldecido"3. A continuación le pregunta por Creonte: “¿Todavía está ahí mandando?”, lo que evidencia que la escena discurre en un tiempo indefinido. Los personajes flotan en esa atmósfera de ingravidez propia de los sueños. En ese momento Antígona revela su naturaleza mediadora al autodefinirse como lavandera y asociarse al elemento agua. "Pero no, Ismene, no, hermana. Tú no tenías que venir conmigo a lavar a nuestro hermano sin honra, porque mira, ya está claro, la lavandera soy yo" ${ }^{4} \mathrm{La}$ que lava la sangre derramada y la hace correr. Por esto, Antígona se reconoce en su papel, va cayendo de la mentira en que estaba y gana conciencia, es su anagnórisis lo que se despeja en la categoría de tragedia de Zambrano. La conciencia que alumbra Antígona gana peldaños por momentos: “... la sangre no debe quedarse dura como piedra. No, que corra como lo que es la sangre, una fuente, un riachuelo que se traga la tierra. La sangre no es para quedarse hecha piedra, atrayendo a los pájaros de mal agüero, auras tiñosas que vienen a ensuciarse los picos. La sangre, así, trae sangre, llama sangre porque tiene sed, la sangre muerta tiene sed y luego vienen las condenas,

\footnotetext{
${ }^{3}$ Ibid., p. 46.

${ }^{4}$ Ibid., pp. 46-47.
} 
más muertes, todavía más en una procesión sin fin" ${ }^{5}$. El agua disuelve la sangre y la emboca en manantial y fluye con ella su historia, la desenreda, porque en esto es Antígona contundente: “...no me muero, no me puedo morir hasta que no se me dé la razón de esta sangre y se vaya la historia, dejando vivir a la vida"6. He aquí el sentido más revelador de la obra de Zambrano, el oficio de la piedad que es la vocación-Antígona, dar razón de esta sangre, por la historia propia, y por extensión, de toda historia.

Allector u oyente puede sorprenderle la contraposición historia y vida, pero en Zambrano es lo propio. Véase en esta alusión que oye Ismene la distinción y contraposición de ambos conceptos: “... mi historia es sangrienta. Toda, toda la historia está hecha con sangre, toda historia es de sangre, y las lágrimas no se ven"7. Tendremos ocasión de asociar la historia a la ley vieja que representa Creonte, y la vida a la ley nueva que profetiza Antígona. Profetismo que tiene no pocas analogías con Sócrates y su condena, pues en Sócrates puede verse al hombre que se ofrece en sacrificio en aras de la nueva ley de la polis.

Sin que medie intervalo alguno, desaparece por el fondo del sueño Ismene y se impone el fantasma de Edipo, que ya ve, y se ve a sí mismo. Constata su identidad indisoluble de su desdicha: "Mi padre me abandonó. Y fue el pastor quien se compadeció de mí y cambió mi suerte, mi condena a muerte en condena a vivir abandonado. Y yo iba, como una nube suelta, olvidado de mi padre. Y así, dejado, ¿qué iba yo a hacer? Si hubiera sabido, no habría hecho nada, lo que se dice nada, antes de volver a mi casa, a encontrarme con mi

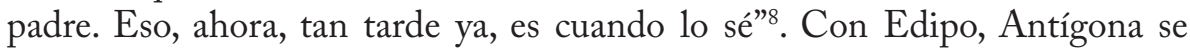
dispone a despejar lo que su padre le había vedado como resistencia última: su madre. Edipo eludía a Yocasta, su madre, y aludía a ella por un pronombre: "Ella", lo que irrita a Antígona, reprochándole algo así como: ¿por qué me lo ocultabas? La dureza con que Antígona se expresa constituye un momento de máxima lucidez: "Cuando dices que soy cruel, entonces me llamas Antígona. Pero es que sale de mí la verdad una vez más sin culpa mía. Ella, la verdad, se me adelanta. Y yo me la encuentro de vuelta, cayendo sobre mí, la verdad cae siempre sobre mí." Gana la conciencia-Antígona al sentirse al descubierto de todo y de todos. La verdad se experimenta como un peso que detiene y pertrifica, y no como algo que nos mueve por la alegría del descubrimiento. Es una muestra más de la inocencia sacrificada y por él, por el sacrificio que soporta hasta el extremo Antígona habrá de ir desatándose, desenredándose el nudo de la entraña familiar y de la historia de la ciudad. Bien claro se lo dice

\footnotetext{
${ }^{5}$ Ibid., p. 48.

${ }^{6}$ Ibid., p. 48.

${ }^{7}$ Ibid., pp. 52-53.

${ }^{8}$ Ibid., p. 50.

${ }^{9}$ Ibid., p. 49.
} 
Edipo en este encuentro: “Tú eres mi razón”. Aunque esto mismo se lo podría haber dicho a Antígona cualquiera de los personajes que la visitan. Porque extraviados en el error, buscan la salida. Buscan salir de la historia que los tiene apresados: esa es su razón que sólo puede poner en circulación Antígona. Se trata de hacerlos nacer más allá de la pesadilla en que yacen encadenados." ¿Cómo voy a poder hacerlos nacer a todos? Pero sí, yo, yo sí estoy dispuesta. Por mí, sí; por mí, sí. A través de mî” ${ }^{10}$.

Vale la pena detenerse un instante para saber con rigor qué nace de la piedad, el oficio de la tragedia. Mucho debe el conocimiento griego a la idea del alumbramiento. Recuérdese a este respecto no más que la mayeútica socrática. Y entre Antígona y Sócrates se tienden puentes evidentes. También sufrió proceso y condena, en el lenguaje de Zambrano fue sacrificado a los ínferos de la ciudad. Ni Creonte, condenando a Antígona, ni los jueces (Anyto y Melyto) que condenaron a Sócrates supieron ver, tampoco quisieron, el anuncio profético de la nueva ley. La verdad socrática habrá de nacer de las tribulaciones de la reflexión; no es mejor ciudadano el que se deja subyugar por la ley - ley de cualquier forma de poder, de las muchas que subyugan al hombre-, sino el que se vincula reflexivamente a la ciudad. El amor a la polis es indisoluble del esfuerzo compartido (diálogo) por alumbrar la verdad. La verdad nace; no es cosa, pues, de imponerla ante-dicha, como sucede con todo poder que se impone desde el terror. Y no hay que olvidar que el profetismo de la nueva ley es el amor, frente al resorte de la vieja ley que es el terror.

El oficio de comadrona de Antígona habrá de ser muy otro, aunque conservándose ese vínculo que hemos subrayado. El saber no nace de la reflexión, sino del delirio que a su término, en su máxima agudeza estalla con inaudita claridad, claridad nacida del extremo mismo del delirio, cuyo fruto es soledad y libertad, liberando, pues, a cada personaje de ser apéndice de la desdicha que abrasa a toda la estirpe. Liberación que convierte al personaje en persona, liberándole de la máscara que le oprime. No otro es el nacimiento que está tras la súplica de Edipo: "Ayúdame, hija, Antígona, no me dejes en el olvido errando. Ayúdame ahora que voy sabiendo, ayúdame, hija, a nacer"11. Esa mayeútica la refuerza la nueva sombra-huésped que visita la tumba de Antígona cuando el fantasma de Edipo se disuelve tras su súplica. Esa nueva sombra es la nodriza Ana. A ti, niña, "te espera otra cosa mejor que el descanso"12. Ana asocia a Antígona por entero al elemento agua: “...estabas siempre pegada al agua y luego con el cantarillo, siempre a vueltas con el agua como si fueras del agua y no de la tierra; del agua, del aire". Asociación que refuerza el ya mencionado

\footnotetext{
${ }^{10}$ Ibid., p. 53.

${ }^{11}$ Ibid., p. 53.

${ }^{12}$ Ibid., p. 56.
} 
oficio de lavandera, el lavado de la roca por el que fluye la sangre de la historia familiar y política, los inferos de la familia y de la polis. Y así se lo hace constar su nodriza: "La historia, niña Antígona, te esperaba a ti, a ti. Por eso estás aquí, tan sola. Por la historia”. ${ }^{13}$ La réplica de Antígona fija admirablemente la acción que inspira la piedad en el oficio de lavandera: “....ahora necesito saber el porqué de tanta monstruosa historia. Contigo me olvidé de estar aquí, y me limpié de todo. Ana, sin tocar tu agua, tú me has lavado. Estoy limpia, limpia. Tú me has lavado. Y ahora necesito lavar"14. A Edipo le había dicho: estoy dispuesta a hacerlos nacer a todos. Ahora, a su nodriza le dice: "necesito lavar". La conciencia-Antígona va ensanchando su ganancia.

Luego viene el fantasma de la madre que acrecienta la conciencia-Antígona despejando el horizonte de su acción: "La sombra de mi madre entró dentro de mí, y yo doncella he sentido el peso de ser madre. Tendré que ir de sombra en sombra, recorriéndolas todas hasta llegar a ti, Luz entera"15. Claro está que ha de recorrer Antígona las sombras como el agua corre y lava; claro está que ha de ser hija y madre virgen, sentirse así para que se cumpla el alumbramiento. Ser madre-mediadora para que se cumpla su particular mayeútica.

Pero a Antígona le estaba reservado ser inspirada por una inspiración contraria, esa que le anima a detenerse ante el terror del poderoso. A dejar la historia cancelada y propagada en forma de mortífera peste. La arpía se cuela en la vivificante tumba de Antígona para impedir que la pesadilla en que se hunde la historia suba a la superficie de la conciencia, pues la arpía es < de las que se deslizan por los laberintos, cuchicheando>. No olvidemos que el cuchicheo es el rumor en que la verdad queda detenida en su infierno. Valga pues este aforismo que improvisamos: El rumor es el infierno de la verdad. El rumor confunde, la arpía dice: "A mí, me temen. A ti, alguien te ama. Es lo mismo". A lo que replica Antígona invocando la nueva ley que profetiza y encarna y sobre todo, desmantelando la envilecida confusión de la harpía: "No, es todo lo contrario. La Ley del Amor es muy distinta de la Ley del Terror y ni siquiera se puede decir que sean todo lo contrario"16. La arpía sale expulsada de la intimidad de Antígona. Las palabras con las que la expulsa invocan la fuerza y el motor de la nueva ley que profetiza Antígona: "Vete, razonadora. Eres Ella, la Diosa de las razones disfrazada. La araña del cerebro. Tejedora de razones vete con ellas. Vete, que la verdad, la verdad de verdad viva tú no la sabrás nunca. El amor no puede abandonarme porque él me movió siempre, y sin que yo lo buscara. Vino él a mí y me condujo" ${ }^{17}$. La sombra de los hermanos

\footnotetext{
${ }^{13}$ Ibid., p. 58.

${ }^{14}$ Ibid., pp. 58-59.

15 Ibid., p. 63.

${ }^{16}$ Ibid., pp. 65-66.

${ }^{17}$ Ibid., pp. 69-70.
} 
ahonda en el hundimiento familiar y proyecta el triunfo de Creonte. Tebas es ya propiedad de él, el que os venció a los dos y a todos, sin ser por ello victorioso"18. Tomémosle prestada a Marguerite Yourcenar la caracterización última de Creonte, pues "acostado en el lecho de Edipo, descansa sobre la dura almohada de la razón de Estado" ${ }^{19}$. En contraposición, "el péndulo del mundo es el corazón de Antígona"20. Pues en él afloran los frutos, los frutos del sacrificio, su sentido.

Del diálogo con los hermanos y Hemón nace el plano y el alzado de la ciudad prometida, Polinices es su alarife, "fundaremos la ciudad de los hermanos...en ella no hay sacrificio, y el amor, hermana, no está cercado por la muerte. Allí el amor no hay que hacerlo, porque se vive en él. Nadie nace allí, como aquí de este modo. Allí van los ya nacidos, los salvados del nacimiento y de la muerte...uno piensa sin darse cuenta, sin ir de una cosa a otra, de un pensamiento a otro. Todo pasa dentro de un corazón sin tinieblas. Hay claridad porque ninguna luz deslumbra ni acuchilla, como aquí, como ahí fuera" ${ }^{1}$. Por su parte, Creonte, la persuade para hacerla engranaje de la razón de Estado, reduciéndola al primitivo estado de catástrofe y hundimiento. La pretensión de Creonte es que Antígona se doblegue frente a la voluntad de hierro de la heroína: no traspasar la puerta de la tumba ("esa puerta"), con voluntad de retornar, sometiéndose a la halagadora servidumbre de su razón de Estado, pero no es Antígona espécimen de la servidumbre voluntaria, sirviéndonos del concepto que acuñó magistralmente el barón de la Böetie. Creonte se dirige a ella con voluntad de ganársela: "Como siempre, te adelantas: antes a mi justicia, ahora en mi clemencia. Vengo a sacarte de esta tumba. La muerte de mi hijo, precipitado como tú, me impidió sacarte de aquí a tiempo para que celebrarais vuestras nupcias. Yo quería sólo darte una lección.”22 Antígona se planta en una admirable resistencia que se concreta en un reiterado no. Es de notar que ante Creonte, como ante la arpía, Antígona hace gala de fina ironía y hasta espeta con sarcasmo. No sucede lo mismo en la intimidad de las restantes sombras. Sólo hace Antígona gala de ellos ante aquellos que ostentan el poder y sirven a la Vieja Ley, como Creonte, o ante aquellos que le sirven declaradamente, como la arpía. La persuasión con la que Creonte trata de ganarse a Antígona sacándola de la tumba y convirtiéndola en su cómplice y aliada logra erigir en torno a la doncella un muro sin asedio posible que la hace invulnerable, ya sin temor ni temblor. Pisa un lugar no en la tierra. En contraposición al reino de Creonte: “ya no pertenezco a tu reino", el reino que

\footnotetext{
${ }^{18}$ Ibid. , p. 73.

${ }^{19}$ Yourcenar, M., Fuegos, Trad. Emma Calatayud, Alfaguara, Madrid, 1982, p. 57.

${ }^{20}$ Yourcenar, M., Fuegos, cit., p. 57.

${ }^{21}$ La tumba de Antígona, Mondadori, Madrid, 1989, pp. 79-80.

${ }^{22}$ Ibid., p. 85.
} 
es encrucijada de todas las historias, Antígona muestra su reino en ese más allá indefinible e inapropiable. Ese reino que adivinaba Polinices inasequible para la imaginación, pero diáfano para la iniciación: "Estoy ya entrando en un reino. Voy ya de camino, estoy más allá de donde a un alma humana le es dado el volver". ${ }^{23}$ En esas cimas que ha alcanzado Antígona la comunicación con Creonte se hace imposible. Ante las súplicas del rey por rescatarla de la tumba y devolverla a Tebas como si nada hubiese pasado, Antígona opone el seco escudo del no. Se interpone una Babel entre ellos. "¿Y qué diré a tu hermana que te espera?"-le pregunta Creonte con ánimo desesperado por ablandarla, y le replica Antígona: "Díle, si te acuerdas bien, -no cambies mis palabras- que viva por mí, que viva lo que a mí me fue negado: que sea esposa, madre amor. Que envejezca dulcemente, que muera cuando le llegue la hora, que me sienta llegar con la violeta inmortal, en cada mes de abril, cuando las dos nacimos"24. Naturalmente para Creonte eso son cosas suyas: no te puedo entender, dice en el abismo de su impotencia el poderoso, pero ¿cómo? Si ese sol que sigue Creonte, ya no es el mío-concluye Antígona.

El monólogo final de Antígona es el cumplimiento de su vocación. E1 delirio errático del desvarío con que se abría la obra se ha ido amansando en los sucesivos encuentros, a través de ellos, porque eso es lo propio de Antígona: atender al juego de todos, al juego total, naturalmente, pagando prenda: "Porque la prenda pagada es el inevitable sacrificio que libra de la carga heredada y la genérica. Se paga por ser hijo y por ser simplemente hombre y sólo entonces se abre el camino de la vida individual; sólo a partir de entonces se puede ser uno mismo. Al atender al juego total, como Antígona, se cierra el proceso trágico. El justo que paga abre el camino de la libertad"25 (25). La herencia de Antígona es ese camino. Acaso por ello haya sido tan solicitada en los derrumbes de la historia, porque entonces lo que se invoca es la vida que descubre la maravillosa lámpara de Antígona: la Nueva Ley.

${ }^{23}$ Ibid., p. 86.

${ }^{24}$ Ibid., p. 87.

${ }^{25}$ Zambrano, M., El hombre y lo divino, Méjico, F.C.E., 1986, pp. 224-225. (Nota adicional) Frente a la forma peculiar de M.Zambrano de escribir arpía con hache en el texto de Mondadori, he preferido escribirla sin hache conforme a la ortografía académica. 


\title{
AdAPTACión de un TEMA CLÁSICO A UNA TENDENCIA DEL TEATRO ESPAÑOL DEL SIGLO XX: LA NIETA DE FEDRA De Halma Angélico
}

Aurora López Universidad de Granada

\begin{abstract}
Dentro de las incontable reelaboraciones que se han realizado en el mundo moderno y contemporáneo del tema literario de Fedra e Hipólito, existe una muy interesante reescritura, apenas conocida y nunca estudiada con atención, titulada La Nieta de Fedra, publicada bajo el pseudónimo de Halma Angélico (Madrid, 1929), que corresponde a la escritora balear María Francisca Clar Margarit (Palma de Mallorca, 1880 - Madrid, 1952), curiosa y muy interesante dramaturga, perteneciente además a un tiempo en que eran muy escasas las mujeres que escribían teatro. Esta nueva versión del personaje de Fedra guarda una curiosa relación con la Fedra (1910) de Unamuno, y La malquerida (1913) de Benavente, aspecto que se contempla en este trabajo.
\end{abstract}

\section{Halma Angélico.}

Es necesario de vez en cuando recapacitar sobre el camino andado por las mujeres durante siglos, seguir manteniendo la llama encendida sin dejar de luchar para que no se extinga. Este lugar, Mar del Plata, tiene el poder del influjo y el peso de escritoras pioneras a las que personalmente admiro: Alfonsina Storni y las hermanas Victoria y Silvina Ocampo. A la memoria de las tres dedico esta investigación sobre una mujer poco conocida, autora teatral que ha ocupado un pequeño espacio en la dramaturgia de comienzos del siglo $\mathrm{XX}$ y que nos ofrece una reescritura del mito de Fedra en una de sus obras cuyo título es La nieta de Fedra.

Nuestra dramaturga, María Francisca Clar Margarit, que se esconde bajo el pseudónimo de Halma Angélico, nació en Palma de Mallorca en 1888, año natalicio igualmente de una gran luchadora por los derechos de la mujer, Clara Campoamor. Debido a que era hija de militar, vivió por algún tiempo en la isla filipina de Luzón, de la que su padre había sido nombrado gobernador. Después de la independencia de las Filipinas, en 1898, la familia se instala en Madrid, estudiando María Francisca en el Colegio del Sagrado Corazón.

La escritora se casa a la edad de 21 años y tiene dos hijos. Se sabe que se separó pronto de su marido y que se dedica a escribir cuentos y artículos de prensa en diarios como $\mathrm{ABC}$, Heraldo, Blanco y Negro, y también en revistas femeninas, como Mujer y Mundo Femenino. 
Publica sus dos primeras obras teatrales en los años 1920 y 1922 bajo un pseudónimo distinto, Ana Ryus; eran sus títulos Los caminos de la vida (1920) y Berta (1922); la segunda de éstas se publicará de nuevo en 1929, esta vez con el título de La nieta de Fedra, adoptando entonces la autora el nuevo pseudónimo de Halma Angélico. En 1932 estrena en el Teatro Muñoz Seca de Madrid Entre la Cruz y el día, con la compañía de Margarita Robles y Gonzalo Degrás manteniéndose en cartel desde el 11 al 26 de junio.

En 1936 la Editorial Aguilar publica un volumen prologado por Cristóbal de Castro con el título Teatro de Mujeres, que contenía una selección de tres autoras Pilar Valderrama, Matilde Ras y Halma Angélico. La obra de nuestra autora que se edita lleva por título Al margen de la ciudad. Plantea en ella nuestra dramaturga el tema del deseo reprimido, al que pone cotos una educación determinada. Halma Angélico se opone a lo considerado moralmente correcto por la sociedad del momento, llegando al extremo de indicar en una acotación que una de las protagonistas saliese desnuda de una piscina; como era de esperar, tan censurable acción no llegó a producirse, entre otras razones porque la obra no se representó.

Finalmente el 25 de agosto de 1938 se estrena en el Teatro Español de Madrid $A K$ y la humanidad. La obra se basa en un cuento ruso y suscitó una auténtica guerra de los cenetistas contra nuestra autora, que pertenecía a dicho sindicato. La polémica se sustentó por una acusación de plagio del cuento de Jefin Sosulia. La consiguiente suspensión de la representación finalmente llevó a la autora a presentar su renuncia al Sindicato de Autores con la baja en dicho sindicato "por la campaña que la prensa confederal realiza contra su adaptación de $A K$ y la Humanidad". La guerra civil española llevó a la cárcel a la autora, por una duración de tres meses, bajo la acusación de republicanismo. Murió en Madrid el 9 de noviembre de $1952^{1}$.

Con estas pocas notas biográficas podemos imaginar la intensa actividad luchadora de nuestra autora, que fue precisamente la última presidenta de una institución que se preocupó por la formación feminista, el Lyceum Club. Perteneció además a la Asociación de Mujeres de España, de la que fue vicepresidenta en 1935, así como a la Unión de Mujeres de España.

\section{Algunas consideraciones sobre las mujeres y el teatro.}

La mitología clásica ha sido utilizada en la escritura de mujeres en todos los géneros literarios, logrando a través de distintas recreaciones o

${ }^{1}$ Los datos referentes a la vida de Halma Angélico, así como a sus publicaciones, los tomo fundamentalmente de la magnífica introducción de Fernando Doménech Rico, en AK y la Humanidad de Halma Angélico. Comedia inspirada en el cuento original del escritor ruso contemporáneo Jefin Sosulia (1938), Madrid, Publicaciones de la Asociación de Directores de Escena de España, 2001. 
transformaciones una propia expresión de sus propios yo y de los problemas sociales de su entorno. Por otra parte, dentro de la dramaturgia femenina, las obras del teatro greco-latino, portador de innovaciones del mito en los diversos autores y épocas, aportan no pocas reflexiones a las autoras y las empujan a realizar originales, en las que juega el deseo de presentar su propia autoridad en la creación.

Dentro de los géneros literarios cultivados por mujeres, el teatro, debido a múltiples factores derivados de la labor de los críticos, del desconocimiento y la opinión generalizada de que se trata de un género no adaptado a las mujeres..., también de la no menos problemática puesta en escena, ha sido el más tardío en poner de manifiesto la presencia de nombres de cultivadoras y de obras de creación teatral femenina. Sin embargo, una vez más la ausencia de las mujeres en este campo de la creación literaria no era tan absoluta y contundente como venía afirmándose; también aquí la labor de recuperación de autoras y de textos realizada en los últimos años por críticos y críticas feministas ha dado a luz a un alto número de autoras que cultivaron y cultivan diferentes modalidades teatrales ${ }^{2}$.

Dentro del panorama teatral español que media entre 1918 y 1936, la investigadora Pilar Nieva habla de 98 títulos de obras dramáticas que están firmados por 40 autoras y adaptadoras, recogidos en la prensa periódica. Dentro del grupo de autoras totalmente olvidadas la investigadora cita las siguientes: Pilar Algora, Halma Angélico, Adelina Aparicio y Osorio, Elena Arcediano, Carmen Baroja, Sofía Blasco, María Teresa Borragán, Adela Carbone, Carmen Díaz de Mendoza (Condesa de San Luís), María Luisa Madrona, Isabel Oyarzábal, Matilde Ras ${ }^{3}$. Estoy de acuerdo con la investigadora en que la situación social y política de la época es siempre necesaria para abordar las causas de este desajuste que, sin poder entrar en detalles, serían de forma esencial socialmente el bajo nivel educativo, que empieza a ser piedra de toque en los principios y actividades de la Institución Libre de Enseñanza, y a su lado una dependencia familiar de las mujeres, tanto de padres como de maridos,

${ }^{2}$ Por recordar algún ejemplo conspicuo, de notable interés resulta la labor realizada por Pilar Nieva de la Paz con la publicación Autoras dramáticas españolas entre 1918 y 1936, Madrid, CSIC, 1993; por su parte Juan Antonio Hormigón dirige la recopilación de datos sobre autoras desde el siglo XVI al XX en Autoras en la Historia del Teatro Español (1500-1994), vols. I y II, Madrid, ADE, 1996-1997. Labor muy destacada es la llevada a cabo por María José Ragué, no sólo con su fundamental monografía El teatro de fin de milenio en España (de 1975 hasta hoy), Barcelona, Ariel, 1996, sino con trabajos que interesan a la pervivencia del teatro antiguo, en los que tiene siempre presentes las reescrituras femeninas, como el ya clásico Lo que fue Troya. Los mitos griegos en el teatro español actual, Madrid, Asociación de Autores de Teatro, 1992 (sin olvidar que ella misma es muy interesante dramaturga, como puede comprobarse en creaciones como Lagartijas, gaviotas y mariposas (Lectura moderna del mito de Fedra), $\quad$ Murcia, Universidad, 1991.

${ }_{3}^{3}$ Pilar Nieva de la Paz, Autoras dramáticas españolas entre 1918 y 1936, cit., p. 63. 
siempre relegadas a un espacio privado que las elimina de la esfera política, sin tener siquiera acceso al voto.

La dedicación al teatro implica la necesidad de estrenar en locales comerciales, donde se contempla como elemento básico el éxito económico. No obstante nuestras autoras prescinden un tanto del aspecto comercial y presentan sus innovaciones, de corte un tanto feministas como La nieta de Fedra, en los llamados teatros de salón ${ }^{4}$, como el Teatro de la Escuela Nueva, fundado por Rivas Cherif en 1920, quien posteriormente fundó E1 Cántaro Roto (1927) y El Caracol (1928). Especial recuerdo merece aquí la fundación de un teatro-tertulia, llamado Fantasio, llevada a cabo por Pilar de Valderrama 5 .

\section{La nieta de Fedra.}

La obra que nos ocupa lleva en la portada, además del título y pseudónimo que ya conocemos, la leyenda "Teatro irrepresentable". Cuenta con un prólogo de Alejandro Bher, pseudónimo de María Valero de Mazas, seguido de otro prólogo de la autora. Está editada en Madrid, en los Talleres Tipográficos Velasco, Meléndez Valdés, 52, Año 1929.

El prólogo lleva una cita de la propia Halma en modo alguno inconsecuente: "Si has sufrido mucho y luchado por vencerte..." Considera a la autora con talento, que escribe desde dentro afuera, dando a entender que la escritora no sigue preceptivas literarias específicas asimiladas sino que deja libertad a su creación y la considera una "pluma alta". Refiriéndose a la obra, remarca la personalidad de todos los personajes: la sirvienta vieja, los dos paletos, los dos seminaristas, la bruja, y los dos personajes femeninos centrales: Berta y su hija Ángela. De Berta el prólogo nos dice: "estatua viva de la soberbia castigada", de Ángela afirma que "sabe ser fuerte por el solo impulso del corazón”. Como punto final de este prólogo, quiero destacar la máscara lingüística con la que oculta su rostro la autora, utilizando un nombre de hombre para de este modo dar más autoridad y trascendencia al escrito.

Halma Angélico abriga el convencimiento de que ha escrito una obra con pocas posibilidades de representarse, teniendo más episodio narrativo que puramente teatral, con una preocupación de desvelar las causas que provocan las acciones de sus personajes. Sabe que cuenta con antecesores muy valorados, pero se anima a escribir también ella, hacerlo pensando quizá que no son mujeres las que hablan de sí mismas, sino hombres.

\footnotetext{
${ }^{4}$ Para una información más amplia cf. Pilar Nieva de la Paz, Op. cit., p. 168 ss., donde se estudian los teatros caseros y todo lo referente al mundo teatral de esos años.

${ }^{5}$ Mayor información en Shirley Mangini, Las modernas de Madrid, Barcelona, Ed. Península, 2001, pp.187-193, de gran interés por su atención a los hechos teatrales.
} 
Nos encontramos con la técnica propia del discurso femenino: en primer lugar, la llamada captatio benevolentiae de la retórica greco-latina, que en las escritoras tiende a ser una de las estrategias para hacerse escuchar, consistente en rebajarse ellas y poner como valiosos los escritos masculinos, entrando de puntillas en dicho espacio, aunque reafirmando su personalidad de mujer escritora. Así Halma ha jugado con un título que tuvo un espacio en el teatro greco-latino, Fedra, pero la reescritura del mito le hace pensar en otras anteriores, apelando a la autoridad masculina de dos grandes autores: Racine y Unamuno. El deseo de autoría se muestra en el título La nieta de Fedra, que explica muy bien todo lo dicho: "he querido nombrar mi obra de este modo por respeto a la valía del asunto, y, ya que varios maestros de la Literatura, entre ellos Racine y nuestro (sic) gran Unamuno sintieron la misma inquietud de trasladar a diferentes tiempos la misma complicación tejida de diferente modo, yo, respetando la altura de estos maestros, anonadada por su grandeza y mi pequeñez, no me atrevo a dar a mi humanizada Fedra (Berta en este caso), el nombre clásico, ni tampoco hurtárselo del todo con dudosa fidelidad”. E1 texto continúa queriendo darle a esta Fedra una filiación diferente a la clásica al definir al personaje "mi Berta, justamente castigada en su soberbia, lucha con una pasión semejante a la de aquella". Así ha introducido un motivo para lograr la atención del lector que la retórica clásica contemplaba para un tipo de exordio: un asunto nuevo. Finaliza la presentación con una consideración que es ni más ni menos que una justificación de la pervivencia y de recepción de un texto clásico: "Así me amparo en el escudo glorioso de un nombre consagrado, que, a través de los siglos, se sucede en el mundo literario en diferentes formas de concepción, con mayor o menor acierto, pero sin interrumpir su estela jamás, por ser tan fatídicamente humano".

La obra se desarrolla en dos espacios temporales con dos decorados distintos, que marcan la ambientación en la que se mueven personajes diferentes, manteniéndose solo dos, Berta y la criada Paula, en las tres "jornadas" en las que se divide la obra. Dichas "jornadas" se subdividen en diferentes escenas.

La primera "jornada" se desarrolla en el interior de una vivienda y sirve de introducción para presentar al personaje Berta desde el punto de vista de la educación recibida de su madre, Mónica, mujer soltera que ha ocultado a su hija no solo su procedencia, sino que ha urdido una mentira: su marido ha muerto. La madre ha mantenido una educación que pretende evitarle caer en su propio comportamiento y educa a su hija en la rigidez, en una moralidad cristiana, creando una persona carente de humanidad a la que ha procurado que no le falte nada. Hay que añadir que la propia madre es precisamente todo lo contrario, una mujer cariñosa que está pendiente de esa hija y que rechazó luego al hombre padre de la joven, afrontando un papel difícil en la sociedad en la que vive. 
Paula, que lleva como criada en la casa veinte años, es de la misma edad que Mónica y ha sido su apoyo, su confidente y en el momento ambas están preocupadas por Berta, que sale con un joven. A ello se une una enfermedad de corazón que padece Mónica, que es tratada por un médico amigo, quien conoce al joven que anda con Berta; el médico le ha explicado la situación de madre soltera de Mónica, cosa que no importa al joven, también médico, que alaba la decisión de Mónica de no querer casarse y "olvidarse de razones y perjuicios que la sociedad tiene en cuenta".

Mónica denuncia lo que conlleva ser mujer en circunstancias como las suyas, en el seno de una sociedad que se preocupa de las apariencias, el mal, lo feo antes que lo bello. Un diálogo posterior entre Berta y Mónica refleja la falta de consideración y un orgullo personal de una "doña perfecta" en la hija, refiriéndose en este caso a las prostitutas: "Toda mujer tiene un honor que defender; si no sabe hacerlo, no merece compasión sino desprecio".

El drama madre-hija llega a su punto álgido en la confesión de la madre y en la crueldad de la hija para con ella. Paula, la criada profetiza: "teme el castigo que merece tu soberbia"

En la segunda "jornada" han transcurrido 17 años, en los que Berta ha quedado viuda con una hija, Ángela, y se ha vuelto a casar con un viudo Martín Conde, que también tiene un hijo, Lorenzo; además, tienen también un hijo de ambos. Es ahora realmente cuando el tema Fedra comienza.

El decorado nos traslada a un vestíbulo de una casa de campo perteneciente a un hacendado, Martín Conde. Estamos ahora en ambientes rurales, en los que se desarrolla una sociedad que a la autora no le es ni mucho menos indiferente, pasando revisión a personajes que son tipologías, como los dos amigos Sebastián y Cosme, que rehúyen responsabilidades personales después de haberse divertido con una joven a la que uno de ellos ha dejado embarazada.

No queda excluido el clero, esta vez en formación, representado por Lorenzo y por Román, con maneras de pensar religiosamente diferentes, donde se intuye claramente en el último una gracia sarcástica que no deja de ser producto de su origen social bajo, que intenta paliar empleando un lenguaje cargado de frases latinas. Dicho personaje refleja a las mil maravillas la educación que recibían en el seminario los jóvenes con relación a las mujeres, consideradas como un peligro encasillándolas en dos tipos: ángel o demonio. Además utiliza lo que es un servicio a la sociedad como un medio para acceder a puestos de importancia, cosa que no alcanzarían por otras vías las clases bajas. Lorenzo, en cambio, refleja en todo la educación recibida, con una buena disposición que incluso le llevó a entrar en el seminario porque le gustaba a su madre.

Dentro de esta crítica religiosa no se excluye la de las órdenes religiosas femeninas, que no aceptan el ingreso en sus filas de mujeres que no vayan 
provistas de una buena dote. La figura que centraliza esta cuestión es María Misericordia, amiga de Ángela. La joven acude a Martín para que le ayude a solucionar un doble problema, la falta de dinero y todo el rechazo que provoca su condición de "inclusera", palabra utilizada por Román, que dice: "No tiene nombre y en muchos conventos no la quieren".

Para que no falte nada en el análisis crítico del panorama humano y social, el drama también plantea el problema de la emigración, causada por suprimir los grandes hacendados el arriendo de sus tierras a los que las cultivan, prefiriendo proceder a la venta de las mismas.

Llegamos así al tema Fedra cuyo hipotexto más próximo, recordando las afirmaciones del Prólogo, se encuentra en los dramas homónimos de Racine ${ }^{6}$ y Unamuno ${ }^{7}$. Parece claro que la $\mathrm{Fe} d r a$ de Racine es la base de la creación de la joven Ángela, la Aricia francesa con la que Racine puso ante el público una modernización hecha para una sociedad diferente, que busca divertirse y enredarse en líos amorosos, que se interesa por problemas sucesorios y por la guerra. Igualmente la irrupción de un triángulo amoroso es producto de esta misma sociedad. La Fedra de Racine siente el poder de los celos al mismo tiempo que el amor apasionado por Hipólito. Igualmente Berta sufre de celos más odiosos todavía porque es su hija Ángela ${ }^{8}$ el objeto de los mismos,

${ }^{6}$ De la abundante bibliografía existente sobre la Phèdre de Racine, de la que también yo me he ocupado en diversas ocasiones, quiero recordar aquí: ediciones: Oeuvres de Racine (con el título Phèdre et Hippolyte), Paris, C. Barbin - J. Ribou, 1676 ("achevé d' imprimer", marzo de 1677); Oeuvres de Racine (con el título Phèdre), Paris, C. Barbin - D. Thierry, 1687; trads. esps.: de R. Chacel, Madrid, Alfaguara, 1983; de M. D. Fernández Lladó, Madrid, Cátedra, 1999; Estreno: 1 de enero de 1677, Hôtel de Bourgone, París; A. W. Schlegel, Comparaison entre la Phèdre de Racine et celle d'Euripide, Paris, 1807; L. Goldmann, Jean Racine dramaturge, Paris, L'Arche, 1956; A. Niederst, Racine et la tragedie classique, Paris, P.U.F., 1978; A. López, "Amor y culpa en Fedra: Eurípides, Séneca, Racine", en A. Pociña - A. López, Fedras de ayer y de hoy..., cit., pp. 147-169; A. López, "Nuevo escándalo de Fedra en el París de 1677: el estreno de Phèdre et Hippolyte de Jean Racine et de Jacques Pradon”, en A. Pociña - A. López, Fedras de ayer y de boy..., cit., pp. 323-335; etc.

${ }^{7}$ Primera edición en la Revista La Pluma (Madrid), 1921, núms. 8, 9 y 10; M. de Unamuno, Teatro completo. Prólogo, ed. y notas bibliográficas de M. García Blanco, Madrid, Aguilar, 1959; estreno, 25 de marzo de 1918, Teatro Ateneo de Madrid; traducida al it. por Gilberto Beccari, R. Carabba Editore, Lanciano, 1921. Entre la abundante bibliografía, cf. F. Lázaro Carreter, "El teatro de Unamuno", Cuads. de la Cátedra Miguel de Unamuno 7 (1956) 5-29; A. Franco, El teatro de Unamuno, Madrid, Ínsula, 1971; J. S. Lasso de la Vega, "Fedra' de Unamuno", en De Sófocles a Brecht, Barcelona, Editorial Planeta, 1974, pp. 205-248; A. Pociña, "Seneca e le sue opere nel teatro spagnolo del XX secolo”, en I. Dionigi (ed.), Seneca nella coscienza dell'Europa, Milano, Mondadori, 1999, pp. 299-325; C. Morenilla, "La obsesión por Fedra de Unamuno (1912), Villalonga (1932) y Espriu (1978)”, en A. Pociña - A. López, Fedras de ayer y de boy..., cit., pp. 435-480; etc.

8 Sólo conozco otro caso de reescritura del tema de Fedra en el que la protagonista tenga una hija que intervenga como personaje autónomo en el desarrollo de la obra: se trata, sorprendentemente, de Phaedra's Love (1996), de Sarah Kane, donde Fedra tiene una hija, Estrofa, que tiene un papel fundamental en el diálogo con su madre en la Escena 3. 
pues ama a Lorenzo y es correspondida. Además la solución final del drama difiere poderosamente en este hipotexto en que no existe la muerte física de la protagonista: Fedra es condenada a vivir por su marido, Martín, incapaz ella misma de darse muerte debido a sus problemas educacionales.

La nieta de Fedra se acerca a la de Unamuno en la composición del ambiente, rural en ambos casos, con ideas, creencias y perjuicios muy semejantes: curiosamente, tres años después de la composición de la Fedra unamuniana, se estrena en Madrid, el 12 de diciembre de 1913, La Malquerida de Jacinto Benavente, que también resulta en cierto modo una reescritura, desde luego más alejada, del problema amoroso familiar que sirve de núcleo a las versiones de Fedra. Descubrimos, pues, una tendencia a un tipo de drama rural, familiar, de costumbres, que subyace en la base de las tres obras que contemplamos, por orden cronológico la Fedra de Unamuno $(1910)^{9}$, La Malquerida de Jacinto Benavente $^{10}$ y La nieta de Fedra de Halma Angélico. Tanto Berta como la Fedra unamuniana y la Raimunda de Benavente se mueven constreñidas por su condición de amas de casa rurales, por la sociedad ancestral que las rodea, pero sobre todo por su férrea ideología cristiana, de la que no se había librado tampoco la Fedra de Racine, por más que el dramaturgo francés pretendió mantener su drama en el pasado clásico.

Ángela es el personaje modélico, capaz de salvar a su madre de una situación embarazosa en la que la pasión desenfrenada de Berta ha estallado dentro de un espacio escénico marcado con una iluminación baja. La contrafigura, Ángela se matiza siempre como comprensiva, alegre, amante de los libros, de la naturaleza, siempre dispuesta a ayudar. Se diría que es más hija de su abuela, Mónica, que de su madre, y ello se debe a la acción de su criada Paula, una "nodriza" clásica muy especial que sigue las líneas de cariño y ayuda marcadas por los cánones clásicos a esta figura de las tragedias.

Berta es un carácter seco, adusto, concentrado, con mucho genio, producto sin duda del orgullo de ser una mujer sin fisuras morales en su pasado, pero que sufre la derrota de no ser la que fue, de amar a quien no debe. Para matizar esta situación la autora rompe el silencio de ese amor furtivo recordando Ángela cómo encontró a su madre besando una antigua fotografía de Lorenzo

${ }_{9}^{9}$ Aunque no se estrena hasta 1918, y no se publica hasta 1921, la Fedra de Unamuno circula ya a finales de 1911, llegando una copia al actor Fernando Díaz de Mendoza, el marido de María Guerrero, y al hispanista italiano Gilberto Beccari, que la traducirá y publicará en italiano. Toda esta información aparece muy bien documentada en M. García Blanco, "Introducción” al vol. XII de las Obras completas de Unamuno, p. 57 ss.

${ }^{10}$ Es indudable que Benavente conocía por lo menos la existencia de la Fedra de Unamuno, todavía no estrenada ni publicada. Está documentada la antipatía que el filósofo sentía por Benavente y su teatro; sin embargo, no consiguió aquél que su Fedra protagonizada por la famosa María Guerrero, que en cambio llevó a escena La Malquerida poco después, en 1913, desempeñando el papel principal de Raimunda. 
de pequeño, que se parece al hermanito de ambos. La reacción inmediata es el enfurecimiento de Berta, que casi pega a su hija creyendo que pueda sospecharse algo de su pasión por el hijastro, aunque no es esta la intención de la joven. La utilización del parecido Teseo joven - Hipólito sigue perdurando a través de las reescrituras, ahora modernizado con ayuda de la fotografía.

En una situación de desespero se queda sola en escena hasta que aparece Paula, quien sabe lo que le está ocurriendo a Berta, llegando a hacerle confesar que lucha por dominarse y que vencerá. Se ha mostrado de nuevo el cariño de Paula por Berta, reproduciendo las diversas situaciones, presentes en tantos hipertextos, del diálogo en Fedra y la Nodriza.

Llegamos así a la "jornada" tercera. Lorenzo confiesa a su padre su deseo de no volver al seminario, hecho que agrada a Martín, y que trasmite a Berta, produciéndose en ella una reacción rara. Quedan en escena Lorenzo y Berta, quien se da cuenta del enamoramiento del joven hacia su hija. La confrontación juventud-madurez, diferencia de belleza, provoca una relajación peligrosa, contemplada por una mala mujer, Mela, que hará de mensajera del hecho y que conseguirá todavía una mayor preocupación en Berta. En la escena VII, motivada por la oscuridad, por la confusión de Lorenzo que piensa que es Ángela a la que se declara, se va rompiendo la contención y llega a la confesión apasionadamente, sin trabas. Ángela contempla el proceso y como siempre se dispone a ayudar fingiendo que lo que ha sucedido es una cuestión suya y así se lo trasmite a Lorenzo.

La venganza corre a cargo de Martín-Teseo, quien conoce todo el asunto e innova con una solución de estilo propio: da paso al matrimonio de los jóvenes y ordena que se besen. La reacción que esperaba Martín se produce y la acotación escénica habla por si misma: Berta, tremante, sintiendo renacer en ella la pasión con mayor fuerza, se revuelve como una leona. Berta confiesa su pasión y pide que la mate, negándose Martín a hacerlo para que vea la felicidad de la pareja, lanzándole la palabra que sabe la lastimará más: Ramera.

Localizaciones diferentes, ambientes diversos, innovaciones acordes con los tipos de sociedad, denuncias que se enmarcan en ellas, permanencia de un mito con reescrituras diversas que llega para dar a las autoras sus propias visiones.

Halma Ángélico deja parte de su legado como mujer en la conversación de los dos personajes femeninos que más le agradan: Ángela y Paula. Dan valor a las madres solteras que se ocupan de sus hijos, culpando a los hombres por el abandono. La soberbia, una socialización de la culpa incluyendo en ello la educación que lleva a demonizar a las mujeres cuando son capaces de matar a sus bebés, sin culpar a la propia sociedad por ello. 
Berta es producto de una educación, una víctima del orgullo de ser como es, que queda desamparada ante la noticia dada por su madre de que es hija natural, por lo que rechaza a su madre y provoca su muerte. Es en este punto necesario señalar lo poco interrelacionadas que están madres e hijas en las reescrituras del tema, puesto de relieve de una manera especial por Unamuno. Los componentes mentales de la mencionada sociedad provocan en la protagonista la desazón que supone la soledad al sentirse excluida de ella. Apasionada, como las Fedras de las que es hija, o nieta, se arma con una coraza propia, un carácter duro, que contrasta con el poco coraje de exigir al marido que la mate.

Como hemos visto en la referencia a las otras obras la autora siguió luchando para alcanzar metas de libertad en la sociedad.

Para terminar, diré que la autora ha sido muy inteligente al poner en la portada de su drama “Teatro Irrepresentable”, por ese afán de meticulosidad explicativa de las escenas, que contrasta con el ideal de su Fedra expresado por Miguel de Unamuno. 


\title{
De Albert Camus a alejo carpentier: MITO Y TRAGEDIA CLÁSICA
}

\author{
Inmaculada López Calahorro \\ Universidad de Granada
}

\begin{abstract}
La obra de Alejo Carpentier se contempla como una polifonía de géneros, en la que el teatro de origen clásico ocupa un lugar fundamental. Así puede analizarse el conjunto de su obra en torno a los efectos de la Poética de Aristóteles, temor, compasión y catarsis. A los distintos trabajos que ya hemos realizado en este sentido, ahora sumamos este análisis que profundiza en la relación entre la obra de Carpentier y la creación teatral de Albert Camus, de modo que el modelo clásico presentado por el cubano pudo participar de la mediación de obras como Caligula o Los justos.
\end{abstract}

En este trabajo analizamos la influencia del teatro de origen clásico en la obra de Alejo Carpentier a través de la mediación de las obras teatrales de Albert Camus, en concreto Calígula (1945) y Los justos (1949) ${ }^{1}$. Aunque estamos ante una creación novelística, la de Carpentier, en cambio se puede decir que los géneros literarios se difuminan en ella aglutinando distintos códigos poiéticos ${ }^{2}$ que se hacen esenciales en su arquitectura literaria, integrando y marcando presencias y ausencias temáticas claramente identificadoras de esos otros modelos literarios. Desde un plano metafórico podemos decir que este entramado de códigos se asemeja al de estilos arquitectónicos que viene a reflejarnos también en su prosa. Es lo que Graziella Pogolotti viene a concretar a través de la mirada de Carpentier, de la que dice que "se somete a un voluntario ejercicio de selección" de modo que "la ciudad no es suma de monumentos arquitectónicos. No es tampoco un mero despliegue de estilos diversos. En ella, los tiempos, el presente y el pasado se solapan" (Pogolotti 2007: 182). Y, como los tiempos o los estilos, en la narrativa carpenteriana se enmascaran

${ }^{1}$ Sobre la relación entre ambos autores hay acercamientos puntuales. En nuestro libro Alejo Carpentier. Poética del Mediterráneo Caribe (2010) y en el artículo "Albert Camus y Alejo Carpentier. La luz del Mediterráneo Caribe” (en prensa), hemos profundizado en la relación entre sus obras literarias. Para el tema que nos ocupa sobre el teatro partimos de manifestaciones semejantes entre ambos autores como las siguientes: "Hay un sentimiento que conocen los actores cuando tienen conciencia de haber desempeñado bien su papel [...]. Esto era precisamente lo que yo sentía: había desempeñado bien mi papel. Había hecho mi oficio de hombre" (Camus, Bodas). "No hay mejor destino para el hombre que el de desempeñar cabalmente su oficio de Hombre'. Ese oficio de hombre, he tratado de desempeñarlo lo mejor posible. [...] Para mí terminaron los tiempos de la soledad. Empezaron los tiempos de la solidaridad' (Carpentier, Ensayos).

${ }^{2}$ Entendemos poiético en su sentido clásico de poíesis, esto es, como el acto de la creación artística. 
igualmente los códigos poéticos y los trágicos, conformando un magnífico palimpsesto que responde a la figura de un creador poeta, un mediador que, en palabras de Pageaux, se encargará de "ensamblar los elementos dispares, fragmentos de la naturaleza de la historia que solemos llamar 'real maravilloso" (Pageaux 2004: 112-3)3.

La obra de Alejo Carpentier la hemos estudiado en función de los efectos de la poética de Aristóteles, temor, compasión y catarsis (López Calahorro 2006) ${ }^{4}$. Ahora profundizamos en la posible mediación que también pudo ejercer la obra teatral de Albert Camus sobre el cubano, Calígula y Los justos, y que vamos a centrar en dos obras esenciales que evidencian la relación con la tragedia griega, "El acoso" (1956) y "El recurso del método" (1974). Las cuatro obras tienen como motivo temático central el tema del poder. Si la épica de Homero y Virgilio convive en la prosa de Carpentier entre viajes a las islas y las selvas, tanto las físicas como las de la memoria, haciendo de Ulises y de Eneas dos personajes fundamentales para la representación de estos viajes individuales e inquietudes personales del hombre moderno, son los personajes de la tragedia griega los que se asoman desde el principio de su obra literaria para ejercer sobre el lector una presión que lo conduce a la contemplación de un conflicto propio del siglo XX: el individuo vs. la colectividad. Podemos decir que los personajes de la tragedia vinculan la obra carpenteriana a procesos colectivos, en correlación con la dialéctica desarrollada de tiempo personal frente al tiempo de la historia, o, en palabras de Camus, rebelión frente a revolución, lo que viene a evidenciar el gran conflicto del siglo XX en torno al concepto "humanismo" . En la tensión de estos dos términos nos asoma el mito y la tragedia clásica para explicarnos, como hará Camus en El hombre rebelde (1951) que "hay una naturaleza humana, como pensaban los griegos, y contrariamente a los postulados del pensamiento contemporáneo. ¿Por qué rebelarse si no hay, en uno, nada permanente que preservar?" (Rebelde: 24). ¿Y qué hay de permanente en el ser humano que haya que preservar tal y como exponían los griegos? La rebeldía para Camus no es ni envidia ni

${ }^{3}$ En definitiva, en su obra encontraremos con absoluta naturalidad tanto una arquitectura poética donde elementos de las ciudades y de la selva confluirán para componer una poesía semejante a la que embargó a Masson entre pájaros de mármol (y que acaso recuerdan el cielo paralizado por los ojos de Gorgona (López Calahorro 2010: 79), o donde podemos escuchar de lejos los clamores trágicos de Filoctetes, mezclados con otros de Edipo entre las líneas de su narrativa.

${ }^{4}$ Incluso los estudios más novedosos inciden en algunos de estos elementos, como es el reciente libro de Anke Birkenmaier: "Carpentier incluso compara el poder catártico de un concierto de la Novena Sinfonía con el de la tragedia griega en tiempos de Aristóteles" (Birkenmaier 2006: 199).

${ }^{5}$ Este tema lo hemos desarrollado más ampliamente en: (López Calahorro http://www. lajiribilla.cu/2010/n468_04/468_06.html) Actualmente está en prensa. 
resentimiento, pues todo ello va contra el hombre en sí. Antes bien, "el hombre en rebeldía, por el contrario, en su primer movimiento, se opone a que toquen lo que es. Lucha por la integridad de una parte de su ser" (Rebelde: 26). La rebeldía, como vendrá a insistirnos Camus, es positiva, individualiza ${ }^{6}$, lo que se resume extraordinariamente en "Me rebelo, luego existimos" (Rebelde: 31). Esto es lo que ocurre en la narrativa carpenteriana que, lejos de reivindicar modelos colectivos condenados al fracaso, salva a determinados personajes, individualizados en todos los casos, con una clara coincidencia con personajes como Edipo cuya ceguera final representa la lucidez personal, la conciencia de su integridad. De este modo, la revolución colectiva del siglo de las luces es un fracaso, pero no la rebelión de Sofía, por poner uno de los ejemplos más significativos. Las desapariciones finales de los protagonistas tal y como sucede ante la bajada del telón del teatro permiten el proceso del tiempo y de la historia, esto es, se diluye el individuo y el alcance ya es colectivo. Esto es lo que representa la huida final de Edipo, como es la muerte de Calígula o de los protagonistas de las obras señaladas de Carpentier. Las reflexiones de Camus nos permiten pensar que la puesta en escena a través de esenciales agones es el instrumento para la rebeldía: "Calígula: No, Escipión, jeso es el arte dramático! El error en que caen todos esos hombres es que no acaban de creer en el teatro. Si no, sabrían que cualquier hombre puede permitirse representar las tragedias celestes y convertirse en dios. Basta con endurecerse el corazón.” (Calígula, 96).

A la luz de esta interpretación comprendemos también una de las razones por las que la representación teatral es tan importante en la novela carpenteriana, con lo que nos sorprende ya desde su primera obra narrativa, Écue-Yamba-Ó (1933), a pesar de ser la obra en que la temática afrocubana y etnológica la distingue del resto ${ }^{7}$. Con estas aparentes breves referencias a la tragedia griega Carpentier ejerce sobre los lectores una presión constante que nos obliga a imaginar a actores y coro de origen griego, los espectadores, el recital de agones y acompañamiento de coturnos, o las muertes escenificadas

${ }^{6}$ Por ejemplo, no sirve el colectivo se "ama a la humanidad en general para no tener que amar a los seres en particular" (Rebelde, 27).

7 Sin embargo, en ella ya se guarda el germen de un material preciado que seguirá utilizando durante toda su narrativa: así los coros trágicos a través de un "batallón de niños descalzos" que gritará "como un eco, en distinto diapasón: -Un negro preso, un negro preso (Ecué, 133). Pero también a través de un Menegildo que mirará al suelo y "su perfil era efigie de la testarudez" (ibid.), imagen que volverá a repetir en otras obras evocando a Antígona; o en esas breves referencias que nos mostrarán cómo "una mañana todos los chicos amanecían alzados en coturnos, como trágicos antiguos, con una lata de leche condensada debajo de cada pie" (Ecué: 173). Y todo convivirá con el escenario teatral de la santería, "mágico teatro, alumbrado, alumbrado levemente por unas candilejas diminutas colocadas dentro de tacitas blancas" (Ecué: 29). 
detrás del escenario, caso de El acoso. Es más, Camus escribe: "Antes de entrar en el reino de las ruinas, somos, por vez postrera, espectadores" (Bodas: 68), tan cerca de las palabras con las que Carpentier inicia el prólogo de El reino de este mundo ${ }^{8}$. Incluso podemos llevar más allá la asimilación del escenario teatral en la obra carpenteriana: la que identifica o diferencia la casa con el teatro como advertimos en Camus ${ }^{9}$. Será en El acoso donde la representación teatral de tragedia griega se identifique por completo con el ritmo de la vida del personaje, pues desde el principio sabremos que "Repartidos están los papeles en este Teatro, y el desenlace está ya establecido en el 'después' -hoc erat in votis'-, como está la ceniza en la leña por prender” (Acoso: 25). Esta arquitectura novelística integrada en la teatral, junto con el tema del atentado terrorista, pone de manifiesto la relación entre El acoso y Los justos.

En todas las obras de Carpentier Edipo ocupa un lugar fundamental. También para Camus que lo introduce en "El mito de Sísifo": "Pero las verdades aplastantes desaparecen al ser reconocidas. Edipo, por ejemplo, obedece primero al destino sin saberlo. A partir del momento en que sabe, su tragedia comienza" (Sísifo: 158). Para Camus, Edipo representará la victoria absurda: "Pese a tantas pruebas, mi avanzada edad y la grandeza de mi alma me llevan a juzgar que todo está bien" (Sísifo: 158). Edipo es un héroe mítico ambiguo como lo es Calígula. Como decía Adrados (1999: 188), es un héroe de lo humano, una ambivalencia que lo sitúa en una dimensión parecida a lo que ocurre con Calígula en orden inverso. Ambos personajes, por consiguiente, nos trasladan al territorio resbaladizo donde lo mítico y lo histórico difuminan sus límites, y lo hacen para ejemplificar con sus historias o mitos teatralizados el carácter del poder adquirido que los condena a la ceguera o a la muerte, respectivamente, en ambos casos como ejemplo de esa victoria absurda. Ambos sostienen el peso del destino: el Calígula de Camus dirá que "No puede entenderse el destino, y por eso me he erigido yo en destino. He adoptado el rostro estúpido e incomprensible de los dioses" (Calígula: 96). La referencia a la epidemia o peste de la obra de Sófocles está asumida por el emperador romano, que asevera: "Hasta ahora mi reinado ha sido demasiado feliz. No ha habido ni una epidemia de peste ni una religión cruel, ni siquiera un golpe de Estado; en una palabra, nada que os permita pasar a la posteridad. Y, en parte por eso, procuro compensar la prudencia del destino. [...] Vaya, que yo sustituyo a la peste" (Calígula: 131).

8 "A fines del año 1943 tuve la suerte de poder visitar el reino de Henri Christophe -las ruinas tan poéticas, de Sans-Souci” (Reino: 11 ).

${ }^{9}$ Es el caso de El siglo de las luces, con la casa y la puerta con aldaba a la que está obligado a llamar el que penetrará en sus arcanos secretos, Víctor Hugues, para, a partir de entonces comenzar el juego de los disfraces de personajes de tragedia que posteriormente serán realidad en la historia de sus vidas. 
E1 Edipo de Carpentier aparecerá explícitamente en obras como El siglo de las luces (1962). Pero también está la evocación a la peste o al miasma, la misma de Camus, tanto en esta obra como en El reino de este mundo (1949). Edipo ya estaba en los escenarios franceses que ambos pudieron presenciar. En este sentido destacamos la crónica que el entonces joven Carpentier escribía en 1928 a propósito de Jean Cocteau, a quien definirá como "el acelerador de tragedias tebanas" (Crónicas: 94$)^{10}$, a quien le hace decir ${ }^{11}$ : "En esta tragedias sólo quise contraer la acción, para acentuar su violencia y destacar el ritmo de la fatalidad... La historia de Edipo me parece algo como una causa célebre, un proceso famoso, que se desarrollara en la Antigüedad. Siempre vemos a Grecia como una columna blanca. Imaginad ahora un páramo bajo el cielo huraño. Muros de piedra, muros de ladrillo; rejas, cloacas, cámaras bajas, puertas secretas, metamorfosis y una epidemia de peste" (ibid.). Luego añadirá que "Los dioses griegos tenían la crueldad de la infancia; por ello la tragedia antigua parece siempre un combate entre grandes insectos feroces..." (ibid.). La "causa célebre" o el "proceso famoso" es el que Calígula sabe contar de sí mismo, esa es su absurda verdad: "Lo que ansío hoy con todas mis fuerzas está más allá de los dioses. Voy a hacerme cargo de un reino en el que imperará lo imposible" (Calígula: 37), tan cerca del absurdo de El reino de este mundo de Carpentier, donde un negro se convierte en tirano de su propio pueblo. E1 teatro es el lugar donde el emperador representa su obra legítima y cruel, de ahí que inste a "Que entren los culpables. Necesito culpables. [... ¡P úblico, quiero tener mi público! ¡ueces, testigos, acusados, todos condenados de antemano!" (Calígula: 39). Por su parte, en la obra de Carpentier también estará esta tragedia cruel aparentemente de la infancia, en lo que llamará el "Gran Teatro de la Universal Devoración", en el que "encendíanse las luminarias del pezloro, en tanto que el pez-ángel y el pez-diablo, el pez-gallo y el pez-de-San Pedro, sumaban sus entidades de auto sacramental al Gran Teatro de la Universal Devoración, donde todos eran comidos por todos, consustanciados, imbricados de antemano, dentro de la unicidad de lo fluido..." (Siglo: 251), o en la edificación del palacio de Sans Souci, en la que "las escaleras del infierno comunicaban tres baterías principales con la santabárbara [...]". Allí "varios toros eran degollados, cada día, para amasar con su sangre una mezcla que haría la fortaleza invulnerable" (Reino: 75), fortaleza en la que un rey que,

${ }^{10}$ Sobre el tema de Edipo en la obra de Carpentier, $c f$. nuestro reciente trabajo (López Calahorro 2010).

${ }^{11}$ Sobre la relación de Camus con Carpentier, $c f$. el texto siguiente del francés: "A veces, en esos estrenos teatrales, que son el único sitio en que coincido con eso a lo que se le da el insolente nombre de 'el todo París', me da la impresión de que la sala va a esfumarse, de que ese mundo tal y como aparenta ser, no existe. Son los otros los que me parecen reales, las notables figuras que alzan la voz en el escenario" (A. Camus, El revés: 18). 
como Calígula, también "esperaba, cerca del cielo que es el mismo en todas partes" (Reino: 78).

Por otro lado, Edipo marca en ambos autores el motivo del parricidio. Esta acción infesta toda la tragedia, tal y como Tiresias tratará de explicar al soberano en un agón intenso inicial que no aceptará Edipo, pero que le hará conectar el destino individual con el colectivo. En la obra de Albert Camus Calígula desgrana la razón de su existencia. Él no es un tirano, sino un emperador que comprende la "utilidad del poder", pues "el poder brinda una oportunidad a lo imposible", para luego señalar que "con eso hay que vivir" (Calígula: 33). El destino le pesa como le pesaba a Edipo, le pesa el dolor por la muerte de su hermana, relación incestuosa que transforma en el motivo de parricidio que asoma tanto en Calígula de Camus como en El acoso de Carpentier con el personaje de la nodriza. Así el joven Escipión dirá que "al matar a mi padre ha elegido por mí" (Calígula: 44). Este asesinato del padre es lo que los iguala en el destino de su muerte, de modo que Calígula lleva al extremo de señalar que “¡No!, no me asesinarán aquellos a cuyos hijos o a cuyo padre mandé matar. Ésos lo han entendido, están conmigo, tienen el mismo sabor en la boca. Me asesinarán los otros"(Calígula: 144). La alusión a la acción parricida es evidente asimismo en el Edipo de Carpentier, pues en El recurso del método escuchamos de fondo que "Así, ciertas noches, oyéronse los lamentos de Ájax, los clamores de Edipo, incestusoso y parricida, en el HemicicloNorte, usado por los estudiantes como Teatro Antiguo" (Recurso: 160), o en El acoso, con "metopas en los balcones, frisos que corrían de una ojiva a un ojo de buey, repitiendo cuatro veces [...] el tema de la esfinge interrogando a Edipo" (Acoso: 51-2). La acción parricida-matricida en El acoso va conformando un personaje híbrido de materiales de tragedia griega, entre Edipo rey de Sófocles y Orestes de Eurípides, entre hijo de Layo, Yocasta y Clitemnestra ${ }^{12}$.

Esta situación híbrida de hijos parricidas incluso se traslada a los tragediógrafos que pudieron servirle de modelo a Carpentier. En este caso nos interesa el personaje del Orestes de Eurípides, con el que innova el autor griego mostrándonos un personaje solo, abandonado, enfermo y aterrorizado, cuidado por su hermana Electra. Y así lo vemos en Carpentier: el miedo atenaza al parricida: "Las manos que se acercaban a su rictus, el sudor de sus miembros [...]. Y cuando volvió a sentir el metal sobre su piel recogida, clamó por la madre, con un vagido ronco que le volvió en estertor y sollozo a lo más hondo de la garganta” (Acoso: 127). Es el miedo, con el que vuelve también a Sísifo (“ $; O h$, yacer de bruces en el suelo frío, con este peso de piedra que arrastro -la mejilla puesta en la piedra fría, las manos abiertas sobre la piedra fría; aliviada mi fiebre, y esta sed, y este ardor que me quema las sienes, por la

\footnotetext{
${ }^{12}$ Sobre esta relación entre las distintas obras y tragediógrafos, $c f$. Losada (1999).
} 
frialdad de la piedra!) (Acoso: 132). Si Camus integraba en "El mito de Sísifo" el mito de Edipo, Carpentier integra ambos en el de Orestes. El miedo lo evoca Calígula, como "ese hermoso sentimiento absoluto, puro y desinteresado, de los pocos cuya nobleza proviene del vientre" (Calígula: 58). El miedo que está también en Los justos, donde el atentado terrorista, compartido con $E l$ acoso, ocurre también a la puerta de un teatro. La relación fraternal semejante a la de Orestes y Electra es la que expresa Dora hacia Kaliayev, el poeta que habrá de morir por cometer el atentado: "Bueno, pues hace tres años que tengo miedo, ese miedo que apenas si te deja mientras duermes, y que encuentras totalmente fresco por la mañana" (Los justos: 43$)^{13}$. Es el miedo que está ligado al ejercicio del poder, pues, el poderoso está condenado a la soledad y sólo la muerte puede salvarlo de esa lógica. En este sentido su imagen es semejante a la del minotauro ${ }^{14}$. Por eso junto a la figura del minotauro existe la contrafigura de un héroe-salvador representado en Teseo. Es así que leemos en esta clave a Calígula que "duerme dos horas cada noche y el resto del tiempo, incapaz de descansar, se lo pasa deambulando por las galerías de su palacio" (Calígula: $133)^{15}$. En el mismo sentido nos dirá que: "Es curioso. Cuando no mato, me siento solo. Los vivos no bastan para poblar el universo y ahuyentar el hastío. Cuando estáis aquí, me hacéis sentir un vacío infinito que no puedo mirar. Sólo estoy bien entre mis muertos"(Calígula: 143). Por su parte, Carpentier también construye sus laberintos y sus minotauros, así en El reino de este mundo, en el que se levanta el palacio de Sans Souci como lugar que identifica al que habrá de quedar muerto en el fondo del laberinto. La soledad consciente semejante al personaje de Camus está evocada en el Primer Magistrado que dirá que "Vivo aquí rodeado de ministros, funcionarios, generales y doctores, todos doblados en zalamerías y curbetas, que no hacen sino ocultarme la verdad. Vivo en la caverna de Platón" (Recurso: 240-1). Finalmente el protagonista de El acoso, cuyo personaje solitario está condenado a morir en el laberinto del teatro, pues "No saldré. Aplaudirán y se encenderán las luces, y será la confusión bajo las luces [...]." (Acoso: 154) para luego seguir señalando que "Nadie permanece ante un escenario vacío, en tinieblas, donde nada se muestra. Cerrarán las

${ }^{13} \mathrm{O}$ en Voinov, que nos dice "Tengo miedo y siento vergüenza de tener miedo. [...] Siempre he tenido miedo" (Los justos: 67). O cuando Dora vuelve a experimentar el frío: "Tengo tanto frío que tengo la impresión de estar ya muerta [...]. Nos envejece tan deprisa todo esto" (Los justos: 124), y dirigido a Kaliayev: "Con tal que no tenga frío. Boria, ¿sabes cómo se ahorca?" (Los justos: 128).

${ }^{14}$ Sobre esta cuestión del poder, la soledad y la figura del minotauro hemos reflexionado con más profundidad en Francisco Ayala y el mundo clásico.

${ }^{15}$ En este texto se observa la similitud con lo que hace el minotauro en "La casa de Asterión" de Borges, deambulando de un lado para otro de la casa donde vive. Podemos decir que la lectura del texto del argentino, aunque escrito dos años después de la obra de Camus, nos permite leer el texto del francés-argelino en este sentido. 
cinco puertas con cerrojos, con candados, y me echaré sobre la alfombra [...]. Dormir: dormir primero. Más allá empezará otra época)"(Acoso: 156). Dormir para que llegue la muerte, como está acostado Orestes al comienzo de la obra de Eurípides, pero más allá: será el instrumento que hará desaparecer la verdad del teatro para situar a los personajes en el espacio de la historia. Aquí es clave la frase que Calígula dice al final de su obra: "nada hay, ni en este mundo ni en el otro, hecho a mi medida" (Calígula: 150) y que vuelve a situarnos en el fondo de $E l$ reino de este mundo de Carpentier. La muerte es la única salvación, ante la mano invisible que lo apuñalará dirá: “¡A la historia, Calígula, a la historia!”. El sueño y la necesidad de historia estarán también en el Primer Magistrado de El recurso del método. Su comienzo es: “...pero si acabo de acostarme. Y ya suena el timbre. Seis y cuarto. No puede ser. Siete y cuarto”, y así el final: "Duermo. Me despierto. Hay veces, al despertar, que no sé si es de día, si es de noche. [...] Saber la hora. Seis y cuarto"(Recurso: 337). Es el final del teatro, se cierra el telón de la tragedia y nuestros personajes mueren o desaparecen para entrar en la historia y contar el tiempo. Como Edipo, el Primer Magistrado dirá al final: “-'Desterrado'...-'Expulsado'...-'Extrañado'...-'O huido'...'Escapado'...-'En fuga'...”.

Desaparecido el tiempo mítico que nos propicia la función del teatro, alcanzada la rebeldía después del intercambio de diálogos en intensos agones, quedará ya el camino abierto para la historia, para la colectividad. Le dirá Escipión a Calígula antes de despedirse: "Te dejo, sí, porque creo que te he entendido. Ni tú ni yo, que tanto me parezco a ti, tenemos ya salida" (Calígula 141). En El recurso del método todo lo comprendió el Primer Magistrado cuando en su agón con 'El estudiante' le dirá: "Para ti, debo ser algo así como un Calígula... ¿¿no?", y éste le responde: "Más bien el caballo de Calígula" (Recurso: 243). Y, como Calígula, o su caballo, que uno no puede entenderse sin el otro, el Primer Magistrado también estará condenado a desparecer: "para que quede en la Historia, debo pronunciar una frase a la hora en que me lleve la chingada. Una frase. Leí en las páginas rosadas del Pequeño Larousse: Acta est fabula". 


\section{Bibliografía}

(Debajo de las referencias bibliográficas de las obras de Camus y Carpentier anotamos en paréntesis la forma con que se citan en nuestro texto, a fin de que sea más fácil para el lector la identificación de los textos)

Adrados, Francisco Rodríguez, "Del teatro griego al teatro de hoy", Madrid, Alianza, 1999.

Birkenmaier, Anke, Alejo Carpentier y la cultura del surrealismo en América Latina, Madrid, Iberoamericana, 2006.

Camus, Albert, El revés y el derecho [1939], Madrid, Alianza, 2006

El verano. Bodas, Barcelona, Edhasa, 2000.

Bodas [1939] incluye: "Bodas en Tipasa", "El viento de Djémila", "El verano en Argel", "El desierto". En el mismo libro también se incluyen los ensayos pertenecientes a El minotauro o Alto de Orán

___ El mito de Sísifo [1942], Madrid, Alianza, 1981. (Sísifo)

___ Calígula [1945] Madrid, Alianza, 1999. (Calígula)

—_Los justos [1949], Madrid, Alianza, 1999. (Los justos)

El hombre rebelde [1951], Alianza, 2001. (Rebelde)

Carpentier, Alejo, Alejo, Écue-Yamba-Ó [1933], Madrid, Alianza, 1989. (Ecué)

___ El reino de este mundo [1949], Barcelona, Mondadori, 1995. (Reino)

__ El acoso [1954] Barcelona, Seix Barral, 1992. (Acoso)

—__ El recurso del método [1974], México, Siglo XXI, 1988. (Recurso)

- Crónicas I, prólogo de J. A. Portuondo, La Habana, Arte y Literatura, 1976.

—_Ensayos, México, Siglo XXI, 1990. (Ensayos)

De Diego, Rosa, Albert Camus, Madrid, Síntesis, 2006.

López Calahorro, Inmaculada, "Edipo a la búsqueda de la historia en la obra de Alejo Carpentier", Alejo Carpentier: Un siglo entre luces, ed. de A. Salvador y A. Esteban, Madrid, Verbum, 2005, pp. 32-53.

"Sobre el tiempo de Edipo y las Geórgicas de Virgilio en Alejo Carpentier", en Maestro y sabio. Homenaje al Profesor Juan Jiménez Fernández, ed. de J. L. de Miguel y A. Jiménez, Jaén, Universidad de Jaén, 2006, pp. 29-43. 
___ Alejo Carpentier y el mundo clásico, Granada, Universidad de Granada, 2006.

- Francisco Ayala y el mundo clásico, Granada, Universidad de Granada, 2008.

- Alejo Carpentier. Poética del Mediterráneo Caribe, Madrid, Clásicos Dykinson, 2010.

"Albert Camus y Alejo Carpentier. La luz del Mediterráneo Caribe", en prensa.

Losada, Marcela, “Traslación semántica de una estructura ausente (El acoso), C. Álvarez y Rosa Ma Iglesias, Murcia, Universidad de Murcia, 1999.

Pageaux, Daniel-Henri, "El área Caribe de Alejo Carpentier. Espacio, novela, mito", En el centenario de Alejo Carpentier (1904-1980). Foro Hispánico 25 (2004) 109-117.

Pogolotti, Graziella, "El ojo de Alejo", Alejo Carpentier: acá y allá, ed. de L. Campuzano, Pittsburgh, Universidad de Pittsburg, 2007, pp. 179-198. 


\title{
Platón y Lorca: filosofía en la escena (EL PÚBLICO)
}

Concepción López Rodríguez

Universidad de Granada

\begin{abstract}
Federico García Lorca cuenta con una obra dramática titulada El público. Cuando se representó, resultó poco inteligible. Gran parte de su "extrañeza" deriva del hecho de plantear "ideas en acción”, más que contarnos una historia con personajes identificables. Un buen caudal de esas ideas halla su fuente en los diálogos de Platón, sobre todo el Banquete y el Fedro. De ellos adapta Lorca a su manera los diferentes tipos de Eros y la configuración del alma.
\end{abstract}

De todas las obras dramáticas que compuso el poeta granadino Federico García Lorca, El público ${ }^{1}$ ha sido una de las más difíciles de interpretar, tal vez por ese ropaje surrealista que la adorna pero que en definitiva no resulta tan decisivo ni tan profundo. Lo que verdaderamente caracteriza a esta obra, entre otras cosas, es la ausencia casi general de auténticos personajes con nombre propio; lo que actúa sobre el escenario son ideas y representaciones de entidades. De entre todo ese material ideológico resultan claramente perceptibles y sustanciales las aportaciones que Platón ofrece a García Lorca y que afectan tanto al contenido de la obra como a ese diseño despersonalizado de la mayor parte de sus protagonistas, al ser conceptos los que se mueven sobre el escenario, es decir "ideas" en el más puro sentido platónico.

Esta presencia del filósofo griego en la escena lorquiana no procede ex nibilo como bien ha constatado la crítica $^{2}$; una de las lecturas asiduas $\mathrm{y}$, podemos decir, preferidas de Federico son determinados Diálogos de Platón, entre los que se encuentran El Banquete y el Fedro. Sin duda, esas lecturas llevadas a cabo por el poeta granadino fecundan esta obra cuyos ejes, la verdad, el amor, la homosexualidad y la muerte se ven nutridos y definidos por la fuente inagotable de ideas del filósofo heleno que le confieren a El público la solidez de una obra de tesis. Y ¿qué tesis plantea la obra lorquina? La respuesta es múltiple pero se puede resumir de la manera siguiente: la búsqueda de la verdad.

${ }^{1}$ Las citas referentes a la obra lorquiana, El público, están tomadas de la bien realizada edición llevada a cabo por María Clementa Millán, Madrid, Cátedra, 2001.

${ }^{2}$ Por ejemplo, Rafael Martínez Nadal (El público. Amor y muerte en la obra de Federico García Lorca, Madrid, Hiperión, 1988 (3a ed. ampliada), p. 87) manifiesta: "Que en la obra de Lorca se perciban ecos de temas platónicos no debe extrañarnos; el problema del uno, de la unidad, de la reunión de mitades le preocupó siempre, sobre todo en la época en que se leía -o releía- los Diálogos Socráticos." 
En El Banquete 3 de Platón la idea de lo bello (la belleza) preside el Diálogo: a ella aspiramos en virtud del Eros (el deseo); esta idea es revelada mediante los caminos de la doxa (opinión) y el concepto de la verdad (aletheia). Tal esquema grosso modo se reproduce en El público, obra presidida por el concepto de la verdad, que, frente a las apariencias, supone la dicotomía central de la obra, cima de la pirámide por donde descienden las diversas formas de la realidad. Vinculado al concepto de verdad, supeditado a él, surge el Eros lorquiano, el auténtico, en antagonismo con el Eros de la doxa (entendida de forma negativa), aparente, esclavo de la opinión. Sin embargo, la esencia platónica, la idea, no es contemplada aquí solamente en el ámbito erótico sino que se extiende al ámbito social, expresado en el propio público, entre lo que le gusta ver y lo que debería ver, lo que quiere frente a lo que en realidad es: la verdad desnuda descarnada, desprovista de cualquier amable representación.

Si concretamos y nos acercamos a las páginas de la obra lorquiana, descubriremos, al margen del principio general expresado antes, momentos concretos, materializaciones de esa filosofía platónica dramatizada. Está claro que el tema aquí ha de supeditarse a unas breves pinceladas; espero, no obstante, que resulten claras y probatorias.

El público está estructurado en seis Cuadros. El segundo de estos Cuadros se titula "Ruina Romana", título que obedece al lugar donde se desarrolla, un espacio intermedio entre "el teatro al aire libre" y "el teatro bajo la arena"; pertenece al reino teatral subterráneo, el alejado del mundo de las apariencias, por tanto, está más cerca del teatro verdadero. En este Cuadro aparece una figura totalmente cubierta de pámpanos rojos, denominada Pámpanos, tocando una flauta sobre un capitel, y una segunda figura, Cascabeles, cubierta de cascabeles dorados, que danza en el centro de la escena. Se reconoce en la primera figura al dios del teatro, Dionisos; la significación de la segunda no ha sido aclarada del todo; existen varias propuestas: Orringer ${ }^{4}$ se inclina a pensar que se trata de una figura representativa del teatro moderno, un arlequín tal vez; en cambio, Martínez $\mathrm{Nadal}^{5}$ alude al mito de Ciso y Baco como trasfondo de estos dos personajes. Probablemente, dada la superposición de caracteres y de la acumulada simbología en casi todos los personajes y las

${ }^{3}$ Esta descripción de la filosofía del Diálogo es debida a Marcos Martínez Hernández en su Introducción a la traducción de El Banquete (Vid. Platón. Diálogos III: Fedón, Banquete, Fedro, Madrid, Gredos, 1988, p. 178).

${ }^{4}$ Dice N. R. Orringer ("Rafael Urbano`s platonic eroticism in Lorca`s theater", Ojáncano. Revista de literatura española 12, 1997, pp. 21-41): "The Figure with Red Grapevines and a flute, Martínez Nadal maintains (241-242), represents Dionysus or Bachus: the Figure wearing jinglebells, I would argue, stands for the modern clown, an ancestor of the Dionysian character".

${ }^{5}$ Rafael Martínez Nadal ha dedicado a este episodio de Pámpanos y Cascabeles una publicación específica: “Baco y Ciso”, en Cuadernos del Sur, XI, 1972, pp. 228-240. 
continuas metamorfosis, la figura de Cascabeles actúe de forma duplicada y sea a la vez uno y otro -arlequín y Ciso-, en un zeugma simbólico muy del gusto de Federico. Ambos personajes inician un diálogo, en aparente juego lingüístico sin trascendencia, de continuas propuestas de metamorfosis. " $\dot{b}$ Si yo me convirtiera en una nube?”, dice Cascabeles. Responde la figura de Pámpanos: "Yo me convertiría en ojo". Pero, más allá del simple entretenimiento, las palabras de uno y otro, en su burlesco tono, exponen las constantes alternativas del ser. En una de estas propuestas, dice Cascabeles: " ${ }_{\dot{b}} Y$ si yo me convirtiera en pez luna?" Responde Pámpanos: "Yo me convertiría en cuchillo". El pez luna y el cuchillo son símbolos recurrentes en la obra lorquiana y están cargados de erotismo.

El juego de las metamorfosis propuestas no carece de significado, a pesar de esa "aparente ingenuidad". Consideremos el "pez luna", sus vinculaciones con la "unidad del ser" y su trasfondo platónico. Para ello, previamente, hemos de exponer algún fragmento del diálogo perteneciente a este segundo Cuadro ("Ruina Romana"). Las palabras más significativas del mismo se pronuncian inmediatamente después de la entrada en escena de un Niño que cae del techo vestido con una malla roja y después de la entrada del anunciado Emperador de los romanos y de su Centurión; además, también aparecen en escena los cuatro Caballos con sus trompetas; estos Caballos son protagonistas destacados de la obra junto con los diferentes tipos de Hombres (I, II, III) y poseen una clara ascendencia platónica ${ }^{6}$. En el mencionado diálogo entre el Centurión, la figura de Pámpanos, la figura de Cascabeles y el Emperador se plantea la búsqueda del "uno":

Centurión. El Emperador busca a uno.

Figura de Pámpanos. Uno soy yo.

Centurión. ¿Cuál de los dos?

Figura de Pámpanos. Yo.

Figura de Cascabeles. Yo.

Centurión. El emperador adivinará cuál de los dos es uno. Con un cuchillo o con un salivazo. ;Malditos seáis todos los de vuestra casta!

La relación entre ese "pez luna" y el tema de la "unidad del ser" podrá entenderse mejor si acudimos a las fuentes platónicas. Cuando Aristófanes en El Banquete toma la palabra, introduce un elemento, principal motor, que se

${ }^{6} \mathrm{El}$ importante valor de los Caballos y su vinculación al mito platónico del alma concebida como "la conjunción de fuerzas que hay entre un tronco de alados corceles y un auriga" ha sido puesto de relieve por mí en otro trabajo. Vid. Concepción López Rodríguez, "Los caballos del alma: el sustrato platónico de El público de Federico García Lorca”, incluido en La tradición clásica en la obra de Federico García Lorca (ed. José María Camacho Rojo, Granada, Universidad de Granada, pp. 461-493). 
debe anexar, en el análisis de El público, a los dos anteriormente citados ("pez luna" y "la unidad"): se trata de Eros, la dynamis del ser. Dice Aristófanes, al explicar la naturaleza humana cuya raíz es precisamente ese Eros:

"En primer lugar, tres eran los sexos de las personas, no dos, como ahora, masculino y femenino, sino que habia, además, un tercero que participaba de estos dos, cuyo nombre sobrevive todavía, aunque el mismo ha desaparecido. El andrógino, en efecto, era entonces una cosa sola en cuanto a forma y nombre, que participaba de uno y otro, de lo masculino y lo femenino, pero que abora no es sino un nombre que yace en la ignominia. En segundo lugar, la forma de cada persona era redonda en su totalidad, con la espalda y los costados en forma de circulo [...] Como llegaron a ser poderosos los hombres, incluso para los dioses, tras pensarlo detenidamente, dijo, al fin, Zeus: me parece que tengo el medio de cómo podrían seguir existiendo los hombres y, a la vez, cesar de su desenfreno haciéndolos más débiles y más útiles para nosotros, por ser más numerosos [...] Dicho esto, cortaba a cada individuo en dos mitades [...]. Así, pues, una vez que fue seccionada en dos la forma original, añorando cada uno su propia mitad se juntaba con ella y rodeándose con las manos y entrelazándose unos con otros, deseosos de unirse en una sola naturaleza, morian de hambre y de absoluta inanición, por no querer hacer nada separados unos de otros. Desde hace tanto tiempo, pues, es el amor de los unos a los otros innato en los hombres y restaurador de la antigua naturaleza humana. Por tanto, cada uno de nosotros es un simbolo de hombre [...] al haber quedado seccionado en dos de uno solo"'.

Más adelante dice Platón (192d) en un texto sobre el mismo tema, muy interesante: "Amor es, en consecuencia, el nombre para el deseo y la persecución de esa integridad".

La idea de fusión entre las dos partes que conforman al ser enamorado no es una idea o expresión puntual que aparezca solo en este contexto de $\mathrm{El}$ público y que afecte solo a la figura de Pámpanos y Cascabeles, por ejemplo; también afecta a la relación de Pámpanos con el Emperador, como se deduce de las palabras que intercambian, y supone una constante en toda la obra: la ambición de la unidad primigenia caracteriza las ansias del Director con el Hombre I (Enrique-Gonzalo, los dos únicos protagonistas principales que tienen nombre propio). Según se desprende del resto de la pieza, el poeta granadino no encuentra una solución esperanzadora a esa búsqueda porque la unión total fracasa en la muerte que anula el Eros o, desde otro punto de vista, lo culmina.

El símbolo de unidad que representa el pez luna sigue persistiendo hasta el final de la obra. Veamos unas palabras del Cuadro sexto:

${ }^{7}$ Vid. Platón, El Banquete, 189 e y ss. La cita pertenece a la traducción de Marcos Martínez, Op. Cit., pp. 222 y ss. 
Señora. ¿̇Dónde está mi hijo? Los pescadores me llevaron esta mañana un enorme pez luna, pálido, descompuesto, y me gritaron: ;Aqui tienes a tu hijo!

La Señora recibe en sus brazos el cadáver de su hijo, el Hombre I, transformado en pez-luna; el hombre tal vez haya logrado satisfacer sus deseos, pero está muerto.

Si damos un paso más, encontraremos también en Platón un cercano paralelo a este lorquiano pez luna. Para ello, citaremos las ilustradoras palabras de Luis Martínez Cuitiño ${ }^{8}$ :

"La complicación simbólica del pez luna radica en que constituye una construcción bíbrida que tiene en una de sus caras a la luna-andrógino, pero Lorca innova creando un simbolo personal transformando el otro miembro del andrógino en pez. Para hallarle explicación a la presencia del pez hay que volver al discurso de Aristófanes en El Banquete de Platón. Alli Aristófanes metaforiza la condición el hombre con el lenguado: "cada uno de nosotros es una contraseña de hombre, al haber quedado seccionados, como los lenguados, en dos de uno que éramos (Platón, 1999, 84)”.

Fracasa, en un sentido, la añorada culminación del Eros, porque tras ella no existe nada, solo una verdad inmutable, universal y constante, no producto de la doxa sino de la episteme: la muerte que, como hábil Prestidigitador (es un personaje que aparece al final de la obra) ha manipulado nuestros continuos deseos.

\footnotetext{
${ }^{8}$ Vid. Luis Martínez Cuitiño, El mito del andrógino, Buenos Aires, Corregidor, 2002, p. 60.
} 


\title{
Sófocles y Antonin Artaud. \\ LA TRAGEDIA Y EL TEATRO DE LA CRUELDAD: TENSIÓN Y DESGARRO DE UNA INTERIORIDAD PERDIDA
}

Jorge Mallearel

Universidad de Morón

\begin{abstract}
Intentarenmos pensar, desde el carácter trágico del teatro griego del siglo $\mathrm{V}$ a. C., los conflictos insolubles que puede albergar cualquier existencia humana. En efecto, aquellas tragedias al dramatizar los padecimientos sufridos por sus héroes o heroínas de-velaban una precariedad existencial universal. Esta percepción nos impulsó a dos reflexiones. La primera: a pensar el escenario trágico como el sitio donde se plasmaba la interioridad más despojada, siendo este escenario el vehículo descarnado por el que el hombre cobra conciencia de su "incompletitud". La segunda: a mostrar que estas expresiones despojadas desgarran a los discursos de las prácticas jurídicas y morales.
\end{abstract}

\section{Introducción}

Las tragedias suelen mostrar una cara excepcional del hombre. Los contratiempos de sus personajes se empobrecen frente a un análisis moral o jurídico. Es posible que las comunidades se desplomaran con la habitualidad del incesto, o con un ejército de "Medeas" que decidieran resolver sus celos apuñalando el cuerpo inocente de sus hijos. No obstante, es sabido que nadie está libre de experimentar estas denominadas aberraciones. Quizás es la aitia o necesidad la que abraza a cualquier individuo y lo lleva a esas experiencias "hiperbólicas". Aunque las narraciones psicológicas y los escritos del derecho busquen atenuar esos paroxismos - una encasillando, la otra con castigo y encierro - ello no impide su flujo. Lo ingobernable aparece sin más. Esa corriente de hybris, de desmesura, empuja al hombre al abismo de aquello que late en él, aún sin que lo sepa, no porque sea parte de su yo inconciente, sino porque es la tensión propia del ser, o de fuerzas misteriosas que empujan por salir y extinguirse. Existe en todo hombre un potencial oculto, pero disimulado detrás de conductas y símbolos. Dicha potencialidad in-definida anida en la naturaleza bumana, nos ronda. Está más allá de toda determinación o "biografía". Es una naturaleza sin contornos, como los restos de una violenta extinción o conflagración. La tragedia griega suele presentar ante el público, en las desdichas de sus personajes, este estado de apertura. Artaud, con el teatro de la crueldad quiere dar cuenta de ese estado, lamentándose de la dramaturgia psicológica, la cual recorta, según él, "escenas íntimas de la vida de unos pocos fantoches, transformando al público en voyeur $[. .$.$] nos han$ 
desacostumbrado (sigue) a esa acción inmediata y violenta que debe tener el teatro" ${ }^{\prime}$.

\section{E1 héroe sometido.}

Las expresiones vertidas nos conducen a pensar que algo incontrolable brota entre los pliegos de la naturaleza, del mismo modo que cuando en una sociedad se instala una peste, loimós. Ésta, arrasa sin piedad, se lleva en su torbellino todos los límites. Los muertos yacen tirados en la vía pública, las casas no vuelven a cerrarse, los cementerios se colman. En Edipo surge algo similar, pues sus límites comienzan a desvanecerse. Puede suponerse que él configura o reúne en sí, más que el sueño no resuelto de matar al padre y el deseo por su madre, una disolución y una generación. Por un lado, se disuelven las certezas absolutas: la de ser rey, amante y padre. Por otro, en Edipo se genera una vivencia: la infinitud compleja y ambigua del hombre.

Tomaremos a Edipo para revelar que detrás de la religiosidad de los mitos que invocan las obras trágicas aparece oculta una "vacilación", debido a la mezcla de dos planos: el divino y el humano. Así, para que la conciencia trágica se presente, dice Vernant "es preciso, en efecto, que los planos humanos y divinos sean lo bastante distintos para oponerse [...] sin cesar, sin embargo, de aparecer como inseparables". ${ }^{2}$ La huella divina es portadora de una oposición o conflicto que algunas dramatizaciones saben desandar. Conflicto que no es cualquier conflicto, éste es insoluble, y se debe a que en el plano divino todo es posible sin luchas. En el hombre también todo es posible, pero no sin una guerra interior.

Edipo, Medea, Antígona, viven ese agonismo, esa guerra, pero fatalmente. Fatalidad que conduce generalmente a una disolución. En el rey Edipo, dicha disolución se dio rápidamente. Tanto como padre, esposo, hijo y hermano. ¿Cuál es el rostro de Edipo? Exclama él mismo: "soy hijo de impuros, tengo hijos comunes con aquella de la que yo mismo -¡desdichado!- nací”3. Si pensamos que toda biografía es un límite, Edipo es carencia de biografía, pues en su figura los límites se van desplomando. ¿Quién es en verdad? Su contorno no es claro: ¿es hermano o padre de Antígona e Ismene? ¿Es Rey o un simple vagabundo que ni casa tiene? Sin embargo, ésta no es una mirada pesimista, precede a todo pesimismo.

Por otro lado, son los temas teatrales que Artaud aceptaría. Pues, para él compondrían, junto a la locura, el crimen y la guerra, temáticas de una metafísica que no busca una verdad última. Seguramente sospecha que el teatro

\footnotetext{
${ }^{1}$ Artaud, 1964: 87.

${ }^{2}$ Vernant J. P., 2002: 85.

${ }^{3}$ Sófocles, 1977: 1361.
} 
que abandona esta dirección más universal, sólo relata pequeñas vicisitudes domésticas, burguesas. La tragedia edípica hace estallar esta necesidad oculta, y su figura se torna la cara visible que la habitualidad invisibiliza. De este modo, cuando Artaud compara al teatro con la alquimia, que es el doble de una objeto material, dice que "el teatro debe ser considerado también como un Doble, no ya de esa realidad cotidiana y directa de la que poco a poco se ha reducido a ser la copia inerte, tan vana como edulcorada, sino de otra realidad peligrosa y arquetípica, donde los principios, como los delfines, una vez que mostraron la cabeza se apresuran a hundirse otra vez en las aguas oscuras". ${ }^{4}$ En efecto, ciertos temas que estas obras representan asoman como un torbellino siniestro, y tan pronto como se hacen público deben hundirse. Así, velozmente Edipo abandona la ciudad, sale de la vista de todos, se invisibiliza detrás del peregrinar sin rumbo. Presiento que el deseo de estas representaciones es plasmar el horror de la crueldad. En el teatro de Antonin Artaud, esta "crueldad" no se reduce a una definición próxima a lo material. Es decir, no alude a carne quemada, torturada, o a los restos de un cuerpo luego de un festín sangriento. De ningún modo, cuando Artaud habla de la crueldad relata que en ella "hay una especie de determinismo superior [...] una especie de dirección rígida, de sumisión a la necesidad" "Las tragedias parecen volcar ese determinismo y sumisión de carácter devorador. El proyecto artaudeano quiere imponer dicho carácter, en el que el incesto, el parricidio o el filicidio, surgen descarnados, sin maquillajes. Medea, por ejemplo, mata sus hijos porque sus celos son más profundos que el amor hacia sus hijos. Los celos le roen el corazón de tal manera que el "sentimiento materno" retrocede. La cultura, en este acto, se desgarra.

Cierta experiencia trágica griega y la idea que Artaud tiene del teatro intentan evadir el corsé de cualquier conocimiento o vestimenta teórica. Lo expuesto en las tragedias, quizá se asemeja a la experiencia interior que describe Bataille en estos términos: "La experiencia interior responde a la necesidad en la que me encuentro [...] de ponerlo todo en tela de juicio (en cuestión) sin reposo admisible. Esta necesidad funcionaba pese a las creencias religiosas; pero tiene consecuencias tanto más completas cuando no se tienen tales creencias. Las presuposiciones dogmáticas han dado límites indebidos a la experiencia: el que sabe ya, no puede ir más allá de un horizonte conocido"6. Estimo que las tragedias y el teatro de la crueldad parecieran motivados por esa experiencia despojada. Artaud, por su parte, intenta ser fundante, lo cual no implica fundamentar, al estilo de brindar argumentos lógico-racionales que ensayen una explicación. Fundante en cuanto a lo que origina. La palabra griega

\footnotetext{
${ }^{4}$ Artaud, 1964: 49.

${ }^{5}$ Artaud, 1964: 104.

${ }^{6}$ Bataille, 1972: 14.
} 
arkhe es seductora en este sentido, ya que su semántica nos devuelve, además de origen, comienzo y principio, también, mando, poder, autoridad y potencias celestiales. Los significados presentados acuden, de algún modo, a producir la atmósfera teatral. En efecto, por un lado, aparece en escena una naturaleza ingobernable, un poder. Por otro, lo humano se hace súbdito de potencias celestiales, de "autoridades" sobrehumanas que hacen estéril cualquier acción contra esa necesidad implacable.

\section{Ciudad trágica}

Recorrer la tragedia edípica nos permite percibir qué anida en el corazón del héroe y mostrar, a su vez, que este tipo de representaciones son el Doble de esa crueldad que habita en el fondo de lo que denominamos vida. Para tal fin, la tragedia utiliza un material mítico, el cual contiene transgresiones como el incesto, el parricidio o el matricidio. Este material es introducido dentro de la ciudad para que surja lo impensable, lo imposible. Es un poner delante para expulsar. Edipo sufrió tal expulsión, pues su conducta era un peligro político. Su figura se hace arquetípica. Sófocles la lleva a la cumbre y luego deja que se desplome estrepitosamente. Edipo confía en la felicidad, como todo hombre, sin reparar que sólo es una morada frágil. Su inteligencia sagaz lo convierte en rey pues vence a la Esfinge, pero, quizá, no ve que "la creación y la vida misma sólo se definen por una especie de rigor, y por lo tanto de crueldad fundamental, que lleva a las cosas a su final ineluctable"'. Sófocles, despliega en el hombre Edipo este rigor. Al comienzo lo presenta como el sabio que con clarividencia conquista el poder de Tebas y, sin saber que es el asesino de su padre y esposo de su madre, cumple con aquel rigor ineluctable. La ambigüedad se traslada por la escena, porque es la propia ambigüedad de la naturaleza humana, que unas veces goza de una dicha indescriptible y otra de desventuras funestas. Dice Edipo delante del pueblo que fue a suplicarle que lo libere de la peste: "he venido en persona, yo, el llamado Edipo, famoso entre todos". ${ }^{8}$ En tanto, la ciudad lo considera "el primero de los hombres en los sucesos de la vida y en las intervenciones de los dioses". También, en la antistrofa 2 le anuncian: "Tú, que, tras disparar el arco con incomparable destreza, conseguiste una dicha por completo afortunada" ${ }^{10}$. Aquí tenemos el rostro triunfante del héroe. La ciudad lo glorifica y enaltece por su juicio recto. Edipo es discernimiento salvador.

Pero el arte teatral continúa, y sobre los elogios caerá lo implacable,

\footnotetext{
${ }^{7}$ Artaud, 1964: 105.

${ }^{8}$ Sófocles, 1977: 7.

${ }^{9}$ Sófocles, 1977: 32.

${ }^{10}$ Sófocles, 1977: 1197 (Antistrofa 2).
} 
confirmando que "toda ascensión es un desgarramiento"11. Esta es la crueldad a la que alude Artaud. Dice: "toda vida más fuerte se abre paso a través de las otras"12. En efecto, una nueva vida comienza a empujar a la anterior. A la vida en la cual era rey, esposo y sabio, empuja la nueva vida que le espera en la soledad. Es azote de sí mismo, no por una cuestión psicológica ni de maldad natural, sino porque, en palabras de Antonin Artaud: "El tema de Edipo rey es el incesto, y alienta en la obra la idea de que la naturaleza se burla de la moral; y de que en alguna parte andan fuerzas ocultas de las que debiéramos guardarnos, ya se llame destino o de cualquier otro modo". ${ }^{13}$ Estas fuerzas, lejanas al orden positivo y racional, sólo se padecen. Vernant lo dice así: "El parricidio, el incesto no corresponden ni al carácter de Edipo, su ethos, ni a una falta moral, adikia, que hubiera cometido" ${ }^{14}$. Esas aberraciones se deben a una fuerza que arrasa, o a la "crueldad en el sentido de apetito de vida, de rigor cósmico y de necesidad implacable". ${ }^{15}$ No obstante, para vivir sin terrores las sociedades "prefieren" inventar diques religiosos, científicos o jurídicos. La tragedia, en su trasfondo, retorna el carácter nada excepcional de estas transgresiones.

\section{El devorar como forma vital.}

Pensar las tragedias es aceptar una tensión insuperable, desechándose cualquier síntesis superadora. El corazón trágico golpea al ritmo de esta tensión inacabable. En efecto, las dos cegueras de Edipo no resuelven el incesto y tampoco la "trasgresión".

Ahora bien, uno de los posibles caminos en el que la obra Edipo Rey canaliza esta tensión es en el carácter simbólico que se halla en la Esfinge y en la peste. Es decir, quizá no sea sólo parte de la fortuna que Edipo al ingresar a Tebas tropiece con una devoradora como la Esfinge. Edipo abandona Corinto, temeroso por el vaticinio del oráculo. Al hacerlo empieza a ser devorado por el viaje. Los acontecimientos tebanos comienzan a deglutirlo. Llega a Tebas luego de matar a Layo, su padre. Esta ciudad "devora" al viajero que huyó de Corinto. El hombre común que es, luego de vencer a la Esfinge, desaparece tras la corona de rey y de esposo. Por último, todo este torbellino de sucesos, junto al cúmulo de dicha y felicidad que le otorgara el poder, comienza a apagarse mientras la imagen de rey es deglutida por la del errante ciego. Se convierte así en su propio devorador en el momento mismo que descubre verdaderamente quién es. Edipo a esta altura es representación del caos. Su ser

\footnotetext{
${ }^{11}$ Artaud, 1964: 105.

${ }^{12}$ Artaud, 1964: 105.

${ }^{13}$ Artaud, 1964: 120.

${ }^{14}$ Vernant, 2002: 113.

${ }_{15}$ Artaud, 1964: 105.
} 
padece el desorden de una ciudad contagiada por una epidemia. La analogía es viable siempre que aceptemos que una peste desata caos, exceso y confusión. Vayamos a ese panorama ampliado. Escribe Sófocles: "La ciudad, como tu mismo puedes ver, está ya demasiado agitada y no es capaz todavía de levantar la cabeza de las profundidades por la sangrienta sacudida. Se debilita en las plantas fructíferas de la tierra, en los rebaños de bueyes que pacen y en los partos infecundos de las mujeres ${ }^{16}$. La normalidad se ve interrumpida. En una epidemia gobiernan situaciones signadas por la agitación y la confusión. Edipo experimenta ambos signos por medio de los acontecimientos que lo dominan. Las certidumbres entran en una zona conflictiva. Si la peste se caracteriza por la hybris, desmesura, quién mejor que él la simboliza. Edipo, como la ciudad apestada, es arrastrado por un torbellino que desconoce. Otros vínculos entre Edipo y la peste son la destrucción y la muerte gratuita: Layo, los ciudadanos, Yocasta. Aquí es posible imaginar una triple alianza: Edipo, la peste y el teatro artaudeano. Escribe Artaud: "Hay en el teatro como en la peste, algo a la vez victorioso y vengativo" ${ }^{17}$. Más aún, la peste "toma imágenes dormidas, un desorden latente y los activa de pronto transformándolos en los gestos más extremos; y el teatro toma también gestos y los lleva a su paroxismo"18.

\section{Conclusión}

Intentamos, a partir de la tragedia Edipo Rey, resaltar la precariedad humana y cómo el mundo puede tornarse un lugar extraño, como el propio cuerpo cuando la enfermedad lo avasalla. Las tragedias se desarrollaron al "amparo" de esa precariedad. En sí mismo el teatro trágico tomó conciencia de ello, quizás esta sugerencia dentro de la tragedia en cuestión sea elocuente: "ningún mortal puede considerar a nadie feliz con la mira puesta en el último día, hasta que llegue al término de su vida sin haber sufrido nada doloroso" ${ }^{19}$.

Otra cuestión que quisiera destacar en este cierre es lo que atañe a la territorialidad de la escena. No al espacio geográfico sino al topos existencial. Dice Vernant: "El dominio propio de la tragedia se sitúa en esa zona fronteriza en la que los actos humanos vienen a articularse con las potencias divinas" ${ }^{20}$. La escena se enmarca en un espacio "entre". Es un espacio de desgarro y oscuridad. En él crecen los sueños prohibidos. Esos sueños en los cuales el alma, no repara, según Platón, "en violar con la imaginación a su madre, o en unirse a

\footnotetext{
${ }^{16}$ Sófocles, 1977: 23 ss.

${ }^{17}$ Artaud, 1964: 27.

${ }^{18}$ Artaud, 1964: 27.

${ }^{19}$ Sófocles, 1977: 1529.

${ }^{20}$ Vernant, 2002: 85.
} 
cualquiera, sea quien fuese, hombre, dios o animal" ${ }^{21}$. En este espacio teatral quedan fusionados los límites y la apertura en el que todo, absolutamente todo, puede suceder. Por eso Artaud insiste en decir que la representación teatral "nos restituye todos los conflictos que duermen en nosotros, con todos sus poderes y da a esos poderes nombres que saludamos como símbolos". ${ }^{22}$ Son esos símbolos escénicos los que hacen de este teatro, un lugar en el que el centro de lo que acontece esté en constante desplazamiento. El sitio está entre la humanidad y esos demonios dormidos que empujan a conductas infernales. El teatro es el arte que nos "alimenta" de esa angustiante encrucijada, dejándonos en ella. El personaje Edipo es encrucijada. Vive entre la dicha y el tormento, entre lo bello y lo espantoso: es padre y hermano, hijo y marido, es asesino de su propia sangre, es salvador y destructor de la misma ciudad. Por eso la tragedia, deja que el hombre se presente, como "una especie de monstruo incomprensible y desconcertante"23. Desconcierto fatal que le anuncia que en él merodea sin asentimiento la perdición.

\footnotetext{
${ }^{21}$ Platón, 1985: IX, 571c

22 Artaud, 1964: 27.

${ }^{23}$ Vernant, 2002: 84.
} 


\section{Bibliografía}

Artaud, Antonin (1964), El teatro y su doble, Argentina. Editorial Sudamericana. Bataille, G. (1972), La experiencia interior, Madrid, Taurus Ediciones.

Platón (1985), República, Buenos Aires, Editorial Universitaria de Buenos Aires.

Sófocles (1977), Edipo Rey, Barcelona, Editorial Planeta-De Agostini.

Vernant, Jean-Pierre - Vidal-Naquet, Pierre (2002), Mito y tragedia en la Grecia antigua, Vols. I y II, Barcelona, Ediciones Paidos Ibérica. 


\section{Os CLÁSSICOS EM MARIONETAS}

Susana Maria Marques

Universidade de Coimbra

Inscrever na contemporaneidade a fascinante tradição popular das marionetas, suscitando no público actual uma reflexão efectiva sobre as inquietações da existência humana, foi um desafio superado com reconhecido mérito e sucesso por João Paulo Seara Cardoso, fundador do Teatro de Marionetas do Porto (TMP). Tal repto implicou uma recriação do conceito da marioneta convencional, que se viu então concebida sem os habituais fios, manipulada por actores visíveis para o público e que com ela interagiam. As convicções de Seara Cardoso instigaram-no a um experimentalismo tradutor de um modo próprio de estar no teatro, assente também na congregação de múltiplas linguagens, em especial relacionadas com as hodiernas tecnologias digitais.

$\mathrm{O}$ presente trabalho constitui uma singela homenagem a este homem do teatro falecido há alguns meses, o qual fez questão de incluir nas produções da sua Companhia temas de inspiração clássica, ainda que filtrados pela escrita de um autor barroco, António José da Silva, o Judeu.

Inscrever na contemporaneidade a fascinante tradição popular das marionetas, suscitando no público actual uma reflexão efectiva sobre as inquietações da existência humana, foi um desafio superado com reconhecido mérito e sucesso por João Paulo Seara Cardoso, fundador e director artístico do Teatro de Marionetas do Porto (TMP). Tal repto implicou uma recriação do conceito da marioneta convencional, que se viu então concebida sem os habituais fios que a tornavam próxima do homem, e manipulada por actores visíveis para a plateia, que com esta interagiam. Na inovação, o desejo claro de identificar no boneco animado um duplo dos mortais, um veículo de comunicação entre o actor e o espectador - capaz de tudo, mesmo de voar, se preciso fosse-, distanciava-se da imitação do comportamento dos efémeros e permitia que estes se deixassem surpreender: "se fazemos coisas muito próximas da vida", afirmou Seara Cardoso, "é impossível que o teatro seja um espelho dessa vida. (...) Não me interessa fazer teatro para fazer as coisas tal qual elas se passam no mundo. Cada vez se faz mais um teatro em que as pessoas não são surpreendidas". “... minha atracção pelas marionetas foi no sentido de procurar um teatro 'não naturalista', uma linguagem que melhor

1 João Paulo Seara Cardoso numa entrevista a Fátima Dias Iken in http://www. marionetasdoporto.pt/joao-paulo-seara-cardoso/66-1998-hei [consult. 10 Março 2011]. 
pudesse reflectir o mundo actual e o homem"2. As convicções do director da Companhia portuense instigaram-no a um experimentalismo tradutor de um modo próprio de estar no teatro, assente também na congregação de múltiplas linguagens, em especial relacionadas com as hodiernas tecnologias digitais. A paixão pela maquinaria em geral, para lá da vontade de explorar continuamente diversas técnicas das marionetas, no intuito de encontrar sempre soluções adaptadas a necessidades diferenciadas, é evidente nas suas encenações e nas cenografias que teimava em criar e construir, reflexo decerto da frequência na Faculdade de Engenharia Civil do Porto enquanto estudante.

Crítico em relação ao teatro tradicional, para o qual preconizou uma modernização, nomeadamente pela valorização do elemento visual em detrimento do texto, procurou nas marionetas uma forma de reagir à convenção.

A presente reflexão constitui uma singela homenagem a este homem do teatro falecido há alguns meses atrás, que fez questão de incluir nas produções da sua Companhia temas de inspiração clássica, mesmo se filtrados pela escrita de um autor barroco, António José da Silva, o Judeu (século XVIII).

É inegável a atracção de Seara Cardoso pelas óperas cómicas de temática greco-latina com que o Judeu animou os pátios lisboetas de outrora ${ }^{3}$ : nele, o Director do TMP encontrou afinidades como o gosto pela técnica dos bonifrates, a capacidade de inovar o paradigma tradicional, a reflexão crítica sobre problemas da sociedade contemporânea respectiva. Perseguido e condenado à morte pela Inquisição, o Judeu reelaborou motivos clássicos em peças que escreveu para serem representadas por marionetas. Numa época dominada pela Inquisição, recorrer a temas da Antiguidade convertia-se à partida num meio de escapar à censura das obras e, em simultâneo, de abordar questões fundamentais da sociedade portuguesa. Em consonância com o teatro barroco em geral, as produções de António José da Silva apelavam aos sentidos, ora pelos cenários variados, ora pelos efeitos especiais utilizados, ora pelo reiterado apego ao fantástico e às surpresas da intriga, motivadores do deleite da audiência.

A identificação de Seara Cardoso com a produção teatral de António José conduzi-lo-ia a repor em cena, séculos mais tarde, $A$ Vida de Esopo (em 1989) e Os Encantos de Medeia (em 2005), ajustadas a linguagens, técnicas, vivências e contextos distintos, num cruzamento eficaz entre Antiguidade

2 João Paulo Seara Cardoso numa entrevista a Elisabeth Gruen in http://www. marionetasdoporto.pt/joao-paulo-seara-cardoso/58-2001-westdeutschezeitung [consult. 10 Março 2011].

${ }^{3}$ Sobre a produção teatral de António José da Silva, cf. Picchio, L. S. (1969), História do Teatro Português. Lisboa: 185-195; Rebello, L. Francisco (1991), História do Teatro. Lisboa: 47-50. 
Clássica, Barroco e Modernidade 4 . Deste modo, a possibilidade de representar os clássicos e/ ou as respectivas adaptações dramáticas em marionetas não constitui uma novidade per se do TMP, como se sabe, mas é um hábito já nos teatros francês e espanhol do século XVII, que influenciou o século XVIII português e, de modo particular, António José da Silva. Seara Cardoso regressou à tradição, reinventando porém a concepção do títere em palco ${ }^{5}$, como ficou dito, e garantindo-lhe uma universalidade que ultrapassou a infantilização a que o teatro de marionetas se viu sujeito durante boa parte do século XX.

Nas encenações que dirigiu, o Director do TMP encurtou os originais escritos pelo Judeu e introduziu-lhes algumas adaptações, na mira sobretudo de facilitar a percepção dos mesmos ao espectador contemporâneo e de não os tornar demasiado demorados e enfadonhos. Como na Grécia antiga, os actores/ manipuladores dos bonifrates converteram-se em simultâneo em cantores e bailarinos, concentrando diversos papéis na mesma pessoa, também por questões relacionadas com a dimensão da própria Companhia. Seara Cardoso manteve o relevo concedido pelo Judeu ao elemento musical, evidenciando um trabalho de pesquisa da estética da representação, que se traduziu por exemplo na escolha sugestiva da música de cravo, instrumento de referência no Barroco, para o acompanhamento de $A$ Vida de Esopo, ou no recurso propositado a um compositor italiano para trabalhar Os Encantos de Medeia num registo adequadamente associado à época de António José da Silva. Insistiu nos efeitos especiais, na senda das criações do Judeu, granjeadores de um manifesto desejo do primado do elemento visual na performance, a acentuar a incursão pelo domínio do fantástico no qual também se inscreve a opção pela marioneta, favorecedora da interacção em cena entre manipuladores, 'homens-bonecos', seres não humanos e abstracções/ alegorias.

Bem informado sobre o contexto e sobre o sentido das peças que encenava, Seara Cardoso procurou inovar, enquadrando-as num registo actual, passível de cativar e de questionar o público moderno.

Curiosamente, a última encenação que dirigiu constituiu à partida um desafio diferente, porquanto se tratou duma experiência de teatro de rua, levada a cabo num espaço público urbano, aberto às massas. Inspirada na Lisistrata aristofânica, Make love, not war, o título da produção apresentada pela primeira vez em Maio de 2010, no Festival Internacional de Teatro de Rua de Santa Maria da Feira, e reposta em Maio de 2011, no Porto, nos eventos de Serralves em Festa, testemunha que a máxima hippie dos anos sessenta do século passado

\footnotetext{
${ }^{4}$ A propósito d'Os Encantos de Medeia de António José da Silva, cf. Silva, M. F. (2002), “Tragédia feita comédia. Os Encantos de Medeia do Judeu”, in López, A., Pociña, A. (eds.), Medeas: versiones de un mito desde Grecia hasta hoy - II. Granada: 819-846.

${ }^{5} \mathrm{Em} A$ Vida de Esopo e n' Os Encantos de Medeia, os actores que manipulam as marionetas são visíveis para o público, sendo que no caso d' Os Encantos interagem com eles.
} 
encontra raízes na Grécia antiga. É sobre essa performance em particular que se propõe uma abordagem propiciadora do estabelecimento de um paralelo entre o original grego e a adaptação contemporânea, a diversos níveis ${ }^{6}$. Nesse sentido, e na linha do que se vem tornando uma prática comum no estudo da recepção do drama antigo, as reflexões sobre a performance decorrem do diálogo entre a investigação e o contributo dos próprios actores ${ }^{7}$, cuja experiência de representação é susceptível de proporcionar novas perspectivas a qualquer estudioso.

O fascínio pessoal de Seara Cardoso por Aristófanes prende-se com uma identificação notória com o espírito atento à época e muito provocador do comediógrafo ateniense dos séculos V-IV a. C., com o seu insurgimento contra os males - ou os 'malvados' - que enfermavam a sociedade, com o gosto pela comicidade crítica, com a capacidade de agitar consciências pelo recurso a personagens-tipo e, de um modo geral, com um encanto particular do Director do TMP por textos clássicos, "porque são as obras fundadoras".

Inspirar-se na Lisistrata (411 a. C.), uma peça que faz a apologia da paz e da conciliação entre os homens nos últimos anos da Guerra do Peloponeso, é apostar à partida numa mensagem intemporal e universal.

Como se sabe, em 411 a. C., Aristófanes, instigado pelo caos gerado por um longo conflito armado que opunha Gregos contra Gregos, e por jogos políticos constantes que arruinavam ainda mais a Atenas em que vivia, preconiza em Lisistrata a união entre os Helenos como solução salvadora e de libertação da Grécia. Nesse sentido, dá voz às mulheres, vítimas da guerra e da instabilidade social, a quem coloca simbolicamente reunidas na Acrópole ateniense: por norma arredadas do foro político, são todavia essas hábeis governantes domésticas quem se revela afinal capaz de gerir questões tradicionalmente associadas ao domínio masculino, ora da gestão militar, ora política, valendo-se da sexualidade feminina como arma poderosa e eficaz. De resto, o confronto entre sexos é um tema em geral sobrevalorizado pelas releituras da peça ao longo dos tempos, porquanto motivo favorecedor de comicidade, que relega para um plano de menor visibilidade a importância concedida por Aristófanes ao contexto conturbado que experimentou de forma particular na Atenas da segunda metade do século $\mathrm{V}$ a. C.

${ }^{6}$ Uma palavra de agradecimento ao TMP, e em especial à actriz/ manipuladora de marionetas Sara Henriques, pela disponibilidade manifestada e pelas informações concedidas.

${ }^{7}$ A propósito da intersecção entre distintas áreas no estudo da recepção do drama clássico nas performances contemporâneas, cf. Hall, E., Harrop, S., eds. (2010), Theorising performance: Greek drama, cultural history and critical practice. London.

${ }^{8}$ João Paulo Seara Cardoso numa entrevista a Ricardo Miguel Gomes in http://www. marionetasdoporto.pt/joao-paulo-seara-cardoso/177-2010-uportoalumni-pilotar-marionetascom-engenho [consult. 11 Abril 2011]. 
A participação efectiva das mulheres nas decisões da sociedade civil é uma outra temática com frequência destacada por produções da Lisistrata aristofânica, peça em que as personagens femininas se convertem nos principais agentes de imposição de uma paz e de uma normalidade profundamente desejadas ${ }^{9}$.

Numa época de crise como a que caracteriza o mundo contemporâneo, Seara Cardoso entendeu mostrar a indignação perante questões que se sentia incapaz de controlar, a nível da política nacional e mundial, através da encenação de um texto da Antiguidade com uma mensagem que considerou actual: as fronteiras espácio-temporais diluíram-se, gerando um elo entre a cena e os politai hodiernos. O investimento reiterado do director do TMP em textos clássicos, da Antiguidade ou da Época Moderna (cf. Macbeth (2001), Máquina-Hamlet (1997)), sublinha a sua convicção no potencial e na vitalidade dos mesmos no universo coevo. Ao dar voz a uma peça escrita há longos anos atrás, é possível criarem-se metáforas com a nossa existência humana e incitarse o público de hoje a sentir ressonâncias na sua própria vida, a identificar-se com questões suscitadas pela performance, a reflectir sobre o universo em que vive.

Sem desmerecer o relevo outorgado pela comédia à sexualidade e ao confronto entre feminino e masculino, susceptíveis de enquadrar a Lisistrata em modernos catálogos de literatura erótica, como bem observa M. F. S. Silva, geradores de "uma comicidade forte que a peça muito explora e que os auditórios antigo e moderno aplaudem sem reserva ${ }^{10}$, Seara Cardoso colheu também o sentido mais esquecido do texto, de desacordo e mesmo de revolta face às decisões políticas tomadas pelos poderosos, despoletadoras de crises que afectam o quotidiano do homem comum.

A reposição do original aristofânico em locais públicos de passagem implicou alterações, seja ao nível do texto, seja ao nível da cena. Na verdade, a obra foi condensada, sofrendo cortes e pequenas adaptações, no intuito, uma vez mais, de facilitar a percepção do auditório actual e de cativar a sua atenção, bem como de garantir ao espectáculo um ritmo dinâmico.

Um desfile inicial, comum neste tipo de performance de rua, e adequadamente animado por música ao vivo, expunha de modo sucessivo os diversos intervenientes em confronto, através do cruzamento de múltiplas linguagens, apelativas à concentração dos transeuntes. No espaço público da cidade, acessível a uma audiência alargada, se criam 'visões do que a sociedade

\footnotetext{
${ }^{9}$ Sobre as mensagens transmitidas pela Lisistrata aristofânica, cf. Silva, M. F. S. (2010), Aristófanes. Comédias, Lisboa, 517 sqq.

${ }^{10}$ Silva, M. F. S. (2010): 517.
} 
pode ser e argumentos contra aquilo que é ${ }^{\prime 11}$, como nota com oportunidade Cohen-Cruz ${ }^{12}$, pelo que este tipo de produções de rua se associa em regra a manifestações de natureza sócio-política, expressivas de uma maior contiguidade entre teatro e quotidiano ${ }^{13}$.

A concepção do espectáculo para exibição num espaço aberto, de dimensões consideráveis ${ }^{14}$, como cenário natural de actuação, constrangeu o encenador a transformar as marionetas em modernas máquinas de cena, com alguns metros, que ganharam em visibilidade e em expressividade. Surgiram assim grandes estruturas metálicas, ora a representar o Coro de Velhos e o de Velhas, ora a simbolizar a Acrópole, com Lisístrata no topo e duas figuras femininas noutros pisos, sugerindo a reunião de várias mulheres de distintas origens por uma causa que a todas afectava. Uma máscara identificativa do sexo de cada um dos dois Coros e a criação de curvaturas nas estruturas metálicas traduziam de modo expressivo a avançada idade dessa personagem colectiva, corporizada apenas por um actor para cada uma daquelas duas máquinas de cena. Nesta redução a duas vozes, solucionavam-se desde logo questões orçamentais, bem como dificuldades usuais com que se deparam as equipas técnicas hodiernas na preparação de qualquer Coro, componente a que o público moderno não está de resto muito adaptado ${ }^{15}$.

A imagem da Acrópole, por sua vez, local de concertação feminina e de protecção da guerra levada a cabo pelos homens, apresentava dois seios proeminentes, a remeter para o tema da sexualidade que perpassa por toda a peça - o objecto de desejo dos guerreiros tornava-se-lhes patente e, em simultâneo, dolorosamente interdito, em nome de valores como a paz ou a família. Em paralelo, um dos componentes visuais que conferia tonalidade bélica ao espectáculo, o canhão, imaginado nos moldes de uma estética contemporânea, exibia também um elemento fálico que reiterava, em termos visuais, a importância da dicotomia sexual na Lisistrata.

Dispor de um local amplo para a actuação, sem palco nem a costumada plateia em frente, implicava ainda adaptações a nível da interpretação: o

${ }^{11}$ Cohen-Cruz, J., ed. (1998), Radical street performance, London, New York: 6.

${ }^{12}$ Cohen-Cruz, J., ed. (1998), Radical street performance. London, New York: 6.

${ }^{13}$ A este propósito, cf. Correia, A. B. (2003); Teatro de rua radical: arte, política e espaço público urbano. Coimbra. Oficina do CES 92. Disponível em http://webopac.sib.uc.pt/ search S74*por?/dteatro+de+rua/dteatro+de+rua/1,1,1,E/I856 b1523007\&FF=dteatro+de+r ua\&1,1,1,0/startreferer//sea [consulta em 22.06.2011].

${ }^{14}$ Como bem observa Correia, A. B. 2003: 7-8, 'esta actividade teatral sem paredes não pode ser vista como a versão ao ar livre dos espectáculos que ocorrem nos equipamentos artísticos convencionais ou nos edifícios ou locais que designamos como teatros'.

${ }^{15}$ A aliança entre espectáculo de rua e marionetas/ máquinas de cena não é uma novidade instituída por Seara Cardoso, mas uma modalidade muito em voga nos EUA nos anos 60 do século passado, ligada em especial a acções de protesto político (cf. Correia, A. B.: 13 sqq). 
corpo e a voz dos actores viram-se obrigados a uma dilatação que pressupôs uma pesquisa prévia da estética representativa, nomeadamente em termos de movimentos, para que funcionassem bem visualmente. Nesse sentido se procedeu, por exemplo, à substituição dos tradicionais coturnos por andas flexíveis, susceptíveis também de quebrar a ligação com o teatro naturalista, menos eficaz, na perspectiva de Seara Cardoso. Na verdade, essa opção, ainda que exigente a nível de trabalho físico, de gestualidade, de movimentos, permitia dar a noção de que se estava a representar, marcando um distanciamento em relação à realidade que o Director do TMP desejava, porquanto concebia como favorável à comunicação actor/ público.

A escolha dos figurinos obedeceu também ao princípio da dilatação característica de um espectáculo ao ar livre, muito visual: vários apontamentos com cores fortes, designadamente a saia vermelha de Lisístrata, num guarda-roupa conciliador com o tempo em que vivemos.

A evocar a presença da música nas produções da Antiguidade, Make love, not war contou com música ao vivo, a partir de um projecto musical de Jonathan Saldanha que pretendia contagiar o público: sons sugestivos de agitação, de confronto, mas também de animação, de festa, passíveis de desencadear uma explosão de emoções.

Se não temos conhecimento do sucesso da peça aristofânica por altura da sua estreia, em 411 a. C., sabemos porém que, no caso do Make love, not war, o público, corpo da cidade, considerável e heterogéneo, com diferenças etárias, sociais, culturais, aderiu em geral de modo positivo, seguindo com atenção uma performance em que quase parecia pertencer à cena, pela proximidade física entre actores e essa audiência que podia trocar de lugar, sair e voltar ao longo do espectáculo. Além dos temas abordados, motivos de reflexão a nível colectivo e individual, o fascínio pelo aparato visual contribuiu decerto para a identificação de ressonâncias com a actualidade. $\mathrm{O}$ riso foi uma reacção muito frequente, assim como os comentários ao que ia acontecendo/ sendo dito/ ouvido em vários momentos da performance, sinal do envolvimento efectivo da audiência. Para lá da música, as máquinas de cena, os movimentos notáveis dos actores em cima das andas, o fogo-de-artifício são elementos sem dúvida caracteristicamente associados por qualquer espectador a esta experiência teatral, porquanto proporcionadores de um intenso impacto visual.

$\mathrm{O}$ facto de a performance decorrer à noite salientou o recurso a um lugarcomum do espectáculo de rua, no final da peça, que, a fazer jus ao espírito da comédia antiga, e das próprias representações em vias públicas, era de festa: fogo-de-artifício, a marcar a conciliação entre homens e mulheres.

Make love, not war, uma produção que não prevê muitas digressões, seja pelos custos implícitos no transporte das várias máquinas de cena, seja também porque conta com vários actores convidados, revelou-se um espectáculo com 
muita cor, som, movimento, ritmo e humor, apresentando uma perspectiva diferente das marionetas convencionais, em articulação com o facto de se constituir como teatro de rua.

$\mathrm{Na}$ era da imagem, o elemento visual sobressaiu de modo notório, cumprindo os desejos do encenador e estimulando a criatividade e a implicação do público, em ambiente festivo. Reflectindo o entendimento brechtiano do teatro como meio de consciencialização e de intervenção sócio-política, Make love, not war constituiu-se como uma performance promotora da reflexão e do debate, 'no intuito de ser uma via de acesso à cidadania ${ }^{16}$.

\footnotetext{
${ }^{16}$ Correia, A. B. (2003): 23.
} 


\section{Bibliografia}

Aristófanes. Comédias (2010), Trad. de M. F. S. Silva, Lisboa.

Barata, J. O. (1998), História do teatro em Portugal (século XVIII): António José da Silva (O Judeu) no palco Joanino, Lisboa.

Cohen-Cruz, J., ed. (1998), Radical street performance, London, New York.

Correia, A. B. (2003), Teatro de rua radical: arte, politica e espaço público urbano, Coimbra, Oficina do CES 192. Disponível em http://webopac.sib. uc.pt/search S74*por?/dteatro+de+rua/dteatro+de+rua/1,1,1,E/I856 b $\underline{1523007 \& \mathrm{FF}=\text { dteatro+de+rua } \& 1,1,1,0 / \text { startreferer//sea }}$ [consulta em 22.06.2011].

Hall, E., Harrop, S., eds. (2010), Theorising performance: Greek drama, cultural bistory and critical practice, London.

Picchio, L. S. (1969), História do Teatro Português, Lisboa, 185-195.

Rebello, L. Francisco (1991), História do Teatro, Lisboa, 47-50.

Silva, M. F. S. (2003), 'Tragédia feita comédia. Os Encantos de Medeia do Judeu', López, A. e Pociña, A. (edd.), Medeas. Versiones de um mito desde Grecia hasta hoy. Granada: 819-846.

Schoenmakers, H., Mavromoustakos, P. (2010), "Changing attitudes towards ancient drama in theatre practice”, Silva, M. F. S., Marques, S. H., eds., Tragic Heroines on Ancient and Modern Stage. Coimbra.

Styan,J.L.(1983), Modern drama in theorie and practice 1:realism and naturalism, Cambridge.

Wiles, D. (2000), Greek Theatre Performance: an Introduction, Cambridge.

Websites:

- http://www.marionetasdoporto.pt. 


\title{
Os mitos E a CONDição humAna: $A S$ CONFRARIAS, DE JoRGE Andrade e ANTÍGONA, de Sófocles
}

\author{
Andréia Garavello Martins \\ Universidade Federal de Minas Gerais
}

\begin{abstract}
Nosso artigo pretende focalizar o diálogo entre as obras $A s$ Confrarias, do dramaturgo modernista brasileiro Jorge Andrade, e Antígona, de Sófocles. As Confrarias (1969) se passa em torno de um cadáver insepulto e nas ruas da cidade de Ouro Preto do século XVIII. Cumprindo a tríade social, religiosa e política da tragédia, As Confrarias não só dialoga com Antígona pelo tema em comum, um cadáver execrado pelas forças dominantes, e a luta para enterrá-lo, mais ainda pela discussão sobre os excluídos, seja pela raça, gênero ou classe social. A oposição da mulher (Marta/Antígona) diante do poder, faz-se através de sua força ligada à terra fértil, útero gerador de toda a existência, dilacerada pelos intesses do Estado.
\end{abstract}

Pretendemos, neste trabalho, focalizar o diálogo entre as obras $A s$ Confrarias (1969), do dramaturgo modernista brasileiro Jorge Andrade e Antígona, de Sófocles. Em 1970 a Editora Perspectiva lançou, sob a supervisão do próprio Jorge Andrade, a coletânea de suas obras dramáticas com o título de Marta, a árvore e o relógio. Faz parte dessa coletânea a trilogia composta de As Confrarias, Pedreira das Almas e Sumidouro e inclui também suas obras mais conhecidas, A Moratória, Veredas da Salvaçãa e Os Ossos do Barão, montadas por diretores como Antunes Filho, José Celso Martinez, Ulisses Cruz, para citar alguns.

É importante dizer que As Confrarias é um texto inédito; bem como a trilogia completa, apenas Pedreira das Almas já foi montada algumas vezes. A trilogia aborda o tema de uma sociedade fragmentada e seus confrontos de classes, de forma que Andrade não só dá rosto e voz aos excluídos, mas também nos deixa vislumbrar a angústia de alguns poderosos. Por isso as questões abordadas fazem parte da condição humana: a fé, o amor, os valores sociais, a ordem e sua subversão, as leis, os laços de sangue, a perda. Além disso, a própria arte também é abordada a ponto de As Confrarias poder ser lida como um metateatro: o filho de Marta torna-se ator e interpreta alguns monólogos no decorrer do espetáculo. Dessa forma o autor torna possível um questionamento sobre o fazer artístico por meio da personagem Marta.

Apesar de ser considerado um dos maiores dramaturgos brasileiros, as peças de Jorge Andrade não são montadas com frequência, talvez devido ao alto custo da produção. Contudo seu nome está entre os melhores e mais respeitados dramaturgos brasileiros. Um dos maiores críticos brasileiros, 
Anatol Rosenfeld, afirma que a obra de Andrade acrescenta à visão épica da saga nordestina a voz dramática do mundo bandeirante (Andrade, 1970. p. 599).

Ainda quanto à construção da peça, podemos afirmar que As Confrarias dialoga com Antígona em sua estrutura de tragédia clássica, cumprindo a tríade social, religiosa e política, e colocando até - não que isso tenha sido um propósito do autor - a questão da ligação entre Dioniso e as origens da tragédia. Vejamos: As Confrarias se passa em Ouro Preto, século XVIII. Marta, a protagonista - a voz que se revolta, símile de Antígona no mito grego - é uma mulher que teve sua terra cultivada e produtiva devastada pelos garimpeiros após a descoberta de ouro. Este é o primeiro aspecto a ser observado: Dioniso é o deus da fertilidade, da colheita, e sua ligação nunca foi com a aristocracia, mas com os camponeses.

O marido de Marta, Sebastião, é morto a pauladas e seu corpo é exposto como um crucificado preso a uma árvore porque tinha pedido a Marta que, depois de morto, deixasse-o lá, na sua terra e pregado a única árvore que sobrou. O filho, José, deixa as terras rumo à cidade, tornando-se ator, engajado na luta política dos inconfidentes, sendo também morto, durante uma apresentação em praça pública. Marta, carregando o corpo do filho, busca sepultura para ele nas três principais confrarias de Ouro Preto: a dos brancos, Confraria do Carmo; a dos negros, Confraria do Rosário; e dos mestiços, Confraria de São José.

Podemos notar que a estrutura dramática permite uma montagem tendo como cenário a própria cidade de Ouro Preto; e a via crucis de Marta assemelha-se a uma procissão fúnebre. A morte nessa dramaturgia se liga indissoluvelmente à vida, à tumba, à ressurreição, recuperando nitidamente seu substrato mítico, a saber, o mito do "Dioniso Zagreu".

Sabemos, por suas falas e atitudes, que a única igreja na qual Marta acredita é a própria terra, mas mesmo assim obriga os confrades a enterrarem o corpo do filho pelo seu discurso crítico em resposta a cada negativa que esses lhe davam:

MARTA: e não me venha falar novamente em mortos, José. Enquanto sonha com eles, não pode mesmo compreender os vivos. [...]

(Andrade, 1970. p. 65)

MARTA: Que o odor do corpo dele (do filho) torne insuportável a vida na cidade. [...]

(Andrade, 1970. p. 58)

MARTA: Meus mortos não serão mais inúteis. Devem ajudar os vivos. Para que serve um corpo esquecido como galho de árvore... ou como laje! [...]

(Andrade, 1970, p. 43) 
Sob esse mote, Marta estabelece um confronto dialético com cada um dos confrades, semelhante à Antígona diante da oposição da tradição e de Creonte.

[...] Mas à medida que eu vou retenho fortes esperanças

Que eu chegue como alguém, amada por meu pai, amada por você mãe, amada por você, meu próprio

Caro irmão - pois, quando você morreu, eu lavei e dispus

Seus corpos propriamente com minhas próprias mãos

E fiz libações em suas sepulturas.

E agora! -

Polinices -

Por cuidar de seu corpo,

Essa é minha recompensa! [...]

(Sófocles, Antigona, vv. 958-965)

Por isso, de todo o ciclo, escolhemos para análise a peça As Confrarias, porque acreditamos que ela não só dialoga com Antígona pelo tema em comum, um cadáver insepulto, mas também pelo cadáver de ambas as peças ser execrado pelas forças dominantes. José, filho de Marta, não se encaixa em nenhum dos padrões exigidos pelas igrejas e seus confrades: ele não é branco, não é negro, é pardo, e ainda é ator - as pessoas que se dedicavam a esse ofício não tinham o direito de serem enterradas em solo sagrado.

A luta para enterrá-lo promove debates entre Marta e os confrades, além de uma discussão sobre os excluídos, sejam pela raça, gênero ou classe social. Assim como Antígona descumpre uma lei do Estado, do poder, Marta também enfrenta, com argumentos e um discurso retórico, a poderosa igreja, no intuito de enterrar o corpo do filho: é a oposição da mulher diante do poder por causa de sua força ligada à terra fértil, útero gerador de toda a existência, dilacerada pelos interesses do Estado. Antígona, por sua vez, descumpre as ordens de Creonte para cumprir um ritual acima das leis humanas no sentido de ser um ritual ligado às tradições, à família: um ritual sagrado. As palavras de Marta para o filho, José, em cena flashback, demonstra a determinação e a força dessa mulher, assim como Antígona:

MARTA: (diante da imagem - da virgem) Meu filho vai ter paz. O seu também. Vamos! Nesta noite escura, nossos passos vão soar como gemidos de agonia e de parto. (volta-se odienta) Uma confraria cativa em gargalheiras de sangue, de crença, de interesses, de leis, torna-se covil de tiranos. Não seria aqui que deixaria o corpo do meu filho. Os que estão aqui, para que servem? Para o respeito só de vocês. Nada mais!

MINISTRO: Então, porque veio em nossa igreja?

MARTA: Porque antes que o dia amanheça... vocês vão enterrá-lo.

MINISTRO: Nós?! Os carmelitas?! 
MARTA: Vocês também. (olha à sua volta) Não nesta mina de ouro. (Andrade, 1970, p. 35, 36, grifo nosso)

As Confrarias e Antígona mostram-se como um julgamento que recorre à exumação, para compreender, defender e acusar; e à libertação e redenção do passado: Marta torna úteis seus mortos; Antígona se sacrifica para pôr término à maldição de sua família. Antígona, a divina insensata, luta como um verdadeiro herói trágico, assim como Marta. Pode-se argumentar que Marta é mãe e Antígona, irmã. Quanto esse aspecto é elucidador o que nos diz Rómulo Pianacci:

Como todo lo que es trascendente em la tragédia ocurre fuera de escena, en la llamada "estética de la abstinência", Antigona entra ya decidida a jugar su rol desde el principio. En primer lugar, ya el nombre Antígona implica la Idea de lucha y agressividad. Según Lacan: "Ella es omós, se lo traduce como inflexible. Literalmente quiere decir algo no civilizado, crudo”. Para Judith Butler, Antígona se encuentra "emergiendo no como una madre sino - en sentido etimológico - en el lugar de la madre” (Pianacci, 2008, p. 59).

Outros elementos parecem recriar os aspectos da tragédia em As Confrarias, ou seja, a intenção de um espetáculo grandioso estabelecido como evento político-religioso, como, por exemplo, a mistura de raças, ritmos, crenças. Outro aspecto que aproxima o texto de Jorge Andrade do texto trágico é a grandiosidade. Seu texto exige um espetáculo monumental - um dos motivos, talvez o principal, como já citado, do ineditismo da peça. Jorge Andrade não pensava na possibilidade de montagem durante o auge da ditadura, então criou um grande espetáculo também em cenários (além das cenas em flashbacks nas terras produtivas onde Marta e o marido moravam, o cenário possui quatro igrejas de Ouro Preto, a do Carmo, do Rosário, das Mercês e a de São José, todas ricamente ornadas com o ouro das minas exploradas).

Sobre esse e outros aspectos da tragédia, Sir Arthur Pickard-Cambridge faz uma análise completa de todas as festas ligadas a Dioniso, chegando às Grandes Dionísias. Ele demonstra, pelo estudo das obras e das peças em cerâmica que retratavam algumas cenas de tragédias apresentadas no séc. IV, o aparato necessário para a montagem de uma tragédia: a riqueza dos figurinos, o número do coro, as danças, a orquestra, e todo o maquinário que, supõe-se, sustentava o cenário e os efeitos desejados (Pickard-Cambridge, 1968, p. 5961; 79-82; 156-167; 177-180; 232-246). Podemos notar a necessidade dessa mesma riqueza de detalhes pelas rubricas do autor de As Confrarias:

Ao abrir-se o pano, o fundo da cena está iluminado mostrando o altar do consistório da Igreja do Carmo. O altar e o teto são dourados, e as paredes 
Os mitos e a condição humana: As confrarias, de Jorge Andrade e Antígona, de Sófocles.

pintadas. Em frente ao altar e em volta de mesa ricamente trabalhada estão sentados os componentes da Mesa da Ordem Terceira de Nossa Senhora do Monte do Carmo. Ao lado, bancas altas sustentam grandes livros de registros. (...) Em primeiro plano, à esquerda, um andor suntuosamente ornamentado com Nossa Senhora dos Passos, colocado sobre quatro cadeiras. (Andrade, 1970, p. 25)

Dessa forma, a semelhança entre a tragédia sofocleana e a peça brasileira se dá não apenas no tema, mas também na estrutura, na força das personagens femininas e até na preocupação com a montagem do espetáculo. $\mathrm{O}$ sublime da peleja daqueles que acreditam e confiam na terra remete à divindade grega mais humana e artística, Dioniso, sendo este a ponte mais explícita entre o divino e o humano. Assim, o filho de Marta e o irmão de Antígona são apenas pretextos para a elucidação da força feminina e a importância da terra não só para a vida e sobrevivência no campo, mas também necessária e digna para ser alvo de disputa e luta na hora da própria morte. 


\section{Bibliografía}

Agambem, Giorgio, O que é contemporâneo? e outros ensaios, Tradução: Vinícius Nicastro Honesko, Chapecó, SC, Argos, 2009.

Alexandre, M. A. "Tradução e/ou adaptação para o teatro: texto escrito e texto performático". In Ravetti, G. \& Arbex, M. Performance, exílio, fronteiras: errâncias territoriais e textuais, Belo Horizonte: Dep. de Letras Românicas, Faculdade de Letras/UFMG, Poslit, 2002.

Andrade, Jorge, Marta, a árvore e o relógio, São Paulo, Perspectiva, 1970.

Andrade, Rachel Gazolla de, Para não ler ingenuamente uma tragédia grega: ensaio sobre aspectos do trágico, Edições Loyola, São Paulo, 2001.

Aristóteles, História dos animais, I, tradução de Maria de Fátima Sousa e Silva, Lisboa: INCM, 2006.

Aristóteles, Poética, in: "Os Pensadores, Aristóteles". Tradução: Ana Maria Valente, São Paulo, Nova Cultural, 2000.

Auerbach, E., Lenguaje literario y publico en la baja latinidad y en la edad media, Barcelona, Editorial Seix Barral, 1969.

Barata, José Oliveira, Estética Teatral - antologia de texto, Temas e Problemas, série: Teatro, Lisboa, Moraes Editores, 1981.

Bakhtin, Mikhail Mikhailovitch, Estética da criação verbal, Tradução: Paulo Bezerra, 5a Ed., São Paulo, Editora WMF, Martins Fontes, 2010.

Borges, J.-L., A metáfora. In: Mihailescu, C.-A. (org.), Esse oficio do verso, Tradução de José Marcos Macedo, São Paulo Companhia das Letras, 2000.

Brandão, Junito de Souza, "Mitologia Grega", v. 2, Petrópolis, Editora Vozes, 2003.

Brandão, Junito de Souza, Teatro Grego: tragédia e comédia, 9a Ed., Petrópolis, Vozes, 1985.

Brandon, S. G. F., Diccionario de Religiones Comparadas, Vol. II, Madrid, Ediciones Cristiandad, 1975.

Burkert, W., Religião grega na época clássica e arcaica, tradução de M. J. Simões Loureiro, Lisboa, Fundação Calouste Gulbenkian, 1993.

Costa Filho, José da, Teatro Contemporâneo no Brasil: criações partilhadas e presença diferida, Rio de Janeiro, 7Letras, 2009.

Dupont, F., L'acteur-roi, Paris, Les Belles Lettres, 1985.

Fo, Dario, Manual minimo do ator, Tradução de Luca Baldovino e Carlos David Szlak, São Paulo, SENAC, 1998. 
Girard, René, $A$ violência e o sagrado, Tradução: Martha Conceição Gambini, São Paulo, Editora Universidade Estadual Paulista, 1990.

Harvey, Sir Paul, Dicionário Oxford de literatura clássica grega e latina, Trad. Mário da Gama Kury, Rio de Janeiro, Jorge Zahar Ed., 1998.

Kerényi, Carl, Dioniso - Imagem Arquetípica da Vida Indestrutivel, Trad. Ordep Trindade Serra; ver. Rosana Citino, São Paulo, Odysseus, 2002.

Maffesoli, Michel, O Instante Eterno: o retorno do trágico nas sociedades pósmodernas, Tradução: Rogério de Almeida e Alexandre Dias, São Paulo, Zouk, 2003.

Magaldi, Sábato, O texto no teatro, São Paulo, Perspectiva, 1989.

Moriconi, Ítalo, A Provocação Pós-moderna: razão histórica e política da teoria de hoje, Rio de Janeiro, Diadorim, 1994.

Nietzsche, Friedrich, O Nascimento da Tragédia ou Helenismo e Pessimismo, Tradução: J. Guinsburg, São Paulo, Companhia das Letras, 2007.

Pianacci, Rómulo E., Antígona: una tragedia latinoamericana, California, Gestos, 2008.

Pickard-Cambridge, Sir Arthur, The Dramatic Festivals of Athens, 2a ed., Oxford, Clarendon Press, 1968.

Rojo, S., A companbia della Fortezza e o teatro de Augusto Boal. In Ravetti, G. \& Arbex, M., Performance, exílio, fronteiras: errâncias territoriais e textuais, Belo Horizonte, Dep. de Letras Românicas, Faculdade de Letras/ UFMG, Poslit, 2002.

Rosenfeld, A. O mito e o herói no moderno teatro brasileiro, São Paulo, Editora Perspectiva, 1982.

Rosenfeld, A. Texto/Contexto, 3ª Ed., São Paulo, Perspectiva, 1976.

Saravia, Maria Inés, Sófocles: una interpretación de sus tragedias, La Plata, Universidad Nacional de La Plata, 2007.

Sophocles. Antigone, Tradução: Reginald Gibbons e Charles Segal, Oxford, Oxford University Press, 2003. 


\section{Dos Antígonas cubanas en el nuevo milenio}

Elina Miranda Cancela Universidad de La Habana

Aunque en 1941 la puesta en escena de Antígona de Sófocles funda Teatro Universitario, y en alguna medida marca la presencia de mitos clásicos en el teatro cubano de la segunda mitad del siglo XX, a diferencia de lo que acontece con Electra o Medea, por ejemplo, sólo en los primeros años de la década de los '90 este mito clásico motiva una versión de autor cubano publicada o representada en el país. A partir de fines de siglo y sobre todo en la primera década de este milenio, los mitos clásicos sirven de punto de partida de un número relativamente grande a piezas de autores cubanos de distintas generaciones, entre ellas dos que retoman la tragedia sofoclea de la hija de Edipo: Antígona, de Reinaldo Montero, estrenada en 2010, pero escrita desde 2006 y con una lectura dramatizada en 2009, y la también titulada con sólo el nombre de la heroína griega, Antígona, del joven dramaturgo Yerandy Fleites, publicada en 2007 por la revista Tablas. Nos proponemos, por tanto, en nuestra exposición, estudiar comparativamente ambas obras y ubicarlas entre las diversas posibilidades significativas que esta figura del teatro griego ha recibido en el teatro de las Anrillas Mayores.

Antígona, a partir de su plasmación como heroína trágica en la obra de Sófocles, ha sido probablemente una de las figuras míticas que más relecturas ha suscitado en el teatro moderno, así como estudios significativos dentro del área de la filología y la tradición clásicas. Su resonancia en tierras de Nuestra América, según acuñara José Martí, ha quedado demostrada recientemente en la tesis de Rómulo Pianacci titulada precisamente Antígona, una tragedia latinoamericana ${ }^{1}$.

Sin embargo, su presencia en versiones representadas o publicadas en Cuba es relativamente tardía, no obstante haber sido este país el primero de las tres Antillas Mayores en que se produjo, en 1941, una puesta en escena del texto de Sófocles, bajo la dirección de Ludwig Shajowicz. Saludada por intelectuales y escritores de la talla de Alejo Carpentier, actuó como acta de fundación de Teatro Universitario, así como de un seminario en que se formaría toda una generación de directores y actores, al tiempo que contribuiría a que Virgilio Piñera escribiera su Electra Garrigó, iniciadora de un teatro nacional verdaderamente contemporáneo, la cual, a su vez,

\footnotetext{
${ }^{1}$ Publicada en Irvine, Gestos, 2008.
} 
favoreció el acercamiento a los mitos y cánones griegos de otros notables dramaturgos ${ }^{2}$.

No obstante, solo a fines del siglo pasado se produce el estreno por primera vez de una versión dramatúrgica propia ${ }^{3}$, mientras que en el primer decenio de este nuevo milenio, como parte de un número relativamente notable de obras basadas en mitos clásicos ${ }^{4}$, se estrenan o editan varias versiones de la tragedia sofoclea ${ }^{5}$, de las cuales al menos dos han gozado de cierta difusión: una debida a un escritor y dramaturgo ya reconocido, Reinaldo Montero, quien en 1997 había publicado y puesto en escena su versión de la Medea de Eurípides y que termina en 2006 su Antigona, obra de la que en diciembre del 2009 se hace una lectura dramatizada y se estrena en 2010; otra, la de Yerandy Fleites, recién egresado del Instituto Superior de Arte, el cual publica en la revista Tablas, en 2007, su texto en torno al personaje sofocleo, parte de una especie de trilogía, entonces en proceso, sobre heroínas trágicas, todas adolescentes.

En su Antígona Montero no pretende un apego al texto de Sófocles semejante al mantenido con el de Eurípides en su Medea: ya no marca la alternancia de episodios y stásima; la acción se maneja libremente así como la caracterización de los personajes, de los cuales, o bien prescinde, como de Hemón, o bien amplía su papel en escena, tal como acontece con Eurídice y Tiresias; pero utiliza el mismo juego metateatral en que los personajes son conscientes de la tradición en que se inscriben, al tiempo que procura un tono elevado, a veces poético, aunque el diálogo se salpique por frases cotidianas.

Estructura su obra en dos partes de 11 y 10 escenas respectivamente, denominadas "La culpa" y "El castigo", inspiradas quizás en la estructura díptica de Sófocles, pero con la diferencia de que la muerte de Antígona se retarda casi hasta el final mismo de la pieza, de modo que tanto ella como Creón pueden sopesar su decisión.

Como en la obra sofoclea Antígona e Ismene se enfrentan a la muerte de

${ }^{2}$ Cf. de la autora, Calzar el coturno americano, La Habana, Ediciones Alarcos, 2006; Letras Cubanas, 2007.

${ }^{3}$ Se trata de "Antígona", pieza que el grupo Estudio Teatral de Santa Clara, dirigido por Joel Sáez, comienza a montar en el primer tercio de 1993 y estrena en 1994. Con ella el grupo gana el primer premio en el Festival de Teatro de Camagüey de ese año.

${ }^{4}$ El Estudio Teatral de Santa Clara estrenó de Joel Sáez Los Atridas en 2008 y Casandra en 2009. De Norge Espinosa se representó Icaros en 2003, así como Medea sueña Corinto, de Abelardo Estorino en 2009; se publicó de Yerandy Fleites Pérez Jardín de héroes (Editorial Abril, 2007; subió a escena en 2009), mientras que en la revista Tablas se dio a conocer en 2007 de Maikel Rodríguez de la Cruz el texto de su Medea reloaded y hay noticias sobre otras obras, algunas en proceso de edición.

${ }^{5}$ Pepe Santos, por ejemplo, hizo una representación de una obra titulada Contraantígona, en 2004, pero no se ha podido localizar el texto ni otros datos sobre esta puesta en escena de carácter limitado. También hay noticias de al menos otra más pero que no ha sido publicada ni representada. 
sus hermanos y la orden de Creón de dejar insepulto el cadáver de Polinices, pero el incesto asumido por la protagonista como acto liberador del propio miedo que la transgresión encierra, sustenta su determinación, al tiempo que se subraya la confrontación con el gobernante al cual "la muerte no le basta. Tiene que humillar" (escena 1).

No le preocupa a Tiresias el problema sexual, ello caería en la esfera de lo privado, sino cuando Creón confunde la moral con la soberbia y declara a uno hijo de la patria y a otro hijo de puta (escena 2), el Héroe y el Traidor (escena 4). Entonces sí se está en la órbita de lo público. De ahí que la actuación de Antígona, defendida siempre por esta como estrictamente personal, se convierta en conflicto público, puesto que a diferencia de Ismene, quien no estaría en desacuerdo con enterrar al hermano discretamente, reivindica su derecho a actuar sin ocultamientos.

También en esto se opone a Creón, para quien el conflicto radica en optar por ser considerado por la opinión pública un asesino o un gobernante débil. Sus excesos en el poder le proporcionan dolores de cabeza que solo alivia apelando al sexo con una Eurídice incondicional a la cual desprecia en cualquier otra faceta que no sea la de simple remedio de sus apetencias.

En época en que se impone la necesidad de redefinir límites entre lo privado y lo público sin soslayar su interrelación, la Antígona de Montero reclama una libertad de amar que no se detiene ni en el tabú del incesto, de actuar sin dobleces tanto en una esfera como en la otra. En una especie de Tebas, marcada por la presencia del $\operatorname{mar}^{6}$, la heroína se enfrenta a los esquemas establecidos, subvierte con sus cuestionamientos las definiciones asentadas más allá de las relaciones de poder- y, a diferencia de su hermana, no acepta estereotipos ni doble moral, pero tampoco quiere ser usada por otros.

Al final, dentro de una expresa metateatralidad que devuelve a los personajes a una especie de limbo de la tradición teatral -"caprichos del autor" como afirma Tiresias desde un mundo al que no sabe cómo ha llegado-, Antígona, sombra ella misma, se aferra a la búsqueda de lo que estima su razón de ser, sin reparar en la amenaza de olvido; mientras que, entre los vivos, se mantienen los Creontes - puesto que en la obra se augura su fin, pero este queda en suspenso-, los cuales, como nuevos Midas, corrompen todo lo que tocan.

En la Antígona que Yerandy Fleites escribe aún siendo estudiante, al igual que en la de Montero, prima la ambigüedad sobre el espacio y el tiempo. "De

\footnotetext{
${ }^{6}$ Montero evoca expresamente la definición de la insularidad dada por Virgilio Piñera - "la maldita circunstancia del agua por todas partes"- en su poema "La Isla en Peso", en 1943, solo que la transforma en "bendita", por ironía pero también consciente de su opuesto, la apertura que los puertos suponen, tan presente en su Medea.
} 
esta Tebas sin Tebas", afirma su Creonte; aunque la presencia del mar, en una, $y$, en ambas, expresiones identificables en el contexto cubano, las vinculan al país de origen. La contaminación de elementos modernos - aspecto también coincidente con Montero-, pero sobre todo la misma cotidianidad de las acciones de los personajes y el uso de un lenguaje sin el tono elevado propio de la tragedia, trasladan a nuestros tiempos y a nuestras circunstancias personajes que como Antígona y Creonte no dejan de estar conscientes de su estirpe teatral.

Con José Watanabe, el poeta peruano quien en el 2000 diera a conocer una Antígona cuya puesta en escena estuviera a cargo del grupo Yuyachkani, tiene en común Fleites el interés por la figura de Ismene; pero a diferencia del primero, en quien la tragedia de los que han permanecido en silencio cobra cuerpo en la hermana de Antígona, en el cubano la actitud de plegarse a los hechos de que Sófocles la dotara como contrapunto efectivo, es sinónimo también de un modo de entender la vida, enajenada por frívolas revistas y cigarrillos, así como por una obcecada limpieza de ama de casa sin mayores perspectivas.

Es esta Ismene - mayor que su hermana, fea y enamorada sin esperanza de un Hemón, guapo pero mudo- la que abre y cierra la obra tratando de hacer entender sus razones, a manera de círculo dentro del cual quedan comprendidos los hechos que pretende reducir y asimilar con argumentos a la esfera de su cotidianidad y frustración vital.

Antígona, casi una niña, no necesita razonar su acción, como sí lo hace la heroína griega. No conocía prácticamente al hermano, pero ha sentido la necesidad de hacer algo por su cadáver insepulto. Contenta de su acción, entona una especie de canto centrado en la paradoja vivos/muertos, resorte efectivo de la ironía trágica de Sófocles. Mas su enfrentamiento principal no es con Creonte sino con Ismene, amante de la pulcritud pero con los pulmones deshechos por tanto humo de cigarrillos; mientras que ella no vacila en ensuciarse las manos al enterrar a su hermano. Quiere saber los porqués, acepta los riesgos y hace suya, como para que no quepa duda sobre su identificación, las emblemáticas palabras de su modelo ático, pero con un significativo agregado: "No nací para jugar al odio, manita, sino al amor"7.

En muchos aspectos Creonte se asemeja a Ismene y ambos entrarían en la definición de "basura" dada por esta, la cual, según afirma, mata, como pasó con $\mathrm{Edipo}^{8}$, al cual, a su vez, el tío confiesa que amaba pero también odiaba. No

\footnotetext{
${ }^{7}$ Y. Fleites, "Antígona”, en revista Tablas, 3-4, La Habana, 2007, p. XXXII. El subrayado es de la autora

8 "A nuestro padre le cayó una basurita, una simple basurita en el ojo y murió de una terrible infección por restregarse con las manos sucias. No restregarse, no moverse, no aniquilarse, no fumar. De algún modo con él murió también la humanidad". Y. Fleites, "Antígona”, en: Tablas, vol. LXXXVII, La Habana, julio-diciembre 2007, p. XXIV.
} 
experimenta este Creonte ninguna peripecia ni anagnórisis y su importancia en la obra disminuye, al tiempo que es consciente de su papel en el mito9.

Por su juventud no desconfía esta Antígona de las irónicas promesas del tío. Al ser arrastrada, Antígona forcejea y muerde, como antes se había resistido a los guardias tirándoles terrones, pero no entiende muy bien a dónde la llevan. "A las bambalinas" es la respuesta de Ismene como para confinar lo heroico a los lindes teatrales. Para ella estos "no son tiempo de héroes, sino de seres vivos que necesitamos respirar"10.

La oposición principal no es, por tanto, entre vivos y muertos, ni generacional-aunque el papel de lo jóvenes sea una preocupación fundamental-, sino entre los "héroes" y la gente que acepta lo establecido, se pliega a las circunstancias, pretende una vida tranquila, sin sobresaltos, llena de pequeñeces y razonamientos justificativos, como los de la propia Ismene, en pretendida demostración de las virtudes de su propuesta. Es ella la que aparentemente triunfa; por ese algún crítico ha calificado la obra de Anti-Antígona ${ }^{11}$.

Sin embargo, la heroína de Fleites, al igual que la de Sófocles, actúa en función de lo que estima su deber, aunque tenga que desafiar lo establecido y, al final, su recuerdo deviene esperanza y reivindicación, según tiene que admitir la propia Ismene: "se ha puesto de moda", según su decir. Adquiere matices distintos, pero su acción continúa ofreciendo un paradigma y una fuente de reflexión; por tanto, sigue siendo Antígona aunque en una nueva versión.

Al igual que en la obra estrenada en 1994 por el Teatro Estudio de Santa Clara dirigido por el entones joven director Joel Sáez, en estas de la primera década de este siglo se mantiene los atuendos griegos, mas no se pretende, en ninguna de las tres, una representación arqueológica, sino establecer contrastes entre pasado y presente mediante la contaminación con otros "repertorios" culturales, en el sentido atribuido al término por Iser ${ }^{12}$. Se procura, por tanto, que el posible receptor capte la actualidad del mito y remita el conflicto no a un pasado ya superado, sino lo entienda en función de sus circunstancias, al tiempo que la heroína griega deviene emblema de inquietudes y expectativas propias.

9 "Sabes cuántos mitos circundan esta ciudad? ¿Sabes acaso tú, muchacha, la cantidad de literatura que se está haciendo ahora mismo en el mundo a costillas mías? Sí, yo soy el malo. Yo soy el malo de esta historia, y eso es un problema irremediable”. Ibid., p. XXIX

${ }^{10}$ Ibid., p. XXXII. XXIII

${ }^{11}$ Cfr. Habey Hechavarría Prado. "Anti-Antígona”, en Tablas, volumen ya citado, p. XXII-

${ }^{12}$ Se utiliza el término "repertorio" en el sentido utilizado por Wolfgang Iser de realidad extraestética que apela a un saber determinado del lector: convenciones, normas, tradiciones, contexto socio-cultural, valores de la época y hábitos de percepción que permiten la descodificación del texto. Cfr. Wolfgang Iser, El acto de leer. Teoría del efecto estético, Madrid, Taurus, 1987. 
Pero Sáez usa prácticamente las mismas palabras de las tragedias sofocleas que reestructura en función de centrarse en la historia y las motivaciones de Antígona, con su consiguiente adaptación, puesto que quiere rescatar la teatralidad, de modo que el peso recae sobre la expresividad actoral y la puesta es equivalente, en alguna medida, sobre todo por el carácter efímero del hecho teatral potenciado por este colectivo, a los performances de las artes plásticas. De ahí la imposibilidad de una publicación: la obra solo existe como puesta en escena en que, a pesar de los fracasos, Antígona proporciona un modelo de la necesidad de obrar y apostar por las utopías.

Sin embargo, tanto para Montero como para Fleites el hipotexto trágico continua siendo relevante, así como la importancia de expresar una lectura propia a través de nuevas versiones y de ahí la libertad en su tratamiento, subrayando ambos, aunque de maneras diferentes, el carácter metateatral de sus piezas, en las cuales la tradición y su transgresión resultan polos imprescindibles para entender sus objetivos y subrayar sus propuestas de relectura a la luz de conflictos e inquietudes muy actuales.

Enfrentada a la redefinición de los límites entre lo público y lo privado o a un ambiente de lugares comunes, como resguardo de frustraciones, en fin, a los estereotipos entronizados, la Antígona sofoclea con su tenaz resistencia mantiene su vigencia a las puertas de un nuevo milenio marcado con tantos cuestionamientos e incertidumbres. El diálogo transgresivo refuerza la pervivencia al tiempo que hace propios mitos y cánones clásicos. 


\title{
Mito e política: \\ VARIAÇÕES SObRE O TEMA DE $A N T I ́ G O N A$ NAS RECRIAÇÕES DE António Sérgio e de Salvador Espriu
}

\author{
Carlos Morais \\ Universidade de Aveiro
}

\begin{abstract}
Nesta conferência, pretendemos estudar duas Antígonas ibéricas de cariz político -a do português António Sérgio (1 $1^{\mathrm{a}}$ ed.: 1930; $2^{\mathrm{a}}$ ed.: c. 1950; $3^{a}$ ed.: 1958) e a do espanhol Salvador Espriu (1 ${ }^{\mathrm{a}}$ ed.: [1939] 1955; 2a ed.: [1963-1964; 1967] 1969)-, que têm a particularidade de apresentarem ambas um processo de reescrita que se estende por três décadas. Com estas sucessivas reelaborações, produzidas em locais e em momentos diferentes, pretendem os dois autores não só conformar o tratamento do mito à evolução do seu pensamento, mas também adaptá-lo às mutações sócio-políticas, operadas durante as duas longas ditaduras ibéricas.
\end{abstract}

0 . Num século assolado por vários conflitos internos e externos, atravessado por longas ditaduras, recortado por diferentes crises de valores e por conflitos ideológicos, e marcado ainda pelo lento e não fácil reconhecimento do papel da mulher na sociedade, a actuação modelar da filha de Édipo, transformada em mito sobretudo pelas tragédias de Sófocles ${ }^{1}$, encontrou na Península Ibérica, bem como nos países americanos de expressão portuguesa e espanhola, um palco ideal para poder evoluir ${ }^{2}$.

Foi neste contexto sócio-político que o português António Sérgio e o espanhol Salvador Espriu, entre outros, escreveram recriações deste mito

${ }^{1}$ Das quatro tragédias conhecidas que puseram em cena a filha mais velha de Édipo - Sete contra Tebas de Ésquilo, Antígona e Édipo em Colono de Sófocles e Fenícias de Eurípides foram as peças sofoclianas, principalmente Antígona, as que mais contribuíram para fixar, no imaginário colectivo, os traços gerais do carácter desta frágil mas determinada jovem heroína, figura secundária das antigas lendas da Casa Real de Tebas.

${ }^{2}$ Ignoradas por estudiosos do mito, como S. Fraisse (Le mythe d'Antigone, Paris, Armand Colin, 1974) ou G. Steiner (Antigones, Oxford, Clarendon Press, 1984), as recriações ibéricas, bem como as de países americanos de expressão espanhola e portuguesa têm sido recentemente objecto de vários estudos, de entre os quais destacamos os livros de C. Morais (coord.), Máscaras Portuguesas de Antigona, Aveiro, Universidade de Aveiro, 2001; de José Vicente Bañuls Oller \& Patricia Crespo Alcalá, Antígona(s): mito y personaje. Un recorrido desde los orígines, Bari, Levante Editori, 2008; de Rómulo E. Pianacci, Antígona: una Tragedia Latinoamericana, Irvine, Gestos, 2008; e de Rose Duroux et Stéphanie Urdician, Les Antigones Contemporaines (de 1945 à nos jours), Clermont-Ferrand, Presses Universitaires Blaise Pascal, 2010; e ainda os artigos de Maria de Fátima Sousa e Silva, "El don de la inmortalidad. Sófocles y algunas Antígonas del siglo XX” in A. P. Jiménez, C. A. Martín, R. C. Sánchez, Sófocles el Hombre, Sófocles el Poeta. Málaga, 2004, pp. 89-100; e de Aurora López y Andrés Pociña, "La eterna pervivencia de Antígona", Flor. Il. 21 (2010) 345-370. 
grego, que exploram, em particular, os mitemas da fraternidade e do protesto contra uma decisão injusta e autoritária de Creonte ${ }^{3}$. Ainda que escritas em momentos e locais diferentes, estas duas releituras, de cariz marcadamente político, têm a particularidade de apresentarem ambas um processo de reelaboração textual, com o objectivo não só de conformar o tratamento do mito à evolução do pensamento de cada um dos autores, mas também de adaptá-lo às mutações sócio-políticas, operadas durante as duas longas ditaduras ibéricas.

1. Abrindo o conjunto das sete recriações produzidas em Portugal no século passado, Sérgio compõe a primeira versão de Antígona, em 1930, durante o seu exílio, em Paris 4 . Por si considerada um «estudo social em forma dialogada ${ }^{5}$ » e não um drama para ser representado, este texto alegórico encerrava um inquestionável intuito político-pedagógico: despertar as consciências para a necessidade de resistirem à ditadura militar, no poder desde 28 Maio de 1926, e de se empenharem civicamente na luta pela democracia e pela liberdade.

Em torno do agon central entre Antígona e Creonte vão-se posicionando as diferentes personagens, que sublinham, todas elas, pelo diálogo dramático, o pensamento do autor relativamente a acontecimentos que marcaram a vida política do nosso país, em finais da terceira década do século XX: o tenentismo, o reviralho de Fevereiro de 1927, a situação política dos exilados, conotados com os Citas, ou seja, com os comunistas, a desastrosa política financeira de Sinel de Cordes e o fim da ditadura de Primo de Rivera ${ }^{6}$.

${ }^{3}$ Simone Fraisse (Le Mythe d'Antigone, Paris, 1978, p. 18) estabelece ainda outros mitemas para o mito de Antígona. Estes, que não coincidem em absoluto com os da estudiosa francesa, são dois dos que, em nossa opinião, estão na base das múltiplas recriações que se foram produzindo na literatura ocidental. De facto, com o tratamento destes mitemas, o tragediógrafo grego doava não só à Atenas do século de Péricles mas também à eternidade uma Antígona que se transformaria num modelo de piedade e de dedicação familiar, num exemplo de mulher ciente do seu papel na sociedade, num paradigma de resistência e de contestação à tirania.

${ }^{4}$ António Sérgio, Antígona. Drama em três actos, Porto, Ed. da República, 1930. As outras seis peças portuguesas sobre o tema, produzidas no século passado, são as seguintes: Júlio Dantas, Antígona. Peça em 5 actos, inspirada na obra dos poetas trágicos gregos e, em especial, na Antígona de Sófocles, Lisboa, Livraria Bertrand, 1946; João de Castro Osório, A Trilogia de Édipo, Lisboa, Sociedade de Expansão Cultural, 1954; António Pedro, Antígona. Glosa Nova da Tragédia de Sófocles em 3 actos e 1 prólogo incluido no 1. ${ }^{\circ}$ acto, Porto, Círculo de Cultura Teatral, 1957 (este texto, escrito expressamente para ser representado pelo Teatro Experimental do Porto, foi concluído, em Moledo do Minho, a 20 de Novembro de 1953); Mário de Sacramento, «Antígona. Ensaio Dramático», in Teatro Anatómico, Coimbra, Atlântida Editora, 1959, pp. 103-124; Hélia Correia, Perdição. Exercício sobre Antígona. Florbela. Teatro, Lisboa, D. Quixote, 1991; Eduarda Dionísio, Antes que a Noite Venha, Lisboa, Cotovia/Teatro Nacional D. Maria II, 1992 [pp. 33-42: "Falas de Antígona"]. A este elenco podemos acrescentar a recriação, já do nosso século, de Armando Nascimento Rosa, Antígona Gelada, Coimbra, Cendrev, 2008.

5 [A. Sérgio], "A Antígona de António Sérgio e os mocinhos da Acção de Coimbra", Seara Nova 243 (19.3.1931) 46.

${ }^{6}$ Para uma interpretação mais detalhada da peça à luz dos acontecimentos políticos da 
Neste constante jogo de implícitos e de máscaras, Creonte, criptónimo de Carmona, representa o que Sérgio define como arbitrária política da força (1930: 36) ${ }^{7}$. Tal como qualquer tirano, consegue manter-se no poder à custa da neutralização de toda e qualquer oposição, pela perseguição, pelo crime e pela instauração de uma censura e de uma vigilância policial apertadas, expulsando, pouco a pouco, «do direito cívico - exilados, proscritos, caluniados, presos - os mais altos e claros cidadãos de Tebas» (1930: 26), polis que, na peça, representa o Portugal dos anos vinte do século passado 8 .

Apoiando-se nos partidários da realeza e em membros do Colégio dos Sacerdotes ${ }^{9}$, orienta repetidamente o seu discurso e a sua acção em defesa da religião e da Ordem, contra a impiedade dos senhores da desordem, os democratas e filósofos da liberdade, financiados pelo ouro estrangeiro. E para mais facilmente impor essa ordem, preconiza um governo forte e seguro, sustentado pela 'união perfeita' (1930: 35$)^{10}$ e centrado na figura de um chefe:

CREONTE - O maior dos bens é um governo forte, que imponha a ordem a todo transe e que não deixe falar os idealistas. Ora, a ordem da sociedade exige um chefe; exige, meu filho, a obediência de todos ao arbítrio do chefe. Diante da sociedade,- um homem é nada; um filósofo,- nada. A sociedade acima de tudo. Ora, a sociedade encarna no chefe; no caso presente, a sociedade sou eu. (1930: 69)

Ao confundir a sociedade e a lei que a regula com a sua vontade, Creonte é, no dizer de Antígona (símbolo da contestação dos democratas e exilados à ditadura militar), um cego que não vê a luz (1930: 57). Precisamente a «luz da inteligência clara» e livre (1930: 21-22), que orienta e encoraja a heroína,

época, veja-se o nosso estudo "A Antígona de António Sérgio: um estudo social em forma dialogada”, Ágora 3 (2001) 111-138 (= C. Morais (coord.), Máscaras Portuguesas de Antígona, Aveiro, 2001, pp. 13-38).

${ }^{7}$ A partir de agora, todas as citações das recriações dramático-panfletárias de António Sérgio serão feitas apenas pelo ano de edição (1. ${ }^{\mathrm{a}}$ : 1930; 2..$^{\mathrm{a}}$ : c.1950; 3. ${ }^{\mathrm{a}}$ : 1958), seguido do número da(s) página(s). Para as citações completas ver bibliografia final.

${ }^{8}$ Sobre as representações alegóricas e paródicas do espaço na Antígona de António Sérgio, veja-se o nosso estudo "Ambiência clássica em invectivas às ditaduras militar e salazarista", in Francisco de Oliveira, Cláudia Teixeira, Paula Barata Dias (coords.), Espaços e paisagens. Antiguidade clássica e heranças contemporâneas. Vol. 2: Linguas e Literaturas. Idade Média. Renascimento. Recepção, Coimbra, APEC/CECH, 2009, pp. 459-465.

${ }^{9} \mathrm{Na}$ nossa perspectiva, há aqui uma clara alusão aos monárquicos e a Salazar (em ascensão política) e seu núcleo de apoiantes do Centro Católico.

${ }^{10}$ Referência implícita à efémera União Nacional Republicana, criada em finais de Setembro de 1927 e extinta em Fevereiro de 1928 — a primeira força congregadora das correntes afectas à ditadura, que viria a apoiar a eleição de Carmona - , ou à União Nacional, que atravessará todo o Estado Novo como partido único situacionista, formada em meados de 1930, altura em que Sérgio terá escrito a sua tragédia. 
levando-a a sacrificar a sua vida em defesa de uma ordem que não é sustentada pela força do autoritarismo, mas que «vem da alma, (...) da justiça, do respeito mútuo, do trabalho magnânimo para bem do povo» (1930: 56).

Inovando relativamente ao arquétipo, a peça termina com uma mensagem de esperança num futuro melhor, traduzida na instauração, no final do acto III, de uma democracia magnânima, tolerante e liberal, inspirada na «santidade de Antígona» e dedicada a «Palas, a persuasiva, deusa da luz e da liberdade» (1930: 122-123). Não obstante esta mensagem de esperança, a ditadura, volvidos vinte anos, persistia ainda, sob a presidência de Óscar Carmona, mas agora moldada à figura e pensamento político de Salazar. Os ventos de mudança e a onda de democratização que varreu a Europa, saída da Grande Guerra, não haviam logrado abalar as estruturas firmes do Estado Novo, surgido da constituição de 1933.

Assim, com o intuito de espicaçar as consciências, que progressivamente se deixavam tomar pelo torpor, Sérgio, cerca de $1950^{11}$, retorna à sua Antigona, dedicando-a «a todos os que nasceram para serem livres [...] e aos poucos que actua[va]m para bem do povo sem buscar as auras da popularidade». Este renovado «diálogo histórico-filosófico-político em forma dramática» ${ }^{12}$ acabaria por ficar inédito, tendo-se perdido, metade da segunda parte do acto II e a quase totalidade do acto III. Contudo, o que nos resta deste dactiloescrito é o bastante para podermos comprovar as inegáveis e constantes preocupações cívicas do autor, que recorre a interlocutores simbólicos, emblemas de opiniões e de tendências políticas, para expressar o seu pensamento político.

Embora investidas de novas funções, de acordo com a mudança dos temas tratados e dos alvos de contestação, as personagens são sensivelmente as mesmas. E, como seria de esperar, o princípio do conflito trágico apresenta-se próximo do original grego, ainda que adequado à realidade sociopolítica portuguesa. Ao decreto de Creonte, considerado um capricho, um desvario de ditador, contrapõe Antígona, num discurso de inflamada retórica, ridicularizada pelo tirano, as leis não escritas e universais da consciência, que estão na base do Bem e da Justiça.

Neste debate de princípios, a máscara do tirano grego continua a ocultar Carmona, mas agora convertido em símbolo da ditadura fascista (c.1950: 4), que, durante anos, contou com o «apoio inconcusso de todos os governos de autoridade e de força - o do Mussilandro, o do Efrâncoras, o do Petenião, o do Hitlérides» (c.1950: 48) ${ }^{13}$. Uma ditadura que vai resistindo ao tempo,

${ }^{11}$ Para a datação deste texto, ainda inédito, veja-se o nosso estudo "A dramatização do mínimo essencial do mito de Antígona em António Sérgio", Forma Breve 5 (2007) 70, n. 6.

${ }^{12}$ Definição inserida no frontispício do dactiloescrito (c. 1950).

${ }^{13}$ Referência paródica aos grandes ditadores europeus de Itália, Espanha, França e Alemanha: Mussolini (1922-1943), Franco (1939-1975), Pétain (1940-1944) e Hitler (1933-1945). 
graças à censura, aos instrumentos de tortura, aos campos de morte lenta, à espionagem e delação, ao controlo dos movimentos suspeitos da oposição pela "Polícia-do-Estado" (c.1950: 4), comandada pelo oficial Ortágoras, que assim passa a desempenhar papel diferente do que lhe fora atribuído na $1 .^{\mathrm{a}}$ edição. Para além desta instituição de base, própria de todos os nazi-fascismos, como escreve Sérgio no prólogo (c. 1950: 4), o regime, a fim de promover os seus ideais na família e na sociedade, conta com o apoio da alta hierarquia da Igreja Católica ${ }^{14}$ e de organismos fundamentais para a sua exaltação, como a "Mocidade Tebana" e a "Alegria no Trabalho", que estavam ao serviço da "Propaganda-Política", dirigida por Nicócoras, máscara que oculta António Ferro, responsável pela promoção da imagem de Salazar ${ }^{15}$ e mentor da designada «Política do Espírito» ${ }^{16}$.

Nunca subindo ao palco fictício onde os actores são ideias, o ditador português, ocultado pela máscara de Ceréfilo - o que gosta de Ceres, deusa da agricultura e das colheitas - é recorrentemente invocado, no decurso da acção. À semelhança da deusa que empresta o seu nome à formação deste híbrido, também a álgida figura que se oculta por detrás dele é, entre os seus opositores, o plebeu, o campónio tacanho, o «marechal do orçamento» (c. 1950: 92), que impiedosamente colhe os tributos do povo, com o objectivo de a todo o custo conseguir obter o saldo nas contas públicas de Tebas, sendo incapaz, como refere Antígona, de apreciar a dignidade do espírito, o amor da verdade e da justiça:

${ }^{14}$ Sobre a comunhão de interesses entre o Estado e a Igreja, parodiada por Sérgio (c.1950: 72-73), vide o nosso estudo "Ambiência clássica em invectivas às ditaduras militar e salazarista", in Francisco de Oliveira, Cláudia Teixeira, Paula Barata Dias (coords.), Espaços e paisagens. Antiguidade clássica e heranças contemporâneas. Vol. 2: Linguas e Literaturas. Idade Média. Renascimento. Recep̧cão, Coimbra, APEC/CECH, 2009, pp. 459-465.

15 Responsável, desde 1933 até 1949, pelo Secretariado de Propaganda Nacional (SPN), designado a partir de 1944 Secretariado Nacional de Informação, Cultura Popular e Turismo (SNI), António Ferro, autor do livro Salazar: o Homem e a sua Obra (traduzido para várias línguas), foi o principal promotor da figura de Oliveira Salazar, aqui e no estrangeiro. Caracterizado, na peça, como "escravo do Ceréfilo (i.e., Salazar), o da Propaganda" (c.1950:31), António Ferro surge na peça sob a máscara de Nicócoras. Neste nome, com sonoridade grega, é possível vislumbrar uma amálgama do "Ni" da sigla SNI (Secretariado Nacional de Informação) e "cócoras", a atitude servil de quem está incondicionalmente ao serviço do poder, como era o caso, na óptica de Sérgio, de António Ferro, principal responsável pela política cultural do regime e pela promoção da imagem do seu chefe, para o que contava com as actividades da Mocidade Portuguesa e da Fundação Nacional para a Alegria no Trabalho (FNAT), igualmente satirizadas na peça.

${ }^{16}$ Conciliando as velhas tradições populares e os antigos valores nacionais com a modernidade daquele tempo, este programa cultural tinha como objectivo primordial glorificar o regime e o seu chefe. Para a teorização da "Política do Espírito", veja-se António Ferro, Entrevistas a Salazar (pref. de Fernando Rosas), Lisboa, Parceria A. M. Pereira, 2007, pp. 225-229, e ainda 57-59 e 155-159. 
Antígona - Com sua alma tacanha de cultivador de aparências, de calculador astucioso, é incapaz de apreciar a dignidade do espirito, a profundez da consciência, o largo voo idealista, o amor da verdade, da sinceridade e da luz. Sem humanidade e sem chama, delicia-se à grande na concupiscência do mando, e para poder deliciar-se na concupiscência do mando consente e encobre todas as malversações dos seus homens. A podridão mascarada é o seu ideal de política. (c.1950: 94 b-c)

Indómita e generosa, como a da peça sofocliana, a heroína sergiana, expressando admiração por todos os que, na escuridão de Tebas, protestam e se indignam, está decidida a erguer-se contra esta "podridão mascarada», contra o despotismo de Creonte e de Ceréfilo que a todos asfixia, guiada pela luz clara e livre do Espírito, da Razão (1958: 21-22). Na defesa da dignidade, da liberdade e da justiça, a jovem filha de Édipo encarna, nas palavras de Sérgio, inscritas no prólogo, uma faceta «de anti-fascismo, da aspiração à liberdade, do revolucionismo social» (c. 1950: 4) $)^{17}$.

É a esta 2. a edição reformulada que Sérgio, retocando-as, vai buscar as três primeiras cenas, para formar o corpo central da sua "Jornada Sexta" do Pátio das Comédias, das Palestras e das Pregaçôes, que constitui, assim, a sua terceira variação sobre o mito de Antígona. Composto em finais de 1958, após a sua prisão a 22 de Novembro, por "actividades subversivas" ${ }^{18}$, este opúsculo surge na sequência das conturbadas eleições que opuseram Américo Tomás a Humberto Delgado ${ }^{19}$. Trata-se de um apólogo de contestação à «tirania hipócrita» de Creonte (1958: 12), máscara que serve de disfarce não a Carmona, como acontecia nas duas primeiras versões, mas a Américo Tomás e ao poder despótico salazarista que esteve por trás da sua eleição. Apesar de muito reduzido, o núcleo dramático deste opúsculo contém já a necessária retórica de protesto, decorrente do debate entre Isménia, símbolo dos derrotistas e dos que, por causa dos laços familiares, se desviam do «combate pelas ideias e do heroísmo cívico» (1958: 29; cf. c.1950: 4) e a sua irmã, a temerária Antígona, que representa todos os que lutam contra o asfixiante totalitarismo do Estado Novo. A este breve agon entre as duas irmãs, o autor junta um breve prólogo, onde se convida o público a recuar ao passado e a apreciar as suas actuais

${ }^{17}$ Tal como na $1 .^{\text {a }}$ edição, partilham destes seus ideais o já morto Polinices, essência sublimada do espírito revolucionário (c.1950: 5), o jovem Hémon, ponderado e respeitado pelos democratas, o cáustico adivinho Tirésias e ainda Critóbulo, um oficial do exército que admira os que lutam pela libertação das almas, na trincheira rectilínea e clara da consciência (c.1950: 39).

${ }^{18}$ Sobre este assunto, vide J. Baptista, Disse chamar-se António Sérgio de Sousa: auto da prisão, inquirição e desterro do autor dos Ensaios em 1935, Lisboa, Caminho, 1992, pp. 67-84.

${ }^{19}$ Para o enquadramento das seis jornadas do Pátio das Comédias, das Palestras e das Pregações, Lisboa, Inquérito, 1958, veja-se o nosso estudo "Un exercice d'actualisation et d'exégèse du mythe d'Antigone (António Sérgio, Jornada Sexta do Pátio das Comédias, 1958)", in Rose Duroux et Stéphanie Urdician (eds.), Les Antigones Contemporaines (de 1945 à nos jours), ClermontFerrand, Presses Universitaires Blaise-Pascal, 2010, pp. 295-305. 
venturas pelos grandes males da Tebas de outrora (1958: 7-8), e um epílogo onde se oferece a exegese não só deste texto dramático, mas também das outras duas versões. Pela boca do Ouvinte, que neste epílogo traduz o pensamento do autor, a Antígona é classificada como Kantista e cristã ${ }^{20}$. Mas, na sua verdadeira essência, ela é política ${ }^{21}$, como reconhece o próprio Sérgio, quando, no prólogo

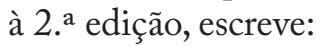

... ante os factos políticos do meu tempo, eu lembrei-me por meu turno de que existia - Sófocles e rabisquei este apólogo (...). Através do artifício de uma antiga história, eis o debate que é de hoje, sobre temas sociais que são de hoje. Mais: em linguagem que é de hoje, com modos de pensar que são de hoje, sem nenhum rebuço ou cautela. (c. 1950: 3-4)

2. Idêntico processo de reelaboração progressiva do mito grego para fins políticos foi usado em Espanha, como dissemos já, por Salvador Espriu.

Nos começos de 1939, quando a Espanha estava a sair de uma violenta guerra civil e a Europa estava a meses de entrar numa não menos violenta Guerra, Salvador Espriu, tal como fizera Sérgio em 1930, recorre igualmente ao mito de Antígona para escrever um texto comprometido ideologicamente ${ }^{22}$ que sublinha o horror de uma insensata guerra entre irmãos, que tanta destruição trouxe a Tebas, polis que alegoricamente representa Espanha. Mas, ao contrário de Sérgio, Espriu, algo ingenuamente, fá-lo sem críticas violentas. Como sublinha Maria del Carme Bosch, "Espriu no vol fomentar l' esperit de revolta, sinó de pau"23. Inspirando-se sobretudo no arquétipo sofocliano, mas bebendo igualmente nas Fenicias de Eurípides e nos Sete contra Tebas de Ésquilo, a sua Antigona é construída em torno de dois agones que sublinham o seu desejo de paz e de fraternidade. No primeiro, numa atitude que traz à memória a Jocasta das Fenícias, a heroína esgrime argumentos com Etéocles, tentando promover a concórdia e assim impedir o confronto fratricida. No segundo, tal como acontecia em Sófocles, movida por sentimentos fraternais

${ }^{20}$ Esta recriação de Sérgio é kantista, porque, contra a razão absoluta de Estado, proclama não tanto «os direitos da piedade religiosa [e] do amor fraterno», como a de Sófocles, mas mais «os direitos da livre consciência humana, os da lei racional a que se eleva o espírito, eterna e imprescritível» (1958: 28), o espírito que, no dizer do Actor, se eleva «contra o poder que corrompe - que corrompe sempre» (1958: 30). E é também cristã, porque, de acordo com o pensamento de Sérgio, o ideal democrático por ela defendido, sendo homogéneo com o do cristianismo, «é a tradução política do Evangelho»e «tem o carácter de uma religião».

${ }^{21}$ De facto, na origem destes três exercícios dramático-panfletários estão, como vimos, contextos políticos propícios à revitalização do mito de Antígona: a ditadura militar, o salazarismo e a fraude eleitoral de 1958.

${ }^{22}$ Esta é uma de quatro Antígonas catalãs; as outras são as de Guillem Colom (1935), Joan Povill i Adserà (1961) e Josep M. Muñoz Pujol (1965).

23 “Les nostres Antígones", Faventia 2 (1980) 98. 
que a levaram à transgressão do édito que impedia a concessão de honras fúnebres ao irmão Polinices, enfrenta o tio na certeza de que acima da lei humana estavam as leis divinas.

Mas, se na primeira versão em dois actos, escrita em 1939 e publicada apenas em $1955^{24}$, com um prólogo "à maneira de Eurípides" redigido em 1947, Espriu se serve do mito para "superar el espiritu de guerra civil, sus oposiciones y odios" 25 , com o passar dos anos, decide reescrever e renovar a sua tragédia, para a adaptar a novos contextos sócio-políticos. Este processo que se prolonga no tempo tem em mente dois objectivos fundamentais: denunciar e condenar a cruel ditadura instaurada em Espanha e reafirmar, num contexto de grande repressão, a identidade da língua e da cultura catalãs.

Publicada em 1969, em Barcelona, esta segunda variação, ainda que conserve a mesma linha de acção em torno dos dois agones já referidos, apresenta-se estruturada, não em duas, mas em três partes, incorporando textos e reformulações redigidos entre Novembro de 1963 e Fevereiro de 1964, numa altura em que o regime franquista celebrava os 25 anos de "paz", e acrescentando ainda novas personagens, que alteram o sentido original desta releitura mítica ${ }^{26}$.

Continuando a ignorar a figura de Hémon para que o amor conjugal não ofusque o amor fraternal ${ }^{27}$, introduz a figura do povo que, no final da primeira parte, entoa um amebeu em versos alexandrinos, interpretando assim um papel idêntico ao do Coro da tragédia grega. À semelhança dos velhos no párodo da Antígona de Sófocles (vv. 100-161), as diferentes vozes do povo, num diálogo lírico com todas as personagens que se encontram em palco, à excepção de Antígona, exultam pela salvação de Tebas, numa alusão evidente ao triunfalismo das celebrações oficiais dos 25 anos de paz, promovidas pela máquina de propaganda de Franco.

Nunca subindo ao palco desta alegoria política de Espriu, o ditador está sempre presente no pensamento de todos, sobretudo no do Lúcido Conselheiro,

${ }^{24}$ Salvador Espriu, Antígona. Palma de Mallorca: Ed. Moll, 1955.

${ }^{25}$ Palavras de Espriu, retiradas de uma entrevista conduzida por Roman Gubern, publicada em Primer Acto 60 (1965) 14.

${ }^{26}$ Esta edição, com o n. ${ }^{0} 54$ da colecção «Antologia Catalana», dirigida por Joaquim Molas (na edição crítica, recebe a sigla $B$ ), inclui um prólogo de Maria Aurèlia Capmany e contempla ainda revisões produzidas no datiloescrito de 1967 . Refira-se ainda que, antes desta segunda edição, Ricard Salvat publica, em Janeiro de 1965, no n. ${ }^{\circ} 60$ da Revista «Primer Acto» (pp. 2737), a tradução castelhana de uma versão da Antígona de Salvador Espriu, que contempla já as remodelações de 1963-1964. Nas citações da Antígona de Espriu, seguimos este texto que, na edição crítica, recebe a sigla Btrad.

${ }^{27}$ Como refere J. Malé, em “'Car hem aprés que l' amor vençe la mort'. L'amor en els mites feminins de Salvador Espriu", J. Malé - C. Miralles (eds.), Mites Clàssics en la literatura catalana moderna i contemporània, Barcelona, 2007, p. 137, este era o único amor que poderia ter evitado uma guerra tão cruel. 
figura acrescentada, nesta segunda versão, ao elenco de quatro conselheiros, que agora surgem sem nome ${ }^{28}$. Com uma atitude de distanciada lucidez, pouco subserviente relativamente ao tirano, esta personagem é responsável, numa das suas intervenções, pela associação de Creonte a Franco, que descreve de forma impressiva, tornando evidente a intenção do autor de se servir do mito para criticar o ditador que se perpetuava no poder, esmagando sem contemplações os seus opositores:

EL LÚCIDO CONSEJERO - ( $A$ su amigo) No es difícil convivir en Tebas, es imposible. Creonte lo sabe como tú y yo lo sabemos, pero, claro está, nunca babrá de confesarlo. Miralo bien: obeso, nada atractivo, com esos ojos de mirada fija y glacial como de serpiente. (...) Mientras viva, es probable que nos mantegamos en paz, porque está dispuesto a aplastar sin contemplaciones a todo aquel que se le oponga. Pero casi es un viejo y sus hijos y seguidores no valen nada. En Tebas, Creonte no puede instituir perpetuamente a Creonte. Cuántos años vivirá, veinte, tal vez treinta? Si no se lo lleva mucho antes una muerte violenta. (p. 35)

Símbolo da oposição a Creonte e vítima das arbitrariedades do seu poder ditatorial, Antígona é também alvo de uma reformulação do seu carácter por parte de Espriu, cujo objectivo é sublinhar e exaltar a sua determinação e o seu heroismo. De facto, ao invés do que acontece na versão de 1955, a filha de Édipo, após a realização dos rituais fúnebres na companhia de Eumolpo, não tenta fugir. Assumindo a responsabilidade do seu acto, vai ao encontro dos guardas, afirmando que se entregará de livre vontade a Creonte para ser julgada pelo seu acto de assumida rebeldia.

Condenada a morrer lentamente numa gruta, privada de luz, aceita, sem resistência, o seu destino e parte acompanhada pelos guardas, não sem antes dirigir mais um apelo, este inflamado, à reconciliação nacional:

ANTÍGONA - Calmad el pueblo, que vuelva a sus casas, que cada uno vuelva tranquilo a su hogar. No sé si muero com justicia, pero sé que muero con alegria. Privada de la luz, en una lenta espera, recordaré la ciudad hasta el último momento. (...) Que la maldición acabe conmigo y que el pueblo olvide lo que le divide y pueda trabajar. Que el pueblo pueda trabajar, y ojalá que tú, rey, y todos vosotros lo queráis asi y lo sepáis servir. (p. 37)

Também neste caso, em mais uma adequação da obra ao novo contexto político centrado na figura do sinistro e indefectível ditador Franco, estas

${ }^{28}$ Estes Conselheiro que, na edição de 1955, eram personagens com nome (Ènops, Periclimen, Deípilos e Àstacos), na edição de 1969, passam a figuras anónimas. Com esta despersonalização, Espriu pretendia dar mais profundidade ao mito e destacar a figura do Lúcido Conselheiro. 
palavras de Antígona, que resumem o espírito apaziguador e conciliador da obra, são dirigidas não ao povo de Tebas, como na edição de 1955, mas a Creonte e aos Conselheiros e constituem o verdadeiro fim da tragédia, onde não há lugar para o relato do suicídio da heroína, como acontece no original grego. Assim, a longa fala do Lúcido Conselheiro, escrita para a edição de 1969, é um excurso que pode muito bem ser ignorado, como sugere aliás a didascália, uma vez que, limitando-se a vislumbrar o destino das personagens, nada acrescenta em termos dramáticos.

3. Tal como fizera Sérgio, Espriu, revivificando o mito de Antígona, escreveu um texto comprometido ideologicamente, que foi sendo progressivamente conformado à evolução do seu pensamento e adaptado às novas circunstâncias políticas, vividas em Espanha, depois da insensata guerra civil e durante a ditadura de Franco, que, tal como Salazar em Portugal, se perpetuou no poder durante décadas.

Nestas duas recriações ibéricas, escritas em locais e em momentos diferentes, com múltiplas variações, a heroína, emprestando a sua voz à do autor, surge sempre intrépida a condenar a tirania, que a todos sufoca, e a reivindicar a liberdade e o respeito pela dignidade da consciência humana, princípios fundamentais da democracia. 


\section{Bibliografia}

J. Baptista, Disse chamar-se António Sérgio de Sousa: auto da prisão, inquirição e desterro do autor dos Ensaios em 1935, Lisboa, Caminho, 1992.

J. Vicente Bañuls Oller \& Patrícia Crespo Alcalá, Antígona(s): mito y personaje. Un recorrido desde los origenes, Bari, Levante Editori, 2008.

María Carmen Bosch,"Les nostres Antígones", Faventia 2 (1980) 93-111.

W. Burkert, Mito e mitologia (trad. port.: M. H. Rocha Pereira), Lisboa, Edições 70, 1991.

J. M. Camacho Rojo, La Tradición Clásica en las Literaturas Iberoamericanas del siglo XX: Bibliografía analitica, Granada, Universidad de Granada, 2004.

J. M. Castellet, “Obra de Salvador Espriu”, Primer Acto 60 (1965) 7-8.

Rose Duroux et Stéphanie Urdician, Les Antigones Contemporaines (de 1945 à nos jours), Clermont-Ferrand, Presses Universitaires Blaise Pascal, 2010.

Salvador Espriu, Antígona, Palma de Mallorca, Ed. Moll, 1955.

Salvador Espriu, Antigona (2.a versión - 1963), tradução para o espanhol de Ricard Salvat, publicada em «Primer Acto» 60 (1965) 27-37.

Salvador Espriu, Antígona. Barcelona, Ediciones 62, 1969.

Salvador Espriu, Primera història d' Esther. Antígona, Barcelona, Ediciones 62, 1975 («Collecció universal de butxaca El Cangur», 9), pp. 65-103.

Salvador Espriu, Antígona y Fedra, Barcelona, Empúries, 1985 (com estudo introdutório de Alfred Badia).

Salvador Espriu, Antígona (edició crítica a cura de Carmina Jori i Carles Miralles; estudi introductori i notes de Carles Miralles), Barcelona, Centre de Documentació i Estudi Salvador Espriu / Edicions 62, 1993.

António Ferro, Entrevistas a Salazar (pref. de Fernando Rosas), Lisboa, Parceria A. M. Pereira, 2007.

Simone Fraisse, Le mythe d'Antigone, Paris, Armand Colin, 1974.

Roman Gubern, «Entrevista con Salvador Espriu», Primer Acto 60 (1965) 13-17.

Pilar Hualde Pascual \& Manuel Sanz Morales, La literatura griega y su tradición, Madrid, Ediciones Akal, 2008.

Vítor Jabouille et al., Estudos sobre Antígona, Mem Martins, Inquérito, 2000.

Aurora López \& Andrés Pociña, "La eterna pervivencia de Antígona”, Flor. Il. (2010) 345-370.

J. Malé, “'Car hem aprés que l'amor vençe la mort'. L'amor en els mites feminins 
de Salvador Espriu", in J. Malé - C. Miralles (eds.), Mites Clàssics en la literatura catalana moderna i contemporània, Barcelona, 2007, pp. 123-145.

Carlos Morais (coord.), Máscaras Portuguesas de Antígona, Aveiro, Universidade de Aveiro, 2001.

Carlos Morais, "A Antígona de António Sérgio: 'um estudo social em forma dialogada", Ágora 3 (2001) 111-138.

Carlos Morais, "A dramatização do mínimo essencial do mito de Antígona em António Sérgio", Forma Breve 5 (2007) 67-76.

Carlos Morais, "Ambiência clássica em invectivas às ditaduras militar e salazarista", in Francisco de Oliveira, Cláudia Teixeira, Paula Barata Dias (coords.), Espaços e paisagens. Antiguidade clássica e heranças contemporâneas. Vol. 2: Linguas e Literaturas. Idade Média. Renascimento. Recep̧cão, Coimbra, APEC/CECH, 2009, pp. 459-465.

Carlos Morais, "Un exercice d'actualisation et d'exégèse du mythe d'Antigone (António Sérgio, Jornada Sexta do Pátio das Comédias, 1958)", in Rose Duroux et Stéphanie Urdician (eds.), Les Antigones Contemporaines (de 1945 à nos jours), Clermont-Ferrand, Presses Universitaires BlaisePascal, 2010, pp. 295-305.

Carlos Morais, "A retórica de protesto nas Antígonas de António Sérgio", in Pereira, Belmiro Fernandes \& Várzeas, Marta (org.), Retórica e teatro: a palavra em aç̧ão, Porto, U. Porto Editorial, 2010, pp. 351-364.

Rómulo E. Pianacci, Antígona: una Tragedia Latinoamericana, Irvine, Gestos, 2008.

María José Ragué Arias, "La ideologia del mito. Imágenes de la Guerra Civil, de la posguerra y de la democracia surgidas a partir de los temas de la Grécia Clásica en el teatro de siglo XX en España”, Kleos 1 (1994) 63-69.

M. J. Ragué-Arias, Els personatges femenins de la tragèdia grega en el teatre català del XX, Sabadell, Editorial, 1990, pp. 41-47.

António Sérgio, Antígona. Drama em três actos, Porto, Ed. da República, 1930.

António Sérgio, Antígona, c. 1950 (2. a edição dactiloscrita, profundamente remodelada).

António Sérgio, Pátio das Comédias, das Palestras e das Pregações. Jornada Sexta, Lisboa, Inquérito, 1958.

[A. Sérgio], "A Antígona de António Sérgio e os mocinhos da Acção de Coimbra”, Seara Nova 243 (19.3.1931) 45-46.

Maria de Fátima Sousa e Silva, "El don de la inmortalidad. Sófocles y algunas Antígonas del siglo XX" in A. P. Jiménez, C. A. Martín, R. C. Sánchez, Sófocles el Hombre, Sófocles el Poeta. Málaga, 2004, pp. 89-100.

George Steiner, Antigones, Oxford, Clarendon Press, 1984. 


\title{
El mito de Fedra en la literatura Árabe clásica de ORIGEN ORIENTAL
}

\author{
Celia del Moral \\ Universidad de Granada
}

\begin{abstract}
En esta comunicación analizaremos la versión árabe del mito de Fedra y su huella en la literatura árabe a través de obras como el Sendebar y Las Mil y una noches, comparándola con sus antecedentes griego y latino. Analizaremos las características de los personajes, los escenarios en que se mueven y la intención moralizante de estas obras, enmarcado en la corriente misógina que desde la India y a través de la literatura árabe se extiende por Europa a lo largo de la Edad Media.
\end{abstract}

Pocas cosas se pueden añadir ya al mito de Fedra e Hipólito y de su influencia en la Literatura universal que no hayan sido dichas en el magnífico libro editado por Aurora López y Andrés Pociña: Fedras de ayer y de hoy, fruto de un Simposio internacional celebrado en Granada en 2005.

En este libro encontramos (como bien saben muchos de los presentes) la figura de Fedra y de los otros personajes que forman parte de la tragedia analizados desde todos o casi todos los puntos de vista, así como las numerosas versiones que el mito ha dado lugar desde la antigüedad clásica hasta nuestros días.

Sin embargo, los que nos dedicamos al estudio de la Literatura árabe clásica, echamos de menos una versión del mito en esta literatura en una obra de origen oriental, como es la India o la antigua Persia, y que a través de las traducciones realizadas durante el califato abbasí, entre los siglos VIII al X, fue conocida y adaptada a la cultura árabe-islámica, formando parte de Las mil y una noches, la obra más emblemática de la literatura árabe, y, viajando simultáneamente a Occidente, es decir a al-Andalus, de donde fueron de nuevo traducidas al castellano a través de la Escuela de Traductores de Toledo y difundida por toda Europa. Me refiero al Sendebar, Syntipas o Sindibad, conocida en Occidente a través de su traducción con el título de Libro de los engaños e los asayamientos de las mugeres ${ }^{1}$, un libro de clara intención misógina, destinado a demostrar las maldades y mentiras inherentes al sexo femenino, cuya historia marco o hilo conductor recrea el mito de Fedra en su versión oriental.

Como se ha dicho ya repetidas veces, estamos ante una situación de carácter universal que nace de la propia naturaleza humana y que puede darse

${ }^{1}$ Ed. de Ma Jesús Lacarra. Madrid: Cátedra, 1995; véase también Versiones castellanas del Sendebar. Ed. y prólogo de Ángel González Palencia, Madrid - Granada, 1946. 
en cualquier tiempo y cultura: el hombre maduro, casado de antemano con otra $\mathrm{u}$ otras mujeres, que tiene un hijo único durante mucho tiempo deseado, que en su madurez o vejez se enamora y casa de nuevo con una muchacha joven, para que le de nuevos hijos y le haga vivir la ilusión de una segunda juventud. Al convivir en una misma casa o palacio el hijo joven o adolescente con la nueva esposa de su padre, de la misma o parecida edad, surge entre ellos el amor o la pasión, cuya iniciativa puede venir de parte de uno o de otro, y de ahí nace la tragedia al chocar el amor del hijo o de la joven esposa con los derechos legítimos del padre y con la sombra del incesto planeando sobre el triangulo amoroso. El final es variado, según las versiones: en unos casos termina con la muerte de ambos a manos del padre, o una condena, o el destierro o el perdón, según la cultura y la religión del momento.

E1 Sendebar, Syntipas o Sindbādal-Hakim una conocida obra perteneciente al género narrativo, como el Kalila y Dimna o Las mil y una noches, con una estructura muy similar a estas dos: la técnica de cuentos de cajón e historiamarco, cuyo origen es incierto y ha dado lugar a todo tipo de teorías, puesto que no se conoce el original. La opinión más extendida es que tiene su origen en la India, al igual que las otras dos obras citadas, en una fecha incierta, y que de allí pasó a Persia y a través del pahlevi fue traducido a la literatura árabe, donde es mencionada por algunos autores en el siglo X. De Oriente viajó a al-Andalus, siendo por último traducido del árabe al castellano en el siglo XII por encargo del infante D. Fadrique, hermano de Alfonso X el Sabio.

Otras hipótesis hablan de un origen persa, del s. VI, quizás de influencia helenística, o incluso de un origen hebreo (Sindabar), por su parecido a algunos pasajes bíblicos como la historia de José y la mujer de Putifar. Sea como sea, el original se ha perdido, no hay noticias de su autor ni de la fecha en que fue compuesto, pero lo cierto es que a partir de su traducción al castellano en el siglo XII fue conocido e imitado en toda Europa y tuvo una gran influencia en la narrativa occidental. Entre otras versiones encontramos la Historia de los Siete Sabios de Roma o la Historia lastimosa del Príncipe Erasto ${ }^{2}$.

En Las mil y una noches aparece recogido entre las noches 578 y 606, con el título de "Historia que trata de las astucias de las mujeres y de su gran picardía", título muy semejante al de la traducción castellana, y dado que esta obra es una recopilación posterior de historias y cuentos de muy diversa procedencia, añadidos a un manuscrito primitivo -probablemente de la misma procedencia que el Sendebar-, es muy posible que el original utilizado para la traducción al

\footnotetext{
${ }^{2}$ Versiones castellanas del Sendebar, op. cit.

${ }^{3}$ Las Mily Una Noches. Traducción, introducción y notas de Juan Vernet. Barcelona: Planeta, 2000, 2 vols, II, 297-369.
} 
castellano y la historia insertada en Las mil y una noches sea la misma, si bien los traductores al castellano la adaptaron a la sociedad medieval cristiana, mientras que los traductores al árabe la islamizaron.

La conexión con el mito de Fedra ya fue señalado por Vicente Cristobal en su artículo: "Recreaciones novelescas del mito de Fedra y relatos afines" ${ }^{4}$. Como señala este estudioso del tema, aparece con cierta frecuencia en la literatura india, citando a Frenzel que lo hace derivar del Kumala indio, puede tratarse de una influencia del mito griego o de una coincidencia temática puesto que como ya se ha dicho, es un tema universal.

En cuanto a los personajes, coinciden en líneas generales con los de la tragedia greco-latina. Si en Eurípides y Seneca hay cuatro personajes principales: Fedra, Hipólito, Teseo y la nodriza, junto con otros secundarios como el mensajero y el coro, en el Sendebar encontramos: el rey Alcos de Judea, que sería el equivalente a Teseo, la reina madre (sin nombre), una de las 90 mujeres del rey, el príncipe (sin nombre) que sería el equivalente a Hipólito, la favorita, que representa a Fedra y los 7 sabios (de entre los 900 del reino), en especial uno de ellos que ocupa el lugar de preceptor del príncipe, de nombre Çendubete, deformación del nombre original de Sendebar, Sindibād o Syntipas, este personaje podría ser el equivalente a la nodriza, pero que en vez de ayudar o aconsejar a la madrastra, aconseja y vela por el Príncipe, mientras que la madrastra no tiene quien la defienda y debe hacerlo sola.

En Las mil y una noches los personajes principales son: el rey (esta vez sin nombre, su esposa (que era su prima), el príncipe, la concubina (favorita del rey) y el sabio, de nombre Sindibād, original del que derivan los otros nombres como Sendebar, Syntipas o Çendubete. Aquí la historia marco está mucho más esquematizada que en los anteriores.

En la versión de Los siete sabios de Roma, el personaje de Teseo está representado por el emperador Ponciano, la emperatriz es hija de un rey, el príncipe se llama Diocleciano, la madrastra es hija del rey de Polonia y de nuevo aparecen los siete sabios (aquí, de Roma) que dan nombre a la obra. Todos estos sabios que aconsejan y cuentan historias a modo de ejemplos para convencer al rey de las maldades de las mujeres, podrían ser el equivalente al papel del coro en la Fedra de Seneca o el Hipólito de Eurípides.

La localización de la historia varía en cada obra, como es natural, dependiendo de la cultura y de la época, aunque en unos casos esté más definido que en otras, lo cual nos demuestra la universalidad del mito. Si en la tragedia clásica el mito se localiza en Atenas, en donde reinaba Teseo, en el Sendebar

\footnotetext{
${ }^{4}$ Cuadernos de Filología Clásica, 24 (1990), 111-125.
} 
(según la versión castellana) Alcos es el rey de Judea. En Las mil y una noches no indica de donde era el rey no donde se localiza la acción sino que como en muchos de los cuentos de esta obra, la acción queda indefinida en el espacio y el tiempo, lo que le da una mayor universalidad.

Dice Sharazad:

"Me han contado que en lo más antiguo del tiempo y en lo más remoto de las edades hubo un rey que tenía muchos soldados y auxiliares y era generoso y rico, pero había llegado a cierta edad y no tenía ningún hijo varón. Se dirigió a Dios por mediación del Profeta y le pidió que le diera un hijo varón que heredase el reino después de su muerte y que fuera la niña de sus ojos. Acto seguido se dirigió a la habitación en que vivía, mando llamar a su prima, que era su esposa, y se unió a ella. La esposa, con la ayuda de Dios, quedo embarazada y así estuvo hasta el momento del parto. Entonces dio a luz un hijo varón, cuyo rostro era como la luna en su decimocuarta noche....".

En las versiones derivadas del Sendebar la acción se sitúa en Roma (Historia de los siete sabios de Roma) o en Padua (Historia lastimosa del Principe Erasto) ${ }^{6}$.

En cuanto a la intención de la obra, si en la tragedia griega y latina la intención de la obra es la propia tragedia y la imposibilidad de luchar contra el destino, en el Sendebar y en Las mil y una noches la intención es didáctica, moralizante y misógina, la finalidad es educar a los jóvenes de clase alta en todos los aspectos de la vida que deberían conocer. Se trata del género literario conocido como adab, que abarca todas las disciplinas del saber y que no tiene un equivalente exacto en la literatura occidental.

Entre los muchos conocimientos que se suponía debían de conocer los jóvenes cultos, está el distinguir la mujer buena y honesta de la mala y adultera y para ello se componen una serie de libros de adab donde se trata de demostrar la maldad y la astucia de las mujeres a fin de que el joven no cayera en sus redes y supiera elegir una buena esposa (aunque la realidad es que la esposa generalmente la elegía su familia, ya que los matrimonios en las clase alta, como en otras muchas culturas, era un convenio entre familias que respondía más a cuestiones económicas o alianzas de poder que a los sentimientos de los contrayentes. De todas formas, parece ser que la virtud, honradez o maldad de las mujeres era un tema que entraba dentro de la formación de los jóvenes y por ello encontramos en la literatura árabe abundancia de obras o de capítulos (dentro de obras misceláneas) sobre este tema, y en este caso se acude a los cuentos o apólogos para ilustrar el mensaje que se quiere trasmitir a la sociedad. Como hilo conductor o historia marco (historia cañamazo) el autor elige un

\footnotetext{
${ }^{5}$ Las Mil y una Noches, II, 297.

${ }^{6}$ Véase, Ángel González Palencia, Versiones castellanas del Sendebar, op.cit.
} 
argumento bien conocido desde la antigüedad y que es, ni más ni menos, que el mito de Fedra e Hipólito, adaptado a la cultura oriental:

Un rey que no tiene hijos pero que desea ardientemente un heredero, que en una coyuntura astral favorable se une a su primera esposa y concibe un hijo que goza de todos los atributos: belleza, inteligencia, bondad... pero un vaticinio le avisa de que este hijo estará en peligro durante siete días si pronuncia una sola palabra. El rey consulta al sabio preceptor Sindibād que le aconseja llevarle a un lugar de placeres donde pueda oír música y permanecer seguro hasta que pasen los 7 días. El rey manda llamar a una de sus concubinas, la más hermosa, y le pide que lo acoja en su palacio y lo cuide y proteja hasta que pasen los siete dias?.

Como "el muchacho era de una belleza y armoniosidad indescriptibles, pasó una noche en el palacio y, al verlo, el amor llamó al corazón de la favorita del rey, y no pudiendo dominarse se lanzó sobre él.

El muchacho le responde: "Si Dios quiere, cuando salga y vaya a ver a mi padre, lo pondré al corriente de esto y te matarä".

Entonces la concubina se presentó ante el rey y se echó sobre él llorando y sollozando. El rey le pregunta: ¿QQué tienes, cómo está tu señor? ¿̇Acaso no está bien? Ella contesta: "Mi dueño, mi señor ha querido poseerme y matarme, yo me he negado, he huido y no quiero volver ni junto a él ni al palacio". Al oír tales palabras el padre del muchacho se enfureció, convocó a sus visires y les dio la orden de que mataran a su bijo.

A partir de ahí, los visires tratan de retrasar la ejecución demostrando al rey que el muchacho es inocente y que la culpable es la favorita, contándole al rey una serie de historias en las que se muestran las maldades y los engaños de las mujeres, historias contrarrestadas por otras que cuenta la favorita para demostrar su inocencia.

Finalmente el rey se convence de la culpabilidad de la mujer y la inocencia de su hijo y cuando pasan los siete días y el príncipe puede hablar le cuenta a su padre otra historia similar y lo que había pasado en realidad entre la favorita y él:

"Juró en nombre de Dios grande y de su noble profeta que habia sido ella la que le habia tentado. El rey le creyó y añadió: "Te doy carta blanca acerca de la mujer; si quieres, manda matarla, o haz lo que quieras". Le respondió el hijo: "Expúlsala de la ciudad", y asi el hijo del rey vivió con su padre en la más cómoda de las vidas hasta que llego el destructor de las dulzuras y el separador de los amigos."

Los personajes en el Sendebar y en Las mil y una noches, aún siendo básicamente los mismos (salvo el papel fundamental del sabio preceptor), aparecen desdibujados y en algunos casos ni siquiera tienen nombre propio,

\footnotetext{
${ }^{7}$ Las Mil y una Noches, II, 297-298.

${ }^{8}$ Ibíd., II, 369.
} 
sin la fuerza ni la personalidad que tienen en la tragedia greco-latina, porque aquí lo que interesaba era poner de relieve la maldad intrínseca de las mujeres.

Los árabes no conocieron el teatro hasta fechas recientes, a partir de la nahda (renacimiento cultural árabe) y el contacto con Occidente, a finales del siglo XIX y comienzos del XX.

Las razones por las que no incorporaron el teatro a su cultura en una época como el periodo abasí en que se incorporaron otras muchas disciplinas de la cultura greco-latina, así como de la persa, india, etc. no están demasiado claras.

Hay una teoría que sostiene que al traducir en la Dār al-Hikma (Casa de la sabiduría) de Bagdad la Poética y la Retórica de Aristóteles, los traductores se confundieron o no entendieron bien los conceptos porque no tenían noción alguna de lo que era el teatro y tradujeron el término 'comedia' por $b i \hat{y} \vec{a}$ ' (sátira) y tragedia por madīh (panegírico) ${ }^{9}$ pero esta teoría parece demasiado simple y quizás haya que buscar otras razones.

Es muy posible que las razones sean más bien de índole moral y religiosa: en primer lugar, las continuas alusiones a los dioses del Olimpo iban radicalmente en contra del Islam, que erradicó por completo la idolatría y persiguió a los idólatras (asociadores, en el Corán). Por otra parte, la propia temática de la tragedia griega, con amores ilícitos, incestos y demás, atentaban de frente contra la moral islámica.

Por tanto, parece lógico que en esta sociedad donde la religión y el estado van tan unidos y es difícil separar uno de otro, se desechara por completo este género y se tradujeran solamente del griego y el latín obras científicas de materias que interesaban a la sociedad árabe medieval como las matemáticas, medicina, botánica, geografía, etc. y en el terreno de las letras se limitaron solamente a la filosofía y a la crítica literaria que interesaba enormemente a los filólogos de Kufa, Basra y Bagdad.

Sí se tradujeron, en cambio, los repertorios de cuentos y apólogos procedentes de la India que entraron en la literatura árabe a través del persa, ya que contenían mensajes didácticos y morales que interesaban para la educación de los jóvenes príncipes y nobles, y entre estas obras destacan las tres ya citadas: el Kalila y Dimna, el Sendebar y Las mil y una noches, si bien se piensa que estas obras, al pasar a la literatura árabe, fueron convenientemente islamizadas, eliminando todas las referencias a los antiguos dioses de estas culturas anteriores al Islam.

Por tanto, el mito de Fedra, es de suponer que forma parte de esa sabiduría ancestral, como la fábula y los refranes, que puede que surgiera en Grecia y de

${ }^{9}$ Véase Amjad Trabulsi, La critique poétique des arabes, jusqu'au Ve siècle de l'Hégire (XIe siècle de J.C.). Damasco, 1955, 74-75. 
ahí se extendió por Oriente y Occidente, o puede ser que surgiera en Oriente y los griegos la perfeccionaran y la transformaran en una de sus más célebres tragedias. 


\title{
LA TRAGEDIA DE LA INMIGRACIÓN: LA POÉTICA TRÁGICA COMO INTERTEXTO PARA LA FORMACIÓN DEL GROTESCO CRIOLLO
}

\author{
Pablo Moro Rodríguez \\ Univ. Nal. del Centro de la Provincia de Buenos Aires
}

\begin{abstract}
El Grotesco Criollo es reconocido como uno de los géneros teatrales más representativos de la tradición argentina. Diferentes estudios apuntan a la formación del grotesco a partir de la evolución del sainete, evolución temática, espacial y de puesta en escena que se produce en la década del'20. Armando Discépolo es el máximo representante del género con sus obras: Mateo, El organito, Stéfano, Relojero y Cremona. En ese pasaje del sainete al grotesco la poética trágica interviene a manera de superposición con los temas y personajes del sainete de manera que se convierte en un principio rector para la formación del grotesco. Así pues, pretendemos hacer un repasao por los distintos grotescos de Armando Discépolo para comprobar cómo son utilizados los procedimientos de la tragedia a modo de elementos constructivos del género teatral analizado. Discépolo se servirá de esos procedimientos para mostrarnos un héroe trágico que fracasa en su deseo de "hacer la América", el género trágico se convierte en el medio de expresar "la tragedia de la inmigración".
\end{abstract}

Desde la denominación "grotteschi" para los dibujos encontrados en la Domus Aurea de Nerón el término grotesco ha venido a designar a las formas artísticas en las que predomina lo deforme, el distanciamiento y sinsentido de lo real, la mezcla de lo lógico y lo ilógico, etc. En general una inversión de la lógica del realismo que ha dado grandes obras en las artes plásticas, en la novela o en el teatro. Grotesco fue la denominación utilizada por Pirandello para sus piezas en las que se producía una inversión de la comedia burguesa. De modo similar, el esperpento valleinclanesco o el humor de Arniches funcionan como la expresión contraria al realismo burgués imperante en las tablas de su época; y similar actitud encontramos en el "grotesco criollo", género teatral netamente argentino que, después de años de postración, vino a reivindicarse como la expresión teatral nacional paradigmática. "Grotesco en dos actos" fue el subtítulo de Mateo, de Armando Discépolo (1923) y, a pesar de que Osvaldo Pellettieri considera que Mustafá (1912) ya pertenece a la poética del grotesco discepoliano (1987:345), podemos decir que con esa obra se inicia al género.

No nos queremos detener a relatar las relaciones, semejanzas y diferencias, con el grotesco pirandelliano, labor que fuera extensamente tratada por Ordaz (1987:3-8). Simplemente observemos cómo en el caso argentino la inversión de un género popular, como es el sainete, va a ser el elemento estructural en la conformación de un nuevo paradigma dramático. Eso es lo que asemeja 
(en cuanto inversión) y lo que lo diferencia (en cuanto se refiere a un género diferente) del grotesco de Pirandello. Discépolo, con la presentación de Mateo, sabía que su obra precisaba de una acotación que advirtiera de la diferencia de género que se estaba produciendo en el escenario, puesto que ese texto se alejaba del horizonte de expectativas del público del momento.

Fue Viñas el que, en los años sesenta, llamó la atención sobre este género, que no había gozado de gran éxito entre el público (quizás por ese alejamiento de los cánones impuestos). A partir de su estudio Grotesco, inmigración y fracaso (1973) la crítica ha sido unánime en analizar el grotesco criollo como una deformación del sainete criollo. Estamos ante la inversión de un género.

Es en este punto en el que nos queremos centrar. Prácticamente, en toda la bibliografía sobre el tema encontramos una descripción del género en el que se lo asocia con lo trágico. Sin embargo, la utilización de "trágico" parece referirse a algo genérico, a la expresión cotidiana que asociaría el término con la desgracia. Nuestro interés parte en el planteamiento de si no podemos tomar el término "trágico" en un sentido más estricto y afirmar que la inversión del sainete en grotesco se produce en la medida en que la poética trágica se utiliza de forma intertextual para la composición del texto. Es decir, que lo grotesco nace de la asunción del elemento trágico dentro del universo del sainete criollo. Puede parecer un dato menor pero su dimensión se amplía si tenemos en cuenta que estamos hablando de textos dramáticos que han de convertirse en espacio escénico (Ubersfeld, 1996:65) o, más comúnmente, son textos que han de llegar a una puesta en escena. Para la dramaturgia -y uso este término en el sentido que utiliza Pavis en su Diccionario del teatro: "extraer los significados complejos del texto eligiendo una interpretación particular" (Pavis, 1998: 148)- la presencia de la poética trágica es un dato no menor que modifica la manera de plantear el trabajo de dirección escénica. Para Discépolo, lo grotesco no consistía solamente en agregar comicidad a una acción trágica, o elaborar elementos dramáticos en medio de una situación cómica, sino que lo grotesco era una actitud, una visión del mundo, por tanto, una estética globalizadora que se da no solamente en el texto, sino que se encuentra, sobre todo, en el trabajo de puesta en escena: en el gesto, en la palabra, en el ritmo... En conclusión, aceptar y asumir lo trágico en un grotesco criollo implica un serie de consecuencias en el plano de lo actoral o de lo escenográfico que rige el trabajo estético del director de escena.

Volvamos, por tanto, a la pregunta planteada y veamos si, cuando hablamos de "lo trágico" nos referimos solamente al término común o a la poética de la tragedia. A grandes rasgos, a partir de la descripción, luego asumida como normativa, de la tragedia por parte de Aristóteles en su Poética, los elementos que conforman el universo trágico básico son la metabolé (o cambio de fortuna) y la anagnórisis (o reconocimiento) (Aristóteles, 1982:118). Para llegar a ese 
punto el héroe ha vivido en el error (hamartía) y ha insistido en su accionar equivocado (hybris), de manera que de forma irónica y desmesurada (contra la sofrosine deseable) termina siendo víctima de la situación que él mismo ha creado. El reconocimiento del error en un momento en el que ya no habrá posibilidad de solución cargará de patetismo la situación final y la imagen de su caída.

Si tomamos como base este esquema argumental básico, como elemento archipoético (Dubatti, 2002) que atraviesa el tiempo y las poéticas particulares, podemos observar que realmente, en el grotesco discepoliano hay un intertexto trágico.

Veamos los casos de Mateo (1923), El organito (1925), escrita con colaboración con su hermano Enrique Santos y Stéfano (1928), considerada por la crítica como la obra paradigmática y en la que mejor se muestran los procedimientos del grotesco criollo.

Además del tema propio del género, el fracaso de los inmigrantes en la Argentina de los años 20, en las tres obras encontramos rasgos temáticos similares en la medida en que las tres plantean el conflicto héroe-familia, los protagonistas se dirigen hacia un destino funesto del cual no pueden escapar empujados por un determinismo que no tiene origen divino, sino social y, sobre todo, económico. El héroe es un hombre común, un inmigrante que llegó al país con la idea de "hacer l'América", pero que se encuentra al límite de sus posibilidades económicas.

Mateo, adentrándonos propiamente en el esquema narrativo de la tragedia, plantea la caída del héroe, Miguel, que no acepta el progreso, representado en el automóvil. Su insistencia (hybris) en no querer abandonar el coche para adaptarse a los nuevos tiempos es la que lleva a la familia a la pobreza. En su desesperación participará de un robo, pero la vejez de su caballo hará que tenga un accidente y la policía encuentre el coche, por lo que Miguel será atrapado (metabolé). La aparición de su hijo Carlos vestido de chofer-Deus ex machina que salvará a la familia- le hará comprender su error (anagnórisis) pero ya es tarde para volver atrás y pagará con la cárcel su decisión. Miguel es apresado en medio de su angustia (patetismo). Irónicamente, a lo largo del texto, Miguel ha ido anunciando su propio destino, a modo de coro:

MIGUEL- ¿Yo chofer? Antes de hacerme chofer -que son los que me han quitado el pane de la boca- ¡me hago ladrón! ¿YYo voy a morir col látigo a la mano como murió mi abuelo!.... (Discépolo, 1987:318)

En El organito el anti-héroe, Saverio, en su desmesurada avaricia (hybris) es capaz de dejar a sus hijos en la miseria y el hambre, abandona a su cuñado, que lo acompañó durante veinte años y se asocia con un hombre-orquesta al que está dispuesto a entregarle a su propia hija con tal de no perder la sociedad 
que le reporta grandes beneficios económicos que no reparte con su familia. Es un Harpagón contemporáneo, que vive de la limosna pero que mantiene su poder aplastando a los que lo rodean. El encuentro con su hijo mayor, Nicolás, será el momento del cambio de fortuna y del reconocimiento de su desmesura. Sus hijos terminarán delinquiendo y su hija camino del burdel. En la cima del patetismo Anyulina, su mujer, le dará un bofetón tras el cual Saverio llama a los hijos que se marcharon. No hay solución posible, todo su mundo está condenado a desmoronarse.

El Organito y Stéfano son considerados por Pellettieri las dos obras del grotesco canónico (2002:466). Esta última es, para gran parte de la crítica, la obra cumbre del género y en la que mejor se perfilan los procedimientos del grotesco, por tanto, la que de manera más eficaz ha asumido la poética trágica en el intertexto con en sainete. En Stéfano, a diferencia de las otras dos, encontramos una referencia al error inicial (hamartia), provocado por una educación malsana que fomenta el exitismo y la falta de autocrítica.

ALFONSO.- Todo para él. Todo para él. Así quisiste a Stéfano, el hijo entelegente, así lo criaste, e ve a lo que hamo yegado.

M. ROSA.- No remueva, Alfonso, no remueva. (Discépolo 1969, 52)

El orgullo provocado por este error le conduce -a modo de bybris- hacia un autoengaño plagado de ironía, puesto que en la medida en que el héroe más quiere huir de la situación más se adentra en ella a causa de su ceguera para detectar el engaño. El coro (Radamés) advierte y anuncia sistemáticamente su final fatídico, pero no es escuchado. El reconocimiento de su falta se hará de manera progresiva a partir del descubrimiento de su despido de la orquesta y de los motivos por los que ha sido despedido: desafina (hace la cabra). Este descubrimiento arrastrará al personaje a una caída envuelta de patetismo hasta la muerte. La fábula expuesta por Discépolo, como vemos, responde a una clásica estructura de tragedia

Sin embargo, no queremos cerrar estas páginas sin hacernos un planteamiento más en cuanto al universo trágico en el grotesco discepoliano. Consideramos que el planteamiento sobre la tragicidad va más allá de su estructura: ¿qué tiene de trágico?, ¿qué empuja a los anti-héroes hacia la destrucción?, ¿sigue siendo catártico su devenir?, es decir -y siguiendo a Albin Lesky- ¿el texto discepoliano es trágico en cuanto a la situación o plantea un conflicto absolutamente trágico?

Pellettieri afirma que Mateo es un "texto indeciso entre el sistema viejo (el sainete) y el sistema nuevo (el grotesco)"(Pellettieri, 1987:44) y es en este texto donde encontramos mayor presencia de elementos sainetescos, sobre todo, en su intento por acomodar un "final feliz" propio del género popular. Miguel cae preso, pero Carlos salvará a la familia con su nuevo trabajo de chofer. 
En El organito, al contrario, no hay posibilidad de reconciliación. Los hijos se han marchado, han caído en la delincuencia y Severino no va a poder mantener la sociedad con Felipe.

Stéfano, por su parte, plantea una doble posibilidad, como apunta $\mathrm{M}^{\mathrm{a}}$ Teresa Sanchueza-Carvajal (Sanchueza-Carvajal, 2004: 342): un posible final feliz, en el que Esteban, como continuación de su padre, consigue salvarse de un destino similar, aprendiendo la lección:

STÉFANO.- (...) Todo es luminoso para usté en esta noche oscura en que sólo veo su pensamiento. (Por el padre) Un campesino iñorante que pegado a la tierra no ve ni siente; (Por él mismo.) Un iluso que ve e siente, pero que no tiene alas todavía; (Por Esteban.) Un poeta que ve, siente e vola ¿eh? (Está muy cansado.) Todo se encamina a un fin venturoso, ¿no? Todo está calculado en el universo mundo para que usté cante su canto, ¿no? Lo he comprendido. (...) (Discépolo 1969, 84)

O bien, un final en el que se plantea la repetición de la tragedia por parte de Esteban. Esta segunda posibilidad reforzaría la idea del conflicto absolutamente trágico, al igual que en El organito, en el que no hay posibilidad de escapatoria y -según el planteamiento de Lesky (Lesky 2001, 74)- impediría la conciliación final al modo de algunas tragedias griegas, pongamos por ejemplo el final de la trilogía La Orestíada, de Esquilo.

Por tanto, la diferencia entre Mateo, obra que inicia el género, pero todavía muy pegada al sainete y El organito y Stéfano, obras del grotesco canónico, radica, entre otros aspectos, en la asunción de un universo absolutamente trágico, sin reconciliación posible, que trasciende del texto y apunta directrices para su puesta en escena.

Un último aspecto al que queremos prestar atención es a la visión de la familia que se desprende de estas dos últimas obras y que nos acerca hacia una estructura familiar típicamente mediterránea en la que los personajes femeninos, desde su posición aparentemente pasiva, empujan las decisiones de los hombres hacia el error. En El organito, Anyulina será la que empuje a sus hijos a abandonar el hogar, la que anime a su hija a buscarse la vida, aunque se desprenda del texto que va a ser en el mundo de la prostitución.

En Stéfano, más compleja en su estructura de personajes, los masculinos y femeninos actúan de manera similar. Los hombres: Don Alfonso, Stéfano y Esteban (Radamés lo dejamos de lado por su carácter de personaje coro, de materialización de la conciencia colectiva) caminan hacia la autodestrucción. Sus decisiones van encaminadas al fracaso. Don Alfonso decide vender todas sus posesiones para seguir la quimera del hijo. Stéfano desprecia todo su talento en la inacción y la falta de convicción. Esteban (si asumimos la lectura de la no reconciliación) va a seguir los pasos del padre. Los personajes femeninos, 
por otro lado, se muestran pasivos pero determinantes en la progresión de la acción: María Rosa será la que convenza a Alfonso de vender todo para ir detrás del hijo. Margarita abandona a Stéfano a su suerte y se dedica en exclusividad a su hijo, Neca, ocupando el rol que le correspondía a Margarita, se hará cargo de su padre sin ver cuál es la verdadera naturaleza de su tristeza. Vemos, por tanto, que la postura de Discépolo en este texto va encaminada a una visión simbólica de la mujer en el plano de la tradición cristiana como la incitadora a la perdición. La dualidad Eva-María de la simbología cristiana se resuelve en la dualidad María Rosa-Ñeca: la primera como iniciadora del error trágico, la segunda como la bondad pasiva que acepta su destino sin oposición alguna. Margarita, por su parte, asumirá un papel intermedio de mujer pasiva que, poco a poco, se irá inclinando por el rol de M. Rosa en la medida en que ella repite el esquema educativo con Esteban.

En conclusión, el grotesco discepoliano asumió la estructura narrativa de la poética trágica en su inversión del sainete criollo. Como hemos comprobado en estas páginas, lo "trágico" que apunta la crítica va más allá de un sentido coloquial asociado a la desgracia, sino que se asume como procedimiento compositivo y como universo imaginario para la generación de una poética teatral que surge en un período de crisis económica y social. La inmigración, como tema central del grotesco, será vista en su lado oscuro, los anti-héroes serán aquellos que vinieron a hacer la América y terminaron en el fracaso. Lo patético de su situación será el contrapunto al final feliz del sainete. Una llamada de atención para un público inserto en una sociedad cambiante e incierta. Discépolo recurre, como tantos otros escritores a lo largo de la historia, al uso de lo grotesco para mostrar, como el esperpento valleinclanesco, el mundo a través de un espejo deformado. 


\section{BibliografíA}

Aristóteles (1982), Poética, Caracas, Ediciones de la Biblioteca de la Universidad Central de Venezuela.

Azor Hernández, Ileana (1994), El neogrotesco argentino, Caracas, CELCIT

Discépolo, Armando (1969), Obras escogidas (seleccionadas por el autor). Buenos Aires. Jorge Álvarez.

Discépolo, Armando (1969), Obras escogidas (seleccionadas por el autor). Buenos Aires: Jorge Álvarez.

- (1987), Obra dramática de Armando Discépolo. Buenos Aires: Eudeba.

Dubatti, Jorge (2002), El teatro jeroglifico. Herramientas de poética teatral, Buenos Aires, Atuel.

Kayser-Leloir, Claudia (1977), El grotesco criollo: estilo teatral de una época, La Habana, Casa de las Américas.

Lesky, Albin (2001), La tragedia griega, Barcelona. El Acantilado.

Ordaz, Luis (1987), "Acercamientos y diferencias de los "grotescos criollos" de Armando Discépolo con los "grotescos" pirandellianos", en VV. AA., Cuartas Jornadas de Investigación Teatral, Buenos Aires, ACITA; 3-8.

Pavis, Patrice (1998), Diccionario del teatro. Dramaturgia, estética, semiología, Barcelona, Paidós

Pellettieri, Osvaldo (1987), "Estudio preliminar", en Discépolo, A., Obra dramática de Armando Discépolo, Buenos Aires, Eudeba.

(ed.) (1994), De Goldoni a Discépolo. Teatro italiano y teatro argentino 1790-1990, Buenos Aires, Galerna.

(2002), Historia del teatro argentino en Buenos Aires. La emancipación cultural (1884-1930). Volumen II, Buenos Aires. Galerna.

Sanchueza-Carvajal, Ma Teresa (2004), Continuidad, transformación y cambio: El grotesco criollo de Armando Discépolo, Buenos Aires, Editorial Nueva Generación.

Thénon, Luis (1996), La memoria y el olvido. Del teatro de la colonia al movimiento de teatro independiente 1610-1950, San José de Costa Rica, Universidad de Costa Rica.

Ubersfeld, Anne (1996), La escuela del espectador, Madrid, ADE.

Viñas, David (1973), "Grotesco, inmigración y fracaso", en Discépolo, Armando, Obras escogidas, Buenos Aires, Editorial Jorge Álvarez, VIILXVI, volumen I. 


\section{“ÉL Y ÉL, UNIDOS POR EL AMOR NEFANDO...": MATERNIDAD Y TRAVESTISMO EN MEDEA ES UN BUEN CHICO DE Luís Riaza}

Hernán Ocantos IES N² "Mariano Acosta"

Luís Riaza en Medea es un buen chico desanda un camino de continuidad con la tragedia euripídea. Desde la sustitución y el travestismo de sus personajes masculinos propone una serie de correspondencias dadas desde el conflicto de los límites trazados por el género y el cuerpo. La Medea griega reniega de su condición, desearía haber nacido hombre. Aquí se revela el eje que une a los personajes, el español rompe con la figura legendaria, la sustituye por un hombre aunque de alguna manera Medea ha dejado de ser mujer al cometer el filicidio.

La concepción de la obra de teatro como medio de transmisión ideológica, y no tan sólo como una actividad de estricto corte burgués y elitista, se hace patente en la dramaturgia de Riaza. Este pensamiento supone una continuación de la línea trazada por Lorca en la voz de uno de sus personajes:

"MOSQUITO (...) Yo y mi compañia venimos del teatro de los burgueses, del teatro de los condeses y de los marqueses, un teatro de oro y cristales, donde los hombres van a dormirse y las señoras... a dormirse también"'.

La ruptura y la continuidad con lo clásico van de la mano con la transgresión al sistema. El propio Riaza expresa que “... los oscuros gusanos de cada dramaturgia son los mismos y siempre procura uno librarse de ellos con los mismos exorcismos. Los de mi teatro particular puede que consistan en un ataque sañudo, terco y más o menos solapado contra todo teatro". Medea es un buen chico se encuentra enmarcada en el llamado periodo de la Transición, momento que se presenta como una especie de desierto estéril en cuanto a la composición del mapa político español, el desencanto con la democracia y la nefasta presencia de los rezagos del franquismo tales como la censura y su forma más acabada: la autocensura . Existe otro problema para que el mito filtrado por la mano labradora de Riaza se extienda por las conciencias de los españoles: la representación. $\mathrm{O}$ mejor expresado, la ausencia de la misma. ${ }^{3}$ Probablemente

\footnotetext{
${ }^{1}$ Lorca García, Federico, Los titeres de cachiporra. Tragicomedia de Don Cristóbal y la señá Rosita, Madrid, Cátedra, 1998, pp. 134-135.

${ }^{2}$ Riaza, Luís. "Pequeño paseo ante el retrato de una dama y sus perritos resplandecientes", prólogo a Retrato de dama con perrito, Madrid, Fundamentos, 1976, p. 15.

${ }^{3}$ Sólo ha sido representada en enero de 1985 en una coproducción entre el Círculo de Bellas
} 
para que su teatro realmente forme parte de un sistema revolucionario, tal como lo plantea Roland Barthes, le falte uno de los pilares que sostienen dicho sistema: llegar regularmente a un público masivo ${ }^{4}$. En este arduo contexto la función social y divulgadora del teatro se esfuma.

Las tragedias griegas han sido fundantes de las temáticas desarrolladas a lo largo del periodo contemporáneo de la literatura española en general y del teatro en particular, al tiempo que fueron utilizadas popularmente como "metáfora de la situación vivida". En su Medea es un buen chico, el español Luís Riaza traza un camino de continuidad entre sus travestidos personajes de la Nodriza y Medea y el mito de Eurípides. Esta correspondencia está presentada bajo el indudable influjo de la derrota, el hilo que enhebra ambas obras es la inocultable decepción de los protagonistas y la ineludible puesta en marcha de una serie de mecanismos de los cuales va a surgir la tragedia. Medea y Nodriza, hombres, sin hijos, enmascarados con el turbio maquillaje de la desgracia, no son capaces de engendrar para luego matar, no pueden seguir la línea filicida planteada por Eurípides. Riaza disfraza el mito. Esto explica por qué los personajes son biológicamente varones. La Medea clásica reniega de su condición de madre, ve como un castigo la posibilidad materna, para evitar este conflicto Riaza trasviste al personaje, lo sustituye, de alguna manera repara el deseo negativo de la Medea mítica ya que su Medea desea algo a lo que no puede acceder: la maternidad. Por el contrario en Eurípides el personaje reniega de su capacidad procreadora y si, tal como ha sucedido, el hecho ya está consumado sobreviene el desenlace fatal. El personaje griego desearía haber sido hombre, de modo que comparte esa suerte de travestismo con su homónimo español:

"MEDEA.- un hombre, cuando le resulta molesto vivir con los suyos, sale fuera de casa y calma el disgusto de su corazón [yendo a ver a algún amigo o compañero de edad]. Nosotras, en cambio, tenemos necesariamente que mirar a un solo ser. Dicen que vivimos en la casa una vida exenta de peligros, mientras ellos luchan con la lanza. ¡Necios! Preferiría tres veces estar a pie firme con un escudo, que dar a luz una sola vez" (Medea, versos 243-251)

Artes de Madrid y el Centro Nacional de Nuevas Tendencias Escénicas, dirigida por Luis Vera.

${ }^{4} \mathrm{El}$ semiólogo francés plantea en su artículo El teatro popular de hoy del año 1954, que para que el teatro adquiera carácter de revolucionario debe reunir tres condiciones: 1legar regularmente a un público masivo, presentar un repertorio de alta cultura y practicar una dramaturgia de vanguardia. A los efectos propone el abordaje de un repertorio clásico, en el sentido amplio del término.

${ }^{5}$ Ragué-Arias, María-José. "Del mito contra la dictadura, al mito que denuncia la violencia y la guerra”, en Foro Hispánico 27 Mitos e identidades en el teatro español contemporáneo, Amsterdam-New York, Editions Rodopi, 2005.

${ }^{6}$ Eurípides, Medea, Traducción y notas de González Medina, Alberto y López Férez, Juan 
Aquí subyace el eje que une a los personajes, Riaza quien se refiere al derrotero amoroso de Medea y Jasón como "el culmen del amor-odio/ más o menos hetero." , rompe con la figura legendaria, la sustituye por un hombre aunque de algún modo la Medea clásica pierde su condición de mujer al cometer el filicidio. Los personajes de la obra española viven dentro de esa especie de vestíbulo de sucio vodevil, no deben luchar con la lanza, deben luchar contra el muro infranqueable que supone su cuerpo y su limitación natural. Lo sustancial estriba en que la Medea euripidea puede volver a ser madre, está naturalmente dotada para ello. Los hombres, no. De todos modos la mirada del amor nefando, en el estricto sentido del término, no impide que los personajes se vean y sean vistos "como los amantes bienvistos/de dios, de sus iglesias / y de sus respetables fieles". El amor pecaminoso, el de la práctica del coito anal, nos traslada a una doble percepción del conflicto: la del arte y la de los receptores de la obra. Por un lado Medea y Nodriza simbolizan la destrucción de los prejuicios en relación con el género: aman, se desean, necesitan sentirse queridos, anhelan la maternidad/ paternidad como fin trascendente de sus opacas vidas. Por otra parte, la mirada de los otros, la de la España posfranquista y democrática, sigue funcionando como una especie de índice policíaco que imparte juicios y sentencias a esos personajes que se miran mientras esperan el dictamen moral de la sociedad. En efecto, como la "pareja de maricas no puede tener niños" (Riaza; 204) éstos serán sustituidos por perros de peluche y por la fantasía imaginaria de los personaje y del auditorio. Por momentos Nodriza parece cumplir la función de esa voz sentenciosa del afuera que se cuela en la obra, no admite a Medea ni como madre, ni como mujer:

"MEDEA.- Del niño: ¿̨a quién te parece que ha salido, a su padre o a mi? NODRIZA.- De la señora sacó el espiritu desparramado. Nada encuentro del señor en la criaturita.

MEDEA.- ;Tu resentimiento te nubla los malditos ojos!

NODRIZA.- Si la señora quiere que le confirme la paternidad del señor, sólo tiene que fijar las respuestas de su humilde sierva..." (Riaza, 207 $)^{10}$

En este doble cruce de falacias, o sea, el de la ficción teatral y el de la maternidad, vislumbramos un ápice de esa voz externa. No obstante, inmediatamente Nodriza se muestra incapaz de sortear la confusión impuesta

\footnotetext{
Antonio, Madrid, Editorial Gredos, 2000, p. 82.

${ }^{7}$ Riaza, Luís. Teatro escogido. Medea es un buen chico, Madrid, Asociación de autores de teatro, 2006, p. 204.

${ }^{8}$ Ibid. 7, p. 203.

${ }^{9}$ Ibid. 7, p. 209.

${ }^{10}$ Ibid. 7, p. 208.
} 
por el mecanismo de sustitución riaciano, en particular en el episodio que la muestra en un primer contacto con su propio perrito/hijo:

"Nodriza.- (...) (Baja a sus <dominios>. Vacia una botella de leche en el cacillo y coloca éste sobre la cocina. Saca luego un perro del arcón y lo coloca sobre la mesa.) mi vientre, en este mundo!"11

En un plano simultáneo Medea se encuentra hablándole sobre el miedo a la oscuridad a su propio primogénito apócrifo. Ambos personajes ingresan al juego de roles, ambos son emboscados por sus propias trampas de identidad.

Este trayecto entrecruzado genera un acercamiento, una mímesis entre ambas obras, la clásica y la contemporánea. La idea desarrollada por Simone de Beauvoir "no se nace mujer; llega uno a serlo", luego analizada minuciosamente por Judith Butler quien pone en evidencia algunas limitaciones de la concepción de la francesa manifestando que: "Beauvoir sostiene rotundamente que una <llega a ser> mujer, pero siempre bajo la obligación cultural de hacerlo. Y es evidente que esa obligación no la crea el $\langle$ sexo . En su estudio no hay nada que asegure que la persona que se convierte en mujer sea obligatoriamente de sexo femenino"12. En efecto, Butler expresa que la teoría de la encarnación en la que se sostiene el análisis de Beauvoir se encuentra restringida por la reproducción de la distinción cartesiana entre libertad y cuerpo, y que dicha diferenciación debe replantearse en virtud de la jerarquía implícita de los géneros. La teoría queer ha ampliado el abanico de dudas y ha ofrecido una buena cantidad de respuestas a estas cuestiones. Para el caso de la obra abordada, el dilema parece recorrerse en dos sentidos. Por un lado, los personajes de un modo superficial y accesorio simulan ser mujeres, más allá de que probablemente en ese burdo remedo de la apariencia corporal se asemejen más a una caricatura del mito que al mito mismo. Esta presencia femenina en el ser interior tanto del protagonista como de su antagonista, es llevada al extremo por el autor español al proponer esa especie de metamorfosis erótica que se pone en acción cuando la maltratada Nodriza debe secar a su ama. La ocultación da paso a la aparición masculina, pues Nodriza afirma que quien juega con las uñas en el lacerado cuerpo de Medea no es ella, es Jasón, tensión que amplía el efecto de transformación: el hombre que se erige en mujer y que accede a actuar como hombre. Los límites se difuminan, se disuelven, se amalgaman en el juego corporal. Pero la disyuntiva no se cierra tan sólo en el plano corporal, la angustia devenida de la soledad, fruto de la

\footnotetext{
${ }^{11}$ Ibid. 7, p. 208.

${ }^{12}$ Butler, Judith, El género en disputa, Barcelona, Paidós, 2007, p. 57.
} 
opresión ejercida por ese monstruo del afuera mencionado en la nana que se canta al inicio, se expresa en el plano de la interioridad en las elocuentes palabras de Nodriza:

"MEDEA.- Yyo, nodriza, ¿̇te amo?

NODRIZA.-La niña sólo se ama a símisma, pero no es correspondida debidamente... »3

Por otra parte, y de aquí el conflicto con el género, los personajes no pueden ingresar al mundo femenino debido al límite impuesto por su cuerpo, tienen pene, no pueden engendrar, no pueden parir $y$, por consiguiente, no pueden matar. La toma de conciencia de la limitación, es decir de su verdadera fisonomía, los subleva:

"MEDEA.- Algún día te daré de vergajazos, nodriza...

NODRIZA.- Llegado el momento, pondré mi culo a disposición de la verga de madame... (Besa el culo a MEDEA.)

MEDEA.- ;Aparta tus hocicos de mí! ;Me llenas de ambigüedades!"14

Tal como expresa Beatriz Preciado en su propuesta de contrasexualidad ${ }^{15}$, los personajes no dejan de ser un producto del contrato social heterocentrado cuyas performatividades normativas se hallan impresas en sus cuerpos como verdades naturales. La rebelión ante este producto será factible el día que se libere o se desprivatice o se resexualice el ano, en este sentido el fragmento citado ut supra resulta premonitorio. Además tal como se mencionó en las líneas precedentes, los personajes se hallan inmersos en un ambiente ganado por el tufo de la derrota, las ambigüedades son las que no les permiten imponerse ni siquiera en el plano del juego simbólico: se trata de personajes andróginos que no podrán sortear ese destino. Los dos aspectos que dan título al presente trabajo se encuentran en el momento culminante del texto riaciano, cuando el proceso de desmitificación del mito ya ha sido puesto en marcha: Medea debe consumar el asesinato de su hijo/perrito al tiempo que se reconoce en ese mundo estéril y masculino:

"MEDEA.- Falta la última baza de la partida sin bordes que se juega entre Jasón y yo... (Acaricia al perro que se encuentra en la cama.) Y la baza eres tú hijo mio; el rastro más profundo que Medea deja de su paso por este mundo desabrido y ácido..."

${ }^{13}$ Ibid. 7, pp. 213-214.

${ }^{14}$ Ibid. 7, p. 217.

${ }^{15}$ Preciado, Beatriz, Manifiesiesto contra-sexual, Madrid, Editorial Ópera prima, 2002, pp. 18-19. 
Inmediatamente la alusión a Jasón y al afuera amenazante:

“(...) Ya regresas de tu vivir en el ajeno afuera, tú, Jasón (...) Ya regresas después de haber esparcido tu esperma de la perpetuación...”

Y luego, al fin, la confesión, el reconocimiento de su propio ser, el de su incapacidad reglada por la convención del sexo:

"...Después de haber traicionado al pobre y estéril invertido, al triste marica que Medea es... (Coge al perro en los brazos.) Pero no, estéril no... Conmigo tuviste bijos no enviados por las divinidades preñadoras... (Besa al perro.) Tú fuiste el hijo de la imaginación, capaz de vencer al dios embutidor de vida hasta la repetición y el estrago y la náusea... Tú fuiste el hijo del hombre Jasón y del hombre Medea, y no del dios que dispusiera que el hombre naciera del preceptivo vientre de la mujer"16.

Recordemos que durante la España franquista y opresiva tanto los movimientos como el debate sobre la liberación sexual se encontraban en la clandestinidad. En la inmediata Transición estas voces van a exigir urgentes reivindicaciones más allá de las dificultades de la consumación de un movimiento sólido ${ }^{17}$. La clandestinidad de los personajes no puede correrse del ámbito cerrado propuesto por el autor español, ni Medea ni Nodriza escaparán del cerco impuesto por el monstruo amenazante del afuera.

Como sostiene Steiner ${ }^{18}$ el hombre es ennoblecido por el rencor vengativo o la injusticia de los dioses y esto no lo vuelve inocente, lo purifica como si hubiera pasado por las llamas. Riaza invoca a esos dioses y subvierte la tradición mítica desde la treta del artificio, desde la tergiversación del género, su protagonista no puede ser purificada por los dioses:

"MEDEA.- Echa agua en el baño.

NODRIZA.- No bañaremos, a pesar de todo, a la señora. No procede durante las horas profanas.

MEDEA.- La purificación no será la de Medea. Trae el agua y marcha a descansar." ${ }^{\text {99 }}$

El agua solamente traerá el aliciente de la muerte simbólica de su hijo/ perro.

${ }^{16}$ Ibid. 7, p. 240.

${ }^{17}$ Las divergencias internas llevará a que los grupos de lesbianas se unan a las feministas heterosexuales en procura de obtener el derecho del divorcio, la contracepción y el aborto; por otra parte los gays se promulgarán en función de una ley estatal para derogar la homofobia.

${ }^{18}$ Steiner, George, La muerte de la tragedia, Caracas, Monte Ávila Latinoamericana, 1991

${ }^{19}$ Ibid. 7, p. 239. 
Queda claro que las denominadas minorías de antaño siguen manteniendo esa indigna posición dentro de las consideraciones de las sociedades contemporáneas, incluso más allá de concretos avances en materia legislativa. Toda la gama de los subgrupos que conforman este grupo mayor sigue padeciendo esta segregación, por caso los transexuales y los travestis siguen relegados a acatar el magro destino trágico que los está aguardando a la salida de su clóset interior: sus puestos de comando están delimitados por la prostitución y la pornografía. En este aspecto Riaza sí se muestra un paso al frente de todas las posiciones y teorías: el mito le permite atizar el fuego de la conciencia, aunque más no sea para acercarse mínimamente al dilema de la identidad de esas minorías obligadas a la ocultación. La pieza nos permite acercarnos a este significativo tema mediante el grito acallado de los infaustos personajes y su representación en la sociedad española de aquellos tiempos.

En la obra de Eurípides, luego de cometer sus asesinatos e inmediatamente después de que el Corifeo anuncia el suceso a Jasón, Medea expresa que el dolor la libera y responsabiliza por la muerte de los niños a su esposo. Una vez más las tragedias se ligan, si atendemos a los vaivenes del género y del cuerpo puestos de relieve por el poeta griego al regalarle el centro de la escena a la mujer, a Medea. 


\section{Bibliografía}

Barthes, Roland, Escritos sobre teatro, Barcelona, Paidós, 2009.

Bertens, Hans, Literary theory. The Basics, Londres, Routledge, 2007.

Boring Zatlin, Boring, "Theatre in Madrid: The difficult transition to democracy", Theatre Journal, 32, Nº (Dec. 1980).

Butler, Judith, El género en disputa, Barcelona, Paidós, 2007.

- Deshacer el género, Barcelona, Paidós, 2006.

"Sex and gender in Simone de Beauvoir's Second sex", en Yale French Studies, N772, Simone de Beauvoir: Witness a century, (1986).

Cantó Sabuco, Assumpta, "La Teoría Queer: características y consecuencias en el estado español", en Teoría Queer: de la transgresión a la transformación social, Fundación Centro de Estudios Andaluces, 2009.

García Lorca, Federico, Los titeres de cachiporra. Tragicomedia de Don Cristóbal y la señá Rosita, Madrid, Cátedra, 1998.

Oliva, César, Teatro español del Siglo XX, Madrid, Síntesis, 2004.

Preciado, Beatriz. Manifiesto contra-sexual, Madrid, Editorial Ópera prima, 2002.

—_ Testo yonqui, Madrid, Espasa Calpe, 2008.

Ragué-Arias, Maria-Josep. "Del mito contra la dictadura, al mito que denuncia la violencia y la guerra”, en Foro Hispánico 27 Mitos e identidades en el teatro español contemporáneo, Amsterdam-New York, Editions Rodopi, 2005.

Riaza, Luís, Teatro escogido. Medea es un buen chico, Madrid, Asociación de autores de teatro, 2006.

"Pequeño paseo ante el retrato de una dama y sus perritos resplandecientes", prólogo a Retrato de dama con perrito, Madrid, Fundamentos, 1976.

Ruiz Pérez, Pedro, "Teatro y metateatro en la dramaturgia de Luís Riaza”, en Anales de Literatura española, Universidad de Alicante, 1993. 


\title{
El mundo clásico en el teatro de Lope de Vega: VARIACIONES DEL ABORDAJE A TRAVÉS DE SU MODELO DRAMÁTICO
}

\author{
Mayra Ortiz Rodríguez \\ Univ. Nacional de Mar del Plata - CONICET
}

\begin{abstract}
A través del análisis de un corpus conformado por comedias urbanas de Lope de Vega, se plantea que las referencias al mundo clásico sufren variaciones en su abordaje según avanza el modelo dramático del poeta. La producción dramática de Lope de Vega se considera como un proceso en evolución, escindida en tres períodos (denominados Lope-preLope, Lope-Lope y Lope-postLope). El corpus de trabajo está compuesto por seis comedias que se corresponden con los tres períodos citados, en la cuales se observan ciertas características diversas en el grado de complejidad de las alusiones a la cultura greco-latina.
\end{abstract}

Resulta casi imposible ceñir la vastedad de la obra de Lope de Vega dentro de un marco constructivo rígido y determinado. Sin embargo, en lo que respecta a su teatro, la crítica de los últimos años coincide en hablar de un modelo dramático en evolución, escindido en tres períodos y determinado por un proceso de madurez escritural, la búsqueda de su propia afirmación como dramaturgo y la formación de un espectador capaz de decodificar sus propuestas cada vez más complejas; todo ello constituye una prueba irrefutable de la progresión de un modelo teatral fijado en El arte nuevo de hacer comedias en este tiempo ${ }^{1}$. Esta evolución se refleja en una multiplicidad de aspectos y en sus diversos tipos de comedias; si nos remitimos a las referencias al mundo clásico en el teatro de Lope, resulta productivo observar esta progresión en sus comedias de capa y espada. Esto se debe a que, si bien se caracterizan por trazar los elementos del enredo (los amores encontrados, los celos, la clandestinidad...), en ellas se retrata un ambiente urbano y coetáneo a sus espectadores en el que sobreabundan las referencias culturales más diversas, lo cual es causado porque "la heterogeneidad del auditorio determina que la multiplicidad de planos sea un

${ }^{1}$ F. Weber de Kurlat (1976), al analizar el corpus textual de comedias de Lope de Vega, habló de dos períodos dramáticos discernibles entre sí, considerando el abordaje de los tópicos y las cuestiones formales. De ese modo abrió un camino para que las últimas líneas de investigación y aproximaciones de la crítica, entre las que se encuentran los trabajos insoslayables de J. Oleza (1986, 1997, 2003), F. Pedraza Jiménez (1998, 2003) y M. G. Profeti (1992, 1997, 1999), afirmen la existencia de un modelo dramático en evolución escindido en una periodización tripartita. Esas tres etapas fueron identificadas ut supra como Lope-preLope, Lope-Lope y Lope-postLope, esta última también llamada por J. M. Rozas (1990) de senectute, aunque resulta cuestionable la denominación dado que la producción del poeta en su ancianidad de ningún modo puede relacionarse con la decadencia u opacamiento de la edad, más bien todo lo contrario. 
rasgo central del teatro áureo. No sólo convive la acción elevada del galán con la 'voz de la cotidianeidad' del gracioso, sino la lírica tradicional, folklore, cuentecillos, con citas cultas, versos latinos, referencias mitológicas y clásicas, elevación culterana en una pluralidad estrófica enriquecedora, dentro del corsé fijo de una duración pactada" (Diez Borque 1988: 99).

Es un rasgo común en las comedias urbanas de Lope la insistencia por parte de una pluralidad heterogénea de personajes en recalcar las pautas de diferenciación y pertenencia entre los estratos. Sin embargo, algunos de estos aspectos no son verbalizados como tales en forma directa sino que se infieren de la construcción del discurso de los caracteres. Sus parlamentos denotan la posesión de una determinada enciclopedia, conjunto de conocimientos específicos que se identifican (hace cuatro siglos lo hacían los espectadores, hoy nosotros lectores) con un estamento social en particular².

En el caso de las comedias urbanas del primer período dramático de Lope de Vega, se observa una escisión radical entre el saber de la nobleza y los conocimientos que detentan los personajes del estado llano. En Las ferias de Madrid, que sería previa a 1596 (Morley, y Bruerton 1968), se caracteriza a los miembros del estrato superior por la demostración ostensible de su capacidad intelectual. Así, el conjunto de caballeros, bajo máscaras del estado llano, se distinguen como nobles por su conocimiento dado que citan fragmentos literarios (en los que refieren reiteradamente al Niño Amor y a la estrella de Venus ante las fluctuaciones amorosas), al punto que son echados de una boda por "afrentar a los hombres / con sátiras envueltas en letrillas". Leandro, el galán, es comparado con Durandarte por sus pares y elabora una referencia mitológica que encarna un juego de palabras con su propio nombre: menciona que $A$ Ero rindió Leandro.

En oposición a los nobles, los criados encarnan todo el bagaje de la sabiduría popular al ser punto de anclaje de refranes y de leyendas urbanas. Ello se debe a que "con respecto al culteranismo, se contraponen, en Lope, dos estilos: alto y bajo; culterano y popular; del héroe y del gracioso"(Rubens 1963: 94).

La otra comedia del primer período también plantea una divergencia notable entre el bagaje de los estratos. En La viuda valenciana, que dataría del lapso comprendido entre 1595 y 1603 (Morley, y Bruerton 1968), la protagonista, Doña Leonarda, abre la acción con un libro en sus manos (nada menos que las Oraciones de Fray Luis de Granada, considerado el mejor tratadista de Retórica del siglo XVI y uno de los mejores oradores religiosos

\footnotetext{
${ }^{2}$ De este modo, el verso dramático "engloba en un universo de signos escénicos supratextuales y funciona en relación y de acuerdo con ellos. (...) Por su nivel de estilización puede convertirse en signo supratextual que indica la condición social del personaje: oposición del lenguaje del caballero-galán y del criado-gracioso" (Díez Borque 1988: 107).
} 
de ese siglo), y si bien plantea a la lectura como un entretenimiento y no por agudeza ya que no estaría bien vista en una dama, poco después cita a "todos los que han escrito" para justificar su concepción negativa acerca de las segundas nupcias, y "a cuantos han estudiado" para referir el abordaje de la preocupación amorosa. Tras su extensa argumentación, su tío le recrimina que ella habla "como oración en latín", pero él también demuestra erudición literaria en sus parlamentos, del mismo modo que lo hacen los tres galanes que se disputan su cortejo, con proliferación de referencias cultas. Ellos entablan un contrapunto de sonetos como lamentos de amor, en los que conjugan poéticamente elementos de la naturaleza y citan referentes de la cultura clásica, como Tulio, al que un caballero invoca por su retórica; otro se compara por su declamación con Píramo y Tisbe, y luego se equipara a Doña Leonarda con Medea. Después, al caracterizarse como vendedores y, en el aura de su disfraz, uno de los galanes, haciéndose pasar por un estampero, jura por el emperador Aurelio y compara la casa con un templo de Tebas por sus múltiples puertas, al tiempo que presenta una serie de iconografías que refieren a la tradición clásica. Una de ellas es Venus y Adonis de Tiziano, lo cual puede ser leído como un intento de Lope de reflejar la relación peculiar de los protagonistas, dado que la dama persigue al galán tal como ocurre en el cuadro del veneciano, en el que se invierte el mito y Venus aparece tratando de evitar que su amado huya de su vera ${ }^{3}$.

Los tres galanes conforman una unidad en su cortejo a la dama y también su discurso plantea rasgos de uniformidad (dado que en todos los casos establecen referencias cultas clásicas), aunque uno de ellos se destaca, Otón, dado que en sus parlamentos proliferan aún más este tipo de alusiones, del mismo modo que en este aspecto se destaca el discurso del viejo Lucencio y de su amigo cortesano. En oposición, los criados también esbozan referencias mitológicas, aunque vagas, y lo hacen en escasas oportunidades (un ejemplo lo constituye la criada de la dama, que alude al mito de Leandro). Pero lo llamativo es que se encargan de destacar, una y otra vez, la enciclopedia de Camilo, el galán, como rasgo distintivo de su nobleza; él entabla parlamentos en los que las referencias cultas sobreabundan: llama Iris, mensajera de Diana, a la criada de su amada, y Mercurio al suyo, y compara su situación con la de

\footnotetext{
${ }^{3}$ Sin embargo, resulta curioso que Leonarda condene con cierta falsa moral el resto de las representaciones iconográficas que porta el fingido estampero y que describen a través de su discurso informado, en todos los casos pertenecientes a la cultura canónica no española e inaccesible para el estado llano (tanto el representado en la comedia como el espectador en el corral de comedias). Es que en la época las estampas de tema profano eran mayoritariamente de procedencia extranjera (por ello tenían acceso sólo quienes tenían un poder adquisitivo elevado), y de allí que aquí se mencione que se trata de reproducciones de Tiziano, Rafael, Martín de Vos y Federico Zúccaro. (Morán Turina y Fortús Pérez 1997: 273-274).
} 
Psique $^{4}$. Los criados mencionan que "bien habla" y recalcan sus conocimientos de historia, a la vez que notan "que es muy leido”. Sin embargo, Urbán, el vasallo de jerarquía más elevada, atenúa la concepción sobre la capacidad discursiva excelsa de su amo y aconseja a sus pares "no lo toméis tan polido", lo cual se relaciona con su oposición al proceder especulador de los nobles. Pero ellos son quienes detentan la sabiduría considerada como válida, y en suma al galán, el resto de los caballeros también demuestran ciertas estrategias ligadas al conocimiento, como la capacidad de construir sátiras y de elaborar referencias a la cultura canónica. En cuanto a la dama, también efectúa ciertas alusiones de este tipo: compara la buena fama con el Ave Fénix, refiere a Roldán y a Aquiles, y, en su búsqueda de libertad, indica: No procuro ser nombrada / ni comer, como Artemisa, / las cenizas que ya pisa / la muerte con planta helada. Sin embargo, ella plantea una consideración de la lectura como entretenimiento y no por agudeza (dado que no estaría bien vista en la mujer), de modo que representa y aún autoproclama un entendimiento menor al del protagonista, al punto que su criada lo cuestiona y defiende al galán por su discurso. La sabiduría, como es evidente, resulta patrimonio noble y masculino por excelencia, lo cual se desdibujará progresivamente en las siguientes fases dramáticas de Lope de Vega.

Pero hasta aquí las referencias al bagaje cultural grecolatino son por momentos superficiales; a medida que avanza el modelo en evolución del dramaturgo se profundizan paulatinamente (posiblemente debido a que el receptor se iba adecuando) y se ponen en boca de quienes no ostentan el saber unívoco y canónico.

En su segundo período de producción dramática, la escisión estamental en torno a la capacidad intelectual y el acceso al conocimiento no es tan notoria, dado que los límites adquieren cierta permeabilidad. Una de las obras que deja en evidencia esta progresiva pérdida de la radicalidad es $E l$ acero de Madrid, de 1606 (Morley, y Bruerton 1968), en la que, en principio, algunos rasgos se identifican con la mencionada escisión, como la aparición de alusiones sobre mitos en los diálogos de damas y caballeros ya en las dos primeras escenas, y que luego se propagan en toda la obra, sobre todo -tal como ocurre en las comedias ya mencionadas- las referencias al Niño Amor como causante del enredo. Los galanes además retratan poéticamente a sus amadas en parlamentos en los que sobreabundan las referencias históricas, mitológicas, bíblicas y de otros campos de la cultura canónica, mientras

\footnotetext{
${ }^{4}$ De hecho, toda la comedia constituye una inversión de un relato-fuente: el mito de Psique y Eros referido por Apuleyo en su Asno de Oro. (Cf. Rull 1968). No es casual que la referencia directa a ello sea efectuada por el protagonista masculino noble, poseedor del saber a priori indiscutido en este status quo.
} 
que el criado describe a las mujeres mencionando lo más banal, material y cotidiano: tabernas, pan, aguardiente, letuario, basura, tiendas, síntomas de enfermedad. Sin embargo, vasallos y damas también esbozan la posesión de un entendimiento o sabiduría valorizada por los demás. Salucio, criado serio, cabal y menospreciado por su amo (Otavio, uno de los galanes que no logra conquistar a la protagonista), entabla parlamentos sumamente líricos en los que refiere, por ejemplo, a la "rosa de Alejandría". Beltrán, el criado gracioso, invoca a Baco y desde un comienzo refiere a la tía que custodia a la dama como "Circe cruel". Es destacable que finge conocimiento para simular pertenencia al estrato superior, y lo hace bajo las vestiduras de médico. En esta instancia verbaliza un notorio falso latín (del que había proclamado saber un poco) posiblemente como guiño humorístico al público pero también como indicador de que el desdibujamiento de los límites interestamentales no podía tener lugar más allá del factor lúdico. Es notorio además que su amo temía que el resto de los galanes y el viejo custodio de la honra de la dama notaran la evidencia de la falsedad en el uso de la lengua vernácula, pero ninguno de ellos posee el conocimiento ni la suspicacia suficientes como para darse cuenta de esto. Sin embargo, el anciano sí posee una certeza que da cuenta, casi como la voz del dramaturgo, de la particular interacción de este teatro con su sociedad: "No en balde se inventaron las comedias / primero en Grecia que en Italia y Roma/ alli se ven ejemplos y consejos / porque son de la vida los espejos"

En La discreta enamorada, obra que también pertenece al segundo período dramático de Lope, compuesta de 1604 a 1608 (Morley, y Bruerton 1968), se observa algo similar. En ella se plantea como válido privativamente al conocimiento noble y masculino: así, Lucindo, el galán, cuando observa cierta astucia en el proceder de la dama, de inmediato la identifica con un hombre puesto que manifiesta su deducción de que debe poseer "ánimo varonil". Por ello proliferan en boca de este caballero las alusiones al mundo clásico: para él su pretendida es una diosa, es Fénix divina, es Hero; para otro de los galanes ella es la décima musa del Parnaso y es fénix solo que en su giro veloz ha visto Apolo. Además, Lucindo se compara en sus padecimientos a Tántalo y abiertamente dice a su amada Fenisa: Te quiero hacer Proserpina I de este abrasado Plutón. Sin embargo, criados y damas, como ya se esbozó, también son poseedores de cierta sabiduría asociada a la cultura canónica. El vasallo Hernando, pese a aparecer preocupado constantemente por cuestiones superficiales y a mostrar una veta materialista frente a la supuesta espiritualidad de los nobles, representa la sabiduría de vida (su amo le pide consejo y él replica: yo te enseño el vivir) a la vez que menciona ciertos cultismos, por lo que manifiesta "Estoy hecho un Cicerón" (aunque luego los empaña al pronunciar algunos erróneos, como "selvas de varia lición"). En el caso de las mujeres nobles, también su entendimiento se ve atenuado: sobre 
el fin de la comedia se destaca "qué bien dice" la dama, quien hace alusiones del mundo clásico -como su referencia a que tomó a la Ocasión por el copete-, aunque en un comienzo su madre la llama "bachillera" de manera peyorativa, a modo de insulto.

La posesión de bagaje cultural considerado como superior, como se observa, ya no corresponde exclusivamente a los caballeros, aunque tal irreverencia tenga lugar en el segundo período lopesco sólo de modo atenuado y momentáneo. Sin embargo, esto se profundiza en su etapa de senectute. Así, en La moza de cántaro, de 1625 (Morley, y Bruerton 1968), los nobles son aún quienes detentan la posesión del conocimiento, aunque esto conlleva considerables variantes respecto del período previo. El Conde, la viuda Doña Ana y el galán entablan un contrapunto de sonetos en el que cada uno elige un tema acorde a los valores que encarna: el Conde alude a tópicos bélicos (centrado en la figura de Marte); la dama, al amor frente al desdén; y el caballero describe a la supuesta moza de cántaro (en realidad es una mujer noble encubierta) de quien se ha enamorado. Lo curioso es que quien juzga el contenido de los sonetos es Doña Ana.

Por otra parte, la construcción de la figura de la dama protagonista también abre un nuevo panorama en torno a la posesión de bagaje cultural. Doña María desde un comienzo es definida con un perfil culto y contestatario: no quiere casarse y se burla de la supuesta "pluma diestra" de sus pretendientes que su criada defiende, al punto que llega a aconsejarle "Hazte boba". Al encontrarse perseguida por haber dado muerte al ofensor de su padre, se atavía como una criada, pero sus parlamentos contrastan notablemente con sus vestiduras. Un mesonero en Adamuz y un indiano notan su aparente pobreza, pero ella al hablar detenta una enciclopedia propia de la nobleza, puesto que realiza continuas referencias mitológicas.

En cuanto a los criados, también se produce una trasgresión respecto de la norma que escinde estamentos a través de la posesión de una enciclopedia con elementos de la cultura clásica. Es destacable la posición del vasallo del Conde, quien formula un parlamento sumamente poético en el que retrata a una de las damas con lenguaje elevado, donde invoca a las cultas musas y refiere a Doña Ana como una Venus de marfil con alma; además, él es quien describe los engaños urdidos por los nobles. Damas y criado, así, ocupan el lugar de sabiduría que antes sólo detentaban los miembros masculinos de la nobleza.

Finalmente, es destacable otra obra del período de senectute de Lope, dado su nivel de ruptura respecto de la perspectiva de un comienzo. Las bizarrías de Belisa, última comedia fechada de Lope, en 1634, presenta particularidades que hasta invierten las concepciones formuladas en la primera etapa. El uso de cultismos ya no es privativo de los hombres nobles, sino más bien todo lo 
contrario. Juan, el caballero protagonista, se considera capaz de elaborar versos; pero a la vez reconoce que la dama posee mayor enciclopedia que él y por ello aclara: "Pero advertid que no soy / culto; que mi corto ingenio / en darse a entender estudia", aunque su discurso es de gran lirismo y belleza, con vastas alusiones mitológicas, y con una invocación a Catón y a Séneca cuando su criado lanza aforismos sobre su situación. Pero la advertencia acerca del supuesto escaso caudal de su bagaje cultural se debe a que Belisa, la protagonista, detenta una enciclopedia y un uso del lenguaje destacables: como una constante reniega de Amor y retoma la referencia a mujeres de la antigüedad clásica para exculparlas -y exculparse- y responsabilizar a Cupido del enredo; y se compara con Faetonte al recoger en su coche a Don Juan y sentir que éste roba su libertad. La dama domina el discurso y a través del mismo logar infundir celos a Lucinda, su contrincante que también declama cultismos, al punto que arma una disputa contra ella en la que el arma son las palabras. Exclama "Déjame tomar la espada Iy matar esta mujer", aludiendo a la pluma, y proclama: "que no hay veneno más fuerte / que las letras de un papel / pues tantas veces en él / bebe la vida la muerte". De este modo, la escritura, vía de todo su conocimiento, se constituye como su herramienta fundamental.

En lo que atañe al estado llano, el criado del galán es caratulado como "osado" por hacer versos, y pese a que otros vasallos sí remiten simplemente a la sabiduría popular, su caso es distinto dado que ocupa la posición superior dentro del orden jerárquico intraestamental. Las referencias de este criado al ámbito de la cultura canónica proliferan (alude a Alejandro a poco de entrar por primera vez en escena, compara a Belisa con la reina de Troya), al punto que critica positivamente el soneto que la protagonista envía al galán con un marcado conocimiento sobre lírica, que ella reconoce. Sin embargo, este criado "baja" a la cotidianeidad las alusiones más elevadas, y se refiere a Lucrecia como "la casta y en camisa", a Porcia como "avestruz de bierros encendidos" y Artemisa es desde su perspectiva "sepultura de maridos". Esto se debe a la imposibilidad final de superar a la nobleza en cualquier aspecto prima en última instancia, y el criado recita una silva paródica sobre un galán que lanza requiebros a un simio. Más allá de este guiño de comicidad, es innegable que posee una capacidad ligada al ámbito intelectual hasta entonces vedada a los personajes del estado llano.

En conclusión, las marcas de conocimiento cultural, evidentemente, son distintivas de cada sector de esta sociedad. Y si bien las referencias cultas aquí mencionadas constituían conocimientos que circulaban en la época independientemente de los textos escritos (la iconografía, sobre todo la emblemática, era accesible y corriente para todos los sectores de la sociedad), convencionalmente existía una correspondencia de la cultura clásica y canónica con el estamento noble y de la cultura popular con el estado llano. 
Pero justamente su convulsión -dada la época que retratan estas comediastambién se refleja en las contaminaciones que hacen que las líneas de este tipo de fronteras, progresivamente y a través del modelo en evolución de las obras dramáticas de Lope, se tornen borrosas. 


\section{Bibliografía}

Fuente de datos primaria: Comedias de Lope de Vega, editadas por la Biblioteca de Autores Españoles (B.A.E.), Madrid, 1943.

Arellano, Ignacio, Historia del teatro español del siglo XVII, Madrid, Cátedra, 1995.

Arellano, Ignacio, Convención y recepción. Estudios sobre el teatro del Siglo de Oro, Madrid, Gredos, 1999.

Bennassar, B., "Las jerarquías sociales o la acumulación de desigualdades", en La España del Siglo de Oro, Grijalbo, Crítica, 1983, cap. 8.

Caro Baroja, Julio, "Religión, visiones del mundo, clases sociales y honor durante los siglos XVI y XVII en España", en Pitt-Rivers y Peristiany, Honor y gracia, Trad. de Paloma Gómez Crespo, Madrid, Alianza, 1992.

Defourneaux, Marcelin, La vie quotidienne en Espagne au siècle d'or, Traducción al español de H. Maniglia, Buenos Aires, Hachette, 1965.

Díez Borque, J. M., El teatro en el siglo XVII, Madrid, Taurus, 1988.

Díez Borque, J. M., Teatro cortesano en la España de los Austrias, Madrid, Teatro Clásico, 1998.

Domínguez Ortiz, Antonio, Las clases privilegiadas en la España del Antiguo Régimen, Madrid, Istmo, 1973.

Domínguez Ortiz, Antonio, "El sistema jerárquico y las clases privilegiadas", en El Antiguo Régimen: los Reyes Católicos y los Austrias, Madrid, Alianza, 1978, cap. 6.

Elias, N. La sociedad cortesana, México, 1982.

Elliott, John, "Introspección colectiva y decadencia en España a principios del siglo XVII", en Poder y sociedad en la España de los Austrias, Barcelona, Ed. Crítica, 1982, cap. 6.

Ferrer Valls, Teresa, Nobleza y espectáculo teatral (1535-1622), Valencia, UNED, 1993.

Fiadino, Elsa Graciela, "La comicidad en Las ferias de Madrid de Lope de Vega”, en Mabel Brizuela, Cristina Estofán, Gladys Gatti y Silvina Perrero (coords.), El hispanismo al final del milenio. Vo Congreso Argentino de Hispanistas, Córdoba, Comunicarte, 1999, pp. 399-406.

García Lorenzo, L. y Varey, J. E., Teatros y vida teatral a través de las fuentes documentales, London, Tamesis Books, 1991. 
Maravall, J. A., Teatro y literatura en la sociedad barroca, Madrid, Seminarios y Ediciones, 1972.

Morán Turina, José Miguel y Portús Pérez, Javier. El arte de mirar: la pintura y su público en la España de Velázquez, Madrid, Istmo, 1997.

Morley, G. y Bruerton, C., Cronología de las comedias de Lope de Vega, trad. cast. Revisada por Morley, Madrid, Gredos, 1968.

Oleza, Joan, "La propuesta teatral del primer Lope de Vega", en Oleza, Joan (ed.), Teatro y prácticas escénicas II: La comedia, London, Tamesis, Books, 1986, pp. 251-308.

Oleza, Joan, "E1 Lope de los últimos años y la materia palatina", en Estaba el jardin en flor. Homenaje a Stefano Arata, Criticón. Nro. 87-88-89, Presses Universitaires du Mirail, Toulouse, 2003, pp. 603-620.

Oleza, Joan, "Las opciones dramáticas de la senectud de Lope", en Díez Borque, J. M. y Alcalá Zamora, J. (eds.), Proyección y significados del teatro clásico español, Madrid, SEACEX, 2004, pp. 257-276.

Pedraza Jiménez, Felipe y González Cañal, Rafael (eds.), La década de oro en la comedia española: 1630-1640. Actas de las XIX jornadas de teatro clásico, Almagro, julio de 1996, Almagro (Ciudad Real), Festival de Almagro, Universidad de Castilla-La Mancha, 1997.

Pedraza Jiménez, Felipe, "Algunos mecanismos y razones de la escritura de Lope de Vega”, Criticón, 74, 1998, pp. 109-204.

Profeti, Maria Grazia, "El último Lope", en Pedraza Jiménez, Felipe y González Cañal, Rafael (eds.), La década de oro en la comedia española: 1630-1640. Actas de las XIX jornadas de teatro clásico, Almagro, julio de 1996, Almagro (Ciudad Real), Festival de Almagro, Universidad de Castilla-La Mancha, 1997, pp. 11-39.

Rennert, Hugo y Castro, Américo, Vida de Lope de Vega, con notas adicionales de Fernando Lázaro Carreter, Salamanca, Anaya, 1998.

Rozas, Juan Manuel, "Lope de Vega y Felipe IV en el Ciclo de senectute", en Estudios sobre Lope de Vega, Madrid, Cátedra, 1990, pp. 73-131.

Rubens, Erwin Félix, "El sistema dramático de Lope", en Lope de Vega. Estudios reunidos en conmemoración del $I V^{\circ}$ centenario de su nacimiento, $\mathrm{La}$ Plata, UNLP Departamento de Letras - Trabajos, Comunicaciones y Conferencias, 1963, pp. 85-112.

Ruiz Ramón, Francisco, "Introducción” a América en el teatro clásico español. Estudio y textos, Pamplona, Ed. Universidad de Navarra, 1993, pp. 11-72.

Rull, Enrique. "Creación y fuentes de La viuda valenciana de Lope de Vega", Segismundo 7-8 (1968) 25-40. 
Vila Vilar, Enriqueta. «Historia y Literatura: un largo debate para un caso práctico», Nuevo Mundo Mundos Nuevos [En línea], Debates, 2009. URL: http://nuevomundo.revues.org/index52533.html

Villarino, Edith Marta: «Algunos procedimientos de lectura y escritura en Las ferias de Madrid, de Lope de Vega», en Mabel Brizuela, Cristina Estofán, Gladys Gatti y Silvina Perrero (coords.), El hispanismo al final del milenio. Vo Congreso Argentino de Hispanistas, Córdoba, Comunicarte, 1999, pp. 407-418.

Villarino, E. M. y Fiadino, G., "Del escenario al «respetable»: el camino hacia un modelo dramático en evolución", Aristas. Revista de estudios e investigaciones de la Facultad de Humanidades. Monográfico "Los escenarios de la lectura. Teorías, prácticas, legitimaciones" (Marcela Romano, coord.), IV, 4, 2007, 53-72. Mar del Plata, EUDEM ISSN 1667-4944.

Weber de Kurlat, Frida, "Hacia una sistematización de los tipos de comedia de Lope de Vega", en Chevalier, M. et alii (dirs.), Actas del Quinto Congreso Internacional de Hispanistas, Instituto de estudios ibéricos e iberoamericanos, Bordeaux, 1977, pp. 867-871.

Weber de Kurlat, Frida, «Lope-Lope y Lope-preLope. Formación del subcódigo de la comedia de Lope y su época”, Segismundo 12, $1976(2)$. 


\section{Teseo y las princesas de Creta en $A M O R$ es MÁs Laberinto}

Mónica G. Paladino Universidad Nacional de Mar del Plata

El uso del mito como espejo de comportamiento es tradicional en el teatro cortesano del s. XVII. Sor Juana Inés de la Cruz no escapa a esta moda en su comedia (compuesta en colaboración con fray Juan de Guevara) Amor es más laberinto. El ambiente ofrecido por los reyes y príncipes del pasado mitológico de Creta y Atenas había sido aprovechado por Lope y Calderón. Sor Juana reorganiza la función alegórica de los protagonistas (Teseo, Minos, Ariadna, Fedra) según su interés por el modelo político virreinal y la figura femenina e intelectual de su época. Incluso, en la Loa que precede a la comedia, recurre a la figura de Jano y al mito de la Edad para reforzar su propósito alegórico.

Un ejemplo de cómo un estilo, una moda, una cultura de época puede transformar la esencia y el sentido de los mitos clásicos y, de ese modo, reinterpretar la tradición, es lo que puede verse en el teatro español del Siglo de Oro y en su sucedáneo novohispano. “...eran obras que se destinaban a solaz de los Reyes y de la corte, ora en el Palacio, ora en el Buen Retiro, y en las cuales más se atendía al prestigio de los ojos que a la lucha de los afectos y los caracteres, ni a la verdad de la expresión”. Afirmaba Marcelino Menéndez y Pelayo. Y añadía: "En vano sería buscar en estas obras nada del espíritu de la teogonía helénica, nada del carácter que los griegos pusieron en sus divinidades. Son unos dioses del Olimpo enteramente distintos de como estamos acostumbrados a imaginarlos".

Y tenía razón. La intención de Calderón era otra muy distinta que la de imitar a los dioses de la Hélade. Lo mismo puede afirmarse de los héroes de la mitología a los que recurrió este teatro.

La comedia de Sor Juana Amor es más laberinto, adhiriendo a los moldes culteranos e inspiada en los modelos de Calderón y sus epígonos, parece sostenerse en su relectura del mito del laberinto de Creta.

El éxito de la comedia mitológica es producto del gusto de la época y esto se combina con el ya generalizado (y reclamado por el público) tratamiento del tema amoroso. También ha contribuido al desarrollo de este asunto en particular la atracción que el legendario laberinto ejercía sobre los autores del barroco en general.

Específicamente nuestro interés en esta obra de la monja mejicana, surge a partir de otros estudios sobre la Fedra latina (Ovidio, Séneca) y sus reescrituras modernas o transducciones fílmicas (vg. la película argentina Las ratas -basada en la novela homónima de José Bianco- que se exhibe en este 
encuentro), que forman parte de un proyecto de investigación en curso en nuestra Facultad de Humanidades. La obra editada por nuestros distinguidos invitados, Andrés Pociña y Aurora López Fedras de ayer y de hoy (Granada, 2008), que el colega Dr. Pianacci nos acercó cuando había recién aparecido, ha sido motivadora. De allí parte la idea de acercarnos a la versión de Sor Juana Inés a quien ya teníamos en cuenta por otros trabajos del pasado en relación con los mitos ${ }^{1}$.

La más resistente significación del mito que involucra a Teseo y las princesas de Creta se esparce, como es sabido, desde el contenido moral que, según los clásicos de la literatura grecolatina, encierran hechos tales como el monstruoso acoplamiento de Pásifae con el toro, la muerte del minotauro a manos del héroe, el cruel abandono de Ariadna por parte de Teseo o la atrevida trasgresión de Fedra al enamorarse de Hipólito, el hijo de su esposo. Estas escenas han dado lugar a muy destacadas páginas en varios géneros, pero tales núcleos dramáticos del mito son expresamente evitados o minimizados por esta comedia.

Mediante un proceso de transformación, en las distintas épocas se produce lo que se ha constituido como actualización de los mitos y leyendas del mundo antiguo. Así lo expresa un trabajo de Rina Walthaus:

"Al dirigir el drama mitológico a ese auditorio tan heterogéneo del siglo XVII tan propenso a protestar cuando no le agrada la representación - el dramaturgo tratará de conseguir una identificación de parte del receptor. Varias técnicas concretas - digamos, de superficie - pueden servirle para conseguir una identificación inmediata. Harto conocido es el anacronismo que caracteriza el teatro mitológico del Siglo de Oro: los personajes clásicos se visten y se comportan como personas del siglo XVII, sirviéndose del lenguaje, de los códigos y de la etiqueta propios de la época."

Dicho esto resulta difícil imaginar la recreación, en estas obras, de monstruosos adulterios, crueles abandonos de heroínas sacrificadas o incestos $\mathrm{y}$ homicidios.

La transmisión y pervivencia de estos mitos en una recreación posterior resulta ser un proceso en el que la tradición (continuidad) y la recreación

${ }^{1}$ El mito de Faetón (Ovidio, Metamorfosis, libro II) ha sido objeto de estudio (Paladino, UBA, 2000) y motivo de clases donde se expone la apropiación de Sor Juana. La autora lo elige como motivo alegórico en relación con su persona y su intelectualidad.

2 "Mundo antiguo, contexto barroco: la polifonía de intertextos en la comedia mitológica del siglo XVII. (Hero y Leandro de Mira de Amescua)", en Agustín de la Granja y Juan Antonio Martínez Berbel (eds.), Mira de Amescua en candelero. Actas del Congreso Internacional sobre Mira de Amescua y el teatro español del siglo XVII (Granada, 27-30 octubre de 1994), Granada, Universidad de Granada, 1996, vol. I, pp. 629-643. 
(innovación) se complementan dialécticamente. Los mitos, sus dioses, sus héroes y heroínas se presentan como polivalentes y susceptibles de ser interpretados de modo diverso y así plasmados en nuevas obras literarias. La creatividad de cada artista, en su tiempo, reelabora o adapta el material y refleja de su época las ideas, la cosmovisión y las preocupaciones.

No otra es la lectura que hoy podemos hacer del trabajo de esta autora: una religiosa enclaustrada con vocación intelectual reprimida por el poder de la Iglesia y, como toda la sociedad novohispana colonial, sometida al capricho de las autoridades virrenales.

La obra de Sor Juana Amor es más laberinto fue representada por vez primera el once de enero de 1689, según la Loa que precede a la primera edición del Segundo Volumen de las obras de Sor Juana Inés de la Cruz del año 1692 en Sevilla y en sus reimprsiones de la época colonial. La representación formó parte del espectáculo del festejo oficial en el día del cumpleaños del recién llegado Virrey de Nueva España, Conde de Galve.

Este trabajo sobre una comedia mitológica compuesta en colaboración con fray Juan de Guevara y representada en el siglo XVII en la corte virreinal de Nuava España se concentra justamente en ese aspecto de «recreación», en el análisis de las nuevas implicaciones ideológicas y psicológicas que se incorporan al mito, con lo cual la sustancia mitológica se actualiza.

\section{Los antecedentes}

En obras como El Laberinto de Creta de Lope de Vega y la jornada segunda de Los tres mayores prodigios de Calderón (de 1621 la primera y de 1636 la segunda) los autores escenifican la materia mítica de Teseo, vencedor del Minotauro en el laberinto de Creta, adaptada a las costumbres y moral del siglo XVII, con algunas adiciones para completar el argumento. La fuente pricipal utilizada por estos autores está en las Metamorfosis de Ovidio, y en Las Metamorphoses de Jorge de Bustamante, traducción al romance de la obra latina que circuló profusamente desde el siglo XVI y también de manuales y compilaciones del Renacimiento. Seguramente Sor Juana utilizó el libro de Vincenzo Cartari o Cartario Le imagini de i dei degli Antichi, para la representación de Jano (figura que correspondería indudablemente a la figura del virrey por la fiesta romana el mismo mes de su cumpleaños). El otro personaje alegórico de la Loa que da inicio al espectáculo es la Edad con sus cuatro estaciones, que representaría a la propia Sor Juana (de la Loa no nos ocuparemos especialmente aquí aunque es merecedora de otra ponencia $)^{3}$.

${ }^{3}$ Para un análisis exhaustivo de la alegoría que contiene la Loa precedente a la comedia cf. Rodriguez Garrido, J. A., Escritura femenina y representación del poder en Ámor es más laberinto' de Sor Juana Inés de la Cruz (Loa y Comedia), Biblioteca Virtual Miguel de Cervantes, 2005. 
La obra calderoniana que pudo servir de modelo Los tres mayoresprodigios, consta de tres episodios, en cada acto representa una historia diferente, y tiene por protagonistas a tres héroes mitológicos: Jasón, Teseo y Hércules. Nos interesa el segundo que no hace más que narrar la historia de Teseo, su aventura del Laberinto y la muerte del Minotauro, con algunos motivos de pasión amorosa de las hijas del rey Minos. Sin embargo, es en el tercero donde Calderón pone de relieve el más importante tema de su teatro que es el honor y la honra. El hecho de enriquecer las fábulas, que desde el Renacimiento circulaban merced a la lectura de las obras de Ovidio y Virgilio, era lo que hacían legítimamente los autores del Siglo de Oro.

Por último, no dejaremos de lado otra comedia homónima de la de Lope, cuyo autor fue Tirso de Molina. No se trata esta ponencia de una comparación entre los textos y la comedia de Sor Juana sino de señalar, someramente, la instalación que habían asumido en este contexto hispano y novohispano los relatos sobre Minos, Teseo y toda la secuela mitológica de estos personajes.

Antes de entrar de lleno al argumento unas palabras acerca de Agustín de Salazar y Torres y de Juan de Guevara, dos coautores de las obras de nuestra dramaturga. Según Guillermo Schmidhuber -también ilustre visitante de Mar del Plata- la monja mexicana fue la coautora de La segunda Celestina. Esta Celestina mestiza tiene un itinerario maravilloso. Agustín de Salazar y Torres (1642-1675) fue uno de los comediógrafos poscalderonianos más importantes. Nacido en Almazán de Soria, pasó a Nueva España antes de cumplir cinco años, en compañía de su tío Marcos de Torres y Rueda primero obispo de Campeche y luego virrey en 1648. Estudió en la Unversidad de México y regresó a España y murió a los 33 años dejando inconclusa La segunda Celestina. ${ }^{4}$ Lo más interesante del asunto es que Agustín de Salazar y Torres compuso una comedia que al decir de Thomas Austin O'Connor, citado por Schmidhuber, se relaciona temática y estructuralmente con Amor es más laberinto, con lo cual se puede afirmar que Guevara y Sor Juana Inés le rindieron allí homenaje al autor novohispano. Salazar y Torres, ingeniosamente, había titulado la suya Elegir al enemigo; junto con el título que dio Sor Juana a la suya, Amor es más laberinto, resultan mucho más sugerentes que los correspondientes de los consagrados españoles: Tirso y Lope se contentaron con titular sus comedias sobre el asunto El laberinto de Creta.

${ }^{4}$ Para el itinerario que hace a Sor Juana coautora de La segunda Celestina cf. "Sor Juana Inés de La Cruz- Agustín de Salazar y Torres La segunda Celestina”, Edición, prólogo y notas de Guillermo Schmidhuber, Mexico, 1990. 


\section{La obra y su significado}

Personas que hablan en ella:

Minos, Rey de Creta

Ariadna, Infanta, su hija

Fedra, Infanta, su hija

Teseo, Príncipe de Atenas

Atún, su criado gracioso

Baco, Príncipe de Tebas

Racimo, su criado

Isidoro, Príncipe de Epiro

Licas, embajador de Atenas

Tebandro, Capitán de la guarda

Laura, criada de Fedra

Cintia, criada de Ariadna

Dos Soldados

Música

Acompañamiento

La comedia de Sor Juana (Jornadas Primera y Tercera) y de Juan de Guevara-autor de la Segunda- ha sido tratada como una típica pieza de enredo, en las que la trama amorosa tiene una importancia básica. Obviamente se incluyen acciones en las que el tema de las relaciones amorosas es ampliamente desarrollado. Todo gira en torno al amor.

El triángulo amoroso, tremendamente complicado, es el recurso básico: en la intriga se insertan todo un conjunto de oposiciones donde los elementos del mito son agrupados y ubicados en un mismo tiempo y espacio (el de los hechos del Teseo en Creta) donde las infantas se disputan el amor del héroe. El triángulo se complica y duplica por la presencia en palacio de dos príncipes, Lidoro y Baco, que pretenden a las infantas y, además, el conjunto de los sirvientes que también resultan enamorados de las respectivas ayudantas de palacio.

Como toda comedia del tipo (la dama siempre termina casada con el caballero) Teseo se queda con Fedra pero en el enredo, un príncipe que pretende a Ariadna desde el principio y que, coincidentemente, se llama Baco, contrae matrimonio con ella luego de que la salvadora del héroe padece (no gravemente) el abandono.

Junto al tema del amor, el fundamental, son identificables otros colaterales. Entre ellos el tema de las relaciones paterno-filiales, al que se le da cierta relevancia como puede verse en otra obra fuente de inspiración de los autores, la ya nombrada de Salazar y Torres Elegir al enemigo. También, como es de esperar, se desarrolla el tema del honor y la honra. 


\section{La historia recogida}

La fábula reinventada por Sor Juana y Guevara presenta aspectos poco frecuentes del uso del mito, como la presencia de las hermanas compitiendo por Teseo en la corte de su padre Minos, rey de Creta.

Según las numerosas fuentes citadas por los mitógrafos, y en síntesis de Ruiz de Elvira ${ }^{5}$, las relaciones de ambas princesas con el héroe se dan en muy distintos momentos del desarrollo de la leyenda. Es el hermano de las hijas de Minos, Deucalión, quien mucho después de la muerte del Minotauro a manos de Teseo da a Fedra en matrimonio; en cambio Ariadna huye de Creta con Teseo y los atenienses, tras haber traicionado a su padre y ayudado al héroe. Pero (en casi todos) es abandonada en la isla de Naxos, según algunos por orden de Mercurio, o por voluntad propia, por necesidad, por desprecio y olvido (Catulo LXIV), porque Baco le hace olvidarse de ella para su propio provecho (Theocr. II 45), porque le parecía una deshonra llegar a Atenas con ella, la hija del enemigo (Higino fab. 43), por simple crueldad (Ov. Met. VIII 175ss.), porque amaba a otra (Hesíodo citado por Plutarco Thes. 20).

Como puede verse, el comportamiento de Teseo al abandonar a su salvadora, enamorada al punto de traicionar a su propia estirpe, es un dato muy importante en el desarrollo del relato mítico. No es el caso de la comedia sorjuanina.

La finalidad alegórica, la presentación de Teseo como espejo de comportamiento del gobernante virtuoso, esto es, el tópico del speculum principis, supera el interés de cualquier anécdota. Aunque debemos decir que, de manera inconveniente, resulta el asesino de uno de los pretendientes de Fedra en un duelo causado por un error del mensajero. Sin embargo, el parlamento de su llegada en la Jornada Primera exime de todos lo yerros posteriores y es el motor del enamoramiento de las infantas. Vale citar unos versos: antes de contar sus hazañas ante Minos, se señala -como modelo de comportamientola superioridad de la virtud por encima del origen (un elemento que puede resultar autorreferencial de la autora)

Luego no será altivez que cuando le debo al Cielo, de nacimiento y valor tan conformes privilegios, me precie de mi valor más que de mi nacimiento.

\footnotetext{
${ }^{5}$ Ruiz de Elvira, A., Mitología Clásica, Madrid, Gredos, 1975.
} 
Teseo, al igual que Jano en la Loa aparece caracterizado como príncipe ejemplar. Sus hazañas se narran dando oportunidad de presentar los casos(donde impone orden y justicia y elimina a tiranos y bandoleros-Creonte, Procusto, Escirón) que en su conjunto representan al hombre esforzado, prueba de su superioridad moral. Hay un implícito paralelo entre Teseo y Jano ya que en la tradición mítica se los considera como héroes fundadores del estado: Jano como el rey más antiguo de Italia, Teseo como el iniciador de la democracia ateniense $e^{6}$.

El mayor valor de un gobernante, el vencerse a sí mismo, lo expresa Teseo, en estos versos en ocasión del relato del rapto de Helena:

Pero la mayor victoria
fue, Señor, que amante tierno
de la belleza de Elena,
la robé. No estuvo en esto
el valor--aunque el robarla
me costó infinitos riesgos--
sino en que, cuando ya estaban
a mi voluntad sujetos
el premio de su hermosura
y el logro de mis deseos
de sus lágrimas movido
y obligado de sus ruegos
la volví a restituir
a su Patria y a sus deudos,
dejando a mi amor llorando
y a mi valor consiguiendo
la más difícil victoria,
que fue vencerme a mí mesmo.

Junto a la tradición de los textos políticos, dice Garrido ${ }^{7}$ que Sor Juana "además, hace uso de las obras sobre varones ilustres cuyos parámetros más notables se hallaban en los libros de Petrarca (De viris illustribus) y de Bocaccio (De casibus virorum illustrium) Teseo es uno de los héroes que estos libros suelen incluir" A nosotros nos parece que también el Teseo de Plutarco puede ser la fuente ${ }^{8}$.

\footnotetext{
${ }^{6}$ Cf. Rodriguez Garrido, J. A., Escritura femenina y representación del poder en Ámor es más laberinto' de Sor Juana Inés de la Cruz (Loa y Comedia), Biblioteca Virtual Miguel de Cervantes, 2005.

${ }^{7}$ Idem, p. 629.

8 "Pues para el arrojo de Teseo con ocasión del tributo de Creta, ofreciéndose él mismo, bien fuese para pasto de una fiera, bien para víctima sobre el sepulcro de Androgeo, o bien, que era lo más leve de cuanto se dice en la materia, para sufrir una servidumbre oscura e ignominiosa,
} 
La figura del Rey Minos sirve de contraejemplo a las virtudes morales del héroe a causa de su deseo de venganza, que está en relación con la llegada de Teseo a Creta para que se cumpla el sacrificio respectivo de los atenienses por la muerte de Androgeo, su hijo: I, 203-270:

\author{
cada año a Atenas envío \\ que echen suertes, y al que salga, \\ fuercen a venir a Creta, \\ donde tengo en las entrañas \\ del Minotauro el sepulcro \\ que mi enojo le señala; \\ y aunque pudieran templar \\ en parte, mi enojo, tantas \\ malogradas juventudes, \\ cuyas vidas desdichadas \\ más que alimento a la fiera, \\ se lo han dado a mi venganza, \\ he quedado satisfecho \\ nunca, que no se restaura \\ con muchas que no lo son, \\ una frente coronada; \\ hasta que hoy, que la Fortuna, \\ para Atenas tan contraria \\ cuanto favorable a Creta, \\ hizo que la suerte airada \\ en el Príncipe cayese; \\ porque en iguales balanzas, \\ si fue Príncipe el difunto, \\ lo sea el que satisfaga \\ también por su infeliz muerte, \\ y no quede Atenas vana \\ de tener Príncipe, cuando \\ por su causa, en Creta falta. \\ Muera Teseo, y con él \\ mueran de su infame patria \\ las que en su valor tenían \\ bien fundadas esperanzas; \\ que no poco lisonjeo
}

\footnotetext{
bajo el poder de hombres injustos y crueles, haciendo voluntariamente aquella navegación con las doncellas y los jóvenes, no será fácil decir cuánto se necesitó, o de osadía y magnanimidad, o de justificación en las cosas públicas, o de deseo de gloria y de virtud." (Uno de los mayores problemas de estos análisis es la dificultad para establecer los textos con que contaba la Biblioteca de Sor Juana).
} 
mi enojo, al pensar que acaba

toda la vida de un reino

reducido a una garganta.

Ariadna dice de su padre, tras escuchar a Teseo: que le falta la noblezala quien la piedad le falta y, en otro momento, en aparente fórmula laudatoria que contradice la imagen del anciano prudente representada en el Jano ejemplar de la Loa:

\section{ARIADNA: Felices edades vivas porque vean que no empaña \\ en ti el ardor del acero, la prudencia de las canas.}

Fuera de las hazañas de Teseo y las crueldades de Minos se imponen los amores profundos y enredados de Fedra y Ariadna. La primera activa, ingeniosa, solidaria y finalmente defraudada, acaso por sus propias tretas (casi una Sor Juana autobiográfica) y Fedra más pasiva, igual de bella y con suerte mejor ya que parece que Teseo se enamora de ella porque la ve primero.

Sor Juana no es la única que reúne a ambos personajes y a ambas historias amorosas. Aquí resulta una fecunda reunión, propicia para el enredo y la comedia de 'faldas y empeño' de Sor Juana, como la caracterizara Schmidhuber. En otra época y en otra lengua también lo hizo Georg Conrad en su Phäedra de 1864. En el primer monólogo de Fedra, el personaje, en los siete versos finales, confiesa que ama a Teseo, aunque este sólo tiene ojos para su hermana Ariadna. Como ya en la versión de Racine, Teseo enamora a las dos hijas de Minos cuando va al palacio de Cnosos.

Sobre el asunto principal de la trama, el amor, vale la pena citar los parlamentos de las princesas enamoradoas, algunos de los cuales son de alto contenido poético, lo más destacado de la Jornada Segunda (compuesta por Juan de Guevara):

FEDRA:Si encuentro sombras, y la luz no veo

de un bien que se dilata, por ser mío, cuando más cerca está, más me desvío de un peligro que toco y que no creo.

Si es cobarde, y se alienta mi deseo

teniendo por razón mi desvarío, y de la noche mi ventura fío, lóbrego ensayo de medroso empleo, quien está, como yo, tan asistida de un mal tan firme y un penar tan vario, sólo espera una muerte repetida; 
que el esperar, que es muerte de ordinario siendo el mayor contrario de mi vida, más allá de la muerte es mi contrario.

ARIADNA: El manto de la noche, en sombras tinto, que medroso vistió de mis temores tupido laberinto de pavores, no es mayor que mi obscuro laberinto.

Parecido a mi suerte, no es distinto el color de sus trágicos horrores, porque sin luz me pinta los rigores que yo sin descansar hago y me pinto.

Sin que hagan intermisión mi amor constante de alivio, mi tormento, que es la herida que apetezco, más viva y penetrante me lisonjea, cuanto más sentida; pues por vivir muriendo, tengo amante mi tormento por alma de mi vida ${ }^{9}$.

Para terminar, volviendo a la idea de que Sor Juana se vale de la alegoría, corresponde describir a la figura como una representación más o menos artificial de generalidades y abstracciones perfectamente cognoscibles y expresables por otras vías. Como figura retórica es una de las preferidas del barroco y aquí la encontramos utilizada para promover, además, el placer intelectual de autor y público en la unidad del espectáculo teatral palaciego. No es ocioso añadir que permite además una reflexión sobre el poder civil a través de las correspondencias con las figuras del mito.

${ }^{9}$ Las alusiones a aspectos o partes concretas de esta comedia en este trabajo están referidas a la edición de Alfonso Méndez Plancarte y Alberto G. Salceda, incluida en el tomo IV de las Obras completas, 4 vols. México, Fondo de Cultura Económica, 1951-1957, 


\title{
El CiClo troyano y las Pircas diaguitas en SILENCIO DE PIEDRA De Guillermo Montilla Santillán
}

\author{
Liliana Pégolo, Florencia Meardi, Cristian Ramírez, Ulises Romero \\ Universidad de Buenos Aires - UBACyT
}

De manera semejante a El jardin de piedra, el tucumano Guillermo Montilla Santillán se apropia del mito clásico a fin de producir un texto donde el relato legendario es funcional a una teatralidad contemporánea y provincial, ambientada en el noroeste argentino. En Silencio de piedra, Montilla Santillán recurre al motivo de la ciudad asediada y a la mujer robada, enamorada de su raptor, para exponer el destino de quienes defienden su territorio frente a los designios de los poderosos. Así Héctor, Casandra y Aquiles, Helena y Paris, entre otros personajes de la tradición históricoliteraria nacional, vuelven a protagonizar el relato, en torno a las pircas diaguitas, mientras se debaten por el dominio de una mina a cielo abierto. Las relaciones entre los textos están establecidas desde el comienzo y será el propósito de esta comunicación analizar los intersticios intertextuales que se producen entre la trama mítica y su representación contemporánea, para comprobar que el mito sacraliza el espacio dramático, transformándose en textualidad simbólica.

Una vez más, de manera semejante a lo textualizado en El jardín de piedra, donde en el ingenio zafrero conviven monstruos locales como "el Familiar" y helénicos como el Minotauro, el dramaturgo tucumano, Guillermo Montilla Santillán, se apropia del mito clásico, en particular del ciclo troyano, para producir un texto en el cual el relato legendario es funcional a una teatralidad contemporánea y provincial, ambientada en el noroeste argentino.

En Silencio de piedra ${ }^{1}$, Montilla Santillán recurre al motivo de la ciudad asediada por enemigos superiores en fuerzas y recursos, y a la mujer robada enamorada de su raptor, evocadores ambos de la narración homérica de la mítica Troya, para exponer el destino de quienes defienden su territorio frente a los designios inexpugnables de los poderosos. Así es que Héctor, Casandra y Aquiles, Helena y Paris, entre otros personajes pertenecientes a la tradición histórico-literaria nacional como Facundo, vuelven a ser protagonistas del relato, en este caso, en torno a las pircas diaguitas, mientras los bandos se debaten por el dominio de una mina a cielo abierto.

Como ocurre en otras producciones de Montilla Santillán el mito se encuentra en el sustrato del texto emergente operando como inspirador

\footnotetext{
${ }^{1}$ La obra está fechada por el autor el 11 de febrero del año 2009.
} 
de una textualidad dramática innovadora, que combina las preocupaciones ecológicas y la denuncia del intervencionismo de poderes económicos trasnacionales con las estructuras del relato legendario, que iluminan el conflicto desde una perspectiva simbólico-alegórica. A la lectura en clave de los motivos argumentales debe sumarse la impronta folclórica de los elementos constitutivos del lenguaje dramático en el que se incluye la copla popular, mixturando la prosa y el verso junto a la solemnidad críptica del discurso profético.

Como afirma Jorge Dubatti en Concepciones de teatro. Poéticas teatrales y bases epistemologías (Buenos Aires,2009), las producciones literarias que entremezclan universos en apariencia disímiles "suelen ser espacios de heterogeneidad, tensión, debate, cruce, hibridez de diferentes materiales y procedimientos, espacio de diferencia y variación”. El texto de Santillán enmarcado en esta perspectiva teórica "propicia la complejidad y la multiplicidad interna", por el hecho de sorprender a través de las contradicciones temporales y espaciales desafíando la lógica de los modelos canónicos.

No obstante, las relaciones entre los textos son "saludables" en lo que respecta al resultado final y es ese resultado el que se analizará a lo largo de la comunicación; particularmente los intersticios intertextuales que se producen entre la trama mítica y su representación contemporánea, a fin de comprobar que el mito sacraliza el espacio dramático, recuperando las potencias y los saberes humanos al transformar "lo invisible en visible".

\section{Puede que sea resumen lo de arriba}

Como puede leerse en el resumen de la presente comunicación, el dramaturgo tucumano Guillermo Montilla Santillán se apropia una vez más del mito clásico ${ }^{2}$ con la finalidad de instalar en el contexto argentino y latinoamericano la permanencia de las matrices míticas ${ }^{3}$. Así como en otra obra del mismo autor, El jardin de piedra ${ }^{4}$, donde el universo minoico se

${ }^{2}$ Obsérvese la reflexión de N. Fry, en El gran código. Barcelona, Gedisa, 1988, p. 62, sobre el mito: "La mitología no es un datum sino un factum de la existencia humana: pertenece al mundo de la cultura y civilización que el hombre creó y que aún sigue habitando”.

${ }^{3}$ Kusch, R., Pozo de América, en Obras Completas IV, Rosario, Editorial Fundación Ross, pp. 9-10. El autor clasifica los mitos, especialmente, americanos en tres tipos: creación, caída y redeción o escatológicos. El de creación da elementos para entender el modo del domicilio existencial. El de caída que marcaría la distancia teológica entre el sujeto y lo absoluto. Finalmente, el que aquí nos concierne, el de redención que fijaría la culminación de un proceso de hybris o inmersión de la existencia en lo negativo que atraviesa el mito.

${ }^{4}$ Cf. Pégolo, L. - Cardigni, J. - Meardi, F. - Ramírez, C. - Romero, U., "De Teseos y Minotauros: El jardín de piedra de Guillermo Montilla Santillán”, en: López, A. - Pociña, A. (eds.), En recuerdo de Beatriz Rabaza. Comedias, tragedias y leyendas grecorromanas en el teatro del siglo XX, Granada, Universidad de Granada, 2009, pp. 479-489. 
entrecruza con el ingenio zafrero, Silencio de piedra está construido a partir del ciclo troyano, constituyéndose este como un sustrato sugerente de los conflictos eternos del hombre que pugna por la conservación de su identidad ${ }^{5}$.

Es evidente, al confrontar los títulos de la producción de Montilla Santillán, que la piedra ocupa un lugar de privilegio en el imaginario teatral, sobre todo porque el término adquiere un valor polisémico: en el primero, sugiere el ámbito aparentemente inexpugnable del laberinto-fortaleza del “jardín”; en el segundo, es el espacio mudo, incorruptible y referencial de las culturas en peligro de expoliación frente al avance extranjero. La pirca diaguita, construida de piedra, sirve de límite contenedor para la casa-corral que, en este caso particular, se convierte en la muralla aborigen, signo-eje dentro de un sistema de signos más amplio que incluye particularmente a la palabra. Esta no se limita al texto propiamente dicho, sino que el epígrafe, una copla perteneciente al poeta y cantor popular Atahualpa Yupanqui, reflexiona sobre el destino del hombre que debe abrirse camino entre la dureza de la piedra, de manera semejante a los ríos que heraclíteamente se oponen a ella y la transforman ${ }^{6}$.

La presencia física y arquitectural de la pirca, que remite al modelo comunitario pre-hispánico, se transforma a través de la acotación autoral ${ }^{7}$, en un denotatum o signo existencial ${ }^{8}$, en la medida en que sus defensores detentan la "piedra" como apellido; asimismo al revisar el conjunto completo de las personae dramáticas se visualiza la presencia del mito clásico con el que la historia dramatizada se entretejerá, estableciéndose una serie de relaciones intertextuales que se estrecharán y alejarán a lo largo del texto ${ }^{9}$.

${ }^{5}$ Silencio de Piedra no está editado en libro. El texto nos fue cedido por el autor en formato digital, y lleva como fecha final de composición el 11 de febrero de 2009. Señalemos que esta obra no es una "reescritura" o "adaptación" de ninguna tragedia clásica: los personajes de Montilla Santillán y sus acciones traducen en un relato autónomo los elementos presentes en el mito troyano, reconocibles, pero a la vez sin depender de manera ancilar de éste. El mito es aquí un sustrato más en los niveles simbólicos del texto. Por otra parte, de acuerdo con las concepciones actuales de escritura dramatúrgica, Silencio de Piedra consiste en un "texto dramático preescénico de primer grado". Seguimos la clasificación propuesta por Dubatti: "Una clase de texto literario dotada de virtualidad escénica, escrito a priori, antes e independientemente de la escena, que guarda un vínculo transitivo con la "puesta en escena." Dubatti, J, Cartografía teatral, Buenos Aires, Atuel, 2008, p. 137.

${ }^{6}$ Yupanqui, A., "Pasar la vida entre piedras, / Nuestro destino / Pasar la vida entre piedras / Como los ríos."

7 "Interior de una casa cercada de pircas, en las montañas Diaguitas del Norte Argentino."

${ }^{8}$ Eco, U., en La estructura ausente. Introducción a la semiótica. Barcelona, Lumen, 1989, pp. 285 ss., toma las consideraciones de G. Klaus Koenig, sobre la semiótica de Morris, para elaborar el concepto de denotata del signo arquitectónico.

${ }^{9}$ Entre los personajes que denotan una significación mítica se encuentran Héctor, del que se recuerda su condición de "domador de caballos", y la bella Helena, protagonistas del conflicto de la estirpe de los Piedra; asimismo aparecen otros que, como Facundo, está privilegiado con 
$\mathrm{Y}$ es precisamente esta dialéctica de las referencias textuales, entre Troya y la soledad pre-cordillerana, la que motivó nuestro interés sobre Silencio de piedra, pues advertimos que el texto impone, siguiendo a J. Dubatti, "espacios de heterogeneidad, tensión, debate, cruce, e hibridez de diferentes materiales y procedimientos, espacios de diferencia y variación" que instan al análisis. El texto de Montilla Santillán, enmarcado en la perspectiva teórica de las poéticas teatrales y de la literatura comparada, "propicia la complejidad y la multiplicidad interna"10, por el hecho de sorprender a través de las anacronías temporales y las diferencias espaciales, desafíando, en particular, la lógica de los modelos canónicos.

La primera "contradicción" -que es solo aparente- se advierte en otro elemento paratextual como es la dedicatoria; en ella el autor evoca a su abuelo sobre el cual destaca su condición gauchesca de pialador; a esta se agrega metafóricamente el hecho de "pialar" o atar sueños, tarea esta no diferente a la de contar historias ${ }^{11}$, como lo suelen hacer los abuelos hacia sus nietos, sosteniendo la transmisión oral de los relatos que constituyen la identidad de los pueblos en el hecho de "atarlos" a los orígenes y las causas. Frente a la evocación, la donación del texto a través del cual el autor asume, metatextualmente, su labor de narrador en el presente que vigila para asirse al pasado legendario, especularmente reflejado en el presente:

A Don Laurindo Santillán Sal, pialador de sueños, contador de historias, hombre de bien y abuelo.

Para vos, Tata, que me contaste tantas historias para conciliar el sueño, para soñar en la vigilia. Ahora me toca a $\mathrm{mi}^{12}$.

¿Cuál es la historia que el autor "contará" dramatizada? Aquella que se debatió frente a las murallas de Troya y la que las tradiciones post-homéricas transmitieron sobre la destrucción de la ciudad, a partir de la noche fatídica en la que el caballo de madera, abandonado ante sus curiosos habitantes en

la carga semántica de portar el nombre de uno de los héroes más controvertidos de la historia argentina del XIX. En el caso de Bórquez, remite al apellido de un militar chileno que participó en la pacificación de la Araucanía y fue destinado, hacia finales del 1800, a luchar en la zona de la Puna de Atacama. Están también personajes de los que se habla de manera narrativizada, como los Guanco, representados por el número tres, y una referencia sumamente importante de la figura de Aquiles al que no se nombra y Bórquez dice de él que "hay uno entre ellos, un gringo de crines bayas y ojos brillantes que de sólo mirar mete miedo. Y hay rumores sobre él [...] Qué es mitad diablo. Que le rebotan las balas como si tuviese la piel de hierro".

${ }^{10}$ Dubatti, J., Concepciones de teatro. Poéticas teatrales y bases epistemologías, Buenos Aires, Colihue, 2009.

${ }^{11}$ Bettelheim, B., en Psicoanálisis de los cuentos de hadas, México, Grijalbo, 1988, p. 53, afirma lo siguiente con respecto a la semejanza entre los mitos y los cuentos de hadas, ya que ambos "nos hablan en el lenguaje de los símbolos, representando el contenido inconsciente".

${ }^{12} \mathrm{El}$ autor utiliza la cursiva en la dedicatoria. 
la playa, ("sólo el potro gigantesco se alzaba como quien quiere alcanzar el cielo"), dio muestra del ardid de los que serían los vencedores. Con el recurso de la metáfora y del oxímoron, la voz de Alcira, que representa a la maldecida Casandra, se alza para dar a conocer vaticinios prodigiosos, aún no cumplidos ("Vivo por dentro, muerto por fuera, aguardando ser llevado detrás del muro de piedra, para trocarlo todo en cenizas.").

El temor que se agiganta en la oscuridad de la noche hace que los hermanos Piedra (Héctor, el mayor; Facundo, el más resuelto a devolver a Helena, a la que no se nombra, y Juan, que teme por la endeblez del adobe, en consecuencia de las defensas) discutan por la decisión a tomar. Se encuentran en la encrucijada trágica que ya está establecida de antemano: ¿cuál es el precio que se debe pagar por el amor de una mujer? ¿Vale este el desapegarse de la tierra? ¿O debe cumplirse el sacrificio expiatorio que se le exige al héroe? ${ }^{13}$ Así habla Héctor:

"Héctor: Aquí, detrás de las pircas y el adobe nos defenderemos.

$[\ldots]$

Facundo: Héctor, hermano, de rodillas te lo imploro, por el bien de todos, entregála.

Héctor: De pie, hermano, de pie. La noche no es apta para decidir caminos. Dejemos que la jornada nos alcance.

$[\ldots]$

Héctor: Mi amor es tierra. Maldito sea mil veces si no hiciera lo mismo por cualquiera de ustedes. Maldito sea."

Los conceptos de Benjamin recordados por Szondi nos permiten reflexionar sobre la intención de Montilla de recrear el modelo trágico, principalmente en lo que respecta a su significación simbólica: en el ejemplo anterior se percibe una nueva oposición: la del sometimiento a la tierra como sostén de la ley antigua y la necesidad de salvación del pueblo a través de su violación. El héroe se enfrenta a las decisiones personales e individualistas (la de sus hermanos, incluso la de Jerónimo, un Paris enamorado, que aún no ha aparecido en escena) para fundar una ley nueva que acabará con su existencia para permanecer en la palabra de una comunidad distante ${ }^{14}$.

De lo expuesto hasta aquí pueden desprenderse dos direcciones de análisis: por un lado resulta significativo interpretar Silencio de Piedra como

${ }^{13}$ Szondi, P., en Teoría del drama moderno. Tentativa sobre lo trágico, Barcelona, Ensayos / Destino, 1994, p. 230, recuerda la posición de W. Benjamin sobre la tragedia ática frente al drama barroco: La poesía trágica descansa en la idea del sacrificio. Pero el sacrificio trágico se diferencia de cualquier otro por su objeto (el héroe) y constituye al mismo tiempo un comienzo y un final. Un final porque es un sacrificio expiatorio debido a los dioses, guardianes de la ley antigua; un principio porque se trata de una acción sustitutiva en la que se anuncian nuevos contenidos de la vida del pueblo.

${ }^{14}$ Ibid., p. 231. 
una manifestación muy personal de la poética simbolista surgida en Europa a fines del siglo XIX, con evidentes proyecciones a lo largo del siglo XX y en la actualidad. ${ }^{15}$ Por otro, las concepciones de tierra y mundo mítico imbricadas en esta obra reclaman que no dejemos de lado la fuerza territorial que genera el teatro como experiencia convivial: la pirca no es un elemento simplemente referencial ni mucho menos de "color local" sino un organizador de la experiencia de interpretación semántica, tal como desarrollamos a continuación.

Con respecto a la poética del drama simbolista, resulta esclarecedor recordar los seis niveles de construcción simbolista propuestos por Dubatti:

- Simbolismo sensorial: la imagen escénica apela a lo extracotidiano por varias vías; en el caso de Silencio de Piedra, esto se advierte en el recurso musical (el "lejano golpe de bombos y tambores", indicado en una acotación final, está en correlación con el último parlamento de la obra: "Que hagan callar a las piedras, si es que pueden." Y con el silencio que cierra la obra: "Abrupto silencio."), en las voces de los muertos (que son "sombras esfumadas, salidas de la nada"), en el manejo de la luz velada. (Se verá que la "oscuridad" indicada en las acotaciones es un correlato del "silencio".)

- Simbolismo narrativo: la obra maneja una temporalidad que produce enlaces lógicos y causales imposibles de ser entendidos de un modo "objetivo" o exterior. Varias acotaciones indican: "Días antes", "presente", "mediodía”, "noche", "días después", "meses después". Se evita la linealidad expositiva racionalista y la gradación de conflictos.

- Simbolismo referencial: se intenta crear enlaces entre lo visible y lo invisible, lo presente solo a nivel metafísico, maravilloso o ancestral. La presencia de los sueños como presagio o índice de lo terrible es recurrente:

"Alcira: Soñé con un caballo. Un caballo de piedra. [...] Escuché al viento soplando entre sus patas, silbando entre las lajas que dibujaban sus crines. Parecía un tributo, pago a la tierra por tanto daño, por tanta sangre. Parecía muerto. Pero por dentro latía”16.

${ }^{15}$ El movimiento simbolista opera en la idea de que el mundo exterior registrado por nuestros sentidos no es la realidad última sino solo el reflejo de un ámbito de revelaciones absolutas que permanece oculto. Esta realidad auténtica puede evocarse por distintos recursos simbólicos. Tal como afirma Jaime Rest: "El empleo de procedimientos simbólicos ha sido característico de la literatura en todas las épocas, pero la denominación simbolismo suele emplearse en forma específica para designar un movimiento poético que se originó en Francia en las postrimerías del siglo XIX y que tuvo honda y decisiva gravitación en el desenvolvimiento de las experiencias vanguardistas de diversas lenguas". Cf. Rest, J., Conceptos fundamentales de la literatura moderna, Buenos Aires, CEAL, 1979, p. 145.

${ }^{16}$ Más adelante Alcira anticipará el destino final de los defensores al afirmar: "Vendrán por miles, no por cientos y serán tantos que el horizonte quedará oculto detrás de sus sombras. Como las langostas en los sembradíos lo consumirán todo. ¡Ay! Héctor, si pudieras verlo ahora. $\mathrm{Si}$ pudieras ver como yo antes de que el tiempo llegue. Correrá la sangre hasta enrojecer los 
La referencia al caballo de Troya no es un gesto erudito y vacío, sino que subraya la presencia de las fuerzas míticas como realidades profundas, telúricas: se trata de un caballo de piedra, como las pircas y la tierra que rodea todo.

- Simbolismo lingüistico: Basado en la belleza y fuerza alusiva de las palabras, vistas no como un enlace directo con la realidad, sino muchas veces en relación a lo inefable. (Recordemos el título de la obra y la indicación de silencio final.) Como hemos dicho, la obra se abre con la voz de Alcira, la adivina:

"El prodigio fue simple. Adormecidas y solas sobre largas extensiones de arena las tiendas cantaban con el viento. En el silencio que a gritos despuntaba con el alba, sólo el potro gigantesco se alzaba [...] Forjado en la madera arcana de los escudos y las picas".

En Silencio de Piedra no solo hay un desarrollo buscado de lo metafórico sino que se encuentran pasajes líricos que necesitan una modalización eminentemente "artística", es decir, autónoma, no realista.

- Simbolismo semántico: el teatro simbolista es concebido como un jeroglífico; se construye un símbolo (que puede ser un personaje, un objeto o un espacio) integrado en una situación dramática que no "expone" una tesis como en el drama realista sino que estimula al espectador a que perciba lo desconocido. En el caso de Silencio de Piedra, es evidente que el símbolo es el espacio: la tierra y la piedra son esencias últimas de realidad solo comprensibles en su silencio elocuente. Los personajes se movilizan en defensa de la tierra ante "los gringos" y sus ofertas monetarias, o ante el gobierno con sus falsas promesas de no tocar el agua para llegar a la mina. En este asedio, es el adobe el que tiene que resistir, porque un hombre sin tierra no es nada. Y es precisamente Héctor quien afirma: "Prefiero morir en mi tierra que vivir sin ella".

Simbolismovoluntario: se trata de un tipo de teatro basado en la complicidad del espectador para acceder a los sentidos desplegados por la obra. Recordamos nuevamente con Dubatti que en la concepción de mundo simbolista operan "la recuperación de potencias y saberes humanos perdidos o por desaparecer: el misterio, la magia, la visión, la fascinación por las formas de lo desconocido más allá de los límites de la materia y de la razón"17.

Pero también hablábamos antes de la fuerza territorial del teatro. Consideramos que Silencio de Piedra no construye sus sentidos en la intertextualidad literaria sino en un procedimiento que podríamos llamar inter-territorialidad. No es el peso de las alusiones clásicas lo que estructura la

ríos. La muerte beberá aún después de estar saciada, se llevará a todos. A los más bravos y a los cobardes. A todos".

${ }^{17}$ Dubatti, J., idem nota 8, pág. 152. 
obra sino las relaciones que se generan entre el espacio de la escena y el mito clásico entendido como territorio suprahistórico; pero también, y de un modo más fuerte, entre el territorio de los personajes y su contexto inmediato: la tierra misma donde se desarrolla la obra, donde ha sido creada, donde vive el público que traduce y produce los símbolos. La defensa de la tierra es también la defensa de una poética particular, local por naturaleza inevitable, pero no "localista". Si como dijimos antes, esta obra puede considerarse un texto preescénico, imaginamos que una puesta en escena del texto deberá indagar de qué modos esa virtualidad teatral presente multiplique en los aspectos no verbales la fuerza simbólica de la escritura poética.

Finalmente, desde la perspectiva de Kusch, lo descrito anteriormente con respecto al simbolismo se puede encuadrar dentro del concepto de cultura que expone el pensador argentino del siguiente modo:

"Cultura no es sólo el acervo espiritual que el grupo brinda a cada uno y que es aportado por la tradición, sino además es el baluarte simbólico en el cual uno se refugia para defender la significación de su existencia. Cultura implica una defensa existencial frente a lo nuevo, porque si careciera uno de ella no tendría elementos para hacer frente a una novedad incomprensible"18.

Específicamente, a partir de esta noción de cultura se puede comprender cabalmente la resignificación del mito aludido a través de la importancia concedida a lo autóctono (las pircas, la tierra, el agua, la doma y las canciones) y su defensa aún a costa de la propia vida ya que aquí se juega el sentido de la misma. Así, la cultura está íntimamente ligada al suelo "que no es ni cosa, ni se toca pero que pesa" ${ }^{19}$ y que además brinda arraigo en los momentos críticos. Piénsese en la canción entonada por los hermanos y recibida de los antepasados cuando esperan la segura muerte. De la combinación de los conceptos de suelo y cultura, el autor propone la necesidad de la geocultura ${ }^{20}$ como la actividad de pensar a partir de los problemas y vivencias latinoamericanas, más allá de la tradición racional occidental. En este sentido, el mito griego renace en el problema actual de la minería y en una comarca donde la tradición se respira en el ambiente y escapa al logocentrismo de Occidente.

${ }_{18}$ Kusch, R., Esbozo de una antropología filosófica americana, Buenos Aires, Ediciones Castañeda, 1978, pp. 13-14.

${ }^{19}$ Kusch, R., Geocultura del hombre americano, en Obras completas III, Rosario, Editorial Fundación Ross, 2000, p. 110.

${ }^{20}$ Kusch, R., idem, 1978, pp. 15-18. 


\title{
LAS MUJeres en BACANTES De EurípIdes: MÉNADES DE Hades y PERRAS DE LÝSSA
}

Ceecilia Josefina Perczyk Universidad de Buenos Aires

\begin{abstract}
En la Atenas clásica la razón caracteriza a las instituciones de la ciudad y la locura, definida en oposición a la razón, delimita el mundo de las bestias. De modo que la polis, caracterizada por la razón, es el espacio monopolizado por los ciudadanos varones y la naturaleza, como la dimensión de lo irracional, es el mundo de las mujeres. Con esta premisa, Eurípides en Bacantes construye la representación de la locura con dos recursos: la animalización "bestial" de los personajes femeninos y la elección del ritual báquico como escenario de la manifestación femenina del descontrol. Por tanto en esta investigación me propongo abordar la construcción de la locura en Bacantes de Eurípides a partir del análisis de estos ejes haciendo hincapié en la importancia que reviste lo femenino.
\end{abstract}

\section{Introducción}

En la Atenas clásica la razón caracteriza a las instituciones de la ciudad y la locura, definida en oposición a la razón, delimita el mundo de las bestias. De esta manera la pólis, caracterizada por la razón, es el espacio monopolizado por los ciudadanos varones y la naturaleza, como la dimensión de lo irracional y por ende de la locura, es el mundo de las mujeres. Con esta premisa, Eurípides en Bacantes construye la representación de la locura en base a dos recursos: la animalización "bestial" de los personajes femeninos y la elección del ritual báquico como escenario de la manifestación femenina del descontrol. Por tanto en la presente investigación me propongo abordar la construcción discursiva de la locura en Bacantes de Eurípides a partir del análisis de estos dos ejes haciendo hincapié en la importancia que reviste lo femenino en esta obra trágica.

En este sentido, el recurso poético de la animalización es particularmente aplicable a los personajes femeninos de la obra en tanto su condición de mujeres les confiere un estatuto de alteridad radical del que la animalización viene a dar cuenta. El estudio de este recurso, esencial para relevar la indisciplina que supone el abandono de la razón "masculina" y civilizadora, llevará a abordar el tratamiento de los personajes en clave de monstruosidad. Con este método investigaré de qué manera se articula la representación de la locura con la experiencia de la muerte, en su vertiente de poder de destrucción que es capaz de aniquilar al hombre y no como un estado diferente de la vida, 
asociado con las figuras masculinas en el imaginario griego. Y, por otro lado, el análisis del ritual báquico, como el escenario elegido por el autor para representar la locura, me permitirá indagar acerca del carácter violento de la locura que se manifiesta en el asesinato de Penteo y el despedazamiento de los animales en el bosque.

\section{La animalización "bestial" de los personajes femeninos}

Con el objetivo de estudiar de qué manera se construye la representación de la locura, abordo la construcción de los personajes femeninos y Dioniso a partir del recurso de la animalización. A efectos de este trabajo me centraré en las referencias al perro y a la serpiente porque estos animales forman parte de la composición de lo monstruoso en la Antigua Grecia (Vernant, 1986: 70) y tienen una estrecha relación con la experiencia de la muerte.

El primer animal en el cual me detengo es la serpiente. En el tercer episodio, el mensajero describe la conducta de las bacantes en el Citerón:

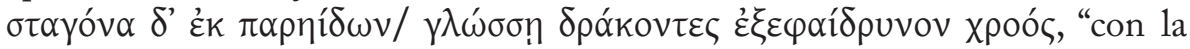
lengua las serpientes limpiaban de su piel las gotas que caían de las mejillas" (vv. 767-768) ${ }^{1}$. El efecto de animalización en este caso es por contacto ${ }^{2}$. De igual manera Dioniso, el conductor de las mujeres, es caracterizado por las serpientes que adornan sus cabellos:

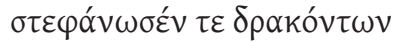

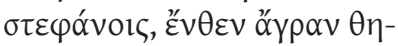

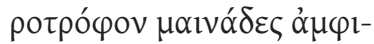

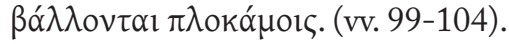

lo coronó con coronas de serpientes, por lo que, desde entonces, las ménades ponen alrededor de sus bucles esta presa devoradora de fieras.

Además, cuando las mujeres del coro exhortan a que el dios se manifieste,

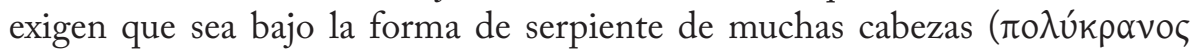

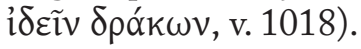

Este animal vincula a Baco y a sus seguidoras con Medusa, quien se caracteriza por su cabellera de serpientes. Gorgo representa para el hombre la alteridad extrema; la experiencia del sujeto con la muerte, puesto que a través de su mirada ella despoja con violencia al hombre del mundo de los vivos y lo precipita al Hades. Esta relación con Medusa se encuentra en la obra: al igual

\footnotetext{
${ }^{1} \mathrm{E} l$ texto griego de los pasajes de Bacantes corresponde a la edición de Murray (1913), y la traducción me pertenece.

${ }^{2}$ Ver también v. 698.
} 
que la mirada de Gorgo (Ilíada XI, vv. 36-37), la locura de Dioniso tiene como efecto el miedo que aterroriza al ejército armado (v. 305). En cuanto a este reptil cabe señalar dos aspectos que son complementarios. En primer lugar, la serpiente juega un importante papel en las ceremonias dionisíacas; su uso es mencionado por Demóstenes (Cor. 260) y Plutarco (Alex. II 6.3.) $\mathrm{Y}$ en segundo lugar, este animal en el ámbito griego simboliza el mundo de los muertos y a los dioses de los Infiernos; de hecho, se han encontrado recipientes utilizados para el culto de los muertos con estos reptiles (Burkert, 2007 [1977]: 44).

Continuo entonces con el segundo animal que es el perro, en cuyo caso el mecanismo de animalización es la identificación directa. Ágave llama a sus compañeras perras (v. 731) y Dioniso es denominado conductor de la jauría (v. 1145). La referencia a este animal es anudada al mito de Acteón, primo de Penteo. En boca de Cadmo:

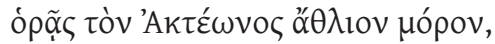

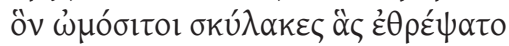

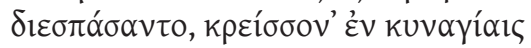

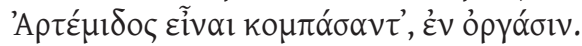

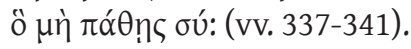

Ves el destino desgraciado de Acteón, al que despedazaron las perras devoradoras de carne cruda que él mismo crió, por haberse jactado de ser mejor en las cacerías que Ártemis, por los bosques sagrados. ¡Que no te pase a ti!

La versión del mito presenta innovaciones respecto del relato tradicional que tienen por fin aproximar el destino del rey de Tebas al de su primo. Eurípides concibe la falta de Acteón como un desafío a la divinidad, es decir, se trataría de una lucha contra un dios al igual que la disputa llevada a cabo por Penteo contra Dioniso. La otra innovación significativa tiene que ver con el cambio de género del animal, en el mito tradicional se habla de "perros" mientras que en la tragedia quienes destruyen a Acteón son las "perras devoradoras de carne cruda" (ANDRADE, 2003: 82-83). El mito de Acteón es nuevamente citado en los vv. 1290-1291 cuando Cadmo le informa a Ágave que ha matado a su hijo en el mismo lugar en el cual las perras dieron muerte a su otro nieto. E1 atributo dado a las perras, devoradoras de carne cruda, remite directamente a un aspecto fundamental de la celebración dionisiaca: la omophagía (v. 139). Se trata de la ingesta de carne cruda como el punto culminante del ritual báquico

${ }^{3}$ Como podemos observar en la Ménade con piel de leopardo y cinta en el pelo de serpiente del interior de un kilix ático de fondo blanco pintado por Brigos, siglo $\mathrm{V}$ a. C, Staaliche Antikensammlungen und Glyptothek, Munich, nº 2645. 
de acuerdo a una inscripción del s. III encontrada en Mileto. ${ }^{4}$ En el caso de Penteo las perras son su madre y las ménades:

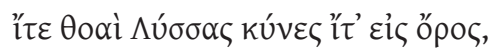

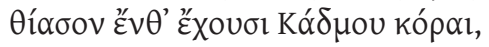

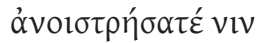

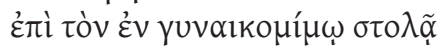

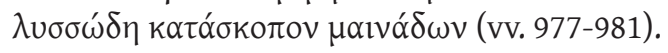

Id, veloces perras de Lýssa, id hacia el monte, donde tienen el thíasos las hijas de Cadmo, aguijoneadlas contra el rabioso espía de las ménades con ropa que imita a las mujeres.

El coro invoca a las perras de Lýssa para que se lancen contra Penteo y lo enloquezcan. Esta figura femenina es un daimon que personifica la furia en la guerra y la ira frenética. A su vez este nombre propio era utilizado como sustantivo para designar la locura en términos generales. Es utilizado de esa manera en los vv. 850-851 cuando Dioniso comunica a sus seguidoras el plan para que Penteo se vista con atuendos femeninos, las exhorta del siguiente

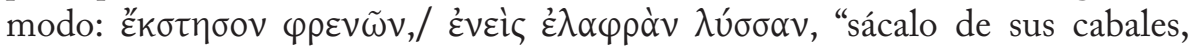
infundiéndole una ligera lýssa". Ahora bien, propongo el adjetivo "rabioso" para traducir lussóde, y no "enloquecido" con el objetivo de señalar el vínculo con el perro, y de esa manera destacar el carácter animal y no humano de la locura; puesto que el sustantivo lýssa también se utilizaba para designar la locura producida por la rabia. Este último rasgo es significativo puesto que Ágave, una vez poseída por Baco, echa espuma por la boca como una perra rabiosa (v. 1018).

La referencia al perro aparecerá nuevamente en el diálogo entre el Corifeo y Ágave. Ésta mientras lleva en su tirso la cabeza de Penteo, comenta cómo

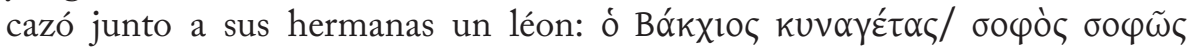

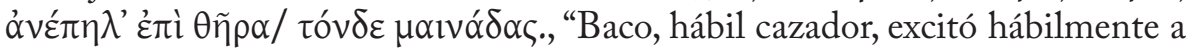
las ménades contra esta bestia." (vv. 1189-1191). El dios excita, como si fuesen perras de caza, a las mujeres para que atrapen a Penteo, confundido con un león, y lo descuarticen. Rodríguez Cidre (2010) señala que esta imagen de la perra como victimaria es recurrente en el imaginario griego y es utilizada para caracterizar tanto mujeres mortales como diosas o monstruos femeninos, por ejemplo: Hécuba (Eurípides, Hécuba, 1173), Clitemnestra (Esquilo, Agamenon, 607), Hécate (Porfirio, Abst., IV, 16), la Escila (Odisea, XII, 85-92), las Erinias (Sófocles, Electra, 1388), entre otras. A su vez, cabe destacar que en diversas

\footnotetext{
${ }^{4}$ Milet, Abh., Berlín, 1908, pp. 22-25.
} 
mitologías y también en la griega, el perro es un animal asociado con la muerte ${ }^{5}$ (al igual que la serpiente).

Para finalizar el análisis de la construcción de personajes vinculados con la locura a partir de la relación con estos dos animales es interesante observar que el autor también utiliza este recurso en Heracles. En esa tragedia Eurípides describe a $L y$ ssa con la cabeza llena de serpientes y la mirada que petrifica como Medusa (vv. 883-884). A su vez produce en el héroe síntomas asociados con la rabia puesto que Heracles arroja espuma como un perro rabioso (vv. 931934). En ambas tragedias se repite un modelo: los padres -Ágave y Heraclesasesinan a sus hijos habiendo sido enloquecidos por una divinidad.

\section{La elección del ritual báquico como escenario de la manifestación femenina del descontrol}

Los aguijonazos de Dioniso hacen que las mujeres dejen sus hogares y abandonen sus tareas domésticas para dirigirse hacia la montaña con el objetivo de honrar al dios (vv. 116-119). De modo que éstas al convertirse en seguidoras de Baco renuncian a las normas de la ciudad y pasan a habitar un espacio que no es monopolizado por los ciudadanos varones. La bacanal, llevada a cabo en ese espacio donde la naturaleza rige, se convierte en el escenario de la muerte. Puesto que a la celebración -que da la impresión de una perfecta comunión con la naturaleza, en la que emerge libremente la fecundidad animal y vegetal (vv. 680-727)- sigue un segundo momento marcado por un horror inusitado: las mujeres con sus propias manos son capaces de desmembrar animales (vv. 734747). El placer y el horror confluyen en esta celebración de la misma manera que la vida y la muerte son aspectos constitutivos de la ambigüedad de Baco. De hecho, Heráclito de Efeso (fr. 15) sostiene que Dioniso y Hades son lo mismo. Si bien la apreciación está inmersa en su teoría de los contrarios -puesto que el primero representa la vida exuberante y el segundo la muerte- expresa también una identificación entre ambas figuras que resulta pertinente a la hora de analizar esta obra, en la cual hay dos momentos identificables por su oposición: a la tranquilidad de las mujeres en el monte sigue el descuartizamiento de los animales.

En el mismo sentido, Dioniso en esta tragedia es vinculado con Ares, el dios de la guerra:

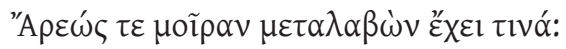

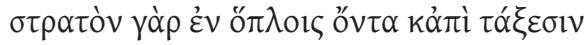

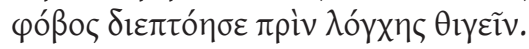

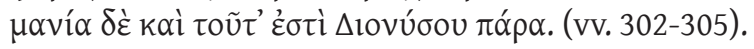

\footnotetext{
${ }^{5}$ Chevalier, J. \& Gheerbrant, 1993 [1969]: 816.
} 
También tiene una participación en el dominio de Ares, pues el miedo aterroriza al ejército en armas y en orden de batalla antes de tocar la lanza. Y esto también es locura que proviene de Dioniso.

Ares es la personificación de la fuerza bruta y la violencia, así como de los horrores de las batallas. Así Eurípides confiere un carácter violento a la locura dionisíaca por su relación con esta figura capaz de infundir el pánico en las tropas armadas.

El asesinato de Penteo en el bosque acontece con la misma lógica que el sparagmós de los animales. A la escena de las mujeres coronando de hiedras el tirso y cantando (vv. 1054-1057), sigue la exhortación de Dioniso a sus seguidoras para que atrapen al rey y lo maten (vv. 1079-1081). El efecto de la exhortación es la locura dado que éstas comienzan a girar sus pupilas de un lado a otro, que como veremos más adelante es uno de los síntomas de la "enfermedad sagrada". Las bacantes bajan del árbol a Penteo y Ágave da

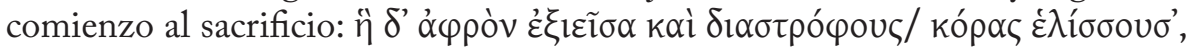

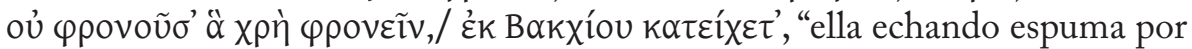
la boca y girando las pupilas desencajadas, no pensando lo que hay que pensar, estaba poseída por Baco" (vv. 1122-1124). Los síntomas que presenta Ágave, la secreción de espuma -como la de un perro rabioso- y el descontrol ocular tienen una correlación con los síntomas descriptos en el tratado hipocrático Sobre la enfermedad sagrada (10, 2-5). Este tratado hipocrático versa sobre el funcionamiento mental y se dirige principalmente a la discusión de la "enfermedad sagrada", cuadro que constituye el modelo de las perturbaciones mentales severas para la medicina griega. Así Eurípides utiliza un cuadro que es conocido por el público como propio de episodios de pérdida de la cordura (Theodorou, 1993: 34). Cabe destacar que el cuadro presentado por la hija de Cadmo es el mismo que Heracles manifiesta en la obra homónima (vv.867868).

Al desmembramiento de Penteo (vv. 1125-1139) sigue la sugerencia de Ágave de realizar un banquete para comer la presa cazada por ella (vv. 1184, 1242). La omophagía, la ingesta de carne cruda (en este caso con el agravante de ser carne humana) constituye el instante más álgido -intrínsecamente violento- de la experiencia de la celebración dionisiaca.

\section{Conclusión}

Dioniso, como dios de la ambigüedad, retrotrae al hombre a un estadio previo al de la civilización, el del salvajismo. Es por esto que las mujeres tebanas, una vez convertidas en bacantes, se funden con el mundo animal rompiendo todo lazo con el oíkos. Tras abandonar a sus recién nacidos amamantan a 
cachorros de ciervos y lobos (v. 700) y luego desgarran a sus presas, terneras y toros, con sus propias manos (v. 735). La animalización es un recurso que utiliza el autor para dar cuenta del estatuto de alteridad radical de la locura, estatuto que por otra parte las bacantes adquieren por ser mujeres, puesto que lo femenino en la cultura griega se corresponde con lo no humano. De esta manera es construida la representación de la locura como lo no humano en el hombre. El escenario de la locura es el ritual báquico, un espacio ofrecido por Dioniso a las mujeres que tiene como punto culminante la muerte. Una experiencia religiosa que es violenta en esencia y en potencia, y que toma la forma de la comunión con la naturaleza.

Para concluir, dado que esta presentación tiene como marco un congreso con eje la pervivencia de los Modelos Clásicos en Iberoamérica, España y Portugal, me interesa destacar una puesta española de esta tragedia, Las Bacantes, un espectáculo de Salvador Távora realizada con La Cuadra de Sevilla y Manuela Vargas en el año 1987. En la escena del despedazamiento de Penteo se escuchan ladridos de perros por los altavoces que irán subiendo su intensidad hasta que finalmente se funden con los ladridos de dos perros que suben al escenario. Las bacantes les dan carne, se trata del cuerpo destrozado de Penteo que es devorado por los animales en el proscenio. Cuando estos terminan de engullir los restos siguen dócilmente a Dioniso. De modo que en esta representación se recupera la figura del perro pero ya no como recurso poético referido, sino como un animal concreto que participa materialmente en el desarrollo de la acción. 


\section{Bibliografía}

Andrade, N. (2003), Euripides, Bacantes, Buenos Aires, Biblos.

Dodds, E. R. (1963), Euripides' Bacchae, Edited with introduction and commentary, Oxford, Clarendon Press.

Kirk, G. S. \& Raven, J. E. (1974 [1966]), Los flósofos presocráticos. Historia crítica con selección de textos, Madrid, Gredos.

Littré, E. (1849), Oeuvres Complètes d'Hippocrate (vol. 6), Amsterdam, A.M. Hakkert.

Murray, G. (1913), Euripidis Fabulae, Oxford, Clarendon Press.

Roux, J. (1970), Les Bacchantes, Paris, Les Belles Lettres.

Seaford, R. (1996), Euripides, Bacchae, Warminster, Aris \& Philips.

Burkert, W. (2007 [1977]), Religión griega. Arcaica y clásica, Madrid, Abada.

Chevalier, J. \& Gheerbrant, A. (1993 [I969]), Diccionario de los simbolos, Barcelona, Herder.

Rodríguez Cidre, E. (2010), Cautivas Troyanas. El mundo femenino fragmentado en las tragedias de Eurípides, Córdoba, Ordia Prima.

Theodorou, Z. (1993), "Subject to emotion: exploring madness in Orestes", Classical Quarterly 43 1, 32-46.

Vernant, J. P. (1986), La muerte en los ojos, Barcelona, Gedisa. 


\title{
El nuevo Orfeo. \\ La visión de Vinicius de Morales Sobre el encantador de ALMAS
}

María José Pérez

Universidad Nacional de Mar del Plata

\begin{abstract}
La presente comunicación tiene como finalidad problematizar la figura mítica de Orfeo. Uno de los posibles creadores de la lira, con todo lo que significaba este instrumento para el espíritu griego. Personaje relacionado con diversos rituales, conocedor del culto de Dioniso. Amante de tal calaña que enfrentó a los Infiernos para recuperar a su amor. Dicha problematización nos permitirá abordar adecuadamente al Orfeo que llegó a nuestras manos de la mano de Vinicius de Moraes. Y comprender cada rasgo desarrollado por dicho dramaturgo en Orfeo de la Concepción.
\end{abstract}

Nuevamente nos encontramos ante un personaje mitológico que maravilló en todas las épocas. Orfeo, famoso entre los griegos, ha cautivado la mente de muchos hombres a través de los siglos. Muchos son los intelectuales que han abordado la figura de este extraño ser. Entre los cuales podemos mencionar a Virgilio, Ovidio, Eurípides, Calderón de la Barca, Jacopo Peri, Marcel Camus.

Pero, ¿quién es éste Orfeo capaz de hipnotizar tanto la mente de los antiguos como las del siglo XXI? La mayoría de las personas conocemos el elemento predominante de su ser: la música. Él era el cantor por excelencia. Ante el dulce sonido de su lira los arboles, animales y rocas se rendían a sus pies. Los griegos estaban convencidos de que poseía el poder de dominar tanto el mundo orgánico como inorgánico.

Éste hecho quedó inmortalizado en diversos vasos, monedas o esculturas que nos muestran o representan dicha imagen. En algunos lo podemos ver encantando a las fieras con melodías, en otros aparece acosado por las ménades. Existen vasos de origen itálico que lo ubican en el mundo de los muertos, rodeado de deidades subterráneas. También aparece en murales de Pompeya, tañendo la lira, cercado por animales pacíficos o algunos de naturaleza sanguinaria, como por ejemplo, el león que se han vuelto amigable por el poder de su música.

Sobre él dice Guthrie:

"El poder de la lira era de ablandar los corazones de los guerreros y volver sus pensamientos hacia la paz, así como podía subyugar hasta las fieras. No sólo animales sino también personas se reunían en su torno para escuchar el canto"1.

\footnotetext{
${ }^{1}$ Guthrie, W.K. C., Orfeo y la religión griega, Buenos Aires, Editorial Universitaria de
} 
La imagen que poseemos sobre Orfeo casi se toca con la poesía, pero en verdad tenemos escasos datos sobre él. Por lo cuál podríamos reformular nuestra pregunta a: ¿Qué sabemos fehacientemente de Orfeo? Y es aquí que la necesidad de datos precisos nos sumerge en la oscuridad.

Y nos obliga a sumar los diferentes sucesos conocidos para poder tener una idea acabada sobre él. Entre los datos que poseemos podemos enumerar como importantes los siguientes, la existencia de una relación entre Orfeo con el movimiento religioso que posteriormente se denomino orfismo. El viaje de nuestro personaje con los Argonautas y su historia de amor con Eurídice. También contamos con novedades sobre su muerte, la cual es, según algunos, mediante el rayo de Zeus. Y para otros son las ménades quienes la llevan a cabo.

El ser de Orfeo cobra vida cuando se unen todas estas piezas, motivo que nos da lugar a realizar las aclaraciones pertinentes.

Comenzaremos por la relación que se da entre el orfismo y Orfeo.

Se sabe que Orfeo fue considerado por los griegos como el fundador de cierto tipo de religión. Su persona aparece en la historia como profeta y maestro humano. Orfeo ofrecía a su tiempo una relectura de la religión ya presente en ese momento. Todos aquellos hombres que aceptaran a Orfeo como profeta y vivieran la vida bajo sus preceptos y aceptaran su teogonía serian los llamados órficos.

De esto da testimonio González Delgado:

"Orfeo era el profeta de una doctrina de carácter mistérico, modificación de los misterios dionisiacos, y sus enseñanzas estaban incorporadas en textos sagrados. Fue el fundador de una secta mistérica que ha pasado a la historia con el nombre de "orfismo". No era una doctrina nueva y distinta, sino una modificación particular de la religión dionisiaca”.

Ahora bien, no contamos con abundantes fuentes directas sobre el orfismo, lo cual hace difícil afirmar que práctica o creencia puede denominarse órficas. Así como también dificulta adjudicarle dichas prácticas y cosmogonía a Orfeo, ya que es probable que sean de otros personajes. Los cuales utilizaron el nombre del poeta para revestirlos con un halo de prestigio y autoridad.

Lo cierto es que se cree que el orfismo tenia como sustento una literatura, esto es, se fundaba en una serie de escritos sagrados, que dicha literatura relataba diversas andanzas de nuestro cantor y además, como ya se dijo, poseía

Buenos Aires, 1970, p. 42.

${ }^{2}$ González Delgado, R., El Mito de Orfeo y Eurídice en la literatura Grecolatina hasta la Época Medieval, Oviedo, 2001, p. 18. 
una cosmogonía. Esto no es extraño ya que en la antigüedad, además de Hesíodo existieron varios teólogos entre los cuales se encontraría Orfeo, como así también se nombra a Acusilao de Argos, Epiménides de Creta y Ferécides de Siro.

Hay testimonios sobre dicha literatura sagrada atribuida a Orfeo desde la antigüedad, entre ellos de Platón, Eurípides, Eudemo. Sobre este punto podemos leer en Orfeo y la Religión Griega de Guthrie:

“...la existencia de una literatura sagrada atribuida a Orfeo, no faltan testimonios de ella para los siglos V y IV a.C., y, además, de que en esos siglos ya se consideraba de gran antigüedad. Orfeo encabeza la lista cuando Alexis, un poeta cómico del siglo IV, describe un montón de libros representativos; "Ven y escoge de éstos cualquier libro que quieras. Están Orfeo, Hesíodo, tragedias, Quérido, Homero, Epicarmo"3.

También podemos afirmar que bajo el concepto de orfismo se encuentran una serie de rituales, prácticas y conocimientos de diferente tenor y carácter. Ejemplo de esto, son los testimonios con que contamos sobre no introducir en los templos telas de lana y de no ser sepultados con ellas como manda el hierós lógos órfico y también nos llegan comentarios sobre la prohibición de comer carne y seguir una dieta estrictamente vegetariana.

Hemos de tener en cuenta que el orfismo fue, ante todo, una forma de vida, tal como lo serian un tiempo más tarde el epicureísmo, el estoicismo y el cristianismo. Por lo cual es lícito suponer que los órficos deberían seguir determinados preceptos o mandatos, inclusive tenían rituales de iniciación. Se dice que Orfeo fue el primero en mostrar a los seres humanos el sentido de los ritos de iniciación.

Ahora bien, sobre la figura de Orfeo son escasos los datos. Tenemos noticias de que su origen se consideraba generalmente tracio, así lo dicen la mayoría de los estudiosos, por ejemplo Karl Robert.

"aun cuando sea dudoso si su patria fue Tracia, en todo caso se lo localizo allí desde época muy temprana, y después pasó por tracio durante toda la antigüedad" ${ }^{4}$.

Se cree que Orfeo es hijo de una musa, Calíope ${ }^{5}$ Y su padre seria Apolo o Eagro, un rey Tracio, no contamos con relatos sobre su nacimiento, salvo

\footnotetext{
${ }^{3}$ Guthrie,W. K. C., Orfeo y la religión griega, Buenos Aires, Editorial Universitaria de Buenos Aires. 1970, p. 12.

${ }^{4}$ Guthrie, W. K. C., Op. cit., p. 28.

${ }^{5}$ Suelen mencionarse como su madre también a las musas Polimnia, Menipe o Clío.
} 
una referencia al pasar en los Argonautiká órficos, en donde se describe la celebración del matrimonio de su madre con Eagro en una caverna ubicada en Tracia.

"De allí me encaminé de prisa a la nivosa Tracia, a la tierra de los libetrios, mi propia patria, y entré en la famosa caverna donde mi madre me concibió en el lecho del magnánimo Eagro"6.

En cuanto a la expedición de Jasón y los Argonautas en busca del vellocino de oro nos llegan diferentes testimonios por medio de la literatura griega, entre ellos de Hesíodo, y también Píndaro. De hecho, fue el gran poeta lírico quien nos proporciona la primera tentativa de un relato conexo sobre dicho viaje y menciona a Orfeo entre los navegantes.

El papel que le otorgan a Orfeo en la expedición es el de entonar la cantinela que da ritmo a los remeros. Su dulce cantar no sólo tranquilizó a los remeros sino que también calmó las tempestades. Además se pensaba que debido a su melodiosa y armónica música habían podido salvarse de las sirenas.

Así es como mediante su hipnótica música Orfeo pasa a ocupar un lugar entre los héroes, en la versión órfica de este mito, nuestro héroe cumple además de lo mencionado, un papel de características religiosas ya que en ella aparece celebrando diferentes tipos de sacrificios, unos en honor de los dioses, otros de purificación.

Ahora bien, cuando finaliza dicha expedición Orfeo, convertido prácticamente en un héroe retorna a los brazos de Eurídice, su gran amor. Esta era probablemente una ninfa o dríada tracia.

La versión más difundida del mito nos ubica en la celebración de la boda de Orfeo y Eurídice. Momento en el que ésta se vio acosada por Aristeo. Eurídice al no estar interesada en caer en los brazos de Aristeo huyo de él y mientras corría para alejarse fue mordida por una víbora. Motivo por el cual muere y la existencia de Orfeo se torna sombría y triste. Este no concebía su vida sin ella, le faltaba la mitad de su alma, por lo cual tomo la determinación de bajar a los infiernos en su búsqueda. Pocos son los vivos que han estado en este lugar, entre ellos podemos recordar a Odiseo, Teseo y Adonis.

El hades es la encarnación de lo prohibido, es el Más allá, el lugar de donde nadie puede volver. Es un mundo de dioses, muertos y fantasmas. La vida, el movimiento, la música, no tienen aquí lugar, ni razón de ser. Este viaje le aporta a Orfeo conocimiento y saberes negados a la mayoría de los humanos, él ha visto otro mundo, otra realidad. El hades esta alejado del mundo humano y es casi imposible ingresar a el si no ha muerto. Pero Orfeo altera los ordenes

\footnotetext{
${ }^{6}$ Guthrie, W. K. C., Op. cit., p. 29.
} 
y parte hacia el Más allá, con la pretensión de ingresar y retornar de allí con vida y además recobrar algo que ya no le pertenece, su amada.

Para tal fin llevó su lira para seducir con su dulce melodía a Caronte, Cerbero, los dioses infernales y todo aquel que se atravesara en su camino, a los cuales encantó mediante su mágica música, los persuadió para que dejaran ir hacia la luz, hacia el mundo de los vivos a su gran amor. Orfeo no fracasa en su propósito y los dioses infernales le entregan el objeto de su deseo. Nuestro Orfeo cambia las leyes de la vida y de la muerte. Él es un héroe armado con la lira y persuasivas palabras. Pero le entregan a su amada bajo la condición de partir hacia el mundo de los vivos, hacia lo luminoso sin mirar hacia atrás, debe marchar con su mirada fija, no girar su cabeza. Debe guiar a Eurídice con el sonido de su lira, pero la curiosidad pudo más, y en un momento determinado Orfeo inclina su rosto hacia atrás para ver los pasos de su amada, por lo cual los dioses retienen nuevamente a Eurídice.

Sobre este episodio podemos leer en el Banquete, $179 \mathrm{~d}$ :

"A Orfeo, el hijo de Eagro, lo despidieron del Hades sin haber logrado nada, después de haberle mostrado el fantasma de su mujer, a por quien había bajado: pero sin entregársela, ya que lo consideraban cobarde, porque era citaredo: no se atrevió a morir por amor del mismo modo que Alcestis, sino que intentó por todos los medios penetrar con vida en el Hades. Pues bien, por esta causa le impusieron un castigo e hicieron que su muerte fuese a manos de mujeres".

Tras la pérdida definitiva de la mujer amada, autores como Virgilio y Ovidio, lo muestran eludiendo la compañía de las mujeres, mostrándose célibe. Aparece rodeado de la naturaleza, en soledad. Su postura es más femenina que masculina.

Éste es Orfeo. Y su mito ha llegado hasta nuestros tiempos, renovándose, enriqueciéndose. Muchos son los dramaturgos que se han apropiado de el, como es el caso de Jean Cocteau, Vinícius de Moraes y Tennessee William.

Vale mencionar que en los últimos tiempos la visión de Marcel Camus sobre Orfeo, llevada al cine en 1959 y denominada Orfeo Negro alcanzó gran popularidad. Dicha película esta inspirada en la obra teatral Orfeo de la Concepción del diplomático y compositor brasileño Vinícius de Moraes. Está película merece una mención ya que alcanzó tal relevancia que hace pocos años se han emprendido estudios sobre su influencia en la cultura popular brasileña. El Orfeo de Camus es un músico de ensueños, responsable del amanecer. Su cuerpo es sonido, y su sonrisa poesía. La banda sonora de dicho film es digna de Orfeo.

El Orfeo de Vinicius de Moraes relata la historia de un músico muy popular y querido de un morro carioca, él cual como ya se imagina está perdidamente enamorado. Aparece una tercera en discordia, antigua novia de 
Orfeo, llamada Mira quien incita a Aristeo a que cometa una locura. Es éste quien mata de una puñalada a Eurídice.

Esta "Tragedia carioca", se encuentra ubicada en la actualidad. Y es dividida en 3 actos. El primero y el último acto tienen lugar en un morro de Río de Janeiro y el segundo en la ciudad baja. La acción se desenvuelve en la noche, en el centro de la escena la choza que pertenece a los padres de Orfeo. Lejos la ciudad. Una dulce guitarra y Orfeo cantan su amor por Eurídice. En la escena aparecen los padres de Orfeo, Mira y Aristeo. Aparece luego La Dama Negra ante Orfeo, que niega que alguien la haya convocado, pero ella insiste que esa noche alguien partirá junto a ella.

Con el retorno de Eurídice, los amantes ingresan a la choza bajo el influjo de la pasión, mientras Aristeo y la Dama Negra acechan. Más tarde, luego de despedirse de Orfeo, Eurídice es apuñalada.

El segundo acto, acontece el martes de carnaval. Orfeo llega al club "Los Mayorales del Infierno" penando, loco de dolor, busca a su amada en la frenética fiesta presidida por Plutón y Proserpina. La escena esta signada por la presencia de gente, ruido, música, baile y alcohol. Tanto los reyes infernales como el coro de mujeres se burlan de él. Pero mediante su música, el cantor logra escapar.

El último acto se abre nuevamente en el paisaje del morro. Es la hora del crepúsculo y en torno a la choza se encuentran los vecinos. La madre de Orfeo ha perdido el juicio a causa del dolor y culpa a Eurídice por el cruel destino de su hijo. Se la llevan en una camilla. La acción pasa a un boliche en el morro. La figura de Orfeo se muestra en el lugar, por lo cual los ánimos se caldean aún más cuando pregunta por su amada. Mira, celosa comienza a instigar a las mujeres, lo apuñalan salvajemente y destruyen su guitarra. Aparece por último la Dama Negra y oculta el maltrecho cuerpo de Orfeo con su manto blanco, mientras el Coro recita una plegaria por él. ${ }^{7}$

Como se puede ver el dramaturgo sigue los lineamientos generales del mito de Orfeo. La desesperación y angustia del poeta ante la muerte de la amada siguen presente. También se deja ver la figura de las ménades que darán muerte a Orfeo. Esta también la música, y la guitarra que es destrozada en la obra seguramente por el gran poder que le confiere al protagonista.

En fin, si prestamos atención debemos notar que el elemento que está presente en todos los relatos en los que aparece la figura de Orfeo, lo único que está siempre en cada uno de ellos es la música. Su relación con la música lo envuelve en un halo de misterioso y grandilocuente poder. Es mediante su canto que comunica los renovados rituales a los órficos. Es con el dulce teñir

${ }^{7}$ Cf. Pianacci, R., Orfeo en el paraiso. Tradición y relecturas desde América Latina. Cf. Carames, J. L., El cine: otra dimensión del discurso artístico. 
de su lira que es útil y benéfico para los Argonautas. Con su canto vence al caprichoso mar, a las terribles sirenas y calma a los dioses. Es con su música que cautiva y conquista el amor de Eurídice. Y ese elemento el que le permite a él bajar al mundo de las tinieblas, y maravillar a los dioses infernales. Es este elemento el que lo va a caracterizar desde que apareció en la literatura por primera vez, allá por el siglo VI a. C. de la mano del poeta Íbico de Regio, quien se dice sobre él solo un par de palabras a saber: "al famoso Orfeo".

En nuestros días, él sigue siendo música. Clara muestra de esto es la obra de Vinicius de Moraes descripta un par de párrafos antes. Obra en la cual la cuidad solo por Orfeo. Donde el mismo Orfeo dice: "Toda la música es mía ¡Soy Orfeo!”

Es con el dulce sonido de su lira que Orfeo logra un nuevo orden, en el cual es posible estar entre los muertos, pronunciar sonidos divinos cuando sólo es un simple mortal. Orfeo es luz en el infierno, es un bálsamo en el alma de los condenados. Su música que parece hechizar el corazón y la razón de los dioses infernales, de los hombres, de las bestias, de la naturaleza. La palabra y la música se fusionan en Orfeo convirtiéndolo en ser civilizador, pacificador. Su música, su ser potencialmente puede crear mundos. Y...díganme ustedes...si hay algo más divino que esto. 


\section{BibLIOgRAFÍA}

Bauza, Hugo, Voces y visiones: Poesía y Representación en el Mundo Antiguo.

Cabañas, Pablo, El mito de Orfeo en la Literatura Española, Madrid, Consejo Superior de Investigaciones Científicas, 1948.

Calderón de la Barca, Pedro, El Divino Orfeo en Obras Completas, Tomo III, Madrid, Aguilar, 1967.

Carames, Jose Luis, El Cine otra dimensión del discurso Artístico. Vol. I, Universidad de Oviedo.

Cocteau, Juan. "Orfeo", en La Revista de Occidente, Tomo XV, Madrid, 1927.

De Moraes, Vinicius, Orfeo de la Concepción, Buenos Aires, Ediciones de la Flor, 1973.

González Delgado, Ramiro, El mito de Orfeo y Eurídice en la literatura grecolatina basta época medieval, Tesis Doctoral leída en la Universidad de Oviedo (España) en julio de 2001.

Guthrie, W. K. C., Orfeo y la religión griega, Buenos Aires, Eudeba, 1970.

Leal, Juli. "E1 Hades en Luisiana: Orpheus Descending de Tennessee Williams", en El caliu de loikos, a cura de Carmen Morenilla i Francesco De Martino, Bari, Levante Editori, 2004

Lope de Vega, Félix, El marido más frme, Biblioteca Virtual Miguel de Cervantes. htm.

Ovidio Nasón, P., Metamorfosis, Libro X, Madrid, Consejo Superior de Investigaciones Científicas, 1990.

Platón, El banquete, notas y traducción de Antonio Rodríguez Huéscar, Buenos Aires, Aguilar, 1986.

Ramos Gay, Ignacio. "Eurídice surrealista: el ciclo órfico en la obra de Jean Cocteau", en El caliu de l'oikos, a cura de Carmen Morenilla i Francesco De Martino, Bari, Levante Editori, 2004.

Reinach, Salomón, Orfeo. Historia general de las religiones, Buenos Aires, E1 Ateneo, 1964.

Virgilio, Geórgicas, Libro IV, Madrid, Editorial Gredos, 1990. 


\title{
As marcas poeticomusicais de $M E D E L A$ de Eurípides refletidas em Gota d’água de Chico Buarque e Paulo Pontes: UMA VISÃO POR MEIO DA RETÓRICA
}

\author{
Luísa H. Figueiredo Peixoto \\ Universidade Federal de Minas Gerais
}

\begin{abstract}
O presente texto propõe-se a analisar a peça contemporânea brasileira Gota d'água, de Chico Buarque e Paulo Pontes, como revitalização poéticomusical do texto clásssico de Eurípides. Pretende-se comparar o coro das vizinhas da releitura de Medeia em relação ao coro de tradição grega da tragédia euripidiana. Por meio da contraposição entre os coros, buscarse-á apresentar como os autores brasileiros reconhecem a formação de um coro presente na tragédia de Eurípides, uníssono e, ao mesmo tempo, representante de um conflito. Todavia, o coro da peça latino-americana interpõe as vozes dos amigos de Jasão às vozes das vizinhas de Joana que conduzem a história. Será observado o conflito tanto interno quanto externo das ações das personagens Medeia e Joana por meio do recurso poético-musical de colocar a voz masculina em contraposição à feminina, valendo-se também de um recurso retórico.
\end{abstract}

Pretendo por meio desta comunicação refletir sobre os traços poeticomusicais presentes no coro da tragédia Medeia de Eurípides, comparando-o à peça Gota d'água, que revitaliza este mito no teatro brasileiro por Chico Buarque e Paulo Pontes. Mesmo que haja limitações na comparação entre as peças por causa das significativas diferenças entre a cultura grega e a brasileira contemporânea, pretendemos delinear o diálogo poético, escrito em versos, de Gota d'água como uma forma estilística de exprimir as emoções das personagens também vistas na tragédia de Eurípides. A partir do samba, ritmo popular brasileiro, Paulo Pontes e Chico Buarque ilustram a eloquência e valorização da palavra a fim de se reaproximar do discurso retórico presente em algumas passagens na tragédia euripidiana.

A tragédia de Eurípides, datada no século V a.C., narra as ações de uma mulher, Medeia, cujo marido alguns anos mais novo, Jasão, decide abandonála para desposar a filha de Creonte, rei de Corinto, lugar onde habitavam. Medeia, então, decide vingar-se de Jasão matando a seus filhos e provocando a morte de sua noiva. Como apropriação dessa peça, o cantor e compositor Chico Buarque de Hollanda, juntamente com o dramaturgo Paulo Pontes, criaram em 1975 o drama urbano Gota d'água, inspirados em uma adaptação feita por Oduvaldo Vianna Filho, para a televisão. Gota d'água se passa em um conjunto habitacional, chamado de Vila do Meio-Dia, onde habitam Joana, personagem madura e sofredora, representa Medeia, e Jasão, possui o mesmo 
nome, sendo nessa encenação, um sambista jovem e boêmio, que abandona Joana para se casar com Alma, filha de Creonte, também homônimo da tragédia, homem poderoso e dono da Vila. O coro é formado pelos vizinhos de Joana, dentre eles, Egeu e sua mulher Corina, sendo estes semelhantes aos personagens de mensageiro e ama de Medeia, respectivamente. No âmbito religioso, Buarque e Pontes apresentam um sincretismo interessante entre divindades do candomblé, como Ogum e Oxumaré (o candomblé é uma religião panteísta de origem africana, sendo Oxumaré uma divindade que preside o bom tempo, e Ogum, uma divindade da caça e agricultura), imagens e santos do catolicismo (São Jorge e Virgem) e deuses da mitologia grega (Têmis, deusa guardiã dos homens e das leis, e Hécate, considerada deusa da magia, feitiço e da noite).

A adaptação, escrita em um período conturbado e violento do regime militar brasileiro, faz uma crítica pungente ao sistema capitalista e à política do momento em que a peça foi escrita. Desse modo, tal empreendimento provocou uma reflexão acerca do movimento no interior da sociedade, cujas classes subalternas encontram-se isoladas. Os autores de Gota d'água utilizaram a musicalidade por meio do samba, composto por um ritmo e uma marcação populares no Brasil, do mesmo modo que a tragédia possui um ritmo e marcação própria à cultura grega antiga.

Como a releitura Gota d'água foi criada a partir de um complicado contexto político com o intuito de dar voz a uma classe repudiada, interpretaremos Medeia como tragédia política, e não apenas como "tragédia doméstica" ao contrário de alguns helenistas, como Kitto (Kitto, 1961, p. 32) ${ }^{1}$, consideraram. Nesse aspecto, os elementos de heroísmo e racionalidade da personagem bárbara corroboram com a releitura do teatro contemporâneo brasileiro na figura de Joana.

O coro da tragédia de Eurípides, formado por mulheres de Corinto, é substituído pelas vozes das vizinhas de Joana, que conduzem a história. Todavia, este coro é intercalado, por vezes, com as palavras dos companheiros de Jasão, ora o "set das vizinhas" está em primeiro plano, ora o "set do botequim" passa para o primeiro plano; formando um coro polifônico, revelando um conflito e dicotomia entre as partes. Por sua vez, o coro representado na tragédia grega é homogêneo por ser composto apenas pelas mulheres de Corinto; no entanto, também se mostra conflituoso e dividido no decorrer da peça ao ser persuadido por meio de uma retórica bem articulada de Eurípides, onde Medeia pode provocar a compaixão ao expor a situação de exilada e abandonada pelo marido, ora causar o temor, "comparando-a a um touro ou a uma leoa (v.92, 103-104,

${ }^{1}$ Valho-me de uma crítica da interpretação de Kitto, em Coelho, M. C. M. N., "Medeia: o silêncio ético de Aristóteles", Clássica, 1 (1992) 63-68. 
187, 342)" como afirma Coelho (Coelho, 2005); animalizando, dessa forma, as suas ações diante da percepção por parte do coro de que a personagem trama causar males às vítimas que escolheu para se vingar de Jasão.

Ademais, percebe-se, no centro da ação dramática, a revalorização da linguagem, revelando alguns aspectos da tragédia que os autores buscaram ressaltar, sem subjugar a complexidade de Medeia, todavia, desejando que a releitura brasileira se aproxime do público de que se trata, composto por habitantes do Rio de Janeiro, pessoas do povo, como lavadeiras, malandros, operários, gigolôs, sambistas e cozinheiras. Ao mesmo tempo em que denunciam o sistema atual brasileiro em prejuízo da classe trabalhadora, os autores reforçam na apresentação da peça a preocupação com a palavra, fenômeno que desejaram revelar contido nos elementos da tragédia. "A linguagem, instrumento do pensamento organizado, tem que ser enriquecida, desdobrada, aprofundada, [...]. A palavra, portanto, tem que ser trazida de volta, tem que voltar a ser nossa aliada" (Buarque e Pontes, 2001, p. 18).

Depois destas considerações iniciais pretende-se fazer uma análise mais pormenorizada do emprego do coro que Chico Buarque e Paulo Pontes desejam revelar na apropriação da tragédia de Eurípides, utilizando-se da melodia e da coreografia do samba como elementos que contribuem para marcar nos versos ritmados os conflitos da ação dramática, além de dar seguimento sublinhando as vozes das vizinhas de Joana, dos amigos de Jasão, ainda das "vozes off”, de pessoas que cantam na coxia. Como propõe Ribeiro em sua leitura de Gota d'água, "A música reforça o ambiente popular da Vila e mostra-o como espaço de brasileiros de origem diversa, (...): as melodias que acompanham as falas de algumas das personagens têm o ritmo do coco, da embolada, do samba, do ponto de macumba" (Ribeiro, Maria Aparecida, p. 176).

Nas cenas iniciais, as vizinhas revelam o aspecto coletivo da peça e a dor de Joana em relação ao abandono e a atitude de desprezo de Jasão, enfatizada na fala de Corina (Buarque e Pontes, p.26):
Minha filha, só vendo
Tem resto de comida nas paredes fedendo a bosta, tem bebida com talco, vaselina/.../
E ali, menina
Brincando calmamente co'os cacos do espelho estão os dois fedelhos.

esta cena se assemelha à primeira fala da Ama, em Medeia, nos versos 24-25, 26-27, 35-36: 
Jaz sem comer, o corpo abandonado a dor, consumido nas lágrimas todo o tempo /.../

Como uma rocha ou uma onda do mar, assim escuta os amigos, quando a aconselham.

Abomina os filhos e nem se alegra com vê-los.

$\mathrm{Na}$ peça brasileira, o contexto do sofrimento de Joana se mistura aos problemas dos credores de Creonte na Vila com as exigências da noiva de Jasão, resultando em uma música entoada por um dos amigos de Jasão no botequim, cantada em ritmo de uma embolada, diminuindo um pouco a tensão da cena dramática de Joana, ao misturar-se aos problemas de todos da Vila. Esse jogo em cena onde acrescentam-se conflitos diversos que, posteriormente, diluem-se resultando na encenação de uma música, sinaliza as características rítmico-musicais e coreográficas do samba ${ }^{2}$, o qual sofre influências desde seu nascimento, de matriz africana, que se adapta às festividades e sonoridades brasileiras e à vida urbana, resultando na incorporação de novos instrumentos e novas linguagens, desdobrando-se em samba de gafieira, samba de breque, samba-enredo, samba-canção, dentre outros. O samba, então, começa a adicionar à sua constituição rítmica a marcha, formando a partir de sua inserção no meio urbano uma espécie de cortejo, consolidando no modelo inicial do carnaval carioca, assim comenta o autor Mestrinel (Mestrinel F. A. S., O Samba e o Carnaval Paulistano, artigo publicado na edição no 40 de fevereiro de 2010, p. 23):

As escolas de samba cariocas agregavam elementos visuais dos ranchos à musicalidade negra presente no samba, que ganhava uma feição marchada, para tornar mais fluente o desfile dos componentes do grupo carnavalesco. $\mathrm{O}$ caráter marchado designa uma marcação mais constante do pulso musical, que auxiliaria no ato de caminhar e dançar simultaneamente. $\mathrm{O}$ maxixe era dançado em par e sua rítmica, teoricamente, não colaborava para um desfile.

Percebe-se, assim, como o gênero do samba se ajustou a novos cenários sociais e políticos, incluindo sempre instrumentos e adaptando-se a novas linguagens, resultando em um sincretismo e dinamismo constitutivos da

2 s. m. Dança cantada, de origem africana, compasso binário e acompanhamento obrigatoriamente sincopado (o samba rural distingue-se do samba urbano, no caráter musical e coreografia). 2. Música que acompanha essa dança. 3. Bras. Baile popular, sobretudo aquele onde predomina essa dança. 4. Bras. Aguardente de cana. Samba de enredo; o mesmo que samba de enredo. "samba", in Dicionário Priberam da Lingua Portuguesa, 2010, http://www.priberam.pt/ $\mathrm{dlpo/dlpo.aspx?pal=samba[consultado} \mathrm{em} \mathrm{2011-06-15].}$ 
cultura popular brasileira, caracterizando o carnaval. Essa musicalidade e corporeidade do samba reforçam o ambiente popular da Vila do Meio-Dia, mostrando a marca da diversidade nos espaços brasileiros, elementos que nos são revelados nas melodias dos sambas (seguindo sua ancestralidade africana do coco e da embolada) que acompanham, por meio do discurso das personagens, as quais utilizam registros lingüísticos como as gírias e os estrangeirismos para persuadirem seus interlocutores. Esses elementos retóricos que se apropriam do coro, de modo polifônico, são perceptíveis no set das vizinhas, quando estas entoam o refrão na tentativa de consolar Joana e impedi-la de realizar alguma vingança (Buarque e Pontes, p. 54):

VIZINHAS: Comadre Joana

Recolhe essa dor

Guarda o teu rancor

Pra outra ocasião

Comadre Joana

Abafa essa brasa

Recolhe pra casa

Não pensa mais não

Comadre Joana

Recolhe esses dentes

Bota panos quentes

No teu coração

Esses versos são intercalados com as "vozes off” que representam a dor de Joana - "Deixa em paz meu coração/ que ele é um pote até aqui de mágoa/e qualquer desatenção/-faça não/ Pode ser a gota d'água”. Jasão, no set do botequim, sai de cena para dar ênfase à fala de Egeu (p.74):

Quem chama Jasão, não chama à toa

É o cara certo: boa pessoa /.../

Resultado:

mais negro fica este sumidouro

mais brilhante fica o outro lado

e o seu carnaval, mais duradouro.

Em seguida, os vizinhos comentam sobre o casamento de Jasão e Alma, filha de Creonte (p.92):

O coro canta na coxia; os vizinhos e as vizinhas indicados vão entrando em cena e, cantando, vão fazendo uma corrente de boatos coreografada (...)

CORO OFF: Tira o coco e raspa o coco 
De coco faz a cocada

Se quiser contar me conte

Que eu ouço e não conto nada

O centro do fenômeno dramático da peça Gota d'água nos revela como o dramaturgo Paulo Pontes e Chico Buarque desejaram interpretar os elementos retóricos do e a eloqüência múltipla da linguagem no coro, como afirma Torrano (Torrano J. 1995, p.16)- "O coro trágico - com sua multiplicidade em que todo individuo é anônimo e tem somente a personalidade coletiva identificadora do grupo enquanto tal,- figura sempre a condição existencial dos homens mortais." Aristóteles, por sua vez, também responde acerca de qual seria a linguagem da tragédia, enfatizando que a linguagem da tragédia seria um complexo de ritmo, harmonia e canto. ${ }^{3}$ Desse modo, o coro tem um papel essencial por apresentar importantes cantos onde se fundamentam a trama e a retórica da tragédia, valendo-se de seu caráter de festividade e coletividade, os quais contribuem para uma composição de melodia e harmonia diversificadas. A composição melódica, de fato, não prevalece quando se verte o texto grego para o português, mas, de certo modo, nos é perceptível, como nos versos:

132 - Ouvi, ouvi a voz e o grito de clamor da Cólquida infeliz

148 - Ouvi, ó Zeus, ó terra, ó luz, que grito soltou essa desgraçada.

168- Ouvis como fala e grita.

173 - Como poderia ela vir

À nossa vista, receber

Das nossas palavras o som.

A ver se a pesada ira

E capricho abandonava.

Concluindo, a partir da análise comparativa entre as peças Gota d'água e Medeia, procurei mostrar o modo pelo qual o dramaturgo Paulo Pontes e o cantor e compositor Chico Buarque se valeram para revelar a partir de um recurso poéticomusical e retórico ao interporem as vozes das vizinhas de Joana aos companheiros de Jasão; sem deixar de contribuirem com uma apropriação de Medeia revigorada pelo tempero do samba e carnaval, onde os instrumentos e músicos devem estar atentos ao ritmo e marcação; cada parte deve se harmonizar como só um corpo e ritmo, sentindo o risco iminente que "qualquer desatenção/ pode ser a gota d'água".

${ }^{3}$ Aristóteles, Poética, 1449 b 24-28 - 1450 a 8-9. O Estagirita chama de temperada a linguagem que contém ritmo, harmonia, melodia, canto, sendo que algumas partes da tragédia adotam somente o verso, e outras também o conto, dado o fato de se servir separadamente de cada gênero de tempero. 


\title{
Una SORPRENDENTE Pasión POR EL TEMA de FedRa e Hipólito: Sus cuatro reescrituras por Manuel Lourenzo
}

\author{
Andrés Pociña \\ Universidad de Granada
}

\begin{abstract}
Uno de los más prestigiosos dramaturgos del teatro gallego actual, Manuel Lourenzo, ofrece como uno de los rasgos peculiares de su producción la reescritura de temas de la mitología greco-latina. Dentro de esta amplia parcela de sus dramas, destaca su pasión, además de por el tema de Medea, por el de Fedra e Hipólito: en 1973 reelaboró en gallego y puso en escena un muy peculiar Ipólito a partir de Eurípides, que no es una mera traducción como alguna vez se ha dicho; en 1975, publicó en Santiago su farsa Romería ás covas do demo; en 1982 aparece su libreto para ópera (inconcluso) Fedra, inspirado en Séneca; por último, vuelve al mismo tema en Despois do temporal (2007). Estudio de estas cuatro obras dramáticas.
\end{abstract}

\section{Sucinta presentación de Manuel Lourenzo y su teatro.}

La actividad de Manuel Lourenzo en el mundo del teatro gallego es tan prolija y variada como amplia en sus resultados, de modo que serían necesarias muchas horas para presentar una síntesis mínima de sus realizaciones, que han hecho que, a pesar de su dedicación constante y única al teatro en lengua gallega, haya conseguido gozar de un amplio conocimiento y reconocido prestigio en los ámbitos teatrales de toda España ${ }^{1}$. Nacido en Ferreira do Valadouro (Lugo), en 1943, Manuel Lourenzo cursa los estudios de Magisterio en A Coruña, y se dedica a la enseñanza hasta el año 1980; sin embargo, desde mucho tiempo atrás se da a conocer en los ámbitos teatrales, en las facetas más diversas, como creador y animador de grupos y empresas teatrales, como director, como autor, y como investigador de la

${ }^{1}$ Cf., para un acercamiento básico a su biografía y a su obra, entre otros trabajos: Anónimo, "Lourenzo, Manuel”, Gran Enciclopedia Gallega, Santiago - Gijón, Silverio Cañada Editor, 1974, vol. 19, p. 199; Anónimo, "Lourenzo Pérez, Manuel María”, Enciclopedia Galega Universal, Vigo, Ir Indo Edicións, 2002, vol. 11, p. 265. Manuel Lourenzo - Francisco Pillado Mayor, Diccionário do teatro galego (1671-1985), Barcelona, Sotelo Blanco Edicións, 1987, pp. 97-99; Anxo Tarrío, Literatura galega. Aportacións a unha Historia critica, Vigo, Edicións Xerais de Galicia, 1994, pp. 518-532, esp. p. 524; Dolores Vilavedra (coord.), Diccionario da literatura galega, I Autores, Vigo, Editorial Galaxia, 1995, pp. 352-353; María-José Ragué-Arias, El teatro de fin de milenio en España (De 1975 hasta hoy), Barcelona, Editorial Ariel, 1996, pp. 85-86, 296-297; Laura Tato Fontaína, "O teatro desde 1936", en AA. VV., Proxecto Galacia, Tomo 33, A literatura desde 1936 ata hoxe: poesía e teatro; A Coruña Hércules de Ediciones, 2000, pp. 444-511, esp. 487-491; Anxo Gómez Sánchez - Mercedes Queixas Zas, Historia Xeral da Literatura galega, Vigo, Edicións A Nosa Terra, 2001, pp. 344-345; etc. 
historia del teatro gallego. Obtiene el título de Interpretación en el Institut de Teatre de Barcelona en 1975. A su iniciativa se debe el nacimiento y dirección de grupos que tuvieron un significado fundamental en el desarrollo del teatro gallego en los insoportables tiempos de la dictadura franquista, como fueron, y siguen siendo algunos, $\mathrm{O} \mathrm{Facho}^{2}$, Teatro $\mathrm{Circo}^{3}$, Escola Dramática Galega ${ }^{4}$, Compañía de Teatro Luís Seoane ${ }^{5} .$. En la actualidad es uno de los tres miembros del consejo de redacción de la Revista de Teatro Casahamlet (anual, a partir del año 1999), que dirige Francisco Pillado, llevando Lourenzo la dirección del grupo teatral del mismo nombre; con este grupo estrenó en 2000 su obra Últimas faíscas de setembro, curiosa y original reescritura del tema de Medea ${ }^{6}$.

Las obras teatrales de Manuel Lourenzo resultan incontables, incluso teniendo en cuenta que muchas de las que escribió no llegaron a publicarse, en muchos casos por no responder completamente a las exigencias del propio autor. Sin contar de momento las que tienen como base la mitología clásica, tal vez podrían señalarse como sus piezas más destacadas Viaxe ao país de Ningures (Viaje al pais de Enningunlugar, 1976, ed. 1977), Todos os fillos de Galaad (Todos los hijos de Galaad, Premio de teatro O Facho, 1979, ed. 1981), Edén e outros paraísos (Edén y otros paraísos,1981, conjunto de varias piezas cortas, la primera de ellas titulada Edén), Forno de teatro fantástico (Horno de teatro fantástico, 1991, conjunto de cinco piezas cortas), A canción do deserto (La canción del desierto, 1991) y Como un susurro (1992) (ambas en el tomito titulado Teatro

${ }^{2}$ Creado en Coruña en 1965 , es uno de los grandes motores de la actividad teatral gallega hasta avanzada la década de los años 80 , realizando y promoviendo representaciones, lecturas dramáticas, emisiones radiofónicas, de autores gallegos y también extranjeros traducidos al gallego.

3 A Coruña, 1967-1977, con la colaboración del Círculo de Artesanos, anima la vida teatral de a ciudad con representaciones, conferencias, cursillos, y mantiene relaciones con los movimientos de vanguardia de otras partes de España, hasta su disolución, víctima de la represión política, incluso de "amenazas furibundas", en palabras de Lourenzo, para dar paso a la creación de la Escola Dramática Galega (cf. Manuel Lourenzo, "Teatro Circo. A consolidación do Teatro Independente Galego”, Casahamlet 2 (2000) 34-37; C. Lourenço Módia,Teatro Circo. Tres textos, A Coruña, Deputación Provincial, 2010.

${ }^{4}$ Fundada en A Coruña en 1978 por F. Pillado Mayor como presidente y M. Lourenzo como secretario, es la organización más importante en el desarrollo del teatro gallego en los años 80 y 90, publicando hasta el año 1995 sus pequeños pero interesantísimos Cadernos da Escola Dramática Galega, que llegaron a alcanzar 105 números (cf. Miguel A. Mato Fondo, "A Escola Dramática Galega", Casahamlet 2 (2000) 24-29.

${ }^{5}$ A Coruña, 1980, sociedad cooperativa, animada por F. Pillado y M. Lourenzo, con obras de repertorio, gallegas y extranjeras traducidas al gallego, y con sede en la Sala de Teatro del mismo nombre en A Coruña (cf. Anónimo, "Compañía de Teatro Luís Seoane", Casahamlet 2 (2000) 42-43; Maria Pilar Garcia Negro, "Os Cadernos da Compañia de teatro Luís Seoane”, Casabamlet 2 (2000) 52-53).

${ }^{6}$ Cf. A. López, "Visiones de Medea en la literatura gallega", en A. López - A. Pociña, Medeas. Versiones de un mito desde Grecia hasta hoy, Granada, 2002, pp. 87-130, esp. 109-114. 
minimo), A lexión sonámbula (La legión sonámbula, 1995), Veladas indecentes (1996, Premio Nacional de Teatro), Magnetismo (1997), O soño das cidades (El sueño de las ciudades, 1999), O circo da media noite (El circo de la media noche, 2001), Insomnes (2004), Contos troianos (2007), O arame (2008), Nocturno Poe (2009), etc. ${ }^{7}$

Pero además de estas y de otras muchas obras de tema vario, en la producción teatral de Manuel Lourenzo sobresale la frecuente reescritura de grandes temas de la mitología clásica, la mayor parte argumentos de bien conocidas tragedias griegas y romanas. Este tipo de drama tiene una importancia muy notable en el teatro gallego de la segunda mitad del siglo $\mathrm{XX}$; el gran estudioso de la literatura gallega Ricardo Carballo Calero coloca como momento significativo del arranque y triunfo de este tipo de obra, en cierta medida siguiendo el modelo, procedente de Francia, de muchas obras de Anouilh, Cocteau, Gide, Giraudoux, Sartre, etc., en el "Certame Literario do Miño”, celebrado en Lugo en el año 1960. En efecto, concurrieron a aquella convocatoria, entre otras, nada menos que tres obras teatrales de inspiración clásica: Os homes poden ser deuses (Los hombres pueden ser dioses) de José María Gallego, $A$ volta de Ulises (El regreso de Ulises) de José Luis Franco Grande, y Orestes de Arcadio López-Casanova ${ }^{8}$. Por su parte Manuel Lourenzo aparece escribiendo dramas de este tipo ya desde los primeros momentos de su producción dramática, como son los siguientes: Romería ás covas do demo (Romería a las cuevas del demonio, estrenada por Teatro Circo en 1971, ed. en 1975), Traxicomedia do vento de Tebas namorado dunha forca (Tragicomedia del viento de Tebas enamorado de una horca, Premio Abrente 1978, ed. 1981), Fedra (1982), Medea dos fuxidos (Medea de los huidos, 1983, Premio Sociedade Filantrópico-Dramática de Ribadeo, 1984, inédito hasta 2009), Edipo rei (Edipo rey, 1983), Defensa de Helena (Premio Ditea, 1985, ed. 1987), Agamenón en Aulide (estr. en 1991), Clitemnestra e o crime (estr. en 1991, formando parte junto con la obra anterior del espectáculo Ocasos), Electra (1994), O perfil do crepúsculo (El perfil del crepúsculo,1995).

${ }^{7}$ Una lista exhaustiva de la producción dramática de Manuel Lourenzo hasta el año 1995, con indicación de obras publicadas y obras estrenadas, puede verse en María-José RaguéArias, El teatro de fin de milenio en España (De 1975 hasta hoy), Barcelona, Ariel, 1996, pp. 296-297.

${ }^{8}$ Cf. R. Carballo Calero, Libros e autores galegos. Século XX, A Coruña, Fundación Pedro Barrié de la Maza, 1982, p. 367 s.; también M. Lourenzo - F. Pillado Mayor, Diccionario do teatro galego..., cit., pp. 44-45. Un estudio muy bien documentado de la tradición griega que está en la base de estas creaciones se encuentra en el artículo de J. A. Fernández Delgado, "La tradición griega en el teatro gallego", EstClás 38 (1996) 59-89, esp. pp. 61-66.

${ }^{9}$ Publicación conjunta de las piezas Agamenón en Áulide, Liturxia de Tebas, Os persas, Elsinor teatro, Cadernos de Teatro 1, A Coruña, 1995. 


\section{La pasión de Lourenzo por el tema de Fedra e Hipólito. Hipólito.}

Cuando en el año 2005 organizamos Aurora López y yo el Simposio Internacional "Fedras de ayer y de hoy. Teatro, poesía, narrativa y cine ante un mito clásico"10, dedicamos ambos una ponencia al tema de Fedra e Hipólito en Manuel Lourenzo ${ }^{11}$, pues su pasión por el mismo se demostraba por el hecho de haber realizado hasta entonces tres reescrituras muy variadas sobre el tema: un Ipólito (1973) que estaba inédito, una farsa Romería ás covas do demo (estrenada en 1969, editada en 1973), un libreto para ópera titulada Fedra (1982). En nuestro estudio sobre esas creaciones, lamentábamos que de la primera sólo podíamos hablar basándonos en referencias encontradas en escritos del propio dramaturgo, pues ni teníamos el texto, ni Lourenzo, a quien nos une desde hace años una profunda amistad, podía facilitárnoslo, porque no conseguía encontrarlo entre sus innumerables papeles.

Ante la falta fundamental del texto, escribíamos Aurora López y yo: "E1 24 de abril de 1973 se estrenó en el Circulo de Artesanos de A Coruña un Ipólito, al que suelen hacerse escuetas referencias en los estudios sobre Manuel Lourenzo o sobre el apasionante momento del desarrollo del teatro gallego que gira en torno a 1970, pero casi siempre pecan dichas referencias de una inexactitud llamativa. En efecto, al presentarse como un Ipólito de Eurípides en gallego, el lector incurre con toda facilidad en el error de suponer que se trata de una versión, más o menos libre, de la tragedia del griego, cuando en realidad se trataba de una cosa bastante distinta. De acuerdo con un sistema de trabajo y de investigación teatral que estaba en la base de la creación del Teatro Circo (1967-1978), encaminados a la creación y desarrollo de un auténtico teatro independiente gallego, el montaje de Ipólito fue una elaboración de un equipo de trabajo, dirigido por Manuel Lourenzo, formado por dos mujeres y dos hombres, que representarían los papeles fundamentales de la tragedia (Lourenzo, en concreto, el de Teseo). El punto de partida consistía en pasajes seleccionados de la tragedia de Eurípides, traducidos al gallego utilizando una versión española, una versión francesa y el original griego. Esta versión era en verso, y Lourenzo, responsable de la misma, recuerda que incluso la disposición en versos mantenía una correspondencia grande con la del original. Pero a los textos fundamentales, euripideos, de esta versión, que se representaban con máscaras, respondía el trabajo de conjunto con textos de creación propia, obviamente también en gallego, que servían de nexo exegético

\footnotetext{
${ }^{10}$ Publicado luego en forma de libro, Granada, Universidad, 2008.

${ }^{11}$ A. Pociña - A. López, "El tema de Fedra en el teatro gallego de Manuel Lourenzo", en A. Pociña - A. López (eds.), Fedras de ayer y de hoy. Teatro, poesía, narrativa y cine ante un mito clásico, Granada, Universidad, 2008, pp. 524-544.
} 
entre el momento social y dramático de Eurípides y la realidad gallega de 1973, desde el punto de vista teatral, por supuesto, pero sobre todo social, bajo la férrea vigilancia de la dictadura"12.

Pero el teatro de Manuel Lourenzo, siempre vivo, siempre en evolución, no deja de dar sorpresas, ni por sí mismo, con obras nuevas, pero también con cambios constantes en las ya existentes, ni consiguientemente en los estudios que a él se dedican. De este modo, en 2010 la profesora Cilha Lourenço Módia, hija de nuestro dramaturgo, nos ofrece nueva luz sobre esta obra al publicar un pequeño estudio sobre el Teatro Circo, pero ilustrado con tres obras de su fundador, siendo la tercera precisamente el Hipólito, ahora escrito con "h"13. No puedo saber hasta qué punto el texto publicado corresponde al representado en 1973; la responsable de la edición, en una nota introductoria, advierte con relación a las tres obras que presenta, que "todas ellas fueron actualizadas lingüísticamente y revisadas por el autor, que consideró que los textos conservados podían ser confusos por proceder de improvisaciones, mantener elementos que no llegaron a utilizarse teatralmente en los montajes y omitir los fragmentos censurados" ${ }^{14}$. Ahora bien, una experiencia anterior nos hace pensar que los cambios realizados por Manuel Lourenzo en esa revisión pudieron ser mucho más profundos: en efecto, cuando en el año 2000 Aurora López escribió su trabajo "Visiones de Medea en la literatura gallega"15, la versión del drama Medea dos fuxidos que pudo manejar, un texto mecanografiado, generosamente cedido por el autor, que no lo había publicado, ni tenía intención de hacerlo, difiere tanto del que por fin se ha editado en $2009^{16}$, que parece necesario un nuevo estudio y análisis de tan interesante obra.

Sea cual sea la semejanza o la divergencia entre el Ipólito de 1973 y el Hipólito ahora editado, dado que no dispongo del largo espacio de tiempo que me sería preciso para un análisis riguroso de la obra, sobre todo si se piensa que tendré que comentar también otra nueva, me limitaré a completar, ahora con datos objetivos, lo que señalamos Aurora López y yo en nuestro anterior estudio, para el que como dije no disponíamos del texto.

${ }^{12}$ A. Pociña - A. López, Art. cit., p. 530 s.

${ }^{13}$ C. Lourenço Módia, Teatro Circo. Tres textos, A Coruña, Deputación Provincial, 2010. Las tres obras editadas son Crónica do sol de inverno (Crónica del sol de invierno, estreno en 1971), Erros e ferros de Pedro Madruga (Yerros y hierros de Pedro Madruga, estreno en 1972) e Hipólito (1973), como se ve representadas en años consecutivos.

${ }^{14}$ C. Lourenço Módia, Op. cit., p. 8 (el texto orginal, en lengua gallega).

${ }^{15}$ A. López, “Visiones de Medea en la literatura gallega”, cit., pp. 87-130, esp. 88-100.

${ }^{16}$ M. Lourenzo, Medea dos fuxidos e outras pezas, Cesuras, A Coruña, Biblos clube de lectores, 2009. Es curioso leer en la "Nota do autor", que todavía no da por definitiva la edición de Medea dos fuxidos, pues afirma: “...nunca a considerei terminada, nin sequera agora, en que ofrezco pouco máis do que un resumo do texto inicial, irremediablemente destruído” (p. 9). 
El Hipólito de Manuel Lourenzo, como sospechábamos, no es en modo alguno una traducción de la tragedia homónima de Eurípides. Por supuesto, el trágico griego es su fuente argumental y textual esencial, pudiendo asegurarse que el dramaturgo gallego no ha tenido presentes para esta reescritura otras versiones que sin duda conocía, por lo menos la Fedra de Séneca y la de Racine. Pero el tratamiento textual, el desarrollo de la intriga, el planteamiento escénico, la estructura dramática, son del todo distintos, dando lugar a una obra profundamente original.

Por lo que respeta a los personajes y al tratamiento del argumento, Lourenzo presenta cuatro personajes: dos hombres. Anselmo-Teseo e Hipólito, y dos mujeres, Fedra y María-Iaia; tenemos, pues, los cuatro personajes principales de Eurípides, caracterizados como gallegos de nuestros días, sobre todo por lo que se refiere a la persona de Anselmo-Teseo, un rico dueño de una industria maderera, que ha mandado a su hijo Hipólito a estudiar a la Universidad, sin éxito, pues ha abandonado los estudios y regresa al hogar. El desarrollo argumental se simplifica mucho; no hay para nada el viaje de Teseo; al contrario, es Hipólito el que vuelve a casa, olvidando la Universidad. Sin texto hablado, sabemos de una relación de Hipólito y Fedra en un baile, y después, por su vagar, feliz y amoroso, por los campos. Fedra, que nunca habla con Hipólito, se quita la vida. La maldición de Teseo. Asistimos a las últimas palabras de Hipólito, moribundo, en escena.

Además de esta forma particular de organizar el argumento, resulta especialmente llamativa la organización del escenario en tres estrados, que funcionan con independencia o en combinación, según que estén iluminados o a oscuras. Cada uno de los cuatro personajes actuan a título propio, o bien en conjunto de tres, formando un coro.

Tenemos, en breve resumen, una simplificación del desarrollo dramático de la tragedia de Eurípides, presentada en verso y en prosa, en un tiempo indeterminado, en ambiente gallego, sin que este aspecto adquiera relieve de ningún tipo. Es sin duda la reescritura del tema de Fedra e Hipólito más próxima a la versión clásica, en concreto a la euripidea, de las cuatro que escribirá Manuel Lourenzo.

\section{La farsa Romería ás covas do demo y el libreto para ópera Fedra.}

En 1975, se publicó en Santiago la farsa titulada Romería ás covas do demo (Romería a las cuevas del demonio $)^{17}$, pero con tan poco cuidado, con

${ }^{17}$ M. Lourenzo, Romería ás covas do demo, Santiago de Compostela, Teatro Galego Pico Sacro, 1975; la edición contiene muchos defectos de impresión, faltas, incluso supresiones de texto... M. Lourenzo tiene la intención de realizar una edición nueva, con las debidas revisiones. La mejor aproximación que encontramos a esta obra es la de J.A. Fernández Delgado, "La tradición griega 
tantas erratas y omisiones, que Manuel Lourenzo confiesa que fue tan grande el disgusto cuando vio el librito editado, que nunca más quiso abrirlo. No obstante, sobre él podemos realizar nuestro estudio de tan curiosa obra. Y al hacerlo, conviene comenzar por una precisión cronológica: a pesar del año de su publicación, Romería ás covas do demo se estrenó años antes que Ipólito, en concreto el día 11 de octubre de 1969, en el Colegio de los Padres Dominicos de A Coruña. La puso en escena Teatro Circo, bajo la dirección de Manuel Lourenzo, que además desempeñaba el papel de Rañolas.

En consecuencia, la redacción de Romería es anterior a Ipólito, y ambas surgen en un tiempo en que Lourenzo conoce y estudia a fondo el Hipólito de Eurípides, a través de traducciones y del original, y trabaja sobre la tragedia griega para integrarla en su proyecto de creación de un teatro gallego nuevo. Lo mucho que debe Romería al original de Eurípides ha sido estudiado con detalle y acierto por José Antonio Fernández Delgado ${ }^{18}$; pero conviene tener presente que, según información que nos proporciona el propio Lourenzo, la farsa fue redactada en muy poco tiempo, en casa de un amigo suyo, sin tener a mano ningún texto, original o traducción, de la tragedia de Eurípides.

En cuanto a la concepción dramática de la pieza, Romería se genera y construye como una farsa, en tres lances, en la que se ponen en juego todos los recursos y elementos de la farsa gallega tradicional. Esto implica sobre todo que el tema de los amores de Fedra, que en el teatro clásico eran objeto de una tragedia de Eurípides y otra de Séneca, sean tratados de forma cómica, fuertemente paródica, y desde luego con un tenor festivo que destierra de su tratamiento toda trascendencia. En este sentido, las exigencias de la conversión en farsa festiva se anteponen a la fidelidad a las líneas argumentales del original: es de sobra sabido, por ejemplo, que ni en Eurípides ni en Séneca, ni en mayoría de las reescrituras posteriores, Fedra consigue vencer la negativa de su hijastro a ceder a sus amores; sin embargo, en Romería, un Hipólito que hace alarde de ser tan puro y tan casto como sus precedentes, y que para colmo se ha ofrecido a su padre Teseo para cuidar de su casa y de su esposa durante el viaje que éste va a emprender (pp. 23-24), sin embargo acaba manteniendo una relación amorosa total y apasionada con Fedra, como resultado de los efectos de un bebedizo que le proporciona el Demonio (pp. 45-46). El resultado de la puesta en práctica y del éxito del bebedizo arrastra consigo un desenlace también muy original de la farsa de Lourenzo: en el tercer lance, regresa Teseo de su viaje, se entera de la traición de su esposa y de su hijo, y armado con una carabina los sorprende, dando muerte sucesivamente a Hipólito, a Fedra, a

en el teatro gallego", cit., pp. 74-83, con una exégesis muy útil y bien planteada de la relación de la farsa de Lourenzo con el Hipólito de Eurípides.

${ }^{18}$ Art. cit., pp. 61-66. 
la nodriza Iaia y al bufón Rañolas; luego, ya dispuesto a suicidarse, decide de pronto que es mejor disparar contra el mismo Demonio; y para que la farsa tenga el desenlace más adecuado, al final resucitan todos, y bajo la dirección del Demonio celebran con cantos y danzas su entrada en las cuevas del infierno. Nada que ver, en consecuencia, con las tradicionales falsa acusación de Fedra contra Hipólito, maldición de éste por parte de Teseo, desgraciado final del joven, suicidio de Fedra, etc.

Por lo que se refiere a los personajes (Demo, Dama, Fedra, Ipólito, Iaia, Rañolas, Teseo, Coro), todos, con la sola excepción de Rañolas, corresponden con bastante cercanía a los de Eurípides (Afrodita, Hipólito, Criado, Coro, Nodriza, Fedra, Teseo, Mensajero, Ártemis). Las transformaciones que sufren para su galleguización total en Romería son profundas ${ }^{19}$. Y con el fin de llevar a cabo una perfecta construcción dramática de farsa, Lourenzo crea un personaje que no está en Eurípides: se trata de Rañolas, simpática mezcla de bardo popular y de bufón de farsa. Por medio de su presencia se produce una irrupción pujante, y una presencia constante, del mundo folclórico gallego en Romeria. La burla, la parodia, la chirigota sobre temas serios, el chascarrillo escatológico..., ingredientes de la farsa tradicional, se unen a un saber filosófico innato en este personaje, que representa las esencias de un tipo gallego bien diseñado. $Y$ ese tipo, gallego incluso en su nombre, Rañolas, basado en un personaje real, nos conduce al Valadouro natal de Manuel Lourenzo, al presentarse en el primer lance de este modo: “¡Para servir, Xan Rañolas, probe do Valadouro, e poeta gratis" (p. 14).

\section{Fedra, libreto para ópera (1982).}

Ya hemos indicado que este libreto, editado en 1982 en los Cuadernos da Escola Dramática Galega ${ }^{20}$, está inconcluso, en el sentido de que ofrece los textos básicos sobre los que deberá montarse la ópera y componerse la música, pero al no haberse realizado esta segunda parte, el texto inicial quedó sin la revisión y adaptaciones que sin duda hubiera debido experimentar. $\mathrm{O}$ dicho de otro modo: nos encontramos ante un libreto para construir una ópera que nunca se compuso musical y dramáticamente.

Manuel Lourenzo realizó esta versión poética, muy simplificada, a partir de la Fedra de Séneca, a instancias del prestigioso compositor gallego Manuel

${ }^{19}$ Cf. A. Pociña - A. López, "El tema de Fedra en el teatro gallego de Manuel Lourenzo", cit., p. 535 .

${ }^{20}$ M. Lourenzo, Fedra, A Coruña, Cuadernos da Escola dramática galega, no 28, 1982. El único estudio interesante que conocemos sobre esta obra es el de Ma. J. Ragué-Arias, Los personajes y temas de la tragedia griega en el teatro gallego contemporáneo, cit., pp. 88-91, escueto, pero con apreciaciones notables. 
Balboa $^{21}$, sin embargo, circunstancias ajenas a la voluntad de Lourenzo y de Balboa impidieron que se llevase a término su interesante proyecto de una ópera gallega titulada Fedra21, basada esencialmente en la tragedia de Séneca, lo que significa que la desdichada madrastra enamorada ocupaba el papel central y de auténtica protagonista del drama.

Fedra se articula en dos partes, separadas por la llegada de Teseo. La trama se desarrolla en líneas generales sin notables diferencias con la tragedia de Séneca, pero con una marcadísima tendencia a la simplificación, que descarta todo tipo de excursos, de intrincadas disquisiciones mitológicas, de prolongados desarrollos poéticos, que definen en todo su desarrollo la obra del poeta cordobés. Nada puede mostrar de forma más palmaria tal diferencia que la consideración de que a los 1280 versos de la Fedra latina, responde esta $\mathrm{Fedra}$ gallega con un texto bastante breve, de sólo trece páginas; por otra parte, los largos monólogos, las extensas monodias que siembran todo el texto latino: monodia de Hipólito con 84 versos (vv. 1-84), monodia del Coro con 75 versos (vv. 274-359), monodia del Coro con 98 versos (vv. 736-834), monólogo de Teseo con 55 versos (vv. 953-958), relato del Mensajero con 114 vv. (vv. 1000-1114), sólo por recordar las tiradas más prolongadas, no se encuentran en la adaptación realizada por Lourenzo; en ésta sólo encontramos algo semejante en una monodia del Coro, de 45 versos, por lo demás muy breves (hexasílabos), no alcanzando los parlamentos de los personajes más allá de una decena de versos, y esto en raras ocasiones.

Los personajes son los mismos que en Séneca, con la sola excepción de la inexistencia del Mensajero. Una lectura detallada de sus comportamientos y de sus palabras pone de relieve indudables diferencias: así, resulta curiosa la insistencia en la caracterización de Fedra como "eternamente forasteira" (p. 3), como víctima de la "emigración" (p. 3), del abandono de su marido, pero que saca una fuerza tremenda de su amor por Hipólito. Éste, por su parte, ofrece una imagen mucho más atractiva que el joven ególatra y siempre pensando en sí que presenta Séneca, o más aun Eurípides; diríamos que es un muchacho rebelde, que ama la libertad por encima de todo, y la busca y encuentra viviendo al margen de las convenciones sociales y de los enfrentamientos humanos.

${ }^{21}$ Manuel Balboa (1958-2003) es bien conocido no sólo por creaciones como la ópera Romeo o la memoria del viento (1988, sobre textos de Álvaro Cunqueiro), Invención del día (1990, concierto para piano y orquesta de cuerda), El secreto enamorado (1993, ópera con texto de Ana Rossetti), etc., sino además por sus partituras para representaciones teatrales, en Galicia y en el resto de España, y bandas sonoras de películas, como Canción de cuna (1994) y El abuelo (1998), ambas dirigidas por José Luis Garci. En muy diversas ocasiones colaboró musicalmente con montajes realizados por Manuel Lourenzo en el Centro Dramático Gallego y en la Compañía Seoane. Más información en "Balboa Rodríguez, Manuel”, Enciclopedia Galega Unviersal, Vigo, Ir Indo Edicións, 1999, vol. 2, p. 518. 
Sin embargo, además de evitarse todo el preciosismo del relato del original latino, el sentimiento del Ipólito gallego, en su sencillez, casi en su ingenuidad, suena de un modo distinto, tal vez más sincero, y desde luego más próximo a nosotros: él mismo lo resume en dos versos, replicando a la Aya, que no considera que su comportamiento sea el natural en un hombre joven:

IPÓLITO. Que é natural, casar, criar galiñas?

Manter unha querida, dar-se ao vicio?

A pesar de las profundas transformaciones experimentadas en la adaptación de la Fedra de Séneca llevada a cabo por Lourenzo, en las que conviene no olvidar incluso referencias puntuales al mundo gallego, que no alteran la ubicación de la ópera en el mismo ambiente que la tragedia del cordobés, es de destacar el esmero con el que el dramaturgo de Valadouro conserva recursos puestos en juego por Séneca en su tragedia que resultan muy significativos. Así, en el comienzo de la declaración de amor que hace directamente Fedra a Hipólito, elemento muy significativo en la tragedia de Séneca ${ }^{22}$, el rechazo de Fedra a ser llamada madre por Hipólito sigue teniendo la misma fuerza en la adaptación de Lourenzo, a pesar de no tener un desarrollo tan amplio como en el original latino (compárese Sén., Phaedr., 608-611, y Lourenzo, Fedra, p. 8).

De modo semejante, algunos versos después, cuando Fedra confiesa a Hipólito que es su parecido con su padre Teseo, cuando era un muchacho como él, el motivo que ha encendido su amor apasionado, comprobamos que Lourenzo conserva lo esencial de las palabras de la infortunada enamorada, dejando al margen alusiones a pormenores de la leyenda que un público de nuestros días con toda probabilidad no va a entender (compárese Sén., Phaedr., 646-658, y Lourenzo, Fedra, p. 9).

\section{Despois do temporal (2007).}

Pero todavía hay más: que la pasión de Lourenzo por el tema de Fedra e Hipólito sigue siempre viva en nuestro dramaturgo lo demuestra la corta pieza dramática Despois do temporal, compuesta en 2007, y publicada con otras cinco obras suyas en el ya citado libro Medea dos fuxidos e outras pezas (pp. 79-128).

Despois do temporal, a la que Lourenzo hace una breve referencia en la presentación del libro notando que la desvistió "de toda cortesía cando advertín

${ }^{22}$ A pesar de ello, esta Fedra, que fue editada como libretto de ópera, fue puesta en escena, como tragedia, por el grupo Vichelocrego Teatro, de Gondomar (Vigo), dirigido por Margarita Cachaza; dicho estreno tuvo lugar el 12 de mayo de 2000, en el IES Auga da Laxe, de Gondomar. 
que Tania (Fedra) non era tal Fedra para Hipólito (Helio), senón que todo ía do revés, por vontade exclusiva deles dous...”23, conserva del tema dramático greco-latino la base argumental, y poco más. De entrada, Lourenzo la clasifica como un "Comedia en tres actos", cosa que si bien justifica su desarrollo, que no es sino una historia sin alcances trágicos, por su final hubiera podido aproximarse más bien a un asunto de tragedia. Los personajes se apartan muchísimo de los de Eurípides o Séneca: son cuatro, correspondiendo claramente Helio a Hipólito, y Tania a Fedra; pero a ellos se suman Paula, una hermana de Helio, y su novio, después marido, Bruno. Tania es madrastra de Hipólito, y con él mantiene una difícil relación amorosa, que ya existía antes de la reciente muerte de Damián, pocos días antes de comenzar el drama. $\mathrm{Y}$ es en esa circunstancia donde se complica el drama familiar, debido a la herencia de los bienes de Damián, entre su viuda, su hijo y su hija, agravado por la relación moral y socialmente irregular de la madrastra y el hijastro. $\mathrm{E} 1$ asunto se desenvuelve en nuestros días, en un escenario rural totalmente gallego, que coincide con la zona natal del dramaturgo y que es evocado, sin duda intencionadamente, por los topónimos de la alejada A Coruña, pero sobre todo de Burela, Mondoñedo, Foz, Frexulfe, Viveiro. Escenas de Helio y Bruno primero a caballo por los montes, después en un Land-Rover, producen una interesante nota de modernidad teatral y de actualidad cronológica, completada por elementos como el inevitable teléfono móvil... Del tema tradicional permanece sólo rl núcleo del amor de Helio y Tania, ahora un amor correspondido, en parte resuelto por la muerte de Damián (Teseo), pero siempre ilícito, socialmente inadmisible.

Las cuatro reescrituras dramáticas a que da lugar la sorprendente pasión del dramaturgo gallego Manuel Lourenzo por el tema de Fedra e Hipólito ofrecen, además del lógico interés por sí mismas, un curioso y llamativo ejemplo de cuatro posibilidades distintas de reescritura de un tema clásico.

En Ipólito (1973), Hipólito desde la edición de 2010, Lourenzo reescribe una tragedia basada en la de Eurípides, con profundísimos cambios que la convierten, como toda buena reescritura, en un drama suyo, en modo alguno calificable como una traducción del trágico griego.

En el libretto de ópera Fedra (1982), seguimos teniendo una tragedia, ahora en cambio tomando como base el modelo de Séneca. Merece la pena poner de relieve el hecho, no casual, de que Lourenzo mantiene los títulos de los dos grandes dramaturgos, con todo lo que ello significa. En los cambios

\footnotetext{
${ }^{23}$ Medea dos fuxidos e outras pezas, cit., p. 9.
} 
profundos de estructura, sobre todo en su acortamiento, subyace la necesidad de adaptación a un género dramático (musical) distinto.

En la farsa Romería ás covas do demo (1969, ed. 1975) el tema trágico básico se subvierte completamente, y se convierte en una farsa cómica. Es la más profunda, la más completa, la más absoluta reescritura del asunto de Fedra e Hipólito, que da origen a una magistral farsa gallega, por la que sin embargo vaga imperecedero el problema de un amor imposible, que sólo una farsa puede solucionar.

En Despois do temporal (2007), en fin, sólo quedan el Hipólito de Eurípides y la Fedra de Séneca como referentes insoslayables de la base argumental. Un tema eterno, del que Aurora López y yo llevamos registradas ciento ochenta ${ }^{24}$ reescrituras hasta nuestros días, y que sigue incansablemente preocupando a Manuel Lourenzo, dramaturgo gallego.

${ }^{24}$ En el capítulo "Reescrituras del tema de Fedra e Hipólito", en nuestro libro en preparación Otras Fedras; en ese número incluimos reescrituras teatrales, poéticas, narrativas y cinematográficas, dejando al margen tan sólo versiones musicales; como punto de partida para nuestra enumeración de reescrituras tomamos las piezas dramáticas Hipólito (velado) de Eurípide, (no conservado, 432?), Fedra de Sófocles (no conservada, ?), Hipólito(portador de la corona) de Eurípides (428 a. C.), Fedra de Séneca (s. I). 


\title{
$A R S$ RETórica / $A R S$ TEATRAL Y EL DECORUM COMO FACTOR DE ESCRITURA: UNA TRADUCCIÓN ARGENTINA DE MILES GLORIOSUS PARA LA ESCENA ${ }^{I}$
}

Aldo Rubén Pricco Universidad Nacional de Rosario

\begin{abstract}
La ars retórica y la teatral dotan al programa del teatro de Plauto de una plataforma retórica/metateatral/ficcional que construye su auditorio en la medida que, por decorum, releva del colectivo romano doxas y representaciones de los imaginarios, instituye verosímiles e instaura, a la vez, procedimientos de seducción espectacular para su consumo. Este trabajo propone, desde ese presupuesto, una muestra de criterios de traducción-adecuación retórica del discurso plautino y orientaciones de reposición en términos actuales de nomina, dicta y referencias contextuales que operen en el convivium de un modo humorístico supuestamente similar al de la "relación teatral" de la república romana.
\end{abstract}

El complejo fenómeno de la traducción de textos teatrales puede ser asistido por la teoría retórica en tanto se considere la escritura dramatúrgica una práctica enunciativa destinada a transformar al destinatario. En ese sentido, en la tradición retórica latina posterior a la producción plautina (Cicerón, Quintiliano) se observa la insistencia en el hecho de la inexistencia de un auditorio universal, lo que implica para el orador -homologamos ese artífice al dramaturgo y/o al dominus gregis- dar cuenta de un saber concreto, el que proviene del conocimiento de las doxas circulantes, los intereses de clase, los contextos, las procedencias, las idiosincrasias, los gustos y hábitos de una audiencia particular. Sostenemos que en la palliata plautina, a partir de la ars retórica en conjunción con la teatral, emerge la necesidad de fijar el territorio de lo proyectable, los límites y formas de lo legible y aceptable para una audiencia-videncia. Se trataría de una construcción retórica que recoge del colectivo romano intereses, necesidades, e instituye verosímiles, habitualidades y tendencias estéticas.

Si se adscribe a la concepción de teatralidad de triple acontecimiento (convivial, poético y de expectación) según Dubatti (2003), podemos postular

\footnotetext{
${ }^{1}$ Se hace referencia a la traducción de Aldo Pricco (1998) que obtuviera el Premio Teatro del Mundo a la traducción 2006 otorgado por el Área de Historia y Teoría Teatral del Centro Cultural Ricardo Rojas de la Universidad de Buenos Aires y que fuera estrenada por el "Teatro de la Universidad", elenco oficial de la UNR, en la ciudad de Rosario, en ocasión del "XIX Simposio Nacional de Estudios Clásicos" organizado por las Universidades Nacionales de La Plata y Rosario, Argentina (2006) y mantenida en cartel en varias ciudades de Argentina hasta 2010.
} 
la índole de "programa" del teatro de Plauto, consistente en una plataforma retórica/metateatral/ficcional que alimenta la hipótesis de una dramaturgia que construye su auditorio en la medida que, por decorum ${ }^{2}$, releva doxas y representaciones de los imaginarios, e instaura, a la vez, procedimientos de seducción espectacular para su consumo. Esto nos conduce a una traducción del corpus de Plauto que hipotetiza sobre intereses contemporáneos a partir de los cuales se estaría en condiciones de reponer en términos actuales nomina, dicta y referencias contextuales en virtud de las cuales se operaría en el convivium de un modo supuestamente similar al de la "relación teatral" de la república romana.

Desde la perspectiva lingüística se ha asistido comúnmente a la presencia de una doxa del lenguaje "clásico", consistente -en sus versiones más difundidas- en construcciones ricas en léxico, provistas de procedimientos tales como el hipérbaton y un trato coloquial entre los personajes que inscribían el intercambio parlamentario en complicaciones de lo literario por sobre lo pragmático de la escena. En tal sentido la traducción de lo clásico, por pretendidas e discrecionales "purezas", no resultaron habilitadas para el voseo argentino o la recurrencia a léxico, sintaxis y morfología rioplatenses capaces de permitir desde lo fónico un margen lúdico considerable más allá de lo estrictamente semántico. El paradigma español peninsular, en cambio, parecía proveer de matrices institucionalizadas para una adecuación correcta a los fines "clásicos".

La búsqueda de una especificidad lingüística puede facilitar el consumo del componente fónico si la cultura teatral de destino es la argentina, lo que orienta hacia tácticas de verosimilización que incluyan el oído medio del espectador de nuestro país como variable de diseño de una traducción. De allí la inclusión en nuestra traducción de diversas formas del voseo, incluso con su variante regional litoral que registra caídas de sibilantes y vibrantes finales, como así también modelos de ideologemas frecuentes en el discurso de los medios.

Una nota pertinente de la adecuación a cierta coyuntura histórica que permite un símil del militar presuntuoso resulta la puesta en boca del personaje miles de las frases "Un soldado no duda, acciona. La duda es la jactancia de los intelectuales”. Esta alocución, textual, pertenece al entonces teniente Aldo Rico, militar "carapintada" alzado en armas contra la democracia argentina

\footnotetext{
${ }^{2}$ Aunque en sentido general decorum refiera a la "conveniencia", "decoro", "armonía”, en términos de retórica se ajusta a la adecuación entre el dictum y lo que se supone pretende oír (o reaccionar) un interlocutor. Esta conveniencia se desprende del sentido común y de las convenciones de adecuación. No tiene un sentido natural estricto sino eminentemente cultural y fijado, por ende, por las tradiciones. Pueden sumarse mecanismos fisiológicos de la percepción. Cf. Quint., Inst. Orat., X, 1, 17; XI, 1, 4; XI, 3, 150-154, 177.
} 
por segunda vez en enero de 1988 en Monte Caseros, provincia de Corrientes. Tristemente célebre, el movimiento fue uno de los últimos intentos de golpe de estado sufridos por la institucionalidad en la República Argentina y, a la distancia, el episodio discursivo del jefe castrense rendido se aviene a revestir los atributos del fanfarrón plautino.

Tener especialmente en cuenta la etimología de los nombres de los personajes ha resultado otra herramienta que, en virtud de la ratio pocas veces atendida, además de recuperar la vinculación entre máscara y espectadores, opera como un pulso de recuerdo de las condiciones cómicas del personaje. Así, el criterio ha oscilado entre la traducción que reelabora semas y otra que se monta sobre semejanzas de sonoridad. A modo de síntesis entre las dos alternativas el nomen del soldado de Miles gloriosus, Pyrgopolynices, ha sido repuesto como "Virgopolinízame", en abierto juego irónico sexual. El parásito, en cambio, remite a su pasión ingestiva con el simple "Hartotragón" que parte de Artotrogus. En este panorama de nomina, el del servus Sceledrus se aviene a una adecuación a la conducta un tanto pusilánime la asignación de "Estelerdo", que recuerda en cada apelación su condición y sirve para que los actores pronuncien el nombre a manera de burla, como una acción que degrada el rol y lo ubica en la inferioridad necesaria para la distancia cómica.

El caso de las prostitutas comporta, asimismo, un juego semántico: Acroteleutium, está "en la punta" y es, por eso, en nuestra versión, "La Top", en un guiño abiertamente popular de reconocimiento jerárquico de su profesión, mientras que su acompañante y gran hacedora de la fabula, Milphidippa, obtiene, literalmente y por metonimia, el nombre de "Parpadocaído", un signo de lo avanzado de una enfermedad venérea. El semisenex Periplectomenus recibe el nombre de "Enredado", tanto por su implicación en el engaño como por su abierta colaboración con el adulescens Pleusicles, quien de "ilustre navegante" pasa a nuestra traslación como "Ágilmarino", un apelativo que en la dinámica actoral sirve para desplegar juegos de palabras y, a la vez, habilitar ciertas burlas con el adjetivo "gil", que remite a "tonto", una condición asociada al enamoramiento del joven y ciertas torpezas de su accionar. Al mismo tiempo hemos seleccionado "Malabar" para Palaestrio por considerar que la habilidad -característica de un malabarista- para resolver cada imprevisto es clave en su comportamiento, a la vez que el ambiguo "Fiestera" para un hablante argentino -con notas inequívocas de prácticas sexuales promiscuas y colectivas- recoge para nosotros, con cierta hipérbole, el "amor por los banquetes" de Philocomasium, la amante del joven y concubina del miles.

Como se puede apreciar, una adecuación a verosímiles que no dependan de una tradición de lectura sino de una inmediata correspondencia entre apelación, sonoridad y conducta pueden hacerse cargo por decorum de un pasaje a la lengua de destino. Incluso esos nomina, en la puesta en escena, no 
sólo remiten a una persona sino que, una vez mencionados, activan efectos en nombradores y nombrados.

Ciertas referencias de batallas inexistentes que el parasitus lleva a cabo en su ardua labor de obsecuencia por lograr un bocado han sido modificadas en virtud de fraseos conocidos por el espectador. Tal es el caso de los versos 13-15 referidos a los "campos Curculionenses", (Quemne ego servavi in campis Curculioniis, / ubi Bumbomachides Clutomistaridysarchides / erat imperator summus, Neptun nepos?), que preferimos traducir y procesar como " ¿Cuando el Supremo tenía el mando en la batalla de Rajandoquevienepapá?”, dado que se conserva la composición una palabra extensa que, por otra parte, sintetiza la jactancia del militar mediante una locución popular argentina.

En el mismo plano léxico, cada vez que algún personaje se refiere a la pretendida belleza del soldado fanfarrón en vez de hacerlo con "hermoso" utiliza "harmoso", con la vocal "a", al modo de un reconocido personaje popular de televisión, "La Chona”, de las décadas del'60 y'70 interpretado por Haydée Padilla que quedó convertido en un decir extendido. La invitación del esclavo "Malabar" a "Estelerdo" del verso 335 (vin iam faciam, ut stultividum) “QQuerés que te obligue a admitir que sufrís de alucinaciones?” repone el adjetivo stultividum como "boludivisual" y se pretende hacer rendir así un adjetivo (y vocativo de variada índole) de amplio espectro en el uso coloquial argentino. Esta misma máscara, antes de ser expuesta a la farsa de la aparición de "Fiestera" por una de las casas, expone su misión de cuidar la castidad de la muchacha con cadencia de rap, para lo cual el texto se adapta rítmicamente (vs 344-353). Cuando la "gemela" hace su aparición, el perplejo servus intenta retenerla y reconducirla a la casa de su amo el militar (vs.449-452) enunciando un dictum reconocible de Juan Carlos Altavista, otro cómico popular argentino: "Fiestera: ¿Me soltás o no me soltás? Estelerdo: Efectivamente, todo lo contrario".

La hipótesis de estos usos alternativos, que desde un punto de vista filológico parecen no cubrir las correspondencias biunívocas requeridas por algunas posturas sobre la operación de traducción, consiste en que el reservorio léxico, musical, histórico, etc., oficia de resonancia en la memoria del colectivo público capaz de activar el mecanismo cómico por contigüidad o parodia. Se trata de la utilización de parte de una tradición por otra: si la palliata, en su compleja constitución, subsume modalidades más propias de la oralidad que de la escritura a los efectos de una verosimilitud lindante con el simulacro de la improvisación, el componente intertextual -presente en la memoria y los imaginarios- se presta a la complicidad entre los loci del texto de origen y la versión de destino. Los puentes entre ambas culturas resultan dicta sometidos a consumos y dispositivos semejantes. Nos referimos aquí a la tensión entre 
escritura e improvisación del juego teatral ${ }^{3}$ que intenta dotar de "espontaneidad" los parlamentos e interacciones dado que tanto la selección léxica como los préstamos de un decir contemporáneo se originan en ese intento de adaptar la dramaturgia a las condiciones de enunciación, y, particularmente, a los destinatarios.

Como es claro, la traducción de Miles gloriosus que motiva estas consideraciones, no obedece a un orden estrictamente literario sino escénico. Ha sido, justamente, la performance teatral la que ha facultado la textualidad para constatar su funcionamiento en la relación scaena/cavea actual. Esa confrontación ha puesto de manifiesto la complementación entre parlamentos y rutinas actorales vinculadas a dinámicas de clown y estética de cine mudo de principios del siglo XX, conforme a una tradición europea de varieté $\mathrm{y}$ especies dramáticas circenses y populares. Es en esa coreografía teatral en la que el texto plautino, liberado de la carga de doxas clásicas, ha planteado un diálogo efectivo con el espectador. Pueden mencionarse apelaciones a aplausos, pedidos de intervenciones directas al público, solicitudes de cantos corales entre espectadores e intérpretes, rupturas de la fictio plautina ${ }^{4}$ de plena técnica brechtiana, recurrencia a ritmos inscriptos en música de circulación marginal ${ }^{5}$ y soportes gestuales de actores y actrices cómicas argentinas de extenso repertorio que han pasado a formar parte del canon humorístico rioplatense del siglo XX: Los Cinco Grandes del Buen Humor (Jorge Luz, Rafael "Pato" Carret, Zelmar Gueñol, El Flaco García Cambón, Guillermo Rico), Niní Marshall, Pepe Iglesias (El Zorro), Dringue Farías, Nelly Láinez, Pepe Biondi, José Pepitito Marrone, Alberto Olmedo, Juan Carlos "Minguito" Altavista, Carlitos Balá, Tato Bores, Jorge Guinzburg y tantos otros que instauraron en la ficción hilarante modalidades discursivas y protocolos lúdicos quinésicos y gestuales que se extendieron rápida y festivamente a los intercambios sociales cotidianos urbanos.

Es, justamente, esa base de relevamiento de decires relativos a hábitos de humor la que a modo de hipótesis influyó en estrategias de compositio y elocutio dramatúrgica en la traducción de Miles gloriosus. Si uno de los componentes técnicos fundamentales de la escritura plautina resulta el montaje de las atracciones -en términos de Eisenstein ${ }^{6}$ el texto dramático argentino deviene

\footnotetext{
${ }^{3}$ Cf. Slater (1987: 143-146).

${ }^{4}$ Como homenaje, incluso, a rutinas teatrales de los Hermanos Marx y las televisivas de The Three Stooges.

${ }^{5} \mathrm{El}$ caso de la cumbia villera, popular en sectores carenciados de la sociedad argentina y luego extendida a otros grupos sociales, sobre todo de amplia presencia en los medios, es utilizado como formato musical del texto de Plauto para profundizar las marcas del estereotipo y establecer de esa manera el extremo artificio del recurso.

${ }^{6}$ La problemática de la acción eficaz en el teatro, entendida ésta como una manipulación perceptiva, sinestésica, cinestésica y cenestésica del espectador, ha sido probablemente el motor que
} 
objeto para la fijación de prescripciones que tienden a manipular el tiempo futuro del convivium conforme al estímulo constante de la percepción del espectador. Por ello, es frecuente en la comedia de Plauto en general y en El Soldado fanfarrón en particular la táctica constante de la apelación -o sus amagos- a la intervención del público, un dispositivo que sigue la línea de la mayoría de los cómicos mencionados. Nos referimos a que los enunciados plautinos se reservan una gran cuota de manipulación del orden perceptual basándose en la "inclusión" del público en los imponderables de la tradición de la que forma parte. Se trataría de un acontecimiento de efectos de participación cuyo mecanismo reside en la incorporación del espectador en los enunciados, tanto explícitamente en el uso pronominal de un simulacro de interacción dialógica como en la "actuación en citas"7 que se desprende del corpus parlamentario de la obra plautina.

desde la práctica concreta ha concretado los carriles estructurales de muchísimas dramaturgias. Sin embargo, el formato de una especulación teórica específica acerca de la cuestión, ya instalada en el ámbito de las artes audiovisuales y no sólo en la retórica, aparece con fuerza e identidad durante el siglo pasado en las reflexiones de Eisenstein. Es a partir de la puesta en escena de espectáculos teatrales (que luego serán traspoladas al cine) que el director ruso desarrolla una serie de teorizaciones que convergen en un cuerpo conformado por escritos sobre las obras "El mexicano" (1921) y "El ensayo" (1923). Los dos textos fundamentales (1923) se vinculan mayormente con "El ensayo" y revisten el carácter de, prácticamente, un manifiesto programático denominado El montaje de las atracciones. Se trata de una escritura que, encabalgada entre la práctica concreta y la reflexión, indaga acerca de las atracciones y los movimientos expresivos, un territorio aparentemente reservado a la disciplina retórica y, sobre todo, a la instancia actio. Se trata de llevar a un primer plano de las preocupaciones del discurso escénico el diseño de la reacción psicofísica del espectador. El sostenimiento de la teatralidad halla así la inevitabilidad de habilitar una maquinaria de manipulación: el espectador es puesto en la condición de material fundamental del teatro; modelar al espectador según una tendencia (disposición de ánimo) deseada es la tarea de cualquier teatro utilitario (propaganda, publicidad, instrucción sanitaria). Este proceso de modelado, que supone desde el conocimiento retórico un saber del destinatario y su contexto, se apoya en elementos verbales y no verbales del espectáculo a los que Eisenstein denomina "atracciones": la atracción (desde el punto de vista del teatro) es cualquier momento agresivo del teatro, es decir, cualquiera de sus elementos que ejerza sobre el espectador un efecto sensorial o psicológico, verificado experimentalmente y calculado matemáticamente, de modo tal de producir determinados estremecimientos emotivos, los cuales, a su vez, todos juntos, determinan en quien percibe la condición para receptar el lado ideal y la conclusión ideológica a la que tiende el espectáculo. La atracción es un elemento autónomo y primario de la construcción del espectáculo: la unidad molecular, es decir, constitutiva de la eficiencia del teatro y del teatro en general. Este punto de vista, que entiende el espectador como ámbito y objeto de trabajo dramatúrgico, como entidad psicofísica sobre la cual orientar desde la textualidad y su actualización en el espacio-tiempo estímulos concretos para provocar reacciones y organizar -mínimamente- sensaciones, se enlaza, a su vez, con el correlato escénico: el actor. Cf. Eisenstein (1986)

7 De Toro, al caracterizar una hipótesis de actuación distanciada, inherente al posible modelo brechtiano, menciona esta noción que nos parece adecuada a la tipología de la masa parlamentaria plautina, dominada por la melodía, el ritmo y la música. Una "actuación en citas" requeriría del sujeto parlante una distancia respecto de su decir, una apropiación en segundo término que expone la exterioridad de la autoría de su discurso. El acontecimiento recupera de esa manera su status de "mostración" y el texto verbal se aproxima a la "demostración" (1987: 30). 
En efecto, siguiendo estos criterios, el receptor de la obra no parte de cero sino que es consciente de que está en una situación que lo envuelve en el seno de la tradición. La aceptación de tal situación no es un defecto de su capacidad de reflexión, sino la realidad histórica misma que lo define. A esa situación le corresponde evidentemente un cierto horizonte que puede estrecharse o ampliarse, pero que, sobre todo, le permite situar las cosas en su ámbito. El estado de recepción, tanto el percibido por el autor de las comedias a través de su inserción social, como el imaginado, proyectado y diseñado en la escritura, incide de manera relevante en la decisión de contenidos y formatos que, de ese modo se alejan de perspectivas de análisis sólo literarios. En ese sentido, el objeto de estudio no se clausura en el texto dramático, dado que se constituye progresivamente desde su carácter de incompletitud en la actividad del espectador, quien completa y actualiza las potencialidades significativas y comunicativas de la obra. Los enunciados plautinos no son una entidad acabada y cerrada en sí misma sino que adquieren sentido como hecho estético y semiótico en referencia a los momentos de producción y recepción. Es allí la "relación teatral" la categoría que nuclea el análisis del fenómeno y consiste, justamente, en una manipulación del espectador de parte del espectáculo: mediante su acción o puesta en acto de determinadas estrategias seductivo-persuasivas, la dinámica escénica trata de inducir en el espectador determinadas transformaciones intelectuales y pasionales (ideas, creencias, valores, emociones, fantasías, etc.).

Esta dimensión manipulatoria del espectáculo (De Marinis, 2005: 117118) se puede articular en los términos de la teoría semiótica de Greimas en tanto la "relación teatral" - decorum mediante- no consiste sólo en un saberhacer (una transferencia de informaciones, significados, conocimientos) sino también y en mayor medida en un hacer-creer y en un hacer-hacer tendientes a inducir en el espectador, respectivamente, un deber/querer-creer y un deber/ querer-hacer (Greimas-Courtés, 1979: 206-208).

Los itinerarios receptivos de la textualidad de Miles gloriosus se afincan en tradiciones, competencias y habitualidades de rigurosa repetición, a través de formatos y tópicos preestablecidos y conocidos de antemano. En ese sentido, la cultura de destino de una traducción ejerce presiones que atraviesan la neutralidad de una versión filológica y sólo anotada para modelar un texto otro (como toda traductio) que en su índole poética interactúa con interlocutores que el artefacto escénico -como la máquina retórica- debe docere, delectare, persuadere a los efectos de que integren el convivium y le otorguen legitimidad y existencia al mismo acontecimiento teatral.

Este trabajo propone, en síntesis, una muestra de criterios de traducciónadecuación retórica del discurso plautino que, sometida a la confrontación escena/público, ha obtenido una respuesta eficaz en términos pragmáticos 
Aldo Rubén Pricco

y ha permitido constatar -atravesando cánones- continuidades de ciertas tradiciones cómicas en el ajuste retórico de formatos y estereotipos. 


\section{BibLiográfia}

Arnheim, R. (2001), Arte y Percepción visual, Madrid, Alianza. (1985), El pensamiento visual, Buenos Aires, Eudeba.

Bajtin, M. (2002), Estética de la creación verbal, Buenos Aires, Siglo Veintiuno Editores.

Barba, E. y Savarese. N. (1990), El arte secreto del actor, México, EscenologíaUNAM.

Barchiesi, M. (1969), "Plauto e il metateatro antico", Il Verri 31, 113-130.

Beacham, R. C. (1991), The Roman Theatre and its Audience, Cambridge, Harvard University Press.

Beare, W. (1972), La escena romana, Buenos Aires, Eudeba. (1928), "Plautus and his public", CR 42, 106-111.

Brecht, B. (1970), Escritos sobre teatro, Buenos Aires, Nueva Visión.

Calvarese, O. (1998), "Postfazione. Il teatro del corpo estatico", en Eisenstein, S. M., Il movimento espressivo. Scritti sul teatro, (249-264) al cuidado de Montani, P., Venezia, Marsilio.

Castoriadis, C. (1993), La institución imaginaria de la Sociedad, Buenos Aires, Tusquets.

Chalmers, W. R. (1965), "Plautus and his Audience", En T. A. Dorey et R. Dudley (eds.), Roman Drama, London, Routledge.

De Marinis, M. (2005), En busca del actor y del espectador. Comprender el teatro II, Buenos Aires, Galerna. (1997), Comprender el teatro. Lineamientos de una nueva teatrología, Buenos Aires, Galerna.

De Toro, F., (1987), Brecht en el teatro hispanoamericano contemporáneo, Buenos Aires, Galerna.

Dubatti, J. (2008), Cartografía Teatral. Introducción al Teatro Comparado, Buenos Aires, Atuel.

(2007), Filosofía del Teatro I. Convivio, experiencia, subjetividad, Buenos Aires, Atuel.

(2003), El convivio teatral. Teoría y práctica del Teatro Comparado, Buenos Aires, Atuel.

(2002), El teatro jeroglifico. Herramientas de poética teatral, Buenos Aires, Atuel. 
Duckworth, G. (1952), The Nature of Roman Comedy. A Study in Popular Entertainment, New Jersey, Princeton.

Ehrenzweig, A. (1976), Psicoanálisis de la percepción artística, Barcelona, G. Gili. Eisenstein, S. (2001), Hacia una teoría del montaje. Vol. 1, Edición a cargo de Michael Glenny y Richard Taylor, Barcelona, Paidós.

(1986), "Il montaggio delle attrazioni", en "Il montaggio", Opere scelte, al cuidado de Montani, P., Venezia, Marsilio.

Féral, J. (2003), Acerca de la teatralidad, Buenos Aires, en Cuadernos de Teatro XXI, FFyL-UBA, Nueva Generación.

Greimas, A. J. (1983), La semiótica del texto, Barcelona, Paidos. (1966), Semántica estructural, Madrid, Gredos.

Greimas, A. J. y Courtés, J. (1991), Semiótica. Diccionario razonado de la teoría del lenguaje, Madrid, Gredos.

López, A. y Pociña, A. (2007), Comedia romana, Madrid, Akal.

Moore, T. (1998), The Theater of Plautus. Playing to the Audience, Austin University of Texas Press.

Pavis, P.(2000), El análisis de los espectáculos. Teatro, mimo, danza, cine, Barcelona, Paidós.

Perelman, C. y Olbrecht-Tyteca, I. (1994), La Nueva Retórica. Tratado de la Argumentación, Madrid, Gredos.

Pociña, A. y Rabaza, B. (eds.), Estudios sobre Plauto, Madrid, Clásicas.

Pricco, A. (2007), “Teatralidad cognitiva y teatralidad psicofísica en el discurso terenciano: la constitución del auditorio", en Pociña, A., Rabaza, B., y Silva, M. F. (eds.), Estudios sobre Terencio, Granada, Universidad de Granada, pp. 357-371.

- (2005). "La dinámica entre escena y espectadores. Un caso de la comedia plautina", en Dubatti, J. (comp), Escritos sobre teatro I. Teatro y cultura viviente: Poéticas, Politica e Historicidad, Buenos Aires, Nueva Generación/CIHTT/Escuela de Espectadores, pp. 31-54..

Schechner, R. (2000), Performance, Teoría y prácticas interculturales, Buenos Aires, Libros del Rojas-UBA.

Selden, S. (1972), La escena en acción, Buenos Aires, Eudeba.

Slater, N. (1987), Plautus in Performance. The Theatre of the Mind, Princeton University Press.

Ubersfeld, A., Pavis P. et altri (1980), La relation téatrale (textes réunis par Regis Durand), Lille, Presses Universitaires. 


\section{HuYENDO DEL INSULARISMO TEATRAL. LA PASIÓN SEGÚN ANTÍGONA PÉREZ}

José Luis Ramos Escobar Universidad de Puerto Rico

No es hasta 1967 cuando las formas clásicas se funden con situaciones del momento histórico en la obra La pasión según Antígona Pérez. El punto de partida de Luis Rafael Sánchez fue la dictadura en República Dominicana de Rafael Leonidas Trujillo y Molina y el asesinato de las hermanas Mirabal. El análisis comparativo nos brinda el asidero para examinar la construcción dramática en la que se entrelazan técnicas brechtianas con el mito griego y situaciones contemporáneas Los elementos intertextuales y extratextuales son factores determinantes para el análisis intratextual de la perviviencia del mito de Antígona en el teatro puertorriqueño.

Como preámbulo a este congreso y a esta ponencia, el Festival de Teatro Clásico de Mérida en España acaba de presentar en julio tres Antígonas, oscilando entre versiones, adaptaciones y recreaciones. Miguel Murillo, Ernesto Caballero y Emilio del Valle son los dramaturgos representados en esta triada que demuestra la pertinencia del estudio de la pervivencia de las formas clásicas en el teatro contemporáneo.

En el caso del teatro puertorriqueño esta tendencia ha sido poco explorada por la crítica contemporánea. Paradójicamente, la incursión en el teatro clásico griego se correlaciona con el desarrollo del teatro moderno en la isla, llamado por algunos como teatro nacional puertorriqueño. Las primeras muestras significativas ocurren en 1938, año clave para el desarrollo del teatro puertorriqueño. En el certamen auspiciado por el Ateneo Puertorriqueño, celebrado en dicho año, obtuvo el primer premio El clamor de los surcos, obra de Manuel Méndez Ballester que utiliza la forma de la tragedia para plasmar el declive y posterior caída de los hacendados del país Dos años después Méndez recurre con mayor acierto a la forma de la tragedia en Tiempo muerto. Una década después, Méndez trató de adaptar la historia de Edipo a situaciones contemporáneas en Hilarión, pero el resultado fue poco auspicioso. René Marqués intentó asimismo verter acuciantes problemas del momento en moldes clásicos en la obra La muerte no entrará en palacio, utilizando incluso a personajes griegos como Tiresias como parte de la trama. Sin embargo, no será hasta 1967 cuando las formas clásicas se fundan con situaciones del momento histórico de manera más creativa y con mayor profundidad en la acción dramática en la obra La pasión según Antígona Pérez. Utilizando la historia de la hija de Edipo según plasmada por Sófocles, Luis Rafael Sánchez 
traspone los personajes principales al ámbito de los dictadores y la lucha por la emancipación en América Latina. El punto de partida de Luis Rafael Sánchez fue la dictadura en República Dominicana de Rafael Leonidas Trujillo y el asesinato de las hermanas Patria, Minerva y María Teresa Mirabal y de sus compañeros de lucha el 25 de noviembre de 1960. Este hecho fue recogido por Julia Álvarez en su novela En el tiempo de las mariposas y recreado por Mario Vargas Llosa en La fiesta del chivo.

La literatura puertorriqueña, y el teatro en particular, se habían quedado encerrados en los parámetros insulares, con muy poca vinculación con las corrientes y tendencias latinoamericanas y mundiales, y con un total predominio de temas y situaciones isleños. Antonio S. Pedreira fue quien definió de manera certera esta situación con su libro Insularismo de 1934. En la década de 1960 se afirmaba que ningún texto u obra puertorriqueña podía entenderse fuera de la isla. Se llegó al extremo de exigir que ninguna obra podía incluir personajes extranjeros. Contra ese ostracismo creativo reacciona Luis Rafael Sánchez, quien había comenzado su creación dramatúrgica en esa década. Sánchez ya había manejado formas y personajes clásicos en su obra La hiel nuestra de cada día (1961), utilizando a Píramo y Tisbe como referentes para recrear la terrible pobreza que agobiaba a los habitantes del Viejo San Juan. Pero fue la feroz dictadura de Trujillo en República Dominicana la que le proveyó a Sánchez y al teatro puertorriqueño la puerta de salida del insularismo y lo vincularon de manera definitiva al teatro latinoamericano y mundial mediante la recreación de la obra de Sófocles y la incorporación de técnicas brechtianas a su obra.

La Antígona de Sánchez tiene apellido: Pérez, lo cual la convierte en prima lejana de la Antígona Vélez de Marechal. Apellidos comunes que le quitan la pátina de realeza al personaje y le brindan un asidero popular a sus acciones como integrante de clases menos favorecidas. Creón también se concretiza contemporáneo con el apellido Molina, apellido materno del dictador Rafael Leonidas Trujillo y Molina. Trujillo nombró a la capital de República Dominicana Ciudad Trujillo, Creón llamó a la suya República de Molina. Insisto en estas correlaciones entre historia y obra porque algunos críticos han intentado inscribir la obra en la ínsula, aludiendo a personas reales de Puerto Rico como el modelo para los personajes de la obra. Proclamar que la nacionalista Olga Viscal Garriga es el punto de partida de Antígona Pérez es un error fomentado por la miopía insularista que aun permea algunos sectores de la crítica en Puerto Rico.

Etéocles y Polinices se transforman en Héctor y Mario Tavárez, quienes han sido asesinados por las fuerzas de seguridad del estado de Molina por sus actividades sediciosas y están expuestos en la plaza pública para escarmiento de sus simpatizantes. La relación de hermanos de Antígona es transformada por Sánchez en la de compañeros en la lucha contra el dictador, estando en la obra 
del puertorriqueño ambos expuestos al escarnio público. Esa transformación es de carácter ideológico, dado que los lazos de solidaridad no tienen fundamento familiar sino de unidad de propósito y de acción. Consciente de las exigencias del mito, Antígona Pérez reclamará que los hermanos Tavárez dejaron de ser sus amigos para convertirse en sus hermanos, porque Antígona necesita hermanos para completar su acción dramática. Hay incluso una referencia a que hubo una relación amorosa entre Antígona y Mario, eco lejano de la vertiente incestuosa que persiguió a la estirpe de Layo. Cuando Creón insinúa que Mario es impotente, Antígona lo refuta: Puedo dar testimonio de lo contrario. Los Tavárez forman parte del estrato extratextual histórico, teniendo como base a Manuel Aurelio Tavárez, esposo de Minerva Mirabal y conspirador junto a ella en contra de Trujillo.

La Ismene de Sófocles es en la obra de Sánchez Irene Domingo y Zuñiga. Aunque el nombre las acerca, Irene no es hermana de Antígona sino su mejor amiga. Su función dramática es, sin embargo, parecida. Irene trata de persuadir a Antígona de que revele el lugar donde enterró a los hermanos Tavárez. Muestra la misma falta de carácter del personaje griego, pero se añade a su cobardía, la traición. Irene ha establecido una relación amorosa con Fernando Curet, el Hemón de Sánchez, joven militar prometido de Antígona. Éste también ha traicionado a Antígona al aceptar una promoción militar que Creón le ha ofrecido para convertirlo en el carcelero de Antígona.

La obra incluye varios personajes de creación del autor, que se distinguen por su función intratextual: Aurora, la madre de Antígona, Monseñor Bernardo Escudero, portavoz de la iglesia, y Pilar Vargas, primera dama de la República de Molina. Todos forman parte del plan de Creón Molina para minar la resistencia de Antígona. La madre recurre a los argumentos estereotipados de la mujer sometida que no debe inmiscuirse en cuestiones de hombres. La defensa que hace Antígona de los deberes y responsabilidades de la mujer constituye un alegato muy vinculado al movimiento de liberación femenina. Monseñor Escudero recurre al chantaje religioso para intentar someter a la obediencia a la rebelde Antígona. Perderás el alma, le advierte el sinuoso monseñor, pero Antígona lo reta: Apostemos, Monseñor. La alianza tácita de los poderes políticos y eclesiásticos sobresale en esta escena, apuntando directamente a la complicidad de la iglesia con algunos regímenes dictatoriales de América Latina. Pilar Vargas, esposa de Creón, funciona al nivel intertextual como Lady Macbeth: instiga, aguijonea y manipula a Creón a que imponga su poder sin titubear, sin consideraciones, sin debilidades. Hace gala de su vocación de poder en su encuentro con Antígona, en quien no logra hacer mella en su férrea determinación de mantenerse fiel a sus ideales. Aunque se ha señalado que estos personajes son de procedencia clásica: Aurora/Yocasta; Monseñor Escudero/Tiresias y Pilar Vargas/Eurídice, nada hay en su comportamiento 
ni trayectoria que les acerque a los personajes de Sófocles, como tampoco hay nada en común entre Edipo y Guillermo Pérez, padre de Antígona que se negó a plegarse a los designios de Creón y fue fusilado. Todos ellos son parte de la dramaturgia de Sánchez para darle motivación y causas a la evolución de la trama.

Otra de las elaboraciones dramáticas de Sánchez para la estructuración de la trama es la transformación del coro griego en un coro de periodistas. Vestidos con pantalón negro y chaqueta deportiva, cinco hombres fornidos intervienen a lo largo de la obra para brindar la información oficial sobre el encarcelamiento de Antígona. Los términos lingüísticos utilizados: sediciosa, enemiga del estado, subversiva, facinerosa..., emanan de la terminología que los estados utilizan constantemente para etiquetar a los opositores y críticos del sistema imperante. Los periodistas se convierten así en portavoces al servicio del dictador, promoviendo como hechos la propaganda del poder. Combinan además las noticias sobre levantamientos y luchas sociales a nivel mundial con reportajes sobre las veleidades de las figuras del entretenimiento más banal e intrascendente. Este anclaje en la historia le brinda contexto específico a la trama, a la par que desnuda la función de agente del sistema del periodismo comercial. En consecuencia, el coro no es voz comunal ni representa la visión y los ideales de la sociedad, sino que se convierte en instancia demagógica y deformadora de la realidad.

Creón Molina y Antígona Pérez son los dos grandes personajes de la obra. El primero, que exige el título castrense de Generalísimo, igual que Trujillo, es un maestro de la manipulación, la intimidación y la tortura. Conoce los resortes del poder y sabe aprovecharse de las debilidades de amigos y adversarios. Antígona encarna el compromiso hecho mujer. Es capaz de sacrificarlo todo por la lucha por la libertad y renuncia a la vida de comodidades y lujos que Creón le ofrece en el exilio. Tiene vocación de sacrificio y sabe resistir todas las presiones, tentaciones y vejaciones que recibe para que ceda. Su pasión tiene ribetes cristianos. Desde el título de la obra se establece ese nexo intertextual. La pasión según Antígona Pérez apunta a fórmulas bíblicas, sobre todo al título de los cuatro testimonios de los evangelistas sobre Jesús: El evangelio según... Por eso, la muerte de Antígona se convierte en acto de liberación para los demás, como sucedió con el asesinato de las hermanas Mirabal, que avivó la llama del levantamiento contra Trujillo. Esto culminó con el ajusticiamiento de éste el 30 de mayo de 1961, menos de año después del asesinato de las Mirabal.

La construcción dramática de Sánchez entrelaza además técnicas brechtianas con el mito griego y las situaciones contemporáneas. Sánchez utiliza la técnica del distanciamiento mediante el personaje narrador, la ruptura de la unidad de espacio y la utilización de letreros y carteles como como 
contrapunto histórico para la acción. El inicio mismo de la pieza comienza con Antígona como narradora de su situación: Empecemos por donde se empieza siempre. Nombre, Antígona Pérez. Esa narración consciente del público que presencia su pasión permite al personaje adelantar acciones, como al principio del segundo cuando dice: El segundo acto comenzará verdaderamente cuando Creón me diga: Antígona, te pareces a mí. O cuando viola el concepto de espacio al presentar a Pilar Vargas como Primera Dama de Molina, aunque Antígona está en el sótano y Pilar en los salones del palacio. Al romper con las unidades de tiempo y espacio, la protagonista demuestra que es sujeto de su historia y no objeto que responde a lo que los demás deciden o hacen con respecto a ella. El tiempo y el espacio le pertenecen porque siendo dueña de su historia sabe que va a morir y que las secuencias de la acción desembocarán inevitablemente en su sacrificio. La técnica brechtiana es entonces no sólo una forma de presentar la trama, sino una reafirmación de la función definitoria que la mujer debe desempeñar en la formación, rescate y transformación de nuestras sociedades. El uso de técnicas brechtianas para resaltar la dimensión social de la obra se hace más evidente con el uso de carteles sobre las columnas que sirven de trasfondo a las acciones de los personajes. Dichos carteles llevan consignas claramente políticas sobre la convulsa situación en varios países latinoamericanos. Consignas radicales entonces, aunque ya manoseadas hoy como Yankee go home o Patria o muerte se mezclan con reclamos sobre a quién pertenece el Canal de Panamá o las minas de Bolivia. Incluso hay un guiño del autor para algún espectador perspicaz al incluir la consigna Bosch para presidente, pues juega con el tiempo para decirnos cuál será el futuro tras la caída de Creón Molina. Recuérdese que Juan Bosch fue el primer presidente constitucional después de la erradicación de la dictadura de Trujillo, a quien Creón tipifica. Son referencias lúdicas extratextuales que enriquecen la repercusión de la obra.

Los elementos intertextuales y extratextuales se convierten así en factores fundamentales para el análisis intratextual de la utilización que hace Luis Rafael Sánchez de las formas clásicas para huir del insularismo que ahogaba la creatividad dramatúrgica de los escritores dramáticos del país En consecuencia, Lapasión según Antígona Pérez presenta evidencia sustancial de la pervivencia de dichas formas en el teatro de la menor de las Antillas y del esfuerzo consciente de Luis Rafael Sánchez de latinoamericanizar nuestro teatro y vincularlo a las corrientes más significativas del teatro mundial.

Este ensayo explora la pervivencia de la forma clásica como alternativa al insularismo teatral en Puerto Rico. El análisis comparativo entre Antígona y Antígona Pérez nos brinda el asidero para examinar la construcción dramática de Sánchez en la que se entrelazan técnicas brechtianas con el mito griego y situaciones contemporáneas. Desde el título de la obra se establece otro nexo 
intertextual. La pasión según Antígona Pérez apunta a fórmulas bíblicas, sobre todo al título de los cuatro testimonios de los evangelistas sobre Jesús: E1 evangelio según... Los elementos intertextuales y extratextuales se convierten así en factores fundamentales para el análisis intratextual de la perviviencia del mito de Antígona en el teatro puertorriqueño. 


\title{
A reconstrução do mito de Orfeu no Carnaval Brasileiro
}

\author{
Ana L. Souza Ribeiro \\ Universidade Federal de Minas Gerais
}

\begin{abstract}
No presente trabalho, pretende-se analisar como o mito de Orfeu, contado na obra Geórgicas de Virgílio, aparece, de maneira palimpséstica, na peça Orfeu da Conceição, de Vinícius de Moraes, produzida no Brasil do século XX. Serão feitas algumas considerações sobre as escolhas do autor brasileiro de forma a justificá-las e relacioná-las ao mito em questão. Pretende-se, então, mostrar como, na obra contemporânea, misturam-se símbolos que retomam a literatura clássica com signos que remetem à cultura e tradição brasileira. A partir desta releitura, na combinação do mito com a festa profana, pagã e popular que é o carnaval, evidencia a mistura das duas culturas no costume e tradição brasileiros.
\end{abstract}

Assim é que, quando ao reler numa velha mitologia o mito grego de Orfeu, o divino músico da Trácia, nele senti a estrutura de uma tragédia negra carioca.

Vinícius de Moraes

Este trabalho consiste em analisar a retomada da literatura clássica representada pelo mito de Orfeu na obra Geórgicas, de Virgílio, na peça Orfeu da Conceição, de Vinícius de Moraes, produzida no Brasil do século XX.

A peça foi produzida em setembro1956 no Teatro Municipal do Rio de Janeiro por Leo Jusi. O elenco foi composto por atores do Teatro Experimental do Negro e participações de Tom Jobim, um famoso compositor, maestro, pianista, cantor. É considerado um dos maiores expoentes da música brasileira e um dos criadores do movimento da bossa nova; foi responsável por musicar e orquestrar a peça. E Oscar Niemeyer, um arquiteto brasileiro, considerado um dos nomes mais influentes na arquitetura moderna internacional, famoso pela construção de Brasília, incumbido do cenário. Embora tenha permanecido somente dez dias em cartaz, a peça foi bem aceita pela crítica na época e, nos dias atuais, é considerada um passo à modernidade musical e teatral brasileira. A apresentação do mito de Orfeu na América mostra - aqui cito Cacá Diegues, cineasta brasileiro - que a ideia de transpor o mito do poeta e músico grego para uma favela carioca nasceu de uma conversa de Vinícius de Moraes com o escritor americano Waldo Frank sobre a Grécia e os negros brasileiros, quando este visitou o Rio de Janeiro no início de 1942. Vinícius, posteriormente, ao reler o mito de Orfeu, na casa do arquiteto Carlos Leão, traçou as linhas gerais da peça, cujo título lhe havia sido sugerido por João Cabral de Melo Neto, um poeta e diplomata brasileiro. Os três atos foram desenvolvidos no Brasil e nos EUA, durante o período em que Vinícius serviu no consulado do Brasil em 
Los Angeles, e arrematados em Paris, em outra missão diplomática no âmbito desse movimento de reflexão e de produção direcionada a manifestações artísticas, culturais e sociais de grupos até então relegados, por meio de um cruzamento de matrizes culturais africanas e greco-romanas (européias).

No texto publicado no programa de Orfeu da Conceição em 1956, Vinícius nos diz em entrevista:

Foi-me fácil escrever, nessa mesma noite, de um só fôlego, todo o primeiro ato da peça, transpondo diretamente o mito grego para o morro carioca. Tudo o que fiz foi colocar nas mãos de um herói de favela, em lugar da lira helênica, o violão brasileiro, e submetê-lo ao sublime e trágico destino de seu homônimo grego - destino que o levou, através da integração total pela música, ao conhecimento do amor no seu mais alto e belo sentido e, pelo amor, às forças incontroláveis da paixão, à destruição eventual da harmonia em si mesmo e no mundo em torno e, finalmente, à sua própria morte (Moraes, p. 37).

Vinícius de Moraes recria o mito nos cenários, levando as figuras mitológicas para o carnaval no Rio de Janeiro, lugar e festa com grande representatividade cultural para o Brasil. $\mathrm{O}$ primeiro ato compreende a formulação das personagens centrais, a sua posição no espaço e tempo, e posteriormente utiliza do embasamento da tragédia, sob perspectivas do destino, tal como deverá o processo de atuação.

O herói Orfeu, que no mito é cantor, músico e poeta de procedência trácia que, com seu canto, acalmava homens, domava feras e comovia até as pedras, na obra supracitada possui o mesmo caráter simbólico e metafórico: o personagem principal, também de nome Orfeu, é reproduzido negro (o negro que tem uma cultura e temperamento específico, e embora interligado no contexto racial brasileiro, sempre manifestou a necessidade de prosseguir na sua própria cultura, proporcionando, deste modo, uma contribuição realmente particular à cultura brasileira, aquela que livra dos preconceitos de cor, credo e classe), boêmio, compositor de sambas, que vive o prazer de cada instante. Mora na favela, particularidade e espaço importante na caracterização nacional e representação do povo brasileiro. Ao invés de uma lira, comum e popular na Antiguidade Clássica, Orfeu toca violão, instrumento que tem as mesmas características no Brasil contemporâneo. Assim como o personagem mítico, deixa em estado de êxtase o morro e o pacifica, causando amor e concórdia. Por causa disso, recebe o sobrenome "de Conceição", o que representa, no Brasil, as pessoas humildes e sem procedência definida. Como no mito, suas canções têm um poder sobrenatural sobre as pessoas É Orfeu que apresenta ao mundo a semente da beleza, que o torna cheio de canto, de poesia e de doçura. 
Em Orfeu da Conceição, o violão pode fazer milagres, é como parte de Orfeu. $\mathrm{Na}$ abertura ele toca em solo a valsa Eurídice, tema romântico da peça, composta por Antônio Carlos Jobim, o mesmo que musicou e orquestrou a peça, e no decorrer do teatro, sola também as introduções dos sambas e os tristes acordes com que Orfeu procura traduzir o sofrimento e os conflitos que lhe saem do interior. $\mathrm{O}$ samba é representado mimeticamente em um aspecto que ilumina o mito de Orfeu.

No livro Platão e o orfismo, Bernabé cita que, na República de Platão, Orfeu aparece como um poeta. Ainda, segundo Bernabé:

A tradição, ademais, atribuía à habilidade musical de Orfeu qualidades sobrehumanas. Era proverbial, desde os primeiros testemunhos, a fascinação que Orfeu exercia sobre os que o ouviam. Platão se refere a esta qualidade em uma referência, mesmo irônica, no Protágoras, na qual compara os discípulos dos sofistas com os seres fascinados pelo canto do citarista trácio: "muitos me pareceram estrangeiros, os que acompanham Protágoras por todas as cidades que passa, encantando-os com a sua voz como Orfeu, e que seguem, fascinados, a sua voz" ${ }^{1}$.

Eurídice, a ninfa mitológica, é eternizada por Vinícius quando este corporifica na sensualidade da mulata brasileira, segundo um valor adquirido e vinculado, desde o Brasil colônia. Sua representação destoa um pouco do mito porque, apesar de encantar Orfeu, é casada com Aristeu. Porém, o fato de ser casada não impede o amor dos dois, que acabam encontrando-se secretamente. $\mathrm{Na}$ mitologia grega Eurídice, quando perseguida por Aristeu, é picada por uma cobra, já na peça em questão, a personagem é assassinada pelo ciumento marido, que acaba ferindo-a com um punhal.

No segundo ato da peça, Orfeu, na louca procura de Eurídice, vai a um clube carnavalesco denominado "Os maiorais do inferno", onde os personagens festejavam o baile, que é presidido por Prosérpina e Plutão, fazendo alusão à sua ida ao mundo inferior, governado por Plutão e Perséfone. Nesta parte da adaptação do mito, Vinícius de Moraes apresenta o cão Cérbero como Leão de Chácara - nome conhecido popularmente, em algumas regiões do Brasil, como vigilante, segurança em festas ou bailes - e o mesmo tenta interromper a entrada de Orfeu, mas acaba sendo persuadido pela música de seu violão, assim como no mito apresentado por Virgílio. Após sua entrada na festa de carnaval, o personagem Orfeu diz:

Onde estou eu? Quem sou eu? Que é que vim fazer aqui? Como é que foi? Isso é o inferno e eu quero o céu! Eu quero a minha Eurídice! Minha mulata linda, coberta de sangue..." (Moraes, p. 60, 1956).

\footnotetext{
${ }^{1}$ Pl. Prot. 315a (OF 949 I) [T 6].
} 
Após todas as indagações, ele procura por seu grande amor, mas não a encontra, e acaba por se embriagar.

Uma questão importante que a peça trata de forma a destoar do mito é não relatar uma Eurídice perdida, justamente pela possibilidade de estar ela presente em todas as mulheres. Fato mostrado na peça com as dançarinas da gafieira que corporificam Eurídice, de forma simbólica apenas. A loucura de Orfeu da Conceição transforma cada mulher, que dança, na amada.

Ponto importante na obra de Vinícius, em que se aproxima da lenda, é quando a Dama Negra fala a Orfeu com a voz de Eurídice - no caso, um apelo à morte para que o músico entrasse em seus domínios. Assim, Eurídice assimila-se à morte, que é a única morada onde se pode alcançar o amor despido do efêmero terrestre.

Orfeu na peça é receptivo a todas as mulheres, e em certo momento encontra-se com Mira, que sua foi pretendida, mas desprezada. Enfurecida com o abandono, Mira influencia outras mulheres e atiram em Orfeu facas e navalhas, provocando sua morte e jogando seu violão do alto do morro. Tal fato em Virgílio acontece pelas mãos das bacantes que destroem sua lira e o decepam. Entretanto sua cabeça vaga pelo rio cantando e dizendo profecias.

A combinação do mito com a festa profana, pagã e popular que é o carnaval evidencia a mistura das duas culturas no costume e tradição brasileiros. $\mathrm{O}$ festejo misturado à música e ao encantamento de Orfeu oferece uma nova paisagem para a materialização do mito, renovando-o. O poder da música, porém, tanto na Antiguidade quanto no novo contexto em que o mito é apresentado, não é o suficiente para salvar Orfeu do amor que o aprisionou e causou sua desgraça.

O mito de Orfeu reúne os grandes temas poéticos da obra de Vinícius: a união entre a música e a poesia, a apresentação marcante da mulher, a obsessão pela morte e a fé no amor absoluto.

$\mathrm{Na}$ obra teatral, o autor se deixou seduzir pelo gosto de uma poesia fácil, que aos versos apresenta um tom bem popular. Segundo Coelho, "como a peça de Vinícius, esta obra transportava para o Brasil o mito grego”. (Coelho, p. 231, 2008).

De acordo com Coelho:

busco mostrar a importância de conhecermos estas versões, para entendermos melhor as adaptações do mito na sociedade brasileira: Orfeu (1999), de Carlos Diegues, e Orfeu do carnaval (1958), de Marcel Camus, ambas baseadas na peça Orfeu da Conceição (1956), de Vinícius de Moraes. Esta comparação pode permitir-nos ainda observar os significados de alterações na assimilação da tradição clássica greco-romana pela literatura e cinema americanos, a partir das especificidades do seu contexto histórico (Coelho, p .222, 2008). 


\section{Bibliografia}

Moraes, Vinícius de, Orfeu da Conceição, São José, Rio de Janeiro, 1960.

Coelho, Maria Cecília Nogueira, Entre a bistória e o mito: Orfeu na América, segundo Sidney Lumet, ArtCultura, Uberlândia, v. 10, n. 17, pp. 221235, jul.-dez. 2008.

Virgílio, Geórgicas, Trad.: Antônio Feliciano de Castilho e Manuel Odorico Mendes, Ed. Brasileira, São Paulo, 1970.

Magaldi, Sábato, Moderna dramaturgia brasileira, Ed. Perspectiva, São Paulo, 2008.

Bernabé, Alberto, Platão e o orfismo: diálogos entre religião e filosofia, Trad. Dennys Garcia Xavier, Ed. Annablume, São Paulo, 2011. 


\title{
El TÉRMINO TRAGICOMEDIA EN EL DRAMA HUMANíSTICO
}

\author{
María Dolores Rincón González \\ Universidad de Jaén
}

\begin{abstract}
Desde mediados del s. XV, la ausencia del texto aristotélico sobra la comedia, la ampliación del número de piezas conocidas de Plauto, el descubrimeinto de códices con las comedias terencianas precedidas del Comentum Donati, y el interés docente y cortesano por las representaciones dramáticas y los espacios arqueológicos, suscitaron preguntas teóricas sobre la estructura, forma y representación del teatro antiguo, y las características del drama humanístico. Una lectura crítica de las praefationes de los dramas del italiano C. Verardi (1440-1500) nos brinda argumentos al respecto y nos ayuda a comprender, a partir de Plauto, el uso del término tragicomedia presente en el título de la Celestina.
\end{abstract}

Desde mediados del s. XV el interés por el teatro antiguo fue en aumento entre mecenas, escritores, y arquitectos en la mayor parte de los centros culturales europeos y de manera especial en Italia. El interés recaía en gran medida sobre la comedia, género del que se disponía de pocas bases teóricas dada la ausencia de un texto aristotélico específico similar al de la tragedia.

El afán por discernir las normas que regían en el texto dramático de la comedia antigua, y todo lo relacionado con su puesta en escena, se vio potenciado con la ampliación del número de piezas conocidas de Plauto y el descubrimiento de nuevos códices con las comedias de Terencio precedidas del Comentum Donati, circunstancias que coincidían con la actividad docente y cortesana relacionada con las representaciones de ambiente profano y el reencuentro, de carácter anticuario, con espacios y restos arqueológicos hasta el momento escasamente percibidos. Entre los escritores italianos de finales del quattrocento y el cinquecento a menudo se suscitaron preguntas teóricas sobre la estructura, forma y representación del teatro antiguo al mismo tiempo que se proponían pautas sobre lo que habría de ser el drama humanístico.

Los comentarios de Donato a Terencio y los praenotamenta de autores recentiores (Guido Iuvenalis,Johannes Calphurnius, Badio Ascensio,entre otros), junto con las ediciones ilustradas de sus comedias formaron un corpus liminar del que surgiría, por amalgama y síntesis, la teoría de la comedia a mediados del s. XVI. Hemos de añadir a este corpus algunos planteamientos teóricos no sistematizados en textos preliminares de ciertas piezas teatrales de finales del s. XV y comienzos del s. XVI, en los que es posible extraer la problemática al respecto como ocurre en las praefationes de dos dramas del italiano C. Verardi de Cesena, en donde su autor, a partir de Plauto, brinda argumentos que nos 
ayudan a conocer la justificación del uso del término tragicomedia como modo de definir la naturaleza híbrida de sus dramas precisamente en un momento en el que no existía una teoría de la comedia propiamente dicha y se ensayaba un modo de imitación a partir de un conocimiento impreciso y confuso con el que se pretendía intuir y reconstruir el tratado aristotélico inexistente.

En este sentido cabe afirmar que el desarrollo del teatro humanístico del s. XV planteó cuestiones claves para la cultura de su tiempo, como sucede con el concepto de imitación de los modelos clásicos, la autonomía y originalidad de los textos particulares, la dependencia del mundo contemporáneo o las propuestas sobre la representación misma. A partir de la segunda mitad del s. XV el interés por la representación de comedias clásicas, y también contemporáneas, contrasta de manera especial con la situación anterior más proclive a la lectura de los textos como auténticas exercitationes de los propios autores.

El italiano C. Verardi (c. 1440-1500) como autor dramático se inscribe en este contexto. Fue secretario de cartas latinas de cuatro Pontífices: Paulo III, Sixto IV, Inocencio VIII, Alejandro VI. Curial muy vinculado al círculo hispanófilo de Roma, en el que se desenvolvieron los cardenales Pietro y Raphaele Riario, B. López de Carvajal, J. Ruiz de Medina, la familia Borja, etc. En sintonía con los objetivos de aquellos personajes, escribió dos piezas teatrales motivadas por dos acontecimientos españoles de 1492: la toma de Granada y el atentado del rey Fernando en Barcelona. Aquellas piezas se titularon: Historia Baetica y Fernandus servatus. Fueron escritas casi de manera simultánea a los acontecimientos y representadas con la misma inmediatez en abril del mismo año y en el mismo mes al año siguiente. El éxito de la representación y la oportunidad política de su divulgación son la clave de una abundancia editorial poco usual en composiciones de tal tipo. Abundancia editorial a la que se incorporaron las imprentas de Salamanca y Valladolid con aportación de sendas ediciones de incunables (1494 y 1497).

Sin embargo, a pesar del éxito en su momento, no se ha destacado lo suficiente su aportación a las bases previas al desarrollo de la teoría moderna de la comedia. En opinión de L. Cabranes-Grant, el uso del término tragicomedia ha de ser valorado como "hallazgo central para el desarrollo del teatro moderno" 1 . Previamente M. Menéndez Pelayo puso de relieve su conexión con el segundo título de la Celestina al afirmar de manera rotunda: Me parece fuera de duda que Fernando de Rojas conocía la obra de Verardo, que por su asunto debió de divulgarse bastante en España, y quizá la lectura de su prólogo le sugirió la idea de cambiar el título de Comedia que habia dado a la Celestina en tragicomedia.

\footnotetext{
${ }^{1}$ Cabranes-Grant, L., "La resistencia a la Tragicomedia: Giraldi Cintio y una polémica sobre Celestina”, Celestinesca 22, 1 (1998).
} 
Obsérvese también que la explicación que da del nombre conviene con la de Verardo y no con la de Plauto. Pero puede admitirse la influencia simultánea de los dos textos. Tengo por seguro que la Celestina estaba escrita antes del Fernandus Servatus, pero en su primitiva forma no se llamaba tragicomedia, sino comedia ${ }^{2}$.

La expresión la usa explícitamente Verardi en la praefatio del Fernandus servatus, en donde leemos: Potest enim haec nostra, ut Amphitruonem suum Plautus appellat, Tragicomoedia nuncupari: quod personarum dignitas et regiae maiestatis impia illa violatio ad tragoediam, iucundus vero exitus rerum ad comoediam pertinere videantur ${ }^{3}$. El término híbrido se justifica a partir de la definición habitual de los géneros de la tragedia y comedia desde la Antigüedad. Definición asumida por Donato en el texto correspondiente y que básicamente se refiere a personajes, materia y desenlace: Inter tragoediam autem et comoediam cum multa imprimis hoc distat, quod in comoedia mediocre fortunae hominum, parvi impetus periculorum laetique sunt exitus actionum, at in tragoedia omnia contra, ingentes personae, magni timores, exitus funesti habentur; et illic in prima turbulenta, tranquila ultima, in tragoedia contrario ordine res aguntur; tum quod in tragoedia fugienda vita, in comoedia capessenda exprimitur; postremo quod omnis comoedia de fictis est argumentis, tragoedia saepe de historia fide petitur ${ }^{4}$.

C. Verardi previamente en la Historia Baetica, tanto en la dedicatoria como en los versos del prólogo, había planteado la dificultad de clasificar su pieza teatral, puesto que siendo sus personajes elevados (reyes, cardenales, consejeros) no tenía cabida dentro de los parámetros de la comedia. La relación exhaustiva de los personajes del teatro de Plauto le sirve para indicar su exclusión del drama: Neque audientur lenonum hic periuria, / Servorum technae, aut meretricum blanditiae; / Avara non usquam lena bic inducitur, / Milesve gloriosus, aut sycophanta impudens, / Edaxue parasitus, vel matrona impotens, / Paterve durus, aut amator cupidus, / Et reliqua, quae in Graiis nostrisque comicis / Spectata praebent voluptatem plurimam ${ }^{5}$.

En la obra todo es púdico y honesto y su final es feliz y dichoso, con lo cual tampoco, de acuerdo con la preceptiva dramática, tiene cabida de manera plena en la tragedia, cuya materia está plagada de los crímenes de los tiranos, las altanerías reales, la soberbia de los poderosos, sin presencia a su vez en la Historia Baetica. Algo similar ocurre con el desenlace de esta historia que concluye con la toma de la ciudad de Granada por los Reyes Católicos.

\footnotetext{
${ }^{2}$ Menéndez Pelayo, M. (1943), Los orígenes de la novela. Obras completas, t. XV, Madrid, p. 292, n.

${ }^{3}$ Verardi, Carlo et Marcelino, Fernandus servatus, ed. H. Thomas, Revue Hispanique 14 (1914), p. 437

${ }^{4}$ Donato, De com., IV-2.

${ }^{5}$ Verardi, Carlo et Marcelino, Historia Baetica. Prologus, (ed. M. D. Rincón), Granada, 1992, p. 154.
} 
Verardi era consciente de la novedad del tratamiento de la materia dramática, que le obliga a mezclar los dos géneros y advierte a los espectadores sobre falsas expectativas: Requirat autem nullus hic comoediae: / Leges ut obseruentur, aut tragoediae: / Agenda nempe est historia, non fabula ${ }^{6}$.

En definitiva, se enfrentaba al reto de representar una historia verídica, no una fábula inventada. Una historia auténtica y bien conocida, que ofrecía una poderosa carga de ejemplaridad. Es una forma didáctica de exponer la ejemplaridad de unos hechos realmente acontecidos, la ejemplaridad de una bistoria vera, no de una fabula ficta. Con el título mismo lo está confirmando: Historia Baetica.

La historia transformada en teatro y el teatro concebido -en ello es precursor del desarrollo posterior del drama escolar y hagiográfico- como un instrumento didáctico eficaz que dirigido a reyes y príncipes adquiere la naturaleza del speculum que a través del oído y de la vista muestra el camino que conduce a la fama imperecedera: Acta complexus sum, historiamque interlocutoribus personisque ita contexui atque distinxi, ut totam rem, ita uti gesta est, posset Populus Romanus non solum auribus percipere uerum etiam oculis intueri ${ }^{7}$.

La materia de sus dos dramas, historias reales, le obliga a enfrentarse a una situación mixta entre comedia y tragedia; no exactamente con el valor que Plauto da al término tragicomedia en los versos del Prologus del Amphitruo: Post, argumentum buius eloquar tragoediae. / Quid contraxistis frontem? quia tragoediam / Dixi futuram hanc? Deus sum; commutavero / Eandem hanc, si vultis; faciam ex tragoedia / Comoedia ut sit, omnibus eisdem versibus. /Vtrum sit, an non, vultis? Sed ego stultior / Quasi nesciam vos velle, qui divus sim. / Teneo quid animi vostri super hac re sit. / Faciam ut commixta sit tragicocomoedia, / Nam me perpetuo facere ut sit comoedia, / Reges quo veniant et dii, non par arbitror. I Quid igitur? quoniam huic servos quoque parteis habet / Faciam, sit, proinde ut dixi, tragicocomoedia ${ }^{8}$.

La gran diferencia con la interpretación plautina radica especialmente en su sentido moralizante: en la comedia de Plauto no se persigue la moraleja sino la risa, la diversión, que trasgrede el respeto a los personajes mitológicos, descendidos del Olimpo para mezclarse o actuar a tono con la galería de los personajes cómicos. Verardi cita el texto de Plauto para justificar su licencia formal y de esta manera se convierte también en paradigma de la libertad en el uso de los modelos clásicos del que da abundantes pruebas la comedia humanística.

\footnotetext{
${ }^{6}$ Íbidem, pp. 152-156.

${ }^{7}$ Carlo Verardi, Ad Raphaelem Riarium, Historia Baetica, (ed. M. D. Rincón), Granada 1992, p. 142.

${ }^{8}$ Plauto, Amph. 51-63.
} 
Pero si la licencia formal la extrae de Plauto, el sentido ético de la licencia lo haya en Lactancio: cum officium poetae sit in eo, ut ea, quae gesta sunt uere, in alias species obliquis figurationibus cum decore aliquo conuersa traducat ${ }^{9}$.

Verardi apoyándose en el carácter de vera historia de su obra, intuye algo que con anterioridad escasamente se había percibido: que lo "trágicocómico" permite una dramatización más dinámica de los hechos históricos, lo que será utilizado después en la escenificaciones de pasajes bíblicos, terencios cristianizados (con sus conexiones con el teatro jesuítico), y hasta las últimas consecuencias en las comedias historiales de Lope y lo bistories de W. Shakespeare.

Es una concepción de lo trágico-cómico que no pretende aplicar a un género, sino a una obra concreta, como lo hace Plauto. En esta situación Verardi sólo cuenta con el Amphitruo como precedente y aun así sigue manteniéndose una diferencia: es una historia verdadera que exige un tratamiento in alias species obliquis figurationibus cum decore aliquo ${ }^{10}$ como sugiere Lactancio. Sugerencia que le permite tejer la historia verdadera en diálogos de personajes, en texto representable para que el Pueblo Romano no sólo conozca de oídas sino que también compruebe con sus ojos lo ocurrido.

Entre la composición de la Historia Baetica y el Fernandus servatus debió de transcurrir poco más de un año. Durante ese tiempo C. Verardi reflexiona y madura los planteamientos expuestos en la primera pieza, que se resumían en la necesidad de compaginar las fabulas fictas del teatro y la nova et vera historia: Apporto non Plauti aut Neuii comoedias, / Quas esse fictas scitis omnes fabulas; / At nouam nobis ueramque fero historiam ${ }^{11}$.

La búsqueda de una forma dramática que sirviera de medio fiel para representar unos hechos bien documentados y contemporáneos fue algo original en el marco italiano del momento. Las producciones dramáticas de tema histórico y de carácter profano escritas en latín fueron escasas durante la Edad Media y el Renacimiento; cabría citar: la Ecerinis (c.1314) de Albertino Mussato; De casu Caesenae (1377) de autor inseguro; De captivitate ducis Iacobi (1470) de Laudivio dei Nobili; en la Cauteriaria de Barzizza, el Philodoxus de Alberti y la Chirsis de Aeneas Silvio, pero sólo se dan pinceladas de realidad, generalmente de toque autobiográfico. El esfuerzo de Verardi tiene claros precedentes en los intentos de algunos de estos humanistas de emular a los dos grandes comediógrafos latinos, Plauto y Terencio, en composiciones nuevas. Pero frente a estos precedentes la originalidad de Verardi se basa en

\footnotetext{
${ }^{9}$ Lactancio, Institutiones, I, 11, 24.

${ }^{10}$ Officium autem poetae in eo est ut ea quae vere gesta sunt, cum decore aliquo conversa transducat (Isidoro, Etimologiae, VIII 7, 10).

${ }^{11}$ Apporto non Plauti aut Neuii comoedias, / Quas esse fictas scitis omnes fabulas; / At nouam uobis ueramque fero historiam (Historia Baetica, Prologus, vv. 4-9)
} 
el respeto estricto a los hechos históricos en el caso de la Historia Baetica, en escoger acontecimientos fuera de Italia y en pretender exceder el espacio de la representación para erigir un testimonio válido para todos los pueblos cristianos. Verardi no se propuso crear caracteres pero tampoco los personajes, concretamente de la Historia Baetica, se diluyeron en lo meramente simbólico.

La rápida divulgación de las dos comedias humanísticas de C. Verardi es prueba de éxito inmediato en Europa debido a su temática, a intereses políticos $y$, en algunos casos, especialmente a la novedad literaria de sus planteamientos . En el caso de España, dos ediciones de incunables constatan su éxito y, como ya señalábamos, cabe suponer que la presencia del término tragicomedia en el título de la segunda edición de la Celestina (1502) sea el resultado de la lectura de los textos de Verardi aunque en su argumentación explícita el autor se base en la mezcla de elementos cómicos y trágicos referidos al inicio y el desenlace de la obra y no se valga de todos los argumentos utilizados por Verardi: El primer auctor quiso dar denominación del principio, que fue placer, llamóla comedia. Yo, viendo estas discordias entre estos estremos parti agora por medio la porfía y llaméla tragicomedia ${ }^{12}$.

Precisamente el que Rojas no preste atención, ni intente justificar la mezcolanza de lo narrativo con lo dramático, tan cuestionada por la crítica literaria posterior, ni argumente sobre la naturaleza mixta que ha impedido la adscripción de la Celestina al género de la novela o de la comedia humanística, reafirma aun más la posibilidad de la dependencia de Verardi en cuanto a la utilización del término tragicomedia que frente a esa problemática podría tener un valor secundario, a pesar de que con su uso el autor la haya adscrito al teatro.

En cualquier caso, el nombre de tragicomedia quedó en la literatura española del siglo XVI a partir de La Celestina: Gil Vicente, que en tantas cosas fue tributario de ella, llamó tragicomedias a una sección entera de sus obras. En 1539 se publicaba en Burgos la Tragicomedia alegórica del Paraíso y del Infierno refundición castellana de una de las Barcas del mismo Gil Vicente. Una de las piezas de la Turiana, atribuídas a Juan de Timoneda, lleva el título de Tragicomedia Filomena. En la numerosa serie de las Celestinas sólo la de Sancho Muñón se titula Tragicomedia de Lisandro y Roselia.

La Historia Baetica y el Fernandus servatus resultaron también un estímulo para composiciones de carácter histórico, representadas, a veces, para celebrar acontecimientos políticos o militares. Siguieron el modelo de historia dramatizada Pedro de Lerma con su Comedia o Farsa sobre la figura del cardenal Cisneros (Alcalá, 1508) hoy perdida. B. Barrientos habla de su tragicocomedia De Illiberitanorum maurorum seditione sobre la sublevación de los moriscos de la Alpujarra (Salamanca, 1569). También perdida la comedia

${ }^{12}$ Rojas, F. de, La Celestina, (ed. M. Criado), Madrid, 1976, p. 17. 
o drama de Antonio $\mathrm{Pi}^{13}$ dedicada a $\mathrm{D}$. Juan de Austria por la victoria de Lepanto y que, al parecer, fue representada por sus alumnos en Barcelona. En Barcelona debió de imprimirse en 1543 la Tragedia Delphinus de Francesc Satorres.

En definitiva, a partir de F. de Rojas, ya durante el s. XVI, la palabra tragicomedia está asociada a la Celestina, pero es preciso tener presente que la historia de la literatura está en deuda con el autor de la Historia Baetica y el Fernandus Servatus, que supo reutilizar el término plautino, justificó su aplicación y lo divulgó a finales del s. XV.

${ }^{13}$ Torres Amat, F., Memorias para ayudar a formar un Diccionario Critico de los escritores catalanes, Barcelona, 1836. Facsímil, Barcelona /Sueca, Curial, 1973. 


\title{
Vestigios de Valerio Flaco en El Vellocino de oro de LOPE DE VEGA
}

\author{
Antonio Río Torres-Murciano \\ Universidad de Santiago de Compostela
}

\begin{abstract}
En El vellocino de oro de Lope de Vega se hallan algunas innovaciones introducidas en el mito de los argonautas por Valerio Flaco, como son la comparación de los trabajos de Hércules con la busca del vellocino y la aprobación dada a esta empresa por Júpiter frente a la reluctancia de los dioses del mar. Puesto que Lope no pudo haber recibido de otras fuentes antiguas estos elementos, que tampoco se encuentran en las compilaciones mitológicas al uso, es necesario concluir que los tomó directamente de Flaco, cuyo nombre había incluido en los índices de la Arcadia y del Isidro.
\end{abstract}

La comedia mitológica $E l$ vellocino de oro, pieza cortesana de Lope de Vega famosa por el incendio que, en mayo de 1622, interrumpió su estreno ante el rey Felipe IV en los jardines de Aranjuez ${ }^{1}$, se abre con un diálogo entre la Fama y la Envidia a lo largo del cual la segunda anuncia el objeto de la representación ${ }^{2}$ :

Aquella historia que canta

Ovidio, de donde tuvo

principio el Tusón de España.

(187-189)

La busca del vellocino de oro, posteriormente identificado con el Toisón de la insigne orden de caballería heredada de la Casa de Borgoña por los Austrias españoles, constituye uno de los mitos más recreados por la literatura

${ }^{1}$ Acerca de las características y circunstancias de la célebre representación, cf. M. Menéndez y Pelayo, Estudios sobre el teatro de Lope de Vega, vol. II (Obras completas, vol. XXX), Madrid, CSIC, 1949, pp. 212-226; J. M. Díez Borque, "Sobre el teatro cortesano de Lope de Vega: El vellocino de oro, comedia mitológica” en J. Canavaggio (ed.), La Comedia, Madrid, Casa de Velázquez, 1995, pp. 155-177 (159-164); T. Ferrer Valls, "El vellocino de oro y El amor enamorado en la producción dramática cortesana de Lope de Vega: las obras de madurez”, en J. Berbel et al. (eds.), En torno al teatro del Siglo de Oro. Actas de las XI-XIII Jornadas de Teatro del Siglo de Oro, Almería, Instituto de Estudios Almerienses, 1996, pp. 49-63 (50-51), J. A. Martínez Berbel, El mundo mitológico de Lope de Vega. Siete comedias de inspiración ovidiana, Granada, Universidad de Granada, 2002 <http://hdl.handle.net/10481/4414>, pp. 409-410, 506-509.

${ }^{2} \mathrm{El}$ texto de El vellocino de oro se cita por la edición digital de la Biblioteca Virtual Miguel de Cervantes (Alicante, 1999) <http://www.cervantesvirtual.com/FichaObra.html?Ref=888>, basada en la realizada para la Biblioteca de Autores Españoles por M. Menéndez y Pelayo (ed.), Obras de Lope de Vega, vol. XIV, Madrid, Atlas, 1966, pp. 102-133. 
grecorromana. ${ }^{3}$ Pero la mención explícita de Ovidio hizo que se identificara en la obra del Sulmonense (concretamente, en Metamorfosis VII 1-403, más que en Heroidas XII) la fuente principal, y quizás única, de la que se habría servido Lope para la redacción de su comedia. Esta era la tesis sostenida por Henry M. Martin en un casi centenario estudio que hasta tiempos muy recientes ha sido citado como autoridad ${ }^{4}$, en el que aseveraba, además, que no hallaba en $\mathrm{El}$ vellocino de oro rastro cierto de las Argonáuticas griegas de Apolonio de Rodas ni de las latinas de Valerio Flaco ${ }^{5}$.

Por cuanto respecta a Flaco, la afirmación de Martin nos parece discutible. Para empezar, resuenan claramente unos versos de las Argonáuticas romanas en el pasaje en el que el Jasón de Lope le repite a Fineo las engañadoras palabras con las que su tío Pelias le ha encomendado la búsqueda del vellocino ${ }^{6}$ :

Hércules tiene vencidas las difíciles empresas del mundo, en Europa y Asia; como la sierpe Lernea, el fiero león de Arcadia, y la calidonia fiera. Mató al gigante Aqueloo; y así, no queda que emprendas sino el vellocino de oro.

(1104-1112) sed neque bella videt Graias neque monstra per urbes

ulla: Cleonaeo iam tempora clausus biatu Alcides, olim Lernae defensus ab angue Arcas et ambobus iam cornua fracta iuvencis.

ira maris vastique placent discrimina ponti. (I 33-37)

En la comedia de Lope, el pérfido Pelias anima a Jasón a llevar a cabo la única gesta que las hazañas de Hércules han dejado a su alcance, siguiendo una reflexión análoga a la que llevaba al Pelias de Valerio Flaco a enviar a su odiado sobrino a la Cólquide, tras advertir que en Grecia no había posibilidad alguna de encargarle una empresa que le acarreara la muerte. Entre los trabajos de Hércules, el león de Nemea y la hidra de Lerna son mencionados tanto por Flaco como por Lope, cuya referencia al "gigante Aqueloo" podría proceder de la interpretación

${ }^{3}$ Dejando aparte obras parcial o totalmente perdidas como las Medeas de Enio, Acio, Ovidio y Lucano, contamos con las de Eurípides y Séneca, con la Pítica IV de Píndaro y con los dos poemas épicos de Apolonio de Rodas y de Valerio Flaco, fuentes a las que hay que sumar las noticias de los mitógrafos (Apollod., I 9.16-24; Hyg., Fab. III, XIV, XXI, XXII).

${ }^{4}$ Ex. gr. Díez Borque, op. cit. (n. 1), p. 172.

${ }^{5}$ H. M. Martin, "Lope de Vega's El vellocino de oro in relation to its sources", Modern Language Notes 39, 1924, pp. 142-149 (147). Acerca de la posible utilización de otras fuentes antiguas por Lope, cf. A. Pociña, "Tres dramatizaciones del tema de Medea en el Siglo de Oro español: Lope de Vega, Calderón de la Barca y Rojas Zorrilla”, en A. López y A. Pociña (eds.), Medeas. Versiones de un mito desde Grecia hasta hoy, vol. II, Granada, Universidad de Granada, 2002, pp. 751-777 (761-767). 1980).

${ }^{6}$ El texto de las Argonáuticas se cita por la edición teubneriana de W.-W. Ehlers (Stuttgart, 
que se suele dar a la vaga alusión valeriana a "los dos novillos" derrotados por el Tirintio ${ }^{7}$. Si, además, tenemos en cuenta que este curioso planteamiento del encargo de Pelias no se halla en ninguna otra fuente antigua conservada, razón por la cual ha sido generalmente atribuido a la inventiva de Valerio, deudora en este punto del prólogo del Hercules furens de Séneca ${ }^{8}$, cobra fuerza la hipótesis de la imitación directa, a la que hay, sin embargo, un argumento de peso que oponer. Porque, como bien ha demostrado Juan Antonio Martínez Berbel ${ }^{9}$, el texto seguido aquí por Lope es el de la libérrima traducción de las Metamorfosis de Ovidio realizada por Jorge de Bustamante ${ }^{10}$, quien, al igual que el Fénix, localiza al león de Nemea en Arcadia y atribuye a Hércules la caza del jabalí de Calidón, hazaña en la que no le concedían parte alguna los testimonios antiguos ${ }^{11}$. No parece, pues, descabellado suponer que, para amplificar la narración parcial que del mito de los argonautas había hecho Ovidio, se sirvió Bustamante de las Argonáuticas de Flaco, que pudo haber conocido cuando estudiaba en la Universidad Complutense ${ }^{12}$, y que de Bustamante recibió Lope la relación, originalmente valeriana, entre el mandato de Pelias y los trabajos de Hércules. La deuda de El vellocino de oro con la versión del cántabro es, por lo demás, tan evidente que ni siquiera parece dable afirmar que el Fénix se haya servido directamente del texto latino de las Metamorfosis ovidianas a la hora de redactar su comedia ${ }^{13}$. Pero, como se verá a continuación, pueden identificarse en esta

${ }^{7}$ De los ambo iuvenci (I 36) uno sería el toro de Creta (mejor que el Minotauro o el toro de Maratón, muertos por Teseo) y el otro el río Aqueloo, a quien Hércules rompió un cuerno (cf. Ov. Met. IX 85-86).

${ }^{8}$ En concreto, de los versos en que Juno mostraba su desesperación por no saber ya qué peligros idear contra su aborrecido hijastro Hércules, que había salido airoso de todas sus asechanzas (3074). El eco ha sido reconocido por todos los intérpretes del pasaje valeriano a partir de P. Langen C. Valeri Flacci Setini Balbi Argonauticon libri octo, Berlín, Calvary, 1896-1897, p. 23.

${ }^{9}$ Op. cit. (n. 1), pp. 478-482.

${ }^{10}$ En adelante, se seguirá al citar esta obra la paginación de la edición de 1595 (Las Transformaciones de Ovidio en lengua española, repartidas en quinze libros, con las Allegorias al fin dellos, y sus figuras, para provecho de los Artifices, Amberes, Pedro Bellero). Acerca de la primera edición, aparecida hacia 1540 sin indicación de autor, impresor, fecha ni lugar, cf. L. Carrasco Reija, "La traducción de las Metamorfosis de Ovidio por Jorge de Bustamante", en J. M. Maestre Maestre et al. (eds.), Humanismo y pervivencia del mundo clásico II. Homenaje al profesor Luis Gil, vol. II, Cádiz, Universidad de Cádiz - Ayuntamiento de Alcañiz, pp. 987-994 (987-988).

11 "Porque las marauillosas y grandes cosas que darte gloria de vencedor pudiessen, como fue el leon de Arcadia el puerco de Calidonia, la serpiente Lernea el gigante Acheloo, todo lo ha vencido y sojuzgado Hercules, y no queda ya cosa ninguna tan señalada como estas para que tu ahora emprendas, sino tan sola vna que en este punto me ha venido a la memoria en la qual si tu essa tu osada ynuencible y fuerte persona osas auenturar, venciendola saldras el mas afamado y victorioso hombre del mundo: porque es la conquista del velocino de oro, que en la ysla de Colcos esta" (p. 98a).

${ }^{12}$ Acerca del paso de Bustamante por las aulas de Alcalá, donde publicó en 1524 el maestro Lorenzo Balbo de Lillo la primera edición española de las Argonáuticas latinas, cf. M. Menéndez y Pelayo, Biblioteca de traductores españoles, vol. I (Obras completas, vol. LIV), Madrid, CSIC, 1952-1953, p. 258; Carrasco Reija, op. cit. (n. 10), p. 987.

${ }^{13}$ Martínez Berbel, op. cit. (n. 1), p. 444. 
vestigios valerianos que no se hallan en la obra de Bustamante, ni tampoco en los repertorios y compilaciones que circulaban en la época ${ }^{14}$.

Mientras que el Jasón de Bustamante aceptaba con ingenuo entusiasmo la incitación de Pelias a la aventura ${ }^{15}$, el de Lope parte, como el de Flaco, a pesar de haber adivinado las malvadas intenciones de su tío:

Y puesto que vi su envidia, no quise que conociera, ni en mi valor cobardía, ni en sus intentos bajeza. $(1120-1123)$
Mox taciti patuere doli nec vellera curae esse viro, sed sese odiis immania cogi in freta.

(I 64-66)

Poco antes de que el héroe de Lope supere las pruebas que le granjearán el vellón de oro, se le aparece el dios Marte ${ }^{16}$ para vaticinarle el éxito de una gesta que cuenta con el soberano beneplácito de Júpiter, así como el futuro catasterismo de la nave $\mathrm{Argo}^{17}$. Las concomitancias con Valerio Flaco son, una vez más, llamativas:

${ }^{14}$ Nada se encuentra al respecto en las Genealogiae deorum de Boccaccio, en la Officina de Ravisius Textor, en la Mythologia de Natale Conti o en el Dictionarium de Carolus Stephanus.

15 "Oydas por Iason estas no pesadas nueuas, luego accepto la empresa y partido de la presencia del tio desseoso de mostrar su bastante persona en tan gran cosa...” (p. 98b).

${ }^{16} \mathrm{E} 1$ dios Marte, que en el mito tenía un papel secundario por haberle sido consagrado el vellocino, había sido introducido en la narración como personaje por Valerio, que lo presentaba como enemigo de los argonautas. Pero el Marte magnánimo de Lope procede directamente, como ha señalado Martínez Berbel, op. cit. (n. 1), p. 456, del de Bustamante, que acogía con benevolencia a los hermanos Frixo y Hele después de que hubieran huido de las asechanzas de su madrastra a lomos del carnero de vellón de oro: "Frixo en llegando a esta ysla luego consagro el carnero al Dios Marte; al qual esta oblacion y sacrificio fue grata y muy acepta: y con admirable majestad y alegria baxo del cielo a la tierra a recebirle con graciosa y afable cara" (p. 97b).

${ }_{17}$ Mientras que, para Apolonio de Rodas, la Argo es solamente una nave especialmente renombrada, Flaco la presenta desde el comienzo de su poema como la primera que franqueó los mares (prima deum magnis canimus freta pervia natis, I 1), hazaña por la que mereció ser transformada en constelación (Alammifero tandem consedit Olympo, I 4). Bustamante alude a la prioridad de la nave de los argonautas en la historia de la navegación ("esta dizen que fue la primera que començo a andar sobre las aguas, p. 98b), pero no menciona el catasterismo evocado repetidamente por Valerio (I 303-304, IV 692-693, V 294-295). 
La invención de la nave Pegasea

Júpiter te agradece, $\mathrm{y}$ ha mandado que con cuarenta y cinco estrellas sea imagen en el círculo dorado, y que de la bellísima Medea tengas favor contra el dragón alado y los toros de fuego, pues al hielo de su desdén te dio favor el cielo. (2006-2013) deus haec, deus omine dextro

imperat; ipse suo voluit commercia mundo

Iuppiter et tantos hominum miscere labores. (I 245-247)

inde meae quercus tripodesque animaeque parentum

hanc pelago misere manum. via facta per undas

perque hiemes, Bellona, tibi.

(I 544-546)

El patrocinio prestado por Júpiter a la empresa de los argonautas, entendida como heroica apertura del tráfico marítimo y comienzo de las guerras entre Asia y Europa, constituye una invención original de Valerio, aventurada por Jasón en el primero de los pasajes citados y confirmada por el propio dios en el segundo. Y, tanto en Lope como en Flaco, la actitud favorable del dios supremo se opone a la de los indignados númenes del mar, quienes, reunidos en consejo, rechazan la navegación como si se tratara de una irrupción sacrílega en sus dominios ${ }^{18}$ :

En los palacios, sobre blanda arena, de perlas y corales fabricados, al Rey que el proceloso mar enfrena, ¡oh, hermanos, cuanto hermosos,

envidiosa propuso una sirena, [desdichados!, y a los marinos dioses convocados, que os diese el agua eterna sepultura; así trata la envidia a la hermosura.

Ese animal dorado pretendía que fuese a su deidad sacrificado sobre fuego del ámbar que el mar por atrevido a su cristal sagrado. [cría,
Heu quaenam aspicio? nostris modo concitus ausis aequoreos vocat ecce deos Neptunus et ingens concilium. fremere et legem defendere cuncti bortantur. (I 211-214)

${ }^{18}$ En Lope, la indignación de la sirena se debe a la incursión en sus aguas del carnero que porta a Frixo y a Helenia, atrevimiento que precede (y, en cierto modo, preludia) la travesía de la Argo, objeto de la cólera de Neptuno en Flaco. El concepto pesimista de la ilicitud de la navegación se halla ya en Horacio (Carm. I 3, 21 ss.) y en Séneca (Med. 301 ss., 595 ss.), pero es genuinamente valeriana la idea de reunir al comienzo del relato a las deidades marinas en un concilio análogo a aquellos que, desde Homero, solían tener lugar entre los olímpicos, tal como le recuerdan al lector los ilustres precedentes evocados por el pasaje (Verg., Aen. X 2, 9697; Ov., Met. I 167-252). Cf. A. Zissos, Valerius Flaccus' Argonautica, Book I. A Commentary, Oxford, OUP, 2008, pp. 191-193; S. Romano Martín, El tópico grecolatino del concilio de los dioses, Hildesheim, Olms, 2009, pp. 306-311. 
En la idea de que el viaje de los griegos a la Cólquide inauguraba los conflictos intercontinentales que habrían de culminar con la guerra de Troya, Valerio había presentado el rapto voluntario de Medea como preludio del de Helena, enfatizando una analogía de cuño herodoteo ${ }^{19}$ que, retomada por Lope con una despreocupada inversión cronológica, ha llamado en El vellocino de oro la reiterada atención de Martínez Berbel ${ }^{20}$ :

Medea, cuya hermosura es de aqueste reino Elena, no para incendios de Troya, ni para infamias de Grecia. (1056-1059)

Temiendo que la deshonra suceda a Colcos que a Grecia, siendo yo Elena, y él Troya. (1663-1665)

¡Fieras, aquí moriréis, que me da favor y esfuerzo la nueva Elena, que a Grecia, no a Troya, en mis naves llevo! (2042-2045)

\author{
nec vellera tantum \\ indignanda manent propiorque ex virgine \\ rapta \\ ille dolor, sed -nulla magis sententia menti \\ fixa meae-veniet Phrygia iam pastor ab \\ $I d a$, \\ qui gemitus irasque pares et mutua Grais \\ dona ferat. quae classe debinc effusa \\ procorum \\ bella, quot ad Troiae flentes hiberna \\ Mycenas, \\ quot proceres natosque deum, quae robora \\ cernes \\ oppetere et magnis Asiam concedere fatis! \\ (I 546-554)
}

quemque suas sinat ire domos nec Marte

cruento

Europam atque Asiam prima haec

committat Erinys.

namque datum hoc fatis trepidus

supplexque canebat

Mopsus, ut in seros irent magis ista nepotes

atque alius lueret tam dira incendia raptor.

(VIII 395-399)

Los ecos hasta aquí señalados, a los que quizás podría añadirse algún otro, ${ }^{21}$ delatan la presencia en El vellocino de oro de algunas de las más peculiares

${ }^{19}$ Mientras que Heródoto (I 1-4), al plantear la archaeologia de las guerras médicas como una pugna entre Europa y Asia sustanciada en una serie de raptos recíprocos (Ío, Europa, Medea y Helena), realiza una lectura racionalista del mito, que seguirá Licofrón (Alex. 1291 ss.), Valerio, que reduce la cadena a los dos únicos eslabones que le interesan (Medea y Helena), refuerza la naturaleza literaria del viejo relato, de acuerdo con un diseño que será imitado por Estacio (Ach. II 72-79). Cf. A. Río Torres-Murciano, "El designio de Júpiter en Valerio Flaco. Providencia, historia y tradición literaria”, CFC. ELat 30, 2010, pp. 131-163 (141-142).

${ }^{20}$ Op. cit. (n. 1), pp. 475, 495, 503-504, 514.

${ }^{21}$ El rapto final de las colcas por los argonautas (2148-2157), que justamente han señalado 
innovaciones introducidas en la leyenda de Jasón por Valerio Flaco, cuyas Argonáuticas (al menos el libro I, y probablemente también el VIII) deben, pues, contarse entre las lecturas que se dieron cita en la mente de Lope cuando componía este drama. Y no es de extrañar, puesto que ya antes había incluido en los índices de dos de sus obras más ambiciosas el nombre del épico flavio ${ }^{22}$, cuyo retrato había tenido a bien instalar, junto con los de los demás épicos posvirgilianos, en el fabuloso palacio de la Poesía que se describe en el libro V de la Arcadia $^{23}$ :

Atentamente miraban los pastores la guarnecida sala de aquel palacio, no de diversas labores ni ricas sedas, sino de solos cuadros de parecidos retratos de poetas famosos y de algunas epigramas, debajo de los cuales estaba la Envidia entre Zoilo y Aristarco, tan vivos que parece que decían que Ovidio era lascivo, Estacio duro, congojoso e hinchado, Silio Itálico vulgar y humilde, y Valerio Flaco y Lucano más atrevidos que graves.

como hallazgo de Lope tanto Martínez Berbel, op. cit. (n. 1), p. 497, como Pociña, op. cit. (n. 5), p. 767, podría estar inspirado en los versos valerianos que narran los reproches hechos a Jasón por Eetes (cur age non templis sacrata avellere dona / omnibus atque ipsas gremiis abducere natas, I praedo, libet?, VII 48-50), o en los que recogen el lamento de la madre de Medea (Aesonide, non hoc Pelias evadere furto / te iubet aut ullas Colchis abducere natas, VIII 155-156).

${ }^{22} \mathrm{El}$ autor de las Argonáuticas romanas comparece en no menos de tres ocasiones (s.v. Argos, Jasón, Valerio Flaco) en la "Exposición de los nombres poéticos y históricos" que acompaña a la Arcadia (Madrid, 1598), así como en la lista de "Los libros y autores que se citan para la exornación de esta historia" con la que se ilustra el Isidro (Madrid, 1599). Cf. E. S. Morby (ed.). Lope de Vega: La Arcadia, Madrid, Castalia, 1975, pp. 68 n. 29, 293 n. 131, 422 n. 124; A. Sánchez Jiménez (ed.), Lope de Vega: Isidro, Madrid, Cátedra, 2010, p. 650. Hay que reconocer, empero, que Lope no cita a Flaco en las notas del Isidro ni en las de la Jerusalén conquistada, mientras que sí menciona en las unas y en las otras a Silio Itálico y a Estacio. Cf. A. K. Jameson, "Lope de Vega's Knowledge of Classical Sources", Bulletin Hispanique 38, 1936, pp. 444-501 (466-467, 470-472).

${ }^{23} \mathrm{El}$ texto de la Arcadia se cita por la edición de Morby, op. cit. (n. 20), p. 422. 


\title{
CONSEJERAS, INSTIGADORAS Y HECHICERAS: Similitudes entre el PERSONAJE DE LA NODRiza, EN EL Hipólito de Eurípides y el de Celestina, en la Celestina de Fernando de Rojas
}

\author{
Ana Cecilia Rivabén \\ Universidad Nacional de Mar del Plata
}

\begin{abstract}
En el presente trabajo, frente al personaje tradicionalmente virtuoso de la anciana servidora, prudente y confiable, analizaremos, en una primera instancia, la figura controversial de la Nodriza de Fedra quien se revela, en su rol instigador, como el instrumento fatídico que desata la catástrofe final: el suicidio de Fedra y la muerte de Hipólito, maldecido por su propio padre. Finalmente, en una segunda instancia, intentaremos demostrar la similitud de este personaje con el de La Celestina, obra homónima de Fernando de Rojas, en dos rasgos particulares: el de la intermediación y el del conocimiento de sortilegios, palabras mágicas y hechizos.
\end{abstract}

En la historia de la literatura griega han aparecido ancianas servidoras que desempeñaron un papel ciertamente tradicional: se manifestaban siempre de una manera anónima a la sombra de su señora. Si bien estas fieles nodrizas no fueron protagonistas, ocuparon un lugar destacado por los valores que poseían acordes a su longevidad: el de ser consejeras prudentes y confiables. Tal es el caso, por ejemplo, de Eurinoma de quien Homero nos la presenta más como una estimada ama de cría que la anciana esclava de Penélope o el de la Nodriza de Medea, quien ya en el monólogo inicial se siente atemorizada ante la actitud decidida de vengarse de su señora por haber sido etimasmêne (deshonrada) y edikemêne (ultrajada, humillada).

Sin embargo, no todas las nodrizas de la épica y de la escena han tenido el papel distinguido de ser la "prudente consejera". Precisamente, en el presente trabajo, frente al personaje tradicionalmente virtuoso de la anciana servidora que nunca sobrepasa las funciones propias de su condición servil, analizaremos, en una primera instancia, la figura controversial de la Nodriza de Fedra quien, excediéndose en sus atribuciones, se revela en su rol instigador como el instrumento fatídico que desatará la catástrofe final: el suicidio de Fedra y la muerte de Hipólito, maldecido por su propio padre.

Finalmente, en una segunda instancia, intentaremos demostrar ciertas similitudes entre este personaje y el de la Celestina, obra homónima de Fernando de Rojas, principalmente en dos rasgos particulares: el de la intermediación y el del conocimiento de sortilegios, palabras mágicas y hechizos. 


\section{La Nodriza como instrumento provocador del trágico destino de los protagonistas}

Los hombres que crean a los personajes de la tragedia antigua conocen el orgullo de saberse descendientes de dioses, y sus primeros personajes fueron las figuras mitológicas que gobernaban el humano albedrío. En el teatro griego (...) por la puerta central pasaban solamente los personajes olímpicos, héroes y dioses. Por las puertas laterales, los mensajeros, los subalternos, los criados. Hay, pues, clases entre los personajes de ficción. La aristocracia que gobierna la ciudad gobierna también su reflejo escénico. (...) El honor, la dignidad, las pasiones interesan solo en los altos personajes (...). Más todavía: para ellos es la dignidad de la escena (Díaz-Plaja, 1965 : 53).

Sin embargo, junto a estos héroes o dioses coexisten también una serie de personajes “menores", los denominados oiketai; esto es, figuras complementarias que aparecen breve y esporádicamente careciendo de personalidad trágica. Si bien la Nodriza de Fedra pertenece a este último grupo, creemos que su función en el desarrollo de los acontecimientos, en la segunda versión del Hipólito de Eurípides, es destacada y definitoria porque es por su intermediación que se produce el desenlace fatal.

En un comienzo, Fedra se presenta enferma por un amor cercano a las formas del incesto ya que padece una pasión irracional por su hijastro Hipólito. Pero, preocupada por su eukleîa (buena reputación), expresa su respeto permanente al aidôs (vergüenza, sentido del honor), e incluso su temor a la sanción social. Y precisamente, conociendo la visión ética y aristocrática de su señora, percepción basada en esta agathê dôxa (noble creencia), es su Nodriza quien comprende que el origen del desborde sentimental sufrido por Fedra se debe a la intervención de los dioses: manteîas âxia, (ciencia adivinatoria) (vv. 236) ${ }^{1}$ y, especialmente, a la irritación de Afrodita sobre ella: orgầ theâs, (las iras de la diosa) (vv. 438)2.

Ya en el prólogo, en su monólogo inicial, la misma Cipris anticipa que castigará a Hipólito por su osado desprecio hacia ella, inspirando en Fedra un amor incestuoso e irracional: deinô êroti toîs emoîs bouleûmasin, ([Fedra] llenó su corazón con un terrible amor, a causa de mis designios) (vv. 26-28).

Conocido el secreto amor de Fedra, la Nodriza escandalizada por la confidencia, solamente quiere morir: ôkk anâsjeto, ([Mujeres, estas cosas] son intolerables); apalajthésomai bîou thnêsko, (Me mataré para poder terminar con

${ }^{1}$ Para las citas en griego hemos tenido en cuenta la versión informatizada del Perseus Digital Library, Gregory R. Crane, Editor-in-chief, Tuft University. La traducción al español corresponde a Nápoli, J. T. (2007) Eurípides. Tragedias, Madrid, Colihue, Tomo 1.

${ }^{2}$ Los números entre paréntesis correspondientes a las citas del texto griego indican los versos. 
mi vida) (vv. 354 y 356-7) y reafirma que la intervención de la diosa sólo les traerá dolor y aniquilación: tên kâme kaî dômous apôlesen, (Ella destruyó a mi señora, a mí y a la casa) (vv. 361).

Pasado el primer impacto de la revelación, la Nodriza cambia de parecer y haciendo uso de una locuaz retórica, le insiste a Fedra que no rehúya de ese amor que la enferma y que siga los impulsos de Afrodita ya que no sólo comprende que su ama no ha sufrido nada extraordinario ni fuera de la razón sino que también interpreta que es necesario despojarse de los malos pensamientos y de las desmesuras para no querer ser superior a las divinidades (vv. 474-475) porque es una diosa la que determinó que estuviera enamorada : theôs eboulêthe tâde, (Un dios determinó esto) (vv. 476).

$\mathrm{Y}$, finalmente, es la osada intromisión de la Nodriza quien, contrariando el pedido de su ama, hace conocer el indecoroso secreto a Hipólito, contribuyendo de esta manera con los planes de Afrodita. Todo se desmorona en el oikos (casa, morada) de Trozen: La confidente y fiel sirvienta se ha transformado de esta manera en la kakôn promnêstrian (la hacedora de males) (vv.589), la despôtu trodûsan lêjos (la que traiciona el lecho del amo) (vv. 590).

Así, pues, con su desbordado actuar y su desmedido e inapropiado decir, ha dado comienzo al trágico final.

\section{La intermediación:}

En este segundo momento, nos interesa analizar exclusivamente las estrategias de dominio y manipulación que se desarrollan en la tragedia Hipólito de Eurípides y en La Celestina de Rojas, y que se convierten en una parte fundamental de las relaciones Interpersonales ${ }^{3}$. Nos ocuparemos pues, sólo de algunas de las coincidencias entre la Nodriza y la protagonista de la obra de Fernando de Rojas en su rol de intermediarias.

En principio, tanto el ama de cría como Celestina ejercen una pseudomaternidad que supone el "cuasi derecho" de ser las válidas receptoras de las más íntimas confidencias o secretos "deshonrosos", tanto para Fedra como para Melibea ${ }^{4}$.

Este carácter de "madres postizas" consigue crear en sus señoras lazos

3 "El motivo de la vieja alcahueta que da consejos amorosos procede de la escena griega y, de ahí, pasa al teatro romano", Tovar y Belfore Mártire, $2000: 245$, nota 76.

${ }^{4}$ Nodriza : ¿Y todavía lo ocultas, aunque te pido algo útil?/ Fedra : Es que a partir de lo vergonzoso maquino algo noble./ Nodriza : ¿Acaso no parecerás más digna de honra una vez que hables?/ (Eurípides, 2008 : 330- 332). Celestina : ¡O cuytada de mí! ¡No te descaezcas! Señora,/háblame como sueles./ Melibea : ¡Y muy mejor! Calla, no me fatigues./ Celestina: Pues, ¿qué me mandas que haga, perla graciosa? / ¿Qué ha sido este tu sentimiento? Creo que se van /quebrando mis puntos./ Melibea : Quebróse mi honestidad, quebrase mi empacho, / afloxó mi mucha vergüenza (...) (Rojas, $2008: 470$ ) 
de dependencia de sus sentimientos y voluntades. $Y$ es en este intento de verse como madres-consejeras, el momento en que la Nodriza y Celestina manifiestan la verdadera función de intermediarialalcabueta porque precisamente ambas logran que los otros deseen exactamente lo que a ellas les conviene: Para la Nodriza es el poder de la sirvienta que sabe todo lo que sucede en el oikos, poder enmarcado en estas secuencias de verbos: "Atrévete [a estar enamorada]"(vv. 476) - "Restablécete [de la enfermedad]" (vv. 477) "Obedéceme" (vv. 508); para Celestina, en cambio, es el dinero: cobra por su servicio de tercera ${ }^{5}$ y esto hace que su trabajo se constituya en un verdadero oficio. De ahí que una vez que la vieja intercesora se convierte en la única esperanza de salvación de Melibea ("Pues ve, mi señora, mi leal amiga, y fabla con aquel señor. (Rojas, F.de, $2008: 453)^{6}$, la joven apasionada está presta a pagarle sus servicios en el acto $\mathrm{X}$, lo que aumentará las ganancias de Celestina ya prometidas/obtenidas de Calixto (la cadena de oro). Y para sacar el mayor provecho posible, la codiciosa tercera se aliará con Sempronio y Pármeno, alianza que desatará, en cambio, las pasiones primitivas de los dos criados y empujará a los tres a su trágico final.

Por otro lado, si bien el ama de cría de $\mathrm{Fedra}^{7}$ no presenta en su determinación moral las negativas características y acciones que sí exhibe Celestina, ambas manifiestan una capacidad extraordinaria para manejar técnicas de persuasión a través de la palabra. ${ }^{8}$ Desde un comienzo la Nodriza alienta a Fedra a la confidencia, en la certeza de que entre mujeres no existen

5 "Como ha estudiado de manera ejemplar P.M.Cátedra en Amor y Pedagogía en la Edad Media (1989) Salamanca : Universidad de Salamanca, los elementos que describen en la obra la intervención de Celestina, no dejan lugar a dudas que constituían una "philocaptio" diabólica y por tanto herética. Celestina parece adecuarse a la descripción frecuente en la literatura doctrinal y pastoral de las viejas que practicaban, de las que decían que eran más eficaces que el propio diablo, para mostrar que ejercían su oficio de tentador" (Lacarra, M.E. (1989) : 21, nota 28).

${ }^{6}$ Los números entre paréntesis se refieren a la(s) página(s) de La Celestina de la edición de Peter Russell, 2008.

7 "Hipólito es el único caso que conocemos en que un trágico re-presenta el mismo episodio mítico. Pese al carácter fragmentario de la evidencia del primer Hipólito, la responsabilidad de la nodriza en revelar la pasión de Fedra puede considerarse una variante introducida en la segunda versión. No se tiene directa evidencia de que esta esclava apareciera en la primera tragedia, aunque hay amplio consenso en admitir que sí. Recientemente E. Mc. Dermott ha defendido la hipótesis de que el rol de la nodriza en el drama original (Hippolytos Kalyptomenos) sería exactamente el opuesto al de la versión que nos ha llegado. Por su parte, W. S. Barrett, en coincidencia con Bruno Snell, sostiene que es posible que el rol disuasor de la nodriza de la Fedra de Séneca estuviera inspirado en el primer drama de Eurípides: "The servant as confidant is a likely device for Euripides but less likely for Sophocles." Barrett (1968) 35. (Gambón, L., 2003).

8 "En la escena de persuasión que sigue a la apología de Fedra (433 y ss), la nodriza da muestras de una gran habilidad retórica al procurar hacer desistir a su señora de la determinación de morir e inducirla a actuar conforme a sus deseos. (Gambón, 2003: 20). 
males indecibles (aporrhêtôn kakôn, 293). A pesar del obstinado silencio de aquella, se dirige una y otra vez a su señora en una peligrosa provocación finalmente exitosa. Con estrategias que van de la violenta recriminación inicial a un moderado tono confidencial, de la interrogación apremiante a la compulsión de la súplica, apelando a Fedra como mujer (293-6), como philos (297-300), como madre (305-6), y finalmente como suplicante (310-33), la nodriza desoye las protestas de su señora y no se detiene ante la renuencia de Fedra a decirlo todo. Argumentando que el silencio es una forma de traición (304-310), la revelación, un medio de procurarse eukleia (332), impulsa a Fedra compulsivamente al legein. (Gambón, L., 2003 : 19-20).

Las dos materializan los deseos ajenos: primero, intuyéndolos y, después, sacándolos a luz. Precisamente, en el Acto X, en el segundo encuentro entre Celestina y Melibea, las palabras de la joven dan cuenta de su sufrimiento: "¿Cómo dizes que llaman a este mi dolor, que assi se ha enseñoreado en lo mejor de mi cuerpo?" (Rojas : 449); ambas reconocen lo que sucede pero Melibea no quiere hablar directamente de su pasión. La sagaz y tenaz "madre-maestra" Celestina quiere provocar su confesión y poco a poco lo irá consiguiendo hasta que finalmente la joven revelará sus sentimiento más íntimos: "Pospuesto todo temor, has sacado de m pecho lo que jamás a ti ni a otro pensé descubrir" (Rojas : 451).

Asimismo, en ambos parlamentos, son las intermediarias las que mencionan el "nombre prohibido". Aclara Peter Russell con respecto a La Celestina: "Este nombre [Calisto] ba venido representando, para Melibea, un verdadero nombre tabú, tabú que finalmente Celestina logra romper en esta escena a costa de hacer a la joven desmayarse. Recuperada y libre al fin del tabú, ahora la joven puede admitir su amor ante al alcabueta". (Rojas : 450, nota 55).

En consecuencia, mientras que Fedra se arrepiente vivamente de haber confiado su secreto y no encuentra otra solución más que la misma muerte ${ }^{10}$, Melibea confesará a Pleberio que Celestina tuvo el mérito de "descubrir la pasión" y de "sacar el secreto amor del pecho". (Rojas : 599), merecimiento que también terminará en tragedia, porque "que crueldad sería, padre mio, muriendo él [calixto] despeñado, que yo viviese preñada?” (Rojas : 600).

${ }^{9}$ Nodriza: ¿Qué dices? ¿Amas, hija? ¿A cuál de los hombres?/ Fedra : Al hijo de la Amazona, cualquiera que haya sido alguna vez su/ nombre./ Nodriza: ¿A Hipólito mencionas?/ Fedra: Escuchas esto de ti, y no de mí. (Eurípides, 2007 : 350-353) Melibea: ¿Cómo se llama?/ Celestina: No te lo oso dezir./ Melibea : Di, no temas./ Celestina : ¡Calisto! (...)” (7) (Rojas, 2008 : 449-450)

10 "Me he perdido al revelar mis desdichas, cuando intentaba curar esta enfermedad de manera amistosa pero ineficaz" (Eurípides, 2007: 596-597); "No sé nada, excepto una cosa: que morir lo más rápido posible es el único remedio para los sufrimientos que ahora padezco". (Eurípides, 2007: 599-600). 


\section{La hechicería o magia:}

En este último aspecto pretendemos comparar, en cuanto a su arte de hechicería, a los personajes que han sido eje de este trabajo, pero de manera sucinta y sólo en algunas características en común, dejando otras para continuar en una segunda etapa.

En primer lugar, haremos referencia al marco histórico-socio-cultural: ambos personajes viven en épocas en las que el uso de la magia y sortilegios es un hecho común. Por un lado, podemos aseverar que en Grecia y Roma se empleaban procedimientos mágicos para lograr fines tales como controlar la naturaleza, la ganadería, y la agricultura. Pero también en múltiples ocasiones se usaba con intenciones torcidas y se destacó sobremanera la hechicería erótica. (Caro Baroja, J., 1995 : 37)..

Reafirman este concepto autores como Homero, en el siglo VIII a.C., al tratar el tema de la magia en la Odisea, en la presencia de la deidad de los hechizos, la maga Circe, señora de la isla de Eea, quien manifiesta su crueldad, celos e hipocresía transformando a los desconocidos o enemigos en animales mediante pociones mágicas. Famosísimas fueron también la Medea de Eurípides, la Enotea de Petronio, la Dipsas de Ovidio, entre tantas otras reconocidas magas.

Por otra parte, con referencia al siglo $\mathrm{XV}$, es bien sabido que gracias a investigaciones de valor científico, es decir, a partir de documentos exhumados de los procesos inquisitoriales, de tratados sobre brujería (tal es el caso del famoso Malleus Maleficarum o 'Martillo de las Brujas'), como también de datos que venían de la historia de las costumbres, ha llegado a nosotros el conocimiento de cuán arraigadas estaban en toda Europa no sólo las prácticas y las creencias mágicas sino también una atmósfera de satanismo más general (Botta, P., 1994 : 43) (11). Precisamente, uno de los investigadores de envergadura, Julio Caro Baroja, dice al respecto: "La magia, [...] aquí, en Europa, desde la época de Homero da pábulo a poetas, dramaturgos y novelistas y en España nos encontramos con que, si no sabemos algo de lo que es la mentalidad mágica, correremos el riesgo de no comprender obras como «La Celestina», el «Quijote» o «El caballero de Olmedo»". (Caro Baroja, 1974 : 176).

Otra muy interesante coincidencia radica no sólo en que en ambas épocas hay una estrecha relación entre la magia y la medicina sino también en el hecho de que las dos eran viejas conocedoras de las artes, los quehaceres mágicos y rituales para curar enfermedades de las mujeres. Así, por ejemplo, en el verso 243 del Hipólito de Eurípides, Fedra llama a su nodriza con el término griego maia. Al respecto dice Nápoli: "[Lo] hemos traducido como nana (por el valor afectivo que encierra), pero que alude en realidad, al oficio de la Partera”. (Nápoli, J. T., 2007 : 182, nota 37). Y puesto que Fedra está enferma, será la Nodriza quien se ocupará de curarla del mal mediante brebajes de encantamiento amoroso (Eurípides, vv. 509-510). 
En cuanto a Celestina que es "un poquito hechicera", en el Acto X, en su segundo coloquio con Melibea, la vieja alcahueta es el médico y Melibea, la enferma. Afirma Botta: "Su especialidad son las 'enfermedades ginecológicas' que sabe tanto diagnosticar como curar: por ejemplo el 'mal de la madre' o algia menstrual de que discurre con Areúsa en el Acto VII. Es además partera y ‘física de niños', y en fin, suele citar algunos tecnicismo médicos que usa con gran propiedad". (Botta, 1994 : 46).

Finalmente, sorprende el grado de similitud de la conjura del mal de amores con palabras mágicas a partir de un objeto obtenido de uno o de los dos amantes, tanto por parte de la vieja aya de Fedra como por parte de Celestina. Así, desde el verso 509 al verso 515, la Nodriza asegura tener en su casa filtros mágicos de amor que liberarán a Fedra de su enfermedad pero para ello se hace menester conseguir algún objeto de la persona deseada o un rizo o un trozo de peplo y obtener de los dos enamorados un solo gozo. Al respecto, expresa Nápoli: "[...] Creemos que su significado es claro, aunque deliberadamente ambiguo. Las dos cosas de las que se habla aquí, y que hay que unir para obtener un único beneficio, son los filtros (y el término alude tanto a los fármacos, ungüentos o brebajes destinados a un objetivo determinado, cuanto a las palabras de encantamiento pronunciadas junto con ellos) y la señal de la persona deseada". (Nápoli, 2007 : 194, nota 58 ).

También la sabia tercera ruega para que Melibea le entregue "una oración, señora, que le dixeron que sabías, de Sancta Polonia para el dolor de las muelas, Assi mismo tu cordón, que es fama que ha tocado todas las reliquias que ay en Roma y Jesulam”. (Rojas : 331-332). Con ello Celestina está aplicando el principio de la magia contaminada o contagiosa según el cual un objeto una vez estuvo en contacto con una persona determinada transmitirá al que lo posea en lo sucesivo las mismas propiedades que la persona anterior (Botta, 1994 : 50). Sin poder precisar más por falta de espacio, podemos concluir este aspecto afirmando que en ambas obras la temática del hechizo y sortilegios juega un papel destacado y que la misma ha sido elaborada con tal precisión simbólica que las palabras empleadas remiten a conjuros de doble sentido: el cultural y el estético.

\section{Conclusión:}

El hecho de que tanto Eurípides como Fernando de Rojas hayan concebido dos arquetipos diferentes en su estilo y en el contexto en el que están enmarcados, pero coincidiendo ambos en la riqueza de su tratamiento con respecto a la intermediación amorosa y a la hechicería, señala el virtuosismo de ambas obras, Hipólito y La Celestina, en su faceta polisémica y en su legado para las numerosas obras posteriores. 


\section{Bibliografía}

Botta, Patricia (1994), "La magia en La Celestina", Dicenda. Cuadernos de Filología Hispánica 12.

Callejo, Jesús (2006), Breve historia de la Brujería, Madrid, Edic. Nowtilus.

Caro Baroja, Julio (1974), De la superstición al ateísmo, Madrid, Taurus.

Díaz-Plaja, F. (1965), "El protagonista y su criado”, en Ensayos elegidos, Madrid, Edit. Revista de Occidente.

Gambón, Lidia (2003), La nodriza y la voz del otro en Hipólito de Eurípides, in V Jornadas de Cultura Clásica: Perresía, licentia verborum y Verdad, Ciudad de Buenos Aires, USAL. PDF.

Homero (2000), Odisea, Madrid, Gredos.

Lacarra, Ma . Eugenia (1989), La parodia de la ficción sentimental en La Celestina, Valencia, Celestinesca, vol.13, No.1.

Mossé, Claude (1990), La mujer en la Grecia clásica, Madrid, Edit. Nerea.

Nápoli, J.T. (2007), Eurípides. Tragedias, Madrid, Colihue, Tomo 1.

Rojas, F. de (2008), La Celestina. Comedia o tragicomedia de Calisto y Melibea, Edic., introd. y notas Peter Russell, Madrid, Castalia.

Tovar, A. y Belfore Mártire, M. T., (2001), Propercio, Elegías, Madrid, Cátedra. 


\title{
“ ¿NO HABRÁ TRANSUBSTANCIACIÓN NI VÍCTIMA EMISARIA!”: SUBVERSIÓN DEL MITO Y DESENCANTO EN ANTÍGONA... ;CERDA! De Luis Riaza
}

Ezequiel Gustavo Rivas Universidad de Buenos Aires

\begin{abstract}
Antígona de Sófocles, considerada durante siglos la mejor tragedia de la producción clásica, ha sido leída e interpretada por diversos ejes, tales como el filosófico, el religioso y el político. Este último, donde la dupla Antígona-Creonte funcionaría como encarnación de los ideales de liberación y revolución frente al poder del establishment dominante. En la España de la última etapa de la dictadura franquista y los primeros años de democracia, el mito de Antígona es re-interpretado y re-leído desde otra óptica: el desencanto ante la corrupción y la inutilidad del sacrificio por los ideales. Así, Riaza, mediante diversos procedimientos tomados del teatro de vanguardia subvierte el mito de la heroína, reinterpretándolo y haciéndolo productivo a la luz de la historia reciente.
\end{abstract}

La figura de Antígona como representante de los valores de libertad y convicción de las propias ideas se inscribe en la larga tradición literaria del texto de Sófocles. Antígona, considerada durante siglos la mejor tragedia de la producción clásica, ha sido leída e interpretada a partir de diversos ejes, entre ellos el filosófico, donde la obra representaría, según Nussbaum ${ }^{1}$, un estadio primitivo de la vida y del pensamiento ético; el eje religioso, con la célebre diatriba entre la "leyes no escritas" sostenidas por Antígona y las "leyes de la ciudad" fijadas por Creonte. Pero sobre todo el eje político, donde la dupla Antígona-Creonte funcionaría como encarnación de los ideales de liberación y revolución frente al poder del establishment dominante, ha sido uno de los ejes más productivos en cuanto a interpretación de esta tragedia. El mito del personaje de la hija de Edipo que se enfrenta incluso hasta la muerte por defender sus convicciones es un Leitmotiv, por ejemplo, del movimiento de independencia griego a fines del siglo XIX. En el siglo XX, las versiones de Anouihl y Brecht son cabales ejemplos de esta última lectura política.

Por otra parte, en España, en el contexto del final de la dictadura franquista y su transición a la democracia, asistimos no sólo a un cambio en la escena política sino además a una importante transformación en los paradigmas teatrales. Las vanguardias, que hasta el momento habían influido en la escena de modo decisivo durante la dictadura de Franco como un modo de

\footnotetext{
${ }^{1}$ Nussbaum (1995: 90).
} 
contestación al régimen y como un lugar de experimentación y libertad, llegan en la nueva democracia a una especie de anquilosamiento y aburguesamiento en el marco de una "institucionalización" de la escena española. La escritura teatral ya no tiene el valor de combate contra el dictador, pues éste ha muerto. En este período, signado por el modelo cultural del PSOE (que ganara las elecciones de 1982), el teatro de resistencia se ve en la obligación de saltar casi de modo directo de la clandestinidad en la que operaba a los escenarios institucionales ${ }^{2}$. Además, este teatro convive con las producciones puramente comerciales, carentes de valor estético y sin ninguna aportación para la actividad teatral revitalizada. Hay, asimismo, una apuesta de parte de los aparatos del Estado en cuanto a la política cultural a una "normalización" que se tradujo, en cierta forma, en modelos estilísticos claros marcados por un tono realista, factura clásica y un volver a mirar los modelos del siglo XIX. Finalmente, el auge del cine como lenguaje y su conquista del espacio del ocio sancionan la postergación de un teatro que, en vez de reafirmar sus postulados como defensa, intenta competir con los nuevos lenguajes que le son rivales. Todo esto provoca un desplazamiento del teatro hacia la masificación y el distorsionamiento de su dimensión social ${ }^{3}$. La escritura de Riaza se ubica así en esta encrucijada histórica y funciona como un verdadero síntoma del cambio de paradigmas. Su dramaturgia, que se nutre a su vez de autores como Artaud y Beckett, pero también Weiss, Ionesco, Brook y de la tradición vanguardista presente en España desde principios del siglo XX (Valle-Inclán, García Lorca), muestra diversos elementos permanentes, que funcionan como instrumentos y constituyentes de su propia poética, como son la irrupción en la escena de objetos inanimados, máscaras, muñecos y sustitutos de humanos y animales; el uso del espacio teatral como símbolo despojado pero a su vez orientado hacia la ceremonia; el uso del mito clásico y la preponderancia de la temática del poder.

Nuestra propuesta de lectura abordará el análisis de Antígona ... ;Cerda! a partir de dos ejes que atraviesan la primera producción riaciana, signada por la transición histórica: el del desencanto ante la corrupción que proviene del poder y el de la inutilidad del sacrificio por los ideales. El mito de Antígona es en esta obra re-interpretado y re-leído por estos dos sentimientos que se respiraban en el aire de la España de fines de los setenta y comienzo de los ochenta, sentimientos ligados, en última instancia, a la temática del poder. Por otro lado, y conformando un principio esencial del "mundo riaciano", el lente del sarcasmo permite "contemplar el tinglado de la sociedad a quienes lo niegan

\footnotetext{
${ }^{2}$ Cf. Ruiz Pérez (2006: 19).

${ }^{3}$ Cf. Ruiz Pérez (2006: 20).
} 
desde adentro al tiempo que se instalan en él", subvirtiendo el mito clásico y reinterpretándolo.

No es la primera vez que en el ámbito de la dramaturgia española contemporánea el mito de Antígona sirve de metáfora para "explicar" la situación presente de opresión, censura y falta de libertad. Es frecuente en la producción del período franquista ver a esta heroína como figura del deseo de reconciliación y perdón en respuesta a la lucha fratricida producto de la Guerra Civil, pero al mismo tiempo como un símbolo de resistencia contra la dictadura de Franco 5 . En el particular mundo riaciano, Antígona es a la vez metáfora y símbolo de una realidad doble, realidad que se nutre del pasado fratricida y devastador de la Guerra Civil pero también del presente impregnado de una atmósfera de desencanto respecto de los ideales revolucionarios y contestatarios al régimen que, frente a la democracia lograda y la institucionalización cultural, en especial en lo concerniente al teatro, ya no tenían sentido. El desencanto viene así a sustituir esa voluntad de lucha contra la dictadura, y en última instancia contra el poder totalitario, que marcó a toda una generación.

\section{El mito de Antígona y el conflicto trágico}

En la obra de Sófocles es sin lugar a dudas donde hallamos la fuente primaria para el mito de Antígona ${ }^{6}$. Como sabemos, la pelea fratricida entre los hijos de Edipo, Etéocles y Polinices por el reino de Tebas pone en escena a nuestro personaje que intenta rendir los debidos honores fúnebres a su hermano, condenado a no ser enterrado por Creonte. La transgresión a esta orden desencadena la máquina trágica poniendo en evidencia el conflicto: la desobediencia de las leyes de la ciudad emanadas del tirano se oponen a las leyes no escritas. La actitud de Antígona plantea una subversión de los valores cívicos con implicancias éticas y políticas para Creonte, puesto que por una parte el muerto pertenecía a la familia cercana y dejarlo insepulto habría sido un franco quebrantamiento de la tradición ético-religiosa, pero por otra parte, como se había convertido en enemigo y "traidor", Polinices debía ser abandonado insepulto y sin honras fuera de los límites de la ciudad ${ }^{7}$. Creonte neutraliza esta tensión evidente para el auditorio, utilizando el vocabulario ético tradicional para hablar sobre el bienestar de la ciudad, pero al mismo tiempo transformándolo y alejándose de su uso ordinario y de la tradición. Para el tirano, lo bueno (agathón) y lo malo (kakón) se identifican con lo bueno y lo malo para el bienestar de la

\footnotetext{
${ }^{4}$ Miras, prólogo-introducción a Antígona... ¡ Cerda! (2006: 248).

5 Así Espriu, Antígona (1939); Jiménez Romero, Oratorio: Antígona (1969); Bergamín, Antígona y la sangre (1983). Cf. Ragué-Arias (2005: 14).

${ }^{6}$ Sobre el mito de Antígona y sus fuentes, cf. Grimal (1981: 33).

${ }^{7}$ Cf. Nussbaum (1995: 95).
} 
ciudad $^{8}$. De ahí que Antígona sea, en cuanto a su comportamiento, la peor ( $k a k e ̂)$, puesto que su ejemplo es de una maldad, a los ojos de su tío, civil: "Éste es mi pensamiento, y que nunca los malvados obtendrán más honras de mi que los justos; pero todo benefactor de esta ciudad, una vez muerto o viviendo será honrado por mi". Creonte se ubica en el centro del conflicto trágico, trasformando sus decisiones autoritarias, que chocan con la tradición, y constituyéndolas como leyes que deben obedecerse. Esto le valdrá la peor de las catástrofes, al darse cuenta de su error y su ceguera. Antígona, quien firme en sus convicciones y resolución, decide continuar adelante con su cometido, enfrenta al tirano y se transforma en heroína, no como ejemplo para el auditorio ateniense (su actitud contumaz es justamente su error) pero lo será para la posteridad. Sófocles presenta la figura de la hija de Edipo como un medio para que resalte el héroe trágico, el tirano autoritario y obnubilado por el poder.

\section{La princesa Pantígona}

Ahora bien, Riaza cambiará los polos al servirse de la historia de Antígona. Ya no será Creonte el protagonista que lleve sobre sí el dilema trágico, sino esta muchacha que adquiere en cierta forma, caracteres de su par opuesto. Toda la pieza estará atravesada por la duplicidad. Desde el Prefacio poético Riaza presenta a Antígona como un personaje que es uno y doble a la vez, en este sentido, muy alejado de su modelo clásico. El título, ya sugerente, muestra la duplicidad del personaje que contrasta con la enterza que se aprecia en el que nos trasmite Sófocles:

"PREFACIO POÉTICO PARA PENETRAR ENTRE PRÓLOGO Y PIEZA, CON LA PERSONALIDAD PROMISCUA DE LA PRINCIPAL PROTAGONISTA, LA PLURAL PRINCESA PANTÍGONA.”

La aliteración buscada refuerza el doble: Antígona es "pantígona", "promiscua" y "plural". Es imagen del ideal revolucionario por excelencia, reforzado por la imaginería en torno al color rojo: "Encarnación de la revolución, / avanzas a través de tres mil años / con tu estandarte color sangre / alrededor de tu pujante pecho, / una túnica hecha girones / y el ombliguito al aire / e, incrustado en él, / el piercing primoroso / de un rojo y rabioso rubi"10. También en la didascalia de escenografía y vestuario, "Antígona" tiene "una túnica roja con a las vestiduras del teatro clásico griego"11.

\footnotetext{
${ }^{8}$ Nussbaum (1995: 96).

${ }^{9}$ Nussbaum (1995: 96).

${ }^{10}$ Riaza, Antígona... ¡ Cerda! (1983: 255, vv. 1-9).

${ }^{11}$ Riaza, Antígona... ; Cerda! (1983: 260).
} 
El primer quiebre en el texto donde Riaza plantea una doble faceta del personaje: "Petite putain respectueuse"12. Este verso, además de mantener la aliteración del título sobre el sonido de la labial sorda, funciona como un verdadero oxímoron y metáfora anticipatoria: Antígona es respetuosa de lo que los dioses dispusieron sobre el tratamiento fúnebre, y por ende, al nivel semántico general de la obra, respetuosa de modelo clásico, pero al mismo tiempo es una petite putain, una 'putita', sintagma que introduce la nueva caracterización de Antígona, en choque con la tradición clásica, y en clave del eje político, anticipando la actitud de muchos supuestos "contestatarios" que se "vendieron" por dinero al poder de turno. Ella es encarnación de la "furia siempre dispuesta / a rebelarse contra toda tiranía" a través de los siglos y en todos los niveles: mítico (Creonte), histórico (Pericles, Tiberio), religioso (obispo Cauchon, quien condenó a Juana de Arco) y político (mariscal Pétain, jefe de estado en la Francia ocupada por el Reich y colaboracionista). En último término, el "tetrarqueja de El Pardo" cierra la lista y es una clara alusión a Franco, quien habitara en el Palacio de E1 Pardo, una vez terminada la Guerra Civil.

Entre los versos 33 y 52 Riaza retoma el mito, haciéndonos saber que Antígona prefirió la muerte como reacción frente al tirano: "Todo por dar preferencia, / sobre el buche de los abantos, / a las tripas alargadas / de las larvas croque-morts, [...] terminando por ello / en un fúnebre agujero / con el bimen intacto / para ser desvirgadita / por Monsieur Death, / a no ser que fuera / por Mister Mort." Efectivamente, Antígona muere sin poder desposarse con Hemón, hijo de Creonte, al cual estaba prometida: "Es el Aqueronte con quien me voy a desposar"13. Riaza rompe la entereza de Antígona y evidenciando su doblez, diciendo que "más te hubiera valido / servirte de tu otra mitad / para ser deszoncellada". La otra mitad, aquí, reforzada por quien debería desvirgarla, también en tres planos: mítico (Hemón, hijo de Creonte), artístico (Raniero de Mónaco, que casó con la actriz Grace Kelly, ícono del cine) y político (Carlos de España, puesto en el trono por Franco). Este uso de su otra mitad, de su doble que se entrega al poder, le hubiese dado la posibilidad de parir "nuevos príncipes" como perpetuación de la estirpe y del poder ${ }^{14}$, y por tanto dejando de lado sus ideales ético-religiosos y optando por el pensamiento político en bien de la ciudad, que se traduce en una verdadera corrupción.

El Prefacio se cierra con un estribillo que resume lo anteriormente expuesto, funcionando como clave de lectura de la obra: "Tenemos una Antígona

${ }^{12}$ Riaza, Antígona... ;Cerda! (1983: 255, v.10).

${ }_{13}$ Sófocles, Antígona, v. 815.

${ }^{14} \mathrm{El}$ tema de la "perpetuación de la especie" como imagen de la perpetuación en el poder se encuentra en otras producciones de Riaza, como por ejemplo Los perros (1986). Para una contextualización de la obra de Riaza en el período de transición, cf. Oliva (2007: 238-239). 
roja / y una Antígona cerda, arrebujadas / ambas dos bajo el mismo pellejo / en forma de bicéfalo revoltijo, / o del doble de novelero prestigio". Para Riaza, los mitos clásicos contienen ya todos los componentes de la modernidad: en la Antígona mítica ya se encuentra la posibilidad del trastocamiento de valores y de la actitud acomodaticia en relación con las instancias de poder que la Antígona contemporánea concentra en su persona.

\section{Antígona, espacio del desmonte}

La desarticulación del mito y su subversión no se dan solamente al nivel del texto, como hemos visto, sino que Riaza despliega una serie de procedimientos escénicos que tienden a hacer visible tal desarticulación. A caballo entre los preceptos simbolistas, presentes ya en la tradición dramática española, como ser el concebir el espacio escénico como todo un símbolo (espacio central, potente iluminación, blancura total de la plataforma), encontramos también elementos de las vanguardias más recientes y del teatro de la crueldad de Artaud (pedazos de carne sanguinolenta, colgajos, animales muertos, maniquíes, piezas ortopédicas $)^{15}$. El espacio se convierte así en símbolo de la violencia que atestigua por un lado la tradición mítica que sustenta la historia de Antígona (el fraticidio de Polinice y Etéocles se constituye en imagen de una inútil guerra intestina, y señala el final de una estirpe) y por otro su correlato con la historia pasada reciente: la Guerra Civil, fraticidio violento que signó a España y se continuó en la dictadura de Franco. El espacio de la sociedad, la pólis, es desmontada, demolida, quebrada y pasa a ser un espacio vacío, espacio de la representación de la violencia.

Los elementos escénicos marcan quiebres en la tradición y demuelen el mito bajo la lógica de la sustitución, uno de los ejes centrales de la poética riaciana. Así, los pollos muertos que encuentra el Coro sustituyen a Etéocles y Polinices, la decoración Luis XV sustituye el espacio del palacio de Tebas por el de El Pardo en Madrid ${ }^{16}$.

Siempre en esta lógica de la sustitución, el personaje de Ismene-CreónHemón también se liga al pasado clásico (el segundo actor representaba más de un personaje en la tragedia, con ayuda de la máscara) y al mismo tiempo muestra una indefinición sexual ligada al cambio de postura política de esos tres personajes, conformando así una tríada viciosa, sin solución y que puede

15 Elementos de la tradición dramática española los encontramos en Valle-Inclán, donde la didascalia escénica conforma un todo que intenta dar hasta el mínimo detalle, conformando el ambiente ideal donde surje el esperpento como deformación de la realidad, y en García Lorca, por ejemplo, en la presentación del espacio en La casa de Bernarda Alba: "Habitación blanquísima del interior de la casa de Bernarda" (Acto I).

${ }^{16}$ Riaza, Antígona... ;Cerda! (1983: 259) 
verse también a nivel del texto, en la ambigüedad del género: "Se destapa IsmeneCreón-Hemón. Aparece vestida con el atuendo de un moderno joven 'contestatario". Antígona despierta a Ismene ("Despierta, Ismene! ¿Cómo puedes dormir?), pero en realidad no sabemos si es Ismene o Hemón o ambos juntos, pues hacia el final de este diálogo la protagonista se dirige en estos términos: "ANTIGONA (a ISMENE-CREON-HEMON).- ;Ya me lo has dicho! Tú prefieres continuar con tu situación. Agarrado como un piojo a tus privilegios de principito regalado "17.

$\mathrm{El}$ encuentro con Creón enfrenta a Antígona con el discurso del poder instalado que "tienta" a la revolucionaria. Este diálogo puede incluso leerse de modo intertextual, puesto que el tío la tienta como si del mismo demonio se tratara al tentar a Jesús: "ISMENE-CREÓN-HEMÓN.- Pues ya ves: también esta vez me acordé. (Se acerca al arca. Saca el collar que llevaba en su faceta isménica. Selo tiende a ANTÍGONA. Ésta lo coge un momento. Lo contempla). ANTÍGONA.La primera de tus tentaciones: la falsa revolución... [...]; Cerdo asqueroso...! Guárdate las estúpidas cáscaras de tu revolución reducida a los signos y a los gestos... ISMENECREON-HEMÓN.- ¿¿Dónde quieres llegar, Antígona? ANTIGONA.- ...Signos que, al propio tiempo, te engordan la faltriquera vendiéndolos como pan caliente a los consumidores de collares, de amuletos, de cantantes rebeldes... ;Rey tendero!; Cerdo, cerdo, cerdo, cerdo...!"18 Es la tentación a la corrupción del poder, al bienestar a costa de la traición. Si no acepta, si no quebranta los ideales del sacrificio, quizás "le arranquen la lengua en algún cuartito de tus sótanos", donde se nota una clara alusión al modus operandi del franquismo: la tortura.

Riaza, en la voz de Antígona, también critica el teatro burgués, que ha transado con el poder: "Mi tio resultó ser todo un orador! Tu Consejo de matusalenes seguro que te aplaudirá a rabiar con piezas semejantes. ¿Por qué no te dedicas al teatro?" Para nuestro dramaturgo, el teatro burgues señala la muerte del teatro, y el único modo de hacerlo renacer es justamente recurriendo a la ceremonia, al rito como origen del mismo; de ahí los recursos escénicos y poéticos que emplea en sus obras. No solamente el teatro es criticado como institución cultural, sino también la Iglesia como aparato de legitimación del poder:

"ANTÍGONA.- [...] Pero no estoy dispuesta a dar gusto a esos verdugos patriotas. No baréis de mi cuerpo el pan de vuestra cena de compinches. Ni de mi sangre, el vinillo que moje vuestro almuerzo de trabajo. ¡No habrá transubstanciación ni víctima emisaria!"'19 Sobre la base del texto de la consagración del pan y del vino, Antígona reniega del sacrificio, renuncia a los ideales de cambio, termina ahogando la voz de la libertad uniéndose al príncipe heredero, Hemón:

\footnotetext{
${ }^{17}$ Riaza, Antígona... ;Cerda! (1983: 265)

${ }^{18}$ Riaza, Antígona... iCerda! (1983: 269-270)

${ }^{19}$ Riaza, Antígona... ; Cerda! (1983: 273).
} 
“Matrimoniaremos, engendrarás en mí reyes y reyes, yo pariré para tí reyes y reyes, y colorín, colorado...!'20

A partir de este momento, asistimos a la transformación del personaje y al final de la obra. Toda la escena se transforma junto con Antígona: pasa de ser roja a cerda, el pollo-Polinices es descolgado y se transforma en el plato del banquete. Todo ha vuelto a una aparente "normalidad". Ambos han derrocado al "vendido pelele de palacio", pero reproducen ellos mismos el esquema de poder, instalándose en el trono de Tebas. La mención de la peste, en el final, última palabra en boca de la protagonista, denota un doble significado y nos da la clave final de interpretación: la peste del poder transforma, quebranta, corroe y tiene como consecuencia el desencanto, la renuncia. Hemón es ahora el rey Edipo. Antígona es su esposa. Ambos comparten el trono. La peste -mitológica como la de Tebas en los tiempos de Edipo, actual como la heredada del franquismono se ha ido, vuelve a la ciudad, y las instituciones políticas, para Riaza, no han sido sanadas o libradas del flagelo.

${ }^{20}$ Riaza, Antígona... ;Cerda! (1983: 273). 


\title{
Animalizar lo masculino: PENTEO EN BACANTES DE EURÍPIDES ${ }^{\mathrm{I}}$
}

\author{
Elsa Rodríguez Cidre \\ Universidad de Buenos Aires - Conicet
}

\begin{abstract}
En la sociedad ateniense se detecta continuamente la referencia al mundo animal salvaje como el lenguaje de un mundo prepolítico y por ello conforma un mecanismo de construcción en el imaginario de la alteridad. Esto es visible en el diseño de las mujeres trágicas frecuentemente animalizadas. Sin embargo, también hallamos personajes masculinos en este registro. Intentamos relevar las referencias corporales de Penteo en Bacantes para calibrar sus cargas sémicas y su función en la estructura de la obra. La animalización presenta una riqueza que invita a su focalización en la tragedia: Eurípides despliega en Bacantes un uso muy importante, con diversidad de mecanismos y de grados de intensidad dramática.
\end{abstract}

Los personajes de la tragedia griega suelen ser objeto de un proceso de animalización. Este habitual mecanismo de construcción de la alteridad se detecta especialmente en los personajes femeninos de Eurípides (a menudo también extranjeras y esclavas, una suerte de alteridad exponencial) pero no es un coto exclusivo de las mujeres sino que es posible también hallar a personajes masculinos en este registro. Nuestro objetivo en esta ponencia es relevar un caso paradigmático, la animalización de Penteo en Bacantes de Eurípides y analizar las referencias a su cuerpo (íntegro primero y descuartizado después) de modo de calibrar sus cargas sémicas y su función en la estructura general de la obra.

La animalización de Penteo se estructura básicamente en torno de su sparagmós o descuartizamiento que ejecutan, llevadas por la locura báquica, las ménades de Dioniso conducidas por Ágave, la madre del protagonista ${ }^{2}$. Es esta escena (vv. 1088 y ss.) la que dispara una serie de animalizaciones generales y específicas sobre el cuerpo del joven rey de Tebas, o más bien, sobre lo que restará de él, su cabeza portada a palacio como trofeo por su madre filicida, agente inconsciente de la venganza del dios sobre aquel que le negara reconocimiento y culto.

El sparagmós de Penteo no se produce sin una preparación del espectador. En efecto, la trama presenta previamente, en los vv. 731 y ss., una escena de

\footnotetext{
${ }^{1}$ La presente ponencia se enmarca en el proyecto PICT 2008-0206 (ANPCyT). La edición base es la de Diggle.

${ }^{2}$ Para un detalle de la iconografía del sparagmós, cf. Hernández de la Fuente (2001: 89-91).
} 
fuerte intensidad dramática en la cual las ménades proceden en el bosque al descuartizamiento de unas reses munidas solo con la fuerza de sus manos y del influjo báquico. Esta escena, que destila sangre y prolifera en la descripción de colgajos de carne, se conjuga con otro elemento dionisíaco, la omophagía. Este consumo de carne cruda reverbera en el auditorio que ha escuchado de boca del coro cómo Dioniso se da al gusto de la carne cruda del cabrito que captura en el bosque (vv. 135-140).

Al mismo tiempo, otro descuartizamiento funciona en esta obra como un trasfondo mítico muy cercano a los protagonistas. Se trata del de Acteón, cuyo cuerpo fuera despedazado por su propia jauría, en el mismo lugar en el que acontecerá el de Penteo, quien a la sazón es su primo ${ }^{3}$. La referencia al sparagmós de Acteón se produce antes y después del de Penteo. En los vv. 337-342, Cadmo intenta poner en razones a su nieto recordándole el funesto destino de su primo, quien en la versión de Cadmo (que difiere del mito tradicional) sufre su muerte por una ofensa directa contra una divinidad:

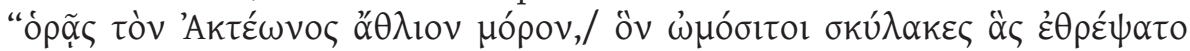

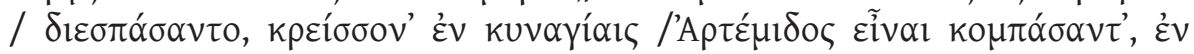

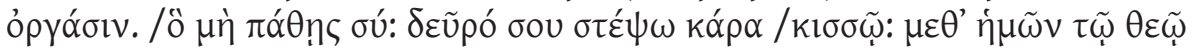

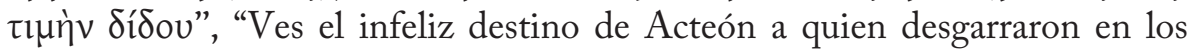
bosques las perras comedoras de carne cruda que él alimentó, por haberse jactado de ser superior a Ártemis en las cacerías. No sufras tú esto: aquí coronaré tu cabeza con hiedra; honra con nosotros al dios". El desafío de Acteón a Ártemis homologa el de Penteo a Dioniso, lo cual sumado al hecho de que Eurípides feminiza a la jauría, hace de la muerte de Acteón una anticipación de la de su primo. Recordemos que Ágave (vv. 731-733) y el coro (v. 977-981) relacionan a las "perras" con las ménades. Rescatemos también la referencia a la carne cruda. Por último, cuando al final de la obra Ágave regrese del influjo báquico y tome conciencia de su filicidio, sabrá de boca de Cadmo que Penteo

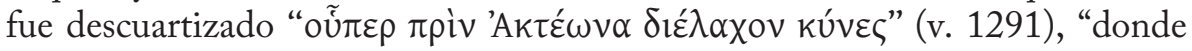
antes las perras se repartieron a Acteón"4.

Más allá de la sugerente relación entre Penteo y Acteón, el mero paralelismo entre el descuartizamiento de las reses y el sparagmós del rey tebano ubica al personaje de lleno en el plano animal. Antes de esta escena, es posible relevar

${ }^{3}$ La madre de Acteón se encuentra entre las ménades, como se ve en los vv. 228-230 y $1227-1232$.

${ }^{4}$ Tangencialmente podríamos incluir otro sparagmós en el horizonte, aquel que sufriera Orfeo (mentado en los vv. 561-563) a manos de las ménades por rehusarse al eros. Este personaje

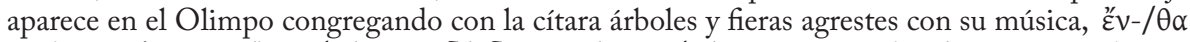

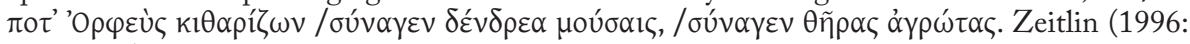
283 n.120) señala que Orfeo rehúsa el eros -o por lo menos el eros heterosexual- después de su pérdida de Eurídice y es despedazado por ménades (así lo presenta Virgilio en Geórgicas 4.516522 y Ovidio en Metamorfosis X.78-83, 11.7). 
referencias a una animalización del rey tebano pero todas se sitúan en un plano más connotativo que denotativo. Así el adivino Tiresias (v. 361) se referirá a

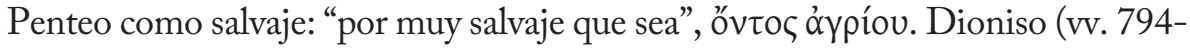
795) califica la conducta de su rival también en clave animal al afirmar que el tebano "cocea" ${ }^{5}$. Asimismo, también en boca del dios se dice que Penteo cae en la red, $\dot{\varepsilon} \varsigma \beta \beta^{\prime} \lambda o v$, siendo $\beta o ́ \lambda o \varsigma$ la red que se emplea para atrapar peces ${ }^{6}$. Por último, una referencia de Dioniso puede leerse también en este sentido cuando el dios explica a las bacantes que prepara el adorno de Penteo con el que partirá

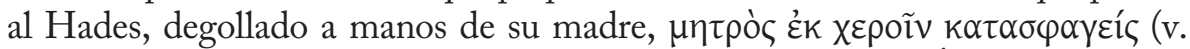
858): el degollamiento (mención equívoca por cierto ya que Ágave en sentido estricto no degollará a su hijo) plantea una valencia animal al situar la referencia en el mundo simbólico del sacrificio ${ }^{7}$. Como vemos, se trata en todos los casos de formas indirectas y contextuales de animalización de Penteo.

Si nos ubicamos en el desarrollo del descuartizamiento, la animalización comienza a tornarse directa. En los vv. 989-992 Ágave se pregunta acerca de quién ha dado a luz al espía de las montaraces cadmeas y su respuesta

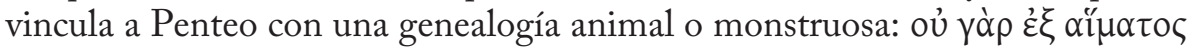

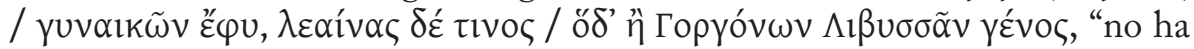
nacido de sangre de mujeres sino de alguna leona o del linaje de las Gorgonas de Libia" ${ }^{\circ}$. Ya a punto de concretarse el sparagmós, el mensajero cita las palabras de Ágave donde anima a las ménades tebanas a rodear en círculo el tronco del

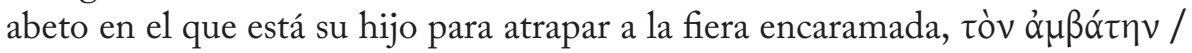
$\theta \tilde{\eta} \rho^{\prime}$ (vv. 1107-1108) ${ }^{9}$. Penteo ha devenido ahora en fiera, pero como señala Dodds (1960: 216), se trata de una bestia que también actúa como humano al

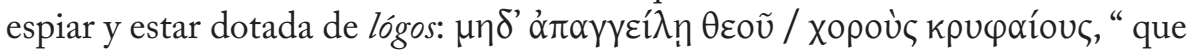
no divulgue las secretas danzas del dios" (vv. 1108-1109)

${ }^{5}$ Penteo amenaza a Dioniso y este le responde que él habría sacrificado al dios antes que

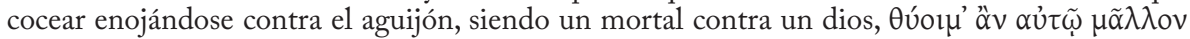

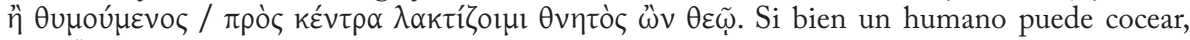
$\lambda \alpha \kappa \tau i \zeta \omega$, los ejemplos son abundantes respecto de animales y es sugerente la idea del rey dando patadas contra un dios y alejándose de su condición humana. Esta metáfora aparece en $f r$. 604, A.A. 1624, A.PV323, Pi. P. 2.94, cf. Seaford (1996: 212). Cf. también Dodds (1960: 180). Roux (1972: 504) se detiene en el uso de la voz media ya que podemos interpretar que Penteo se arroja a sí mismo en la red después de haber rehusado todos los medios de salvación que le fueron ofrecidos. Para esta autora el v. 847 funciona como un veredicto en tanto es la primera mención en la obra de un castigo de Penteo.

${ }^{6}$ Para la metáfora, cf. E.Rh. 730, E. Alexandros fr. 43 y Hdt. I.62.4

${ }^{7}$ Para un estudio de la degollación en clave animal cf. Rodríguez Cidre (2010: 195-226).

${ }^{8}$ Bollack (2005: 82) señala que el enemigo no puede ser más que animal; es la fase monstruosa de la animalidad. Para un estudio de lo monstruoso en el personaje de Penteo, cf. Rodríguez Cidre (2011b).

${ }^{9}$ Para el valor ritual de este verso, cf. Roux (1972: 580-581).

${ }^{10}$ Ver también Seaford (1996: 237). 
A partir del v. 1125 empieza en sentido estricto el sparagmós del rey. En la descripción de la dispersión de las partes del cuerpo el mensajero nos relata que Ágave ha tomado la cabeza y después de hincarla en la punta de su tirso la lleva como si fuera la de un león salvaje ỏ $\rho \varepsilon \sigma \tau$ ́́ (vv. 1141-1142)11. Es la primera vez que nos encontramos con un animal concreto respecto del proceso de animalización de Penteo, aunque en un punto ya viene anunciado con la remisión previa a la sangre de leona ${ }^{12}$. A partir de aquí esta imagen leonina será recurrente. El león aparece como un trofeo de caza codiciado y es así como lo ve Ágave: $\chi \omega \rho \varepsilon \tilde{i} \delta \dot{\varepsilon} \theta \eta ́ p \alpha \underline{~} \delta v \sigma \pi o ́ \tau \mu \omega$

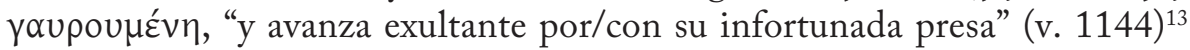
La referencia a este animal está, entonces, ligada fundamentalmente al campo semántico de la caza, en la cual brilla la reina "acompañada" siempre por el dios que la desquicia ${ }^{14}$. Respecto del acto de hincar la cabeza en el tirso, Dodds (1960: 218) sostiene que representa un toque de horror adicional, que bien podría ser otra innovación de Eurípides: en los vasos, Ágave aparece llevando la cabeza por el pelo tanto antes como después de la fecha de Bacantes y cabe notar que en el v. 1277 la madre parece tomar la cabeza de su hijo en sus manos. Roux (1972: 584-585) destaca el carácter escandaloso para los griegos de esta práctica, típicamente bárbara, que en este caso tiene la función de señalar que el castigo del hijo ya está cumplido mientras que el de la madre recién comienza ${ }^{15}$.

En el v. 1168 Ágave entra en escena con el tirso coronado con la

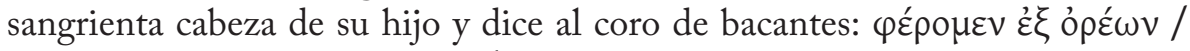

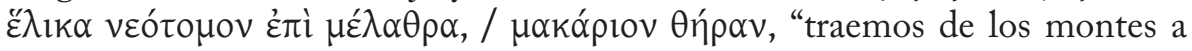
casa zarcillos de hiedra/vid recién cortados, una bienaventurada presa ${ }^{16 ”}$ (vv.

${ }^{11}$ Musurillo (1966: 62) considera que esta escena y la de la descripción de la muerte de la hija de Creonte en Medea conforman "the most nauseating descriptions in all of Greek literature".

${ }^{12}$ Cf. Seisdedos (1985: 289).

${ }^{13}$ Para Seaford (1996: 239) la separación de Ágave de las otras ménades puede relacionarse con el rol de líder en la matanza $(1114,1183,1239)$ y su función dramática permite su entrada patética en soledad.

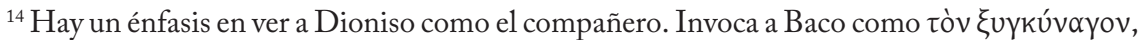

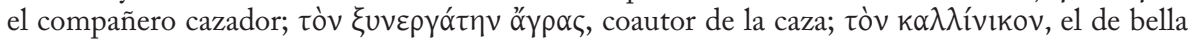
victoria (vv. 1145-1147). Para Dodds (1960: 219) los tres epítetos son paralelos e independientes representando respectivamente la caza, la matanza y el triunfo. Para Roux (1972: 584-585) las tres invocaciones de Ágave recuerdan los tres momentos del drama: la caza, la captura,

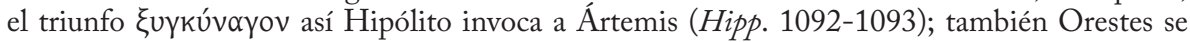
dirige así a Pílades en el momento de morir (IT709-710). Para Seaford (1996:239) la secuencia balanceada de las apelaciones en parataxis es característica de frase ritual como el encomio, cf. A.A. 896-901, P1. Smp. 197de, Gorg. B60-K.

${ }^{15}$ Así Jerjes hace cortar la cabeza de Leónidas y ordena clavarla en una estaca (Hdt., VII, 238). En Il. XVIII, 177, se dice que la intención de Héctor era clavar la cabeza de Patroclo sobre una estaca de la empalizada.

16 Seaford (1996: 242-243) señala que es la primera de las apariciones de makários (1180, 
1169-1171). Aquí los elementos animales y vegetales se entrecruzan pues Ágave identifica el cabello enrulado y la barba de su hijo con las hojas de vid de la punta del tirso ${ }^{17}$. Esta asimilación nos remite al delirio de la madre pero, tratándose de una bacante filicida, nos reenvía a la historia de Licurgo, quien bajo el influjo de la locura dionisíaca, confunde a su hijo con un vástago de viña y lo corta ${ }^{18}$. El dios, vemos, no se restringe al mundo animal para montar sus venganzas.

Las referencias a la caza son en esta sección pregnantes. Ágave explica al

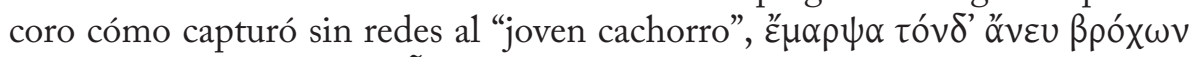

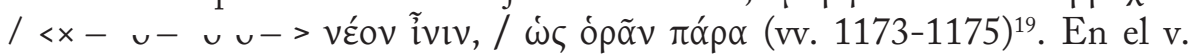
1179 la hija de Cadmo relata el hecho de haber sido la primera en herirlo ${ }^{20}$ y en los vv. 1182-1184 vuelve a referirse a su hijo como fiera y agrega una

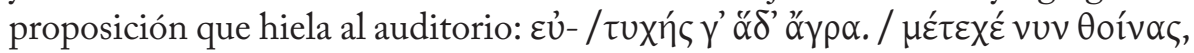
"dichosa, esta cacería; participa ahora del festín". El coro responde con una nueva pregunta que señala los alcances de su involucramiento en la locura de

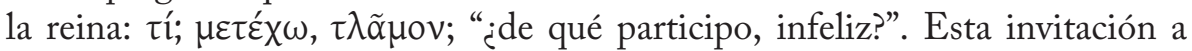
un festín, presumiblemente con los restos de Penteo como plato principal, es demasiado para el coro, como señala Dodds (1960: 224), y es por eso que su actitud de aprobación forzada se rompe ${ }^{21}$. Devendría antropofagia la omophagía dionisíaca que evoca también el tema mítico de que las ménades comen a sus propios hijos ${ }^{22}$.

Las referencias a la caza seguirán multiplicándose y se instalará claramentela tríada de elementos complementarios Dioniso conductor/Ménades cazadoras/ Penteo fiera como se ve en los vv. 1189-92 que recuerdan inmediatamente la descripción realizada por el coro de la captura y consumo del cervatillo por $\mathrm{Baco}^{23}$. La valencia leonina regresa en los vv. 1195-1196 mediante el hápax

1232,1242-3,1258), palabra que en contexto puede evocar (irónicamente) la felicidad traída por la iniciación mística $(72-4,902-5)$ así como la caza en el rito del pasaje a la adultez.

${ }^{17}$ Cf. Dodds (1960: 223).

${ }^{18} \mathrm{Cf}$. Apollod., 3.5.I. Recordemos que estas líneas fueron recitadas en el 53 a.C. en el medio de un aplauso general en la corte por un actor vestido de Ágave que llevaba una cabeza humana real, la de Craso, el general romano, cf. Plu., Crass., 33.

${ }^{19}$ Para el prestigio de la caza sin redes ver Pi. N.3.51-2, P1. Lg. 824a; cf. Seaford (1996: 243). Diggle y Seaford mantienen la laguna textual. Dodds, Roux, Di Benedetto, Torrano y Tovar

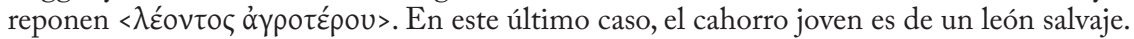

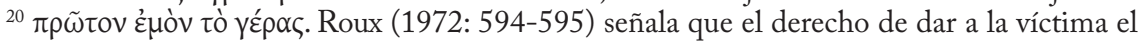
primer golpe es el privilegio reservado al jefe del tíasos, al éxarkhos; la madre de Penteo tiene ese rol a lo largo de toda la pieza $(689,731,982,1114,1125)$.

${ }^{21}$ Cf. Opp., C. 4.304, donde Penteo es transformado en toro y las ménades en panteras que despedazan y comen el toro.

${ }_{22}$ Plut. Moralia, 299e, Apollod., 3.5.2). Cf. Seaford (1996: 244-245). Cf. también Andrade (2003: 95). Roux (1972: 596) señala que Eurípides con mal gusto hace que Ágave presente un pedazo de carne para que las bacantes puedan comprobar la frescura y acepten.

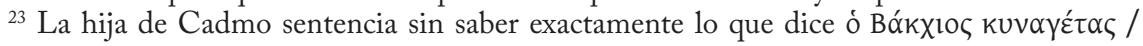


$\lambda \varepsilon \operatorname{lov}_{\tau} \varphi \varphi \tilde{\alpha}$ que describe la naturaleza de la presa, calificada de extraordinaria por Ágave y las bacantes en el marco de un despliegue de altivez en torno de la modalidad (con las manos) y resultados (cabeza de león como signo de victoria)

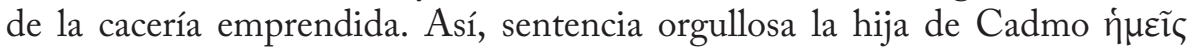

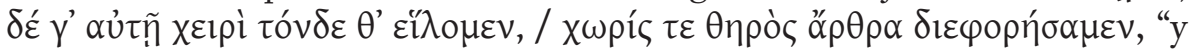
nosotras por propia mano capturamos a éste y descuartizamos los miembros de esta fiera" ( vv. 1209-1210) para pedir a continuación la presencia de su hijo para que cuelgue "en los triglifos esta cabeza de león que presento después de

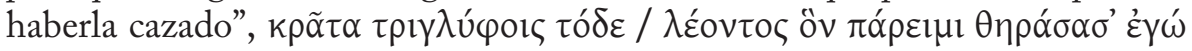
(vv. 1214-1215).

Ahora bien, no es la caza el único marco de referencia para la animalización de Penteo. En efecto, se cruza aquí otro mundo simbólico, el del sacrificio, que explica otro tipo de identificaciones animales del rey tebano. En su delirio Ágave también ve en la cabeza que porta a un joven cachorro, véoৎ ó $\mu o ́ \sigma \chi \circ \varsigma$

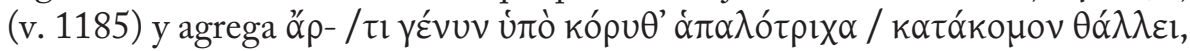
"recién florece su mejilla bajo la mata de suave cabellera que cae" (vv. 1185-

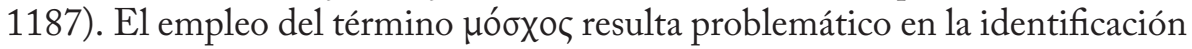
precisa del animal referido. Para las ediciones comentadas consultadas se trata de un ternero: la vellosidad bajo las mejillas de Penteo justifica mejor que una barba en el mentón la comparación con un bovino ${ }^{24}$. Seaford (1996: 244-245) marca cómo la percepción enloquecida de Ágave va variando: Penteo parece primero un león (vv. 1142, 1196, 1215, 1278), luego una hiedra (v. 1170) y ahora un toro (móskhos puede significar eso como por ejemplo en los vv. 678 y 736). Lo cierto es que si la caza requiere de animales salvajes como el león, el sacrificio (1024-1152n.) en cambio atañe a aquellos más en contacto con el mundo humano y social, vale decir, del ganado. Como ternero, Penteo puede adquirir un aspecto más humano -como un joven con su primera barba ${ }^{25}$. Su juventud evoca tanto la edad deseada de la víctima sacrificial como el lazo maternal $(1174,969,974)$. El coro en el v. 1188 mantiene la misma imagen

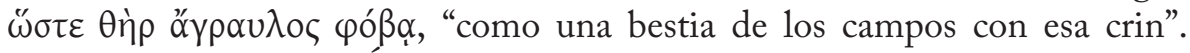
Recordemos el rol de Ágave como bieréa, sacerdotisa del sacrificio en el v. $1114^{26}$.

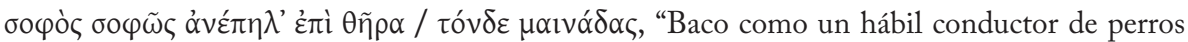
hábilmente incitó a las ménades contra esta fiera” (vv. 1189-1191) y el coro cierra ó үờ óv ớ

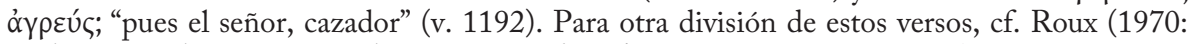
199) y Roux (1972: 595-596). El término ợpeúc es usado también para Apolo y Poseidón. Roux (1972: 596) destaca que el hecho de que esté precedida por őv $\propto \xi$, podría evocar a Zagreus, una divinidad cretense identificada con Dioniso desde tiempos helenísticos y quizás aún en tiempos de Eurípides (Cret. fr. 472, 11-15). Cf. también Dodds (1960: 224).

${ }^{24}$ Cf. Roux (1972: 596).

${ }^{25}$ Cf. X. Smp. 4.23

${ }^{26}$ Cf. Rodríguez Cidre (2011ª). 
De todos modos, caza y sacrificio muestran elementos en común, dejando de lado el obvio de la víctima animal (o animalizada como es el caso aquí). Como interpreta Seaford (1996: 237) la violencia contenida del sacrificio se transforma en la violencia desenfrenada de la caza y remarca que tanto uno como otra son seguidas normalmente de un festín común ${ }^{27}$. Asimismo, Dodds (1960: 226-227) recuerda que las cabezas de las víctimas sacrificiales eran a veces similarmente exhibidas sobre picas ${ }^{28}$.

Este diálogo entre caza y sacrificio lo vemos nuevamente en el último núcleo de la tragedia, central para nuestra cuestión puesto que el anagnorismós de Ágave, conducido magistralmente por su padre, clausura el proceso de animalización de Penteo, quien debe volver a ser humano para que la venganza sea completa. En efecto, mientras que la reina se mantiene en el registro de la gloria cazadora apelando a sus "proezas", incluso cuando Cadmo ingresa a escena con sus servidores acarreando los restos de Penteo (diferentes partes de un cuerpo descuartizado), su padre se posiciona en cambio en el ámbito del

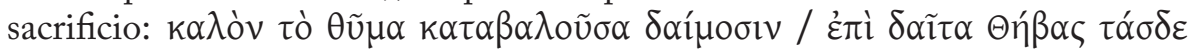
$\kappa \alpha \dot{\mu} \mu \grave{\varepsilon} \pi \alpha \rho \alpha \kappa \alpha \lambda \varepsilon \tilde{\imath} \varsigma$, "tras derribar ${ }^{29}$ la hermosa víctima de sacrificio llamas a un banquete a Tebas y a mî" (vv. 1246-1247). La cazadora, quien ya ha bajado de su tirso la cabeza (cf. 1141 y 1200) que yace en sus brazos ${ }^{30}$, responde no solo reafirmando el elemento cinegético, sino que a partir de él, como plantea Thumiger (2007: 139), viola triplemente su estatuto de madre: no reconoce a su hijo, es la causante de su muerte e incluso lo degrada en su virilidad como

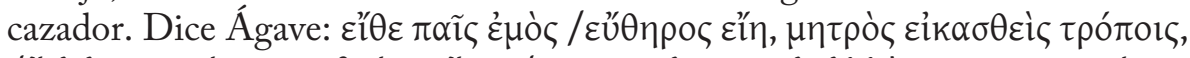

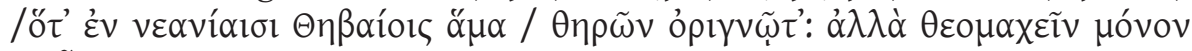

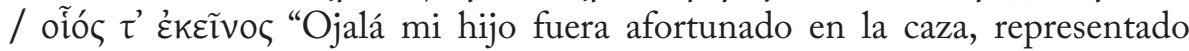
por las maneras de su madre cuando con los jóvenes tebanos conjuntamente persigue las fieras; pero aquél solo es capaz de luchar contra los dioses" (vv.

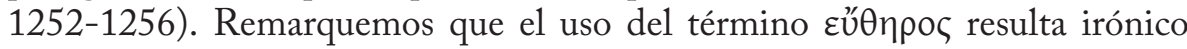
pues su significado de "buen cazador" viene dado desde una etimología que lo sindicaba como "buena fiera" 31 .

La última animalización de Penteo se da precisamente en los versos en los que Cadmo empieza a sacar a su hija del delirio báquico (vv. 1277-1284). Cuando al preguntarle de quién es el rostro que tiene en sus brazos ${ }^{32}$, ella

\footnotetext{
${ }^{27}$ Cf. Seaford (1996: 244-245).

${ }^{28}$ Recordemos cómo el mismo Eurípides en IT, 74 y ss. nos presenta a los salvajes tauros dedicando las calaveras humanas.

${ }^{29}$ Roux (1972: 606-607) señala que $\kappa \alpha \tau \alpha \beta \alpha \lambda$ oṽ $\sigma \alpha$ designa el golpe dado a una víctima de sacrificio (E.Or. 1603).

${ }^{30}$ Nótese cómo se cumple la predicción realizada por el dios en los vv. 968-969, cf. Roux (1972: 606-607).

${ }^{31}$ Cf. Andrade (2003: 96).

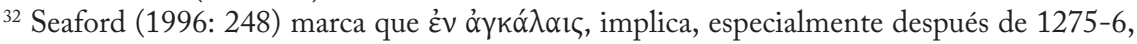




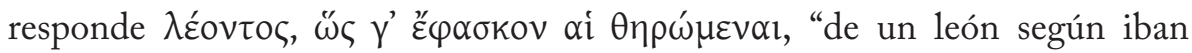
diciendo las cazadoras”. El león sigue presente pero comienza a desdibujarse pues ya no es ella quien afirma que es un león ni se incluye taxativamente en el conjunto de cazadoras. Roux (1972: 610-611) rescata el uso del término

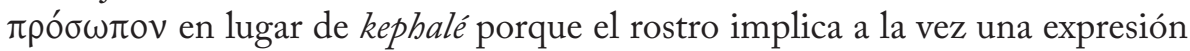
humana y una identidad. Esto nos interesa en función de la re-humanización de Penteo aunque cabe notar que esta referencia también da pie a una larga discusión respecto de la performance de la obra. En efecto, la palabra contiene también la indicación de un juego de escena: en ese momento Ágave tendría la cabeza por los cabellos y no podría ver la mirada que Cadmo la invita a examinar. Pero la naturaleza de esta cefaloforía es motivo de discusión entre los críticos pues unos consideran que se trataba de una cabeza de utilería, otros que Penteo viene representado por la peluca que Dioniso ajustara a su cabeza en la escena del travestimiento y, finalmente, la mayoría de los especialistas sostiene que $\pi \rho o ́ \sigma \omega \pi o v$, aquí como en el conjunto del drama antiguo hasta el s. IV, refiere a la máscara del actor. Ágave portaría la máscara con la que los espectadores reconocían a Penteo, una máscara que en el teatro antiguo se hacía con rostro y cabellos. En este sentido, es significativo que se trate del mismo actor el que interpreta a Ágave y a Penteo (y dado que la última imagen de Penteo para la audiencia era la de un hombre travestido, la única diferencia con Ágave radica precisamente en el cambio de máscara) ${ }^{33}$. Sea lo que fuere, llevada por la serie de preguntas que le formula Cadmo, la infeliz reconocerá que no cree que se trate de una cabeza de león sino la de su hijo Penteo $^{34}$. Una vez que la madre humaniza la cabeza de su hijo, éste no volverá a ser animalizado.

Para concluir señalemos el rol central que cumple la corporeidad de Penteo en el desarrollo general de la obra y en particular en lo que concierne al registro de la animalización. Como señala Drew Griffith (1998: 230-231, 249), deberíamos esperar en el drama un uso importante de órganos corporales como objetos significantes, desde el momento en que el cuerpo es ingresado

un niño en los brazos de su madre; cf. 969, 699-70, E.Cyc. 142, E.IT 834, E.Or. 464, E.Ion 280,1375 , etc.

${ }^{33}$ Cf. Foley (2003: 365-366), Rehm (2002: 209-210), Marshall (1999: 193), Segal (1997: 215, 239, 260-261), Wiles (1999: 174, 225), Taplin, O. (2005 [1978]: 73-74), Seaford (1996: 248). Para un detalle de la iconografía de la cefaloforía, cf. Hernández de la Fuente (2001:91-94).

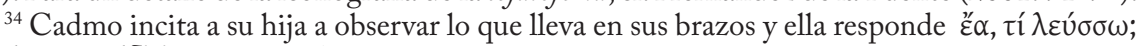

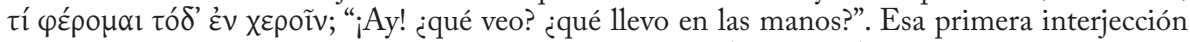
de dolor es la deixis de un inicio de anagnorismós. Dodds (1960: 231) rescata la importancia de la voz media en $\varphi \varepsilon ́ p o \mu \alpha \mathrm{l}$ : Ágave lleva la cabeza como su premio y como su contaminación (cf. fr. I ídion élabon es khéras mýsos). Su padre vuelve a invitarla a examinar la situación y entonces admite ver el más grande de los dolores (nótese aquí la ausencia de juego de palabras entre el término que usa y el nombre de Penteo). 
en escena de una manera en que no aparece en la épica ni en la lírica en tanto instrumento del actor y, desde esta perspectiva, la cabeza de Penteo sólo es comparable "in terms of plurisignation" con los pechos de Clitemnestra en Coéforas (vv. 896-897).

El cadáver de Penteo es sometido a una doble deshumanización. Por un lado, la serie de equívocos que lo convierten en fiera, león, hiedra o ternero. Por otro, su descuartizamiento, desarticulación que convierte un resto humano en un conjunto de colgajos, pasibles incluso de ser considerados plato de un festín. Solo la cabeza, portadora de un rostro que mantiene una ligazón con la identidad perdida, podrá convertirse en el instrumento que rehumanice a Penteo tras haber sido el centro de los mecanismos de animalización experimentados en la obra. 


\section{BibLIOgRAFÍA}

Andrade, N. (2003), Euripides. Bacantes, Buenos Aires, Biblos.

Di Benedetto, V. (1982) , Euripide. Medea-Troiane-Baccanti, Milán, Rizzoli.

Diggle, J. (1994), Euripidis Fabulae III, Oxford, University Press.

Dodds, E. R. (1960), Euripidis Bacchae, Oxford, University Press.

Roux, J. (1972), Euripide. Les Bacchantes, Paris, Les Belles Lettres.

Seaford, R. (1996), Euripides: Bacchae, Warminster, Aris \& Phillips.

Torrano, J. (1995), Eurípides. Bacas, San Pablo, Ed. Hucitec.

Tovar, A. (1982), Tragedias. Las Bacantes. Hécuba, Madrid: CSIC.

Bollack, J. (2005), Dionisos et la tragédie. Commentaire des Bacchantes d'Euripide, Paris, Bayard.

Burian, P. (1997), "Myth into Muthos: the shaping of tragic plot", en Easterling, P. E., The Cambridge Companion to Greek Tragedy, Cambridge, University Press, 178-208.

Drew Griffith, R. (1998), “Corporality in the Ancient Greek Theatre”, Phoenix 52 3-4, 230-256.

Foley, H. P. (2003), “The Masque of Dionysus”, en Mossman, J. (Ed.), Oxford Reading in Classical Studies. Euripides, 342-368.

Hernández de la Fuente, D. A. (2001), "Sparagmos y cefaloforía en Las Bacantes y Las Dionisiacas: El mito de Penteo en Eurípides y Nono", CFC 11, 79-100.

Marshall, C.W. (1999), "Some Fifth-Century Masking Conventions “, G\&R 46 2, 188-202.

Mossman, J. (1995), Wild Justice. A study of Euripides' Hecuba, Oxford, Clarendon Press.

Musurillo, H. (1966), “Euripides' Medea: a reconsideration”, AJPh 137, 52-74.

Rehm, R. (2002), "The Bacchae: The Theatrical Body”, en The Play of Space. Spatial Transformation in Greek Tragedy, Princeton: University Press, 200-214.

Rodríguez Cidre, E. (2010), Cautivas Troyanas. El mundo femenino fragmentado en las tragedias de Eurípides, Córdoba, Ordia Prima.

Rodríguez Cidre, E. (2011a), "Sacrificar en Bacantes: Ágave y el colectivo de mujeres", Actas de las V Jornadas sobre el Mundo Clásico: "Saber y poder. Claves de la constitución de la identidad" (octubre de 2010), Universidad de Morón, (en prensa). 
Rodríguez Cidre, E. (2011b), "Ser hijo de Equión: lo monstruoso en Bacantes de Eurípides”, en Domínguez, N. et alii (eds.), Criaturas y saberes de lo monstruoso II, Buenos Aires, IIEGE/FFyL-UBA, (en prensa).

Segal, C. (1997) Dionysiac Poetics and Euripides'Bacchae, Princeton, University Press.

Segal, C. (1994), "Female Mourning and Dionysiac Lament in Euripides' Bachae", en Bierl, A. \& Möllendorff, P., Orchestra: Drama Mythos Bühne (Festschrift for Helmut Flashar), Stuttgart, 12-18.

Seisdedos, A. (1985), "Significación y desarrollo de las metáforas de animales en Eurípides”, Helmántica 36, 277-293.

Taplin, O. (2005 [1978]), Greek Tragedy in Action, Londres, Routledge.

Thumiger, C. (2007) Hidden Paths. Notions of Self, Tragic Characterization and Euripides'Bacchae, Londres: Institute of Classical Studies.

Wiles, D. (2007) Mask and Performance in Greek Tragedy from Ancient Festival to Modern Experimentation, Cambridge, University Press.

Wiles, D. (1999), Tragedy in Athens. Performance space and theatrical meaning, Cambridge, University Press.

Zeitlin, F. I. (1996), Playing the other. Gender and Society in Classical Greek Literature, Chicago \&London, The University of Chicago Press. 


\section{La filosofía de Séneca en el auto sacramental EL GRAN teatro del mundo de Pedro Calderón de la Barca}

Julio Juan Ruiz

Universidad Nacional de Mar del Plata

La concepción filosófica que concibe a la vida humana como comedia alcanzó su plenitud en la filosofía de Séneca. El filósofo romano en sus cartas a Lucilio nos enseñó a descubrir el valor de un hombre y de su vida por debajo de los vestidos de la púrpura. Esta concepción antropológica está presente en el auto sacramental de Calderón El gran teatro del mundo. Sin embargo, en el dramaturgo del Siglo de Oro Español los planteamientos de la filosofía estoica encontraron una respuesta religiosa que puso el acento de la realidad en otra vida. En este sentido, en la presente ponencia nos proponemos analizar la presencia de la filosofía de Séneca en el conocido auto sacramental del siglo XVII.

\section{Introducción}

En la presente ponencia nos proponemos analizar la presencia de la filosofía de Lucio Aneo Séneca en el auto sacramental El Gran Teatro del Mundo de Pedro Calderón de la Barca. La doctrina del filósofo tuvo importantes resonancia en los pensadores y escritores españoles por su profundo contenido moral.

\section{La vida como comedia}

En el período barroco los textos de la antigüedad como las ruinas fueron altamente estimados. El prestigio de los fragmentos grecolatinos, según Benjamin, se debió a que, a través de éstos, la historia se manifestó en la escena. De este modo, en esta época las alegorías fueron en el reino del pensamiento, lo que la ruinas, en el de las cosas. Por este motivo, los fragmentos de la antigüedad grecolatina constituyeron elementos valiosísimos para construir un nuevo todo: la obra artística. Por esto, durante el barroco no primó la afanosa búsqueda de lo original tan anhelada por el romanticismo; por el contrario, el virtuosismo estético se manifestó en la habilidad del escritor para manipular los modelos de la antigüedad.

La presencia del fragmento de la antigüedad en la obra del escritor barroco se debió más a una motivación ideológica que estética. Esta realidad la podemos observar en el auto sacramental El gran teatro del mundo de Pedro Calderón de la Barca, donde la presencia de un fragmento de las Cartas Morales a Lucilio del filósofo romano Séneca evidencia la comunión ideológica del escritor barroco con el filósofo romano. Esta compatibilidad se manifestó a través de la conocida metáfora que concebía al mundo como una gran comedia, cuyo origen se remonta 
a Platón, pero alcanzó mayor profundidad en la doctrina del filósofo romano Lucio Aneo Séneca. En las enseñanzas de este filósofo se distingue claramente la realidad del ser de su mera apariencia, como lo podemos apreciar en el siguiente fragmento de la carta setenta y seis que Séneca destinó a la educación moral de su discípulo Lucilio: " ninguno de esos que vestidos de púrpura es feliz, no lo es más que los actores a quienes la ficción teatral asigna una clámide o un cetro; cuando el público está presente se pasean solemnes y con coturno; pero al salir de la escena se descalzan y vuelven a su estatura propia"(Séneca, 461). Esta doctrina subyace en el auto sacramental de Calderón.

Esta intertextualidad no es casual, sino que obedece a la congruencia ideológica de la moral del filósofo estoico con la católica. En los albores del cristianismo la afinidad con el filósofo estoico romano llegó a tal grado que Tertuliano lo llamó: "Séneca saepe noster" (Fraile, 1971). En la doctrina moral del filósofo estoico el sumo bien era la virtud, y ésta no era más que el esfuerzo de la razón humana para alcanzar el bien. De este manera, la doctrina ética del filósofo se entrelazó con su concepción antropológica, que consideraba a la razón como bien propio del hombre. Sólo con el perfeccionamiento de la razón el ser, según estas enseñanzas, será: “(...) laudable y habrá llegado al fin de su naturaleza. Esta razón perfecta se llama virtud y es lo mismo que lo honesto" (Séneca, 216). La virtud es, pues, el común denominador entre la moral estoica y la cristiana. Ambas doctrinas concuerdan en que a ésta se llega a través de las obras. En el auto calderoniano, esta premisa es el "liev motiv", pues la vida humana es considerada como una comedia, un paso a la verdadera existencia, la eternidad. A la vida eterna se accede por el mérito de las obras, por eso, como un eterno "ritornello" a los personajes se los exhorta: obrad bien, que Dios es Dios. De esta manera, el auto sacramental evidencia un sesgo anti protestante, el que alcanzó su plenitud en la apología del libre albedrío. Esta doctrina se manifestó en el respeto que el Autor de la comedia humana, Dios, profesa por la libertad de sus personajes, pues aunque éstos obren mal el creador piensa que: "bien pudiera enmendar/ los yerros que viendo estoy/ por eso les di/ albedrio superior/ a las pasiones humanas, / por no quitarles la acción/ de nacer con sus obras" (Calderón, 214).Para algunos autores, el conflicto religioso entre católicos y protestante fue lo que caracterizó al género, lo que ha sido impugnado por el historiador francés Marcel Bataillon. Este historiador consideró al auto sacramental como un producto de la Reforma Española, pues afirma la tesis de que: "el catolicismo español, a mitad del Siglo XVI, no tenía necesidad de reforma, o nada tenía ya por haber sido corregido desde los tiempos de Isabel y Cisneros los abusos o desviaciones que habían podido aquejarlo a fines de la Edad Media" (1976, 462). Pese al peso de la tesis de Maravall, debemos destacar que en este género se manifestó una clara impronta agonal, tal como lo podemos observar en el auto que estamos 
examinando, donde se predica la salvación por las obras en clara oposición a la doctrina protestante de la salvación por medio de la Fe.

\section{La representación y el poder}

La semejanza de la vida con la comedia también estuvo presente en los sermones eclesiásticos del barroco. Así, por ejemplo, en el del famoso predicador dominico Fray Alonso de Cabrera pronunciado durante las exequias de Felipe II, en el que el clérigo predicó que: "es la tierra el teatro en que se presentan las farsas humanas. Esta se queda como la casa de las comedias. Pasa una generación y viene otra, como diferentes compañías de representantes" (Valbuena Prat, 200). La vida, pues, para el hombre del Siglo de Oro Español no era más que representación, tal como lo afirmó Séneca muchos siglos antes en las ya mencionadas Cartas Morales a Lucilio. En la carta sesenta y seis expresó que: "la vida, como la comedia, no importa cuánto duró, sino cómo se represento. Nada interesa el lugar en que acabes. Déjala donde quieras; solamente dale un buen fin" $(1951,226)$.

En El Gran Teatro del Mundo, Dios es quien reparte los papeles y sabe que: "todos quisieran hacer/ el de mandar y regir, / sin mirar, sin advertir, / que en acto tan singular/aquello es representar, / aunque piensen que es vivir" (Calderón, 207). Si mandar es representar, debemos tener presente que, en la cultura barroca, esta palabra aludió a la demostración de poder del soberano a través de la representación teatral montada para el pueblo. La representación política no consistió en oír la voz de los ciudadanos, los representados, como la sostiene los postulados de la democracia representativa, sino en lo que J. Habermas denominó "publicidad representativa" (González García, 1998). Este fenómeno según el filósofo alemán se manifestó en el Medievo en la conciencia que tuvo el señor feudal de su jerarquía social, y en la modernidad a través del fasto, el ceremonial y el protocolo. Posteriormente, al declinar el absolutismo fue un signo distintivo del noble, tal como lo podemos constatar en el Whilhelm Meister de Goethe, donde Whilhem en una carta a su primo explicó que "el noble es lo que representa, el burgués lo que produce"(Habermas, 52).

En suma, tanto Séneca como Calderón tuvieron plena conciencia de que el poder no es más que representación, y ésta se escenifica en una corta comedia llamada vida.

\section{Conclusiones}

Como hemos podido observar, la relación entre ambos escritores no obedece a una mera intertextualidad, sino que posee notables implicancias ideológicas. Éstas, fundamentalmente, se plasman en la primacía de lo ético. 
De este modo, tanto la doctrina moral estoica, como la católica pusieron límites al poder.

Por otra parte, debemos notar que en el barroco se tuvo conciencia de la relación entre el poder y la teatralidad, pese a que esta realidad estuvo presente en la filosofía moral de Séneca, donde la metáfora de la vida como comedia alcanzó mayor profundidad.

La relación que tuvo el teatro de Pedro Calderón con el poder podría darnos las claves necesarias para comprender la "lógica interna" de la hegemonía de los medios de comunicación de masas en el ámbito político que se manifiesta en la actualidad. Este fenómeno fue denominado como "el estado espectáculo" el cual se manifiesta al comprobar que la imagen de los políticos, estratégicamente diseñada para seducir a los votantes, prevalece sobre el debate. La discusión de las ideas fue un pilar fundamental de las democracias del Siglo XIX. Este papel, en nuestro tiempo, lo desempeña la "imagen". Esta primacía no es una realidad exclusiva de nuestra época, sino que también lo fue en los albores de la modernidad, tal como nos enseña el historiador Peter Burke en su ensayo $L a$ fabricación de Luis XIV. En este texto comprobamos que la imagen del soberano era construida con esmero, tal como en la actualidad se hace con la del político. Ésta era desplegada ante los súbditos en un arco amplio de representaciones que iban desde la etiqueta palaciega a la fiesta popular.

En suma, el ciudadano de las democracias, el súbdito de las monarquías y también los ciudadanos romanos debieron discernir la realidad del mero juego de las apariencias. Tuvieron que atravesar una densa bruma de estrategias propagandísticas que el poder desplegaba en el imaginario colectivo en pos de sus fines. 


\section{Bibliografía}

Balandier, G., El poder en escena. De la representación del poder al poder de la representación, Madrid, Paidós, 1994.

Bataillon, Marcel, "Ensayo de explicación del auto sacramental”, en: Durán y Echeverría, Calderón y la crítica. Historia y antología, Madrid, Editorial Gredos, 1976.

González García, José, Metáforas del poder, Madrid, Alianza, 1998.

Séneca, Lucio A., Cartas Morales, Tomo I, Universidad Autónoma de México, 1951.

Calderón de la Barca, Pedro, Obras completas, Madrid, Aguilar, 1967.

Fraile, Guillermo, Historia de la filosofía, Madrid, Biblioteca de autores cristianos, 1976.

Habermas, Jürgen, Historia y crítica de la opinión pública, Barcelona, Editorial Gustavo Gili, 1981.

Valbuena Prat, Ángel, "Notas", en: Calderón de la Barca, Pedro, Obras Completas, Madrid, Aguilar, 1967. 


\section{Los hijos de la fortuna de Calderón, celebración DRAMÁTICA (Y MUSICAL) DE LAS ETIÓPICAS}

Ofelia Salgado

Cambridge - Inglaterra

Los hijos de la Fortuna. Teágenes y Cariclea de Calderón de la Barca constituyó la más célebre adaptación a la escena de las Etiópicas, novela griega de amor y aventuras atribuida a Heliodoro de Emesa, y su publicación, en la Parte tercera de comedias de 1664, llevó a su cumbre la fama de esa "épica en prosa" antigua, después de más de un siglo de intensa difusión de la obra en España. Este drama corresponde a la segunda época de la producción de Calderón, de un teatro de espectáculo, en que el dramaturgo se interesa por temas fantásticos y novelescos, según A. Valbuena Briones. En las letras españolas había sido precedida por la comedia Teágenes y Cariclea de Juan Pérez de Montalván (1638) y antes, por imitaciones novelísticas, como El peregrino en su patria de Lope de Vega (1604) y la obra póstuma Los trabajos de Persiles y Sigismunda. Historia setentrional de Miguel de Cervantes (1617). Por sobre todo, cabe destacar que la adaptación a la escena de Calderón devuelve en cierta forma las Etiópicas a su género original y a sus fuentes prístinas de inspiración en la tragedia griega, en particular el Hipólito de Eurípides.

Los hijos de la Fortuna. Teágenes y Cariclea de Pedro Calderón de la Barca constituyó la más célebre adaptación a la escena de las Etiópicas, novela griega de amor y aventuras atribuida a Heliodoro de Émesa, y su publicación, en la Parte tercera de comedias de 1664, llevó a su cumbre la fama de esa "épica en prosa” antigua, después de más de un siglo de intensa difusión de esa obra en España. Este drama corresponde a la segunda época de la producción de Calderón, de un teatro de espectáculo, en que el dramaturgo se interesa por temas fantásticos y novelescos, según A. Valbuena Briones (1969: 2.1223). En las letras españolas había sido precedida por la comedia "Teágenes y Cariclea” de Juan Pérez de Montalván (1638) y antes, por imitaciones novelísticas, como El peregrino en su patria de Lope de Vega (1604) y la obra póstuma Los trabajos de Persiles y Sigismunda. Historia setentrional de Miguel de Cervantes (1617). Por sobre todo, cabe destacar que la adaptación a la escena de Calderón devuelve en cierta forma las Etiópicas a su género original y a sus fuentes prístinas de inspiración en la tragedia griega, en particular el Hipólito de Eurípides.

En su extensa producción dramática, Pedro Calderón de la Barca (1600-1681) no descuida los temas mitológicos clásicos y acude incluso a la novela antigua para proveerse de asuntos fantásticos o novelescos en su afán de 
crear un teatro de espectáculo. En esta búsqueda, correspondiente a la segunda parte de su producción, no vacila en alimentar su vena creativa en las narrativas épicas de la Antigüedad, como las Etiópicas, de amor y aventuras, la alegoría de las Metamorfosis o El asno de oro de Apuleyo ("Psiquis y Cupido", 1640), o inclusive en una novela en clave inspirada en la primera de las mencionadas, la Argenis del escocés Juan Barclayo (“Argenis y Poliarco”, 1637). Nos concentraremos aquí en su recreación dramática de las Etiópicas, por constituir ésta la culminación de más de un siglo de difusión, intensa lectura e imitación, tanto en prosa como en puestas en escena, de esa obra de ficción que disfrutó de tan "singular acogida en el Renacimiento"1.

En tanto que Valbuena Briones resalta en Los bijos de la Fortuna, Teágenes y Cariclea de Calderón "la habilidad técnica del dramaturgo español al adaptarla", ya que "retiene lo importante del argumento y permanecen los personajes principales, sin mermar el encanto de la peripecia ni el exotismo que caracterizan al texto primitivo"3, Francisco López Estrada sostiene que, comparada con la adaptación a la escena del doctor Juan Pérez de Montalván, publicada en el Segundo tomo de las comedias en 1638, "la obra de Calderón es, a todas luces, inferior a la de Montalván. Mientras éste tuvo buen cuidado de limitar y ordenar los sucesos, Calderón los amontona sin apenas sentido de continuidad, y propende a la comedia de gran espectáculo, con artificios escénicos, cantos corales, descuidando la hechura dramática"4. De lo que ese estudioso no se da cuenta es de que es justamente ese material lo más interesante de esa obra. Cabe recordar al respecto la influencia en Calderón de la Camerata florentina, que, integrada por los músicos Vincenzo Galilei, Jacopo Peri, Giulio Caccini y el poeta Ottavio Rinuccini, creó entre 1573 y 1587 el género operístico ${ }^{5}$, del cual ese dramaturgo proporcionará el primer gran ejemplo en España con su "El golfo de las sirenas", publicado en la Parte cuarta de las comedias, Madrid, $1672^{6}$. Calderón es, en efecto, un libretista, el primer gran libretista del drama musical italianizante en la península ${ }^{7}$. López Estrada no deja de señalar, sin embargo, que "ambas obras, la de Montalván y la de Calderón, de escaso valor literario, son un índice de la popularidad del libro de Heliodoro en este tiempo" ${ }^{\prime}$, es decir, a mediados del siglo XVII, entre 1638 y 1664 .

\footnotetext{
${ }^{1}$ Valbuena Briones 1991: 1225.

${ }^{2}$ Id. ibid.

${ }^{3}$ Id. ibid.

${ }^{4}$ López Estrada 1954: xxxv (“Introducción”).

${ }^{5}$ Grove 1980: 3.645-646.

${ }^{6}$ Valbuena Briones 1991: 1722-1723.

${ }^{7}$ Grove 1980: 3.616.

${ }^{8}$ López Estrada 1954: xxxv (“Introducción”).
} 
Tenemos al menos tres grandes comediógrafos en España en el siglo XVII, Lope de Vega (1562-1635), Juan Pérez de Montalván (1601 o 16021638) y Pedro Calderón de la Barca (sin contar aquí a Cervantes), que conocen a Heliodoro y se ocupan de recrearlo en prosa o en piezas teatrales. Lope lo llama el "divino" ("griego poeta divino") en La dama boba y, como Cervantes, aunque con anterioridad, lo imita en su novela El peregrino en su patria, cuya primera edición es de 1604, es decir, trece años anterior a la publicación póstuma de Persiles y Sigismunda de 1617, pero de una época en que Cervantes mismo se consagraba ya a la imitación del novelista griego. Así lo hace en el Quijote (primera parte, 1605) y en sus novelas cortas que se publican como Novelas ejemplares en 1613 - algunas de esas novelas habían sido escritas antes de 1605, aunque quizás no aquellas que predominarán en el conjunto como recreaciones de las Etiópicas, La Gitanilla, que las encabeza, La ilustre fregona y La española inglesa, que se alternan con otras inspiradas en otros novelistas antiguos, Rinconete y Cortadillo", en Petronio, y el Coloquio de los perros, en Apuleyo ${ }^{10}$.

Elperegrino en supatria constituye un hito en las imitaciones de las Etiópicas en castellano. La crítica, sin embargo, ha querido ver como antecedente de ella la novela Selva de aventuras de Jerónimo de Contreras, cuyo título bien podría definir las características de la novela de amor y aventuras que se dio en llamar "novela bizantina” y de la cual el ejemplo artístico más notable y más admirado en el Renacimiento fue precisamente la novela atribuida a Heliodoro ${ }^{11}$. También creyó verse su antecedente en la Historia de los amores de Clareo y Florisea de Alonso Núñez de Reinoso, publicada en Venecia en 1552, imitación de otra novela antigua, Leucipe y Clitofonte, de Aquiles Tacio. Cabe mencionar aquí que las Etiópicas se consideraron tradicionalmente como el modelo absoluto para la producción del género en la Antigüedad y posteriormente en Bizancio y que disfrutaban en el siglo XVI de un prestigio del que ninguna de las otras novelas griegas o bizantinas llegó a gozar. Piénsese en las palabras del humanista bávaro Vinzenz Heidecker (Opsopœus) sobre los artificios de la obra: "[...] quibus nulli Græcorum authorum secundus est" - "[en los cuales] no es inferior a ningún autor griego", en la epístola dedicatoria al senado de la ciudad de

${ }^{9}$ En esa comedia, Celia, criada de Nise, dice al entregar a ésta un libro: "En cándido pergamino / vienen muchas flores de oro." Responde Nise: "Bien lo merece Eleodoro, / griego poeta divino." Sigue un comentario en verso de la obra, que recuerda el proemio de Jacques Amyot (ver infra). Citado por López Estrada 1954: xxvi.

${ }^{10}$ Salgado 1997: 272-274.

${ }^{11}$ Peyton 1971: 17. En su introducción a su edición de El peregrino en su patria, dice así, en efecto: "Varios eruditos han dado en identificar antecedentes de [esa obra] de Lope. Menéndez y Pelayo, Pfandl, Vossler y Farinelli señalan la Selva de aventuras de Jerónimo de Contreras como modelo." Farinelli ve un antecedente en Il peregrino (1508) de Jacopo Caviceo, cuya traducción castellana apareció en Sevilla en la temprana fecha de 1520. 
Nuremberg de la editio princeps de la obra en griego $(1534)^{12}$, que preparó sobre el manuscrito de la Biblioteca Corviniana (hoy en la Staatsbibliothek de Munich, Codex grecus 357). En cambio, la Selva de aventuras, historia de los desdichados amantes Luzmán y Arbolea, fue publicada recién en 1565, cuando la fama de las Etiópicas estaba ya bien extendida y establecida en Europa y contaba con traducciones al francés, al latín, al italiano y con dos al castellano, la del anónimo de Amberes (Martín Nucio, 1554) y la de Francisco de Vergara, catedrático de griego en la universidad de Alcalá de Henares, que permaneció inédita.

Si nos hemos detenido en los antecedentes de esa novela de Lope lo ha sido para mostrar que en las obras de esa época en las que no se hace mención específica de sus fuentes, éstas quedan sujetas al criterio o la erudición de los críticos modernos. No fue éste el caso ni del Persiles ni de las piezas dramáticas de Calderón y Pérez de Montalván, porque en ellas su autor o bien explícitamente dice que quiso emular a Heliodoro (Persiles) ${ }^{13}$ o bien en su propio título - Los hijos de la Fortuna: Teágenes y Cariclea - se señala el modelo con el nombre mismo de los protagonistas de la narrativa griega, con los que aparecía ya, por otra parte, en sus traducciones a lenguas romances desde la francesa de Jacques Amyot de 1547: Histoire atbiopique d'Heliodorus, contenant dix liures, traictant des loyales et pudiques amours de Theagenes Thessalien et Chariclea Athiopienne [... $]^{14}$. Similarmente, no se identificaron en las Novelas ejemplares de Cervantes unas recreaciones en miniatura de las Etiópicas, porque el novelista no lo declara así. Como en las Etiópicas mismas, su autor dejaba librado al lector erudito el reconocimiento en ellas de los pasajes, líneas de pensamiento e imágenes de las obras literarias en que se había inspirado, en su caso, Homero, los trágicos, Platón y los historiadores griegos del período clásico, Heródoto y Tucídides ${ }^{15}$. En Los hijos de la Fortuna: Teágenes y Clariquea Pérez de Montalván y Calderón hacen explícita su fuente en la narrativa de las Etiópicas de todos entonces conocida y que se había difundido en la península hispánica sobre todo con la traducción del toledano Fernando de Mena, que llevaba precisamente por título La historia de los dos leales amantes Theagenes y Chariclea, y en la cual no se mencionaba el nombre del autor - un ardid quizás para evitar la censura en las ediciones de literatura pagana después de

${ }^{12}$ Opsopœus 1534: fol. a 2 ro.: "[...] mitto uerborum ornatum \& compositionem, \& dicendi artificium, cæterasque orationis uirtutes, quibus nulli Græcorum authorum secundus est $[\ldots] . ”$

${ }^{13}$ Lo anuncia en el "Prólogo al lector" de las Novelas ejemplares. "Tras ella, si la vida no me deja, te ofrezco los Trabajos de Persiles, libro que se atreve a competir con Heliodoro, si ya por atrevido no sale con las manos en la cabeza, [...]." (Cervantes 1976: 1.88).

${ }^{14}$ Amyot 1547.

${ }^{15}$ Feuillâtre 1966; Salgado 2010: 161. 
los edictos del Concilio de Trento - (Alcalá, Juan Gracián, 1587; reimpresa en Barcelona por Gerónymo Margarit en 1614 y en Madrid, por Alonso Martín, a costa de Pedro Pablo Borgia, 1615 y en París, Pedro Le-Mur, 1616, en la edición del intérprete y gramático francés César Oudin). "El título de Teágenes y Clariquea denunciaba a las claras la procedencia del argumento”, decía López Estrada $^{16}$.

La forma dramática para la historia de los amantes Teágenes y Cariclea sólo se adoptará en España en el siglo XVII. De acuerdo con el mismo estudioso, "no cupo mayor reto a las unidades aristotélicas como el que supone esta empresa; pero aun considerando las más extremas condiciones de libertad escénica, el teatro quedaba estrecho para un tal barullo de acción y de personajes"17. Así juzgaba López Estrada: "Ninguna de las comedias inspiradas en este libro fue de gran importancia, pues era de una dificultad extraordinaria meter el inmenso enredijo de la Historia Etiópica en los límites de espacio, lugar y tiempo de un argumento de comedia"18. Como la pieza de Juan Pérez de Montalván es muy rara, sólo hemos podido ver los resúmenes de su argumento publicados independientemente por George William Bacon, entre las "Comedias heroicas" de Montalván, en 1912 ${ }^{19}$, y por Francisco López Estrada, en la introducción de su reimpresión de la traducción de Fernando de Mena (1954) ${ }^{20}$. Después de su resumen, López Estrada concluye que "en conjunto, la comedia es entretenida en lo episódico y por la belleza de algunos parlamentos. Queda a más altura la parte narrativa de acciones realizadas, que la dramática," pero que "son demasiados episodios y sucesos, y el espacio para desarrollarlos es escaso", aunque "la obra es en conjunto una comedia discreta" ${ }^{21}$. Si bien Montalván ha conservado la línea argumental de las Etiópicas, se observa una notable redistribución de roles y la creación de personajes: Nemón (Cnemón) es ahora "príncipe de la China"; Neusiclés, sacerdote de Isis, por ejemplo, en lugar de Calasiris, y entre los personajes nuevos hay que citar Anaximandro, rey de Persia, Eumenes, rey de Egipto, Sinforosa, infanta de Egipto, y muchos criados. Calderón, en cambio, se muestra más fiel al original, aunque agrega un coro de ninfas y músicos, de

${ }^{16}$ López Estrada 1954: xxxii.

${ }^{17}$ Id. ibid.

${ }^{18}$ Id. ibid.

${ }^{19}$ Bacon 1912: 120-124 (Section II, Analyses), y notas, id.: 339-340.

${ }^{20}$ López Estrada 1954: xxxii-xxxiv, tomada del Segrondo Tomo de las Comedias del Doctor Ivan Perez de Montalvan [...] En Madrid. En la Imprenta del Reyno Año 1638. [...], ff. 112vo.134vo.; lleva por título: "Teaganes, y Clariquea [sic]. Comedia famosa del doctor Ivan Perez de Montalban." Según Bacon, el título de la comedia es igual al de Calderón.: "Los hijos de la Fortuna: Teágenes y Clariquea." Aparece aquí el nombre de Cariclea con metátesis: "Clariquea", común a varios autores (cf. López Estrada 1954: xxxii n. 1).

${ }^{21}$ Id.: xxxiv. 
acuerdo, como venimos viendo, con sus fines "operísticos". Calderón es una figura bien conocida en la historia de la ópera ${ }^{22}$.

La presencia de músicos y coros puede verse en la lista de personajes de la comedia de Calderón, que es la siguiente: "Cariclés, viejo; Calasiris, viejo; Nausiclés, mercader; Tisbe, esclava; Idaspes, indio negro; Cariclea, dama india; Persina, Reina de Etiopía, india negra; un Capitán y soldados; Tíamis, bandolero y galán; Termutes, bandolero; Jebnón, bandolero gracioso; Petosiris, galán, hermano de Tíamis; Teágenes, galán; tres caminantes; Admeta, Reina de Menfis; Ninfas de Apolo, músicas; Criadas de Persina, músicas indias; negras; músicos, bandoleros y soldados" ${ }^{23}$. Calderón inicia su drama en la ciudad griega de Delfos, con la vista exterior del templo de Apolo. Entra primero un coro de Ninfas (sacerdotisas de Apolo) cantando y luego los ancianos sacerdotes Cariclés (de Apolo, y padre adoptivo de la protagonista Cariclea) y el egipcio Calasiris (de Isis). Convocan al pueblo a la ceremonia sagrada en el templo el primer solsticio de junio. En la escena que sigue, en el interior del templo vuelven a aparecer Cariclés y la tropa de músicos. Cantan dentro y salen luego "músicas indias negras" (etíopes) y Persina, india negra, reina de Etiopía. Sale Idaspes con las señales de reconocimiento de Cariclea, la banda con letras de oro y joyas en un cofrecillo (en las Etiópicas, es Cariclés quien las muestra). Fuera del templo, la salida de Cariclés y Calasiris es acompañada de chirimías, instrumentos y cajas. Salen por una parte las Ninfas con Cariclea y un hacha encendida y por otra, los Músicos, Teágenes y acompañamiento y el primer acto termina con música y canciones.

En la escena en el bosque en el segundo acto vuelven a tocar chirimías y, a orillas del Nilo, se recrea luego el cuadro de apertura de las Etiópicas: "Córrese una cortina y vése la mesa derribada y algunos como muertos, y entre ellos Cariclea y Teágenes, herido" 24 . Sigue la escena en la gruta con el asesinato de la esclava Tisbe, por error, por parte del jefe de los bandoleros Tíamis. Teágenes se lamenta pensando ser Cariclea la muerta, pero Cariclea aparece viva en el fondo de la cueva, como en la novela (Eth. 2.5.1).

$\mathrm{El}$ acto tercero transcurre en Egipto; Teágenes ha sido hecho prisionero y Cariclea, esclava de Nausiclés. En este acto "se insiste en la peripecia de la acción", como señala Valbuena Briones ${ }^{25}$. Los protagonistas "se salvan de un peligro para caer en otro" 26 . Dicen ser hermanos, "lo mismo que el poema

${ }^{22}$ Lamentablemente, no se conservó la música escrita para esta obra. El compositor de la corte era Juan Hidalgo y nos han llegado varias de sus partituras que acompañaban otras piezas de Calderón (Grove 1980: 617).

${ }^{23}$ López Estrada 1954: xxxiv n. 1.

${ }^{24}$ Valbuena Briones 1991: 1247.

${ }^{25}$ Id.: 1.224.

${ }^{26}$ Id. ibid. 
de Heliodoros, para evitar envidias y asegurar su amor sin recelos”, según el mismo editor ${ }^{27}$. En los confines de Etiopía y Egipto, aparece Persina con acompañamiento de músicos. En batalla con la reina de Egipto Admeta, los etíopes triunfan. La comedia termina con el reconocimiento de Cariclea por parte de sus padres Idaspes y Persina y su matrimonio con Teágenes, que se descubre ser también de linaje real, de Tesalia. La escena final tiene lugar con el sonido de cajas y gran acompañamiento de etíopes y gitanos. El cierre está a cargo de Jebnón (Cnemón). En las Etiópicas, este personaje representa al Hipólito de Eurípides, que ha escapado a la muerte, en exilio en Egipto. Calderón captó el carácter cómico de este personaje en la novela y lo convirtió adecuadamente en gracioso ${ }^{28}$, pero en las Etiópicas Cnemón desaparece de la acción en el libro VI, al esposar la hija del rico mercader griego Nausiclés (Ath. 6.8.1) y hallar así, en una vida sedentaria en la aldea egipcia de Quemnis, el fin de sus aventuras. Con la boda real y los festejos en la capital de Etiopía, Méroe, la novela concluía con un gran finale operístico ${ }^{29}$. En boca de Cnemón había puesto su autor ya en cita aproximada las palabras de Eurípides (Medea,1317), “¿para qué remover y forzar ese secreto, como dicen los autores trágicos?" (Ath. 1.8.7 $)^{30}$, como para recordar toda la teatralidad que imbuía a su propia obra - en Eurípides, Medea dice a Jasón: “¿Para qué agitar [el coro de mujeres] y romper esas puertas?” En una correcta lectura de las Etiópicas, Calderón encomendaba así a Jebnón las palabras finales de esta comedia. También Teágenes, que aparece como un par cómico de Cnemón en el libro I de la novela de Heliodoro, "en su dolor, lanzó rugidos trágicos" (\#th. 2.4.1).

Émile Feuillâtre, en su estudio sobre las Etiópicas, sugería que su autor, aunque no lo nombrara, se sentía más cercano de Eurípides que de Esquilo o Sófocles y proporciona como ejemplo la imagen inicial de la obra, los rayos de sol naciente que iluminan las colinas en el delta del Nilo: "[...] une même lumière éclaire le mont Ida dans les Troyennes et le Parnasse dans Ion" - nos dice - . Dans cette dernière tragédie, tout au début, nous voyons agir le néocore d'Apollon. De même, chez Héliodore, dans la lumière de l'aube apparaît la zacore d"Artémis"31. Calderón debió conocer tan bien a Eurípides como la obra de ficción en prosa que se inspira en gran parte en sus tragedias, las Etiópicas ${ }^{32}$.

${ }^{27}$ Id. ibid.

${ }^{28}$ Respecto de la comicidad de Cnemón, Feuillâtre nos recuerda que Heliodoro "[...] ne cesse de railler Cnémon, sa suffisance et sa couardise.” (Feuillâtre 1966: 118). J. Maillon anota, después de señalar que el adjetivo griego 'haploïós' ("ingenuo") es común en Luciano: "La naiveté de Cnémon introduit une note comique dans toute la premiére partie du drame." (Héliodore 1960: 1.17 n.3).

${ }^{29}$ Salgado 2010: 159.

${ }^{30}$ Grimal 1963: 528 y 1468 n. 528.1.

${ }^{31}$ Cf. Eur. Troyennes, 1066-1070; Ion, 86-88 (Feuillâtre 1966: 116-117).

32 Salgado 2004. 
Refiriéndose no a la pieza dramática que estamos tratando sino a "Las armas de la hermosura" (Parte cuarenta y seis. Primavera numerosa de muchas armonías lucientes en doce comedias fragantes, Madrid, 1679), Valbuena Briones expresaba: “[...] el autor [Calderón], en una línea de pensamiento que podríamos llamar euripidiana, buscó representar una fábula en la que la invención y la fantasía tuvieran un papel primordial"33. Sin duda, tiene presente este estudioso aquí el tratamiento del mito en Eurípides ${ }^{34}$.

Otra pieza dramática de Calderón brinda un nuevo ejemplo de interpretación de la obra de este trágico. Los tres mayores prodigios (Parte Segunda de Comedias, Madrid, 1637) es un experimento (a cargo de tres compañias teatrales diferentes, una para cada acto $)^{35}$ en el que se tratan en cada una de las tres jornadas, respectivamente, los mitos de la conquista del vellocino de oro por Jasón, la muerte del Minotauro por Teseo y los amores trágicos de Hércules y Deyanira. En la segunda jornada, “[...] la queja y maldición de Ariadna anuncian los episodios trágicos que según la mitología envolverán los amores de Teseo y Fedra", según su editor. Teseo debía "escoger entre el objeto de su amor o la correspondencia de gratitud que debe. En este conflicto se deja llevar injustamente de la pasión amorosa," de acuerdo con el mismo estudioso. Esa pasión es la que lo ciega igualmente al condenar al exilio (y a la muerte) a su hijo Hipólito, como le reprocha Ártemis (Hipp. 1586). Pérez de Montalván nos ofrece, muy a propósito, una magnífica ilustración del tema de esa tragedia en la primera de sus novelas ejemplares, La hermosa Aurora (Sucesos y prodigios de amor en ocho novelas ejemplares, Madrid, 1624): "No le disculpe esta vez a Dionisio el amor, con ser disculpa general de cualquier exceso, porque no tiene obligación un hombre a despreciar prendas, que lo son de su sangre, por una mujer que miente cuando llora y llora cuando quiere" ${ }^{36}$ En esta novela, Dionisio representa a Teseo; Arminda, su segunda esposa, dama francesa y principal, a Fedra, extranjera como ella, y Aurora, hija del primer matrimonio de Dionisio, a Hipólito. Hay que recordar que es en la versión del mito que Cnemón relata en las Etiópicas como su historia personal (Ath. 1.9.1-1.17.5), donde la madrastra Deméneta se presenta como la mujer malvada cuyas intrigas inspirarán en el siglo XVII a Racine, gran lector de Heliodoro ${ }^{37}$.

En otra pieza dramática, Calderón parece reflexionar nuevamente sobre el Hipólito de Eurípides. En Amado y aborrecido (Octava parte de comedias escogidas, Madrid, 1657, y Quinta parte de comedias de Calderón, Madrid, 1677), se presentan dos planos de acción, uno "real" y otro complementario,

\footnotetext{
${ }^{33}$ Valbuena Briones 1991: 939.

${ }^{34}$ Cf. Buttrey 1958.

${ }^{35}$ Valbuena Briones 1991: 1547.

${ }^{36}$ Laplana Gil 1999: 20.

${ }^{37}$ J. Maillon en: Héliodore 1960: 1.14 n. 2.
} 
"sobrenatural o mitológico": “[...] las diosas rivales Venus y Diana se interesan en el conflicto interior de Dante [...]. Este quehacer de los dos seres divinos viene a ser una especie de juego celestial. Los personajes semejan marionetas pulsados por las dos celosas diosas antropomorfas," según Valbuena Briones ${ }^{38}$. En Hipólito de Eurípides el argumento se desarrolla en torno de la rivalidad de esas mismas diosas, aunque el conflicto en "Amado y aborrecido" es de índole diferente.

Con una profunda comprensión tanto de esa novela antigua tan admirada en el Renacimiento como fueron las Etiópicas como de la tradición literaria en la que se inspira y que continúa ${ }^{39}$, y sin desdeñar la significación de otros géneros en su trasfondo, como la épica o la historiografía, las adaptaciones a la escena efectuadas por los dramaturgos españoles del siglo XVII devuelven en cierta forma esa novela a su prístina forma original, el drama ${ }^{40}$. La adaptación de la novela al teatro obligó por otra parte a nuestros autores a abandonar la narrativa con un principio in medias res, que había hecho célebres a las Etiópicas, a partir de un procedimiento ya utilizado en la épica: Ulises, en la Odisea, aparece sentado en una roca al comienzo del libro I, como Cariclea al principio del libro I de las Etiópicas, y el lector no sabe qué ha sucedido antes, en los nueve años que siguieron a la partida de Ulises de Troya, lo que el héroe sólo relata en los libros IX, X, XI y XII. Las circunstancias por las cuales Cariclea ha llegado a las costas del delta del Nilo se conocerán con el relato del sacerdote Calasiris en los libros II a V. Jacques Amyot, en el prefacio de su primera traducción de la obra al francés (1547), alaba particularmente esa técnica: "Y por cierto la dispo[si]ción es singular, porque comienza en la mitad de la Historia, como hacen los poetas heroicos, lo cual causa, de prima facie, una grande admiración a los lectores, y les engendra un apasionado deseo de oír y entender el comienzo, y todavía los atrae también con la ingeniosa lección de su cuento, que no entienden lo que han leído en el comienzo del primer libro, hasta que veen el final del quinto, y cuando allí han llegado, aún les queda mayor deseo de ver el fin, que antes tenían de ver principio. De suerte que siempre el entendimiento queda suspenso hasta que viene a la conclusión, la cual deja al lector satisfecho, como lo son aquellos que al fin vienen a gozar de una cosa muy deseada y de mucho tiempo esperada" ${ }^{41}$ El proemio de Amyot en

${ }^{38}$ Valbuena Briones 1991: 1681.

${ }^{39}$ Salgado 2004.

${ }^{40}$ Focio llamó a la novela antigua "drama”, como en Polibio, "acontecimiento (histórico) trágico” (Plb.13.10.12), y lo relativo a ella, “dramaticós” (Focio 1959-1991: passim).

${ }^{41}$ López Estrada 1954: 1xxx-lxxxi. El anónimo traductor de Amberes, 1554, incluyó en su versión castellana de las Etiópicas este prefacio, que es la que utilizamos aquí. López Estrada lo transcribió al final de su introducción a la reimpresión de la traducción de Fernando de Mena (López Estrada 1954: 1xxvii-lxxxiii). 
esa temprana fecha de 1547 constituyó un verdadero "tratado de la novela" de su época, que sentaría los fundamentos del género en las literaturas modernas. López Estrada afirmaba que Calderón en Los hijos de la Fortuna, Teágenes y Cariclea "[...] amontona [los episodios] sin apenas sentido de continuidad, y propende a la comedia de gran espectáculo, con artificios escénicos, cantos corales [...]" ${ }^{42}$, pero, al hacerlo, ese gran estudioso de la recepción de las Etiópicas en la literatura española no comprendió que era allí, precisamente, en el gran espectáculo, los artificios escénicos y los cantos corales, donde el dramaturgo y libretista, en esa última etapa de su producción, seguía las experiencias de la Camerata florentina del círculo del conde Giovanni de' Bardi, con las investigaciones sobre música griega de Vincenzo Galilei y su urgencia por recrear, con música, la escena antigua, como habían hecho los italianos con los dramas musicales Dafne (1598) y Euridice (1600) de Jacopo Corsi. Más que una falencia, fue un logro de Calderón desde el punto de vista de la revivificación de la tragedia clásica en el género de la ópera culta en España ${ }^{43}$.

42 Id.: xxxv.

43 A pesar de los esfuerzos de Calderón, el género operístico no prosperó en España, sino sólo como zarzuela, "[...] the more frivolous, increasingly plebeian zarzuelas of the later 17 th and 18th centuries" (Grove 1980: 3.617). 


\section{Bibliografía}

Amyot J. trad. 1547, Histoire athiopique d'Heliodorus, contenant dix liures, traictant des loyales et pudiques amours de Theagenes Thessalien et Chariclea Athiopienne : nouvellement traduite du grec en françoys, à Paris, pour Jean Longis, libraire [...]. Colofón: Imprimé à Paris par Estienne Groulleau, et fut achevé le quinziesme jour de Février 1547.

Bacon G. W. 1912, "The life and dramatic works of Doctor Juan Pérez de Montalván”, Revue Hispanique 26, 1-474.

Buttrey T. V. 1958, "Accident and design in Euripides' Medea", American Journal of Philology 79.1 (313), 1-17.

Cervantes M. de 1976, Novelas ejemplares, ed. M. Baquero Goyanes, Madrid, Editora Nacional, Biblioteca de la literatura y el pensamiento hispánicos, 2 vols.

Feuillâtre E. 1966, Études sur les Éthiopiques d'Héliodore. Contribution à la connaissance du roman grec, París, Presses Universitaires de France, Publications de la Faculté de Lettres et Sciences Humaines de Poitiers.

Focio 1959-1991, Bibliothèque, R. Henry ed.y trad., París, “Les Belles Lettres", Collection Bizantine publiée sous le patronage de la Association G. Budé, 9 vols.

Grimal P. ed.y trad. 1963, Romans grecs et latins, París, Gallimard, Bibliothéque de "La Pléyade" 134.

Grove G. 1980, The New Grove Dictionary of Music and Musicians, ed. S. Sadie, Londres, Macmillan / Washington, Grove's Dictionaries of Music Inc. / Hong Kong, Peninsula Publishers Ltd., 3.

Héliodore 1960, Les Éthiopiques (Théagène et Chariclée), R. M. Rattenbury y T. W. Lumb edd., J. Maillon trad., París, "Les Belles Lettres", Coll. des Universités de France, 3 vols.

Laplana Gil E. ed. 1999, Juan Pérez de Montalván, Obra no dramática, Madrid, Biblioteca Castro, Edics. de la Fundación José Antonio de Castro.

López Estrada F. ed. 1954, Historia etiópica de los amores de Teágenes y Cariclea traducida en romance por Fernando de Mena, Madrid, Aldus, RAE, Biblioteca de Clásicos Españoles.

Peyton M. A. ed. 1971, Lope de Vega, El peregrino en su patria, Chapel Hill, Univ. of North Carolina Press, Studies in the Romance Languages and Literatures 97 . 
Salgado O. N. 1997, "La Historia Etiópica, un precedente de La Gitanilla en la novela griega”, $A F C$ 15, 270-287.

___ 2004, "Hipólito de Eurípides en la creación de la Historia etiópica de Heliodoro", en: Ética y estética. De Grecia a la modernidad. Tercer Coloquio Internacional, 10-13 de junio de 2003, La Plata, Universidad Nacional, Facultad de Humanidades, CELC-AFG. CDRom.

2010, "Heliodoros Polyhistor: Para una reevaluación de los datos externos de la Historia Etiópica", en: Philologiae Flores. Homenaje a Amalia S. Nocito, M. E. Steinberg y P. Cavallero eds., Buenos Aires, Universidad de Buenos Aires, Facultad de Filosofía y Letras, Instituto de Filología Clásica, 147-165.

Valbuena Briones A. 1991, Don Pedro Calderón de la Barca, Obras completas. Tomo II, Dramas, nueva ed., prólogo y notas de [...], Madrid, Aguilar, $5^{\mathrm{a}} \mathrm{ed}$. 


\title{
E os CLÁSSICOS SE FIZERAM UM ABSURDO...
}

Ana C. Fonseca dos Santos Universidade Federal de Minas Gerais

\begin{abstract}
Aqui refletimos sobre o diálogo que a peça Que venha a Senhora Dona, do académico Jacyntho Lyns Brandão, mantém com o teatro do absurdo e com Alceste, de Eurípides. Ambas apresentam semelhanças estruturais e de enredo: ambas tratam da busca de um substituto para alguém que vai morrer: mostram, de forma realista e satírica, a angústia e o medo humanos diante da inevitável morte. A Senhora Dona se aproxima do teatro do absurdo. $\mathrm{O}$ absurdo da morte ou a morte no teatro do absurdo? É possível abordar a inquestionável Senhora Dona Morte pelo viés do absurdo? É possível (re)ler o teatro antigo nessa perspectiva?
\end{abstract}

Nosso trabalho tem por objetivo refletir sobre o diálogo que a peça vencedora do Concurso de Textos Teatrais do Palácio das Artes, Belo Horizonte, Minas Gerais, de 1980, Que venha a Senhora Dona, do acadêmico Jacyntho Lins Brandão, professor de língua e literatura grega, mantém com o teatro do absurdo e com a obra Alceste, de Eurípides.

As duas peças apresentam, além de semelhanças estruturais, um enredo bem parecido: ambas se constroem em torno da busca de um substituto para alguém que vai morrer. Em Alceste, é o general Admeto, na Senhora Dona vemos um pai à procura de alguém que possa morrer no lugar de seu filhinho ainda bebê.

Assim como a peça euripidiana, a brasileira, Que venha a Senhora Dona, é uma obra que rejeita classificações. Não possui - em termos de teatro antigo e mesmo do teatro contemporâneo - as características de uma comédia, nem de uma tragédia, nem de um drama (sequer o satírico como é o caso de Alceste). Falta às duas, por exemplo, o registro de uma linguagem que oscile entre o tom elevado e o baixo, faltam-lhes - no sério assunto acerca da morte - o tom solene esperado. Entretanto, ambas as peças possuem elementos dramáticos e satíricos, como, por exemplo, uma personagem que possui a irreverência e a desmedida dos híbridos de Dioniso. Como muito bem observou Moreira:

Tomando Alceste como drama satírico, precisaríamos resolver os problemas técnicos em relação ao coro - que não se apresenta formado por sátiros, uma vez que nem sequer o pai Sileno entra em cena -, afirmando que Héracles, embriagado e voraz, substitui a raça dos híbridos de Dioniso, encarnando a irreverência e a desmedida atribuída a eles, pois em meio ao drama da casa de Admeto o herói canta e bebe descontraidamente ${ }^{1}$.

\footnotetext{
${ }^{1}$ Moreira, Flávia, Leituras da Morte, p. 170.
} 
Quanto à peça brasileira, temos Teteca, uma menina muito viva e faladeira que, por ser criança e "ter problema" (como definem as personagens Inacinha e D. Inocência), não tem sobre si as expectativas de discrição que pesam sobre os adultos. Teteca goza de um menosprezo por parte dos familiares.Desconsiderada, como Héracles no contexto da criadagem da casa de Admeto, lhe é permitido explicitar e expor os problemas que são apresentados veladamente pelos outros personagens. Em sua condição de deslocadas (personagens que não pertencem, não se adaptam às normas sociais ou de etiqueta), Teteca e Héracles têm a liberdade de fazer o papel de sátiros nas peças estudadas.

Ambas mostram, de forma realista e contundente, irônica e satírica, a angústia e o medo humanos diante da morte, inevitável a todos os seres viventes. Naturalmente, por uma ser mais de 2000 anos mais nova que a outra, por ser o local de enunciação para uma peça a Grécia, para a outra o Brasil das Minas Gerais, temos obviamente formas diferentes de tratar o mesmo tema, o mesmo sentimento. Entretanto, o que esse trabalho pretende analisar é que, por mais que seja natural que elas sejam diferentes quanto à forma, essa forma se sustenta num substrato comum e por isso não é tão diferente assim. Que isso seja apenas porque o autor brasileiro tenha lido o grego nos parece um argumento bastante fraco. As duas peças são - consideradas as distâncias de tempo e espaço -, marcadas pelas mesmas exceções, a mesma difícil classificação. Acreditamos que elas possam ser lidas como "expressão de seu tempo" ou expressão de um tempo de crise de valores. Para embasar essa hipótese, daqui por diante nos serviremos dos teóricos do Teatro do Absurdo e iniciamos com palavras do húngaro-inglês Martin Julius Esslin, professor de arte dramática que por primeiro utilizou a expressão Teatro do Absurdo. Ele afirma:

Cada um desses componentes do panorama cultural de uma época encontra sua própria expressão artística; o Teatro do Absurdo, no entanto, pode ser identificado como um reflexo do que parece ser a atitude mais autenticamente representante do nosso tempo ${ }^{2}$.

Que venha a Senhora Dona, escrita e encenada no mesmo ano de 1980, apresenta, em sua linguagem, certa semelhança com o teatro do absurdo. Naturalmente, sendo uma obra do nosso tempo, expressa esse tema tão universal, a angústia humana diante da morte, sob a ótica atual. E que forma melhor de fazê-lo do que dialogando com o teatro do absurdo, que deu um passo à frente do teatro existencialista, alinhando forma e conteúdo quando decidiu falar sobre o absurdo da condição humana, sobre a falta de

${ }^{2}$ Esslin, O teatro do absurdo, p. 19. Nosso tempo aqui significa certamente o tempo do autor, a saber, seu período de vida que vai de 1908 a 2002. 
sentidos - de certezas, de pressupostos básicos - tão característica do nosso tempo?

De fato o que nos parece e o que tentamos aprofundar nessa pesquisa ainda iniciante é a pertinência e dependência mesma do teatro contemporâneo em relação ao teatro antigo. À primeira vista estaríamos dizendo um absurdo dos absurdos, entretanto, não estamos sós. Hans-Thiers Lehmann em seu Teatro pós-dramático ${ }^{3}$ utiliza-se da noção de chora para o teatro contemporâneo. Esse complicado termo filosófico aparece pela primeira vez em Platão, no diálogo filosófico Timeu. Grosso modo, podemos entender chora como a região onde ficam todas as ideias, todas as coisas que só existem em potência. Acessáveis, mas ainda não acessadas, pela palavra. Deleuze em seu $O$ esgotado nos apresenta a ideia contrária: a de um ser muito mais do que cansado, tão exausto que se torna esgotado - aquele que esgotou toda a possibilidade. A chora de Platão seria a ideia que, explicita ou implicitamente, paira sobre o teatro que segue a convenção tradicional, inclusive o teatro existencialista de Sartre e Camus. Já o esgotado de Deleuze é a ideia que serve de base ao teatro do absurdo: a possibilidade esgotada, a ação vazia de significado, sustentada somente pela linguagem. No entanto, a linguagem, nesse caso, não é acessada para organizar o real e nomear o possível: é apenas a linguagem em si, vazia, a mais crua exposição do absurdo da condição humana. Segundo Esslin:

O Teatro do Absurdo desistiu de falar sobre o absurdo da condição humana; ele apenas o apresenta tal como existe - isto é, em termos de imagens teatrais concretas 4 .

Dessa forma, nas duas obras analisadas temos a mais absurda das situações: alguém tem que fazer o papel de deus e escolher quem morre no lugar de outra pessoa. Ao mesmo tempo em que a situação é completamente surreal, ela mostra, teatral e concretamente, o desespero humano diante do fato mais inevitável da vida: o de que um dia ela termina em morte.

O conceito de esgotamento é claro em Que venha a Senhora Dona (e diríamos que, avant la lettre, também na Alceste euripidiana), mesmo que não seja levado ao extremo, mesmo que não seja explicitado, como o é no teatro de Samuel Beckett. Os personagens, presos na situação de ter que escolher alguém para morrer no lugar da criancinha que ainda sequer teve tempo de viver, executam no palco uma ação feita somente de linguagem: atiram flechas de palavras uns contra os outros, acusações tolas, incomprováveis, incoerentes. A charada, "exercício de lógica" apresentado por Cibele, é parodiada dezenas de vezes: a cada vez é uma personagem diferente que brinca com o texto, e, mudando um detalhe aqui e outro ali, faz com que o sentido trabalhe a seu

\footnotetext{
${ }^{3}$ Tradução de Pedro Süssekind, São Paulo, Cosac e Naify, 2007, pp. 246-247.

${ }^{4}$ O teatro do absurdo, p. 21.
} 
favor, mesmo que o sentido assim criado não passe de um sofisma. Ainda segundo o professor húngaro-inglês:

O Teatro do Absurdo, por outro lado, tende para uma desvalorização radical da linguagem, para a poesia que deve emergir das imagens concretas e objetivadas do próprio palco. O elemento da linguagem ainda desempenha um papel importante nessa concepção, mas o que acontece no palco transcende, e muitas vezes contradiz, as palavras ditas pelas personagens.

De fato, em Alceste temos a linguagem minuciosamente trabalhada e poética, característica do dramaturgo grego. Contudo, mais importante que a linguagem nos parece ser, também nesse caso, a ação. Não é por acaso que a imagem de Tanathos que permaneceu para a posteridade tenha sido a que Eurípides the deu nessa peça - vestido de negro. A iconografia anterior the dava uma aparência muito bela e clara, como a de Morfeu. Mas Alceste sendo buscada por uma figura tão assustadora, ainda nos braços do marido, the concedendo mais alguns anos de vida, é belíssima. Um Tanathos claro e belo não causaria tanto pavor, não evidenciaria toda a beleza e finitude da vida.

A peça brasileira se encaixa melhor na definição oferecida por Esslin. Sua linguagem é simples, cotidiana, não causa atrito aos ouvidos belo-horizontinos (público ao qual se destinava quando foi encenada). Combinada com a ação, entretanto, produz uma poesia belíssima. A cena familiar provoca uma sensação de proximidade, e, combinada com os dramas tratados (tão comuns entre tantas famílias) - os ciúmes, as invejas, os desentendimentos, as preferências, as críticas -, se torna poética na medida em que mostra a condição humana, em toda a sua solidão e coletividade, em todo o seu paradoxo. Nessa, sim, as ações contradizem as palavras, e isso contribui para que a peça seja não mais incoerente, mas mais enfática, pois une a forma ao conteúdo.

Um pouco mais difícil - mas não impossível - é ir além, e propor leitura semelhante sobre Alceste. De fato, é uma peça escrita e encenada milênios antes do conceito de Teatro do Absurdo. Se ele é uma das expressões mais autênticas da atualidade, pode ser aplicado a uma obra da Antiguidade Clássica? Acreditamos que pode. Embora a elaboração desse conceito seja bem recente, ainda que só agora tenhamos refletido sobre o esgotamento, todos os elementos que compõem o Teatro do Absurdo (a sensação de fastio, de relativização e queda dos valores) existia, com menor ou maior intensidade, desde os tempos da Grécia Arcaica. Mesmo na comédia antiga não é difícil encontrar exemplos de uso sofisticado da linguagem para criar absurdos.

Sendo assim, não propomos aqui que o teatro clássico se encaixe no Teatro do Absurdo. Nem nossa pesquisa foi suficientemente extensa para poder afirmar que o teatro clássico dialoga com o teatro do absurdo. Estamos, sim, querendo

\footnotetext{
${ }^{5}$ Esslin, O teatro do absurdo, p. 22.
} 
afirmar que Alceste dialoga não só com a Senhora Dona de Brandão, mas também com o teatro do absurdo. A partir desse ponto abre-se a possibilidade de que outras peças clássicas possam ser lidas da mesma forma.

$\mathrm{O}$ desfecho de Alceste, que a princípio tendemos a considerar como o final feliz esperado de um drama satírico, é dúbio. A peça termina com um rei marcado pela pecha de covarde, um reino marcado pelo profundo luto pela excelente rainha, e uma rainha ainda muda como as sombras da terra dos mortos. Sim, o corpo de Alceste retornou, mas sua alma ainda é a mesma? Ela se lembra de quem é? Ela poderá, algum dia, voltar a falar? Ela conseguirá se recuperar da assustadora experiência de ter morrido? Não sabemos.

Ao que nos parece, Eurípides, de uma forma muito sofisticada, trabalhou a linguagem de sua obra tão sutilmente que a princípio não se percebe o absurdo criado. Ele, porém, está lá: o absurdo da condição humana já referido por Héracles algumas cenas antes, quando faz um discurso sobre a finitude da vida humana, e sobre como não se deve levar muito a sério a morte de uma estrangeira.

Enxergar uma peça tão antiga como Teatro do Absurdo faz com que observemos por outro ângulo as obras clássicas. Olhar por outro ângulo, na esmagadora maioria das vezes, permite novas descobertas. Acreditamos que ver Alceste dessa forma ajuda a entender por que as peças de Eurípides foram preservadas, lidas e encenadas por mais de dois milênios. $\mathrm{O}$ fato de uma teoria tão moderna poder se aplicar a uma obra tão arcaica mostra o quanto ela é universal. $\mathrm{O}$ quanto, mesmo que a própria cultura em que foi criada tenha se perdido, ela fala aos muitos públicos a que foi apresentada. O quanto ela é capaz de falar a qualquer pessoa.

Ao mesmo tempo, mostra que o autor, ainda que não tenha refletido sobre isso como fizeram Esslin, Beckett, e outros, sabia mostrar o absurdo humano, e sabia o quanto ver esse absurdo escancarado é importante para os seres humanos, pois a arte serve de espelho para nós mesmos; para que, vendo nossa imagem refletida, nós consigamos nos entender.

A forma leve, delicada e poética com que a peça de Jacyntho Lins Brandão dialoga com Alceste nos mostra, também, a sensibilidade desse autor, a forma como ele compreende o que há de mais universal e interessante no teatro clássico, e é capaz de reproduzir essa universalidade sem, contudo, perder a modernidade. O jeito contemporâneo de tratar dos mesmos assuntos mostra sensibilidade, também, para com a sua própria era. E, a nosso ver, é a combinação do que há de mais clássico com o que há de mais contemporâneo que faz da peça Que venha a Senhora Dona uma obra-prima da atualidade. 


\section{Bibliografia}

Brandão, Jacyntho Lins, Quevenha a Senhora Dona, Belo Horizonte, Tessitura, 2007.

Deleuze, Gilles, O esgotado, in Sobre o teatro: Um manifesto de menos; O esgotado, Tradução Fátima Saadi, Ovídio de Abreu, Roberto Machado, Rio de Janeiro, Jorge Zahar, 2010.

Esslin, Martin, O teatro do absurdo, Trad. Bárbara Heliodora, Rio de Janeiro, Zahar Editores, 1968.

Lehmann, Hans-Tiers, O teatro pós-dramático, Trad. de Pedro Süssekind, São Paulo, Cosac e Naify, 2007.

Moreira, Flávia Freitas, Leituras da Morte, in: Sousa e Silva, M. F.; Barbosa, T. V. R. (org.), Tradução e recriação, Belo Horizonte, Faculdade de Letras da UFMG, Faculdade de Letras da Universidade de Coimbra, 2010. 


\title{
Antígona se Vuelve PluRAL EN LA ARgentina: ANTÍGONAS, LINAJE DE HEMBRAS De Jorge Huertas
}

\author{
Susana Scabuzzo \\ Universidad de Bahía Blanca
}

Con AntígonaS, linaje de hembras, Jorge Huertas recrea la versión clásica situándola en la Buenos Aires contemporánea. Como Sófocles, expone problemas acuciantes para la sociedad a la que pertenece $y$, tal como el griego, se remonta a planteos que alcanzan universalidad. Escenas fieles al texto griego, alternan con otras ancladas en duras facetas de la realidad de Buenos Aires. Estos dos universos parecen suturados por el tango, de amargo regusto a tragedia. Las mujeres del Coro de Hembras, fuertes como Antígona, urgen a despertar a la ciudad adormecida, en la que se silencian la violencia y la muerte injusta.

Como señalara Bajtín hace ya más de tres décadas ${ }^{1}$, las grandes obras de la literatura trascienden los límites temporales, exceden el momento de su creación, y se integran en una dimensión que él llama el gran tiempo. Estas obras se caracterizan por poseer una profundidad tal de significados que sus propios contemporáneos no acaban de percibir; por esa misma razón las generaciones posteriores van descubriendo esos tesoros de sentido que el autor, quizás de manera no totalmente consciente en tanto es deudor de su época y de su cultura, depositó en ellas. Estas obras tienen una particular vitalidad que las mantiene vigentes por siglos. En el caso particular de la tragedia griega, la inagotable plasticidad del mito de que se vale para expresar determinados contenidos, es otro elemento a favor de su pervivencia. Sin ninguna duda, Antígona de Sófocles es una de estas obras preñadas de sentidos que cada época va desentrañando.

La multiplicidad de conflictos que encierra la Antígona de Sófocles la hace particularmente apta para sucesivas reescrituras y remisiones: individuo y sociedad, familia y estado, mujeres y hombres, jóvenes y adultos, ley humana y ley divina, razón y pasión, vida y muerte, son confrontaciones constantes en la vida humana. Ello ayuda a explicar la fortuna de esta obra clásica en Europa y en América ${ }^{2}$.

\footnotetext{
${ }^{1}$ Bachtin, M., Estética de la creación verbal, trad. esp., Méjico, 1982.

${ }^{2}$ Para la fortuna de Antígona en Europa remitimos a Steiner, G., Antígonas, trad. esp., Madrid, 2000. Sobre versiones anteriores a Sófocles, cfr. mi tesis doctoral Tratamiento del mito en tres tragedias de Sófocles, Bahía Blanca, 1994, y "El mito de Antígona en Antígona de Sófocles", en Trasiego, Revista de la Facultad de Humanidades y Educacion, Univ. Nac. de Los Andes, Mérida, 1993, 11-17.
} 
Si los conflictos que señalamos en la obra de Sófocles son piezas capitales de su andamiaje, no lo son menos las ambigüedades y contradicciones con que se entrelazan.

Su Antígona es una joven princesa; en tanto mujer, su participación en la vida de la polis y en los espacios públicos debía estar muy restringida. Sin embargo ella, para cumplir con el rito fúnebre que Creonte niega a su hermano, viola la prohibición y se aventura a atravesar la ciudad e internarse sola en la zona inculta donde tuvo lugar la lucha contra los argivos y el combate entre los dos hermanos, espacio propio no de la doncella sino del guerrero. Siendo mujer se atreve a enfrentarse con el varón que posee el poder de la realeza, y en su debate con Creonte exhibe una racionalidad que la época consideraba privativa de los varones ${ }^{3}$. Pese a estos rasgos poco femeninos según el modelo vigente, Antígona aspira a enterrar a su hermano cumpliendo así el rol que la tradición asignaba a las mujeres allegadas a un difunto ${ }^{4}$. Y cuando es llevada a la muerte, lamenta no haber cumplido los pasos esperados en una joven: el matrimonio y la maternidad. También Creonte es contradictorio. Desde el inicio proclama la necesidad de guiarse por la recta razón, y pretende ser el salvador de la ciudad; sin embargo, a medida que avanza la obra su juicio parece debilitarse; en los enfrentamientos con Antígona, con Hemón y con Tiresias se deja dominar por la pasión, y acaba destruyendo a su familia y poniendo en serio riesgo a la ciudad. Hemón, a su vez, razona con la claridad de un varón, pero toma el partido de una mujer. Eurídice, su madre, se retira al interior del palacio, en apariencia para llorar como mujer la suerte de su hijo, pero se da muerte al modo masculino.

Tras las numerosas recreaciones de que ha sido objeto Antígona en variadas lenguas y latitudes, Jorge Huertas, dramaturgo argentino de sólida trayectoria, estrenó en Grecia, en agosto de 2001, AntígonaS; linaje de hembras. Con S mayúscula al final. No caben dudas sobre el lugar en que se desarrolla la acción de esta recreación: la Buenos Aires contemporánea, con su "ágora de Mayo". En ese escenario ciudadano se desarrolla una obra que, tal como la de Sófocles, es de fuerte compromiso político y está firmemente anclada en la conflictiva realidad de la tierra en que nació ${ }^{5}$.

${ }^{3}$ Aristóteles (Pol.1245b-1260a) reserva para el varón libre la capacidad de desarrollar plenamente las facultades deliberativas.

${ }^{4}$ Resulta interesante el análisis que hacen L. Bennet y W. Tyrrell del rol femenino de Antígona en el sepelio en relación con los usos de la ciudad ('Sophocles' Antigone and funeral oratory, AJPh, III (1990) 441-456.

${ }^{5}$ Cfr. Vernant. J-P., Entre mito y política, Méjico, 2002. Por su parte Dubatti señala: "El teatro no necesita reproducir mensajes explícitos o el proselitismo partidista que circula en los discursos sociales. La mayor fuerza política del teatro está en su capacidad metafórica. Alcanza entonces con que el teatro sea bueno artísticamente para que se genere una ilimitada producción de pensamiento político." Dubatti, J. (coord.), Teatro y producción de sentido político 
Apegada fidelidad al texto griego e innovadora creatividad caracterizan esta versión argentina. Huertas retoma los pasajes medulares de Sófocles, y en acabada síntesis produce breves escenas que remiten claramente al texto antiguo: diálogo inicial de Antígona e Ismena, "Discurso del trono" de Creonte y proclama sobre los cadáveres de los dos hermanos, informe del guardián que descubrió el enterramiento de Polinices, debate de Antígona y Creonte, enfrentamiento de Hemón y Creonte, diálogo de Tiresias y Creonte,y despedida final de Antígona.

Estas escenas alternan con otras ancladas en las facetas más duras de la realidad de Buenos Aires y de todo el país. En ellas aparecen personajes nuevos: La Embalsamada Peregrina (cadáver de Evita), Bandoneón, un Coro al modo griego - pero de hembras- y el Río. Ellos insuflan en la tragedia griega un porteño aliento tanguero, y es el tango, con su amargo regusto a tragedia, una forma de sutura de estos dos universos que parecen tan distantes. El tango está presente en las frecuentes menciones de sus autores, en los fragmentos citados, y sobre todo en la música, único lenguaje en que se expresa Bandoneón. (E1 Coro de hembras lo cuestiona, por cuanto lo considera un canto maricón sobre cuestiones intrascendentes, que embotan con sensiblerías el alma de los argentinos). No solamente el tango es exponente de lo popular; el Riachuelo con su podredumbre, y un lenguaje aporteñado y vulgar que a menudo se vuelve lunfardo confieren un tono de provocador desenfado, que alterna con pasajes de exquisita poesía.

El tango, citas de Borges, de la Biblia, del Martín Fierro, el discurso político de Evita, eslóganes publicitarios, se entretejen continuamente en este texto, y al tiempo que proponen al espectador una especie de juego de pistas, reflejan variados rasgos y acontecimientos de la vida nacional.

Señalábamos más arriba los múltiples conflictos que plantea Sófocles. Entre ellos, Huertas destaca la oposición de géneros, que resulta expandida en relación con el texto griego, y se constituye en uno de los ejes que vertebran la obra. El Coro está integrado por las "hembras" que se anuncian ya en el título, y el término con que se las designa es un anticipo de su tratamiento en la obra. Aquí el conflicto no se plantea entre hombres y mujeres, sino entre machos y hembras. Creonte es el macho de esta historia, el más relevante, el que aparece en escena, aunque tras la escena se dibujan variadas formas de violencia machista ${ }^{6}$. Ebrio de poder y de autoritarismo, desprecia todo "lo otro", sean ideas, posturas políticas, personas, particularmente mujeres. Como su par griego, pasa por alto las relaciones de parentesco que guarda con Antígona

en la posdictadura, Buenos Aires, 2006, 13.

${ }^{6}$ Aunque en forma más acotada, la violencia está presente en la Antígona de Sófocles; al respecto ver Panoussis, J., Crainte et violence dans le théâtre de Sophocle, Provence, 2003. 
e Ismena, pues su ley está por encima de todo otro juicio. Considera que su palabra es palabra de Dios, incuestionable, que debe ser cumplida sin vacilación como único medio de mantener salva a la ciudad. Sin embargo, tal como en el texto griego, es por su misma obcecación que se llega al desastre final, debido a que los muertos no recibieron el tratamiento debido. Como otros Creontes argentinos, este no se arrepiente de lo hecho, sigue creyendo que hizo lo que había que hacer, y lo que él sabía hacer; por eso, ante el desastre, se erige en un nuevo Jesús inocente: "Por qué, Dios mío, me has abandonado?" . Este macho autoritario parece condensar todas las conductas abusivas que se mencionan en la obra, particularmente los atropellos cometidos contra mujeres. Son las mujeres las que denuncian con insistencia las mil muertes fratricidas que jalonan la historia argentina, y las repetidas y brutales violaciones de mujeres y niñas. Ismena es la primera en señalar la causa de tantos males: "Cuando la

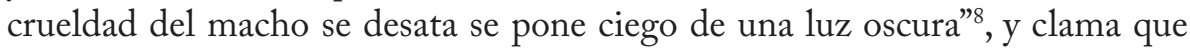
cese la matanza entre hermanos. La muerte recíproca que se han dado Eteocles y Polinices es expandida hasta abarcar toda violencia entre compatriotas; y la muerte de Antígona se vuelve expresión de todos los abusos cometidos contra las mujeres.

Uno de los personajes que incorpora Huertas es La Embalsamada Peregrina, que no es sino el cadáver de Evita que cobra presencia y voz. En su primera aparición celebra la conquista del voto femenino como coronación victoriosa de una larga serie de luchas. Tras la condena definitiva de Antígona y las revelaciones de Tiresias, la Embalsamada retorna a escena para confesar su mentira: "no hay laurel, ni victoria, ni certezas, solo parir argentinos para la masacre entre hermanos" los machos, que se ejerce contra las mujeres y se desfoga también contra el coterráneo "Ley escrita sobre cuerpos de mujer: somos madres de niños crueles que se comen entre sí como en el primer día de las chozas que nadie imaginaba Buenos Aires". Evita urge a las mujeres a "encontrar los días felices".

"Mientras tanto una mujer morirá siempre./Llorarán miles y sufrirán todas./ Nosotras, las que luchamos día a día / alimentando hijos sin padres. / Nosotras, las que abrimos escuelas / e izamos la bandera. / Nosotras las mal paridas / las mal pagadas / las mal cogidas /Nosotras las chinitas catamarqueñas / atravesadas vuelta y vuelta / en el altar del falo atrio./ Mochileras, prostitutas, / niñas ahogadas por el instinto macho. / Siempre habrá una hembrita / y su cuerpo abierto / tirada sobre el altar del falo patrio"10.

\footnotetext{
${ }^{7}$ Huertas, J., AntigonaS, linaje de hembras, Buenos Aires, 2002, 68.

${ }^{8}$ id.,id. 26.

${ }^{9}$ id.,id. 27.

${ }^{10}$ id.,id. 58-59.
} 
Como Polinices, la Embalsamada es un cadáver vejado; como Antígona, una mujer sometida por el varón dominante y belicoso; pero es más que eso, es una figura casi mítica que fuera ya de los límites del tiempo, expresa el dolor de todas las mujeres, y reclama por su dignidad y por la paz.

El diálogo inicial de Antígona con Ismena, que reproduce el prólogo de Sófocles, es fiel al espíritu del texto de partida; en forma condensada plantea el conflicto central de la obra, con las variantes propias del cambio de lugar y de época: Polinices está abandonado al borde le Riachuelo, Ismena enumera muertes entre compatriotas en nuestra historia. Antígona cierra el encuentro diciendo "Llevo en la sangre un tango, un sentimiento de justicia que se baila". Sin embargo el Coro descree de la firmeza de la decisión de Antígona, y la provoca: "Es una hembra. Finalmente será la reina de la sopa tibia y las ventanas cerradas"11. Pero ella cumple la hazaña del enterramiento, y argumenta con fuerza y lógica implacable ante su tío defendiendo la ley eterna de Dios, frente a la convencional de Creonte.

En la escena en que marcha a su último encierro se apasiona lamentando la historia fratricida de nuestra patria y sus propios sueños incumplidos. Pero no muestra debilidad; al contrario, su coraje parece acrecentarse; asume que ella no es una dama correcta, como exige la ciudad, y clama que todo Buenos Aires vocee que ella enterró a su hermano: "Que chamuyen los reos y se pasen el santo. Que griten todas las hinchadas del domingo este gol enorme que no cabe en la garganta. ¡Porteños: Antígona enterró a su hermano!"12.

El Coro de Hembras inicia la obra increpando al Bandoneón para que rompa el silencio en la calma noche de callada violencia, en que la Patria se está muriendo. En los primeros tramos de la obra, frente al Bandoneón, se muestra conmocionada por la situación en que está la Patria, pero su actitud no es lineal; en una escena se refiere a Creonte en forma paródica como el cuarto integrante de la "sagrada Cuaternidad: Padre, Hijo, Espíritu Santo y Creonte", y a continuación denuncia la violencia social a que son sometidos los marginados; todo esto frente al propio rey. Sin embargo, en dos oportunidades, cuando Antígona discute con Creonte y cuando Hemón hace lo propio, este Coro de Hembras se repliega y sus palabras parodian a quienes eluden comprometerse con la verdad: "Yo no vi nada no pensé nada no escuché nada A mí nadie me dijo nada. No averigüé ni contesté ni pregunté"13. En el cuadro en que aparece junto a Antígona que marcha a la muerte, en principio asume hacia ella el gesto desvalorizante de los ancianos tebanos del drama griego

\footnotetext{
${ }^{11}$ id.,id. 29.

12 id.,id. 64-5.

${ }^{13} i d ., i d .44$ y 51.
} 
en idéntica coyuntura. Pero a poco de avanzar la escena cambia su actitud; en uno de los pasajes más significativos se define sin ambages pero lo hace calificándose desde la mirada del varón:

"Nosotras Antígonas / las novias de la mugre/ del hedor madres / las manchadas, las sucias, / las bárbara. / Yo sé cómo se llama mi herida: / Hembras / Yeguas/ Brujas / Locas / Putas"; ${ }^{14}$

y con valor se hace eco del pregón: "Porteños: Antígona enterró a su hermano".

Así, el Coro se sitúa -como Antígona - del lado oscuro de una sociedad dominada por varones; asumen la distancia que las separa del modélico decoro femenino sancionado por ellos.

Un personaje novedoso y de notable peso es El Río, que se expresa en breves monólogos de singular potencia poética. Inicialmente se presenta como parte de la naturaleza inocente anterior al hombre, como heraclítea corriente, "hecho de tiempo"15. Luego, con la aparición del hombre con las manos manchadas de sangre humana, el Río, al par que reniega de su propia inocencia anhela el placer humano de matar, quiere ser tan terrible como el hombre que Sófocles canta en su Antígona. En otro monólogo evoca los vuelos de la muerte, $y$ tantas otras muertes que los hombres escondieron en sus aguas; esa violencia lo llevó a quedar "fuera de la religión de todo", escindido de la inocente naturaleza por obra del hombre. El cadáver de Polinices se pudre a orillas del Riachuelo (aunque Antígona intenta su enterramiento simbólico en un lugar simbólico: Callao y Rivadavia,junto al Congreso); ese despojo atacado por las ratas y sucio de brea expresa el horror de tantos y tantos cadáveres privados de sepultura. Los cadáveres de los combatientes derrotados ante los muros de Tebas que el Creonte griego no permitió sepultar, desgarrados por las aves de rapiña, contaminaron los altares y provocaron una nueva y funesta guerra que acabaría con la destrucción de Tebas. Los cuerpos entregados al Río, que perdió su inocencia en la Argentina, lo volvieron hostil. En la escena final, titulada "Peste y enigma”, el Río "asalta las orillas del hombre", le vomita los muertos, inunda, y su desborde trae peste y hambre, y una calamidad mayor aun: la Esfinge, que al modo del monstruo mítico canta un enigma que la ciudad debe descifrar para evitar más muertes: “¿Quién de nosotros es el agua, / cuál el nombre y apellido /que corre, crece, rebasa / y finalmente siempre pasa?" 16 . Recordemos que el enigma de Sófocles, que aludía a las tres etapas

\footnotetext{
${ }^{14}$ id.,id. 62.

${ }^{15}$ Esta visión del río evoca al Borges de "Arte poética": "Mirar el río hecho de tiempo y agua/ Y recordar que el tiempo es otro río,/ Saber que nos perdemos como el río / Y que los rostros pasan como el agua" (Fervor de Buenos Aires).

${ }^{16}$ Antígonas, 70.
} 
de la vida del hombre, tenía como respuesta, precisamente, el hombre. Pero en realidad esa respuesta era el verdadero enigma a descifrar: ¿Quién es el hombre?, $¿$ Cuál es la identidad verdadera de ese ser multiforme, cambiante, proteico? ${ }^{17}$. Justamente, el cambio, el no ser nunca idéntico a sí mismo, desplegando en el tiempo formas sucesivas. El enigma griego lo pone frente a ese ser monstruoso que anda en cuatro patas, luego en dos y finalmente en tres como frente a un espejo en el que contemplar la multiplicidad que somos cada uno. El acertijo que plantea esta nueva Esfinge tiene mucho en común con el griego ${ }^{18}$;el agua que fluye y siempre pasa expresa el ser del hombre, siempre cambiante, siempre disolviéndose y reconstruyéndose con nueva forma. Pero no olvidemos que fue el hombre, Creonte, quien concedió al Río abandonar su inocencia a cambio del goce cruel de la muerte, propio del ser humano. "por eso [dice Creonte] le entregué los muertos"19. El Río asumió la crueldad del hombre; y el ser del hombre se expresa en el Río.

A la Esfinge que se yergue en nuestra Costanera le hace frente el Coro de hembras; ellas convocan a los tangueros, a los poetas con sus metáforas para descifrar el enigma, a toda la gloria de Buenos Aires, a la ciudad entera, para que la Esfinge no devore a sus hijos.

Hemos dejado adrede para el final la escena en que Tiresias se enfrenta con Creonte. El adivino ciego del mito aparece aquí fundido con Borges, a cuyos textos acude en sus respuestas al rey. Como su par griego, procura que Creonte tome conciencia de la contaminación que ha generado entregando cuerpos al río. Intercede también por Antígona, a quien Creonte considera guaranga y arrabalera como La Embalsamada Peregrina. Por eso Creonte, aludiendo a posturas políticas de Borges, le pregunta “¿quién sos? ¿Aquel enemigo de la Embalsamada Peregrina, o este otro?” La respuesta del adivino es claramente borgeana: "Soy el mismo y el otro. Como todos" ${ }^{20}$ y reseña su mutación: "quise escapar a mi destino sudamericano"..."Ahora [...] me gusta el barro y me seduce la barbarie". Y finalmente expresa en una frase uno de los sentidos capitales de la obra: "Estamos luchando contra el espejo, Creonte. Por eso la batalla es tan inútil”"1.

La Embalsamada celebró una victoria que luego debe desmentir, vencida por el poder masculino abusivo; Creonte pretendió ser el salvador de la ciudad pero su empecinamiento provoca grandes calamidades; el Río, que nació

${ }^{17}$ La Esfinge, como otros varios seres terioantropomórficos vinculados a los ritos de pasaje, tiene una función pedagógica importante: desorientar para liberar de la rutina conformista, del lastre alienante de lo cotidiano. (ver Goux, J., Edipo filósofo, Buenos Aires, 2000).

${ }^{18}$ Y también con el poema de Borges "Edipo y el enigma" (Fervor de Buenos Aires).

${ }^{19}$ Antígonas, 54.

${ }^{20}$ Clara alusión a El otro, el mismo.

21 Antígonas, 55. 
inocente y antes que el hombre, se vuelve hostil y violento al modo humano; el Coro de hembras, que por momentos acepta obediente las palabras de Creonte, cobra luego coraje para asociarse al valor de Antígona y para convocar a la ciudad a enfrentar a la Esfinge. Pero al modo de la griega, la Esfinge espeja el ser del hombre.

Huertas monta este juego de imágenes cambiantes y de violencia inagotable sobre el mito griego, diríamos con Aristóteles sobre el "mythos" de la tragedia griega. Las pasiones que entran en el movimiento escénico del drama de Sófocles están presentes también en esta reescritura, así como las ambigüedades y los juegos de sentido, que llegan hasta el enigma. $Y$ sobre ellas se encabalgan y se entretejen la violencia y las desdichas de Buenos Aires. A partir de la realidad de tanta muerte injusta, de tanto poder abusivo, esta Antígona invita a reflexionar sobre el ser del hombre, su relación con la naturaleza, con los demás hombres; a repensar las relaciones de poder, particularmente las que se dan entre géneros; y a revisar nuestra historia con una mirada nueva. La obra se cierra con una interrogación acuciante "¿Qué será de la Reina del Plata? ¿Qué será de mi tierra querida?”, con la que nos llama a despertar al sonido de Bandoneón. 


\title{
Una Medea portuguesa: \\ EduARda dionísio, ANTES QUE A NOITE VENHA
}

\author{
Maria de Fátima Silva \\ Universidad de Coimbra
}

Antes que a noite venha, de la escritora portuguesa contemporánea Eduarda Dionisio, es una pieza de teatro constuída sobre cuatro monólogos de mujeres célebres como paradigma de pasión y muerte: Julieta, Inês de Castro, Antígona y Medea. El género monólogo permite que cada una haga una ponderación sobre las razones, de orden personal, subyacentes en su drama, y sobre la forma en que orientan su destino. Es en particular el caso de Medea al que voy a dedicar mi atención.

Antes que a noite venha, de la portuguesa Eduarda Dionísio ${ }^{1}$, es un conjunto de cuatro monólogos, bajo el lema 'amor y muerte', pronunciados por cuatro heroínas famosas: Antígona y Medea, de la Antigüedad clásica, Julieta y la portuguesa Inés de Castro de raíz medieval, nacidas todas de una tradición europea que se expandió por el mundo y se hizo intemporal. Encima de aquéllos que son los rasgos esenciales de estos 'mitos' famosos, E. Dionísio se propuso aplicar un proceso de 'trivialización', ajustándolos a un universo muy portugués y lisboeta, que bien puede simbolizarse en la pareja convencional de la prostituta y el marino. Vale la pena escuchar las palabras de la autora (1992: 10-11) sobre los supuestos que orientaron su creación: ‘'Por qué Julieta, Antígona, la Castro, Medea, salidas casi directas de sus tragedias más o menos antiguas, no habrían de desfilar por aquí, al menos con la banalidad que les dio el continuo paso de boca en boca, de cabeza en cabeza, de corazón en corazón? (...) ¿Por qué el amor y muerte de una mujer anónima serán distintos, como eso del amor y muerte de los monstruos sagrados que la literatura fue reduciendo a frases?'

Hecha la opción, que, a pesar de filtrada por un otro contexto cultural, no perdía aun así fidelidad a las historias que le servían de referencia, se hizo necesario pensar en la estructuración: y entonces, sí, la diferencia se radicalizó. El nuevo texto está despejado de la convención de la escritura teatral. Es una sucesión de monólogos, que tal vez no mereciesen llamarse teatro si no fuera la identidad de las voces que los pronuncian, salidas todas de un modelo trágico.

El objeto de este estudio es el caso de Medea, que, en Antes que a noite venha, profiere tres monólogos: Discurso a Jasón, Discurso a sí misma, Discurso al

\footnotetext{
${ }^{1}$ Lisboa, Cotovia, 1992.
} 
público. Atendiendo a su destinatario, las dos primeras hablas pretenden hacer de la historia esencialmente un conflicto entre dos personas, empalideciendo a los demás intervinientes de los modelos tradicionales. La apertura al público, al final, inmortalizará el episodio, confiriéndole una otra dimensión, la que presta universalidad a lo que antes era sobre todo personal.

E1 Discurso a Jasón valoriza un conjunto de elementos conformadores de lo esencial de un recorrido de vida: retrato del héroe, encuentro de la pareja, aproximación y ruptura, desencadenamiento de un espíritu de venganza. Éste es, de los tres, el monólogo más extenso, porque es el que resume los antecedentes de la historia.

\section{Odio tu voz agria}

cuando la escucho surcando el silencio profundo del palacio.

La memoria arranca in medias res y el conflicto se coloca en términos, en primer lugar, verbales. Se ensancha el eterno juego de palabras y la incapacidad de una verdadera comunicación entre los personajes, que son euripidianos. Más que la veracidad o comprensión de contenidos, es sobre todo la disonancia - dentro de un sentido de verbalización de la historia en escena - que molesta. Sólo después el contenido se establece como falso, al mismo tiempo que surge el retrato de Jasón.

\section{Hablas con fingidas felicidades a quien se te cruza}

Como primer rasgo de la personalidad del Argonauta se impone la superficialidad, en esa tendencia para no mantener con quienes están a su alrededor lazos afectivos fuertes. Lo que dice, en pura inconsecuencia, suena agradable, pero es falso. Éste es un supuesto que de inmediato se profundiza:

Saludas sin vergüenza al sol, y a todos,

Como amigos recientes,

Inseguro de tu mórbida decisión.

Con esfuerzo actúas

Como si todo ya te perteneciera en la ciudad.

Jasón viste la eterna piel del héroe viajero, que no tiene ciudad propia y tiende a ser el extraño. Sobra en él una desfachatez que resulta exactamente de esa falta de amarras y del enfrentar constante de lo desconocido. Es un apátrida, optimista, conquistador, osado; finge, sin escrúpulos, sentir philia, esté donde esté; el sol es un símbolo de su universo sin límites. Pero, en verdad, los objetivos que lo motivan son inconsistentes y pasajeros; actúa 'como si...', su vida es un enorme fingimiento en todo lo que toca a vínculos afectivos. Los 
amigos que tiene son recientes, parece desproveído de un entorno familiar o estructuras afectivas estables.

Al mismo tiempo que finaliza este breve retrato, a grandes rasgos, de Jasón - cuya tónica es su instabilidad y falta de raíces -, Medea establece la conexión con la gran etapa de la vida del Argonauta: su encuentro con la hija de Eetes.

Eres hoy el peor de los hombres

Que mujer alguna

Alguna vez concibió

En estos países horrendos

Para donde en mala hora

Cuerpo y alma

Me transporté.

De la identificación del peor de los hombres, pasamos a la relación que mantiene con el sexo opuesto, hasta su individualización en Medea. Jasón representa un 'tipo' de hombre que tal vez sea aceptable a la luz de criterios masculinos; pero que es inconcebible para cualquier mujer. Los sentimientos y su solidez parecen ser lo que separa dos mundos, el masculino y el femenino. Los países horrendos - seguramente Tesalia y Corinto - suponen la pérdida de raíces. Pero mientras que para Jasón, el hombre sin ciudad, el universo es su mundo, para Medea la pérdida de su país es terrible. La mujer vive mal en ese tal limbo de sentimientos. La princesa de Cólquida vuelve a ser, por eso, paradigma de aquélla que, por amor, aceptó una situación contra natura: se exilió por entero, de cuerpo y alma, de forma voluntaria, pero ciega e imprudente.

$\mathrm{Su}$ texto refuerza el estilo confesional, en el rememorar de los sueños de Jasón, que son asimismo las promesas engañadoras por las cuales Medea se dejó seducir:

Serás rey, dices, y poderoso

Por la mano de esa por quien con alarde me remplazaste.

Serás déspota de su cuerpo

Como todo hombre es déspota del cuerpo de la mujer

Que sólo le sirve para traer riqueza y descendencia,

Más alta o más baja,

Según el acaso, el año, el día, el mes.

Bien masculino es el proyecto de Jasón, volcado primero en el poder, por el cual se dispone a todo, incluso a la traición. Por su nueva amada no muestra sombra de sentimiento, solamente interés (tal vez con Medea haya sido también así). Escondiendo el vacío de sentimientos hay el alarde en el 
que se envuelve su nueva elección, golpe terrible contra la colquidense, ilusión para Creusa. Igual ambición le motiva los relacionamientos personales. La relación hombre / mujer - como la concibe el hombre / Jasón - no conlleva afecto ni proximidad. Es el ejercicio de una tiranía únicamente física, con objetivos muy pragmáticos: sacar ventajas inmediatas, las que le traen riqueza, $\mathrm{y}$, a mediano plazo, las que la descendencia faculta. El total acaso regula esta relación, impersonalizada, mecánica, ocasional.

Bien distinta es la aportación femenina a la historia.

Tal vez me hayas amado.

Yo seguro que te amé.

Dejé tierras, padres.

Maté a un hermano.

Con palabras fuertes, porque lacónicas, se hace el retrato del amor de Medea y de los excesos a los que por naturaleza está sujeta. Tal vez ... seguro establecen el gran contraste entre los dos protagonistas del episodio de la Cólquida; lo que en él es duda, en ella es convicción. Ni una sola palabra sobre el vellocino de oro, ni sobre la colaboración de la princesa en la aventura. La omisión de los pormenores del mito universaliza la historia. No es más que una mujer que abandona todo en nombre de la seducción de un desconocido. La brujería también desapareció, para que la humanidad de los argumentos se imponga en plenitud.

En Corinto, todo cambió, allí Jasón dejó de ser quien era:

No eres más que un exiliado inconformado

Con el poco poder que te tocó en el reparto.

Mientes.

Disfrazas con inventados motivos

Los deseos impuros que te corrompen y consumen.

Esa que te ofrecieron es hija de rey.

Fuiste construyendo a sangre fría

En contra de la vida que te entregué

La sensatez que nada pesa.

En el otro plato de la báscula está

En pequeño monte de polvo

El oro de mi amor intenso.

Para mí lo fuiste todo.

Hoy eres otro.

Jasón, en Corinto, es más extraño que en la Cólquida. Es en su tierra donde se siente un exiliado, más exiliado incluso que Medea, porque su mundo es el poder, el trono, y ese tesoro no lo ha conseguido. Tal vez sea en Grecia 
donde la gran aventura de Jasón se desarrolla y fracasa; allí Medea no puede colaborar. Solo, las armas de Jasón son las mismas de siempre, palabras falsas y simulación. Para satisfacer sus proyectos, que nada tienen de la excelencia que se espera de un héroe, que no pasan de las más mezquinas ambiciones, va a usar de nuevo a una mujer. Ésta no tiene perfil ni emociones. No se sabe lo que siente, para que todo no pase del efecto que su intervención origina. Fue una ofrenda pasiva, en la que su voluntad no interfirió. Basta que se diga que 'es hija de rey', éste es su único rasgo de identidad. Puramente circunstancial. Sirvió de estímulo a la ambición del Argonauta, por simple estatuto, nada más. Se volvió el contrapeso, vacío, al amor de Medea, colocado, en desequilibrio, en el otro plato de la báscula.

La elección de Jasón, consciente, a sangre fría, transformó una vez más sentimientos en polvo, un polvo de oro, el único tesoro a conquistar. Al vacío de emociones con el que jugó en el episodio, respondió la intensidad de la pasión de Medea. Se dio la ruptura, todo se volvió distinto de lo que fuera con la mudanza de Jasón, su único responsable. El exilio de la extranjera es, en este caso, de índole sentimental, en una historia que es de amor y muerte.

Como roca, como ola del mar,

Escucho los consejos de esos conciliadores de profesión,

Enviados de las tierras y casas,

En las que nunca nadie supo lo que fuera pasión.

Tengo el cuerpo prisionero del hielo

En que este lago de lágrimas se va volviendo.

No puedo desplegar los ojos del suelo.

Mi mente rueda

Agarrada a la lanza que la pincha.

De nada valió al final

El bárbaro coraje con el que traicioné a los míos y a ti me entregué.

Éste es un paso en primer lugar personal, físico, relativo al pasado y a su identidad más profunda. La renitencia y fuerza de su personalidad se expresan a través de un silencio obstinado, en contraste con las palabras, débiles y falsas, de Jasón. La metáfora de la roca y del paisaje marino sirve al perfil de Medea, la bárbara que vino del otro lado del mar. Es esa renitencia y mutismo que hacen de ella el paradigma de pasión, que, a su alrededor, nadie más consigue comprender. En esos 'conciliadores de profesión' están la Nodriza, Egeo, e incluso Creonte, que, por tradición, buscan abalarla con palabras de renuncia. La reacción de Medea es, ante todo, visual, se ofrece a los ojos imprudentes de los que la rodean sin entenderle la dimensión, el Argonauta en primer lugar. Rígida, llorosa, ojos fijos en el suelo como en una ruptura obstinada con el mundo, Medea se siente presa de una obsesión dolorosa que la hiere, no tanto 
ya en el alma, como en la mente, donde se toman decisiones. Más que el abandono afectivo o la exposición a la xenofobia de los corintios, la idea que destaca es la del vacío, que reveló como inútil su fuga desde la Cólquida, los crímenes cometidos, dejándola a merced de la más completa anulación, esa, ya lo vimos, que es extraña a la naturaleza femenina.

Medea repasa todo el recorrido de una vida, que cumplió ya lejos de su patria:

Hombre, hijos, casa, padres

Nada de lo que tuve y fue

Forma ya parte de este mundo.

La normalidad de Medea - que aquí no es tanto un personaje radical, sino el prototipo de la mujer y sus anhelos -, cuando desaparece, la vuelve de amante en un ser distinto, brutal y desconocido.

Es en esta situación de anormalidad, donde la idea de los hijos se impone:

Antes me quería ver, en el filo de la muerte, en campo de batalla que no venciese

Que ser ésta a quien tocó parir a estos dos hijos

Deshonrados y banidos

En la corriente que te arrastra.

Si no quieres que te pertenezcan a ti

Tampoco han de pertenecerme a mi.

Perros rabiosos serán

Vagueando por esos caminos,

Mordidos en el alma que se abate sobre ellos

Por tu mano de bierro y tu voluntad de cuervo.

Como la Medea de Eurípides (Medea 250-251), la maternidad dejó en esta otra mujer la memoria de un sufrimiento, que ninguna batalla masculina puede igualar. De esos dos hijos, frutos de un amor y motivo de tantos sueños, lo que resta, por culpa de Jasón, son dos vencidos, herederos del exilio que condenó también a sus padres. Del lamento se va pasando a la amenaza, la que se sabe herir más hondo al traidor; las palabras de Medea no sugieren muerte en las sombras infernales, sino muerte en vida; que el exilio y la deshonra de la descendencia sean, para un padre culpado de violencia y ambición, el peor de los castigos.

El sentir de Medea pasa por el filtro de la dureza de las palabras, en el momento justo en el que el amor, con igual violencia, se transforma en odio. Es toda su naturaleza que se rebela, en una reacción fisiológica y visceral. Es largo este cuadro, del tamaño de la profundidad inmensa de su estado de espíritu. 


\section{Lo que me inunda.}

Te veo acomodado en ese otro lecho cálido

Donde todas las noches ella te esperará

$Y$ donde has de repetir los gestos que aprendemos, yo contigo y tú conmigo,

Los dos.

Más que 'odio', 'asco' es la palabra que mejor traduce la náusea que Jasón provoca en la que antes lo amaba. Y esa náusea es síntoma de celos, cuando el recuerdo de la intimidad cómplice de antes se profana, repetida con otra protagonista. De la motivación, se pasa a las consecuencias.

Es un asco tan intenso

Que no sé dónde vaciarlo.

Se derrama en el silencio que sube del corazón a la boca

En palabras

Como fétidos alimentos que ningún estómago puede tragar.

Hiel bebida a tragos, vinagre chupado de la esponja

En el momento de la muerte que me libertará.

Asi resumo la vida odiosa que me ofreces.

La muerte regresa en la boca de Medea, una muerte que tiene como causa un envenenamiento letal. No son, ahora, filtros ni venenos, manipulados por la mano hábil de una maga; sino tan solamente del alma de mujer, ofendida y abandonada, que parece segregar pociones amargas, con efecto tan eficaz como el de cualquier remedio popular. Antes que cualquier otra, es Medea la primera víctima de esta alquimia íntima.

En una réplica de ese 'otro lecho cálido' donde Jasón reproduce los días risueños de antaño, la mujer traicionada encuentra en su lecho la razón de su más grande sufrimiento.

Me quedo estática en ese lecho que fue el nuestro.

Abruptamente, torpemente

Lo pudiste olvidar

Volviéndote salvaje.

Esta quiebra de afectos, que sobrevino de forma inesperada pero no por ello menos radical, que al encanto del héroe hizo suceder una brutalidad genuina, se volvió asco, una reacción pasiva, en la necesidad proactiva de venganza.

Mis ganas de venganza van subiendo desde la inmovilidad, Águila mal herida.

Como bloqueada por la sorpresa de la traición, Medea empieza a renacer 
poco a poco, no para el amor - que ya antes provocara crimen -, sino para la revancha que, en un alma fuerte como la suya, ha de ser tremenda.

Crepitan en los aires chispas de venenos, Arrojo sobre a quien llega la mirada de una leona parida.

Como siempre, la verbalización se vuelve la principal dificultad. En vez de palabras, de odio o recriminación, la reacción de Medea es animalesca, no obedece a la razón, brota del ámago de su naturaleza. Es la de una fiera, con toda la fuerza concentrada en los colmillos y en los ojos. Bajo la imagen de un felino que prepara el ataque a su víctima, se oculta sin embargo algo que garantiza una relación profunda con Medea, la maga que usa venenos y la mujer que vive bajo la memoria dolorosa del parto: dos tópicos inevitables en la tradición de la princesa de la Cólquida.

Es sobre ella misma sobre quien se concentra el segundo monólogo - Díscurso a sí misma -, como apagando la figura de Jasón para que todo el drama se identifique con la palabra nostalgia, que es también el arrepentimiento.

\section{Es una gran nostalgia que alastra \\ Por encima de la rabia que mantengo \\ Sin conseguir ya que crezca como quería. \\ No volveré a ser la que fui.}

A pesar de la ruptura con el pasado, la nostalgia parece más fuerte que la rabia misma. Tiene algo de apaciguador esa memoria, que es, en un primer momento, general e indefinida: de los tiempos apenas, que la vida hizo tan dispares, futuro y pasado. Para esa nostalgia hay que encontrar símbolos palpables y ellos encarnan en el 'mar que dejé', como patria distante e inaccesible, 'cuando tenía padre y madre', en la pérdida de esas que son ataduras personales. Sobrevino, inmunda, la vergüenza, en la frustración de un proyecto de vida que parecía seductor y natural.

El cuerpo que él ya no quiere,

Los hijos paridos en los dolores lacerados,

El coraje que supe tener.

Es este mismo coraje, que se tradujo, en la Cólquida, en la capacidad de matar y traicionar en nombre de un amor, lo que ahora controla cada gesto, en una especie de laboratorio virtual de venganza. Aquel 'azul líquido' de un mar inmenso que recuerda los días de la juventud se transforma, por el gusto amargo de la venganza, en 'verde líquido que del fondo sube y hace morir'. 
Este juego de colores, que cambia agua pura en el más puro veneno, hace del pasado arma del futuro.

Conozco bien ese verde junto a las rocas

Cuando el mar antiguo era muy transparente.

Para hablar de inmediato de venenos:

Ella se ha de envenenar sin darse cuenta (...)

Ella ha de morir.

La rival será, como en Eurípides, la primera víctima de la venganza que se siente sin vuelta atrás. Pero poco sería ella, para apaciguar un odio tan profundo.

Y morirán padre y rey poderoso en una sola muerte, (...)

$Y$ morirán todos los que me pusieron en una soledad de vieja mujer

Que aún no soy. (...)

Roja la sangre que habrá.

Mis hijos la harán correr.

Con ella morirá igualmente Creonte y, con él, como rey, también Corinto, donde Medea contó con tantos enemigos. Con este episodio central en su vida, la nostalgia de la Cólquida como que se desvanece, para dar lugar a otra nostalgia, la de una segunda etapa de su vida, también ella llegada al final.

\section{Guardaré para mí}

La gran alegría que existió en esta casa

Cuando él me trajo de lejos

Yyo lo quise.

Por último, un monólogo final va enderezado 'al público', ahora que los interlocutores de su vida en etapas sucesivas se han apagado. A los que la escuchan, del otro lado del escenario o de las páginas de un libro, es la Medea filicida la que se deja ver. El famoso monólogo, que Eurípides asignó a una madre clavada de dudas (1019-1080) - entre matar o no matar a sus hijos queridos -, se revela ahora como lo que siempre fue: el inventario de razones que llevan a una mujer a liquidar a sus propios hijos.

El primer cuadro de este último monólogo es de inocencia.

Llegaron los crios. Vienen contentos.

Ofrecieron el regalo envenenado

Sin cualquier error en las palabras que tenian que decir. 
Como siempre agentes de un crimen involuntario, es a través de sus manos, cargadas del encanto amenazador de los regalos, como la muerte se propaga. El engaño es genuino, porque ejecutado por la más sincera inocencia. Por primera vez las palabras se vuelven verdaderas en la boca de los que las dicen, sin que, aun así, pierdan el sentido de ilusión que parece formar parte de su naturaleza.

Es a través de los hijos de la esposa preterida como a la nueva esposa será negada la bendición de ser madre.

Ella no será ni madre, ni amante, ni madrastra.

Como es también en ellas donde toma forma toda la historia de una familia destrozada.

Veo la mirada del padre en los ojos de mis hijos mientras juegan en la puerta de casa (...)

Veo la vergüenza de la madre abandonada

En sus correteos.

Con su gesto de ingenuidad, son los niños, como de ellos se espera, que trazan el futuro. Sólo que, porque la historia es de fracaso y ruina, el futuro que se avecina es de aniquilamiento.

Acabadas están las suaves mañanas y las dulces noches

En el lecho que eligió,

El de más poder y más riqueza.

Él no tendrá corona, ni alabanzas, ni felicidad, ni amor

Que no haya sido el mío.

Muerta la novia, a Jasón lo mata en vida, para que pueda disfrutar del fracaso de todo lo que soñó.

Faltaba aún aquel golpe con el que Eurípides inmortalizó la experiencia femenina de Medea.

Clavo un puñal en el centro exacto,

En el pecho de cada uno de los niños

Mientras los beso y abrazo.

Eran mis hijos.

Muchas han sido las interpretaciones que gesto tan radical implicó. ¿Sería odio, acto impensado de una mente trastornada? ¿O antes el acto bien calculado de una esposa celosa? ¿Habría sido el golpe de una madre que, para preservar a los hijos de un futuro incierto, por un supremo amor los mató? La 
Medea de E. Dionísio tiene sus motivos, tal vez mezquinos, porque son sobre todo personales:

La muerte que les doy me pertenece a mí.

Mato al amor más grande que tuve,

Yo que les di la vida.

Nada más parece haber en sus palabras que el placer de disponer de algo que considera suyo y que usa 'en una casi alegría de nacer'. Con este último golpe está terminada la trayectoria humana de Medea, regresando al otro lado de su pasado más remoto, aquél que hace de ella un elemento más en la cadena de descendencia de Helios.

Agarro las riendas del carro del sol.

Toda la tierra está allá abajo de mi,

Hundida entre mares azules que conocí.

En ese milagro de un vuelo que la separa de la tierra y la alza por encima de los humanos, la nieta del Sol va perdiendo, poco a poco, los rasgos de un recorrido de vida que la hizo feroz, en tanto que puramente terrena. Repasa, con placer, el resultado de la venganza contra el traidor. Encuentra para el filicidio un altruismo, que antes, presa a la tierra, parecía no sentir. De sus hijos puede proclamar:

Los salvé del mundo corrompido en el que su padre quería a cambio de traición darles Poder y riqueza.

Para finalmente alcanzar la redención.

Cada vez más lejos

Muy cerca del sol

Empiezo a matar mi nostalgia. 


\title{
El mito de Antígona en Hedor MaLdito de Gustavo Casanova.
}

\author{
María Cristina Silventi \\ Universidad de Cuyo
}

Las tragedias clásicas griegas de Esquilo, Siete contra Tebas y de Sófocles, Antígona, son recreadas por Gustavo Casanova en su obra Hedor maldito ${ }^{1}$. El autor, en una búsqueda constante de acercar al espectador la significación universal de los mitos griegos, selecciona y replantea aquellos pasajes de los dos trágicos que le permiten llevar a escena las secuencias principales del ciclo tebano. Valioso es, también, su aporte original al exhibir cuadros inéditos, como el enfrentamiento y muerte de los hermanos, así como las consecuencias de la maldición, llevadas a un primer plano a través de un tratamiento novedoso del coro que, al mismo tiempo, observa y narra los acontecimientos desencadenantes, mientras los personajes despliegan con lenguaje gestual sus palabras.

Con la convicción de que toda obra que recrea los motivos dramáticos griegos y latinos hace un nuevo aporte a la tradición clásica, me propongo presentar esta breve pieza del dramaturgo mendocino Gustavo Casanova 2 . Realizaré un breve análisis comparativo de esta versión con la de Esquilo, Siete contra Tebas y la de Sófocles, Antígona. Veremos que la novedad principal consiste en el uso que este escritor hace del lenguaje verbal y gestual con el ánimo de hacer comprensible un mito alejado del presente del espectador.

${ }^{1}$ El título de la obra está inspirado en las palabras proféticas que Tiresias le anuncia

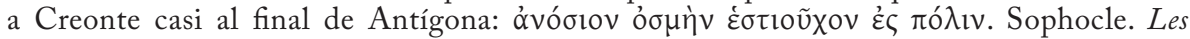
Trachiniennes. Antigone. Texte établi par Alphonse Dain et traduit par Paul Mazon. Paris: Société D’ Édition “Les Belles Letres”, 1955. v.1083, "aroma impuro por los altares de la ciudad” Sófocles. Antígona. Madrid: Gredos, 1992. p. 289, solo que aquí el "hedor” no es "impuro" tal como lo cualifica Sófocles para referirse al cadáver insepulto de Etéocles, sino que es "maldito". La imagen así expresada condensa y anticipa el motivo principal de la pieza.

${ }^{2}$ Gustavo Casanova (1966): Licenciado en Comunicación Social. Facultad de Ciencias Políticas y Sociales. UnCuyo. Licenciado en Arte Dramático. Facultad de Arte. UnCuyo. Actualmente cursa el Doctorado en Artes, especialidad Teatro, en la Universidad de Córdoba. Ha realizado su formación actoral con importantes maestros nacionales e internacionales. Como actor ha participado en más de 25 obras teatrales. Como director comenzó en el 2000 en el elenco "Las sillas" y en el 2005 fundó el grupo "Los Gregoristas" Como escritor ha producido siete obras teatrales. Actualmente es profesor Adjunto de la cátedra "Expresión Corporal" de la Universidad Juan Agustín Maza y profesor Adjunto de la cátedra "Actuación II" de la Licenciatura y el Profesorado de Arte Dramático. UnCuyo. 


\section{El argumento de la tragedia}

La historia, centrada en los hijos de Edipo, comienza con el motivo de la guerra entre tebanos y argivos y el enfrentamiento y muerte de Etéocles y Polinices. Sus hermanas se lamentan frente a los cadáveres y resuelven enterrarlos junto a la tumba de su padre. Pero un mensajero les anuncia la resolución de los magistrados del pueblo que prohíben el entierro de Polinices. A pesar de que Creonte ${ }^{3}$, que ostenta el mando de la ciudad, ordena respetar lo decretado y declara que hará pagar con su vida a aquel que desobedezca, Antígona resuelve llevar a cabo los ritos necesarios para dar digna sepultura a su hermano. Es descubierta por los guardias y Creonte la condena a permanecer en una caverna con escaso alimento hasta su muerte. El hijo de Creonte, Hemón, prometido de Antígona, enfrenta a su padre, pero ante la obstinación de este, se dirige hacia donde está Antígona sepultada en vida. Tiresias, la adivina, anticipa a Creonte nuevas desgracias, si no se retracta de su decisión. Temeroso, Creonte trata de reparar sus acciones, pero ya es demasiado tarde. No solo Antígona ha muerto, sino también su hijo y su esposa, Eurídice.

\section{Las fuentes principales}

Para recrear el mito Casanova se basó en las dos fuentes antes mencionadas. De Esquilo tomó la lucha entre hermanos, las endechas de las hermanas ante la muerte de estos y la resolución de Antígona de enterrar a su hermano pese a lo decretado. De Sófocles recreó el protagonismo de Antígona, la figura despótica de Creonte, Hemón y el coro de ancianos. Veamos cada tragedia en particular.

\section{Siete contra Tebas de Esquilo}

De esta tragedia Casanova ha tomado los primeros momentos del inminente ataque contra Tebas y nos presenta al coro y a Etéocles discutiendo sobre esta situación. El autor ha desplazado al coro temeroso de las jóvenes tebanas y, en su lugar, ha colocado al de ciudadanos de la Antígona de Sófocles, que permanecerá en el transcurso de toda la obra y que, en esta primera escena, desempeña un papel principal, puesto que a través de él se conocen las predicciones de la adivina ${ }^{4}$ y los preparativos bélicos de los argivos ${ }^{5}$. En

\footnotetext{
${ }^{3}$ Hermano de Yocasta y por lo tanto tío de los hijos de Edipo.

${ }^{4} \mathrm{El}$ remplazo de Tiresias por una mujer, fue una elección funcional, pues dentro del elenco contaban con una actriz que se adecuaba al papel. Entrevista con Gustavo Casanova. Junio 2011.

${ }^{5}$ En realidad, el coro en toda la pieza se adecua a la función que Aristóteles en su Poética

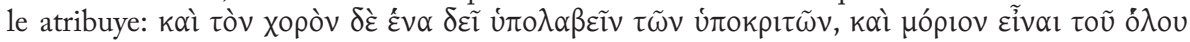


sus parlamentos reconocemos enunciados e imágenes que, en la tragedia de Esquilo, son expresadas por otros personajes. Así, por ejemplo, en la primera intervención utiliza palabras del Etéocles esquiliano: "Coro: - Señor, hasta ayer los dioses se inclinaban hacia nosotros benignos"7. Y más adelante hace suyas las palabras del espía8: - "Coro: Siete caudillos desollaron un toro sobre un herrado escudo. [...] Esos hombres impetuosos mojaron sus manos en sangre y juraron ávidos de venganza, asolar la ciudad y devastar la fortaleza de Cadmo".

Toma, además, muchas imágenes pronunciadas por el coro de jóvenes tebanas como, por ejemplo, "El aire brama enfurecido por lanzas"10, "el choque de los escudo""11, entre otras, que hacen referencia al avance del enemigo hacia los muros.

Por otra parte, la larga tirada de versos que Esquilo emplea para el intercambio dialógico entre Etéocles y el mensajero y que le sirve para destacar a cada uno de los caudillos de ambos bandos, se ve reducida aquí a un breve discurso, de neto carácter apelativo, con el que el coro termina por convencer a Etéocles para que se disponga a la lucha:

Coro: -"Escucha esto y terminarás de convencerte. Cada uno de esos siete tiene asignado entrar a la ciudad por cada una de sus siete puertas. y lo más curioso es que por la última está tu propio hermano, Polinices, que vocifera que te matará o que, si vives, te hará conocer el destierro que tú le has hecho padecer"12.

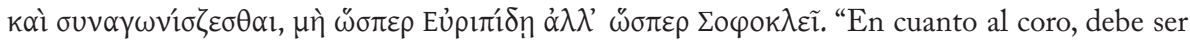
considerado como uno de los actores, formar parte del conjunto y contribuir a la acción, no como en Eurípides, sino como en Sófocles”. Poética. Aristóteles. Madrid: Gredos, 1992.1456 a 25.

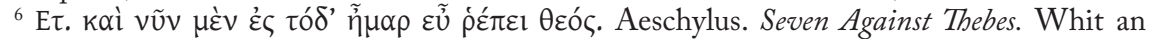
english translation by Herbert Weir Smyth, Ph. D., Eliot. The Loeb Classical Library. London: William Heinemann, Cambridge, Massachusetts: Harvard University Press, MCMLVI. In two volumes. T.I.v. 21 "Por el momento, hasta el día de hoy, la divinidad se inclina a nuestro favor". Tragedias, Esquilo, Madrid, Gredos, 1982, p. 56.

${ }^{7}$ Hedor maldito. Gustavo Casanova. Inédita, p. 1.

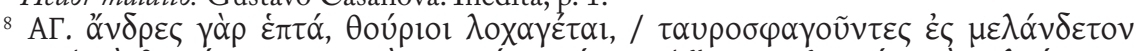

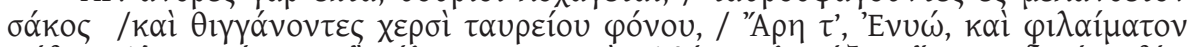

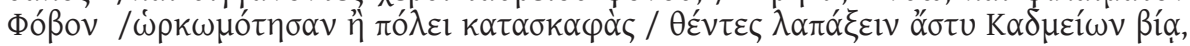
Aeschylus, op.cit. v. 41-46. "Siete héroes, valerosos caudillos, degollaban un toro, dejando que la sangre fluyera sobre un negro escudo; y, con sus manos tocando la sangre del toro, por Ares, por Enio y por Fobo sediento de sangre, juraron o bien destruir nuestra ciudad y saquear con violencia esta ciudad de los cadmeos, [...]”. Esquilo, op. cit., p. 56.

${ }^{9}$ Loc. cit.

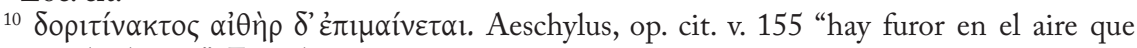
atraviesan las lanzas", Esquilo, op. cit. p., 61.

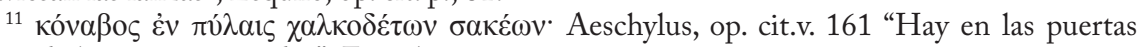
fragor de broncíneos escudos", Esquilo, op. cit., p. 62.

${ }^{12}$ Casanova, Gustavo, op. cit., p. 1. 
Vemos en todos los ejemplos que el coro, al mismo tiempo que informa a Etéocles de la situación, está cumpliendo la función que García Barrientos llamó "presentador del mundo ficticio"13 ante el espectador. Es más, podemos apreciar en sus discursos comprimidos la preocupación del autor por dar a conocer al público datos relacionados con el mito que le permitirán comprender más profundamente la representación. Esta vocación de hacer inteligible el mito la observamos también en las palabras de Etéocles, cuando reconoce que la guerra es consecuencia de la maldición de su padre: "Et: -Oh dioses tutelares, ¿acaso van a dar curso a la maldición de mi padre?" ${ }^{14} \mathrm{Y}$ en la última parte de la primera escena, en donde las palabras del mensajero esquiliano, que relatan el enfrentamiento y muerte de los hermanos, se ven aquí concretamente representadas. Durante la lucha los hermanos se agreden verbalmente y los dos mencionan el odio como el motivo principal de su enfrentamiento. Este sentimiento estará presente hasta el final de la obra y servirá de contraste para resaltar al personaje de Antígona: "Etéocles: -Ay, Polinices, eres merecedor del nombre que tienes ${ }^{15}$. Con el odio no conseguirás nada, con el odio no se gobierna. Polinices: -Es este odio que tanto rechazas, mi impulso para darte muerte"16.

De Esquilo toma también la escena de Antígona e Ismene que, con breves versos alternados, se lamentan ante los cadáveres de sus hermanos ${ }^{17}$. Nuevamente observamos un lenguaje simplificado, de tono actual, estructurado de manera contrastante, que nos recuerda el oximoron sofocleo: "Antígona Herido, heriste. Ismene - Has muerto, habiendo matado"18.

Finalmente, Casanova hace suya la versión de Esquilo que propone la tumba de Edipo en Tebas y no en Colono, como refiere Sófocles en su tragedia Edipo en Colono y se vale de algunos fragmentos de la discusión entre el mensajero y Antígona para presentar el decreto y la postura rebelde de la joven.

\section{Antígona de Sófocles}

El prólogo de la tragedia de Sófocles es recreado aquí con las mismas funciones clásicas. Por medio del diálogo entre Ismene y Antígona el autor

${ }^{13}$ García Barrientos, José Luis, Teoría de la Literatura y Literatura comparada. Cómo se comenta una obra de teatro, Madrid, Síntesis, 2003, p. 42.

${ }^{14}$ Casanova, Gustavo, op. cit., p. 1.

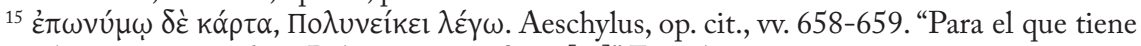
un nombre tan apropiado, a Polinices me refiero, [...]” Esquilo, op. cit., p. 82.

${ }^{16}$ Casanova, Gustavo, op. cit., p. 2.

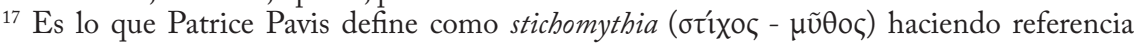
al rápido intercambio (algunos versos, frases o palabras) entre dos personajes y que logra un momento particularmente dramático, Pavis, Patrice, Diccionario del teatro. Dramaturgia, estética, semiología, Buenos Aires, Paidós, 1990, p. 188.

${ }^{18}$ Casanova, Gustavo, op. cit., p. 2. 
pone al tanto al espectador de aquellos datos que terminan de configurar el mito: la ceguera de Edipo, la relación incestuosa, la muerte de Yocasta y Edipo. Al mismo tiempo, define la posición de las hermanas y prepara el terreno para las escenas siguientes.

Desde este momento la obra presenta una gran semejanza en el contenido y en la trama con la tragedia de Sófocles, sin embargo Casanova hace un nuevo uso de pasajes claves, además de suprimir las partes líricas del coro y de emplear un tono actual, casi coloquial. Inclusive los extensos parlamentos de los personajes están reducidos con el fin de relevar el mensaje esencial. Así, por ejemplo, el extenso monólogo sofocleo, que abarca desde el verso 161 al $210^{19}$, es reducido aquí a unas cuantas palabras evitando las argumentaciones sobre el poder y los detalles del decreto: "Creonte - Ya conocen mi decisión. Por mí, nunca tendrán los criminales el honor que corresponde a los ciudadanos justos; por mi parte tendrán honores aquellos que cumplan con el estado, tanto en la muerte como en la vida"20.

En la recreación de las escenas entre el guardián y Creonte también advertimos una selección que pone en primer plano lo más significativo con respecto al mito ${ }^{21}$ : a) el ritual del muerto: "Guardia - Es que vino alguien que enterró al muerto, hace poco, echó sobre su cuerpo árido polvo y cumplió los ritos necesarios"; b) el imperio despótico de Creonte: "Creonte - [...] Y sé que hay gente en la ciudad que en secreto contra mí murmuran y agitan su cabeza, porque no soportan mis órdenes" y c) la responsabilidad de Antígona: "Guardia - Estaba enterrando al muerto: ya lo sabes todo".

Este carácter selectivo se observa también en las intervenciones del coro: "Coro - Es prudente lo que dices"22 y en las respuestas de Hemón a su padre: "Hemón - Entonces gobierna una ciudad desierta ${ }^{23 "}$.

Además de resignificar el lenguaje, Casanova realiza aportes con profundo valor expresivo, como por ejemplo, las palabras que dirige el corifeo a Antígona, cuando se dirige hacia su destino final: "Coro - Ilustre y alabada te marchas por tu propia decisión, fiel a tus leyes, en vida y sola, desciendes entre los muertos" 24 .

En función de los caracteres de los personajes y para profundizar la fuerza dramática, resalta frases proverbiales de Sófocles, pero reducidas a la mínima

${ }^{19}$ Sófocles, op. cit., pp. 255-257.

${ }^{20}$ Casanova, Gustavo, op. cit., p. 5.

${ }^{21} \mathrm{Ha}$ suprimido el discurso de Creonte sobre el dinero, la descripción que hace el guardia sobre cómo descubrieron a Antígona, etc.

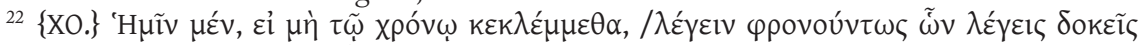
$\pi \varepsilon ́ p 1$. Sophocle, op. cit., v. 681. "A nosotros, si no estamos engañados a causa de nuestra edad, nos parece que hablas con sensatez en lo que estás diciendo”, Sófocles, op. cit., p.274.

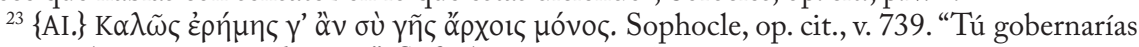
bien, en solitario, un país desierto", Sófocles, op. cit., p.276.

${ }^{24}$ Casanova, Gustavo, op. cit., p. 276. 
expresión. Así, por ejemplo, el célebre verso dicho por Antígona 25 "Antígona - No nací para compartir el odio, sino el amor"26, o las palabras con las que Hemón responde a su padre ${ }^{27}$ : "Hemón - No puede una ciudad, ser solamente de un hombre" 28 , o la respuesta que da Ismene ${ }^{29}$ a Antígona que la describe en su fragilidad: "Ismene - No seas atrevida: si las cosas están así, ate yo o desate en ellas, ¿qué podría ganarse?”30. Esta última expresión, con su valor literal, volvemos a encontrarla en boca de Creonte casi al final de la obra para expresar la misma impotencia, aunque irónicamente, aún no lo sabe: “Creonte - [...] En cuanto a mí, lo que yo mismo até, quiera yo al presente desatar" ${ }^{31}$.

\section{La originalidad del autor}

Respecto de la representación trágica Roland Barthes nos hace el siguiente comentario:

"Cada vez que nosotros, hombres modernos, tenemos que representar una tragedia antigua, nos hallamos ante los mismos problemas, y cada vez aportamos, para resolverlos, la misma buena voluntad y la misma incertidumbre, el mismo respeto y la misma confusión" ${ }^{32}$.

Con dificultades semejantes se encuentra quien recrea fuentes clásicas, pues estas han permanecido en la tradición con la fuerza inalterable de su valor literario, legitimadas por su vigencia. El odio de la guerra, el peso del poder, el respeto a los valores son temas que pueden retomarse en cualquier época y replantearse en cada contexto con igual intensidad.

$\mathrm{El}$ autor de Hedor maldito ha retomado el eje conflictivo tradicional que es el abuso de poder y el valor de las leyes ancestrales, representados en Creonte y Antígona respectivamente. En "duelo oratorio" ${ }^{33}$ se presentan dos concepciones del mundo, dos tipos de moral irreconciliables.

Para reactualizar el drama clásico y hacer inteligible el mito al espectador,

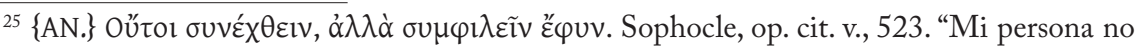
está hecha para compartir el odio, sino el amor", Sófocles, op. cit., p. 268.

${ }^{26}$ Casanova, Gustavo, op. cit., p. 9.

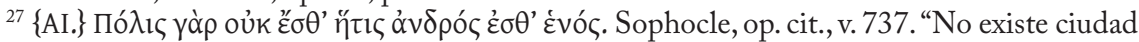
que sea de un solo hombre", Sófocles, op. cit., p. 276.

${ }^{28}$ Casanova, Gustavo, op. cit., p. 13.

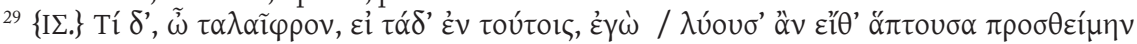

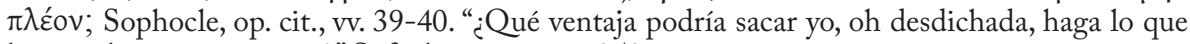
haga, si las cosas están así?” Sófocles, op. cit., p. 250.

${ }^{30}$ Casanova, Gustavo, op. cit., p. 4.

${ }^{31}$ Casanova, Gustavo, op. cit., p. 18.

${ }^{32}$ Barthes, Roland, Ensayos Criticos, Barcelona, Seix Barral, 1967, p. 87.

${ }^{33}$ Pavis, Patrice, op. cit., p. 93. 
Casanova propone un texto renovado, producto del ensamble de dos tragedias de las que ha seleccionado los pasajes que son significativos para entender el mito y los ha empleado como "motivos dinámicos" 34 , de modo que, al mismo tiempo que esclarecen, permiten el avance de la acción.

Para evitar el exceso de información que podría desviar la atención del espectador, ha suprimido las extensas intervenciones del coro e inclusive ha reducido y resaltado de los parlamentos de los personajes principales solo los que funcionan como recurso configurador de sus caracteres. Además, el tono actual casi coloquial con los que recrea los diálogos trae al presente el motivo clásico, le da vigencia y mantiene el interés del espectador.

En cuanto al espacio y el vestuario, el autor presentó una estructura vertical como símbolo de la idea de poder y propuso vestimentas con ribetes de contemporaneidad y estilos orientales (es el caso de Etéocles y Polinices), si bien también ha respetado "algunos elementos que responden al imaginario que la gente tiene de lo griego, como las espadas, cascos y escudos” 35 .

Con un tratamiento novedoso y cargado de dramatismo el autor resuelve la pieza y aporta una pincelada personal al mito. Así vemos que el parlamento del mensajero, que tradicionalmente relataba las escenas de muerte, pues en el contexto religioso de la tragedia no estaba permitido, es desglosado aquí en un lenguaje gestual fuertemente representativo. El mensajero comienza a relatar, pero luego es el coro quien asume protagonismo y continúa narrando al mismo tiempo que sirve de espectador de la escena que reproducen Creonte, el mismo mensajero y luego Hemón y su madre. Eurídice, silenciosa en la obra de Sófocles, interviene activamente mientras repite con compás enajenado su maldición contra los Labdácidas. La escena constituye una innovación ${ }^{36}$ que coloca al espectador frente a una representación dentro de otra representación, donde las palabras del coro se completan visualmente con la actuación de los personajes. El momento de mayor dramatismo se presenta en ese instante en que la espada une en una sola imagen la muerte de la madre y el hijo ante la mirada impotente de Creonte. El cuadro final constituye el aporte más original del autor, porque resuelve en una metáfora visual los últimos momentos de este pasaje del mito resignificando su valor como verdad universal.

${ }^{34}$ Pavis, Patrice, op. cit., p. 325.

${ }^{35}$ Casanova, Gustavo, Entrevista con el autor, junio 2011.

${ }^{36} \mathrm{Al}$ respecto, el autor relaciona esta escena con el cine y la voz en off, planteada como el traspaso de voces: el mensajero cede la voz al coro que narra en off los hechos que suceden en la caverna y lo que pasa en palacio. El espectador ve la escena como si se tratara de un montaje paralelo. Entrevista con el autor, junio 2011. 


\section{Bibliografía}

Abraham, Luis Emilio, Escenas que sostienen mundos. Mimesis y modelos de ficción en el teatro, Prólogo de García Barrientos, Madrid, Consejo Superior de Investigaciones Científicas, 2008.

Barthes, Roland, Ensayos Críticos, Barcelona, Seix Barral, 1967.

Bobes Naves, M. C. y otros, Teoría del teatro, por M. C. Bobes Naves, M. Corvin, J. L.García Barrientos, R. Ingarden, S. Jansen, T. Kowzan, M. Procházka, J. M. Thomasseau, J. Veltrusky, Madrid, Arco, 1997.

Brecht, Bertolt, Escritos sobre teatro, Selección de Jorge Hacker, Trad. de Nélida Mendilaharzu de Machain, Buenos Aires, Ediciones Nueva Visión, 1970.

Castagnino, Raúl, Teoría del teatro, Buenos Aires, Nova, s.f.

López Férez, J. A. (ed.) Historia de la literatura griega, Madrid, Cátedra, 1988.

Rest, Jaime, El teatro moderno, Buenos Aies, Centro Editor de América Latina, 1967.

\section{Fuentes}

Casanova, Gustavo, Hedor maldito, Sin publicar.

Aeschylus, Seven Agaisnt Thebes, With an english translation by Herbert Weir Smyth, Ph.D., Eliot, The Loeb Clasical Library, London, William Heinemann, Cambridge, Masachusetts, Harvard University Press, 1956, T. I.

Esquilo, Tragedias, Trad. y notas de B. Perea, Intr. general de F. Rodríguez Adrados, Madrid, Gredos, 1982.

Sophocle, Les Trachiniennes. Antigone, Texte établi par Alphonse Dain et traduit par Paul Mazon, Paris, Société d'Édition "Les Belles Letres".

Sófocles, Tragedias, Intr. de José Lasso de la Vega. Trad. y notas de Assela Alamillo, Madrid, Gredos, 1992. 


\title{
Las Comedias de Terencio: UNA TRADUCCIÓN PARA LA ESCENA
}

\author{
Marcela A. Suárez, Rómulo Pianacci Adrán, Mariana Breijo, \\ Violeta Palacios, Romina L. Vazquez \\ UBA - Conicet, UNMdP
}

\begin{abstract}
La suerte de las comedias de Terencio difiere ampliamente de la que tuvieron las plautinas. Si revisamos las representaciones de teatro grecolatino llevadas a cabo en Iberoamérica y Europa, advertimos el claro predominio de la comedia plautina y una aparición esporádica de Terencio. Más allá de los motivos que llevan a esta situación, se hace evidente la necesidad, por un lado, de cubrir esta carencia en los estudios de dramaturgia clásica y, por otro, de acercar a un público no especializado la obra de un comediógrafo que durante siglos ha quedado prácticamente relegado al estudio en los claustros universitarios. Para que semejante cometido pueda llevarse a cabo, resulta imprescindible un trabajo conjunto de filólogos y directores teatrales, que conduzca al establecimiento de un texto teatral que, por un lado, pueda ser leído por especialistas y no especialistas en letras clásicas y, por otro, sirva de base para la puesta en escena de las comedias de Terencio.
\end{abstract}

En las representaciones de teatro grecolatino llevadas a cabo en Iberoamérica y en Europa en los últimos años, se puede advertir un claro predominio de la comedia plautina y una aparición esporádica de las de Terencio, presente, no por casualidad, con una única obra: El eunuco. Una rápida revisión de los programas de la Asociación de Festivales de Teatro Grecolatino PROSOPON, puntualiza que tal obra ha sido representada en tres oportunidades: la primera en el año 2008 en el Teatro Romano de Mérida por el Grupo Siberia Extremeña de Talarrubia, Badajoz; la segunda en el mismo teatro dos años más tarde por el Grupo Calatalifa de Odón y finalmente, la tercera, también en 2010, en el Auditorio del Palacio de Congresos de Huesca, Zaragoza, por el Grupo Calatalifa de Madrid.

La escasa presencia del corpus terenciano en los escenarios del mundo está directamente vinculada con la falta de publicación y difusión de sus comedias $y$, particularmente, en la inexistencia de versiones aptas para ser representadas, pese a la publicación en 1966 del trabajo de A. Marquerie ${ }^{1}$, que incluye las versión "representable" de una de ellas: Formión.

Al referirse a Terencio, el autor afirma (1966: 34):

\footnotetext{
${ }^{1}$ Versiones representables de teatro griego y latino, Madrid, Aguilar.
} 
Terencio no respetó la comedia original griega, y, con el mismo criterio, nosotros nos hemos tomado la libertad en esta Versión representable, no erudita, viva y no disecada, de imprimir un ritmo más rápido en algunas ocasiones a la acción, repartir o redondear frases y réplicas y efectuar algunas alteraciones y transposiciones en el diálogo, con esa ambición, tantas veces expuesta en estas líneas, de hacerlo más comprensible y asequible a nuestro público. Sin embargo, conservamos siempre e íntegramente todos los valores y propósitos de la pieza inicial sin suprimir ninguno, respetamos la exposición, el nudo, el desenlace, los cambios de acción y lugar y, por supuesto, la unidad de tiempo.

Pero convendría recordar que Terencio no fue un traductor, sino que escribió sus propias comedias tomando como hipotexto la comedia griega. La lectura de la obra de Marquerie, pues, su confusión en torno a los conceptos de autor y traductor y esta suerte de olvido que se ha ejercido sobre el africano, son los factores que nos han impulsado a plantear, en el marco del proyecto UBACyT 2011-2014, el recorrido generativo de las comedias de Terencio; que se inicia con la traducción filológica y concluye con el texto espectacular y la puesta en escena ${ }^{2}$.

El procedimiento nuclear del proyecto consiste en la confrontación y problematización de los distintos tipos de traducción de la comedia que pueden llevarse a cabo según las diversas formas de recepción contemporáneas de las mismas, a saber, la lectura y el espectáculo teatral.

Como afirma Botton-Burlá (1994: 332): "los procesos básicos que se encuentran implicados en todo acto de traducción son dos: la comprensión del texto original y su formulación en la lengua meta". Cuando el texto que está en juego es un texto clásico latino, esta tarea correspondería a los filólogos, que disponen de las herramientas necesarias para hacer que la vida de la obra continúe, como lo expresa Benjamin (1969: 71). En efecto, los problemas que implica el trabajo con un texto escrito dos siglos antes de Cristo en lengua latina requieren de un minucioso trabajo filológico que permita fijar el texto y lograr una traducción que, además de las cuestiones estrictamente lingüísticas y estilísticas (elección entre el verso y la prosa, cuestiones sintácticas, cuestiones léxicas), favorezca la comprensión de la dimensión semántica, que pone en juego no solamente la pluralidad de sentidos que de por sí la lengua abre; sino también las referencias culturales (mitológicas, históricas, sociales, intertextuales), muchas veces fuera del alcance del espectador contemporáneo.

Sin embargo, un texto teatral supone otras dimensiones más del texto:

${ }^{2}$ En una primera etapa sólo nos dedicaremos a Adelphoe y Phormio, porque presentan una temática que resulta de interés para los lectores y el público teatral de nuestra época y porque han sido escasamente traducidas y llevadas a escena. 
la representación y la ejecución ${ }^{3}$. En esta instancia, no es posible echar mano a ciertos recursos paratextuales que el texto impreso pone en práctica, como por ejemplo las notas al pie. Por tal razón, se vuelve imprescindible el trabajo conjunto del director teatral con los filólogos, de manera que pueda lograrse un texto que al ser puesto en escena, permita acceder a su significado pleno. ¿Es esto posible? Está claro que una traducción total y perfecta no es posible; por el contrario, muchos especialistas en traducción literaria afirman que toda traducción es una re-creación e incluso Peter Newmark (2004: 234) sostiene: "Cuando se pasa una obra de teatro de la cultura de la LO (lengua original) a la de la LT (lengua Terminal) ya no es una traducción sino una adaptación”.

En su Introducción a las actas del Congreso Internacional realizado en Murcia en noviembre de 1995, Ángel Luis Pujante (1996: 16) afirma que la traducción literaria es: "una reelaboración de obras nacidas en una cultura para que funcionen en una cultura receptora distinta y a veces muy distante en el espacio y en el tiempo; una reelaboración que se presta a la apropiación y a la manipulación.” Más adelante agrega que la reelaboración y manipulación parecen haberse dado más claramente en el teatro: "donde siempre se ha aspirado a la máxima libertad frente a los textos”. Efectivamente, el filólogo debe apropiarse del texto para comprenderlo y hacerlo comprender al lector moderno. Pero, ¿qué significa manipulación? ¿Qué significa máxima libertad frente a los textos? Para que el texto sirva para realizar una representación teatral, debe superar las dificultades y distancias que le impiden al espectador moderno no especializado comprender la obra. Manipular el texto y hacer de él una versión libre, más contemporánea, permite quizá que el espíritu del texto original siga vivo, para volver a las palabras de Benjamin, pero indudablemente no permite que la obra permanezca, puesto que se tratará de otra totalmente distinta. ¿Cómo resolver entonces este dilema?

Conviene recordar nuevamente a Pujante (1996: 16-7), quien resume dos aspectos importantes de esta discusión. En primer lugar: "Las traducciones

\footnotetext{
${ }^{3}$ In theatrical contexts, the term 'translation' also covers the semiotics of performing the playtext -costume, acting style, gesture, movement, masks and makeup, music, sound and lighting-. The conventional but problematic criteria of 'performability' adds a practical dimension to the aesthetics and philology brought to bear on the rewriting of the source text (Bassnett 2000; Walton 2006). An initial close translation may be followed by the preparation of the play-text by a dramatist who may not be familiar with the source text and language. The preparation of the play-text may be interwoven with the rehearsal process and the design and direction by theatre practitioners whose knowledge of the source play and its context of production has been mediated via the theatrical traditions to which they belong. Interestingly, this process gives an extended influence to scholarly translations which are used to mediate the source text. Thus the translation of classical texts continues to be a means of negotiating intellectual, aesthetic and cultural status and of practising realignments (Johnston 2007). Baker-Saldanha (1998, 2009), Routledge Encyclopedia of Translation Studies.
} 
filológicas ${ }^{4}$ del teatro clásico son y seguirán siendo necesarias, pero tendría que haber cada vez más traducciones solventes con una orientación teatral". En segundo lugar: "El mundo académico debe abrirse más hacia la representación, pero también el mundo del teatro debe respetar las exigencias filológicas de los textos y evitar prácticas poco dignas, como, por ejemplo, la de realizar y utilizar versiones o adaptaciones que no son sino refritos de traducciones ya publicadas".

Pociña (2000: 160), considera que: "un texto real, auténtico tiene que ser al mismo tiempo representable, una traducción hecha para la escena, y esto es lo que casi nunca ofrecemos los filólogos".

Creemos que una versión representable de una comedia antigua es el producto de la labor conjunta entre el traductor y el director de teatro, fundada siempre en un pretexto o avant-texte: la traducción filológica.

Es por eso que, en una primera etapa, el proyecto propone llevar a cabo una traducción filológica de las comedias, es decir, una versión para ser leída, lo más ajustada al original sin que ello vaya en detrimento de su calidad literaria y debidamente anotada. Para lo cual se recurrirá al uso de ediciones eruditas del texto original de las cuales se tomarán las lectiones establecidas por el editor, a menos que sea necesario adoptar variantes del aparato crítico; cotejo de distintas traducciones en lengua hispana y extranjera pertinentes que enriquezcan las posibles interpretaciones del texto; estudio del corpus terenciano seleccionado en los planos fonético-métrico, morfológico, sintáctico, lexical, retórico y estilístico, análisis de conductas y pautas culturales, especialmente de aquellas relacionadas con el derecho romano y ático, indispensables para la contextualización y comprensión del significado original del texto; reflexión y debate en el seno del equipo sobre las variantes y posibilidades de traducción, para obtener un producto nutrido por distintas lecturas.

Partiendo de la traducción filológica, se abordará, en una segunda etapa, la elaboración del texto espectacular de las comedias.

En opinión de Rómulo Pianacci (2009: 3,7), "la representación de un texto clásico debería servir para hacerlo dialogar con nosotros, tendiendo a

${ }^{4}$ Andrés Pociña (2000: 158) afirma: "No se puede hablar de un único tipo de traducción, sino de varios entre los que el traductor debe escoger en cada caso, según sus propósitos." Dentro de tal multiplicidad el mismo autor consigna dos opciones: la traducción filológica y la traducción teatral. Por traducción filológica se entiende aquella en la que piensan los filólogos, es decir, la versión de una comedia latina, lo más exacta posible sin que ello vaya en detrimento de su calidad literaria. Su finalidad suele consistir en facilitar la lectura de las obras a personas que pueden conocer bien, poco o desconocer totalmente la lengua latina. Su forma de presentación puede ser como ediciones bilingües o como traducción a la lengua moderna exclusivamente. La traducción teatral apunta a las versiones encaminadas a la puesta en escena de una comedia latina. Las posibilidades de comportamiento en este caso son variadas y van desde la versión casi exacta a la libre, incluso a la simple adaptación donde no se descartan en principio las intervenciones del traductor, como el "peinado" o supresión de frases y pasajes completos, la modernización de expresiones y contenidos, el anacronismo coyuntural, etc." 
una comunicación fluida, que sólo puede suceder cuando no se menosprecia, ignora o traiciona ni lo clásico ni lo contemporáneo”. Pero, ¿cómo lograrlo? La respuesta es simple: sobre la base del trabajo conjunto de los filólogos y del director teatral y en virtud de principios claros, tales como la problematización de las distintas posibilidades discursivas y de lengua que permitan la actualización de los elementos patéticos (comicidad - reflexión), la introducción de modificaciones en la estructura misma para adecuar las obras al público contemporáneo, la supresión del anacronismo, el respeto de los resortes intrínsecos de la comicidad del autor, la actualización a través de mecanismos que no distorsionen el espíritu ni transgredan las normas culturales de la época en que las comedias fueron escritas.

Finalmente, el proyecto contempla reunir ambos textos, traducción filológica y texto espectacular, en una publicación destinada a los lectores especializados, teatristas y público en general, que dé cuenta del recorrido generativo de las comedias de Terencio. 
Marcela A. Suárez, Rómulo Pianacci Adrán, Mariana Breijo, Violeta Palacios, Romina L. Vazquez

\section{Bibliografía}

Baker - Saldanha (ed.) (1998, 2009), Routledge Encyclopedia of Translation Studies, New York, Taylor \& Francis e-Library.

Botton-Burlá, Flora (1994), “La traducción”, en Brunel, P. - Chevrel, Y. (dir.), Compendio de Literatura Comparada, México, Siglo XXI, pp. 329-346.

Benjamin, W. (1969), “The task of the translator", en Illuminations, New York, Schocken Books, p. 71.

Newmark, P. (2004), Manual de traducción, Madrid, Cátedra.

López, A. - Pociña, A. (2000), Estudios sobre la Comedia Romana, Frankfurt am Main, Peter Lang.

Marquerie, A. (1966), Versiones representables de Teatro Griego y Latino, Madrid, Aguilar.

Pianacci, R. (2009), “De Hamlet al rey León”, ponencia presentada en el Cruce de Criterios del Festival de Cádiz realizado en octubre del 2009.

Pujante, A. - Gregor, K. (eds.) (1996), Teatro clásico en traducción: texto, representación, recepción, Actas del Congreso Internacional, Murcia, 9-11 Noviembre, 1995, Murcia, Servicio de Publicaciones, Universidad. 


\title{
REBELIONES FILIALES MÍTICAS EN EL TEATRO HISPANOAMERICANO CONTEMPORÁNEO
}

\author{
Stéphanie Urdician \\ Université Blaise Pascal - Clermont-Ferrand
}

\begin{abstract}
El teatro hispanoamericano refleja los tumultos históricos del continente promoviendo la reescritura de mitemas de la rebelión filial. Las estrategias de dicha reapropiación mítica delatan los impulsos contradictorios de la relación con el orden de los padres, que oscila entre reverencia e irreverencia. Las figuras de rebelión convocadas dentreo del repertorio contemporáneo seleccionado (Antígona, Medea, Electra, Orestes, Edipo, etc.) nutren un entramado de intertextos trágico-míticos que escenifican las leyes sociales del parentesco para descifrar el mundo contemporáneo mediante la subversión (del intertexto, de la utopía histórica, del género).
\end{abstract}

Comprender la filiación y la relación de atracción-repulsión hacia el padre biológico, político o simbólico desvela las estructuras sociales en las que surgen nuevas versiones del guión mítico. Concreciones polimórficas y constantes de la violencia atraviesan la historia del continente latinoamericano desde el periodo de la Conquista hasta las revoluciones y dictaduras del siglo XX pasando por los conflictos fratricidas de los procesos de independencia. Cantidad de obras dan cuenta de esta violencia mediante la reescritura de argumentos míticos de rebelión filial dado que el conflicto generacional bien condensa una historia escrita en claves de opresión y rebelión. El recorrido teatral que propongo a continuación delata los impulsos contradictorios de la relación con el orden de los padres - el poder en el ámbito político -, que oscila entre reverencia e irreverencia. Ésta se manifiesta en los actos de rebelión ya sea fecunda cuando el personaje rebelde llega a erigir un nuevo orden ya sea fallida cuando procede de un engaño como en las obras que convocan el tema de la revolución traicionada. El eje que vertebra estas reescrituras consiste en la subversión de intertextos clásicos y utopías históricas.

\section{Hacia subversiones fecundas y paradójicas}

En su revitalización del potencial arquetípico y plástico del material mítico, el teatro hispanoamericano del siglo $\mathrm{XX}^{1}$ participa de la pervivencia de los modelos clásicos privilegiando la genealogía de los Atridas y los Labdacidas.

${ }^{1}$ Osvaldo Obregón, «Pervivencia de mitos griegos en obras dramáticas latinoamericanas contemporáneas», en Teatro latinoamericano. Un caleidoscopio cultural (1930-1990), CRILAUP, Presses Universitaires de Perpignan, 2000, pp. 39-51. 
En la cohorte de figuras míticas reteatralizadas, Antígona ocupa un sitio preeminente. Modelo de rebelión por excelencia, de una rebelión femenina que inscribe su discurso en una dimensión eminentemente política, Antígona cristaliza para la América hispánica el acto revolucionario - «encarnación de la revolución» ${ }^{2}$, la resistencia frente a la opresión ${ }^{3}$.

\section{Una Electra cubana}

En el ámbito caribeño Electra rivaliza con Antígona en la encarnación de hijas rebeldes ${ }^{4}$. Electra Garrigó (1941) de Virgilio Piñera reescribe la figura en clave paródica para cuestionar el maniqueísmo de los modelos políticos exclusivos. La parodia desestabiliza la cultura «oficial» contemporánea del fracaso revolucionario en contra del dictador Fulgencio Batista y de la corrupción generalizada. En esta trasposición mítica, Agamemnón vive junto con Clitemnestra y Egisto formando un trio paternal pernicioso. La alianza del hijo y de la hija, fiel al modelo originario, está al servicio de un deseo de emancipación - frente al padre opuesto al pretendiente de Electra y a la madre que no acepta la partida de Orestes -, posibilitado por la muerte de los padres. Al odio recíproco que relaciona padre y madre se añade el egoísmo de los progenitores que imponen órdenes arbitrarias a su prole. Asimismo alternan escenas de chantaje afectivo -entre padre e hija, madre e hijo- que tratan de contrarrestar la rebelión que se está gestando entre los descendientesherederos.

La rebelión de Electra pasa a primer plano: es ella quien le da el golpe mortal a Clitemnestra al arrojarle su mantón rojo sobre la cabeza ${ }^{5}$. Así es

\footnotetext{
${ }^{2}$ Luis Riaza, Prefacio de Antígona jcerda!, Alicante, Biblioteca Virtual Miguel de Cervantes, 2007 (edición digital de Teatro escogido, Madrid, Asociación de Autores de Teatro, 2006, pp. 243-276).

${ }^{3}$ No me detengo en el presente estudio en esta figura, objeto de varias publicaciones. Sólo menciono a continuación las que vienen a completar el ensayo de George Steiner, Les Antigones, que pasa por alto las versiones ibéricas e iberoamericanas del mito. Cf. Carlos Morais (coord.), Máscaras portuguesas de Antígona, Universidad de Aveiro, 2001; José. V. Bañuls, Patricia Crespo, Antigona(s): mito y personaje. Un recorrido desde los orígenes, Bari, Levante, 2008; Rómulo Pianacci, Antígona: una tragedia latinoamericana, Irvine, 2008; Stéphanie Urdician, "Antigone. Du personnage tragique à la figure mythique ", in : Véronique Léonard-Roques (dir.), Figures mythiques, Clermont-Ferrand, Presses Universitaires Blaise Pascal, 2008, pp. 6994 ; Rose Duroux et Stéphanie Urdician (dir.), Les Antigones contemporaines - de 1945 à nos jours, Clermont-Ferrand, Presses Universitaires Blaise Pascal, 2010 ; Andrés Pociña, Aurora López, "La eterna pervivencia de Antígona”, FlorIlib 21, 2010, pp. 345-370, etc.

${ }^{4}$ De manera inesperada y excepcional es Ifigenia quien celebra la fecundidad de la rebelión en el poema dramático del mexicano Alfonso Reyes. A su Ifigenia cruel (1924) le toca cumplir con una misión redentora. El retrato del personaje femenino se elabora a partir de un desfase con respecto al modelo cuando la Ifigenia amnésica deja de encarnar la figura de víctima de la ley del padre para consagrar un nuevo orden femenino capaz de crear la armonía amenazada por el orden masculino.

${ }^{5}$ Virgilio Piñera, Electra Garrigó, en Teatro completo, Cuba, Letras cubanas, 2006, Acto III, p. 77.
} 
como libera a su hermano al abrirle la puerta de la casa familiar en un gesto a la vez incompleto y paradójico ya que si bien alcanza a fecundar la rebelión de su hermano, no llega a fecundar la suya. Al contrario señala la puerta de la libertad de Orestes, puerta cárcel para Electra que se encierra en la misma tumba doméstica ideada por su padre: «Electra: Aquí está mi puerta. La puerta para no marcharse. La puerta Electra» ${ }^{6}$. Sus últimas réplicas atormentadas por las Erinias consagran la inexorable soledad engendrada por una rebelión que no merece ni castigo ni recompensa ${ }^{7}$. La especificidad de la transposición radica en el distanciamiento de una representación que degrada la tragedia mediante la interpretación farsesca de los padres desdoblados en mimos. El crimen simbólico del padre ofrece un ejemplo notable de la estrategia paródica de la obra que escenifica el parricidio a través de la matanza del gallo epónimo. La obra expone al fin y al cabo la fatalidad que roe una sociedad dominada por el radicalismo de los sistemas enfrentados como lo resume la réplica del Pedagogo-centauro: «Esta ciudad tiene dos enormes piojos en la cabeza: el matriarcado de las mujeres y el machismo de los hombres» ${ }^{8}$. Por eso, desde la apertura dramática, este personaje insta a Electra a que se rebele en contra del orden establecido: «Pedagogo: Sigues la tradición y no me gusta. No te dije acaso que hay que hacer la revolución» ${ }^{9}$. La obra representativa del sincretismo afro-cubano bien condensa la combinación de las fuentes míticas en la transposición del motivo del centauro. Este monstruo antiguo encarna una de las figuras míticas privilegiadas por los modernistas hispanoamericanos. La «sicología ambivalente» y la naturaleza «híbrida» de los Centauros constituye una configuración simbólica capaz de plasmar la hibridez constitutiva de la identidad cubana y más ampliamente hispanoamericana ${ }^{10}$.

\section{E1 minotauro cortazariano}

El mismo motivo mitológico de la hibridez genérica origina la versión original del mito del Minotauro concebida por Julio Cortázar en una de sus primeras incursiones teatrales: Los Reyes (1949) ${ }^{11}$. En esta pieza, la mayor subversión de la fábula mítica se arraiga en la victoria de la pasión incestuosa y clandestina que une a Ariana con su hermano, «el cabeza de toro»,

\footnotetext{
${ }^{6}$ Ibid., Acto III, p. 78.

${ }^{7}$ «Electra: No castigaréis a Electra. Tampoco vais a recompensarla». Electra Garrigó, Acto II.

${ }^{8}$ Ibid., p. 56.

${ }^{9}$ Ibid., Acto I, p. 11.

${ }^{10}$ Pierre Brunel, Dictionnaire des mythes littéraires, Edition du Rocher, 1988: cf. Christiane Séris, «Le centaure figure moderniste», pp. 295-300, Dorita Nouhaud, " Les centaures américains, des santiagos en santiagues ", pp. 301-305.

${ }^{11}$ Julio Cortázar, Los reyes, Buenos Aires, Sudamericana, 1970.
} 
trastornando la recepción clásica que no ve en el minotauro sino el fruto de una unión ilegítima y monstruosa. La rehabilitación de la figura del minotauro se manifiesta desde el diálogo apertural en el que la hija se encara a su padre. La rebelión de los hijos se apoya en una unión y filiación maternal que Ariana reivindica en estos términos: «Ariana: Es mi hermano. / Minos: Un monstruo no tiene hermanos. / Ariana: Los dos nos modelamos en el seno de Pasifae. Los dos la hicimos gritar y desangrarse para arrojarnos a la tierra» ${ }^{12}$. A esta rebelión de los hermanos se añade un nuevo reparto de los roles cuando el poder se ve encarnado por un dúo inesperado - pero sí anunciado en el título - formado por Minos y Teseo. La segunda escena consolida el pacto entre ambos en una serie de réplicas que recalcan su semejanza ${ }^{13}$. La tercera escena viene a contrarrestar la palabra del "bando masculino" dominante que urde la desaparición del minotauro. En este monólogo Ariana sola en escena se aleja de los dos reyes aproximándose al hermano-amante: el ovillo deja de ser el objeto de salvación de Teseo como en el modelo originario para convertirse en la "llave" de la "liberación" (p. 66) del hijo de Pasifae. Así es como J. Cortázar dramatiza una de las obsesiones temáticas que vertebran su obra: la lucha entre la norma arbitraria y la libertad. En boca de Ariana esta dialéctica se nombra "el amor a la libertad" frente al "horror a lo distinto, a lo que no es inmediato y posible y sancionado" (p. 66).

Si la obra convoca los motivos constitutivos del mito -el viaje de Teseo, el ovillo de Ariana, el combate entre Teseo y el Minotauro- cabe notar que reinventa el combate entre dos órdenes -el conformista y el inconformista. El final trágico del minotauro, aparentemente fiel a la fuente clásica evidencia en esta nueva fábula la libertad que alcanza el monstruo, su victoria y su posteridad al representar en el trasfondo mítico de las sociedades el germen de la rebelión: "Minotauro: Yo bajaré a habitar los sueños de sus noches, de sus hijos, del tiempo inevitable de la estirpe. Desde allí cornearé tu trono, el cetro inseguro de tu raza [...] Yo me perpetuaré mejor [...] en la crecida noche de la raza, sustancia innominable y duradera." (p. 70-71)14. En esta muerte liberadora el minotauro cortazariano se asemeja a Antígona que traspasa su muerte alimentando la rebelión de su prolífica descendencia. Como Antígona, Ariana enfatiza la hermandad frente a cualquier otra relación de parentesco para denunciar el orden dominante y abogar por otro nuevo motivado por la libertad.

\footnotetext{
${ }^{12}$ Julio Cortázar, Los reyes, en Obras completas II, Barcelona, Galaxia Gutenberg-Círculo de Lectores, 2004, p. 56.

${ }^{13}$ «teseo: Nunca sabrás cuánto se parece tu lenguaje a mi pensamiento. [...] Hasta en ella nos asemejamos». (Julio Cortázar, Los reyes, op.cit., p. 60)

${ }^{14}$ Ibid., Buenos Aires, Sudamericana, 1970, p. 70.
} 


\section{Cuando la subversión mítica exhibe la abyección contemporánea}

Obras más recientes invierten la función y el impacto de la rebelión al exponer una degradación de las figuras míticas involucradas. Para dar cuenta de esta vertiente dramatúrgica, me detendré en las obras del chileno Benjamín Galemiri y del argentino Alejandro Tantanian, ambos dramaturgos que beben en las fuentes míticas para denunciar la infamia actual.

\section{Edipo y Electra hijos rebeldes en el teatro de Benjamín Galemiri}

Edipo asesor ${ }^{15}$ (2000), reescritura postmoderna de Edipo Rey de Sófocles, revela sus convergencias con el modelo mítico: Oziel, asesor convocado por el rey Saúl para acabar con una guerra civil, mata a su padre y es amante de su madre antes de su destierro. En las 33 escenas, entre las que muchas sólo imparten indicaciones escénicas recalcadas por las mayúsculas, el nuevo Edipo participa de la caricatura del discurso político hipnótico, lleno de vacuidad (valga el oxímoron). Las más veces el falso diálogo está reducido a una ecolalia que imposibilita el intercambio. Un ejemplo relevante estriba en la saturación del prefijo "neo» que invade tanto los discursos " NEOSOFISTICADOS Y NEO-ENFERVORIZADOS » de Oziel y del Coro ${ }^{16}$ como el texto didascálico:

henchidos de un amor neo-bíblico, oziel y judith se toman las neo-manos dominados por las luces ultravioletas del aplastante y neo-angustioso neoentertainment televisor (epílogo - neo-bulimia).

En la opulencia del poder -un palacio con sauna, helicóptero y salas temáticas- se exponen las relaciones incestuosas desde una perspectiva mirona: el «infame Jeremías» filma «los cinco embates sexuales de Judith y Oziel» antes de desvelarlos al rey Saúl quien «EXANGÜE Y NO POR ELLO MENOS EXCITADO, OBSERVA EN LA SALA DE TELEVISIÓN REAL EL ABOMINABLE FLIRT SEXUAL DE JUdith y OZIEL». La revelación del parentesco entre Oziel, Judith y el Rey ya no permite alcanzar la catarsis trágica sino que al contrario asistimos a la instrumentalización del incesto y del parricidio al servicio de la sed de poder de los personajes modernos. La imagen degradada e irónica de Oziel, que subvierte el desenlace trágico del hipotexto de Sófocles, presenta a un «Edipo narcisista [...] que se arranca los ojos cómicamente». Aquella degradación del guión mítico se consagra en el epílogo irreverente:

\footnotetext{
${ }^{15}$ Benjamín Galemiri, Edipo Asesor, en CELCIT: www.celcit.org.ar. Estrenada por Luis Ureta (dir.) y la compañía La Puerta en la sala San Ginés (Santiago).

16 «coro: Orgasmo neo-liberal» (19), «coro: Orgasmo neo-autoritario» (19), «coro: Orgasmo neo-republicano» (23).
} 
APARECE OZIEL CIEGO Y ENVEJECIDO, SENTADO FRENTE AL ENMOHECIDO TELEVISOR FLAT QUE LE REGALARA EL REY SAÚL. SOBRE EL TELEVISOR LA INFAMANTE CORONA REAL, QUE EL ICONOCLASTA OZIEL USA COMO ANTENA.

Una infamia parecida informa la reescritura de su Infamante Electra ${ }^{17}$ (2005). Joshua Halevi, ex senador chileno involucrado en fraudes vive su caída y fracaso en la esfera del poder. Su hija, Dafné, nueva Electra, abogada muy al tanto del mundo de influencias y tecnologías que les toca vivir, actualiza el argumento de la venganza mítica en nombre del honor de su padre. Galemiri vuelve a exhibir los estereotipos del poder corrupto en un estilo muy personal que pulveriza las convenciones dramatúrgicas. Las didascalias siempre subjetivas, líricas, irreverentes y cinematográficas describen los signos ostentosos de los medios de comunicación que rigen la información de las sociedades de consumo y desvían las relaciones interpersonales, en particular las filiales que no dejan de activar una bipolaridad conflictiva entre amor y odio.

\section{Alejandro Tantanian: Juego de damas crueles (1995)}

Esta ambigüedad de la relación filial es decisiva en Juego de damas crueles $^{18}$ (1995) del argentino Alejandro Tantanian. Aquí la obra juega con múltiples planos: simbólico, sagrado, social y sexual. La exposición deja entrever un antes escénico silenciado que convoca la leyenda de Abraham e Isaac. El juego anunciado en el título expone el trayecto de Enrique, el hijo, que invierte la situación inicial cargada de implicaciones incestuosas. Al cometer el parricidio, Enrique se convierte en el instrumento de la venganza femenina, la de sus tres hermanas que delatan una semejanza relevante con las Erinias (divinidades originadas por la sangre de Urano castrado por su hijo Crono).

En la relación afectiva ambigua que el hijo mantiene con el padre, Enrique exorciza los crímenes fundadores que la familia resucita incesantemente. En un monólogo impactante, cuando el hijo carga con el cuerpo de su padre en la espalda - como en una actualización del motivo mítico del amor filial encarnado por Eneas y Anquises -, la subversión de los modelos activados se manifiesta en la confusión de las relaciones de una filiación manchada por la violencia del incesto y el crimen ${ }^{19}$. El vínculo intrínseco entre violencia y

\footnotetext{
${ }^{17}$ Benjamín Galemiri, Infamante Electra (Chili, Editorial Cuarto Propio). Edition consultée : Infamante Électre, traduction de Françoise Thanas, Paris, Indigo \& côté-femmes, 2006.

${ }_{18}$ Alejandro Tantanian, Juego de damas crueles, CELCIT. Dramática Latinoamericana 282, p. 30. http://www.celcit.org.ar Obra estrenada en 1997 en Montevideo (Uruguay) por Mariana Percovich, Espacio no convencional, Caballerizas del Museo Blanes.

19 «DESDE EL CASILLERO DE LLEGADA [...] ENRIQUE: Fue aquella tarde. La herida de mi padre sobre los labios. Mi mirada hundiéndose en la carne abierta. El barro humedece mis labios. En el monte. El sabor de la sangre. El lento regreso. El cuerpo de mi
} 
filiación está profundizado a todo lo largo de la obra puntuada por el motivo recurrente de la «herida púrpura, compleja, abierta», imagen que plasma la naturaleza de una genealogía biológica basada en la sangre. Mientras tanto la repetición polifónica como un eco del oráculo mítico machaca las reglas del juego. Al regresar del monte, «sabían que sólo volvería uno de los dos» ${ }^{20}$. La falta del hijo que regresa con el cadáver de su padre a pesar de la predicción acarrea consecuencias importantes en una obra que exacerba la materialidad del cuerpo, como un intento de compensar el imposible duelo de una sociedad amputada por las desapariciones.

La composición fragmentaria de la obra que consta de once secuencias (desde la «Largada» hasta la «Llegada») entrega un itinerario-mosaico de relatos e imágenes simbólicas sometidos a la arbitrariedad del juego. Las jugadoras recrean, mediante su «muñeco-ficha» que reduplica la figura del hermano Enrique, los relatos fundadores: el incesto (entre padre, hijo, hija, hermano y hermana), el filicidio y el parricidio. Ahora bien la isotopía de la narración elaborada en la recurrencia del verbo «contar» y del vocablo «historia» expone el proceso de transmisión como piedra angular de este juego «cruel», heredero del arte de narrar propio del mito. Cada relato recrea la fundación, la escena del crimen y de un punto de vista sicanalítico el regreso a la infancia. La familia «jugada» adquiere un valor arquetípico a partir de una construcción en palimpsesto que consiste en superponer en un mismo retrato diversas figuras bíblicas y míticas. Así Enrique, el hijo, encarna a Isaac que escapa al sacrificio urdido por su padre mientras recuerda el gesto de Orestes, guiado por las hermanas que exigen la transgresión absoluta de la Ley del Padre al inducirlo a cometer el parricidio, venganza de otra violencia innombrable: el incesto. Las hermanas - Ulrica, Leopolda, Juliana - parecidas a Electra que dirige el brazo armado de su hermano personifican también a las Erinias que castigan al hijo asesino, en el último tiro: «la caída del filo de lleno sobre mi carne, ofreciendo al hijo el mismo destino del padre. Como debe ser.»(«Llegada», p. 30). En resumidas cuentas esta obra muy plástica

padre sobre los hombros. El cuchillo nuevamente bajo mis ropas. El cuchillo que rasgó su carne. La primer herida en todos los espejos. La herida del padre. El primer corte. Sobre el cuerpo de mi padre. (...) La mano del hijo acariciando el cuerpo dormido del padre. Lavar la herida. Y ya no poder acostarme a tu lado. No poder hundir mi sexo en tu boca. Como vos querías. Siempre. (...) Y así poder contarte la historia del padre y el hijo que van al monte. La historia del padre que llevó a su hijo más querido al monte para ofrecerlo en sacrificio, y el hijo decidió defenderse, no quiso ser sacrificado y sacó un cuchillo que escondía bajo las ropas y abrió la carne del padre».

20 «ENRIQUE 1: Saben que sólo volverá uno de los dos» (primer tiro); «ENRIQUE 2: Todas sabían que sólo volvería uno de los dos (reunión)»; «ENRIQUE 3: Falté al pacto. No vine solo. "Sólo volverá uno de los dos.” (reunión); «Ellas sabían que sólo volvería uno de los dos» (desde el casillero de la llegada)». 
juega con la remodelación de los perfiles de figuras míticas que alimentan la composición de los personajes escenificados.

Esta rápida indagación dramática expone varias modalidades de apropiación de los modelos míticos en un repertorio hispanoamericano fundado en un entramado de intertextos trágico-míticos. Las obras herederas de motivos antiguos - entre los cuales el incesto ocupa un sitio protagónico - escenifican las leyes sociales del parentesco para descifrar los excesos del mundo contemporáneo. 


\title{
Mitos y parodia en una comedia burlesca de Calderón DE LA BARCA
}

\author{
Marta Villarino, Graciela Fiadino \\ Universidad Nacional de Mar del Plata
}

\begin{abstract}
La comedia burlesca Céfalo y Pocris (c. 1660), cuyo genotexto lo constituye las Metamorfosis de Ovidio, se representó en el Palacio Real para Carnaval; la víspera se habrían representado Celos, aun del aire matan y Auristela y Lisidante, también de Calderón de la Barca. Esta pieza atípica parodia la totalidad del mundo escénico calderoniano; su tejido textual está sostenido por acciones y estrategias dramáticas de la ópera y de la comedia caballeresca conocidas previamente por el público.
\end{abstract}

El teatro cortesano del Siglo de Oro tuvo un vasto desarrollo en el siglo XVII español, sobre todo en el reinado de Felipe IV, conocido por su afición a las manifestaciones artísticas, particularmente a la pintura, la música y el teatro. Las representaciones realizadas en el Palacio del Buen Retiro, en los distintos espacios destinados a tal fin -el Coliseo, las habitaciones de la Reina, los jardines y el estanque - exigían a los dramaturgos de la época escribir textos adecuados a un público poseedor de una enciclopedia vasta e ilustrada. El autor preferido por el rey y la corte era don Pedro Calderón de la Barca, quien también fue director de representaciones, cuyo trabajo junto con los escenógrafos italianos Cosme Lotti y Baccio del Bianco fructificó en lucidas puestas en escena de comedias mitológicas y palatinas y el nacimiento en España de los géneros teatrales musicales como la ópera y la zarzuela ${ }^{1}$.

Por otra parte, la diversidad de espacios escénicos y la disponibilidad de sumas importantes para las puestas en escena permitieron el incremento de obras complejas, donde el despliegue escenográfico y la música tenían un lugar relevante. Si bien muchas comedias luego se representaron en los corrales, con la subsiguiente simplificación de la tramoya y el atrezzo, el género que logró mejores frutos es la comedia mitológica ${ }^{2}$, en la que se reescribieron mitos, leyendas y fábulas clásicas, cuya fuente principal es Ovidio.

\footnotetext{
${ }^{1}$ Sebastián Neumeister postula que el "traslado de los dioses paganos de la calle al teatro de corte" se produjo con el estreno de la comedia de Lope de Vega El premio de la hermosura, el 3 de noviembre de 1614 en el parque de Lerma, aún al aire libre, pero con decorados, tramoya e iluminación que anticipan el estilo de teatro de corte. El futuro Felipe IV, entonces de nueve años, desempeñó el rol de Cupido. A Lope también se atribuye el mérito de haber compuesto la primera obra íntegramente cantada, "cosa nueva en España”, estrenada en Madrid en 1629, la égloga La selva sin amor.

${ }^{2}$ No mencionamos los autos sacramentales, que requerían tanto o más aparato técnico que las comedias mitológicas por tratarse de teatro religioso, que tenía lugar solamente en festividades determinadas del año litúrgico y estaban destinadas al público heterogéneo de la villa y corte de Madrid.
} 
Ya en el siglo XIV, Boccaccio en su De genealogía deorum gentilium había percibido que los dioses paganos permitían a los poetas más que la coordinación, la acumulación de argumentos, de manera que posibilitaba la escritura ficcional, ya que el mito, al manifestarse en diferentes narraciones y variantes, resultaba flexible y adaptable, afín a la práctica poética (Neumeister, 2000: 18). Por otra parte, no debemos olvidar que mientras la Iglesia disponía -y aún disponepara celebrar sus fiestas de un corpus de figuras y signos utilizados durante siglos, el poder seglar acudía junto con los símbolos de la tradición feudal a la inagotable cantera de los mitos clásicos, para festejar otras fiestas, marcadas por un calendario donde constan onomásticos, acontecimientos dinásticos o de la actualidad. El año 1635 puede verse como una fecha significativa para la historia y posterior desarrollo del teatro mitológico en España; en primer lugar, muere Lope de Vega y se nomina a Calderón como dramaturgo principal de la Corte; por otra parte, se estrena su comedia El mayor encanto, amor, con escenografía de Cosme Lotti, cuyo enorme éxito sentó la base para este género, con más de una docena de obras hasta $1662^{3}$.

Los escritores renacentistas y barrocos habían accedido a los mitos clásicos a través de traducciones como la de Jorge de Bustamante (1541), los textos mismos de Ovidio en su lengua original y de aquellos libros donde la mitología es leída desde su proyección moral, tal es el caso de la Philosophia secreta de Juan Pérez de Moya (1585) y Theatro de los dioses de la gentilidad de fray Baltasar de Vitoria (c. 1620).

Calderón usó estas fuentes en sus comedias mitológicas ${ }^{4}$ con mucha libertad, mezclando personajes de diferentes narraciones, modificando la cronología de los episodios o atribuyendo a un personaje las características o las hazañas de otros, quizás, debido a que este tipo de piezas dramáticas tenían en Calderón un componente alegórico vinculado a su alcance ideológico.

Teniendo en cuenta lo expuesto, pasamos a analizar dos acontecimientos teatrales de 1660, año en que se estrenaron en el Coliseo del Buen Retiro dos importantes obras musicales de Calderón: el 17 de enero La púrpura de la rosa y el 5 de diciembre la por entonces denominada comedia mitológica Celos, aun del aire, matan, que en realidad es una ópera, ya que los diálogos son cantados, con música del reconocido autor Juan Hidalgo, uno de los maestros

${ }^{3}$ Integran ese corpus, entre otras, dos zarzuelas (El golfo de las sirenas y El laurel de Apolo), dos dramas musicales (La púrpura de la rosa y Celos, aun del aire, matan) y una comedia burlesca (Céfalo y Pocris); más tarde, otras tres obras maestras de Calderón: Fiera afemina amor, Fineza contra fineza y La estatua de Prometeo.

${ }_{4}^{4}$ Podemos mencionar piezas tales como La fuente de Mantible, El jardin de Falerina, El castillo de Lindabridis, Hado y divida de Leonido y Marfisa, o las fábulas y fiestas musicales de El hijo del sol, Faetón, Fieras afemina amor, La fiera, el rayo y la piedra, El golfo de las sirenas, Los tres mayores prodigios, La purpura de la rosa... 
compositores más reconocidos de la época. Según los datos, hasta la fecha seguros, el mismo día de diciembre se representó la comedia caballeresca Auristela y Lisidante, del mismo autor. Lo que resulta llamativo es que en el texto dramático de Céfalo y Pocris, la única comedia burlesca de Calderón ${ }^{5}$ que se representó el día 6 , en una reflexión metateatral se introduce una enmienda respecto de la acción en las obras precedentes; leemos:

Antistes: En la comedia de ayer

No se hizo.

Rey: Que se haga en esta.

¿Hay más de pedir prestado

Ese paso a otra comedia?

La comedia burlesca se ha convertido en objeto de estudio de la crítica desde hace unas pocas décadas; entre los principales investigadores podemos mencionar a Ignacio Arellano, Luciano García Lorenzo, Javier Huerta Calvo y al pionero Frédéric Serralta (1980). Existe un corpus muy escaso de estas piezas del siglo XVII, apenas unas cincuenta obras que recibían también el nombre de comedia de disparates, de chanza o de chistes. La mayoría data del reinado de Felipe IV, solían representarse en el Palacio Real durante fiestas cortesanas para Carnestolendas y por San Juan; muchas son anónimas, otras pertenecen a más de un ingenio o no son de dramaturgos de primera línea, salvo Céfalo y Pocris.

Carlos Mata Induráin (2001) observa que su temática es variada -asuntos mitológicos, leyendas grecolatinas o temas extraídos del Romancero- con frecuencia son una parodia de comedias típicas; en ocasiones solo parodian la estructura y los detalles tópicos propios de la construcción dramática en los géneros serios. Suelen ser más breves que las otras comedias - la pieza que nos ocupa tiene unos 2.000 versos frente a los 3.000 habituales-, quizás, como postula Serralta, porque es muy difícil provocar y mantener la risa del público durante mucho tiempo. El crítico francés define los rasgos de la comedia burlesca teniendo en cuenta: la incoherencia cómica en que se basa la trama (venganzas grotescas, supresión o inversión del decoro, muertos que reviven, alegría y celebración festiva de las deshonras); sin embargo, a pesar de lo disparatado del enredo la intriga se mantiene unida mediante un "tenue hilo [...] capaz de enhebrar las situaciones jocosas, [...] que consiste en la condición paródica” (Mata Induráin, 2001: 2). Estas comedias, además de

\footnotetext{
${ }^{5}$ Según Germán Vega García Luengos, en su conferencia “El Calderón que olvidó o repudió Calderón” (IX Congreso de la Asociación Internacional Siglo de Oro, Université de Poitiers, 1115 de julio de 2011) brindó un dato inesperado, al postular que la comedia Céfalo y Pocris debe considerarse atribuida a Calderón. No hemos podido recabar mayor información.
} 
corroer los códigos propios del género, parodian también los motivos líricos como romances, canciones y coplas populares,

Los críticos que han estudiado este género han interpretado las inversiones (caballeros cobardes, reyes grotescos, hijos venales, aprobación de la deshonra) relacionándolas tanto con el valor satírico como con el meramente lúdico de este tipo de comedia. Serralta opta por una interpretación jocosa, en tanto que García Lorenzo prefiere hablar de valor crítico. Más recientemente Héctor Urzáiz se pregunta acerca de la función ideológica que cumplían estas comedias, puesto que daban cabida a fuertes ataques contra algunos principios de la monarquía de los Austrias; mostrando un creciente atrevimiento hacia el final de siglo, como burlarse de las deficiencias físicas del último de los Habsburgo. Por otra parte, se representaban solo ante la corte, ya que su contenido hacía que estuvieran vedadas al vulgo. En ese contexto, ¿`se puede hablar de crítica al poder, a la sociedad, a la ideología dominante? Opinamos que si bien en alguna comedia burlesca pudiera existir alguna forma sutil de desaprobación, más bien se trata de mostrar mediante el distanciamiento burlesco de los mecanismos literarios y teatrales- también sometidos a la parodización- una crítica a la cristalización del modelo de los géneros serios.

La comicidad de estas obras es tanto verbal como escénica. La primera es la más abundante y utiliza todos los recursos verbales jocosos, tales como la acumulación de juegos de palabras, refranes, cuentos tradicionales, disparates, alusiones escatológicas y obscenas, expresiones basadas en la falta de lógica, metáforas cómicas, interpretaciones literales y perogrulladas, entre otras. La comicidad escénica se da sobre todo en el vestuario ridículo y en la gestualidad grotesca y exagerada, como sucede en la danza de matachines que da fin a la comedia de Calderón.

Gran parte de la jocosidad en Céfalo y Pocris está construida sobre la reescritura de un mito de base, abordado en tres ocasiones por Ovidio y sin duda conocido por el público culto de la corte, que durante las dos jornadas festivas identificaría fragmentos de las Metamorfosis (Libro séptimo) y del Ars amandi (Libro tercero), de los cuales Calderón toma casi la totalidad del primer texto ovidiano y solo la segunda parte de la secuencia narrativa del Ars amandi $i^{6}$.

La ópera Celos, aun del aire matan desarrolla el mito con cierta minuciosidad, aunque introduce nuevas dramatis personae así como situaciones cómicas generadas por los personajes secundarios, innovaciones que se producen en razón del nuevo género y para suavizar la tragicidad de la historia ovidiana, según se puede apreciar en la misma estructura de la fábula:

1) Pocris sirve a Diana y lleva ante su presencia a su amiga Aura, pues

\footnotetext{
${ }^{6}$ También desarrolla este mito en los Fastos.
} 
descubre que tiene amores secretos con Eróstrato. 2) La diosa, ante la traición de Aura, la condena a morir atravesada por saetas que dispararán las ninfas y mortales de su séquito. 3) Céfalo, el extranjero procedente de Trinacria, intercede y cubre el cuerpo de la joven para evitar que la maten. Venus, como Aura ha tributado a su culto enamorándose, la transforma en aire y la arrebata a la cólera de Diana. 4) La diosa, presa de la ira, intenta castigar a Céfalo, pero pierde el venablo; el extranjero lo recoge sin conocer sus poderes ni saber a quién pertenece; Pocris lucha con Céfalo por el arma y resulta herida. 5) Eróstrato teme haber sido visto en el lugar y Rústico le cuenta lo sucedido con Aura. -Aquí se produce un intermedio cómico, en el que Rústico pasa a tener el aspecto de animales (león, tigre, jabalí, lobo, perro) por designio de Diana y nadie lo reconoce-. 6) Aura, invisible para todos, vuela en un carro y su dulce voz hace que Céfalo y Pocris se enamoren. 7) Se celebra un rito de homenaje a Diana en su templo de Lidia y los hombres, cuya presencia está vedada, permanecen en la floresta; Céfalo reconoce que no podrá irse de allí a causa del hado; Eróstrato afirma que la primacía entre las diosas la tiene Venus; Céfalo se hace ver con flores para Pocris; mientras tanto, Aura sobrevuela la escena e invita al amor. 8) Diana ve una traición en el atrevimiento del joven y enfurecida, desaparece. 9) Céfalo y Pocris descubren sus mutuos sentimientos, mientras Aura como en sueños, siempre invisible, canta una melodía de amor que ellos incorporan al diálogo. -Se vuelve a producir un intermedio cómico entre Floreta, Clarín y Rústico ${ }^{7}$ - 10) Eróstrato, sin consuelo por haber perdido a Aura provoca un incendio en el templo de Diana; Céfalo salva a Pocris de morir entre las llamas; Aura vaticina que Pocris se ha salvado del ardor del fuego, pero no podrá hacerlo del ardor amoroso. 11) Diana ordena a las Erinias castigar a los tres jóvenes que se rinden a Venus: con celos a Pocris, con dolor y miedo irracional a Eróstrato, con el uso del venablo a Céfalo. 12) Céfalo y Pocris son marido y mujer, pero la joven pide a Clarín que siga a Céfalo y observe con quién se encuentra porque el gracioso le ha oído nombrar a "Laura"; Alecto, invisible, azuza los celos de Pocris dando el nombre de Aura; Pocris teme la venganza de Venus y Amor; Eróstrato sufre por celos y vaga temeroso por el bosque. 13) Céfalo, mientras Pocris lo observa oculta tras el follaje, confiesa a Clarín que Aura en sueños le ha proporcionado alivio a sus pesares; el joven convoca a Aura, quien al ver los celos de Pocris siente que su desgracia ha sido vengada. 14) Eróstrato busca altas peñas para arrojarse al mar. 15) Tesífone perturba los sentidos de Céfalo. 16) Pocris intenta salvar

${ }^{7}$ Las Metamorfosis incluye, interrumpiendo la secuencia del mito, el relato que hace Céfalo acerca de la fiera que asola Tebas, atacando ovejas y seres humanos. Le ponen redes pero la zorra siempre escapa. Le piden a su perro (Lélaps, que le había regalado Procris) para perseguirla. El can la persigue de cerca, pero no logra apresarla y, cuando Céfalo va a usar su jabalina, ambos animales son convertidos en estatuas de mármol, quizá por algún dios. 
a Céfalo, pero el joven al ver movimientos en el follaje cree ver un animal y dispara el venablo hiriendo a su esposa; Pocris confiesa su dolor por la presunta traición, pero Céfalo revela que solo la ama a ella antes de que Pocris muera. 17) Diana llama a sus fieles pues se ha castigado de la traición. 18) Aura eleva a Céfalo y Pocris en su carro: Venus los transforma a ella en una estrella y a él en el Céfiro, en una apoteosis del amor.

Entre las mayores licencias reescriturales de Calderón, creemos que está la transformación del perro Lélaps, regalo de Aura a Céfalo, en la metamorfosis temporal de Rústico, que lejos de realizar las misiones descriptas en el mito, debe seguir a Clarín, nuevo galán de Floreta, para saciar el hambre y vigilar la conducta de su mujer. Otro cambio importante es la inclusión de las Erinias que deben cumplir las tareas impuestas por Diana.

La comedia burlesca Céfalo y Pocris reescribe el mito desarrollado en la comedia anterior, aunque Calderón solo toma los mitemas que conservan el hilo narrativo ovidiano y a la vez parodian la ópera. Veamos, pues.

1) Polidoro, hijo del rey Tebaldo sale del palacio donde se ha encontrado con Aura, hija de Antistes, por una gruta. 2) Llegan Céfalo, rey de Picardía y Rosicler, rey de Trapobana, al reino de Trinacria donde los recibe el gigante que guarda el palacio. 3) Pocris expulsa del palacio a Aura; la joven relata el mito y su significado en el nuevo contexto, sus amores con Polidoro (Pollo de Oro) y la delación que la puso en evidencia, así como presenta a las dos hermanas Pocris y Filis. 4) La justicia apresa a los dos extranjeros y a Aura, a quienes se lleva enmascarados; Céfalo huye por un escotillón. 5) Las hermanas disputan por cualquier nimiedad, quizás a causa del encierro en que viven. 6) Céfalo conoce a Filis que se espulga en el jardín y se enamora de ella, pero cuando ve a Pocris, queda deslumbrado; las dos hermanas tienen experimentan sentimientos por el extranjero, Filis lo acosa y Pocris lo rechaza, a la vez que anticipa su propio fin trágico. 7) El rey descubre a los prisioneros; Aura confiesa la causa por la que Pocris la ha desterrado del palacio. 8) El rey ordena castigar a Aura; el padre la arroja al vacío, pero la joven desaparece en el aire; el gigante declara que la noche anterior ha matado al príncipe con su maza. 9) El rey descubre a Céfalo que juega a la gallina ciega con las dueñas, Pocris y Filis, quienes conocen de donde proviene. 10) El rey revela el agüero por el que sus hijas no pueden ver un hombre; ordena dar muerte a Céfalo y a Rosicler mientras las hermanas siguen dando cuenta de sus diferencias. 11) El rey pide a Céfalo que escoja una de sus hijas para casarse; Céfalo duda y no sabe a quién elegir; las hermanas pelean groseramente. 12) Céfalo elige a Pocris, aunque gustoso se casaría con ambas; Rosicler, enamorado de Filis le pide se la ceda pero terminan jugándola a la taba; Aura, invisible, arrebata el roído hueso y los príncipes sospechan la presencia de deidades. 13) El rey apresura la decisión de Céfalo que prefiere a Pocris por su desprecio; Filis, a 
su vez, desdeña a Rosicler. 14) Los esposos mantienen un diálogo ridículo; Aura se lleva a Céfalo; Pocris por primera vez experimenta celos, causa por la rabia su hermana. 15) Céfalo y Aura dialogan en secreto; ella solicita a Céfalo que con la ballesta de bodoques que le envía Diana mate una fiera. 16) Pocris, celosa, se esconde tras de un jazmín para observar a Céfalo quien al descubrirla apunta la ballesta y tira a matar. 17) Pocris muere y tarde para arrepentimientos, Céfalo lamenta la pérdida de su mujer. 18) El rey perdona a Céfalo, pide mojiganga y para ello requiere la guitarra que cuelga de un árbol como las ofrendas a los dioses. Baile general.

La comedia burlesca introduce personajes y situaciones de Auristela y Lisidante (el príncipe que muere, las dos hermanas y sus disputas por el poder, la situación del reino ante la muerte del heredero), pero lo más notable $-y$ cómico a la vez- es la degradación de los héroes (Céfalo ensucia sus calzas por el miedo que le inspira el gigante, el rey imparte justicia ridículamente, el padre deshonrado toma la situación de su hija como un juego más en el que finge envenenarla para protegerla del castigo real), la modificación o el reemplazo de los nombres (Eróstrato por Rosicler, Pollo de Oro por Polidoro), la estrategia de transformar el palacio en una especie de aparato digestivo que devora y expulsa a quien ingresa a su interior. Los celos llevan a las hermanas a luchar como dos mozas rústicas, con las uñas y arrancándose los moños; Pocris muere de un modo ridículo e indigno de su estirpe, a causa de "¡Un bodocazo fatal / veintidoseno! Porque / ya delante y ya detrás, / Veinte y dos heridas tengo, / Que cada una es mortal".

En este sucinto análisis de sólo un aspecto de estas piezas innovadoras, se puede apreciar sin embargo que la parodia subvierte el espacio en el que habitan dioses y humanos, la ficción se pone en primer plano, tanto cuando se reflexiona sobre la escritura y la práctica teatral como cuando los personajes declaran su verdadero nombre o aluden a representaciones precedentes. Calderón ha creado un mundo al revés, más propio del carnaval que de una fiesta cortesana; la ruptura del decoro y el innegable motivo de risa, aun para sus Majestades, da cuenta de una lucha de poder entre los nobles ambiciosos que no solo agasajaban a sus señores con espectáculos en los que realizaban una exhibición de su riqueza, sino que también eran capaces de dirigir la forma de entretenimiento de la familia real. 


\section{Bibliografía}

Arellano, Ignacio, 1995, Historia del teatro español en el siglo XVII, Madrid, Cátedra.

Aubrun, Charles V., 1976, "Estructura y significación de las comedias mitológicas de Calderón", en Hacia Calderón. Tercer Coloquio Anglogermano, Berlín, Nueva Cork, pp. 148-155.

Brown J. y Elliott, John, 1988, Un palacio para el rey: el Buen Retiro y la corte de Felipe IV, Madrid, Alianza.

Calderón de la Barca, Pedro, 1945, Céfalo y Pocris, Madrid, BAE, Tomo tercero, pp. 489-506.

Calderón de la Barca, Pedro, 1945, Celos, aun del aire, matan, Madrid, BAE, Tomo tercero, pp. 474-488.

Calderón de la Barca, Pedro, 194, Auristela y Lisidante, Madrid, BAE, Tomo tercero, pp. 628-656.

Chapman, W. C., 1954, "Las comedias mitológicas de Calderón”, Revista de Literatura, 5, pp. 35-67.

Di Pinto, Elena, 2003, "Los mecanismos de la risa: de Auristela y Lisidante y Celos, aun del aire matan a Céflo y Pocris", en Giornate calderoniane Calderón 2000. Atti del Convegno internacional. Palermo, 14 al 17 de decembre 2000, ed. Enrica Cancelliere, Palermo, Flaccovio Ed., pp. 997-1006.

García Lorenzo, Luciano, 1994, "Procedimientos cómicos en la comedia burlesca”, en I. Arellano et al. (eds.), Del horror a la risa. Los géneros dramáticos clásicos. Homenaje a Christiane Faliu-Lacourt, KasseReichenberger, pp. 89-113.

Greer, M. y Varey, J., 1997, El teatro palaciego en Madrid. 1586-1787. Estudio $y$ documentos, London, Tamesis.

Huerta Calvo, Javier, 1986, "Anatomía de una fiesta teatral burlesca del siglo XVII. Reyes como bufones”, en J. M. Díez Borque (ed.), Teatro y fiesta en el Barroco. España e Iberoamérica, Barcelona, Serbal, pp. 115-136.

Mata Induráin, Carlos, 2001, "La comedia burlesca del Siglo de Oro: La mayor hazaña de Carlos VI de Manuel de Pina”, Revista Signos 34 (4950), Valparaíso, pp. 67-87.

Neumeister, Sebastián, 1998, "La mitología”, en El teatro cortesano en la España de los Austrias, Cuadernos de Teatro Clásico 10, Madrid, CNTC, pp. 233-243. 
_- 2000. "Los dramas mitológicos de Calderón”, en Calderón en el 2000, Ínsula, No 644-645, pp. 18-20.

Pérez de Moya, Juan, 1995, Philosophía secreta, edición de Carlos Clavería, Madrid, Cátedra.

Publio Ovidio Nasón, 1999, Metamorfosis, 21ª ed., Madrid, Ed. Espasa Calpe.

Serralta, Frédéric, 1980, "La comedia burlesca: datos y orientaciones", en Risa y sociedad en el teatro español del Siglo de Oro, Toulouse, CNRS, pp. 99114.

Sabik, Kazimierz, "Mitología, alegorismo y magia en el teatro cortesano español del siglo de oro"

cvc.cervantes.es/literatura/aispi/pdf/11/11_129.pdf -

Urzáiz, Héctor, s/d. "El desvergonzado en palacio: los graciosos de la comedia mitógica"

www.resad.com/acotaciones/acotaciones17/17hector.pdf - 


\title{
Honor y pasión en FedRA de Miguel de Unamuno
}

Patricia Zapata

Universidad Nacional de la Patagonia Austral

\begin{abstract}
Miguel de Unamuno a través de su versión de Fedra (1911) propone una relectura focalizada en el conflicto de la heroína cuyo discurso textualiza la contradicción entre el deseo y la razón en un contexto signado por la tradición y la moral cristiana. El sentido de lo trágico en esta obra se afianza a través de un personaje atado a las convenciones sociales y su debate existencial que oscila entre el deber ser y el querer. El presente trabajo se propone analizar la construcción del personaje de Fedra a partir del cual es posible plantear el concepto de una femineidad que se debate entre la pasión y el honor, tema que ha sido transversal en la literatura española desde sus orígines.
\end{abstract}

\section{Introducción}

En el exordio de Fedra (1911) leído en el Ateneo de Madrid con motivo de su estreno en 1918, Miguel de Unamuno declara el nexo de su obra con la de Eurípides pero al mismo tiempo explicita la distancia que existe entre una y otra. Este planteo se reitera con antelación al inicio del primer acto al señalar que "el argumento generador de esta tragedia es el mismo del Hipólito de Eurípides y de la Fedra de Racine. El desarrollo es completamente distinto del de ambas tragedias".

La aclaración precedente nos señala entonces que Unamuno realiza una apropiación dramática no desde la literalidad sino a partir de aquellos rasgos del personaje que le sirven a su intencionalidad estética. Es lo que en términos de Dubatti (2005:129) podemos denominar el ritornello. En este sentido, también nos propone un pacto de lectura que mantiene el conflicto de Fedra e Hipólito situados en una España rural a comienzos del siglo XX. Desde este marco, el presente trabajo se propone analizar la construcción del personaje de Fedra a partir del cual es posible plantear el concepto de una femineidad que se debate entre la pasión y el honor, tema que ha sido transversal en la literatura española desde sus orígenes.

\section{Textualidad y semántica del personaje de Fedra}

La resignificación del mito de Fedra en una familia de un ámbito rural en España a comienzos del siglo pasado, nos lleva a reconocer, siguiendo a Dubatti (2005:127) que "las poéticas se constituyen desde la enunciación y basta modificar la enunciación para que un texto ya no sea el mismo".

De acuerdo con este principio, Unamuno define la historicidad de su obra pero mantiene su anclaje con el modelo clásico y conserva la identidad 
de los dos personajes centrales, Fedra que en su composición mantiene el rasgo que la identifica como la madrastra enamorada de su hijastro e Hipólito en cuya caracterización no está la misoginia. En cambio, Teseo y la nodriza, identificados con rasgos más localistas son Pedro y Eustaquia, quien recibe la duda y la culpa en la intimidad de Fedra.

La obra comienza con Eustaquia y Fedra quien desea reconocer su historia en la que aparece desdibujada la figura de su madre cuyos datos ambiguos pero asociados con la fatalidad los cuales según Marcelo también involucran a la hermana y a la abuela. (III,8). Se deriva entonces el recuerdo de la infancia, la vida en el convento y un presente que se focaliza en su matrimonio con Pedro. Desde esta perspectiva del personaje, Unamuno realiza un abordaje que la relaciona con la conciencia y es por ello que tal como señala Zavala (1980:275) el mito no determina la obra. Por el contrario, el desarrollo dramático se observa a partir de la agonía de la vida cotidiana de Fedra que se debate en un pasado donde intuye la causa de su infelicidad y la fatalidad de su presente $(\mathrm{I}, 1)$. El sometimiento del personaje a su desgracia la lleva a buscar el resguardo en la religión. "He querido resistir... ¡Imposible! Pido consuelo y luces a la Virgen de los dolores, y parece me empuja..." (I,1). Es la nodriza la que menciona el motivo de su mal que ha llegado al hogar de Pedro: "Fedra, Fedra, este amor culpable" $(\mathrm{I}, 1)$.

En esta primera escena, el personaje de Fedra está determinado por una maternidad frustrada, el amor ilícito a Hipólito y un marco dominante de la religión. En la recreación del mito, esta aclaración nos permite destacar que Unamuno acomoda el género dramático a su visión del mundo y ello le permite profundizar en el ser humano en un contexto de cambio social y cultural a comienzos del siglo XX en el que Fedra no tiene otra alternativa que luchar entre la pasión y el honor en un contexto signado por la moral cristiana. Tal como su autor lo declara: "esta mi Fedra [...] sólo que con personajes de hoy en día y cristianos por lo tanto -lo que la hace muy otraPodemos señalar entonces que el sentido de lo trágico en esta versión se afianza a través de un personaje atado a la tradición y que lucha entre el deber ser y el querer:

Fedra: - ¡Oh! Yo le rendiré, ¡yo! No puedo más. Esto es más fuerte que yo. No sé quién me empuja desde dentro...Aquel beso de fuego en lágrimas... ¿Y es el deber, es el amor filial, o me desprecia? Sí, sí me desprecia...Una jabalina acorralada... ¿tan fea soy? Quiere a otra no me cabe duda, no es posible si no Mas no, no, no, es leal, generoso, veraz. Sí, sí es su padre. ¡Qué horror! ¡Soy una miserable loca, sí, loca perdida! ¡Virgen mía de los Dolores, alúmbrame, ampárame! No puedo estar sola, llamaré con cualquier pretexto. La soledad me aterra $(\mathrm{I}, 5)$. 
Reaparece el motivo clásico del personaje movido por fuerzas desconocidas que la dominan y la arrastran. El sufrimiento femenino se profundiza en la soledad y en la ausencia de un hijo, tema que se vincula con un mundo en el que los hijos otorgan sentido y trascendencia a la vida opaca de las mujeres.

Fedra: - No cabe resistencia. Esto así, contenido, me abrasa; revelado se curaría mejor. ¡Está escrito, es fatal! Y si al menos tuviese un hijo que me defendiera $(\mathrm{I}, 1)$.

Fedra reconoce ante Pedro de manera indirecta su amor a Hipólito, bajo la supuesta imagen de madre: ¡Le quiero, sí, le quiero con toda mi alma! (I, 2)

En su locura, Fedra amenaza a Hipólito con echarlo si no se rinde y lo persuade con una autoridad materna que ha perdido:

Fedra: ¿Con que no, ¡eh? ¿ con que no? Pues bien, oye y fijate, mis últimas palabras, las definitivas, óyelas y piensa bien en ello. Tu padre ha debido notar ya que no me besas; tu padre ve mi demacración y mi desasosiego; tu padre aunque se calla ha de sospechar ya algo, lo sospecha, ${ }_{i} \mathrm{Y}$ se lo he de decir yo... yo...yo! (II, 3).

En la caracterización del personaje, Unamuno recupera el tópico de la debilidad y la locura femeninas, imagen que se evidencia en el cuerpo y en la mente de Fedra cuando le confiesa a Hipólito sus sentimientos:

-¡Sí, vuelvo! Mira que no como, que no duermo, que no vivo, que tus ojos me queman, que muero de la sed de tus besos, que esto es el suplicio de Tántalo... ¿Por qué no me besas como antes, Hipólito? (II, 3).

En su fragilidad mental, Fedra apela a la juventud de ambos: “¡Y tenemos que vivir, vivir ante todo! Para algo somos jóvenes” (II, 3). El tópico carpe diem como argumento es débil y no tiene posibilidad de concretarse porque tal como lo indica Carmen Morenilla (2008:442):

Fedra es más débil que las heroínas clásicas, no hay en ella lucha, sino que se abandona a la fatalidad; es una muchacha indefensa sacada del convento por la nodriza y que por agradecimiento se casa con un hombre mayor, una muchacha protegida por un hombre maduro [...].

Tal como inicialmente lo planteamos, Unamuno determinó la construcción de la territorialidad de su personaje (Dubatti: 2005:13); sin embargo cabe plantearnos si la versión unamuniana de Fedra es tan distinta de sus referentes clásicos a pesar de la diferencia que pone de manifiesto al inicio de la obra y el alcance simbólico que adquiere el personaje en un contexto español y 
contemporáneo. Fedra es una mujer española de principios del siglo XX, cuya vida está delimitada por el dominio masculino. De hecho el contexto está determinado por la norma que domina la vida social. La fatalidad de Fedra se expresa en un ámbito privado y una vez que ha sido confesado, lo que se persigue es que la crisis familiar no trascienda al mundo exterior, la sociedad no debe involucrarse. Hipólito ante la confesión de Fedra opta por el silencio y Pedro reconoce que a partir de ese momento no pueden vivir los tres en el mismo techo (II, 5) pero le preocupa la mirada de la gente:

¡Diga lo que quiera! Aunque la gente no sabrá nada, no debe saber nada; esto ha de quedarse aquí, enterrado, entre los tres... ¡Si no, haría algo que no puede decirse.

El fragmento nos revela el indicio de un drama de honor que se condice con un concepto enraizado en la tradición española donde el concepto de honra se sostiene a partir de la mirada social, por ello cualquier anomalía en el microcosmos familiar debe preservarse del juicio social.

La versión femenina de Unamuno se detiene en el lugar que juzga a la mujer a partir de una culpa ancestral. Pedro reconoce su responsabilidad por haber expuesto a su hijo y a Fedra en esa situación, pero en Fedra ve la actualización de una culpa asociada con su género:

¿No sabes lo que es culpa? ¡Fue la mujer, la mujer la que introdujo la culpa en el mundo! (II, 9)

Esta mirada negativa, masculinizada, está enraizada en el pensamiento de Fedra quien considera que "nunca hubiese creído que en vaso tan frágil como cuerpo de mujer cabría tanto dolor sin hacerlo pedazos (III, 1).

A la luz de los acontecimientos, el universo masculino no resguarda el honor femenino sino el honor familiar ante el juicio de la sociedad:

[...]Habrá que negar a todo el mundo la entrada en esta casa. Una cárcel...un sepulcro...Que nadie lo sepa, que nadie lo sospeche ni barrunte, que nadie lo

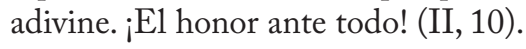

En este sentido, la victimización de Fedra preserva los valores familiares que están orientados por el universo masculino:

No podía vivir más, no podía vivir en este infierno; padre e hijo enemistados por mí y sobre todo sin Hipólito. ¡Sin mi Hipólito! Mas ahora vendrá, ¿no? Ahora vendrá a verme morir, a darme el beso de viático...el último...j ¡No!;El primero! Ahora vendrá a perdonarme. (III, 1) 
Fedra no sólo se castiga con su conciencia sino que también por la mirada de los otros, en este caso de la criada y principalmente de Marcelo al que considera como "demonio de la guarda, mi acusador" (III, 1).Habiendo llegado a este extremo, la muerte para Fedra es la única alternativa posible para restituir el orden familiar que tiene como centro el universo masculino. Asume que es un sacrificio pero está dispuesta a hacerlo:

Y ahora, ante la muerte, podré decir la verdad, toda la verdad a Pedro. Y ellos, padre e hijo, vivirán en paz y sin mí, sobre mi muerte. ¿Se acordarán de este mi sacrificio? (III, 1).

En el discurso de Fedra se textualiza el pecado, la posibilidad del infierno si en un momento de cobardía se negara a aceptar la muerte como un sacrificio.

A pesar de la insistencia de Unamuno en separar su versión de los textos precedentes, el personaje de Fedra es la representación de un orden que se impone sobre el individuo. En especial, la mujer aparece como objeto del orden estructurado por el hombre. A través de Fedra se piensa en los mecanismos sociales inamovibles que pautan la vida social y el orden. Podemos señalar que esta figura femenina está vista desde un ángulo masculino según sucedía en la tragedia clásica y tal como lo señala Díez del Corral (1957:83) pueden ser compañeras del héroe, amantes o esposas pero, en el fondo, no cobran interés sus conflictos femeninos.

Fedra recurre al suicidio como escape y la verdad después de su muerte sólo sirve para resguardar el honor de Hipólito y Pedro y que el orden masculino se restituya.

Pedro: ¡Después de todo ha sido una santa mártir! ¡Ha sabido morir! Hipólito: -Sepamos vivir, padre! (III,14)

Pedro no descalificó a su hijo, se culpó. En definitiva ve en Hipólito una víctima de la fatalidad que comparte con su madrastra; no obstante el personaje que se sacrifica es el de la mujer.

\section{Conclusión:}

La versión española de Unamuno está ligada a la tradición: un personaje femenino que lucha entre el deber que le impone la sociedad y el querer como expresión de sus emociones y sentimientos. No obstante en esa sociedad conservadora no hay lugar ni tiempo que pueda admitir el desliz de Fedra. Sumemos a esta visión que en la construcción del personaje hay un cruce entre la maternidad frustrada, el cristianismo cuya práctica ortodoxa ata al individuo 
a su moral y la tradición, centrada en el honor. Podemos señalar entonces que la subjetivación teatral puesta de manifiesto por Unamuno no contradice el statu quo. Por el contrario, su versión de Fedra es una ratificación de la subjetividad macropolítica que se puede caracterizar como aquello que se expresa en la vida cotidiana y se manifiesta en los grandes discursos sociales de representación con un extendido desarrollo institucional (Dubatti: 2008:115). Evidencia de ello es que el universo masculino organiza el orden y determina que "después de todo ha sido una santa mártir” "iHa sabido morir!”

En Unamuno, Pedro, el esposo de Fedra, ante el engaño y el suicidio no la odia sino que reafirma su aprecio, puesto que la ha ayudado a conocer la verdad y a aceptar el sentido trágico de la existencia.

La verdad se impone como un valor que está por encima de las apariencias. Hipólito reconciliado con su padre exige la verdad: "la verdad después de la muerte", la que antes no quiso exponer para no alterar la paz, el honor y sosiego familiar. 


\section{Bibliografía:}

Díez del Corral, Pervivencia del mito clásico en la literatura contemporánea, Madrid, Gredos, 1957.

Dubatti Jorge, El teatro sabe. La relación escénica. Conocimiento en once ensayos de teatro comparado, Buenos Aires, Atuel, 2005.

Cartografía teatral. Introducción al teatro comparado, Buenos Aires, Atuel, 2008.

Morenilla Carmen, "La obsesión por Fedra de Unamuno (1912), Villalonga (1932) y Espriu (1978)”, en Andrés Pociña, Aurora López (eds.), Fedras de ayer y de hoy. Teatro, poesía, narrativa y cine ante un mito clásico, Universidad de Granada, 2008, pp. 435-480.

Zavala Iris M., "El teatro de Unamuno" en Francisco Rico, Historia y Crítica de la Literatura Española. Modernismo y 98, Barcelona, Crítica, 1980. Tomo 6. 


\section{ÍNDICE DE AUTORES Y DE OBRAS CITADAS}

Abraham, Luis Emilio - 536

Abreu, Ovidio de - 508

Ácıo -450 n. 3

acusilau de Argos - 395

AgAMBEM, Giorgio - 310

alamillo Sanz, Assela - 536

ALberti, Leon Battista

Philodoxus - 445

ALCALÁ Zamora, José - 364

ALCALDE MARTín, C. - 319 n. 2, 330

Alexandre, Marcos Antônio - 310

ALEXIS - 395

ALgora, Pilar - 263

ALMeidA, Rogério - 311

Alonso, L. - 225

Alsina, José - 203

Álvarez, Consuelo - 280

ÁLVAREZ, Julia

En el tiempo de las mariposas - 430

ALves, José Luis

La Hechicera - 221

Amado rodríguez, María Teresa - 23

Амүот, Jacques - 493 n. 9, 494, 494 n.

14, 499, 501

ANDINo, Peky

Medea llama por cobrar - 220 n. 15

ANDRADE, Jorge - 305-310

As Confrarias - 305-309
Marta, a árvore e o relógio - 305

A Moratória - 305

Os Ossos do Barão - 305

Pedreira das almas - 219 n. 8, 305

Sumidouro- 305

Veredas da salvação - 305

ANDrade, Nora - 156, 160, 387, 392,

479 n. 31, 482

ANDRADE, Rachel Gazolla - 310

ANDRADE JARDI, Ricardo

Los motivos de Antígona-219 n. 8

ANGÉLICO, Halma (vide MARGARIT) 261-270

AK y la Humanidad-262, 262 n. 1

Entre la Cruz y el Día-262

Al margen de la ciudad - 262

La nieta de Fedra - 261-270

Anónimo, De casu Caesenae - 445

Anónimo, História do cavalo que defecava dinheiro - 72

ANouilh, Jean - 218 n. 4, 409, 465

Antigona-140, 218 n. 4

Medea-218 n. 4

APARICIO y Osorio, Adelina - 263

APOLODORO - 450 n. 3, 477 nn. I 8, 22

Apolónio de Rodes - 450, 450 n. 3,

452 n. 17

Argonautica -450

APULEYO - 493

Metamorfosis o El asno de oro - 358

n. 4, 492 
Índice de autores y de obras citadas

AQUILES TÁCIO

Leucipe y Clitofonte - 493

Arata, Stefano - 364

ARbex, Márcia - 310, 311

ARCEDIANo, Elena - 263

ARELlano, Ignacio - 185, 363, 553, 558

ARIAS, Sandra -51 n. 5, 59

ARISTARCO - 455

ARISTÓFANES - 85-93, 105-113, 140,

204, 283-285, 298, 299 n. 9, 303

Aves - 85-93, 105-113

Lisistrata-13 n. 3, 112, 297-300

Paz-112, 113

Rãs - 112, 113, 127

ARISTÓTELES - 36, 272, 272 n. 4, 310,

340, 402 n. 1, 406, 516

História dos animais - 310

Poética-20 n. 19, 107, 125, 310, 336,

340, 345, 406 n. 3, 530-531 n. 5

Politica -510 n. 3

Retórica-336

ARNHEIM, Rudolf - 427

ARTAud, Antonin - 241, 287-294, 466, 470

ASCENsio, Badio - 441

Aschenbach, Gustav von - 78-82

Astin, A. E. - 196, 202

Aubrun, Charles V. - 558

AUERBACH, Erich - 310

Augé, Marc - 179, 182, 185

AYAla, Francisco - 280

Azor hernández, Ileana - 345

Baccio del Bianco, Luigi - 551

BACHELARd, Gastón - 85, 87, 87 n. 6, 88,88 n. 7, 90, 91, 93

вACON, George William - 495, 495 nn.

$19,20,501$

BADIA, Alfred - 329

BAJTIN / BACHTIN / BAKHTIN, Mikhail $-310,427,509,509$ n. 1

BaKer, Mona -539 n. 3, 542
BALANDIER, Georges - 489

BALBO DE LILLO, Lorenzo - 451 n. 12

BAlboa rodríguez, Manuel - 414-

415, 415 n. 21

balbuena, Angel - 185

BALDOVINO, Luca - 310

BALDWIN, Barry - 203

BAÑULS OLLER, José Vicente - 219 nn.

6, 7, 225, 319 n. 2, 329, 544 n. 3

BAPTISTA, Jacinto - 324 n. 18, 329

baquero Goyanes, Mariano - 501

baráibar y Zumárraga, Federico -

86 n. 4, 93

barata, José de Oliveira - 303, 310

BARbA, Eugénio - 49, 59, 427

BARBin, Claude -267 n. 6

barbosa, Tereza Virgínia Ribeiro - 25, 25 n. 1, 32, 75, 508

BARCHIESI, Marino - 427

BARCLAYO, Juan

Argenis - 492

BARJACOBA, Maria

Medea Fragmentada - 221

Baroja, Carmen - 263

barrea marlys, Mirta - 106 n. 4, 112

BARRETt, William Spencer - 128 n. 4, 137, 460 n. 7

BARRIENTOS, Bartolomé

De Illiberitanorum maurorum seditione - 446

BARros, Leandro Gomes

O enterro do cachorro - 72

BARTHEs, Roland - 159, 160, 348, 354,

534, 534 n. 32, 536

BARzizza, Antonio

Cauteriaria - 445

BASSNETT, Susan -539 n. 3

Bataille, Georges - 289, 289 n. 6, 294

BAtAillon, Marcel - 486, 489

BAUZÁ, Hugo Francisco - 156, 157, 160,400

веАСНАм, Richard C. $-65,65$ n. 18, 
$68,69,427$

BEARE, W. - 427

BEAUVOIR, Simone de - 350, 354

BECCARI, Gilberto - 267 n. 7, 268 n. 9

Beckett, Samuel - 466, 505, 507

Belfore Mártire, María T. - 459 n.

3, 464

Bellero, Pedro - 451 n. 10

BeLtramo, Laura

Medea, paisaje de hembras -221

BENAVENTE, Jacinto - 268 n. 10

La malquerida-261, 268, 268 n. 10 BENJAMIN, Walter - 381, 381 n. 13, 538, 542

BENNASSAR, Bartolomé - 363

BENNET, Larry J. - 510 n. 4

BÉRARD, Victor - 59

BERGAMín, José

Medea la encantadora - 218 n. 4

La sangre de Antígona - 218 n. 4, 467 n. 5

BERNABÉ, Alberto - 437, 439

Bertens, Hans - 354

BETTELHEIM, Bruno - 380 n. 11

Bezerra, Paulo - 3 Io

BHABHA, Homi - 62

BHER, Alejandro (vide VAlERo DE MAZAS) -264

BIANCO, José

Las ratas -367

BIERL, Anton - 483

BigLeri, Aníbal - 173 n. 4, 177

Birkenmaier, Anke - 272 n. 4, 279

blanco Amores de Pagella, Ángela $-216$

BLASCO, Sofia -263

Boal, Augusto - 311

вовеs naves, María del Carmen - 185, 536

Bocaccio, Giovanni - 552

De casibus virorum illustrium -373
Genealogia Deorum Gentilium 245, 248 n. 5, 452 n. 14, 552

BOfill, Pere -42 n. 2

BOLLACK, Jean - 475 n. 8, 482

BOMPAire, Jacques - 203

Bordieu, Pierre - 72

BoRgEs, Jorge Luis - 61, 62 n. 3, 63, $222,310,511,514$ n. $15,515,515$

n. 18

La casa de Asterión - 277 n. 15

Fervor de Buenos Aires - 515 n. 18

El otro, el mismo- 515 n. 20

Borgia, Pedro Pablo - 495

Borragán, Maria Teresa - 263

Bosch, María del Carmen - 325, 329

вотта, Patricia - 462, 463, 464

BOtTON-BURLÁ, Flora - 538, 542

Boulanger, André - 169

BOURDIEU, Pierre - 72

BRANDÃo, Jacyntho Lins - 209, 503

Que venha a Senhora Dona - 503508

BRANDÃo, Junito de Souza - 310

BRANDon, Samuel G. F. - 310

bravo de laguna romero, Francisco $-216$

BRECHT, Bertolt - 53, 267 n. 7, 302, 423, 424 n. 7, 427, 429, 432, 433, 433, 465, 536

BRIE, César - 49-59

El Cíclope - 50

La Ilíada-50, 50 n. 3, 53 n. 9, 59

La Odissea - 49-59

BRIE, Pablo - 51 n. 5

BRIGNONE, Juan Jerónimo

Ignea Medeas - 221

BRIZUELA, Mabel - 363, 365

вRоок, Peter -466

BROWN, Jonathan -558

Bruerton, Courtney - 356, 358, 359,

360,364

BRUNA, Jaime -125 
BRUNel, Pierre - 542, 545 n. 10

buarque de holanda, Chico - 401406

Gota d'Água-220 n. 15, 401-406

Budelmann, Felix - 136 n. 16

BURCKHARDT, Jacob - 79, 81

BURKe, Peter -488

BURKERT, Walter - 310, 329, 387, 392

BURIAN, Peter - 482

BUSTAMAnte, Jorge de - 245, 247 n. 4,

369, 451, $451 \mathrm{nn} .10,12,452,452$

nn. $16,17,552$

BUTLER, Judith - 308, 350, 350 n. 12, 354

ButTrey, Theodore Vern - 498 n. 34, 501

CABAllero, Ernesto - 429

CABAllero SÁNCHEZ, R. - 319 n. 2, 330

CABAÑas, Pablo - 400

CABranes-Grant, Leo - 442, 442 n. 1

CABrera, Fray Alonso de - 487

cabrero, María del Carmen - 204, 209

CACCINI, Giulio - 492

CAlatayud, Emma - 258 n. 19

CAlderón de la Barca, Pedro - 179185, 245, 249-252, 367, 370, 393, 400, 450 n. 5, 485-489, 491-502, 551-559

Amado y aborrecido - 498

Andrómeda y Perseo. Auto Sacramental -249-251

Auristela y Lisidante - 551, 553, 557, 558

El Castillo de Lindabridis - 552 n. 4

Céfalo y Pocris - 551-558

Celos, aun del ayre matan $-551,552$,

552 n. 3, 554, 558

El divino Jasón - 181

La estatua de Prometeo- 552 n. 3

Faetón - 552 n. 4

La fiera, el rayo y la piedra-552 n. 4

Fieras afemina Amor - 179-183, 552 nn. 3,4

Fineza contra fineza -552 n. 3

Las fortunas de Andrómeda y Perseo250-252

La fuente de Mantible - 552 n. 4

El golfo de las sirenas $-552 \mathrm{nn} .3,4$

El Gran Teatro del Mundo-485-487

Hado y divida de Leonido y Marfisa552 n. 4

Los hijos de la Fortuna. Teágenes y Cariclea-491, 492, 494, 495 n. 20, 500, 501

El hijo del sol -552 n. 4

El laurel de Apolo - 552 n. 3

El mayor encanto, amor - 552

El monstruo de los jardines - 181

La púrpura de la rosa - 552, $552 \mathrm{nn}$. 3, 4

Los tres mayores prodigios $-369,370$, 498, 552 n. 4

Calero Secall, Inés - 105 n. 1

CALlejo, Jesús - 464

CALPHURNIUS, Johannes - 441

CAlvarese, Ornella -427

самасно Rojo, José María - 283 n. 6, 329

CAMÕEs, Luís - 187

campanella, Hebe

Antigona ... con amor -220

CAMPUZANo, Luisa - 220 n. 15, 225, 280

camus, Albert - 271-280, 505

Bodas - 271 n. 1, 274, 279

Calígula-271-279

El hombre rebelde - 272, 273, 273 n. 6

Los justos - 271, 272, 274, 277, 277

n. 13,279

El Minotauro o Alto de Orán - 279

El mito de Sísifo - 274, 277, 279

El revés y el derecho-275 n. 11, 279

El verano -279

camus, Marcel - 393, 397

Orfeu do Carnaval - 438

Orfeu negro - 397

CANAVAggio, Jean - 449 n. 1

CANCELliere, Enrica - 558 
Canciller Ayala

Crónicas - 143 n. 10

cantó sabuco, Assumpta - 354

capmany, Maria Aurélia - 326 n. 26

CÁPONA PÉREZ, Daniela

Antígona. Historia de objetos perdidos -219 n. 8

carballo Calero, Ricardo - 409, 409

n. 8

carames laje, José Luis - 398 n. 7, 400

CARbone, Adela - 263

CARBonell, Artur - 13 n. 3

CARDIGNi, Julieta -378 n. 4

CARdoso, Isabella Tardin - 197, 202

CARDOSo, Joaquín - 142 n. 8

CARDoso, Reni Chaves - 38

cardoso, Zélia de Almeida - 125, 202

CARLO, Omar del

Prosérpina y el extranjero - 211

CARo baroja, Julio - 363, 462, 464

CARPENTIER, Alejo - 271-280, 313

El acoso-272, 274, 276-280

Écué-Yamba-Ó-273, 273 n. 7, 279

Ensayos - 271 n. 1, 279

El recurso del método - 272, 276-279

El reino de este mundo - $451 \mathrm{nn} .10,12$

El siglo de las luces - 274 n. 9, 275

CARrAsco REIJA, Leticia - 451 nn. 10, 12

CARTARI, Vicenzo

Le imagini de I dei degli Antichi 369

CARTledge, Paul - 105 n. 2, 217 n. 2, 225

Casanova, Gustavo - 529-536

Hedor Maldito - 529, 531 n. 7, 534-

536

CAstagnino, Raúl - 536

CAstellet, Josep María - 329

Castillio, António Feliciano de - 439

castoriades, Cornelius -427

castro, Américo - 364
CAstro, Cristóbal de - 262

castro, Marcos de - 38

Castro, Rosalía de - 228, 231, 234

La hija del mar -232

CATÃo - 361

CÁtedra, Pedro M. -460 n. 5

CATULO -372

cavallero, Pablo A. -139 n. 2, 143 n.

10, 145, 502

CAvicEo, Jacopo - 493 n. 11

cecco, Sergio de

El Reñidero-211, 219 n. 6

cervantes, Miguel de - 493, 494 n.

19, 501

Coloquio de los perros - 493

La española inglesa - 493

La Gitanilla - 493, 501

Historia Setentrional - 491

La ilustre fregona - 493

Novelas ejemplares - 493, 494, 494

n. 13,501

El peregrino en su patria - 493

Quijote - 462, 493

Rinconete y Cortadillo - 493

CHAcel, Rosa -267 n. 6

CHALMERs, Walter R. -427

CHAPMAN, W. C. -558

Chevalier, Jean - 389 n. 5, 392

CHevalier, Maxime - 365

Chevrel, Yves - 542

Cicero - 8 o n. 8, 119, 359, 419

De Oratore - 80 n. 8

CILENTO, Laura - 50, 52, 59

cintio, Giraldi - 442 n. 1

CITINo, Rosana - 311

ClAR MARgarit, Maria Francisca (vide

Angélico, Halma) - 261

Clavería, Carlos - 559

cocteau, Jean - 275, 397, 400, 409

coelho, Jacinto Prado - 95, 96 n. 8, 104

coelho, Maria Cecília Nogueira - 402 
Índice de autores y de obras citadas

n. $1,403,438,439$

coelho netto, José Teixeira - 38

COHEN-CRUZ, Jan - 300, 300 nn. 11, 12,303

colom, Guillem

Antigona-325 n. 22

colombani, Maria Cecilia - i 69

CONACHER, D. J. - 128 n. 3, 137

conNolly, Myles - 141

CONRAD, Georg

Phaedra-375

conte, Gian Biagio - 119 n. 1

contr, Natale

Mythologia-245, 452 n. 14

contreras, Jerónimo de

Selva de Aventuras - 493, 493 n. 11, 494

Correia, André Brito - 300 nn. 13, 14, 15, 302 n. 16, 303

correia, Hélia - 96 n. 6, 104

Perdição. Exercício sobre Antígona320 n. 4

Florbela -320 n. 4

CORsi, Jacopo

Dafne- 500

Euridice - 500

CORTÁzAR, Júlio

Los Reyes - 211, 545, 545 n. 11, 546

nn. 12,13

CORTÉs, Eladio - 106 n. 4, 112

CORvin, Michel - 185, 536

cosentino, Olga - 109 n. 7, 112

cossío, José María de - 179, 185

costa, Aída - 125

costa filho, José da -310

COTELlo, Beatriz - 216

COULON, Victor - 112

COURTÉs, Joseph - 425, 428

covarrubias horozco, Sebastián de 179,185

CRANE, Gregory R. - 458 n. 1

CRESCENZI, Luca -78 n. 3, 80 n. 10,
82 n. 16,83

CRESPo AlCAlÁ, Patricia - 219 nn. 6, 7, 225, 319 n. 2, 329, 544 n. 3

CRIADO, Manuel - 446 n. 12

CRIMP, Martin

Attempts to her life - 241 n. 1

CRISTÓBAL, Vicente - 333

Croguennec-Massol, Gabrielle - 29

nn. 21, 22, 30 nn. 26, 30, 32

Cruz, Duarte Ivo - 96 nn. 6, 7

CRUZ, Sor Juana Inés de la - 367-376

Amor es más laberinto - 367, $369 \mathrm{n}$.

3, 370, 373 n. 6

La segunda Celestina-370, 370 n. 4 Cruz, Ulisses - 305

CUNQUeIro, Álvaro - 415 n. 21

CURESEs, David - 220 n. 11

La cabeza en la jaula - 218 n. 4, 220

La frontera - 211, 218 n. 4, 221

Curtius, Ernest Robert - 179, 180, 185

DAIN, Alphonse - 529 n. 1, 536

DANCHES, Antoine - 98 n. 12

DANTAS, Júlio

Antígona-320 n. 4

Dante, Alighieri - 499

DAVIDSON, F. J. - 135 n. 14, 137

Decock, Pablo - 225

DE DIEgo, Rosa - 279

Defourneaux, Marcelin - 363

DEI NOBILI, Laudivio

De captivitate ducis Iacobi - 445

Del Corno, Dario - 112

Delerue, Maria Luisa -38

DELEUZE, Gilles - 505, 508

O esgotado- 505, 508

DEL VALLe, Emilio - 429

De MARInis, Marco - 425, 427

DE martino, Francesco - 225, 400

Demóstenes

De corona- 387

DERMOTt, Emily Mc - 460 n. 7 
DERRIDA, Jacques - 158, 160

Detienne, Marcel - 169

DE TORo, Fernando - 424 n. 7, 427

Deuse, W. - 79 n. 5, 83

DE VITORIA, Fray Baltasar

Theatro de los dioses de la gentilidad552

Dezotti, Maria Celeste - 203, 205, 207, 209

DIAs, Alexandre - 311

DiAs, Paula Barata - 321 n. 8, 323 n. 14,330

DÍAZ DE MENDOZA, Carmen - 263

díaz-plaja, Fernando - 33 n. 1, 38, 458, 464

Di Benedetto, Vincenzo - 82 n. 15 , 83, 477 n. 19, 482

diegues, Carlos - 435

Orfeu -438

Dierks, Manfred - 79 n. 5, 83

DÍEZ BORQue, J. M. - 356, 356 n. 2,

$363,364,449$ n. 1,450 n. 4, 558

díEz del corral, Pilar - 565, 567

DIGGLE, James - 129 n. 6, 132 n. 10, 137,473 n. 1, 477 n. 19, 482

DIODORO - 164, 165

Diógenes, O Cínico - 206

DIÓGENES LAÉRCIO

Vitae Philosophorum - 217

DIONIGI, Ivano - 267 n. 7

Dionísio, Eduarda - 517, 527

Antes que a noite venha - 320 n. 4, 517-527

DI PINTO, Elena - 558

DiscÉPolo, Armando - 215, 339-345

Cremona-339

Mateo-339-343

Mustafá-339

El organito - 339, 341-343

Relojero-339

Stéfano-339, 341-343

DodDs, Eric R. - 83, 164 n. 2, 165, 165

nn. 4, 5, 169, 392, 475, 475 n. 5,
476, 476 n. 14, 477, 477 nn. 17, 19, 478 n. 23, 479, 480 n. 34, 482

DOMÉNECH RICO, Fernando - 262 n. 1, 567

DOMÍNGUEZ, Nora - 483

domínguez y Hernández, Franklin

Antigona-Humor-219 n. 8

domínguez Ortiz, Antonio - 363

DONATO - 441, 443

De comoedia / De com. - 443 n. 4

DOREY, T. A. -427

DRAgo, Alberto

La Navarro - 221

DRAGÚN, Osvaldo

La peste viene de Melos - 211

Drew Griffith, R. - 480, 482

DRYDEN, John - I87

DuArte, Adriane da Silva - 202

DuвAтti, Jorge - 51, 52, 59, 86 n. 2, 87 n. 5, 93, 112, 188, 190, 192, 194, 341, 345, 378, 379 n. 5, 380, 380 n. 10, 382, 383, 383 n. 17, 419, 427, 428, 510 n. 5, 561, 563, 566, 567

DUCKWORTH, George - 428

DUDLEY, Donald R. -427

DUNBAR, Nan - 112

DUPONT, Florence - 3 Io

DURÁN, Manuel - 489

DURAND, Regis -428

DURER, Albrech - 80 n. 10

Duroux, Rose - 319 n. 2, 324 n. 19, 329, 330, 544 n. 3

EAsterling, Patricia - 20 n. 18, 23, 482

Eco, Umberto - 379 n. 8

EHLERs, Widu-Wolfgang - 450 n. 6

Ehrenzweig, Anton - 428

EINEs, Jorge - 51

EIRE, Antonio López - 74 n. 3

eisenstein, Sergej Mikhajlovic - 423, 426 n. $6,427,428$ 
Índice de autores y de obras citadas

eliade, Mircea - 167 nn. 9, 10

ELIAS, Norbert - 363

ELIot, Thomas Stearns - 62, 62 n. 6,

63,63 n. 7, 64 n. 13, 68 n. 28, 69

ELLIOTT, John - 363, 558

ELSNER, Jas - 225

ENIO - 45 O n. 3

EPICARMO - 395

EPIMÉNIDES DE CRETA - 395

ERRANDONEA, Ignacio - 18 n. 12, 23

escobar villegas, Juan Camilo - 217 n. 3,225

ESPINOSA, Norge - 314 n. 4

Icaros -314 n. 4

ESPRIU, Salvador - 267 n. 7, 319, 325329, 567

Antigona - 140, 319, 325-329, 467

n. 5

Fedra -329

ESQUILO - 24, 113, 128, 128 n. 4, 497, 530, 531, 531 nn. 6, 8, 10, 11, 532, 532 n. 15,536

Agamemnon / Ag. - 388, 475 n. 5, 476 n. 14

Coéforas / Ch. -481

Orestiada / Or. 343

Prometeu/Prom. - 13 n. 3, 475 n. 5

Sete contra Tebas / Th. - 319 n. 1, 325, 529-532, 536

Esslin, Martin Julius - 504-508

ESTÁCIO - 455, 455 n. 22

Achilleis / Ach. -454 n. 19

esteban, Angel - 279

Estofán, Cristina - 363, 365

ESTORINo, Abelardo

Medea sueña Corinto-314 n. 4

Eudemo - 395

Eurípides - 13, 24, 25, 26, 31, 49, 77-83, 96, 127-137, 171-178, 218, 238, 240, 247, 267 n. 6, 278, 326, $333,348,349,353,385-393,395$, 401-403, 407, 410-418, 450 n. 3, 457-464, 473-483, 497, 498, 506, $507,525,526,531$ n. 5,561
Alceste / Alc. - 140, 503-508

Alexandros -475 n. 6

Andrómaca - 177

Bacantes / Ba. - 77-83, 167, 237-

244, 385-392, 473-483

Ciclope / Cyc. - 75, 212, 480 n. 32

Cretenses -478 n. 23

Electra-13 n. 3, 98

Fenícias/Ph. -319 n. 1, 325

Hécuba - 388, 482

Heracles Furioso / HF - 389

Hipólito Coroado-13 nn. 3, 4, 127 -

137, 177, 247 n. 3, 333, 410-413, 418, 418 n. 24, 457-464, 476 n. 14, 491, 498, 502, 561

Hipólito Velado (Kalyptomenos) 128, 133 n. 11, 418 n. 24, 460 n. 7

Ifgénia entre os Tauros / IT - $476 \mathrm{n}$. 14, 479 n. 28,480 n. 32

Ion - 480 n. $32,497,497$ n. 31

Medea / Medeia - 25-27, 171-178, 221 n. 19, 314, 347-349, 401-403, 476 n. 11, 482, 497, 501, 522

Orestes / Or. - 276, 278, 392, 479 n. 29, 480 n. 32

Reso/Rh. -475 n. 6

Troianas / Tr. -13 n. 3, 178, 482, 497, 497 n. 31

FABRY, Genevieve - 225

FACINA, Adriana - 27 n. 9, 29 n. 16, 32

FAliu-Lacourt, Christiane -558

FARINELLI, Arturo - 493 n. 11

FAVARETto, Silvia - 32

FÉRAL, Josette -428

FERÉCIDES DE SIRO - 395

FERnÁndez, Carolina Ramos - 29 n. 20, 30 nn. 24, 29, 31 n. 35, 32

FERNÁNDEZ DELGado, José Antonio 13 n. 4, 14 n. 7, 23, 409 n. 8, 412 n. 17,413

FERNÁNDEZ FAREL, Silvina

Medea, paisaje de hembras - 221

FERnández Lladó, María Dolores 267 n. 6

FERnÁNDEZ rocA, Xosé Ángel - 13 n. 1,23 
FERRARI, Juan Carlos

Las nueve tías de Apolo - 211

FERREIRA, Isaac - 23

FERREIRA, José Ribeiro - 104

ferreira, Luísa da Nazaré - 30 n. 23, 32

Ferrer valls, Teresa - 363, 449 n. 1

FERro, António - 323 nn. 15, 16, 329

FERTONANI, Roberto - 80 n. 9, 83

FEUILlÂTre, Émile - 494 n. 15, 497,

497 nn. 28, 31, 501

FIADINo, Elsa Graciela - 363, 365

FialHo, Maria do Céu - 99, 102 n. 15,

104, 127 n. 1, 130 n. 8, 131 n. 9,

137

FIERRo, Martín - 511

FigueIREDO, Guilherme - 195-202

Um deus dormiu lá em casa - 195-

202

Os fantasmas - 202

A muito curiosa história da virtuosa matrona de Éfeso - 202

A rapôsa e as uvas -202

figueiredo, Manuel de -96

Andrómaca-96

Édipo-96

FILHo, Antunes - 305

FILHo, Oduvaldo Vianna - 401

Fischer-Lichte, Erika - 135, 135 n. 15

FLASHAR, Helmut - 483

FLAubert, Gustav - 80, 80 n. 8

fleites Pérez, Yerandi-313-318

Antígona-313-318

Jardin de héroes -314 n. 4

Fo, Dario - 310

Focio - 499 n. 40, 501

Bibliothèque - 501

Foley, Helen - 136 n. 17, 217, 224 n.

$25,225,480$ n. 33,482

FOLINI, Valeria

Antígona la necia - 220 n. 14

fonsecA, Carlos A. Louro - 195, 202
FRAGA, Eudinyr - 27 nn. 6, 10, 32

FRAILE, Guillermo - 486, 489

FRAISSE, Simone - 319 n. 2, 320 n. 3, 329

FRANCO, Andrés - 267 n. 7

FRANCO GRANDE, José Luis

A volta de Ulises (El regreso de Ulises)

$-409$

FRANK, Waldo - 435

FRASCHINI, Alfredo - 216

FRENZEL, Elisabeth- 333

FREUD, Segismund - 41 n. 1, 59, 239

FróEs, Vânia Leite - 39

FRY, Northrop - 378 n. 2

FUENTES MAREL, José

La joven Antígona se va a la guerra219 n. 8

FULGENCIO

Mythologicon-245

Fusillo, Mossimo - 79 n. 5, 81 n. 13, 83

GALEMIRI, Benjamin - 547-548

Edipo Asesor - 547, 547 n. 15

Infamante Electra - 548, 548 n. 17

GALILEI, Vincenzo - 492, 500

GALlego, José María

Os homes poden ser deuses - 409

GALVAN, Elisabeth - 78 n. 4, 79 nn. 5,

6, 7, 80 nn. 8, 9, 83

gambaro, Griselda - 113, 147

Antígona Furiosa - 147, 149-152,

211, 220

gambini, Martha Conceição - 311

GAMBOA, Federico - 142 n. 8

GAмвón, Lidia - 177, 460 nn. 7, 8, 461, 464

GARcía, Clodet

Medea fragmentada - 221

GARcía, José Manuel - 38

gARCía BARRIENTOS, José Luis - 206, 532,532 n. 13,536 
García Blanco, Manuel - 267 n. 7, 268 n. 9

garcía Lorca, Federico - 214 n. 4, 281-285, 347 n. 1, 354, 466

La casa de Bernarda Alba-470 n. 15 El público-281-284

Los titeres de cachiporra. Tragicomedia de Dom Cristóbal y la señá Rosita 347 n. 1, 354

Yerma-214 n. 4

GARCÍA LORENZO, Luciano - 363, 553, 554,558

garcía luengos, Germán Vega - 553

n. 5

garcía negro, María Pilar - 408 n. 5

GARcía Xavier, Dennys - 439

GASSNER, John - 202

GATTI, Gladys - 363, 365

GENÉ, Juan Carlos

Golpes a mi puerta - 220

GenetTe, Gérard - 52 n. 7, 59

GERNET, Louis - 169

GHEERbrant, Alain - 389 n. 5, 392

Gibbons, Reginald - 311

GIDE, André - 409

GiL, Luis - 451 n. 10

GIL VICENTE - 446

Barcas - 446

GIlbert, Sandra M. -64 n. 17

GIRARD, René - 311

Giraudoux, Jean - 187, 409

Anfitrión 38 - 140

La Guerre de Troya no tendrá lugar140

GLenny, Michael - 428

GLUCK, Christoph Wllibald

Orfeo y Eurídice - 155

goethe, Johann Wolfgang - 231

Whilhelm Meister - 487

GOLDHILL, Simon - 225

GOLDMANN, Lucien - 267 n. 6

Goldoni, Carlo - 345 gomes, Francisco Dias - 95-99

Análises e combinaçôes filológicas - 95

Electra-95-103

Ifigénia-95, 95 n. 1, 96

Obras poéticas - 95

GómEz, Pilar - 204, 209

GÓMEZ CRESPO, Paloma - 363

GÓMEZ MAsía, Román

Temistocles en Salamina - 211

Gómez sánchez, Anxo - 407 n. 1

GÓNGORA Y ARGOTE, Luis

Fábula de Polifemo y Galatea - 212

gonzÁlez CAÑal, Rafael - 364

GonZÁlez DElgado, Ramiro - 394, 394 n. 2,400

GONZÁLEZ ECHEVERRÍA, Roberto - 489

GONZÁLEZ GARcía, José - 487, 489

GONZÀLEZ JULIÀ, Luis - 203, 204, 209

GONZÁLEZ MEDINA, Alberto - 177, 348

n. 6

gonZÁlez Palencia, Ángel - 331 n. 1, 334 n. 6

gonzÁlez de Tobia, Ana María - 177

GÓRGIAS / GORG. - 476 n. 14

Goux, Jean-Joseph - 515 n. 17

GRACIÁN, Juan - 495

GRAHAM-JONES, Jean - 109 n. 6, 113

GRANADA, Fray Luis de

Oraciones - 356

GRANDE, Yamila

Antigona,!No! - 220

granja, Agustín de la - 368 n. 2

GRECO, Giovanni - 78 n. 1

GREER, Margaret - 558

GREGOR, Keith - 23, 542

Greimas, Algirdas Julien - 425, 428

GRIFFITH, Mark - 74 n. 4

gRIMAL, Pierre - 125, 139 n. 3, 145,

$158,160,467$ n. 6,497 n. 30,501

GROVE, George - 492 nn. 5, 7, 496 n.

22,500 n. 43,501 
GUbAR, Susan - 64 n. 17

GUBERn, Roman - 326 n. 25, 329

guellerman, César - 172 n. 3, 17

guevara, Fray Juan de - 367, 369-372,

375

GUINSBURG, Jaco - 38, 311

guthrie, William Keith C. - 393, 393

n. 1, 395, 395 nn. 3, 4, 396 n. 6, 400

HABERMAS, Jurgen - 487, 489

HACKER, Jorge - 536

HALL, Edith - 106 n. 3, 113, 135 n. 15,

136 nn. 16, 17, 137, 298 n. 7, 303

HANSEn, João Adolfo - 185

HARDWICK, Lorna - 61, 61 n. 2, 62, 62

n. 4, 69, 209

HARLE, Gerhard - 83

HARMONY, Olga

La ley de Creón - 219 n. 8

HARrop, Stephe - 135 n. 15, 136 nn.

16, 17, 137, 298 n. 7, 303

HARVEY, Paul - 182, 185, 311

hechavarRía prado, Habey - 317 n.

11

HeInemann, William - 531 n. 6, 536

Heidecker, Vinzenz (Opsopoeus) -

493, 494 n. 12

HELFGOTT, Sarina

Antígona-219 n. 8

HELIODORA, Bárbara - 508

HELIODORO - 491-502

Etiópicas - 491-502

HENRICHS, Albert - 134 n. 13, 137

HENRY, René - 501

Heráclito de Éfeso - 389

heredia, Carlos María - 141 n. 4, 142,

145

Memorias de un repórter de los tiempos

de Cristo - 141, 145

Hergoun, Marc - 38

HeRnÁNDEZ DE LA Fuente, David

Alejandro-473 n. 2, 480 n. 33, 482
HERÓdoto / HDT. - 454 n. 19, 475 n. 6, 476 n. 15, 494

HEsíodo / Esiodo - 81, 162, 169, 372, 395, 396

Teogonia-67, 69, 162

Trabajos y Dias - 162

HIDALGo, Juan - 496 n. 22, 552

Higino / Hyg.

Fabulas -245, 372, 450 n. 3

Himno Homérico a Deméter - 207

Hipócrates - 392

Historia lastimosa del Principe Erasto 332, 334

Historia de los Siete Sabios de Roma 332-334

Homero - 50 n. 3, 53, 58, 59, 64, 272, 395, 453 n. 18, 457, 462, 464, 494 Ilíada -59, 140, 387, 476 n. 15

Odisea - 52, 54, 58, 59, 80, 139, 212, 215, 231, 388, 462, 464

Honesko, Vinícius Nicastro - 310

HORÁCIO - 119, 125, 194

Carmina - 453 n. 18

HORMigón, Juan Antonio - 263 n. 2

hrelia, Fernanda - 112

hualde pascual, Pilar - 329

HUCH, Ricarda - 82 n. 16

HUERTA CALVO, Javier - 553, 558

HUERTAs, Jorge - 222, 223, 224 n. 26, 509-516

Antígonas, linaje de hembras - 219-

222, 224, 224 n. 26, 225, 509-516

І́вICо - 399

Iglesias, Rosa María - 280

IKEN, Fátima Dias - 295 n. 1

IMBERT, Julio

Electra-218-219 n. 6

INÉS DE LA CRUZ, Sor Juana - 368-370,

373, 373 n. 6

Amor és más laberinto - 367, 369

369 n. 3

INGARDEN, Roman - 536

IONESCO, Eugène - 466 
Índice de autores y de obras citadas

IRAZÁbAL, Federico - 160

ISER, Wolfgang - 317, 317 n. 12

ISIDORO

Etimologías - 445 n. 10

IUVENALIs, Guido - 441

JABouILle, Vítor - 132 n. 10, 137, 329

JACOBITZ, Karl - 203

JAEGER, Werner - I 69

JAMESON, Ann K. -455 n. 22

JANSEN, Steen - 536

Jelloun, Tahar Ben

Creatura di sabbia - 241 n. 1

Jiménez Romero, Alfonso

Oratorio: Antigona - 467 n. 5

JIMÉNEZ FERNÁNDEZ, Juan - 279

Johnston, Keith - 539 n. 3

Jones, Christopher P. - 203

JORI, Carmina - 329

JOYCE, James - 59

KAFKA, Franz - 59

KAISER, Wolfgang - I87

Kalila y Dimna - 332, 336

KALlendorf, Craig W. -225

KANE, Sarah

Phaedra's Love - 267 n. 8

Kartun, Mauricio - 85-93, 105-113

Bye Misterix - 106 n. 4

La casita de mis viejos -109

Civilización ... o barbarie - 106 n. 4

Cumbia morena cumbia - 109

Pericones-106 n. 4, 113

Salto al Cielo - 85-93, 105-113

kAyser-leloir, Claudia - 345

KERÉNYi, Carl - 311

KIRK, Geoffrey Stephen - 392

кітто, Humphrey Davey F. - 402, 402

n. 1

KLAUs koenig, Giovanni - 379 n. 8

KLEIST, Heinrich von -187

KLINGNER, Friedrich - 194

KNox, Bernard M. W. $-23,128$ n. 3, 137 котт, Jan - 240

Kowzan, Tadeusz - 536

Kraus, Chris -225

KRISTEVA, Julia - 62, 179, 182, 185

KURY, Mário da Gama - 185, 311

KUSCH, Rodolfo - 378 n. 3, 384, 384 nn. 18, 19, 20

LACAN, Jacques - 308

LACARra, María Eugenia - 460 n. 5, 464

LACARra, María Jesús - 331 n. 1

LACTANCIO - 445

Institutiones - 445 n. 9

LAGACHe, Daniel - 41 n. 1, 42 n. 1

LANAud, Michael - 205, 209

LANGEN, P. -451 n. 8

LAPLANA GIL, José Enrique - 498 n. 36, 501

Las mil y una noches - 331-337

LASSO DE LA VEGA, José - 267 n. 7, 536

LÁzaro carreter, Fernando - 267 n. 7,364

LEAL, Juli - 400

LefÈvre, Edwin - 45, 45 nn. 9, 10, 15

Legangneux, Patrícia - 27 n. 7, 32

LE GOFF, Jacques - 38, 217 n. 3

Lehmann, Hans-Thiers - 505, 508

Lemos, Ana Paula - 120

LE-Mur, Pedro - 495

LÉONARD-ROQUes, Véronique - 544 n. 3

Lerma, Pedro de -446

Comedia of farsa - 446

LESKY, Albin - 342, 343, 345

Libro de los engaños e los asayamientos de las mugeres (vide Sendebar) - 331

LICOFRÓN

Alexandra-454 n. 19

Lima, Silvino Pirauá - 72

A peleja da alma -72

LINDSAY, Wallace Martin - 188 n. 1 
LITTRÉ, Emile - 392

LOGIE, Ilse - 225

LONGINO -125

LONGIS, Jean -501

LONGO, Oddone - 134 n. 12, 137

LOPE DE VEGA, Félix - 33-39, 180, 245-

249, 251 n. 10, 355-365, 367, 370, 400, 445, 449-455, 493, 493 n. 11, 494, 501, 551 n. 1, 552

El acero de Madrid - 358

Adonis y Venus - 33, 246 n. 1

El amor enamorado - 449 n. 1

Arcadia - 449, 455, 455 nn. 22, 23

El arte nuevo de hacer comedias -33, 246 n. 2,355

Las bizarrías de Belisa -360

El caballero de Olmedo - 462

La dama boba -493

La discreta enamorada -359

La fábula de Perseo o la bella Andrómeda-245-249

Las ferias de Madrid - 363

Isidro-449, 455 n. 22

Jerusalén conquistada -455 n. 22

El laberinto de Creta - 33, 369, 370

El mejor mozo de España-39

La moza de cántaro - 360

El peregrino en su patria - 491, 493

n. 11,501

El premio de la hermosura - 551 n. 1

El Principe Perfecto - 33-39

La selva sin amor $-551 \mathrm{n} .1$

Los trabajos de Persiles y Sigismunda - 491, 493, 494, 494 n. 13

El vellocino de oro - 33, 449-455

$L$ a viuda valenciana -356

LóPEZ, Aurora-137, 171 n. 2, 173 n. 8, 175, 175 n. 9, 177, 178, 219 nn. 6, 7, 8, 225, 267 n. 6, 7,297 n. 4, 303, 319 n. 2, 329, 331, 368, 378 n. 4, 408 n. 6, 410, 410 n. 11, 411, 411 nn. $12,15,414$ n. $19,418,428,450$ n. $5,542,544$ n. 3,567

López CALAHorro, Immaculada - 272,

272 nn. 3, 5, 275 n. 10, 279

López-casanova, Arcadio

Orestes -409
López estrada, Francisco - 492, 492 nn. 4, 8, 493 n. 9, 495, 495 nn. 16, 20, 496 n. 23, 499 n. 41, 500, 501

LÓPEZ FÉREZ, Juan Antonio - 24, 177, 348 n. 6, 536

López rodríguez, Concepción - 283

n. 6

LORAuX, Nicole - 173, 173 n. 6, 177

LOSADA, Marcela - 276 n. 12, 280

LOTTI, Cosme - 551, 552

LOUBET, Jorgelina

Penélope aguarda - 211n. 1

Loureiro, Manuel J. Simões - 310

LOURENÇO, Frederico - 127 n. 1, 128 n.

4, 132 n. 10, 137

LOUREnço Módia, Cilha - 408 n. 3, 411, 411 nn. 13, 14

Lourenzo, Manuel María - 13-24, 407-418

O arame - 409

A canción do deserto -408

O circo da media noite - 409

Agamenón en Aulide - 14 n. 6, 409, 409 n. 9

Casahamlet-14 n. 6, 23

Clitemnestra e o crime - 409

Como un susurro - 408

Contos troianos -409

Crónica do sol de inverno-411 n. 13

Defensa de Helena - 409

Despois do temporal-407, 416-418

Edén e outros paraísos - 408

Edipo rey -409

Electra - 409

Erros e ferros de Pedro Madruga 411 n. 13

Fedra - 407, 409, 410, 412, 414417

Fedra 21 - 415

Forno de teatro fantástico - 408

Insomnes - 409

Ipólito / Hipólito - 407, 410-413, 417

A lexión sonámbula - 409

Liturxia de Tebas - 13, 14, 17, 18, 23, 409 n. 9 
Magnetismo-409

Medea dos fuxidos - 409, 411, $411 \mathrm{n}$.

16, 416, 417 n. 23

Nocturno Poe - 409

O perfil do crepúsculo - 14 n. 6, 23, 409

Os Persas - 14 n. 6, 409 n. 9

Romería ás Covas do Demo-13 n. 4, 407, 409, 410, 412-414, 418

O soño das cidades -409

Teatro minimo - 408-409

Todos os fillos de Galaad - 13 n. 2, 408

Traxicomedia do vento de Tebas namorado dunba forca-13 n. 2, 14 n. 7, 23, 409

Últimas faíscas de Setembro- 408

Veladas indecentes - 409

Viaxe ao pais de Ningures -408

LUCANO - 450 n. 3, 455

LUCIANO - 203-209, 497 n. 28

Bis accusatus -204

Caronte - 205-207

Diálogo de los Muertos - 203-209

Icaromenipo - 205

LUCILIO - 485, 486

Lugones, Leopoldo

La copa inbalable - 211 n. 1

Luмв, Thomas Wallace - 501

Lumet, Sidney - 439

LYOTARD, Jean François - 59

MACEDo, José Marcos - 310

MACHADO, Roberto - 508

MACLEOD, Matthew - 203, 204, 209

MADrona, Maria Luisa - 263

maestre maestre, José María - 451

n. 10

MAFFESOLI, Michel - 311

MAGALDI, Sábato - 29 n. 14, 32, 311, 439

MAgRini, César

Partenopeo-211 n. 1

MAILLON, Jean - 497 n. 28, 498 n. 37, 501
MALCHIODI PIÑERO, Velia

La Cooperativa de los Diógenes - 211

n. 1

MALÉ, Jordi - 326 n. 27, 329-330

Malleus Maleficarum - 46

MANGINI, Shirley - 264 n. 5

MANigLia, Horacio A. -363

MANN, Thomas - 77-83

Buddenbrook - 78 n. 3

La montagna magica -78 n. 3, 80 n.

10,83

Morte a venezia - 77-83

manojlovic, Tatjana - 96 n. 6, 104

MARAVALL, José Antonio - 364, 486

MARECHAL, Leopoldo

Adán Buenosayres - 212 n. 2, 215

Antígona Vélez-140, 211, 218, 218

n. $6,219,430$

MARGARIT, Gerónymo - 495

MARÍA, Manuel - 228, 229, 234

Edipo-227-229, 236

MARQUerie mompin, Alfredo - 537, 538,542

MARQUÉs, René

La muerte no entrará en palacio - 429

mArques, Susana Hora - 303

marshall, C. W. - 480 n. 33, 482

MARTÍ, José - 313

MARTín, Alonso - 495

MARTIN, Henry M. - 450, 450 n. 5

MARTINDALE, Charles - 225

MARTÍNEZ Berbel, Juan Antonio - 368

n. 2,449 n. $1,451,451$ n. 13,452

n. $16,454,455$ n. 21

MARTÍNEZ CUITIÑo, Luís - 285, 285

n. 8

MARTÍNEZ hernÁNDEZ, Marcos - 282

n. 3,284 n. 7

MARTÍNEZ LÓPEZ, María José - 23

MARTÍNeZ NADAL, Rafael - 281 n. 2,

282, 282 nn. 4, 5

Martins, Leda Maria - 29 n. 17, 32 
MATA INdURÁIN, Carlos - 553, 558

mateus / Matteo, São - 67, 240

Mato Fondo, Miguel A. -408 n. 4

mavromoustakos, Platon - 303

MAZON, Paul- 529 n. 1, 536

MEARDI, Florencia - 378 n. 4

MENA, Fernando de - 494, 495, 499 n.

41, 501

La historia de los dos leales amantes

Theagenes y Chariclea - 494, 501

MENANDRo / MENANDER - 194, 202, 238

Dyskolos - 143 n. 9

mendes, Manuel Odorico - 439

MÉNDEZ BALlester, Manuel - 429

El clamor de los surcos -429

Hilarión - 429

Tiempo muerto - 429

MÉNDEZ PLANCARTE, Alfonso - 376 n. 9

mendilaharzu de machain, Nélida $-536$

MENÉndeZ PElayo, Marcelino - 367,

442, 443 n. 2, 449 nn. 1, 2, 451 n.

12,493 n. 11

MENIPO - 206

MÉRIDIER, Louis - 177

Mestre, Francesca - 204, 209

mestrinel, Francisco de Assis S. - 404

Miguel Jover, José Luís de - 279

mihailescu, Calin-Andrei - 310

MILLÁN, Maria Clementa - 281 n. 1

Minchin, Elisabeth - 59

mira de Amescua, Antonio - 368 n. 2

Miralles, Carles - 326 n. 27, 329, 330

MiRANDA CANCELA, Elina - 9, 26 n. 2,

29 n. 19,30 n. $25,32,218$ n. 5, 220

n. $15,224,225$

MIRAS, Domingo - 467 n. 4

MODERN, Rodolfo

Penélope aguarda - 211 n. 1

MogLiANI, Laura - 91, 91 n. 10, 93, 109, 109 n. 8, 113

Moises, Massaud - 38
MOLAs, Joaquim - 326 n. 26

MOLIÈre, Jean - 187

molina, Horacio Rega - 211-216

Polifemo o las peras del olmo - 211-

216

Molina, Tirso de -370

El laberinto de Creta - 370

MOLlendorfF, Peter von - 483

Montani, Pietro - 427, 428

MONTERo, Reinaldo - 313-318

Antígona-313-318

Medea-220 n. 15, 314, 315 n. 6

MONTI, Ricardo - 109 n. 5

La oscuridad de la razón - 211

montilla Santillán, Guillermo 377-384

El jardin de piedra-378, 378 n. 4

Silencio de piedra - 377-384

Moore, Timothy - 69, 187, 194, 428

MOORTON, Richard - 214 n. 5

moraes, Vinicius de $-393,397,400$, 435-439

Orfeu da Conceição - 393-400, 435439

morais, Carlos - 319 n. 2, 321 n. 6, 330, 544 n. 3

MORÁn TURinA, José Miguel - 364

MORby, Edwin S. - 455 nn. 22, 23

Moreira, Flávia Freitas - 503, 503 n.

1,508

morenilla talens, Carmen - 225,

267 n. 7, 400, 563, 567

MORICONI, Ítalo - 311

MORLEY, Griswold - 356, 358, 359,

360, 364

MORRIs, Charles - 379 n. 8

Mossé, Claude - 464

mossman, Judith - 482

MOURE, Teresa - 227, 232-234, 236

Cínicas - 227, 232-234, 236

mujica LÁinez, Manuel - 220 n. 11

MUÑón, Sancho - 446 
Índice de autores y de obras citadas

Tragicomedia de Lisandro y Roselia 446

MUÑOZ PUJOL, Josep M.

Antigona-325 n. 22

MURILlo, Miguel - 429

MURRAY, Gilbert - 173 n. 5, 177, 386

n. 1,392

mussato, Albertino

Ecerinis - 445

MUSURILlo, Herbert - 476 n. 11, 482

NÁPoli, Juan Tobías - 177, 458 n. 1, 462, 463, 464

nascimento, Aires Augusto - 132 n.

10,137

NEKIWÁ! (vide SAYAR) - 139, 145

NERVAL, Gérard de - 193

neto, João Cabral de Melo - 435

Neumeister, Sebastián - 180, 181,

183, 185, 551 n. $1,552,558,559$

NÉvio - 445, 445 n. 11

Newmark, Peter - 539, 542

NIEDERST, Alain - 267 n. 6

NiETZsche, Friedrich - 79 n. 5, 311

Nieva de la paz, Pilar - 263, 263 nn.

2, 3, 264 n. 4

Nilsson, Martin P. - 169

nocito, Amalia S. - 502

NONO -482

NOUHAUD, Dorita - 545 n. 10

Novais, Fernando - 29 n. 18, 32

Nucio, Martín - 494

NUÑEZ, José Gabriel

Antígona-219 n. 8

NUÑEZ DE REINOso, Alonso

Historia de los amores de Clareo y

Florisea - 493

nussbaum, Martha - 465, 465 n. 1, 467

n. 7, 468 nn. 8, 9

OBREgón, Osvaldo - 543 n. 1

ocAmpo, Silvina - 261

осАMPO, Victoria - 10 o'connor, Thomas Austin - 370

olavo, Agostinho

Além do Rio (Medea) - 220 n. 15

OLbRECHT-TYTECA, Lucie - 428

OLEZA, Joan - 355 n. 1, 364

oliva, César - 354, 469 n. 14

oliveira, Francisco de -321 n. 8, 323

n. 14,330

oliveira, Maria Manuela - 38

OPIANO / OPP.

Cinegética / C. -477 n. 21

ORDAZ, Luis - 339, 345

ORFEU - 393-399

orringer, Nelson R. - 282, 282 n. 4

ORTiz, Pablo - 50 n. 3

osório, João de Castro

A Trilogia de Édipo-320 n. 4

отто, Walter - 164 n. 3, 165 n. 6, 166

n. 7,167 n. 8,168 n. 11,169

oudin, César - 495

ovídio - 25, 245, 247 n. 4, 249, 251, 251 nn. 8, 10, 367, 370, 393, 397, 400, 449 n. 1, 450, 450 n. 3, 455, 462, 551, 552, 554, 559

Ars amandi -554

Fastos - 554 n. 6

Heroides -450

Metamorfosis / Met. - 245, 247 n. 4, 368 n. 1, 369, 372, 400, 450, 451, 451 nn. 7, 10, 453 n. 18, 474 n. 4, $551,554,555$ n. 7,559

OYARZÁBAL, Isabel - 263

PAGE, Denys L. - 177

PAgEAux, Daniel Henri - 272, 280

PANOUSSIs, Ioannis -511 n. 6

PASCUAL, Roberto - 23

PAvis, Patrice - 59, 85, 85 n. 1, 91, 93, $340,345,428,532$ n. 17,534 n. 33, 535 n. 34

Pedraza jiménez, Felipe - 355 n. 1, 364

pedreira, Antonio S.

Insularismo-430 
PEDRo, António

Antígona. Glosa nova da tragédia de

Sófocles - 320 n. 4

PÉGOLO, Liliana - 378 n. 4

Pelletieri, Osvaldo - 91 n. 10, 93, 109, 110, 112, 113, 339, 342, 345

PERCovich, Mariana - 548 n. 18

PEREA, Bernardo - 536

PEReira, Belmiro Fernandes - 330

pereira, M. Helena da Rocha -26 n.

3, 104, 329

Perelman, Chaim - 428

Peres, Lygia Rodrigues V. - 39, 180, 185

PÉREZ, Fortús - 357 n. 3

pérez Jiménez, Aurelio - 279, 319 n.

2,330

PÉREZ DE MONTALVÁN, Juan - 491495, 498, 501

La hermosa Aurora - 498

Teágenes y Cariclea / Clariquea 491, 495, 495 n. 20

PÉREZ DE MOYA, Juan - 559

Philosophia secreta $-552,559$

PÉREZ RODRÍGUEZ, Luis - 23

PERI, Jacopo - 393, 492

PERINELLI, Roberto - 109 n. 5

PETRARCA

De viris illustribus - 373

PETRONIO - 462, 493

peyton, Myron A. - 493 n. 11, 501

PFANDL, Ludwig - 493 n. 11

PI, Antonio - 447

PIANACCI, Romulo E. - 59, 218 n. 5,

219, 219 nn. 6, 7, 8, 225, 308, 311,

313, 319 n. 2, 330, 368, 398 n. 7,

540, 542, 544 n. 3

PICchio, Luciana Stegagno - 296 n. 3, 303

PICKARD-CAMbridge，Arthur - 308, 311

PIcouto, Millán - 231-232, 234, 236

Nausicaa-227, 228, 231-232
PILLADO MAYOR, Francisco - 236, 407 n. $1,408,408$ nn. $4,5,409$ n. 8

PINA, Manuel de -558

La mayor hazaña de Carlos VI-558

PINA, Rui de -38

Crónicas -38

PÍNDARO - 396

Nemeias / N. -477 n. 19

Piticas / P. -450 n. 3, 475 n. 5

PIÑERA, Virgilio - 313, 315 n. 6

Electra Garrigó - 313, 544-545

PINTER, Harold - 187

PIRANDELLO, Luigi - 239, 339, 340

PLATÃo / PLATÓN - 75, 204, 281-285, 293 n. 21, 395, 400, 437, 439, 486, 494, 505

Banquete / Smp. - 281-285, 397, 400, 476 n. 14

Fédon / Fedón - 282 n. 3

Fedro-281, 282 n. 3

Leis/Lg. - 75, 477 n. 19

Protágoras / Prt. - 437, 437 n. 1

República - 294, 437

Timeu - 505

PLAUTO - 61, 63-69, 119-125, 187-

194, 195-198, 201, 238, 419-428,

441, 443-445, 537

Aulularia-61, 63-69, 120, 121

Anfitrión / Amphitruo - 125, 187-

194, 195-198, 443-445

Bacchae - 194

Miles gloriosus - 419-426

PLUTARCO / PLUT. - 164

Alexandre -387

Crasso / Crass. -477 n. 18

Moralia - 477 n. 22

Teseo / Thes. - 372, 373

POCIÑA, Andrés - 137, 171 n. 2, 173 n.

8, 175 n. 9, 177, 178, 194, 219 nn.

6, 7, 8, 225, 267 nn. 6, 7, 297 n. 4, 303, 319 n. 2, 329, 331, 368, 378 n. 4,408 n. 6,410 n. 11,411 n. 12 , 414 n. $19,428,450$ n. 5,455 n. 21 , 540,540 n. $4,542,544$ n. 3,567

pogolotti, Graziella - 271, 280

POLIBIO - 499 n. 40 
Índice de autores y de obras citadas

PONDAL, Eduardo - 228 n. 1

PONTES, Paulo - 401-406

Gota d'Água-220 n. 15, 401-406

PORFIRIO

Abstinentia/Abst. - 388

PóRTUlAs, Jaume - 173 n. 6, 177

PORTUONDo, José Antonio - 279

PORTÚS PÉREZ, Javier - 364

povill i Adserà, Joan

Antígona-325 n. 22

PRADO, Décio de Almeida - 125

PRADON, Jacques - 267 n. 6

PRANDI, Reginaldo - 30 n. 24

PRECIADO, Beatriz - 351, 351 n. 15, 354

PRICCO, Aldo - 419 n. 1, 428

PRocházKA, Miroslav - 536

profeti, Maria Grazia - 355 n. 1, 364

PROPERCIO - 464

PROPP, Vladimir - 240

PujAnte, Ángel Luis - 23, 539, 542

QUeIroz, Rachel de - 64, 66

QUEIXAs Zas, Mercedes - 407 n. 1

QUEIZÁn, María Xosé - 229-231, 234

Antígona, a forza do sangue - 227,

229-231, 236

QUÉRIDO - 395

QUINTILIANO - 419

Institución Oratoria / Inst. Orat. 420 n. 2

RABAZA, Beatriz - 194, 225, 378 n. 4, 428

RABETTI, Beti -69

RABetti, Maria de Lourdes - 64 n. 16, 69

RACINE, Jean - 96, 265, 267, 268, 375, 498

Fedra-267, 267 n. 6, 412, 561

RADRIGÁN, Juan

Medea mapuche -218, 220 n. 15

Ragué-Arias, María José - 13 n. 2, 21

n. $23,23,263$ n. $2,330,348$ n. 5 ,

354, 407 n. 1, 409 n. 7, 414 n. 20,
467 n. 5

Lagartijas, gaviotas y mariposas 263 n. 2

RAMíREZ, Cristian - 378 n. 4

RAMOS GAY, Ignacio - 400

RAs, Matilde - 262, 263

Rasmussen, Iben Nagel - 49 n. 1

Rattenbury, Robert Mantle - 501

RAVEN, John Earle - 392

RAVETt, Graciela - 310, 311

REBELLo, Luiz Francisco - 95, 96 nn. 6,

7, 104, 296 n. 3, 303

REHM, Rush - 480 n. 33, 482

REINACH, Salomón - 400

RENGifo, César

La fiesta de los moribundos-219 n. 8

RENNERT, Hugo - 364

RESENDE, Garcia de -38

REST, Jaime - 382 n. 15, 536

REYEs, Alfonso - 544 n. 4

Ifigenia cruel- 544 n. 4

RIARIO, Raphaele - 442, 444 n. 7

RIAZA, Luís - 347-354, 465-472, 544

n. 2

Antígona. Cerda! - 465-472, 544 n.

2

Medea es un buen chico - 347-354

Los perros - 469 n. 14

Retrato de dama con perrito $-347 \mathrm{n}$.

2, 354

ribeiro, Maria Aparecida - 403

Ribou, Jean - 267 n. 6

RICO, Francisco - 567

RiNCóN GONZÁlez, M. D. - 443 n. 5, 444 n. 7

RINUCCINI, Ottavio - 492

Riobó, Pedro P. - 13 n. 1, 23

Ríos, Juan

La selva - 220 n. 15

RIVAs, Humberto - 106 n. 4

RIVERA, Virgilio Ariel - 113

ROBERT, Karl - 395 
RODRIgues, Maria Idalina - 38

RODRIGUES, Nelson - 27-29

$$
\text { Anjo Negro-25, 27-29, } 32
$$

Rodríguez adrados, Francisco - 274, 279,536

RODRÍGUEZ CIDRE, Elsa - 173, 173 n. 8, 178, 388, 392, 475 nn. 7, 8, 478 n. 26, 482,483

RODRÍGUEZ DE LA CRUZ, Maikel

Medea reloaded -314 n. 4

Rodríguez domínguez, José Pablo 23

RODRÍGUEz GARRIDO, José Antonio 369 n. 3, 373, 373 n. 6

rodríguez Huéscar, Antonio - 400

ROFFo, A. - 113

ROGERs, B. Bickley - 112

ROHDE, Erwin - 79-81

rojas, Fernando de - 442, 446, 447, 457-464

Celestina - 441-443, 446-447, 457464

rojas zorrilla, Francisco - 450 n. 5

Rojo, Sara - 311

RoMANo, A. - I 90, I 92, I 94

ROMANo, Marcela - 365

ROMANo Martín, Sandra - 453 n. 18

ROMERo, Ulises- 378 n. 4

Romilly, Jacqueline de -26 n. 5, 32,

127 n. 1, 128 nn. 2, 3, 4, 137

RosA, Armando Nascimento

Antígona Gelada-320 n. 4

RosAs, Fernando - 323 n. 16, 329

Rosenfeld, Anatol - 72, 306, 311

rossetti, Ana - 415 n. 21

Roster, Peter - 109 n. 5, 113

Roux, Jeanne - 392, 475 nn. 5, 9, 476,

476 n. 14, 477 nn. 19, 20, 22, 478

nn. 23, 24, 479 nn. 29, 30, 480, 482

ROVNer, Eduardo - 109 n. 5

Rozas, Juan Manuel - 355 n. 1, 364

RUBEns, Erwin Felix - 356, 364
RUibal, Euloxio - 13 n. 4, 24

Ruiz de elvira, A.- 372, 372 n. 5

RUIZ PÉREZ, Pedro - 354, 466 nn. 2, 3

RUIZ RAMÓN, Francisco - 364

RULL, Enrique - 358 n. 4, 364

Russell, Peter - 460 n. 6, 461, 464

RYUz, Ana (vide ANGÉlICO) - 262

Berta -262

Los caminos de la vida -262

La nieta de Fedra - 262

SAADI, Fátima -508

SABıк, Kazimierz - 559

sacramento, Mário de

Antígona. Ensaio dramático-320 n. 4

SADIE, Stanley - 501

SÁEZ, Joel - 314 n. 3, 317, 318

Antigona-219 n. 8

Los Atridas - 314 n. 4

Casandra-314 n. 4

SAFO - 232

SAINZ DE Robles, Federico Carlos - 34

n. 2,38

SALA ROSE, Rosa -178

salas, Máximo

Medea, paisaje de hembras -221

salazar y torres, Agustín de - 370,

370 n. 4, 371

Elegir al enemigo - 370, 371

SALCEDA, Alberto G. -376 n. 9

SALDANHA, Gabriela - 539 n. 3, 542

Sobre la enfermedad sagrada -390

salgado, Ofelia N. - 493 n. 10, 494 n. 15, 497 nn. 29, 32, 499 n. 39, 501

SALVADOR, Arias - 279

salvaneschi, Luis María - 223 n. 23, 224 n. 26

El agua de todos los ríos -223 n. 23

Una bistoria en cortocircuito $-223 \mathrm{n}$.

23

Medea de Moquegua / Moquebua 219, 220 n. 15, 221, 221 n. 20, 223, 224, 224 n. 26

Segunda familia-223 n. 23 
Índice de autores y de obras citadas

Tiempo de fantasía -223 n. 23

Un, dos, tres -223 n. 23

Vida y risas del siglo XV - 223 n. 23

SALVAT, Ricard - 326 n. 26, 329

SÁNCHEZ, Florencio

La gringa -215

sÁNchEZ, Luis Rafael - 429-434

La biel nuestra de cada día - 430

La pasión según Antígona Pérez 219 n. 8, 429-434

SÁnCHEZ JimÉnez, Antonio - 455 n. 22 SANChueza-Carjaval, María Teresa 343,345

SANDERs, Julie -62 n. 5, 63 nn. 8, 9, 10,69

SANDOR, Malena

Penélope ya no teje - 211 n. 1

santaliz, Pedro

El Castillo interior de Medea

Comuñas - 220 n. 15

SAntos, Enrique - 341

santos, Idelette Fonseca dos - 67 n.

23, 71,71 n. 1,72

santos, Pepe

Contraantígona-314 n. 5

SANZ MORALEs, Manuel - 32

SARAVIA, María Inés - 311

SARTre, Jean Paul - 59, 409, 505

SAstre, Alfonso - 187-194

Los Dioses y los cuernos - 187-194

satizÁbal, Carlos Eduardo

Antigona y Actriz-219 n. 8

SATorres, Francesc

Tragedia Delphinus - 447

SAVARESE, Nicola -427

SAYAR, Roberto - 139-143

La fundación de Atenas - 139-143

Las sirenas - 139-143

SCHECHNER, Richard - 428

SCHILLER, Friedrich -72

schlegel, August W. -267 n. 6

schmidhuber, Guillermo - 370, 370

n. 4,375
SCHOENMAKers, Henri - 303

schujman, Héctor

Medea-219 n. 6, 221

schwarcz, Lilia Moritz - 29 n. 18, 32

SEAFORD, Richard - 392, 475 nn. 5, 10,

476 nn. 13, 14, 16, 477 nn. 19, 22,

478, 479, 479 nn. 27, 32, 480 n. 33,

482

sEgAL, Charles - 311, 480 n. 33, 483

SEGAL, Eric - 187, 191 nn. 7, 8, 194

SEgura RAMos, Bartolomé - 43 n. 3

SEIBEL, Beatriz - 216

seisdedos Hernández, Antonio -

476 n. 12,483

SELDEN, Samuel - 428

Sendebar, Syntipas o Sindbad al-Hakim $-331-337$

SÉNECA - 13, 25, 41-48, 178, 247, 267

n. $7,333,361,367,407,413,415-$

417, 450 n. 3, 485-489

Agamenón - 41-48

Epistulae ad Lucilium - 485, 487, 489

Fedra $-247,247$ n. 3, 267 n. 6, 333, 412, 414-416, 418, 418 n. 24, 460 n. 7

Hercules Furens - 451

Medea /Med. -173 n. 8, 453 n. 18

SÉRgIo, António - 319-325, 328-330

Antígona-319-325, 330

SÉRIs, Christiane -545 n. 10

SERNA, C. -173 n. 6,177

SERra, Ordep Trindade - 311

SERralta, Frédéric - 553, 559

SERRANO, Ismael

Amores imposibles - 161 n. 1

SERRÃo, Joaquim Veríssimo - 38

SHAKESPEARE, William - 238, 445

Hamlet - 299

Macbeth- 299

SHERo, L. R. - 187, 194

SIKorA, Marina F. - 106, 110, 113

SILIO ITÁLICO - 455, 455 n. 22 
silva, Agostinho da - 125

silva, António José da (O Judeu) 187, 296, 296 n. 3, 297, 303

Os Encantos de Medeia - 296, 297, 297 nn. 4, 5, 303

A Vida de Esopo-296, 297, 297 n. 5 silva, Maria de Fátima - 127 n. 1, 128 nn. 4, 5, 133 n. 11, 137, 297 n. 4, 299, 299 nn. 9, 10, 303, 310, 319 n. 2, 330, 428, 508

silvio, Aeneas

Chirsis - 445

SLATER, Niall - 192, 194, 423 n. 3, 428 sмYтн, Herbert Weir - 531 n. 6, 536 SNELL, Bruno - 460 n. 7

SÓCRATES - 2I 7, 255, 256 SÓFOCLES - 13-24, 97, 104, 128, 128 n. 4, 147-149, 151, 222, 231, 253, 267 n. $7,274,287,288$ n. $3,290,290$ nn. 8, 9, 10, 292, 292 nn. 16, 19, $311,313,314,316,317,319,319$ n. $2,325,325$ n. $20,330,429,430-$ 432, 465, 467, 468, 497, 509, 509 n. $2,510,511,513,514,516,530$, 531 n. 5, 532-536, 547

Antigona-98, 147-149, 220 n. 14, 222, 305-311, 313, 319 n. 1, 320 n. 4, 326, 465, 467, 469 n. 13, 509, 509 n. 2, 510, 510 n. 4, 511 n. 6, $513,514,529,529$ n. $1,530,532-$ 534, 536

Édipo em Colono / O. C. - 14, 23, 319 n. 1, 532

Edipo Rey/O. T. -13-14, 18 n. 13, 21 n. 23, 23, 98, 101, 238-239, 276, 291, 294, 547

Electra-97-99, 101-104, 388

Fedra-418 n. 24

Traquinias - 529 n. 1, 536

sommerstein, Alan H. - 106 n. 3, 112, 113

SONTAG, Susan - 137

SORIANO, Elena

Medea -171-178

sosulia, Jefim - 262, 262 n. 1

SOTELO INCLÁN, Jesús
Malintzin (Medea Americana) - 220

n. 15

souza, Anselmo Vieira de

O castigo da soberba -72

spivak, Gayatri Chakravorty - 63 n. 11,69

steinberg, María Eugenia - 502

steiner, George - 319 n. 2, 330, 352,

352 n. 18,509 n. 2,544 n. 3

STEINER, Rolando

Antigona en el infierno - 219 n. 8

stephanus, Carolus - 452 n. 14

STIEgler, Bernard - 160

stoklos, Denise

Des-Medea - 220 n. 15

sTORNi, Alfonsina - 261

STRAY, Christopher - 209

STYAN, John L. - 303

suassuna, Ariano V. - 61, 63-69, 7175, 119-124

Auto da Compadecida - 71-75, 119, 120, 123, 125

O Casamento Suspeitoso - 69, 119, 120, 122, 125

$A$ história d'o rei degolado - 66, 66 nn. 20, 22, 67 nn. 23, 24, 69

Romance d'A Pedra do Reino e o principe do sangue do vai e volta - 64, 64 nn. 14, 15, 66

O Santo e a Porca - 61, 63-69, 119121, 125

sussekind, Pedro - 505 n. 3, 508

SZlak, Carlos David - 310

szondi, Peter - 381, 381 n. 13

TALES - 217

tantanian, Alejandro - 155-160, 547-549

Una anatomía de la sombra - 155160

Cine quirúrgico - 160

Ispahan - 160

Juego de dramas crueles - 548-550

Los mansos -160

El Orfeo-160 
Índice de autores y de obras citadas

TAPLIN, Oliver - 480 n. 33, 483

TARrío, Anxo - 407 n. 1

TATO FONTAíña, Laura - 407 n. 1

TAYLOR, Richard - 428

teixeira, Cláudia - 321 n. 8, 323 n. 14,330

TEÓCRITO / THEOCR. - 212 n. 2, 372

Idílios - 212

TERENCIO - 194, 202, 238, 428, 441, 445, 537, 538, 541

Adelphoe - 538 n. 2

Eunuco- 537

Formión / Phormio - 537, 538 n. 2

TERTULIANO - 486

TEXTOR, Ravisius

Officina - 452 n. 14

THANAs, Françoise - 548 n. 17

THÉNON, Luis - 345

THEOdorou, Zena - 390, 392

THIERRY, Denis -267 n. 6

THOMAs, Henry - 443 n. 3

thomasseau, Jean-Marie - 536

thumiger, Chiara - 479, 483

TIMONEDA, Juan de - 446

Tragicomedia Filomena - 446

Turiana - 446

Tizón, Jorge L. - 42 n. 2

TODOROv, Tzvetan - 179, 182, 183, 185

TORRANO, Jaa - 69, 406, 477 n. 19, 482 TORRES AMAT, Félix - 447 n. 13

TORRES MURCiANo, A. Río - 454 n. 19

Tovar, Antonio - 459 n. 3, 464, 477

n. 19,482

trabulsi, Amjad - 336 n. 9

Tragicomedia alegórica del Paraíso y del Infierno - 446

TRIANA, José - 29-32

Detrás queda el polvo-219 n. 8

Medea en el espejo - 25, 29-32, 220

n. 15

TUCÍDIDES - 140, 494
TURINA, Morán - 357 n. 3

ubersfeld, Anne - 202, 340, 345, 428

unamuno, Miguel de - 265, 267, 267

n. $7,268,268$ n. $9,270,561-567$

Fedra-261, 267, 267 n. 7, 268, 268

nn. $9,10,270,561-567$

URDician, Stéphanie - 319 n. 2, 324 n.

19, 329, 330, 544 n. 3

URETA, Luis - 547 n. 15

uRZÁIz, Héctor - 554, 559

VALbUENA BRIONES, Ángel - 491, 492,

492 nn. 1, 6, 496, 496 n. 24, 498,

498 nn. 33, 35, 499, 499 n. 38, 502

VALBUENA PRAT, Ángel - 487, 489

valderrama, Pilar de - 262, 264

valente, Ana Maria - 310

VAlenzuela, José Luis

Despojos para Medea - 221

VALÉRIO FLACO - 449-455

Argonáuticas - 450, 450 n. 6, 451,

455,455 n. 22

VAlero de mazas, María - 264

VALÉRY, Paul - 59

valle, Emilio del - 429

VALLE-INClán, Ramón María - 466, 470 n. 15

van DAELE, Hilaire - 112

van steen, Gonda A. H. - 106 n. 3, 113

VARA DONADO, José - 14 n. 9, 18 n. 13, 24

varela, Juan Cruz

Argia - 211 n. 1

Dido-211 n. 1

VAREY, John E. - 363, 558

VARgAS Llosa, Mario

La fiesta del chivo - 430

VARRÃO - 119

VÁRzeAs, Marta - 330

VELTRUSKY, Jiri - 536

VERARDi /verardo, Carlo - 441-447

Fernandus servatus - 442, 443, 443 
n. $3,445-447$

Historia Baetica - 442-447

verardi, Marcelino - 443 nn. 3, 5

vergara, Francisco de - 494

vernant, Jean Pierre - 156, 160, 169,

173, 173 n. 7, 178, 225, 238, 288,

288 n. 2, 291, 291 n. 14, 292, 292

n. 20,293 n. $23,294,386,392,510$

n. 5

VERNET, Juan - 332 n. 3

vidal-naquet, Pierre - 217, 225, 238, 294

vieites, Manuel F. - 13 n. 4, 14 n. 5, 24

vilavedra, Dolores -407 n. 1

VILA VILAR, Enriqueta - 365

VILLALONGA, Llorenç - 267 n. 7, 567

VILlARINo, Edith Marta - 365

viÑAs, David - 340, 345

VIRGILIo - 272, 370, 393, 397, 437, 438

Eneida / Aen. - 214 n. 5, 215 n. 5, 453 n. 18

Geórgicas-158, 160, 279, 400, 435, 439, 474 n. 4

VOLTAIRE

Orestes - 97, 97 n. 11

voss, Johann Heinrich - 80 n. 9

vosSler, Karl - 493 n. 11

WALthaus, Rina - 368

walton, J. Michael - 209

WALton, Richard - 208, 539 n. 3

WATANABe, José - 316

Antígona-219 n. 8, 316

WEber de kURLat, Frida - 355 n. 1, 365

weiss, Peter -466

West, M. L. -69

whitman, Cedric H. - 107, 113

WiATER, Nicolas - 204, 205, 209

wiles, David - 303, 480 n. 33, 483

williams, Tennessee - 397, 400

Orpheus descending -400
WOLFLLIN, Heinrich - 80 n. 10

wOrSTELl DE DORnbrooks, Suellen

Medea del Paraná - 221

Wrigley, Amanda - 106 n. 3, 113

XENOFONTE / X.

Simposio/Smp. -478 n. 25

YOURCENAR, Marguerite -258

Fuegos - 258 nn. 19, 20

Zabalía, Alberto de

El limite - 219

ZAFra, Rafael - 185

zambrano, María - 253-259

El hombre y la divino-259 n. 25

La Tumba de Antígona - 253-259

zanetto, Giuseppe - 112

ZATlin-Boring, Phyllis - 354

Zavala, Iris M. - 562, 567

zayas de lima, Perla - 59, 219 n. 6,

220, 220 nn. 14, 15, 16, 223, 224, 226

Zeitlin, Froma I. - 474 n. 4, 483

ZIssos, Andrew - 453 n. 18

zómbolas, Iánnis (vide BRIGNONE) 221 n. 18 


\section{Volumes publicados na Coleç̧ão Humanitas Supplementum}

1. Francisco de Oliveira, Cláudia Teixeira \& Paula Barata Dias: Espaços e Paisagens. Antiguidade Clássica e Heranças Contemporâneas. Vol. 1 - Linguas e Literaturas. Grécia e Roma (Coimbra, Classica Digitalia/CECH, 2009).

2. Francisco de Oliveira, Cláudia Teixeira \& Paula Barata Dias: Espaços e Paisagens. Antiguidade Clássica e Heranças Contemporâneas. Vol. 2 - Linguas e Literaturas. Idade Média. Renascimento. Recepşão (Coimbra, Classica Digitalia/CECH, 2009).

3. Francisco de Oliveira, Jorge de Oliveira \& Manuel Patrício: Espaços e Paisagens. Antiguidade Clássica e Heranças Contemporâneas. Vol. 3 - História, Arqueologia e Arte (Coimbra, Classica Digitalia/CECH, 2010).

4. Maria Helena da Rocha Pereira, José Ribeiro Ferreira e Francisco de Oliveira (Coords.): Horácio e a sua perenidade (Coimbra, Classica Digitalia/CECH, 2009).

5. José Luís Lopes Brandão: Máscaras dos Césares. Teatro e moralidade nas Vidas suetonianas (Coimbra, Classica Digitalia/CECH, 2009).

6. José Ribeiro Ferreira, Delfim Leão, Manuel Tröster and Paula Barata Dias (eds): Symposion and Philanthropia in Plutarch (Coimbra, Classica Digitalia/CECH, 2009).

7. Gabriele Cornelli (org.): Representaçôes da Cidade Antiga. Categorias históricas e discursos filosóficos (Coimbra, Classica Digitalia/CECH/Grupo Archai, 2010).

8. Maria Cristina de Sousa Pimentel \& Nuno Simões Rodrigues (coords.): Sociedade, poder e cultura no tempo de Ovidio (Coimbra, Classica Digitalia/ $\mathrm{CECH} / \mathrm{CEC} / \mathrm{CH}, 2010$ ).

9. Françoise Frazier et Delfim F. Leão (eds.): Tychè et pronoia. La marche du monde selon Plutarque (Coimbra, Classica Digitalia/CECH, École Doctorale 395, ArScAn-THEMAM, 2010).

10. Juan Carlos Iglesias-Zoido, El legado de Tucídides en la cultura occidental (Coimbra, Classica Digitalia/CECH, ARENGA, 2011).

11. Gabriele Cornelli, O pitagorismo como categoria historiográfica (Coimbra, Classica Digitalia/CECH, 2011).

12. Frederico Lourenço, The Lyric Metres of Euripidean Drama (Coimbra, Classica Digitalia/CECH, 2011). 
13. José Augusto Ramos, Maria Cristina de Sousa Pimentel, Maria do Céu Fialho \& Nuno Simões Rodrigues (coords.), Paulo de Tarso: Grego e Romano, Judeu e Cristão (Coimbra, Classica Digitalia/CECH, 2012).

14. Carmen Soares \& Paula Barata Dias (coords.), Contributos para a história da alimentação na antiguidade (Coimbra, Classica Digitalia/CECH, 2012).

15. Carlos A. Martins de Jesus, Claudio Castro Filho \& José Ribeiro Ferreira (coords.), Hipólito e Fedra - nos caminhos de um mito (Coimbra, Classica Digitalia/CECH, 2012).

16. José Ribeiro Ferreira, Delfim F. Leão, \& Carlos A. Martins de Jesus (eds.): Nomos, Kosmos E Dike in Plutarch (Coimbra, Classica Digitalia/CECH, 2012).

17. José Augusto Ramos \& Nuno Simões Rodrigues (coords.), Mnemosyne kai Sophia (Coimbra, Classica Digitalia/CECH /CHUL, 2012).

18. Ana Maria Guedes Ferreira, O homem de Estado ateniense em Plutarco: o caso dos Alcmeónidas (Coimbra, Classica Digitalia/CECH, 2012).

19. Aurora López, Andrés Pociña \& Maria de Fátima Silva, De ayer a hoy: influencias clásicas en la literatura (Coimbra, Classica Digitalia/CECH, 2012). 

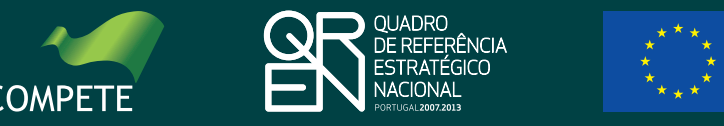